Universidade de São Paulo

Thiago Chaves de Andrade Oliveira

\title{
Sérgio Assad: sua linguagem estético-musical através da análise de Aquarelle para violão solo
}

\begin{abstract}
Dissertação apresentada ao programa de PósGraduação em Música, Área de Concentração Processo de Criação Musical, Linha de pesquisa Técnicas Composicionais e Questões Interpretativas da Escola de Comunicação e Artes da Universidade de São Paulo, como exigência parcial para a obtenção de Título de Mestre em Música, sob a Orientação do Prof. Dr. Edelton Gloeden.
\end{abstract}

São Paulo

2009 
Universidade de São Paulo

Thiago Chaves de Andrade Oliveira

\title{
Sérgio Assad: sua linguagem estético-musical através da análise de Aquarelle para violão solo
}

\begin{abstract}
Dissertação apresentada ao programa de PósGraduação em Música, Área de Concentração Processo de Criação Musical, Linha de pesquisa Técnicas Composicionais e Questões Interpretativas da Escola de Comunicação e Artes da Universidade de São Paulo, como exigência parcial para a obtenção de Título de Mestre em Música, sob a Orientação do Prof. Dr. Edelton Gloeden.
\end{abstract}

São Paulo 
Sérgio Assad: Sua Linguagem Estético Musical Através da análise de Aquarelle para Violão Solo

Thiago Chaves de Andrade Oliveira

Orientador: Prof. Dr. Edelton Gloeden.

Dissertação apresentada ao programa de Pós-Graduação em Música, Área de Concentração Processo de Criação Musical, Linha de pesquisa Técnicas Composicionais e Questões Interpretativas da Escola de Comunicação e Artes da Universidade de São Paulo, como exigência parcial para a obtenção de Título de Mestre em Música.

Prof. Dr. Edelton Gloeden.

Prof. Dr.

Prof. Dr.

São Paulo 


\section{Resumo}

O presente trabalho se propõe a traçar um retrato da linguagem estética e instrumental do compositor e violonista Sérgio Assad (1952). Tal investigação será feita através da contextualização de sua produção através de um relato bibliográfico, da análise de umas de suas obras mais representativas, Aquarelle, escrita para violão solo com um comentário sobre o restante da sua produção. Visto que o compositor pesquisado ainda se encontra em atividade e possui uma vasta produção de música de câmara e como arranjador, este trabalho se propõe a delimitar o escopo à suas composições originais para violão solo.

Palavras chave: Sérgio Assad, música brasileira, pós-modernismo, análise musical, violão. 


\begin{abstract}
This work has the objective of researching the instrumental and aesthetic language of guitarist composer Sérgio Assad (1952). Such investigation will be conducted through a biographical portrait of the composer, an analysis of one of his most important works, Aquarelle, for solo guitar and a commentary about his works for the instrument. Knowing that the composer is still active and has a large body of chamber music and arrangements, this work will focus on his production of original compositions for solo guitar.
\end{abstract}

Keywords: Sérgio Assad, Brazilian music, post modernism, musical analisis, classical guitar. 


\section{Agradecimentos}

A Edelton Gloeden, orientador desta dissertação, pela orientação, paciência e preciosas lições.

À minha família e amigos pelo apoio. A Maurício Orosco, Gilson Antunes, Luciano César Morais, João Paulo Figueiroa pelo suporte. Aos violonistas que gentilmente cederam entrevistas a este trabalho, Aliéksey Vianna, Randall Avers, David Russell e Eduardo Meirinhos.

Um agradecimento especial a Sérgio Assad, por sua disponibilidade, apoio e generosidade. 
Who watches the

Watchmen? (Alan Moore) 


\section{Sumário}

Introdução

1

1.1 Hibridismos da música culta com a música popular no âmbito do repertório para violão

1.2 O Hibridismo no violão brasileiro .................................................... 10

1.3 Sérgio Assad: perfil do compositor instrumentista ............................. 16

1.4 Duo Assad e seus contemporâneos............................................ 24

2. Análise de Aquarelle ............................................................... 28

2.1 Aspectos Gerais da Obra ........................................................... 28

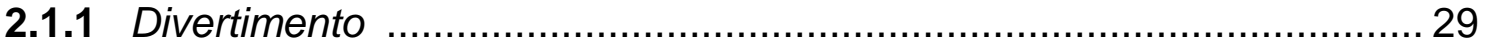

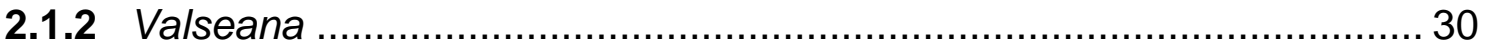

2.1.3 Prelúdio e Toccatina ................................................................. 30

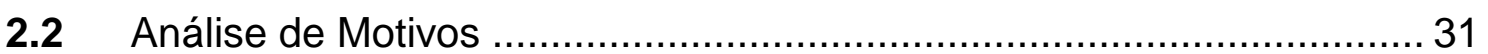

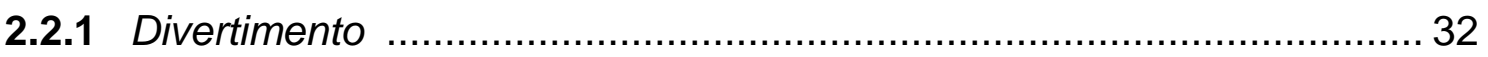

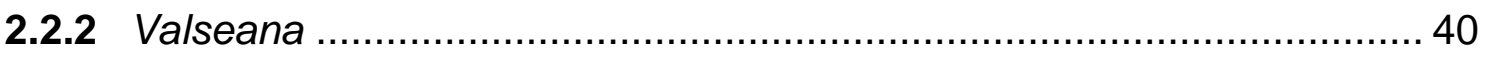

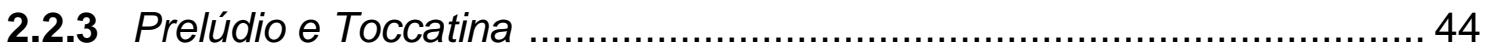

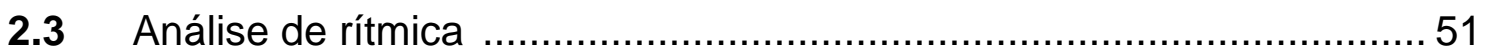

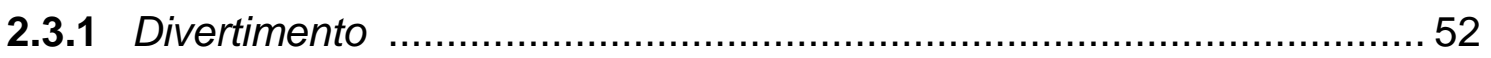

2.3.2 Prelúdio e Toccatina................................................................... 58

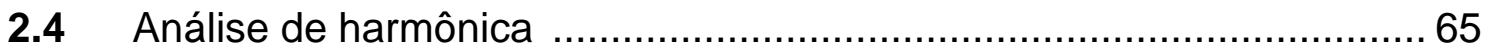

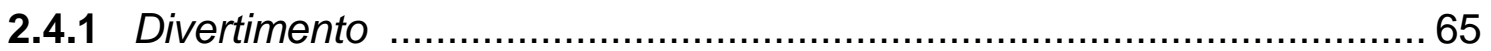

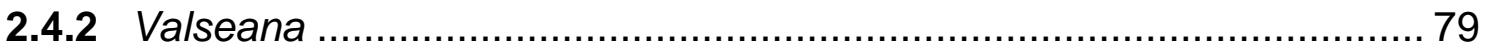

2.4.3 Prelúdio e Toccatina ............................................................... 82

2.5 Análise de escrita violonística ........................................................ 93

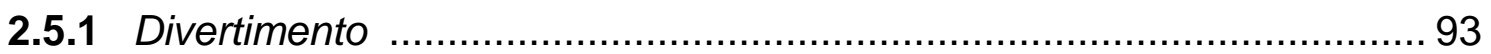

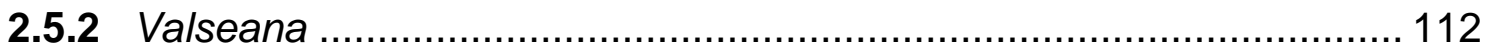

2.5.3 Prelúdio e Toccatina ............................................................... 116

2.6 As influências estéticas em Aquarelle ........................................... 125

2.6.1.1 Radamés Gnattali ...................................................................... 128

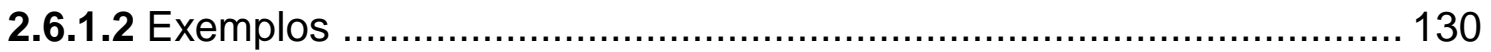

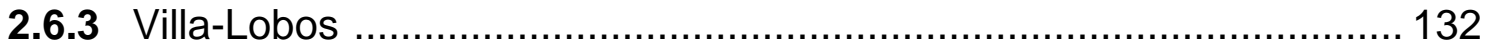

2.6.4.1 Música popular urbana ............................................................. 136

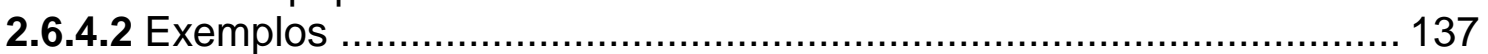

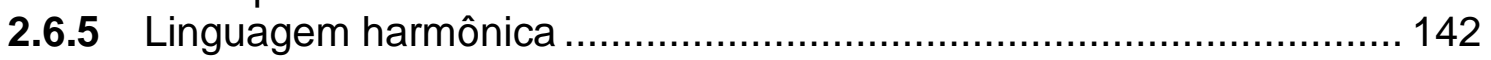

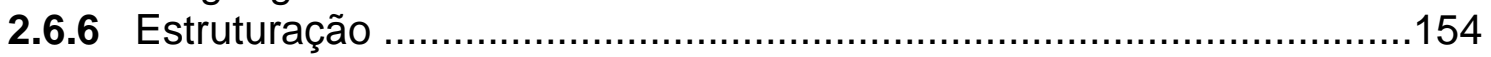

\subsection{Os reflexos de Aquarelle na obra para violão solo de Sérgio Assad}

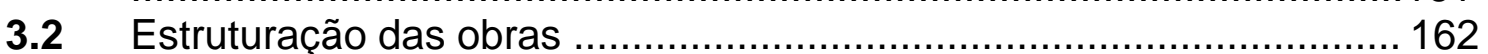

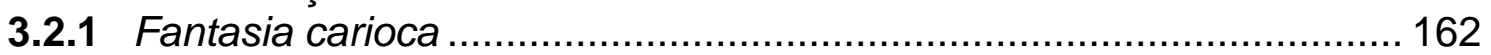

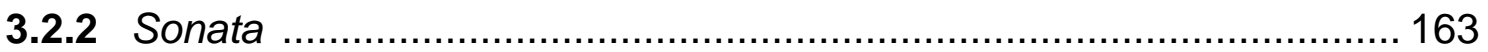

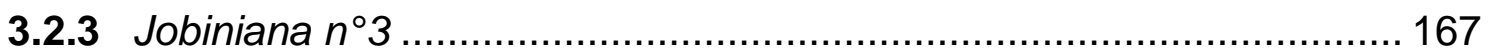

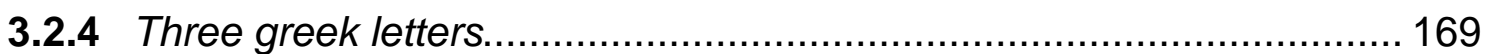

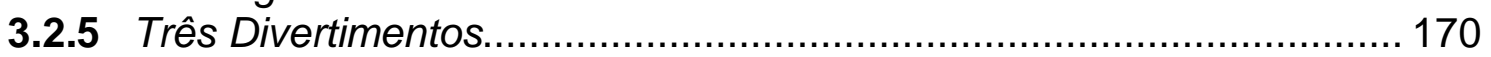

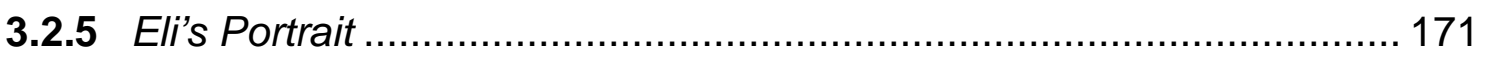

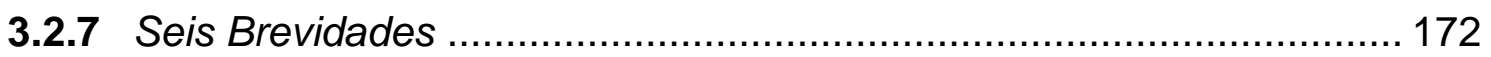


3.3 Exemplos da influência da música popular urbana na obra para violão solo de Sérgio Assad .............................................................................. 173

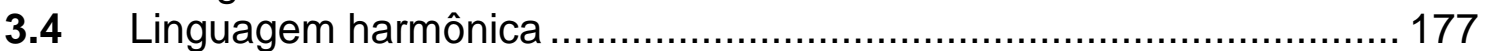

3.5 Elaboração motívica .................................................................. 181

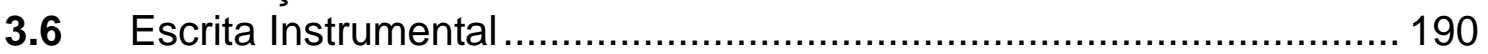

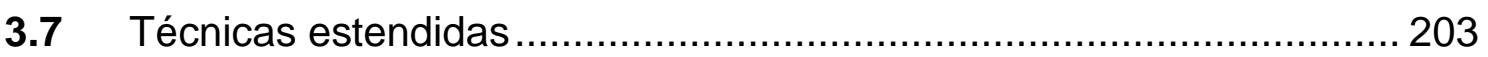

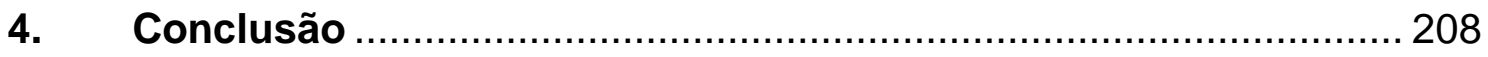

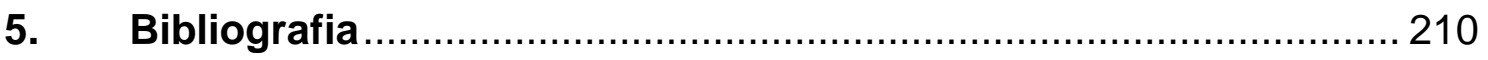

6. Anexos

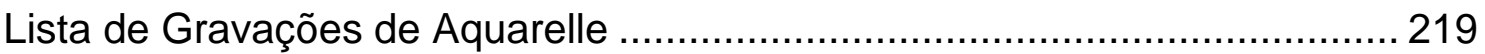

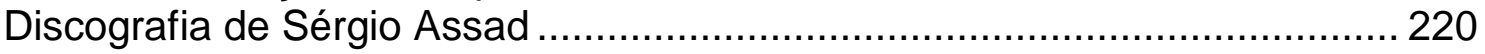

Lista de Composições de Sérgio Assad ................................................... 224

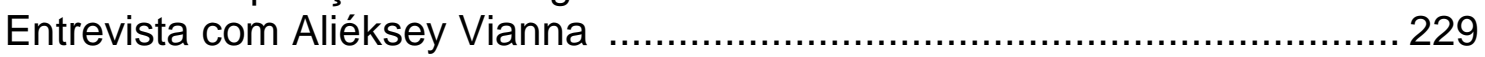

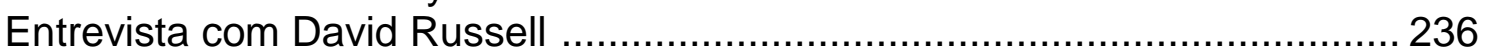

Entrevista com Eduardo Meirinhos ……………….............................. 238

Entrevista com Randall Avers ……................................................. 240

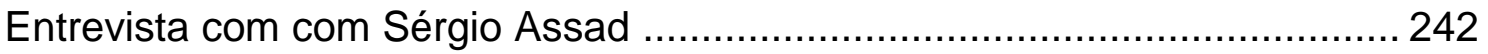

Cópia Xerografada de Aquarelle (em anexo) 
Introdução

O primeiro contato que tivemos com a música de Sérgio Assad (1952) deu-se através de uma gravação da obra integral para violão solo de Heitor Villa-Lobos (1887-1959) ${ }^{1}$. Chamou atenção, o virtuosismo e a musicalidade que nos deixou uma impressão forte e gerou admiração pela arte do violonista. Algum tempo depois nos deparamos com uma gravação de um jovem violonista que executava uma obra de Assad na TV, ocasião na qual constatamos que além de exímio violonista, Assad seria também, em uma análise prévia, um compositor de qualidade. Com o tempo, pudemos perceber as diferentes facetas desse virtuose, seja com os arranjos de obras de Astor Piazzolla (1921-1992) ou nas obras que diversos compositores dedicaram ao Duo Assad formado juntamente com seu irmão Odair Assad (1956). Contudo, o evento que nos fez decidir a pesquisar a música de Sérgio Assad foi um recital do concertista mineiro Aliéksey Vianna (1976) em Uberlândia (MG) em agosto de 2003, no qual pudemos conhecer mais uma de suas obras, a Fantasia Carioca para violão solo, uma composição vibrante, virtuosística e lírica ao mesmo tempo. Após o recital, ao conversar com Vianna, nos foi revelado que o mesmo estaria gravando um $\mathrm{CD}$ exclusivamente dedicado às obras para violão solo de Sérgio Assad ${ }^{2}$, e em seguida nos mostrou informalmente outras obras interessantes do compositor.

Com uma crescente curiosidade, iniciamos uma investigação sobre a produção de Sérgio Assad como compositor através de partituras e gravações, o que nos possibilitou o vislumbre de um compositor com uma obra extensa em que se fundia a complexidade estrutural e temática da música de concerto com a linguagem remanescente da música popular urbana.

Ao iniciar a minha busca por informações com relação ao compositor Sérgio Assad e sua linguagem estética, o que mais chamava a atenção era a ausência de material sobre sua atividade como compositor. Muito era escrito sobre o virtuosismo interpretativo do Duo Assad e seu impacto no cenário internacional do violão de concerto, porém pouco era comentado sobre as

\footnotetext{
1 DUO ASSAD. Heitor Villa-Lobos: Obra Completa Para Violão Solo, Kuarup, KCD 139,1978.

2 VIANNA, Aliéksey. Vianna plays Assad. San Francisco, GSP Recordings, CDGSP 1027, 2005.
} 
composições de Sérgio, que constavam em diversos artigos e entrevistas como adendo.

Outro fator que ainda chamava atenção foram as diversas gravações de Aquarelle, que pode ser considerada a obra mais executada de Sérgio Assad, e a falta de artigos, análises e trabalhos acadêmicos sobre o assunto.

Tal carência nos levou a escrever como trabalho de conclusão de curso em 2006 uma monografia ${ }^{3}$ sobre a obra Aquarelle na Universidade Federal de Uberlândia. Tendo a consciência de que tal pesquisa ainda possuía uma profundidade limitada em diversos aspectos, foi mantido o mesmo tema para a dissertação de mestrado numa tentativa de obter mais respostas para questões deixadas em aberto pelo primeiro trabalho e ao mesmo tempo apresentar uma abordagem mais completa sobre 0 assunto.

O presente trabalho tem como objetivo analisar a Aquarelle, uma das peças mais representativas do compositor, detectar alguns elementos estéticos e instrumentais presentes nesta obra e com isso, traçar um perfil da linguagem musical de Sérgio Assad.

No primeiro capítulo, será feita uma contextualização da linguagem composicional de Sérgio Assad ao traçarmos um perfil do compositor e um relato sobre o resultado dos hibridismos da música popular na música de concerto e seus reflexos sobre a prática violonística atual. Visto que, no Brasil tal prática possui uma história peculiar, será feito um relato sobre tal prática no país.

O segundo capítulo tratará da análise de Aquarelle em seus diversos aspectos e suas implicações estéticas. Será analisada a elaboração motívica, a estruturação harmônica e a rítmica em subitens distintos. Considerando que o compositor da obra possui uma carreira notável como instrumentista, será feita uma análise da linguagem instrumental da obra que será feita em forma de estudo instrumental do autor deste texto sobre a peça, com objetivo de se detectar os elementos técnicos elaborados pelo compositor e de se alcançar propostas técnicas a certas passagens da mesma. Tal investigação nos leva ao subitem final deste capítulo que se trata da análise dos elementos estéticos

\footnotetext{
${ }^{3}$ OLIVEIRA, Thiago Chaves de Andrade. Análise Estético-instrumental da obra Aquarelle de Sérgio Assad. Uberlândia, Departamento de Música e Artes Cênicas, 2006.
} 
levantados por este capítulo, onde serão apontadas as diversas influências estéticas de Aquarelle e como estas se manifestam na obra.

No terceiro capítulo será feito um comentário sobre a obra completa para violão solo de Sérgio Assad até o ano de 2008 bem como uma comparação destas com Aquarelle.

Dentre as diversas fontes utilizadas para a realização deste trabalho destacamos as cópias em arquivo PDF de obras recentes para violão solo pelo compositor e que ainda se encontram sem edição.

A fim de complementar a análise da peça e de se enriquecer o texto, foram realizadas entrevistas com violonistas que tiveram contato com Aquarelle e com as demais obras de Assad tanto em gravações, como em execuções ao vivo. São eles: Aliéksey Vianna, David Russell, Eduardo Meirinhos e Randall Avers. Também foi utilizada como fonte uma entrevista com o compositor conduzida pelo violonista Luciano César Morais, feita em função de sua dissertação de mestrado ${ }^{4}$.

\footnotetext{
${ }^{4}$ MORAIS, Luciano César. Sérgio Abreu: sua herança histórica, poética e contribuição musical através de suas transcrições para violão. São Paulo Escola de Comunicação e Artes, Universidade de São Paulo, 2007.
} 


\subsection{Hibridismos da música culta com a música popular no âmbito do repertório para violão}

Ao tratar do hibridismo da música popular com a música de concerto, procuramos estabelecer parâmetros que nos permitiram classificar tal prática. Definimos hibridismo como a adoção por compositores de orientação erudita de materiais rítmico-melódico e estilístico oriundos da música popular para a reelaboração sob a ótica composicional da música culta. Diversos dos compositores que adotaram esta prática tais como George Gershwin, (1898 1937), Radamés Gnattali, (1906 - 1988) e Frank Zappa (1940 - 1993), tiveram carreiras bem sucedidas na música popular enquanto se dedicavam paralelamente à música de concerto ${ }^{5}$.

Com fins de contextualizar a produção de Sérgio Assad, que apresenta em uma análise prévia características da música de concerto e da música popular, investigamos o surgimento desta fusão na segunda metade do século XX. Ao estruturar este relato, detectamos a recorrência da adoção de temas populares por diversos compositores e instrumentistas de diversos períodos de produção de música de concerto para cordas dedilhadas. Notamos que o diálogo entre o popular e o culto na literatura para instrumentos de cordas dedilhadas, tem sido registrado nas publicações mais antigas que conhecemos hoje, inclusive com reflexos na prática violonística atual ${ }^{6}$.

Como ponto de partida, tomamos a prática do alaúde e da vihuela no período renascentista pelo fato do repertório de ambos os instrumentos terem sido adotados pelos violonistas atuais e pela temática de diversas peças da época estar voltadas à música popular. Um célebre exemplo da incorporação de um tema popular em uma composição para instrumento de cordas dedilhadas é a obra intitulada Diferencias sobre Guardame las vacas do compositor e vihuelista espanhol Luys de Narvaes (c. 1500 - 1555/1560),

\footnotetext{
${ }^{5}$ Devemos ressaltar que mesmo na produção popular de Frank Zappa e George Gershwin ambos compunham em uma linguagem rebuscada e complexa para os parâmetros da música popular. No caso de Zappa as diversas mudanças abruptas de compasso, linguagem harmônica que beirava o atonal, e a prática da música que oscilava entre o texto escrito e a improvisação causam dificuldades na categorização de sua obra.

${ }^{6} \mathrm{O}$ primeiro registro que se tem notícia de música para cordas dedilhadas é o compêndio Intabulatura di Lauto, do Italiano Francesco Spinacino, datado de 1507.
} 
considerada um dos primeiros exemplos de tema e variações de que se tem notícia. Nesta composição Narvaes constrói diversas variações, denominadas na época de diferencias, sobre o tema popular, Guárdame las Vacas. Considerando que a prática de se improvisar variações sobre um determinado tema era comum aos instrumentistas da época, especula-se que a obra se trata de variações improvisadas e grafadas posteriormente.

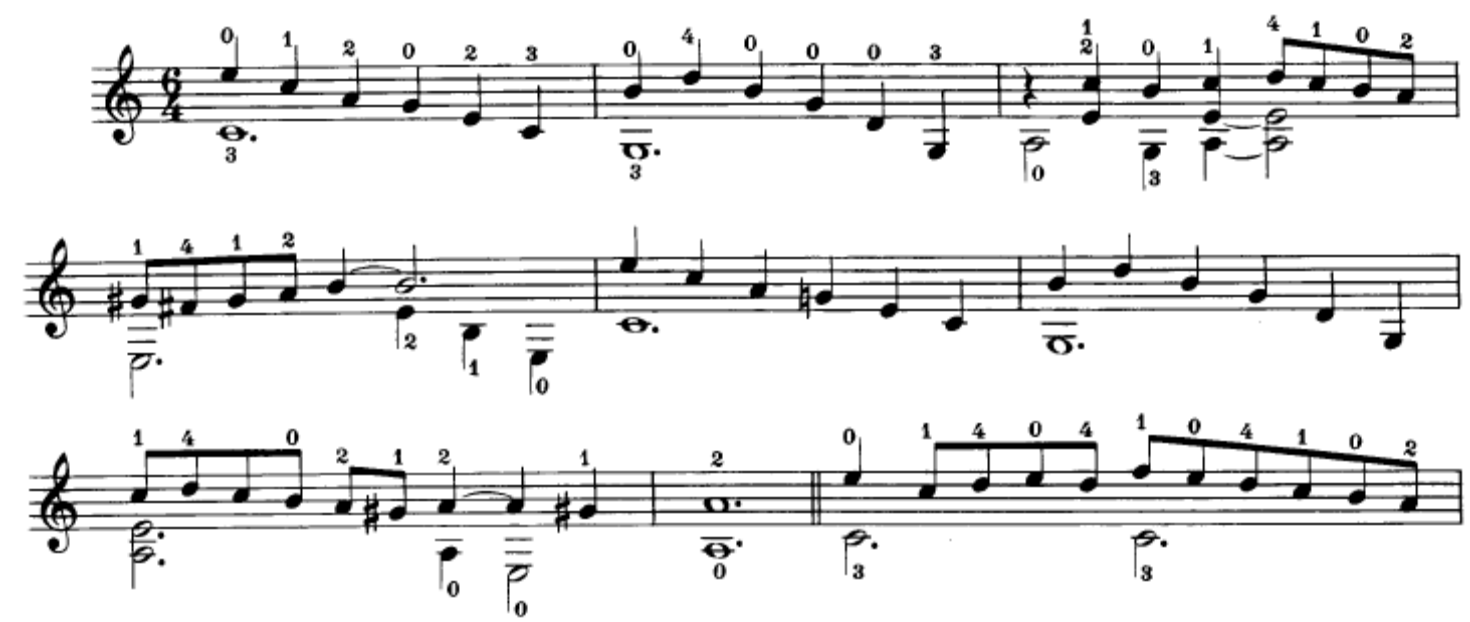

Guárdame las Vacas - Luís de Narvaes

Durante a primeira metade do século XIX, houve o que hoje denominamos de guitaromanie, período caracterizado por uma efervescente produção violonística. Uma das figuras mais proeminentes, o espanhol Fernando Sor (1778 - 1839), elaborou obras inspiradas em temas populares, dentre as mais notáveis, Introdução e Variações sobre "Malbrough s'en-va-t-en guerre" opus 28, foi elaborada sobre um tema popular da época, fato que talvez não fosse tão surpreendente ao se tomar conhecimento do envolvimento de Sor com a escrita de canções populares em sua juventude. 


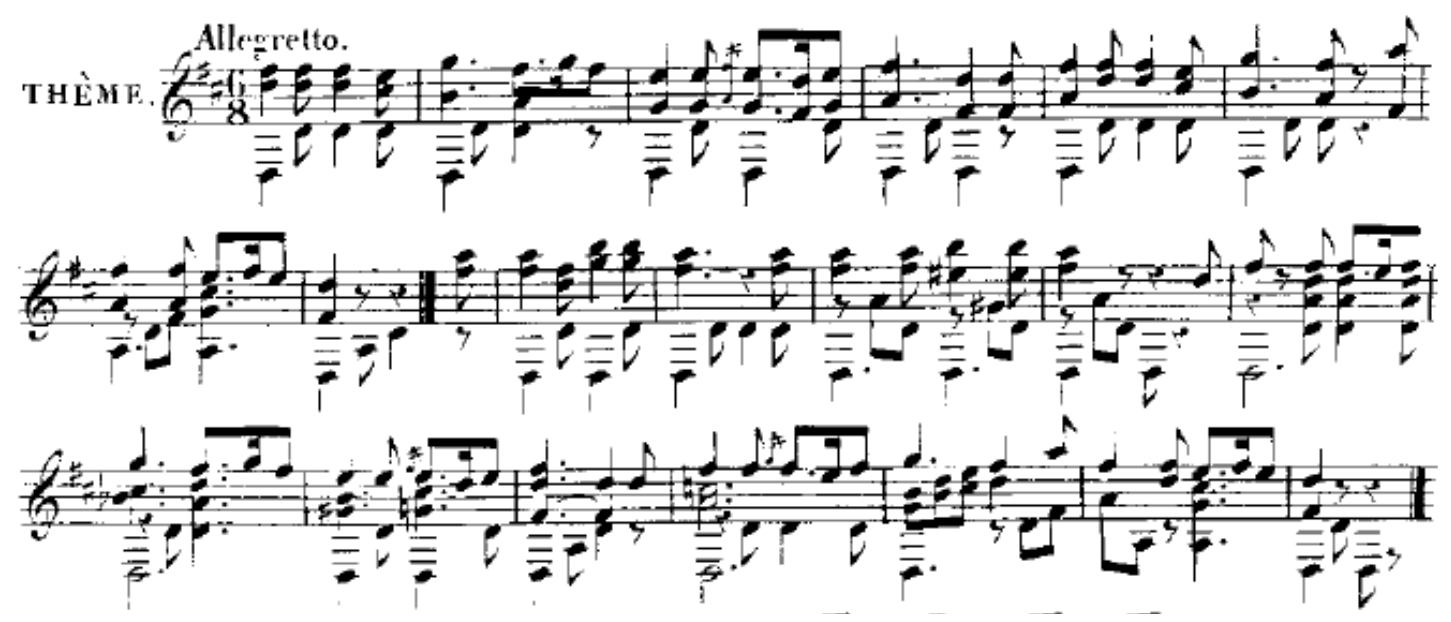

Tema de Introdução e Variações sobre "Malbrough s'en-va-t-en guerre" opus 28Fernando Sor

Outro autor referencial, já na segunda metade do séc. XIX, o espanhol Francisco Tárrega (1852 - 1909), um violonista e compositor de diversas obras de pequeno porte inspiradas em danças de salão da época, também sofreu influência de elementos da música folclórica espanhola ligadas à tradição árabe, tal como vemos no Capricho Árabe, na Dança Mora e em Recuerdos de la Alhambra. Esta ligação da literatura violonística com temas do folclore ibérico obteve continuidade no trabalho do discípulo de Tárrega, o catalão Miguel Llobet (1878 - 1938) que evidencia as suas raízes através de seus diversos arranjos para canções folclóricas catalãs.

Uma figura que teve uma produção atípica para violão foi o violonista e compositor paraguaio Agustín Barrios Mangoré (1885 - 1944). Durante a sua formação, Barrios se encontrava num ambiente cultural dilacerado pela guerra com o Brasil e que se traduziu num estilo que remetia ao romantismo europeu, o folclore, a música popular e a música de inspiração erudita baseada em modelos de períodos diversos. Tal diversidade gerou por sua vez uma vasta obra para violão solo, de amplo alcance estilístico e que em muitas situações era fruto da sua atuação como músico itinerante pela América Latina, visto que escrevia obras de acordo com a necessidade que se apresentava e do tipo de ocasião. Várias destas obras, muitas delas improvisadas em pleno concerto e grafadas posteriormente, eram baseadas em danças populares e folclóricas de cada país em que se apresentava. Algumas destas peças tais como Maxixe, Choro da Saudade, Cueca, Danza Paraguaya, Aire de Zamba, Don Perez Freire, entre tantas várias, demonstravam influências da cultura popular e 
folclórica de cada local visitado por Barrios e ao mesmo tempo sua capacidade de absorção sem perder a sua característica como compositor. A obra de Barrios sobrevive até os dias atuais, é executada por violonistas eruditos e populares que encontram em seu estilo qualidade, personalidade e uma escrita instrumental eficiente.

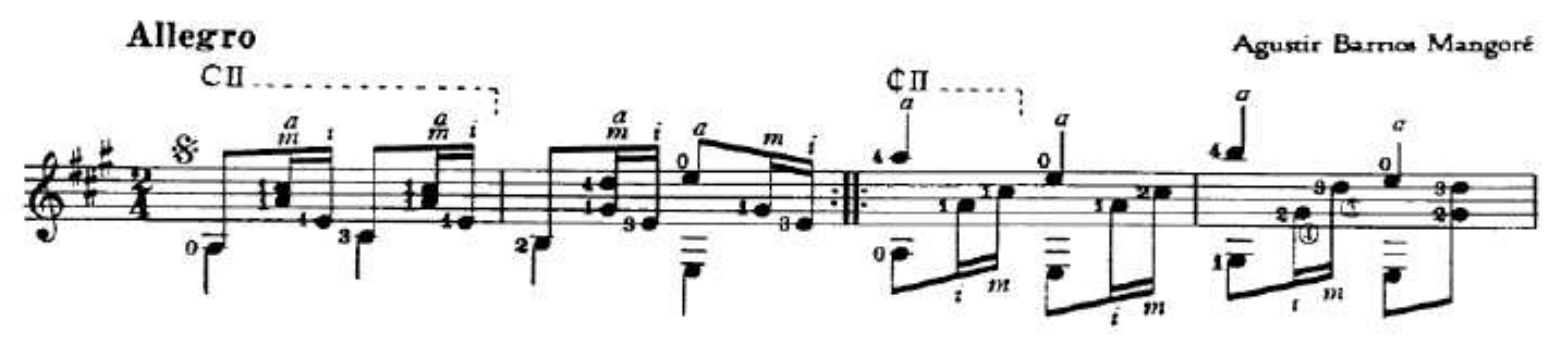

Maxixe - Agustín Barrios

Na primeira metade do século $\mathrm{XX}$, a imagem do violonista de concerto recai nos ombros do espanhol Andrés Segovia (1893 - 1987). Sua inquestionável importância como artista promotor do instrumento e figura emblemática do cânone do violão denominado erudito tem reflexos muito na história do instrumento, visto que o músico foi um dos primeiros artistas a desenvolver um repertório escrito por compositores não violonistas de música séria em padrões de execução e interpretação que ainda servem de referência aos concertistas atuais. Em sua carreira algumas metas foram traçadas para levar o violão ao que Segovia denominava de público seleto. Citamos aqui estas para fins de ilustrar o a concepção musical do virtuose espanhol:

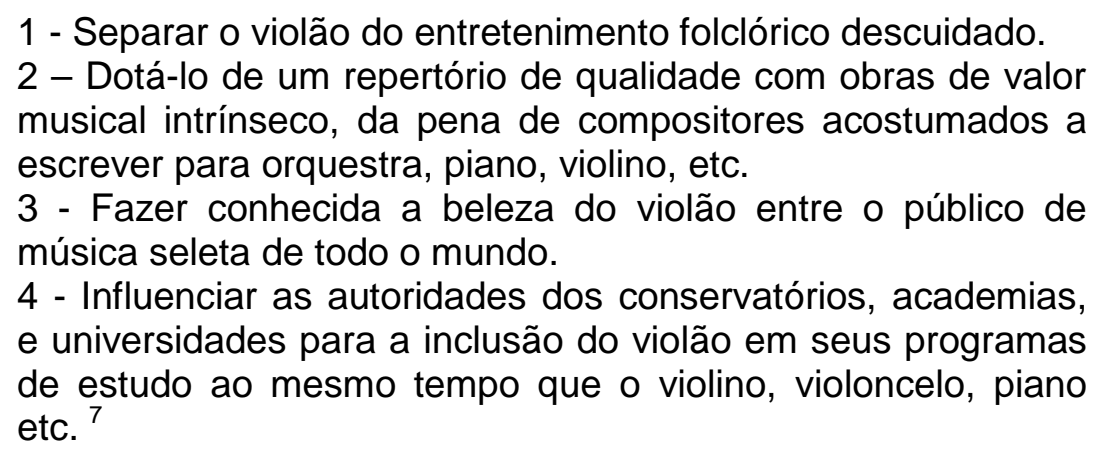

1 - Separar o violão do entretenimento folclórico descuidado.

2 - Dotá-lo de um repertório de qualidade com obras de valor musical intrínseco, da pena de compositores acostumados a escrever para orquestra, piano, violino, etc.

3 - Fazer conhecida a beleza do violão entre o público de música seleta de todo o mundo.

4 - Influenciar as autoridades dos conservatórios, academias, vioa em seus programas etc. $^{7}$

Estas afirmações de Segovia abrem amplas margens para a especulação quanto à ortodoxia de sua concepção musical, porém deve-se ressaltar que o "folclore descuidado" citado pelo violonista provavelmente não

\footnotetext{
${ }^{7}$ C. USILLOS, op, cit pág 109. (tradução nossa)
} 
seria a total exclusão do folclore em seu repertório. Isto pode ser exemplificado no fato de que várias das obras escritas por compositores não violonistas e executadas pelo virtuose espanhol eram de inspiração folclórica como as de Federico Moreno Torroba (1891 - 1982), Joaquín Turina (1882 - 1949), Manuel Ponce (1882 - 1948), dentre outros ${ }^{8}$.

Um violonista que agregaria novos elementos à arte do mestre espanhol, trazendo ao instrumento novos padrões interpretativos seria o inglês Julian Bream (1933). Durante sua carreira, foi o introdutor de diversas inovações que posteriormente se tornariam padrão para as gerações posteriores de violonistas, tal como a gravação de LPs que abordavam estilos específicos dentro do repertório e o estudo de música antiga com a gravação e a execução do repertório em uma réplica de um instrumento de época. Dentre as diversas contribuições de Bream para com a história do violão como instrumento de concerto, talvez a mais importante tenha sido a sua ligação com compositores de relevo dentro do cenário inglês tal como Benjamin Britten (1913 - 1976) Michael Tippet (1905 - 1998), William Walton (1902 - 1983), Malcolm Arnold (1921 - 2006) dentre vários outros que aceitaram suas encomendas e lhes dedicaram obras originais para violão. Nisto, Bream aproximou o instrumento da vanguarda musical trazendo este para o centro dos acontecimentos musicais da época.

Ao citarmos o nome de Julian Bream neste trabalho, um músico considerado extremamente rigoroso com seu repertório e ligado à música de concerto tradicional, abrimos espaço para um evento que pode ser associado ao surgimento do hibridismo do violão clássico com a música popular no final do século XX. Uma das obras dedicadas ao violonista inglês, as Five Bagatelles (1971), do compositor William Walton, se tornou um conjunto de peças extremamente popular no repertório violonístico, adotada por diversos concertistas da época, um deles, o violonista argentino Roberto Aussel (1954). Em 1980, houve um encontro deste músico com o compositor Astor Piazzolla (1921 - 1992), renomado bandeonista e compositor argentino que fundia o

\footnotetext{
${ }^{8}$ Dentre as obras de Heitor Villa-Lobos executadas pelo mestre espanhol, consta no livro de Graham Wade Segovia, A celebration of the man and his music, uma execução em Londres, no Wigmore Hall em 1938 do Choros no1, uma das peças que mais se aproximava esteticamente da música popular escrita pelo compositor. Isto demonstra que, apesar da sua notória busca de aproximar o violão dos instrumentos considerados nobres, a música popular ainda encontrava espaço em seu repertório ainda que de maneira tímida.
} 
tradicional tango argentino com o jazz e a música de concerto, criando uma linguagem particular denominada de Nuevo Tango ${ }^{9}$. Neste encontro, Aussel demonstrou as possibilidades do violão para a encomenda de alguma obra para violão solo do compositor argentino. Dentre as obras demonstradas, estava a Bagatelle nơ3, Alla Cubana, de forte apelo rítmico e com uma melodia característica em sua segunda parte, com identidade próxima à estética piazzollana, o que motivou o autor de Maria de Buenos Aires a compor suas Cinco peças para violão (1981), dedicadas a Roberto Aussell. Apesar de já existirem diversos exemplos similares anteriores à criação da obra de Piazzolla supracitada, esta tornou-se um marco devido a forte repercussão no meio musical e particularmente entre os violonistas. Segue abaixo uma declaração de Roberto Aussel sobre o histórico encontro:

Eu pedi a Piazzolla para escrever alguma coisa para violão. Então um dia eu fui visitá-lo em seu apartamento em Paris. (...) Eu toquei algumas obras de Bach, algumas peças de Weiss e então algumas obras originais para violão de VillaLobos, Barrios, alguma peças contemporâneas de Leo Brouwer e as Bagatelas de William Walton. Naquele momento ele aprendeu um pouco do que poderia ser feito no violão, especialmente quando ouviu a terceira Bagatela de William Walton, ele ficou muito entusiasmado. Eu passei a tarde em seu apartamento e uma semana depois ele me ligou dizendo que havia terminado uma das cinco peças. (tradução nossa) ${ }^{10}$

Iniciava-se o culto à Piazzolla que perdura até hoje nos mais diversos formatos. O precedente aberto pelas Cinco Peças teve conseqüências para o violão de concerto. O que se seguiu, foi a adoção de várias obras que anteriormente eram somente aceitas no ambiente da música popular em recitais de violão erudito. Vários concertistas ativos naquele período se aventuraram em projetos de gravações e concertos com obras de caráter popular. Com isso a execução arranjos de obras de compositores tais como Astor Piazzolla, Egberto Gismonti (1947), assim como os exemplos de violonistas populares como o colombiano Gentil Montaña (1942), o argentino

\footnotetext{
${ }^{9}$ É importante mencionar neste momento, que apesar do nome de Piazzolla ser associado ao tango e à música popular, ele teve uma formação rigorosa com professores tais como Alberto Ginastera e Nádia Boulanger, e escreveu não apenas música popular.

${ }^{10}$ SABA, Théresè Wassily. Roberto Aussell - Tristón. Classical Magazine, Março de 2007, Ashley Mark Publishing Company, Blayton Upon Tyne, 2007, p 11 a 16.
} 
Maximo Diego Pujol (1957), os brasileiros Paulo Bellinatti (1950) e Marco Pereira (1950) ganharam amplos espaços no meio do violão de concerto. Este novo ambiente abriu as portas para que novos interpretes e compositores escrevessem obras que se aproximavam da música popular essencialmente urbana e que distanciavam cada vez mais tanto da música culta tradicional, quanto das vanguardas oficiais do séc. $\mathrm{XX}^{11}$.

\subsection{O Hibridismo no violão Brasileiro}

Ao contextualizarmos o cenário descrito acima, em que Sérgio Assad despontou como concertista e compositor, não podemos deixar de investigar a mistura de gêneros dentro do violão brasileiro, um cenário que influenciou a formação musical de Assad, devido ao fato de que seus pais eram músicos populares amadores.

Assim como na Espanha, o violão no Brasil sempre se encontrou fortemente enraizado na cultura popular não apenas como acompanhador, mas como instrumento capaz de acomodar música popular instrumental, como instrumento de conjunto e como solista. Assim como na península Ibérica, o violão foi associado às classes mais desfavorecidas e à malandragem no início do Século XX, trazendo estigmatização ao instrumento. Um artigo de 1916, do Jornal do Comércio, do Rio de Janeiro, compilado pelo violonista e pesquisador Gilson Antunes, ilustra de maneira clara a visão que se tinha do instrumento na época ${ }^{12}$ :

Poucas semanas depois, o periódico continuava a insistir na "precariedade artística" do violão, assim como da guitarra portuguesa: "A guitarra nasceu para o fado e o violão para a modinha. Violão e guitarra são instrumentos populares, através cujas cordas palpitam tristezas, lágrimas e risos de

\footnotetext{
${ }^{11}$ Durante o século $X X$, a prática composicional oficial sofreu uma forte influência da denominada Segunda Escola de Viena, movimento musical originário da primeira metade do século XX capitaneado pelo compositor austríaco Arnold Schoenberg (1874 - 1951) que foi responsável pela ruptura dos padrões tonais na música e na busca de novos meios de expressão musical.

${ }_{12}$ CASTAGNA, Paulo \& ANTUNES, Gilson. 1916, O Violão Brasileiro já é uma arte. Revista Cultura Vozes, ำ1, ano 88, jan./fev., 1994, p. $37-51$.
} 
dois povos intimamente ligados pela afinidade de raça, de coração e de língua. Acompanhando uma canção sentimental ou dedilhando um fado corrido, a guitarra e o violão falam não só à alma de popular, mas à alma de toda a gente. Uma e outro jamais lograrão alcançar a perfeição sonhada pelos seus cultores apaixonados. As regiões da música clássica não the são propícias, as suas cordas não se dão muito bem nos ambientes de arte propriamente dita.

Tal imagem foi às vezes contestada pela visita do paraguaio Agustín Barrios e da espanhola Josefina Robledo e o subseqüente sucesso de suas apresentações na imprensa em 1916 e 1917.

Após o primeiro concerto de Barrios no Rio de Janeiro, em 24 de julho de 1916, o mesmo Jornal do Comércio que, semanas atrás, publicava fortes censuras ao violão, passa a reconhecêlo, então, como instrumento digno das salas de concerto (...). ${ }^{13}$

A influência do instrumentista paraguaio, através de sua linguagem composicional e personalidade como concertista teria reflexos em uma nova geração de violonistas brasileiros tanto eruditos quanto populares, que através de personalidades musicais distintas enriqueceriam a produção para o instrumento no país.

Diversamente a Barrios, a herança cultural trazida por Heitor Villa-Lobos para o violão brasileiro foi mais ampla e teve conseqüências mais profundas para a história do instrumento no país. Apesar do apelo popular encontrado na obra do compositor carioca, encontramos uma linguagem arrojada, original e que flertava com diversas correntes. Em obras como a Suíte Popular Brasileira (1912 - 1923), encontramos uma paleta de referências estilísticas e atestam que a utilidade do violão para o compositor ia além de um mero acompanhador para as rodas de choro da época, servindo de laboratório para a fusão de formas européias com a linguagem popular brasileira.

O legado de Villa-Lobos e de sua linguagem nacionalista, teve repercussão nas diversas gerações posteriores de compositores brasileiros. Compositores tais como Mozart, Camargo Guarnieri (1907 - 1993), Francisco Mignone (1897- 1986) e César Guerra-Peixe, (1914 - 1993) dentre diversos outros que nos deixaram obras de concerto para violão que, assim como a obra

\footnotetext{
${ }^{13}$ Ibdem p. $37-51$.
} 
para o violão de Villa Lobos, bebiam da fonte da cultura popular.

Apesar da arrojada linguagem do compositor, o ambiente para violão no Brasil ainda era composto quase que exclusivamente por músicos amadores e que tinham pouca instrução musical ${ }^{14}$. Tal cenário, fez com que o influente ciclo dos 12 Estudos para Violão (1929), encontrasse apenas na França, um interprete à altura da obra, neste caso Andrés Segovia que fez algumas gravações nas décadas de 40 e $50^{15}$ :

(...) até os anos 30 pouca gente tocava violão por música no Brasil, tanto que toda a nossa música para violão no século XIX foi publicada em partitura de piano. (...) Villa-Lobos foi um dos primeiros a escrever música de concerto para violão no Brasil ainda na década de $1900(\ldots)^{16}$

Um dos compositores que de certa forma seguiu um caminho traçado por Villa-Lobos, no que tange à elaboração de obras para violão, foi o gaúcho Radamés Gnattali (1906 - 1988). Com sua maneira híbrida de compor, Radamés teve um importante papel que refletirá em suas obras violonísticas, unindo a experiência de arranjador de música popular com a vivência como pianista de concerto e compositor, criando uma linguagem particular que fundia a música popular urbana com a música de concerto. Tal vivência foi fruto de uma necessidade profissional, como nos revela o depoimento do compositor:

Eu comecei como concertista. Terminei meu curso em Porto Alegre e vim para o Rio para ser concertista. Eu tinha qualidades para isso. Mas naquele tempo não havia possibilidade de se viver só de concerto. Hoje, há uma porção de sociedades que dão bolsas, mas naquele tempo não havia. Então eu tive que ir para a música popular para sobreviver.(... $)^{17}$

A obra para violão de Radamés é extensa e inclui um ciclo de dez

\footnotetext{
${ }^{14}$ Para se ter idéia de como o violão brasileiro, apesar do talento de seus intérpretes, ainda sofria com a pouca informação existente. O primeiro concertista brasileiro que se tem notícia, Américo Jacomino, não lia música (1889 - 1928).

${ }^{15}$ Apesar de não haver registrado o ciclo completo, Segóvia gravou os estudos 1, 7 e 8 em diversas ocasiões em LPs das gravadores DECA, MCA, Columbia e HLM.

${ }^{16}$ ZANON, Fábio, Violão com Fábio Zanon. Áudio do programa de rádio dedicado a Radamés Gnattali I. Disponível em: http://vcfz.blogspot.com/2006/08/35-srgio-assad.html. Acesso em 01/05/2009.

${ }_{17}$ GNATTALI, Radamés, Website do Compositor Radamés Gnattali. Disponível em: http://www.radamesgnattali.com.br/site/index.aspx?lang=port. Acesso em01/05/2009.
} 
estudos para violão solo, diversas obras para violão e duo de violões e orquestra, cinco obras para violão solo e uma grande variedade de música de câmara em que o instrumento está incluso. Em sua carreira como arranjador e instrumentista, o compositor teve contato com diversos violonistas que estiveram ligados à era do rádio, tal como Dilermando Reis (1916 - 1977), Aníbal Augusto Sardinha (1915 - 1955) e José Meneses (1921), que atuaram como solistas e cameristas nos diversos experimentos do maestro Radamés.

Embora tenha chegado a tocar piano com virtuose em sua juventude, Gnattali tinha um grande apreço pelo violão, sabia manuseá-lo e a partir dos anos 40 teve um contato contínuo com os grandes violonistas da era do rádio que já se beneficiaram da introdução do violão clássico no Brasil como Laurindo Almeida, José Meneses e Garoto. ${ }^{18}$

Dentre estes experimentos, um dos que possui uma enorme importância no diálogo entre o violão de concerto e o violão popular é o primeiro concerto de Gnattali, intitulado Concertino $n^{\circ} 1$ (1951) para violão solo. O concerto foi dedicado ao violonista cubano Juan Mercadal e a Maria Tereza Teran e possui apenas uma gravação feita por Dilermando Reis feita nos anos 60. Foi uma obra de tremenda importância por se tratar de um dos primeiros concertos brasileiros para violão e orquestra e por se também por ser uma obra híbrida entre as linguagens erudita e popular décadas antes de se tornar moda entre os violonistas de concerto ${ }^{19}$.

Gnattali compunha música com um interprete específico em mente. No caso dos concertos pra violão eles não foram escritos nem para Segóvia, Nem para Yepes, nem qualquer outro dos grandes interpretes internacionais. Ele buscou sua linguagem na raiz do violão solista de música popular e foram pensadas para serem tocados por Garoto ou Laurindo de Almeida que na época tocavam no Bando da Lua de Carmen Miranda.

Hoje pode até parecer corriqueiro, mas respeitemos o Gnattali Visionário. Não só ele um pioneiro do Crossover, por investir

\footnotetext{
${ }^{18}$ ZANON, Fábio, Violão com Fábio Zanon. Áudio do programa de rádio dedicado a Radamés Gnattali III. Disponível em: http://vcfz.blogspot.com/2006/08/35-gnattali-iii.html. Acesso em01/05/2009.

${ }^{19}$ Devemos citar o Concerto Carioca n91, escrito para violão elétrico e orquestra em 1950 como um experimento pioneiro neste gênero, entretanto diversas pesquisas o atribuem à guitarra elétrica devido à sua linguagem e escrita instrumental, o que nos leva a atribuir ao Concertino $n 9$ como concerto para violão e orquestra pioneiro no país.
} 
na forma do concerto com a linguagem e a atitude do violão popular, mas ele foi um pioneiro (...) no concerto para violão e orquestra no Brasil. Os seus dois primeiros concertos foram compostos em 1951, que é o mesmo ano do concerto de VillaLobos, (...). ${ }^{20}$

Neste depoimento fica explícita a importância de Radamés Gnattali para o violão no Brasil, ao mesmo tempo em que demonstra que o hibridismo entre as linguagens popular e erudita é uma prática corriqueira no país, visto que ocorria décadas antes de se tornar comum entre violonistas no cenário internacional.

Apesar de ter se tornado um compositor respeitado e celebrado nos dias atuais, a música de Radamés Gnattali encontrava resistência no cenário de música contemporânea no Brasil da época.

Esta resistência pode ser creditada ao fato de que, apesar de toda a complexidade musical e a variedade de caminhos apontados pela vanguarda, 0 público da música de concerto em geral não absorveu estas inovações e o cenário musical para a música culta se cristalizou na música antiga até o romantismo, num contexto complexo e de ruptura como este não é de se estranha o fato de um compositor como Gnattali por ser considerado retrógrado e de apelo fácil pelos vanguardistas da época.

Cientes desta dicotomia, muitos dos compositores vanguardistas se refugiaram como docentes no meio acadêmico, onde poderiam continuar suas explorações musicais.

No final dos anos 60 e início dos anos 70, a influência dos compositores dodecafônicos estava chegando ao auge. De acordo com alguns relatos, eles de fato assumiram o controle dos departamentos de composição das universidades de todo o país. ${ }^{21}$

Como resultado ao afastamento do público para com a vanguarda musical, o ambiente do ensino universitário se tornou um refúgio para a vanguarda e um local hostil para estudantes que não seguissem as tendências

\footnotetext{
${ }^{20}$ ZANON, Fábio, Violão com Fábio Zanon. Áudio do programa de rádio dedicado a Radamés Gnattali I. Disponível em: http://vcfz.blogspot.com/2006/08/35-srgio-assad.html. Acesso em01/05/2009.

${ }^{21}$ ROSS, Alex. O Resto é Ruído, escutando o século XX. Companhia da Letra, São Paulo, 2007, p 513.
} 
da academia.

A despeito de que comandava o espetáculo os jovens compositores com tendências tonais não se sentiam felizes na academia (...) George Rochberg declarou: \{os compositores dodecafônicos\} fundaram uma igreja com cultural ortodoxa, com sua hierarquia, seus evangelhos, suas crenças e seus anátemas. $^{22}$

No Brasil a situação era similar nas universidades, porém com um agravante de que o país se encontrava sob um severo regime militar, tal situação política criou uma dissidência entre compositores vanguardistas e nacionalistas. O resultado desta disputa foi 0 desfavorecimento do nacionalismo no meio acadêmico devido à sua associação com a revolução de 1964 e sua imagem atrelada ao regime ditatorial subseqüente.

Neste contexto, compositores como Radamés Gnattali encontraram grande resistência em um meio musical em que cada dia mais se influenciava pelas vanguardas européias e que era formado por compositores que se refugiavam no meio acadêmico brasileiro. Não é de se surpreender, portanto, que um jovem compositor como Sérgio Assad e que teve influências da música popular e de Radamés Gnattali tivesse encontrado resistência à sua estética dentro da academia como veremos posteriormente neste capítulo.

Enquanto a nova música de concerto se encontrava afastada do público, o violão ganhava força na música popular com o advento da Bossa Nova e seus desdobramentos posteriores. Nomes como Baden Powell (1937 - 2000) e Paulinho Nogueira (1929 - 2003) ganhavam status de celebridade e colocavam novamente o violão como figura central na música popular como acompanhador e como solista.

Este papel do instrumento no ambiente popular brasileiro tornou comum a prática de instrumentistas populares terem em seus repertórios obras de compositores próximos da estética popular tais como: Heitor Villa-Lobos e Agustín Barrios. Como exemplo desta prática, o autor deste trabalho se recorda de gravações do violonista Raphael Rabello (1962 - 1995), em que este executava juntamente com peças de instrumentistas populares como e Dilermando Reis, de Heitor Villa Lobos juntamente com obras de Agustín

${ }^{22}$ Idem. 
Barrios.

Naturalmente, como era de se esperar num país em que o violão tivesse uma posição privilegiada na cultura popular, que o oposto também ocorresse, visto que diversos concertistas eruditos atualmente adotam obras de violonistas populares como Dilermando Reis, João Pernambuco, Aníbal Sardinha dentre diversos outros em seus repertórios. Pode-se atribuir este flerte a diversos fatores tais como opção de carreira, pressão da mídia, ou ao fato de que, normalmente violonistas clássicos são iniciados na música popular antes de tomarem contato com a música de concerto.

Esta visão panorâmica do desenvolvimento do violão solista no Brasil nos leva a conclusão que a prática híbrida de seus praticantes é um reflexo da posição do instrumento na cultura do país, portanto um desdobramento natural da prática violonística nacional e que conseqüentemente traria reflexos na produção brasileira para o instrumento.

\subsection{Sérgio Assad: perfil do compositor instrumentista}

Visto que o compositor do objeto de estudo ainda se encontra vivo e em plena atividade de suas funções de intérprete, compositor e arranjador sentimos a necessidade de adicionar um breve relato biográfico de sua carreira com a finalidade de se delinear a sua trajetória como músico, sua formação e seus reflexos em sua produção musical como compositor.

Dada a escassez de material bibliográfico sobre Sérgio Assad, as fontes encontradas para a elaboração deste capítulo foram entrevistas cedidas pelo compositor à Revista Violão Pró, Rádio Cultura ${ }^{23}$, revista eletrônica Guitarra e a revista Sounboard. Adicionadas a estas fontes, somam-se entrevistas ao violonista Aliéksey Vianna e ao violonista David Russell, ambas conduzidas pelo autor deste trabalho. Neste capitulo, para que fiquem claras as fontes utilizadas, empregaremos as nomenclaturas "Violão Pró" (para a entrevista

\footnotetext{
${ }^{23}$ Programa Violão apresentado pelo violonista Fábio Zanon em entrevista conduzida pelo violonista Luciano César Morais em 22/08/2006 e disponível em sua tese de mestrado, Sérgio Abreu: sua herança histórica, poética e contribuição musical através de suas transcrições para violão (2007 ECA - USP).
} 
desta revista) e "Rádio Cultura" (para a entrevista realizada no programa violão realizado na estação de rádio citada).

Sérgio Simão Assad nasceu em 26/12/1952 na cidade de São João da Boa Vista, interior do estado de São Paulo. Vindo de uma família de músicos, o pai violonista e bandolinista de choro e a mãe cantora. Ainda na infância, Assad aprendeu os primeiros acordes do violão com um tio e, como autodidata, formou um duo com seu irmão Odair, que também tinha começado a aprender violão juntamente com Sérgio.

O recém formado Duo Assad dominou o repertório do choro em pouquíssimos meses e participou logo em seguida do programa Bossaudade, apresentado pela cantora Elizeth Cardoso na TV Record acompanhando por Jacob do Bandolim ${ }^{24}$.

Aos treze anos, Assad se interessa pela composição de música popular e nesse período escreve as primeiras canções juntamente com o amigo letrista Renato dos Santos Jr. e ganha um festival local. Após dois anos de atividade como compositor popular, acaba desistindo da função por falta de parceiros letristas ${ }^{25}$.

Ainda nesta primeira fase, ainda voltados para o violão popular, os irmãos vencem um concurso de violão promovido pela fábrica Di Giorgio em 1966:

Nós participamos, tinha três categorias, tinha violão clássico, violão popular e o violão infanto-juvenil. (...) Então o Odair fez infanto-juvenil e eu fui para categoria de violão popular. E nós vencemos.

Em 1968 os irmãos tiveram o primeiro contato com uma gravação do Duo $\mathrm{Abreu}^{26}$, que foi decisiva para a carreira dos Assad, vindo a influenciar profundamente a concepção musical de ambos:

\footnotetext{
${ }^{24}$ Jacó Bittencourt (1918 - 1969), também conhecido como" Jacó do Bandolim”, importante bandolinista e compositor popular.

${ }^{25}$ REVISTA VIOLÃO PRÓ, Entrevista com os Irmãos Assad, n. X. Editora Música e Mercado, São Paulo janeiro de 2007 p 22 a 27.

${ }^{26}$ Formado pelos irmãos Sérgio e Eduardo Abreu entre os anos de 1962 e 1975, o Duo Abreu teve brilhante carreira internacional, porém de curta duração. Lançaram 3 discos: The Guitars of Sérgio and Eduardo Abreu (CBS 1968), The Guitars of Sérgio and Eduardo Abreu (CBS 1969) e Concerto for 2 Guitars. Mais informações podem ser encontradas na tese de mestrado em musicologia de Luciano César Morais, Sérgio Abreu: sua herança histórica, poética e contribuição musical através de suas transcrições para violão (2007 ECA - USP).
} 
Ouvimos os irmãos Abreu em fita e ficamos encantados, nunca tínhamos ouvido nada naquele nível, um negócio absurdo. Aí resolvemos que realmente era aquilo que a gente queria fazer. ${ }^{27}$

Ao tomar a decisão de formar um duo com uma orientação estética voltada para a música de concerto, o pai dos irmãos, Jorge Assad procurou o professor Isaías Sávio ${ }^{28}$ (1900 - 1977), que se revelou um encontro infrutífero.

E a gente foi procurar o Sávio, só que meu pai, ele tinha uma noção talvez equivocada que nós éramos gênios. E ele trouxe a gente pro Sávio e ele achou que o Sávio não ficou tão entusiasmado com a gente quanto ele deveria ter ficado. Aí ele disse 'Vocês não vão estudar com esse cara não'. E a gente voltou pro interior. ${ }^{29}$

Podemos deduzir que se este encontro tivesse outro resultado e Assad fosse aluno de Isaías Sávio, provavelmente a sua carreira teria tomado um rumo diferente e teria um envolvimento maior com a música popular, possivelmente tendo se tornado inclusive um violonista do gênero. De acordo com Zanon (2007) ${ }^{30}$ uma das características de Isaías Sávio como professor era de não tolher a tendência de alunos que tivessem a para o envolvimento com a música popular. Isto pode ser observado no fato de que entre seus alunos mais reconhecidos temos tanto um concertista como Carlos Barbosa Lima (1944), quanto músicos populares como quanto Luís Bonfá (1922 - 2001) e Toquinho (1946).

Em 1969, a família Assad muda-se para o Rio de Janeiro, onde Sérgio Assad e seu irmão Odair estudaram por um período de sete anos com a professora de violão argentina Adolfina Raitzin Távora (1921), também conhecida como Mônina Távora ${ }^{31}$, discípula de Domingo Prat e Andrés

\footnotetext{
${ }^{27}$ Odair Assad (Violão Pró).

${ }^{28}$ Professor uruguaio radicado no Brasil responsável pela formação de uma geração de violonistas brasileiros, fundador do primeiro curso oficial de violão no Brasil no Conservatório Musical e Dramático de São Paulo em 1947.

${ }^{29}$ Sérgio Assad (Rádio Cultura).

${ }^{30}$ ZANON, Fábio. O violão no Brasil depois de Villa-Lobos. Revista do Itamaraty. Disponível em: http://www.mre.gov.br/dc/textos/revista12-mat12.pdf. Acesso em 15/12/2008. Acesso em 15/12/2008.

${ }^{31}$ Em seu Dicionário de Guitarristas, Domingo Pratt descreve Monina Távora como uma "concertista precoce". O repertório de um de seus recitais realizado em 1931 aos dez anos de
} 
Segóvia. Foi também professora dos irmãos Sérgio e Eduardo Abreu.

Quando fomos pro Rio, meu pai foi convencido a levar a gente pra conhecer a Monina por um jornalista. Tinha aquela história de violão lá no Rio, Cris Lemos, um grupo ali de violão, Othon Saleiro; aí veio o Elomar Terra também falar da Monina, e falou também que a gente tinha que ir lá conhecer a grande professora. O meu pai levou a gente pra lá e acabou ouvindo o que ele queria ouvir. 'Esses meninos têm muito talento' 'Estou vendo o Duo Abreu de novo'. Pois a Monina é uma pessoa musicalíssima, então brigava muito com a gente, 'Vocês estão fazendo música mas vocês não sentem nada' "Música se faz com as tripas". Mas ela descortinou um mundo pra gente, e era um conto de fadas, 'vocês vão fazer uma carreira internacional, vocês vão conhecer o mundo' que acabou acontecendo mesmo. ${ }^{32}$

Apesar da empatia, houve um choque entre a sistemática rígida e ortodoxa da professora concertista, que, ao contrário de Isaías Sávio não aceitava nenhuma espécie de hibridismo e o ambiente doméstico dominado pela música popular de onde vinham os dois irmãos, especialmente Sérgio Assad, que já se dedicava à composição de canções do gênero.

Quando estudávamos com a Monina tivemos de excluir um pouco a música popular brasileira de nossas vidas. Ela tentava separar as coisas, deixar bem claro que violonista clássico não se misturava com música popular. Crescemos dentro dessa coisa dogmática. Eu gostava de fazer arranjos, mas ela não queria nem saber. Foi um período difícil pra mim. Eu já havia feito arranjos do Piazzolla e gostava muito de tocar as músicas do Radamés Gnattali. ${ }^{33}$

Ao inscrever uma de suas canções em um festival em Campo Grande no Estado do Rio de Janeiro, Sérgio Assad não pôde contar com um arranjador, já que o músico que faria o arranjo não pôde realizar o trabalho. Incentivado por um amigo, o jovem violonista decide fazer o arranjo intuitivamente por conta própria e apesar de não haver vencido o prêmio de melhor canção, acaba recebendo o prêmio de melhor arranjo, para a surpresa do jovem violonista. Partindo dessa experiência escreve os primeiros arranjos para canções de

idade, que inclui obras desafiadoras tecnicamente como Sevilla de Isaac Albeniz, Capricho opus 20 de Luigi Legnani, Estúdio de Tárrega e as críticas favoráveis da imprensa nos dá uma dimensão de seu talento em tão pouca idade.

${ }^{32}$ Sérgio Assad (Rádio Cultura).

${ }^{33}$ Sérgio Assad (Violão Pró). 
Piazzolla e obras de Radamés Gnattali para o Duo.

Aos dezoito anos em 1970, Sérgio Assad inicia um curso de composição no Conservatório Brasileiro de Música, enquanto era aluno particular da compositora Esther Scliar (1926 - 1978). Logo se desilude com o curso devido ao choque da música de vanguarda praticada na academia na época e orientação de sua escrita, fortemente influenciada por Radamés Gnattali e que era considerada excessivamente tradicional para os padrões vigentes no período.

É que eu entrei pra escola de música lá no Rio e todo mundo fazia música dodecafônica naquela época. Aí eu me sentia ridículo com as minhas coisinhas tonais (...) senti tão diminuído que eu parei. Eu só fui retomar essa história de escrever bem mais tarde. (...) Aquela música mais acadêmica, aquele negócio tava com o futuro finito. Só que na época, aquele pessoal todo do meio acadêmico não sabia. (...) Eu era aluno da Esther Scliar, de composição e ela odiava aqueles negócios do Radamés (...) 'Parece quando você ouve Radamés você ouve Emilinha Borba'. ${ }^{34}$

Em 1973 o Duo Assad ganhou o Concurso de Jovens Solistas da Orquestra Sinfônica Brasileira e começou a ocupar um lugar de destaque no cenário musical brasileiro. No ano seguinte gravam um LP pela gravadora Continental juntamente com a Orquestra Armorial, no repertório constava do Concerto para Dois Violões e Oboé de Radamés Gnattali, que se tornaria a grande influência de Sérgio Assad como compositor ${ }^{35}$.

Nos próximos dois anos os irmãos não gravaram e fizeram poucos concertos, um hiato que foi quebrado em 1977 por um convite da gravadora Kuarup, que convidou Sérgio Assad para gravar o Choros n. 1 de Heitor VillaLobos. Tal convite rendeu aos irmãos Assad a oportunidade de gravar a obra integral de Villa-Lobos para violão solo no ano seguinte. O disco havia sido encomendado ao violonista Turíbio Santos (1943), que não pôde realizar a gravação e os irmãos foram convidados às pressas para preparar todo 0 repertório ${ }^{36}$.

\footnotetext{
${ }^{34}$ Sérgio Assad (Rádio Cultura).

${ }^{35}$ Latino America (1974) Continental 9110041/2. LP gravado com a Orquestra Armorial sob a Regência de Cucy de Almeida.

${ }^{36}$ Complete Villa-Lobos works for solo guitar (1978) Kuarup Discos KLP 003/4
} 
(...) não tocávamos Villa-Lobos, não éramos solistas. Nós nos dividimos, cada um aprendeu metade do repertório, em outubro e gravamos no começo de novembro. Fizemos todo esse processo em um mês (...). Foi uma loucura. Hoje não acredito que fizemos isso. ${ }^{37}$

O ano de 1979 trouxe para o duo Assad uma vitória em um concurso de música de câmara ocorrido na Bratislávia, antiga Tchecoslováquia. Os irmãos foram indicados pelo compositor Marlos Nobre (1939) para representar o Brasil na Tribuna de Jovens Solistas. Apesar de se tratar de um concurso de pouca expressividade, a premiação aliada a um desempenho impactante dos irmãos abriu muitas portas para o início de uma carreira internacional.

Em 1980, Sérgio Assad grava um disco solo com obras de compositores vanguardistas premiados no I Concurso Nacional de Composição promovido pela editora Irmãos Vitale em parceria com o Instituto Nacional de Música da Funarte $^{38}$. O jovem compositor havia inclusive enviado uma peça que consistia de uma série de variações tonais para o evento, porém não se classificou ${ }^{39}$.

Eu acho que foi o primeiro concurso para composição para violão. (...) Eles fizeram uma pré-seleção. Tanto que na época eu mesmo coloquei música e não foi classificada. Porque, exatamente por isso, na época o que eu fazia eram umas variações tonais e tal. $E$ tudo que entrou era mais avantguarde. Mas tinham coisas muito boas realmente, acho que tinham coisas ótimas. ${ }^{40}$

Ainda em 1980, houve o Concurso Internacional Villa-Lobos e os irmãos foram convidados informalmente para tocar para os jurados estrangeiros na casa de Olga Praguer Coelho, que havia vivido com Segóvia e, novamente a qualidade da performance dos irmãos foi decisiva para o surgimento para um convite para concertos na Europa. As primeiras apresentações no Velho Continente trouxeram um elemento que viria ser a marca registrada do Duo, o cruzamento do repertório de concerto a arranjos de música popular.

\footnotetext{
${ }^{37}$ Odair Assad (Violão Pró).

${ }^{38}$ Musica Nova do Brasil (gravação solo de Sérgio) (1981) Funarte/Promemus MMB 81.022

${ }^{39}$ Por não constar no catálogo de Assad, chegamos à conclusão que a peça descrita provavelmente ainda era embrionária dentro de seu estilo composicional.

${ }^{40}$ Sérgio Assad (Rádio Cultura).
} 
(...) na Europa, nesse primeiro momento, não queríamos arriscar. Então tocamos o tradicional, Giuliani, Bach, Scarlatti (...) mas quando tocamos Radamés e Piazzolla, a casa veio abaixo. Eles não estavam habituados a esse tipo de música e fomos os primeiros a fazer e foi sucesso absoluto. Investimos mais por ali, voltei a fazer mais arranjos $(. . .)^{41}$

Este primeiro momento descrito pelo violonista na Europa foi o início de uma sólida carreira internacional, uma extensa e regular discografia e extensas turnês por diversos países. Em sua primeira série de programas de rádio sobre violão, o violonista Fábio Zanon descreve a sonoridade do Duo Assad e define o termo cross-over, contextualizando seu surgimento na carreira dos irmãos:

O fato é que, já nos anos 70 , eles estavam à frente dos acontecimentos e buscavam desenvolver um conceito sonoro próprio, que combinava o repertório tradicional, compositores como Gnattali e Marlos Nobre e arranjos sofisticados de Piazzolla ou Gismonti, o que hoje chamamos de cross-over. Nos últimos anos, a maioria dos artistas clássicos tem feito cross-over de uma forma ou de outra, seja por curiosidade ou por pressão comercial. O duo Assad tem minimizado a barreira entre o clássico e o instrumental popular, tratando um com os métodos do outro, há 30 anos, por inclinação natural e pelo respeito à prática do choro, da qual eles mesmos emanaram. Esse jeito de tocar a um tempo brincalhão e detalhado, essa leveza e swing, não é algo fabricado:, é o próprio código genético do duo Assad. O público europeu percebeu isso logo nas primeiras apresentações do duo e, a cada recital novos convites apareceram, até que, no início dos anos 80 , eles se viram forçados a residir no exterior para atender à demanda por mais e mais concertos. ${ }^{42}$

Com o prestígio internacional do Duo Assad, diversos compositores estrangeiros passaram a dedicar-Ihes peças, dentre eles Astor Piazzolla (1921 - 1992). O compositor argentino havia assistido o duo executando um arranjo de Sérgio Assad para uma de suas composições: Escolaso. A interpretação dos Assad deixou Piazzolla de tal maneira impressionado, que o motivou a compor e dedicar ao duo sua obra Tango Suíte.

Toda vez que Piazzolla ia tocar em Paris ele não pra nenhum restaurante depois do concerto. Ele ia pra casa do Michel

\footnotetext{
${ }^{41}$ Sérgio Assad (Violão Pró).

${ }^{42}$ ZANON, Fábio, Fórum de Violão Erudito: A Arte do Violão, Roteiro do Programa 24. São Paulo 10/2003. Disponível em: http://www.geocities.com/thiagomagalhaes. Acesso em $15 / 11 / 2004$.
} 
Ponce, pois ele adorava a comida da Jacqueline, a mulher do Michel. A gente tocou as coisas dele e ele ficou tão entusiasmado, e ele disse naquela noite que ele ia escrever pra gente e aquela peça abriu muita porta.

Apesar do sucesso como interprete ao lado do irmão, a atividade como compositor de Sérgio Assad também foi impulsionado pelo sucesso do duo. As primeiras peças escritas eram executadas timidamente em concerto, mas a aceitação por parte do público e demais músicos levou Sérgio Assad a gravar suas obras juntamente com o irmão e escrever para outras formações. No álbum de 1985, Latin American Music for Two Guitars, ${ }^{43}$ compôs uma Suíte de três movimentos denominada Três Cenas Brasileiras, constituída por três peças (Pinote, Recife dos Corais e Vitória Régia) e, ao sentir falta de um movimento mais lento e introspectivo, improvisou uma pequena valsa que mais tarde foi chamada Valseana.

Nós fizemos o CD de música latino-americana e o produtor veio e nos disse 'Vocês não conseguiriam tocar uma peça lenta? (...) Eu não tinha nada no repertório que fosse lento e latino-americano, mas então eu toquei uma peça curta improvisada. Quando eu escrevi a Aquarelle, eu pensei que eu podia desenvolvê-la, então a segunda parte da Valseana é uma improvisação sobre a primeira baseada na mesma harmonia. ${ }^{44}$ (tradução nossa)

Ao perceber o potencial da pequena peça, Sérgio Assad decidiu construir uma obra maior e mais complexa de três movimentos para violão solo. A Valseana foi expandida e se tornou o segundo movimento e mais outras duas peças foram escritas: Divertimento, Prelúdio e Toccatina. A obra foi completada e estreada em 1988 pelo violonista escocês David Russell, a quem a peça foi dedicada. "Foi idéia do Sérgio. Foi uma surpresa para mim". ${ }^{45}$

A obra de três movimentos foi chamada de Aquarelle e trouxe imediato sucesso e reputação a Sérgio Assad como compositor para violão solo. Tal reconhecimento trouxe encomendas de diversos artistas tais como: o Los

\footnotetext{
${ }^{43}$ Latin American Music for two guitars (1985, relançado em 1993) Elektra/Asylum/Nonesuch \#79116

${ }_{44}^{44}$ Entrevista cedida à revista Soundboard XXXIII n.3. 1997.

${ }^{45}$ David Russell em entrevista cedida a Thiago Oliveira em 2005. Ver anexos página 244.
} 
Angeles Guitar Quartet, o violoncelista Yo-Yo Ma, a soprano Dawn Upshaw, dentre vários outros.

Em 1993, o Duo grava a trilha sonora do Filme Natsu No Niwa do Japonês Shinji Soumai, com composições de Assad, que desta vez adotava uma sonoridade próxima da música Japonesa ${ }^{46}$.

O ano de 2003 trouxe para Assad a primeira experiência como compositor para orquestra. A obra foi o concerto Origenes para dois violões e violino, a estréia do duo ocorreu juntamente com a violinista italiana Nadja Salerno Sonnenberg e trazia influências da música latina e da Europa oriental.

O presente momento da carreira do Duo Assad trouxe um flerte cada vez maior com a música popular e conseqüentemente uma maior exposição a um público que não era mais formado por somente aficionados pelo violão ou pela música de concerto.

Nos últimos quatros anos começamos a colaborar com outras pessoas, o Yo-Yo Ma, o Paquito, o Suarez Paz, a Nadja Sonnenberg etc. Paramos de renovar nosso repertório. Então ficamos tocando o repertório dos outros. É enriquecedor, mas o duo fica tocando o repertório do passado. ${ }^{47}$

Tal sucesso comercial consolidou o Duo Assad como um dos principais conjuntos de música de câmara da atualidade. Trouxe colaborações com artistas diversos e um reconhecimento de público raramente visto no mundo do violão.

Atualmente além dos diversos arranjos, composições e turnês internacionais do duo, Assad até 2006 lecionava no Roosevelt College of Performaning Arts em Chicago, havendo deixado o cargo devido à lotada agenda de apresentações do Duo Assad.

Com este breve relato biográfico pudemos demonstrar as diferentes correntes estéticas que Sérgio Assad teve contato durante sua formação, sua carreira como intérprete e como estas atuaram e o influenciaram como compositor.

\footnotetext{
${ }^{46}$ Natsu no Niwa Suite (1994) GHA \#126029.

${ }^{47}$ Sérgio Assad (Violão Pró).
} 


\subsection{Duo Assad e seus contemporâneos}

Neste item investigamos a trajetória de alguns violonistas que obtiveram o início da carreira internacional no início da década de 80, juntamente com os irmãos Assad, e assim observar a influência do hibridismo da música de concerto e a popular em suas carreiras. Os músicos selecionados para este levantamento foram: David Russell (1953), Manuel Barrueco (1952), e o Los Angeles Guitar Quartet ${ }^{48}$.

David Russell foi vencedor dos concursos internacionais Francisco Tárrega e o concurso internacional promovido pela Sociedade Violonística de Toronto, alcançando posteriormente a fama ao lançar um disco contendo obras de compositores violonistas da segunda metade do Século XIX ${ }^{49}$. Tal repertório era pouco executado e gravado na época, visto que a maioria dos violonistas buscava obras vanguardistas para o instrumento. A gravação de Russell que demonstrava uma técnica imaculada, aliada a um conhecimento de estilo trouxe nova luz a compositores que haviam sido esquecidos tais como Johan Kasper Mertz (1806 - 1856), Giulio Regondi (1822 - 1872), Dionísio Aguado (1784 - 1849), dentre outros. O impacto deste disco sobre o mundo do violão trouxe de volta estas obras a concertos e concursos mundo afora e fez com que Russell embarcasse numa bem sucedida carreira internacional. Recentemente Russell se dedicou a projetos diferenciados tais como: a gravação de um álbum contendo temas folclóricos celtas $^{50}$ e de música popular ${ }^{51}$ que foi vencedor do Grammy Latino em 2005.

Manuel Barrueco (1952), violonista cubano, se refugiou de seu país em 1967 e exilado nos EUA, se tornou aluno do célebre professor Aaron Shearer. Alguns anos depois foi o primeiro violonista a vencer o Artist's Guild Award (1974), o que the proporcionou a possibilidade de uma carreira de turnês internacionais constantes. Em suas gravações e concertos, Barrueco

\footnotetext{
${ }^{48}$ Formado originalmente pelos violonistas norte-americanos Scott Tenant, William Kanengeiser, Stanley Yates e Andrew York.

49 19th Century Music -Aguado, Coste, Broca, Mertz, Regondi - GHA, Belgium - 126002 (1987).

${ }_{51}$ Message of the Sea Telarc International - 80525 (1998).

${ }^{51}$ RUSSELL, David. Aire Latino. Telarc, 80612, (2004).
} 
demonstra a capacidade de transitar em diversos períodos indo ao barroco com Scallatti e Bach chegando a compositores contemporâneos nacionalistas, tais como Leo Brouwer (1939), Heitor Villa-Lobos (1887 - 1959) e Mozart Camargo Guarnieri (1907 - 1993), sempre tendo como marcas registradas a técnica impecável e infalível e um controle absoluto em suas execuções. Recentemente, embarcou em projetos que tinham um forte apelo para com 0 público da música popular, dentre estes, citamos "Nylon and Steel"52, um disco com participação de guitarristas tais como Al Di Meola ${ }^{53}$ (1954), Steve Morse ${ }^{54}$ (1954) e Andy Summers ${ }^{55}$ (1942) e o CD Long Time Ago $^{56}$, que contém obras de Paul Simon (1941), Keith Jarret (1945) e Chick Corea (1941).

O Los Angeles Guitar Quartet foi formado por estudantes de violão da UCLA e era orientado pelo violonista espanhol Pepe Romero (1944), o que fez com que os primeiros passos do conjunto fossem influenciados pelo quarteto "Los Romeros" ao qual pertencia o professor dos jovens estudantes. As primeiras gravações do conjunto demonstravam uma inclinação pela execução de arranjos que iam de obras renascentistas de Monteverdi (1567 - 1643) a obras do século XX de compositores tais como Gustav Holst (1874 - 1934). Atualmente a carreira do Quarteto se concentra na execução de obras de caráter híbrido com a música popular e arranjos para música pop.

O que pudemos observar ao pesquisar a carreira destes interpretes, é que, estes originaram-se de ambientes tradicionais da música de concerto e que em algum ponto em suas trajetórias se enveredaram em projetos que de alguma maneira ligados à música popular com níveis variados de êxito comercial ou artístico.

Pode-se supor que o sucesso obtido pelos Assad com o cruzamento dos gêneros popular e erudito tenha talvez influenciado diversos de seus contemporâneos, visto que na década de 70 os irmãos já executavam obras de

\footnotetext{
${ }^{52}$ BARRUECO, Manuel. Nylon and Steel, Angel Records, B00005ICL0 (2000).

${ }^{53} \mathrm{Um}$ dos mais importantes guitarristas do chamado "Jazz-Fusion" tocou em um trio de violões com Paco de Lucia e John Mc Laughlin lançando um disco de grande sucesso que mesclava a improvisação jazzística e o flamenco.

${ }^{54}$ Formado pela University of Miami em violão erudito tendo sido aluno de Juan Mercadal, Morse fundou o "Dixie Dregs" que mesclava o jazz, o rock, a música country americano e a música barroca. Teve uma constante carreira com o grupo e também como guitarrista solo. Atualmente toca com o grupo de rock Deep Purple.

${ }^{55}$ Ex Guitarrista do grupo pop "The Police", Summers chegando a estudar violão erudito na Califórnia State University at Northridge até 1973.

${ }^{56}$ BARRUECO, Manuel. Sometime Ago, EMI, B000002SKO (1998).
} 
Gnattali e Piazzolla aliadas a complexos arranjos de música popular brasileira, obtendo assim, sucesso internacional nos anos 80. Com este repertório acrescido às composições de Sérgio Assad, devemos ressaltar que este repertório de caráter híbrido não surgiu por interesses comerciais na carreira do Duo Assad, tal fusão de gêneros teve seu surgimento no ambiente doméstico dos irmãos Assad, que tinham por um lado a influência da música popular em casa e uma professora extremamente tradicional nas aulas de instrumento, gerando uma personalidade musical multifacetada que refletiu posteriormente na carreira dos irmãos.

Há o que nós chamamos de música brasileira folclórica, que tem a sua força, mas não é o que eu chamo de música brasileira, que algo diferente. Isto é (...) o tipo de erro feito por muitas pessoas quando elas tendem a achar que a música vinda de um país é música folclórica, mas isto não é verdade. Nós crescemos no Rio, mas nascemos em São Paulo. Nestas duas terras é encontrado um tipo de música chamada Choro, um tipo de música popular brasileira. Mas não é música folclórica, é apenas música popular, e eu acho que bem baseado naquele estilo. ${ }^{57}$ (tradução nossa)

Pudemos concluir pelos diversos exemplos apresentados que 0 hibridismo da música culta com a música popular no violão é uma prática que encontra as suas raízes no violão de concerto tradicional, mas que nas últimas décadas do século $X X$ tem recebido uma crescente influência da indústria cultural e da música popular urbana dada a ruptura ocorrida entre a música erudita vanguardista e o público. Tal intervenção modificou o repertório e orientação estética de diversos intérpretes que, em busca de um público maior para a sua arte, se enveredaram em projetos híbridos com a música popular com graus variáveis de sucesso comercial e artístico. Dentre estes destacamos Sérgio Assad, cuja estética híbrida surgiu naturalmente, fruto do ambiente familiar voltado à música popular e de sua rigorosa formação musical como concertista e compositor.

${ }^{57}$ Sérgio Assad em entrevista concedida à Revista Eletrônica Guitarra em 2003. 


\section{Análise de Aquarelle}

\subsection{Aspectos gerais da obra}

Como visto anteriormente, a obra Aquarelle composta em 1988 e dedicada ao violonista David Russell (1953). Recentemente a interpretação de Russell foi lançada no CD For David ${ }^{58}$, onde, no encarte, Sérgio Assad expõe suas considerações sobre a obra:

Aquarelle é a palavra francesa para aquarela. A primeira vez que vi uma aquarela sendo pintada fiquei impressionado com a quantidade de técnicas utilizadas para espalhar as cores em diferentes texturas que dão uma aparência etérea. Seguindo a idéia de se espalhar pigmentos num pedaço de papel, eu construí um motivo de três notas que como se fossem três diferentes pigmentos para se formar a base de uma paleta. Baseado em um único motivo, eu criei camadas de múltiplas vozes simulando a superposição de vozes em uma aquarela. (tradução nossa)

Ao estruturar esta analise de Aquarelle, decidimos analisar alguns aspectos que auditivamente sobressaíam, além da elaboração motívica citada pelo autor. Estes aspectos foram: estruturação harmônica, rítmica e idiomatismo instrumental. Com base nos dados levantados verificamos as diversas influências estéticas que permeiam a Aquarelle, assim possibilitando um retrato da linguagem composicional de Sérgio Assad.

Constituída de três movimentos: Divertimento, Valseana e Prelúdio e Toccatina, a obra apesar de possuir uma estruturação bem definida em cada movimento, não segue nenhum modelo formal tradicional como veremos a seguir.

\footnotetext{
${ }^{58}$ RUSSELL, David. For David, Music Written for David Russell, Guitar (2009) Telarc International -80707.
} 


\subsubsection{Divertimento}

O primeiro movimento de Aquarelle, Divertimento, é inspirado em seu sinônimo italiano, que de acordo com o Brooke-Ball ${ }^{59}$ (1993) "é um termo do século dezoito para uma peça de música dançante, que era escrita com intenção de ser um entretenimento leve" (tradução nossa). Segundo Vianna (entrevista, 2005, p.4), este primeiro movimento é inspirado no ritmo do gênero marcha rancho, um com ênfase em suas convenções rítmicas e não se trataria de uma obra virtuosística apesar das diversas abordagens feitas por outros músicos que enfatizam este aspecto tais como as feitas pelos violonistas Shin Ichi Fukuda ${ }^{60}$ (1955) e Graham Devine ${ }^{61}$ (1971).

O Divertimento é iniciado com o que podemos considerar como uma introdução constituída a partir da elaboração gradual, do simples ao complexo, de um único motivo de três notas. "A Abertura, Divertimento, é uma fantasia de quatro seções baseada em um motivo de três notas anunciado no início da peça." (Russell, 2009) ${ }^{62}$.

A primeira seção, que denominaremos de Introdução (compassos 1 a 83) não define um campo tonal e apresenta diversas mudanças de métrica e a utilização de ritmos sincopados. Em seguida, a Seção A (compassos 84 a 136) apresenta um novo tema e também procedimentos harmônicos que permitem classificá-la como tonal. Após a repetição da seção A com uma diferente elaboração, uma passagem de ligação conduz ao início da Seção B (compassos 137 a 183), de andamento mais lento. Após a re-exposição da seção A (compasso 84 a 110), o tema inicial desta é utilizado como material para a Coda (compasso 184) ao final da peça.

\footnotetext{
${ }^{59}$ BALL B. Concise Dictionary of Music. Londres: Tiger Books International PLC, 1993.

${ }^{60}$ FUKUDA, Shin-Ichi. Aquarelle, Jvc Victor, B00005GVL5,1994.

${ }^{61}$ DEVINE, Graham. Guitar Collection - Manha De Carnaval. Naxos, B0001N9ZE8, 2004.

${ }^{62}$ RUSSELL, David. For David, Music Written for David Russell, Guitar Telarc International 80707(2009).
} 


\subsubsection{Valseana}

Como exposto no tópico 1.4, Valseana, surgiu de uma improvisação em estúdio durante as gravações do disco Latin American Music For Two Guitars ${ }^{63}$ do Duo Assad. De acordo com Vianna (2005, p. 242), havia a necessidade de uma peça lenta para completar o repertório da gravação do conjunto Três Cenas Brasileiras, de Sérgio Assad, que possuía andamento veloz em seus três movimentos e Valseana surgiu deste momento espontâneo. Esta improvisação em estúdio serviu como ensaio para a composição definitiva da peça; a nova versão, mais longa e elaborada, foi inclusa posteriormente como segundo movimento de Aquarelle e manteve o título Valseana.

Ao contrário das outras peças da suíte, Valseana é uma peça lenta, sem as complexidades rítmicas, mudanças de caráter e cromatismos encontrados nos outros dois movimentos, mas que possui, porém, complexidades advindas de sua elaboração polifônica.

Valseana é composta fundamentalmente de uma introdução (compassos 1 ao 9) e uma única seção que pode ser subdividida em duas partes em virtude do tratamento melódico de cada uma delas. Assim sendo teríamos a seção $A$ (compassos 10 a 34) e a seção A' (compassos 35 a 55), seguida de uma Coda entre os compassos 56 e 58 .

\subsubsection{Prelúdio e Toccatina}

A peça Prelúdio e Toccatina é iniciada por um breve prelúdio (compassos 1 a 15), em compasso quaternário que tem a função atua de peça de abertura. Neste caso, o andamento lento e o caráter expressivo deste Prelúdio servem de contraste à densidade polifônica e andamento vivo da Toccatina.

\footnotetext{
${ }^{63}$ DUO ASSAD. Latin American Music for Two Guitars. 1985, Nonesuch, B000005IYY, relançado em 1993.
} 
De acordo com Grove $^{64}$ (2001), o primeiro exemplo de toccata é encontrado em manuscritos alemães do séc. XV como o as tablaturas de Adam Heborgh e Buxheimer Orgelbuch sendo descritos como prelúdios. O termo toccata foi usado pela primeira vez em 1536, no livro de G.A. Casteliono, Intabolatura de Leuto de Diversi Autori para intitular uma peça de Francesco de Milano, um alaúdista italiano deste período. Desde então, esta forma se desenvolveu no período barroco, chegou ao século XX e se tornou sinônimo de peça livre, virtuosística e improvisada geralmente escrita para instrumento de teclas solo. Em Aquarelle, Assad constrói uma pequena toccata entre os compassos 16 e 126 em que o emprego da forma tradicional da toccata é fundido com elementos rítmicos brasileiros e estruturação harmônica moderna.

\subsection{Análise de Motivos}

De acordo com o próprio compositor, em notas encontradas nos encartes das gravações da Aquarelle de Vianna $(2005)^{65}$ e Russell $(2008)^{66}$, a Aquarelle teve sua escrita a partir de um motivo de três notas elaboradas no início do primeiro movimento, Divertimento. De acordo com Schoenberg (1967) 67., tais fragmentos melódicos são o alicerce temático que permeia todas as elaborações posteriores.

O motivo geralmente aparece de maneira marcante e característica ao início de uma peça. Os fatores constitutivos de um motivo são intervalares e rítmicos, combinados de modo a produzir um contorno que possui normalmente, uma harmonia inerente. Visto que quase todas as figuras de uma peça revelam algum tipo de afinidade para com ele, o motivo básico é considerado o "germe da idéia: se ele inclui elementos [...] de todas as figuras subseqüentes (...).

\footnotetext{
${ }^{64}$ DIVERSOS AUTORES. Grove Dictionary for Musicians. Macmillan Publishers Ltd. 2001.

${ }^{65}$ VIANNA, Aliéksey. Vianna plays Assad. GSP Recordings San Francisco, GSP 1027 CD2005.

${ }^{66}$ RUSSELL, David. For David, Music Written for David Russell, Guitar Telarc International 80707 (2009).

${ }^{67}$ SCHOENBERG, Arnold. Princípios Fundamentais da Composição Musical. Edusp, São

Paulo, 2001.
} 
Esta célula melódica é, portanto, o motivo musical inicial da obra e predomina em todos os três movimentos, conferindo-lhes unidade temática. Veremos a seguir uma análise dos motivos e suas diversas elaborações nos três movimentos da obra: Divertimento, Valseana, Prelúdio e Toccatina.

\subsubsection{Divertimento}

Como vimos anteriormente, o germe para a escrita de Aquarelle, foi o segundo movimento, Valseana. Ao final do compasso 17 detectamos um fragmento melódico, constituído pelas notas fá \#, ré e mi, e que nos leva a crer se tratar de um fragmento melódico gerador do motivo inicial da obra e que foi reelaborado pelo compositor posteriormente.

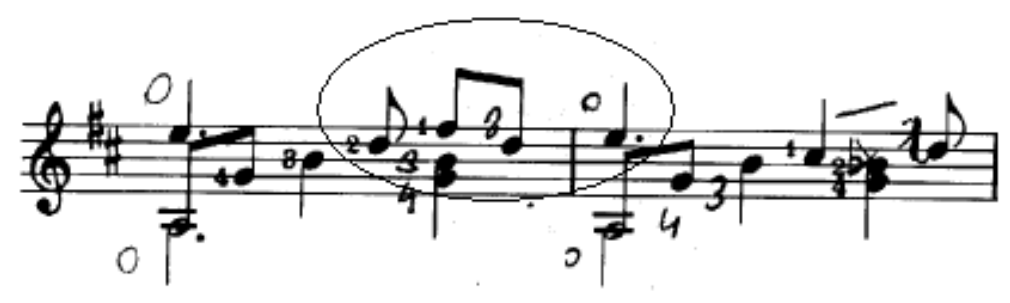

Valseana compassos 17 e 18

O motivo inicial em Divertimento e conseqüentemente no restante da obra é uma transposição deste motivo encontrado na primeira versão de Valseana e é constituído pelas notas ré, si bemol e dó, sendo denominado Motivo 1.

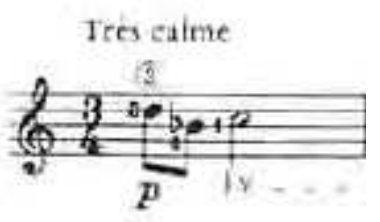

Motivo 1 - Compasso 1 - Divertimento 
O Divertimento é iniciado pela exposição do Motivo 1 no primeiro compasso e repetido no segundo como afirmação do fragmento como célula unificadora da obra. No terceiro compasso, o Motivo 1 é novamente repetido e transposto, gerando um desenho melódico que incorpora a escala de tons inteiros $^{68}$, culminando em um acorde arpejado cujas notas dó si e ré se baseiam no motivo. No sétimo compasso, o Motivo 1 reaparece transposto uma terça maior acima, sendo mais uma vez submetido ao procedimento anterior, porém desta vez em uma frase de maior duração finalizando-se em uma escala de tons inteiros ascendentes. O próximo passo na elaboração seguinte é o acréscimo de uma nota, tornando-se ré, sib, do e láb em um desenho melódico ainda mais longo (compassos 14 a 20).
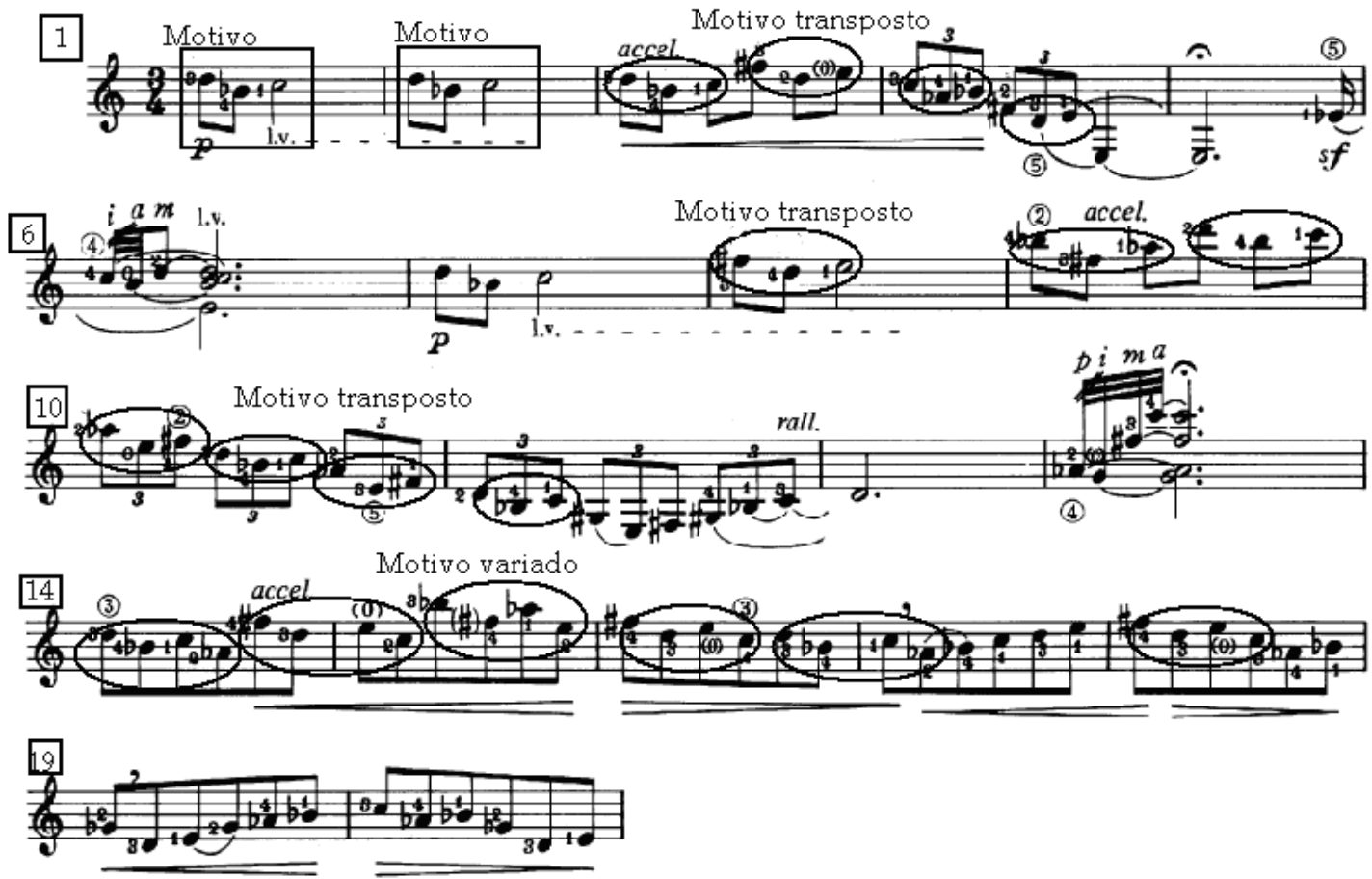

Divertimento compassos 1 a 20

No compasso 23 o motivo inicial é novamente exposto, variado ritmicamente e transposto três vezes, inicialmente uma terça maior acima, seguido de uma segunda maior abaixo e de uma sexta menor abaixo. A rítmica é composta de colcheias pontuadas. A textura apresenta planos sonoros

\footnotetext{
${ }^{68}$ Escala formada apenas por intervalos de tons inteiros e que é também conhecida como escala hexafônica. BERNWARD, SACKER, (1997), p. 321. (tradução nossa).
} 
distintos com melodias em registro grave e agudo executadas em harmônicos 69

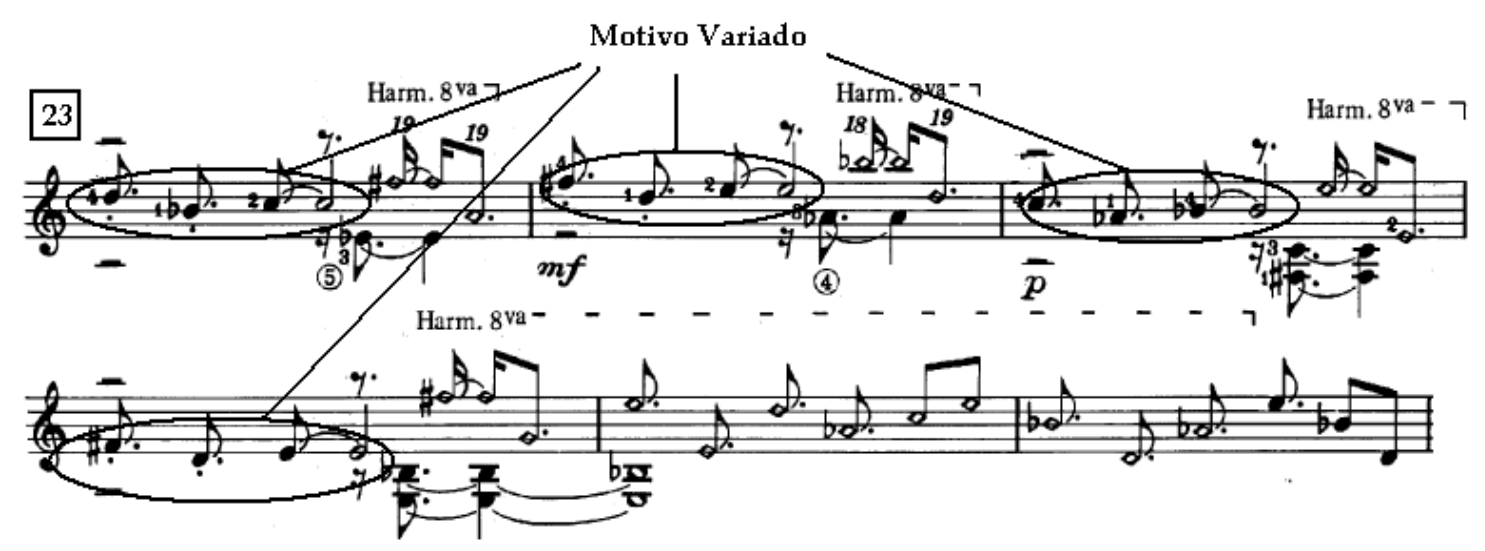

Divertimento compassos 23 a 28

A partir do compasso 22 um novo impulso constituído a partir da mudança de andamento e textura passa a conduzir o texto musical. Notas repetidas no baixo e harmônicos inicialmente (compassos 21 a 28) e o prenúncio de um acompanhamento com nítida autonomia no compasso 30 que se confirma como uma segunda voz na polifonia instaurada no compasso 32 ditam a textura predominante do Divertimento. No compasso 38 o Motivo 1 é reapresentado com ritmo distinto e acompanhamento mais complexo, sendo sucedido das transposições presentes entre os compassos 23 a 26 , numa reapresentação variada da elaboração citada.

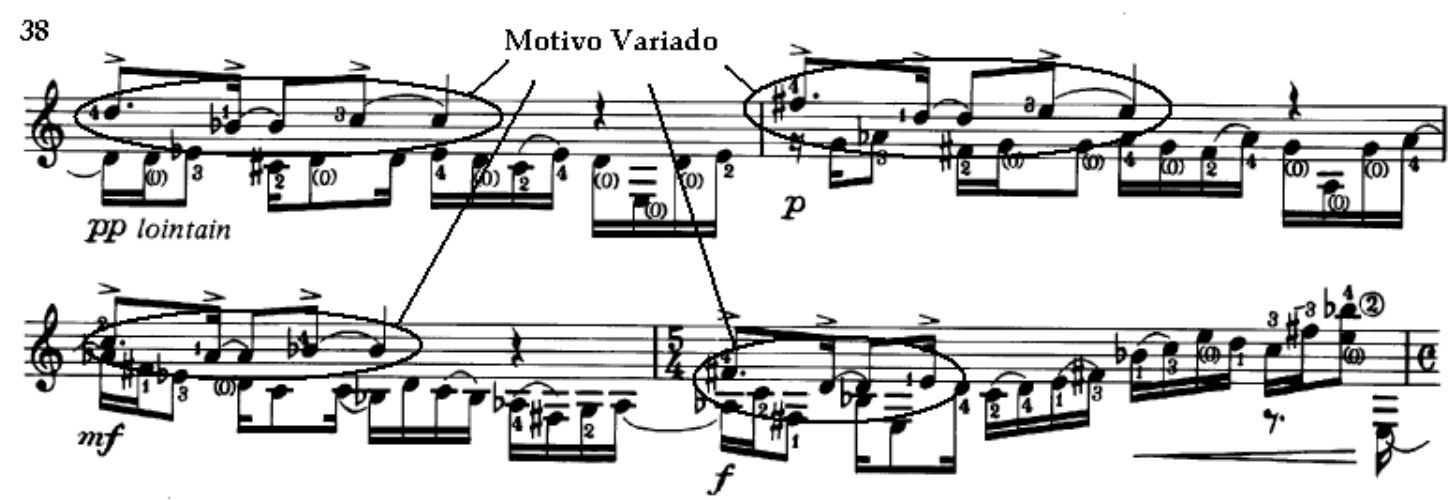

Divertimento compassos 38 a 42

69 "Sons individuais puros que combinados formam um timbre mais complexo. Em um instrumento de cordas, os sons harmônicos são obtidos ao se tocar a corda levemente em certos pontos; harmônicos naturais são obtidos através de cordas soltas e harmônicos artificiais em cordas presas." (HALL LEONARD, 1993, p 153, tradução nossa). 
Entre os compassos 45 a 50 encontramos uma nova variação rítmica e melódica do Motivo 1, que reapresentado em uma textura coral. Nesta passagem detectamos o emprego da fórmula de compasso de 7/8, tríades aumentadas e escala de tons inteiros. As frases presentes têm duração de dois compassos e são transpostas sucessivas de um tom abaixo, mantendo a estrutura harmônica da escala de tons inteiros e sua sonoridade particular.

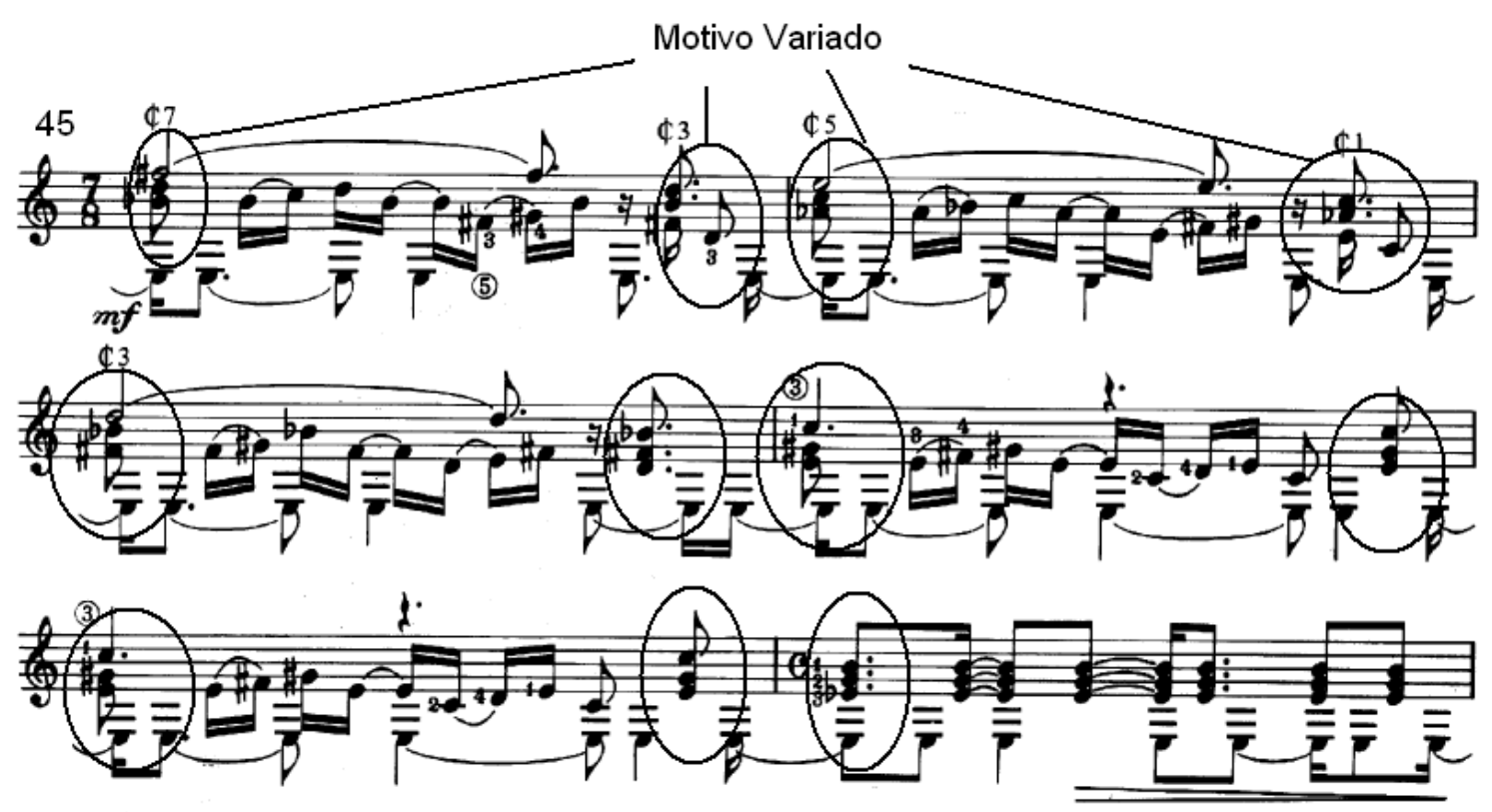

Divertimento compassos 45 a 50

Entre os compassos 63 e 66, o Motivo 1 reapresenta-se novamente reelaborado com variações diversas na voz inferior a partir de elementos musicais já incorporados nas elaborações anteriores. Podemos destacar que no compasso 65, encontramos a apresentação simultânea de uma célula melódica, baseada no motivo 1, que será o fio condutor de diversas elaborações posteriores detectadas na obra sendo que seu contorno melódico sugere uma apropriação do tema principal de Valseana. Denominaremos esta célula de Motivo 2.

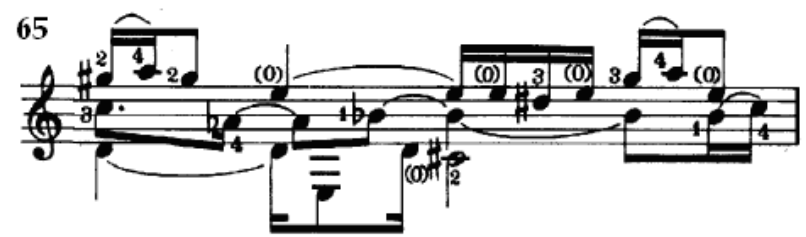




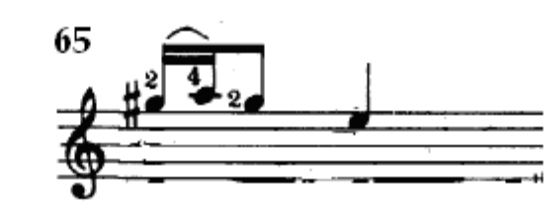

Motivo 2

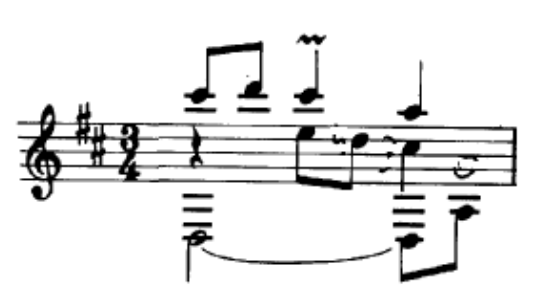

Valseana - compasso 10

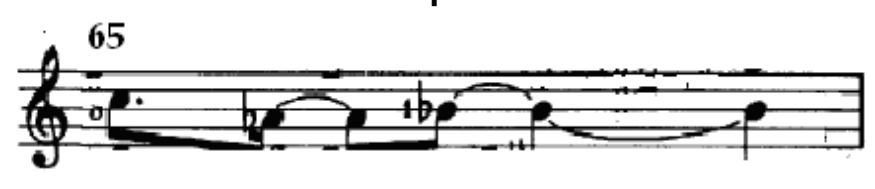

Motivo 1 variado

O Motivo 2 é reelaborado sucessivamente nos compassos 70 e 71, havendo a elaboração simultânea com o Motivo 1 em uma textura polifônica com três vozes independentes. Nos compassos 72 a 74 o compasso é variado para 3/8 em frases mais curtas que as anteriores. No compasso 76 o motivo 2 assume seu contorno completo e caráter definitivos, sendo variado novamente nos compassos 80 e 82, para só então delimitar a Seção A do texto musical no compasso 84 . 

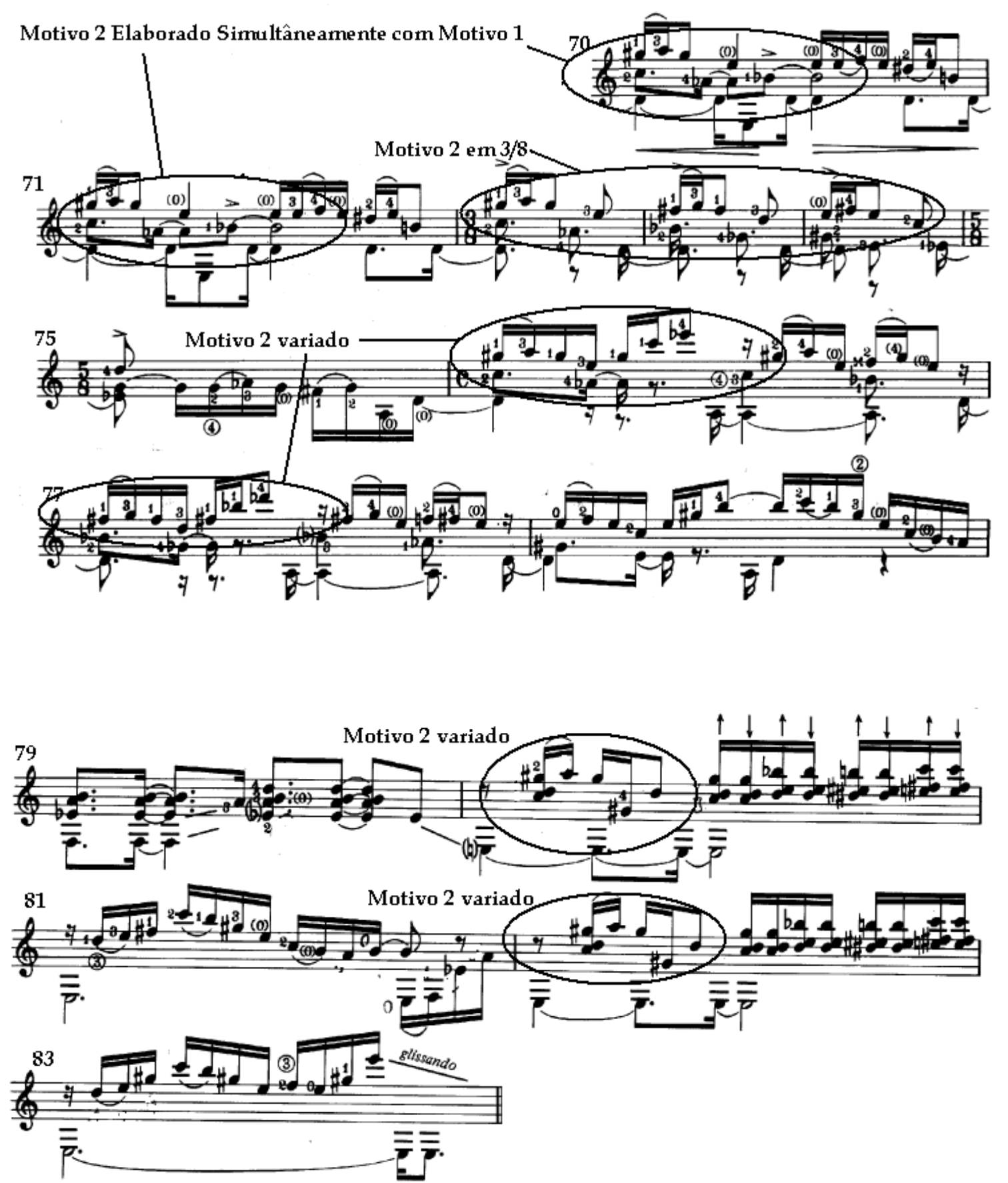

Divertimento compassos 70 a 83

$\mathrm{Na}$ Seção A o Motivo 2 no compasso 84 é novamente variado, recebendo tratamento harmônico semelhante ao do tema principal de Valseana. 


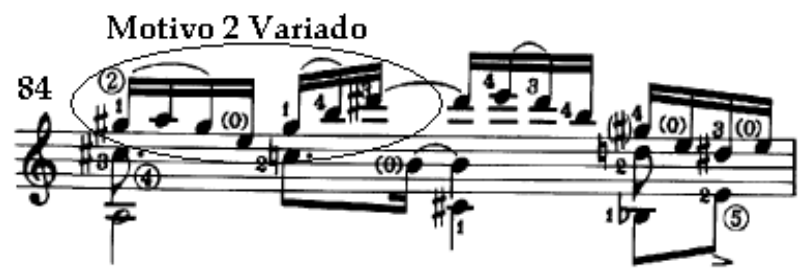

Divertimento compasso 84

O Motivo 1 é retomado na seção $A$ da peça, inicialmente variado ritmicamente e melodicamente no compasso 91.

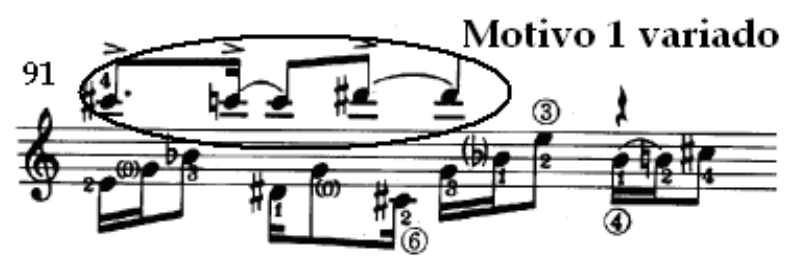

Divertimento compasso 91

O motivo é então retomado em meio a uma densa polifonia entre os compassos 96 e 101, se tornando um tema secundário na elaboração.

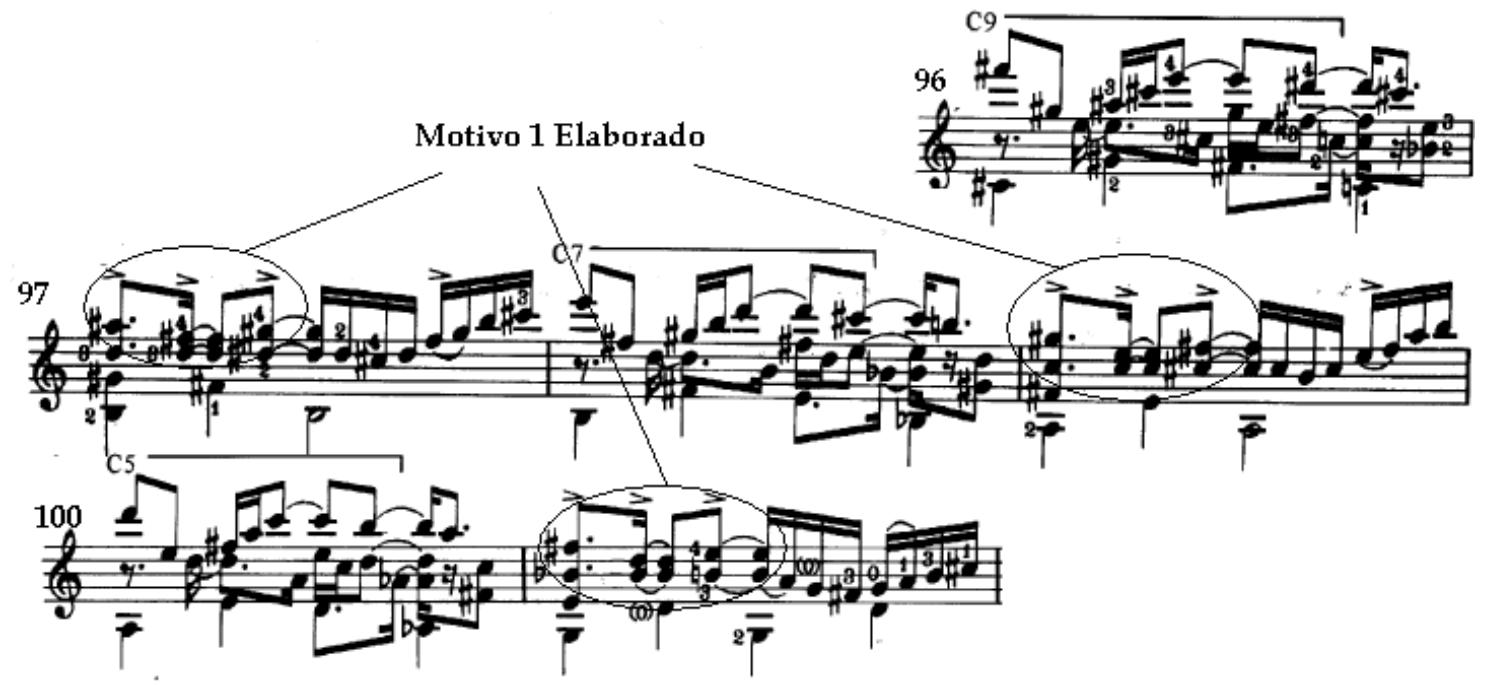

Divertimento compassos 96 a 101

O Motivo 1 é novamente elaborado entre os compassos 103 e 108. Nesta passagem o compasso é alterado para 3/8 juntamente com o contorno melódico, que sofre transposições sucessivas de um tom descendente a cada dois compassos sobre uma marcha harmônica. 


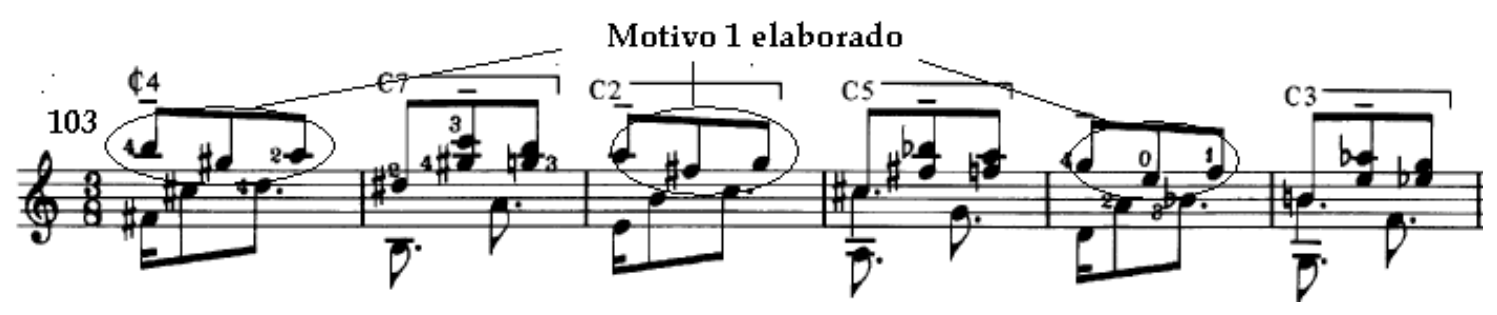

Divertimento compassos 103 a 108

Pudemos constatar que em ambas as elaborações presentes entre os compassos 96 a 101 e 103 a 108, o compositor se utiliza de uma estrutura de três frases construídas em dois compassos cada uma e que são transpostas um tom abaixo a cada dois compassos. Detectamos o mesmo tipo de transposição por tons inteiros na elaboração presente entre os compassos $45 \mathrm{e}$ 49 da peça, caracterizando a recorrência deste recurso composicional.

Após a repetição do Motivo 2 e seus desdobramentos a partir do compasso 111, uma nova variação do Motivo 1, constituída pelas notas "dó\#, ré\# e mi" é apresentada nos compassos 121 e 123 com uma textura coral com motivo secundário, obedecendo o contorno do tema original nos compassos 122 e 124.

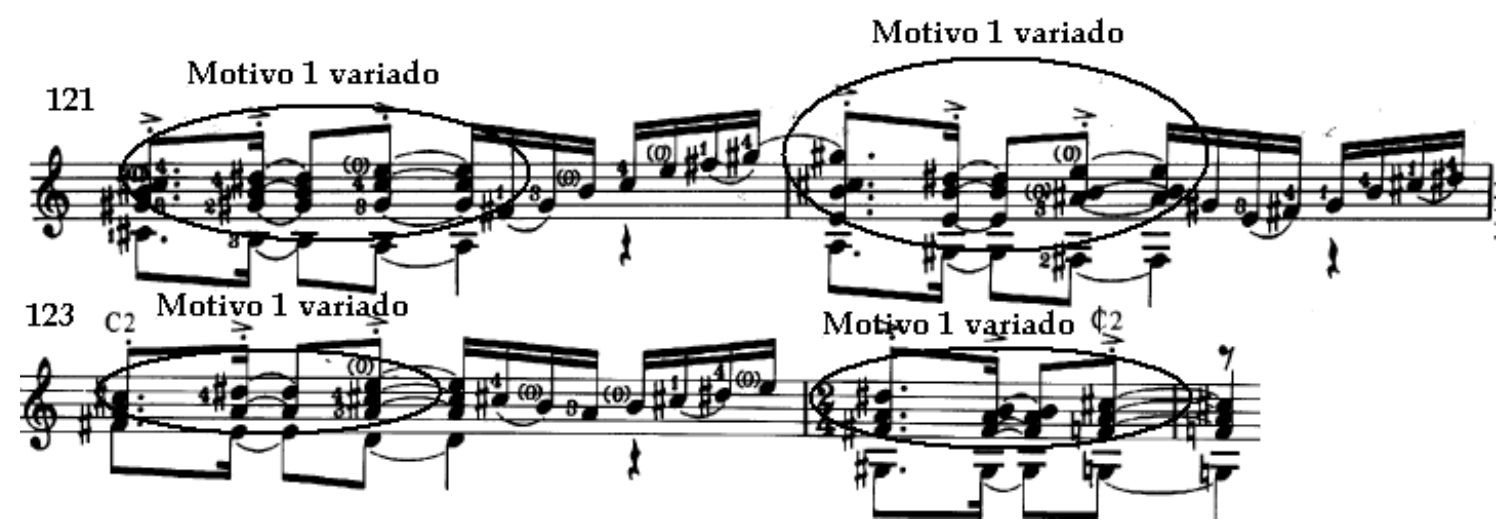

Divertimento compassos 121 a 124

Entre os compassos 133 e 136 o Motivo 1 é novamente abordado, porém nesta elaboração foi mantido o padrão rítmico presente no primeiro compasso, havendo desta vez apenas a variação melódica do motivo. 


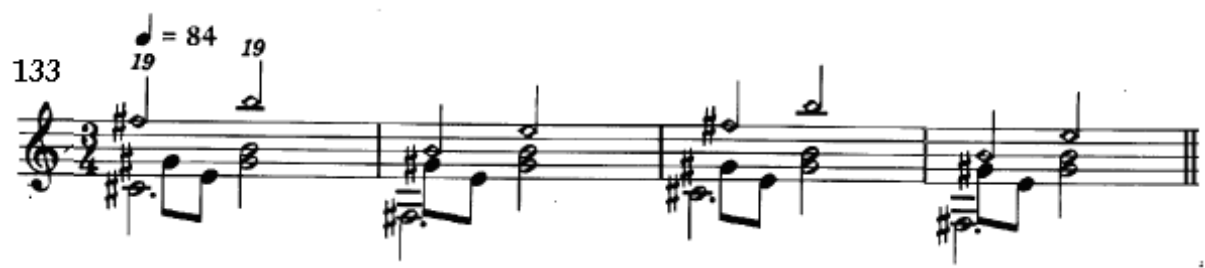

Divertimento compassos 133 a 136

A seção B é iniciada no compasso 137 e é caracterizada pelo caráter expressivo e andamento mais lento. O material temático apresentado é organizado em forma de diálogo entre as vozes aguda e média. Ambas as vozes não possuem similaridades melódicas, sendo caracterizadas pelo jogo rítmico entre colcheias e tercinas.

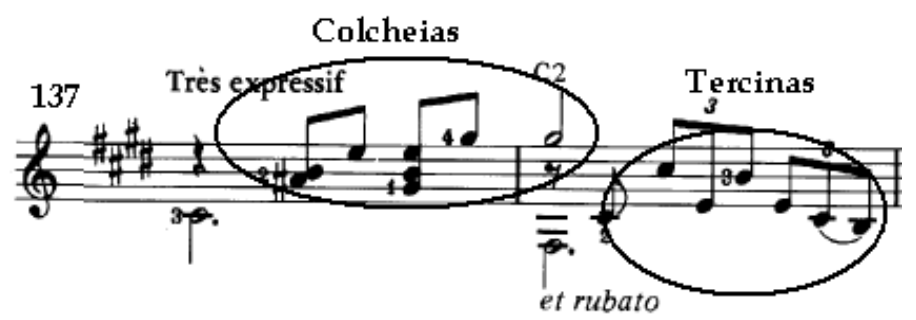

Divertimento compasso 137

Na Coda de Divertimento, compassos 184 a 193, o Motivo 2 é reelaborado, com a mesma tonalidade do compasso 84 (La maior) com utilização pedal tonal e rítmico, com a conclusão da obra na tonalidade de Mi menor, seguida de uma espécie de picardia com um acorde de mi menor em primeira inversão.

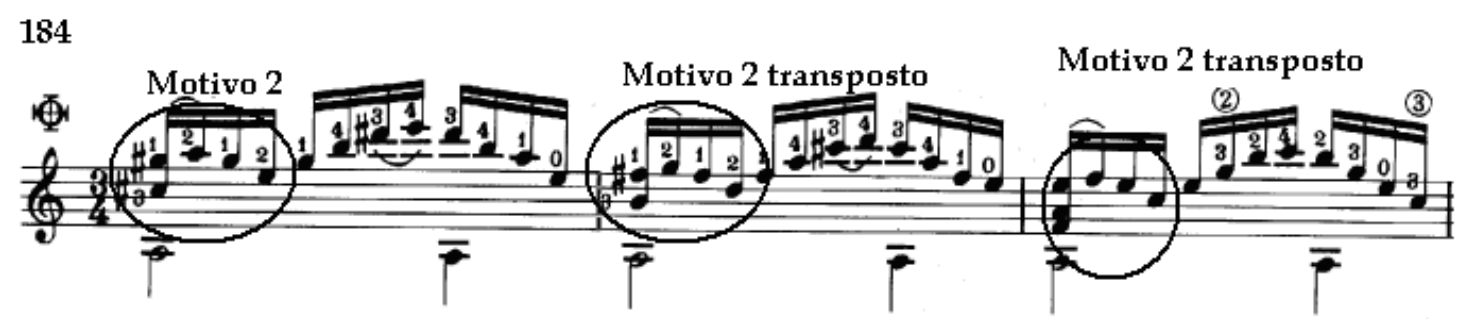

Divertimento compassos 184 a 186 


\subsubsection{Valseana}

$\mathrm{Na}$ Introdução da peça temos o primeiro motivo, formado pelas notas mi, fa\#, sol e lá nos dois primeiros compassos. Este motivo é frisado por sua repetição imediata e, na terceira vez, no compasso 5 , apresenta-se levemente variado no percurso de quatro compassos, ligando-se á Seção A de Valseana.

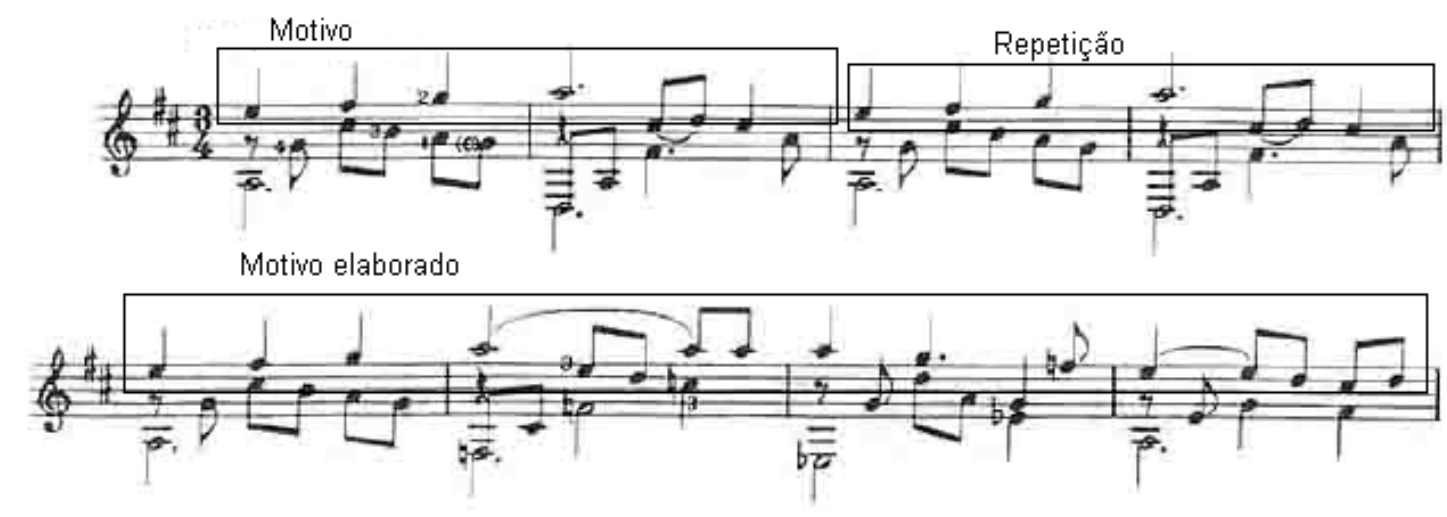

Valseana compassos 1 a 8

No compasso 10 temos então o tema principal da peça cuja simetria ao longo de seus quatro compassos confere equilíbrio na reapresentação com variações melódicas na voz secundária logo em seguida, e reelaborado na Seção A' da obra (compasso 35 em diante) ${ }^{70}$. Entre os compassos 18 e 340 compositor desenvolve um conseqüente ao tema principal (compassos 12 e 13), apresentando-o de forma variada com a melodia na voz superior até o compasso 26 e, em seguida, a mesma uma oitava abaixo, na voz intermediária.

\footnotetext{
${ }^{70}$ Como exposto no item 2.1.2, pode se notar a utilização deste mesmo material temático na seção A do Divertimento.
} 

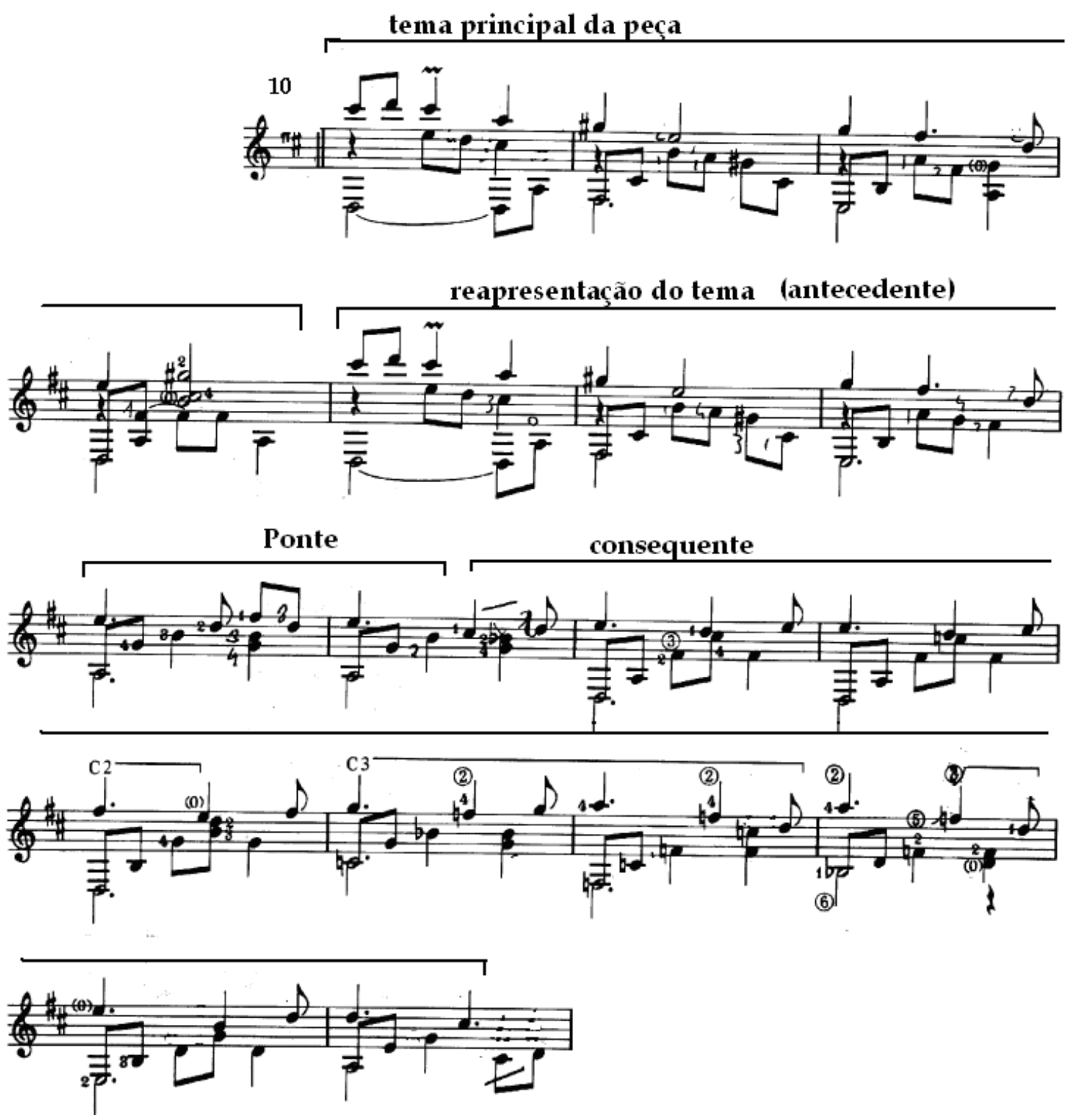

Valseana compassos 10 a 26

O conseqüente para o tema principal elaborado entre os compassos 18 e 26 é então transposto a uma oitava abaixo e reelaborado. Tal elaboração se encontra em registro intermediário e inicia-se com as notas dó\# e ré no último tempo do compasso 26 (anacruse do compasso 27) e segue até o compasso 34 com blocos no acompanhamento em registro agudo e nova anacruse, que sinaliza o retorno da melodia na voz superior, com a finalidade de reapresentar a variação do motivo principal na Seção A', compasso 35. 


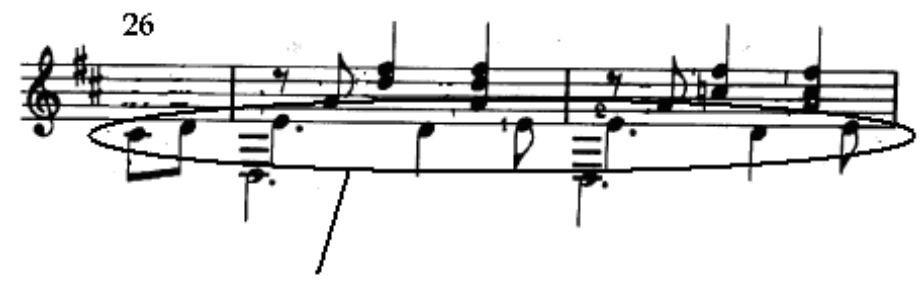

Elaboração do consequente

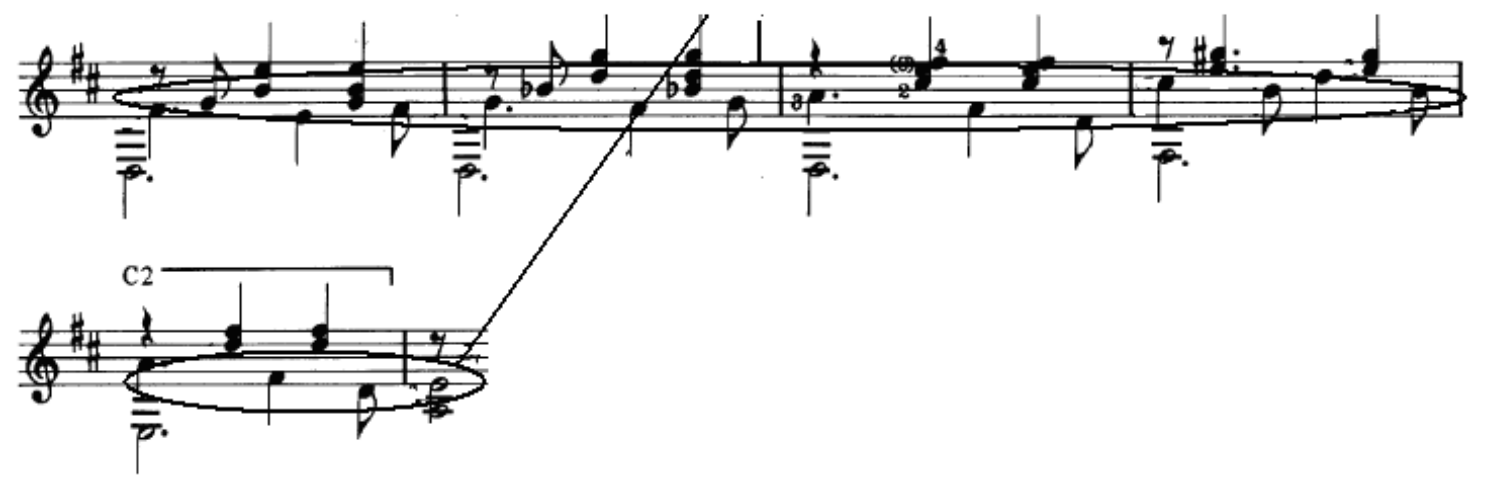

Valseana compassos 26 a 33

A seção A' reapresenta o tema principal de forma variada no compasso 35. A melodia original é variada em grupos de quatro semicolcheias e duas semínimas a cada compasso, na voz superior, com acompanhamento de colcheias na voz inferior.
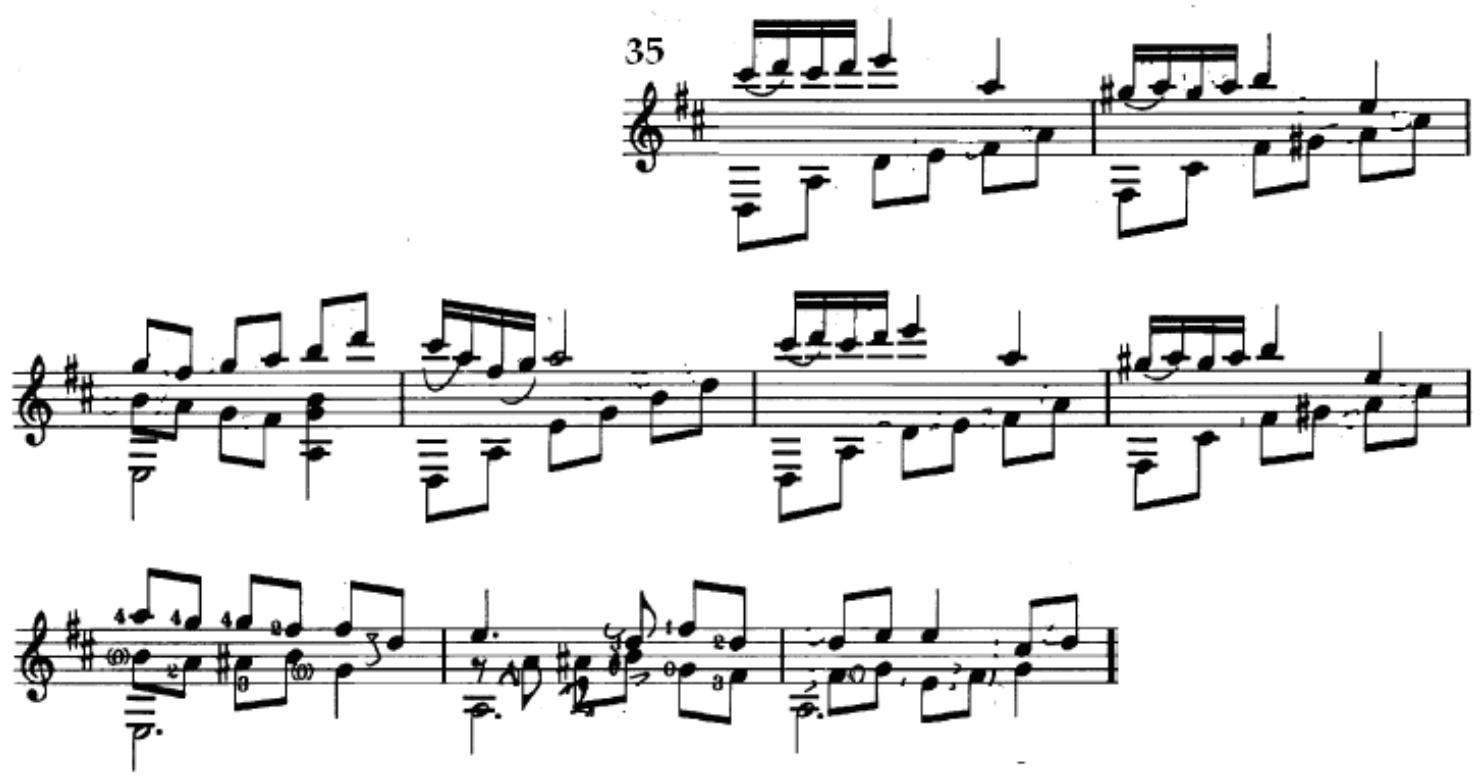

Valseana compassos 35 a 43

No compasso 44 dá-se a re-elaboração do conseqüente da seção $A$. Nesta passagem, verifica-se a manutenção da estruturação harmônica e elaboração melódica similar à ocorrida na primeira parte da seção $A$, presente entre os compassos 34 e 43. 


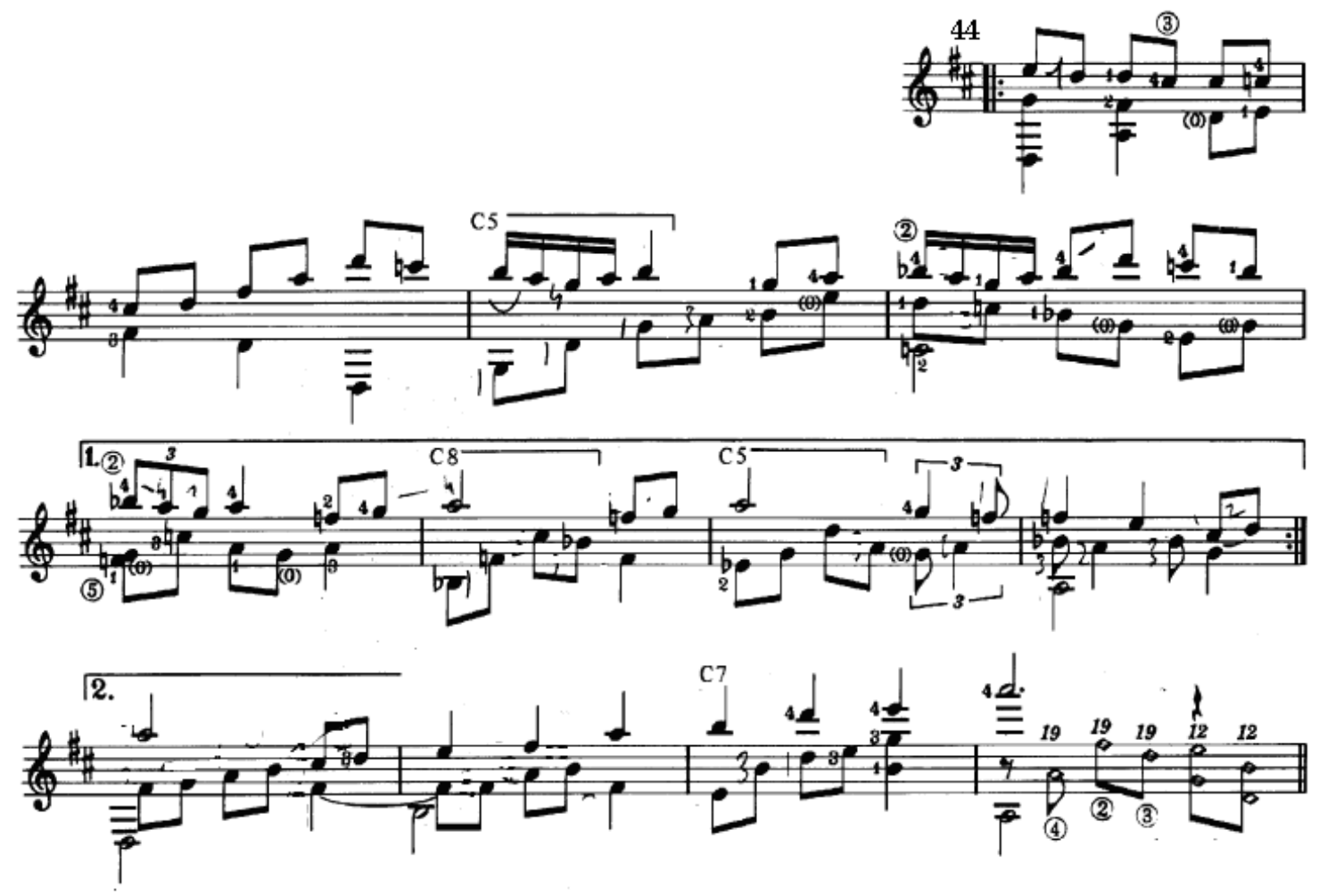

Valseana compassos 45 a 56

Enquanto na voz inferior a rítmica é elaborada em colcheias gerando um efeito de polirritmia, a textura de melodia acompanhada é retomada entre os compassos 48 e 51, em que o compositor utiliza as três únicas tercinas da peça (compasso 48 e 50 ).

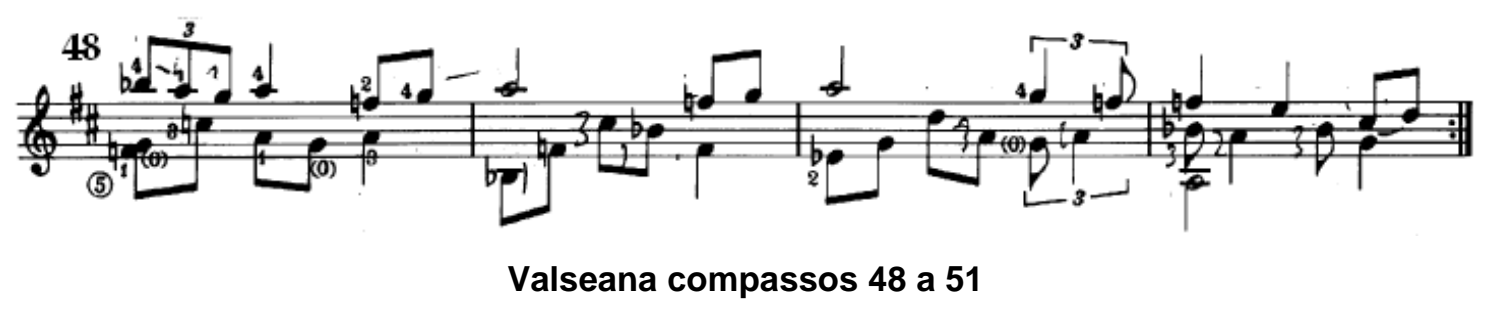

Para finalizar a Seção A', Assad novamente sinaliza um breve retorno da Seção $A$ através da utilização de material temático da Introdução ao longo dos compassos 53 e 54 rumo à dominante no compasso 55. Este retorno de seis compassos somados aos três compassos da Coda de mesmo material temático, dos quais o último apenas faz soar o acorde final (reforçado pela 
indicação I.v. ${ }^{71}$ ), nos dá a sensação novamente de uma frase de simétrica, de oito compassos, reafirmando a noção de equilíbrio e sobriedade na escrita do compositor.

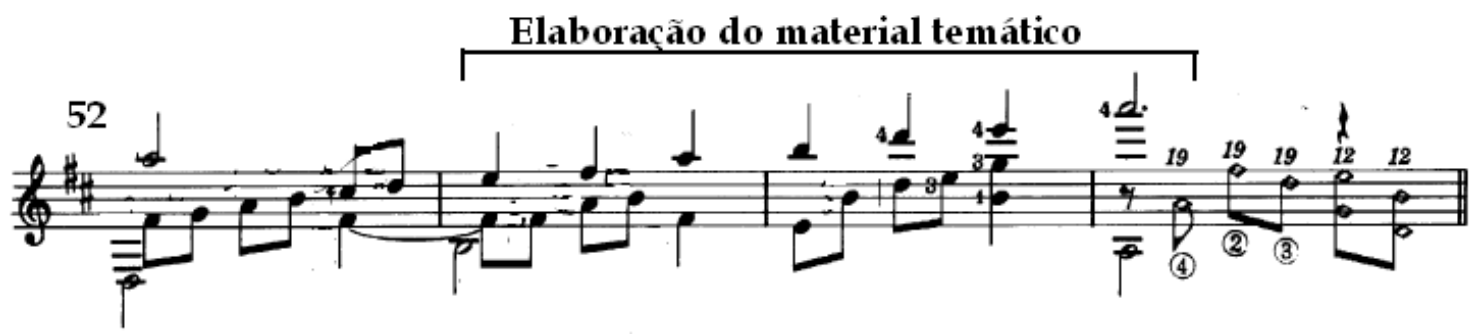

Valseana compassos 42 a 55

\subsubsection{Prelúdio e Toccatina}

A peça é iniciada por um motivo formado pelas notas fá\# ré e mi, sendo este a primeira transposição do Motivo 1 do Divertimento. Podemos deduzir que o caráter Lent et Très Expressif do Prelúdio (fazendo menção a Valseana) e a reapresentação do motivo 1 do Divertimento constituem elementos unificadores (de coesão) para a Suíte como um todo. Este Prelúdio, é então elaborado em 15 compassos conduzindo à seção da Toccatina por uma ponte entre os compassos 9 e 15 .

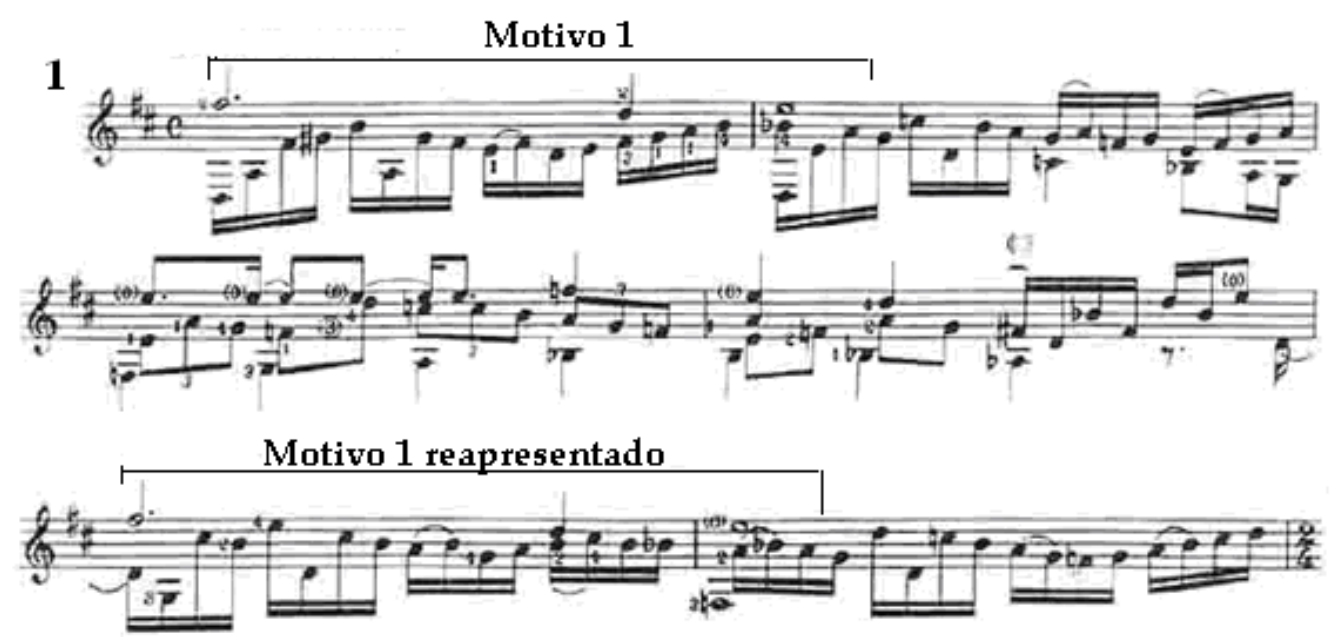

Prelúdio e Toccatina compassos 1 a 6

\footnotetext{
${ }^{71}$ A indicação "l.v.", laissez vibrer, instrui o intérprete a deixar vibrar livremente o som produzido sob a inscrição mesma.
} 
A seção da Toccatina inicia-se com a mudança para o andamento de semínima igual a 126 no compasso 16 . Na passagem presente entre os compassos 16 a 23 o motivo é reelaborado em forma de blocos de acordes onde em forma de pergunta e resposta é elaborada pelo compositor.

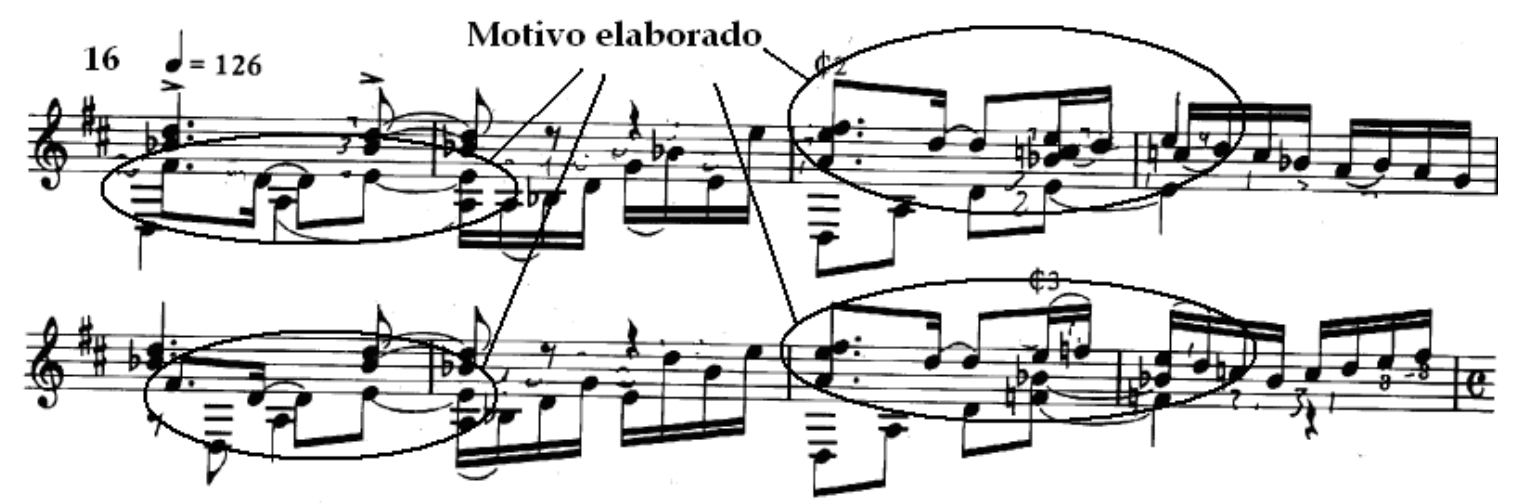

Prelúdio e Toccatina compassos 16 a 23

Este primeiro motivo é reapresentado de forma elaborada quanto a rítmica sobre um acompanhamento de baixo ostinato do compasso 28 até 0 compasso 35 .

Motivo 1
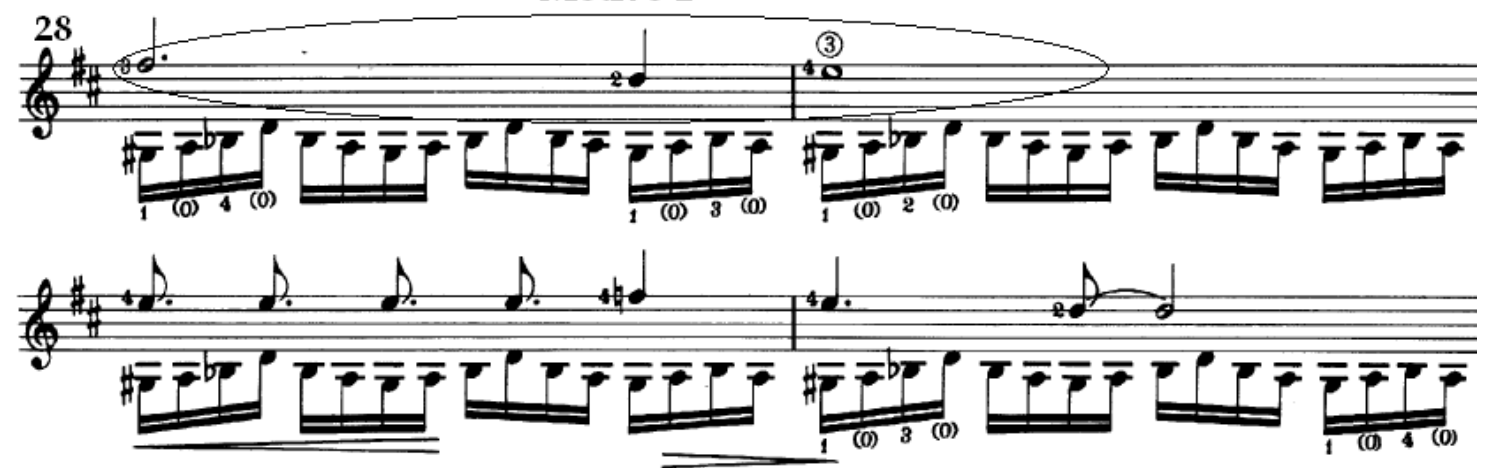

Prelúdio e Toccatina compassos 28 a 31

Encontramos um segundo motivo no compasso 36 (que será denominado motivo 2), formado pelas notas lá, sol, mi e ré. A partir do compasso 36 este motivo é elaborado até o compasso 39 , havendo uma transposição do trecho a uma oitava acima e com uma variação cromática ascendente na linha melódica da voz intermediária. 


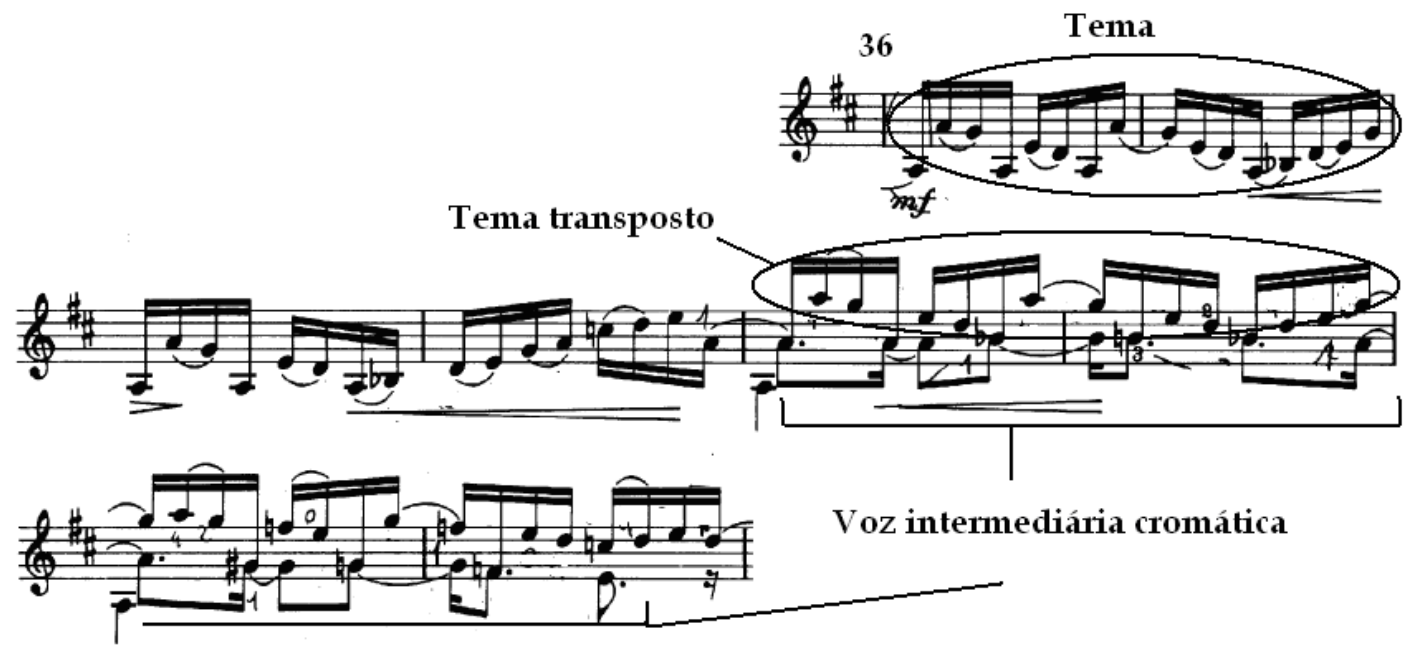

Prelúdio e Toccatina compassos 36 a 43

O motivo 2 é novamente elaborado a partir do compasso 44 até 0 compasso 49, havendo uma repetição desta entre os compassos 50 e 55 , com sutis alterações na voz do baixo.

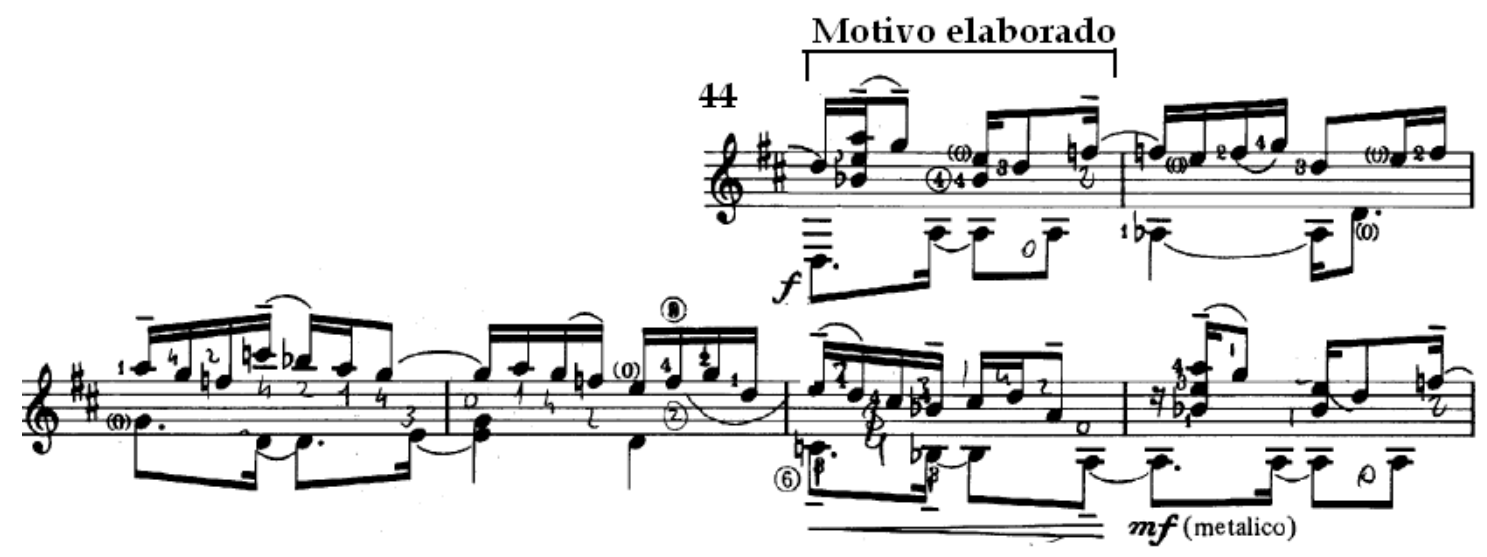

Prelúdio e Toccatina compassos 44 a 49

O trecho do Prelúdio iniciado no compasso 10 e que serve de ligação à Toccatina é reapresentado de maneira variada no compasso 54. Esta elaboração consiste em ornamentações da melodia do trecho inicial com a manutenção de suas notas principais. 

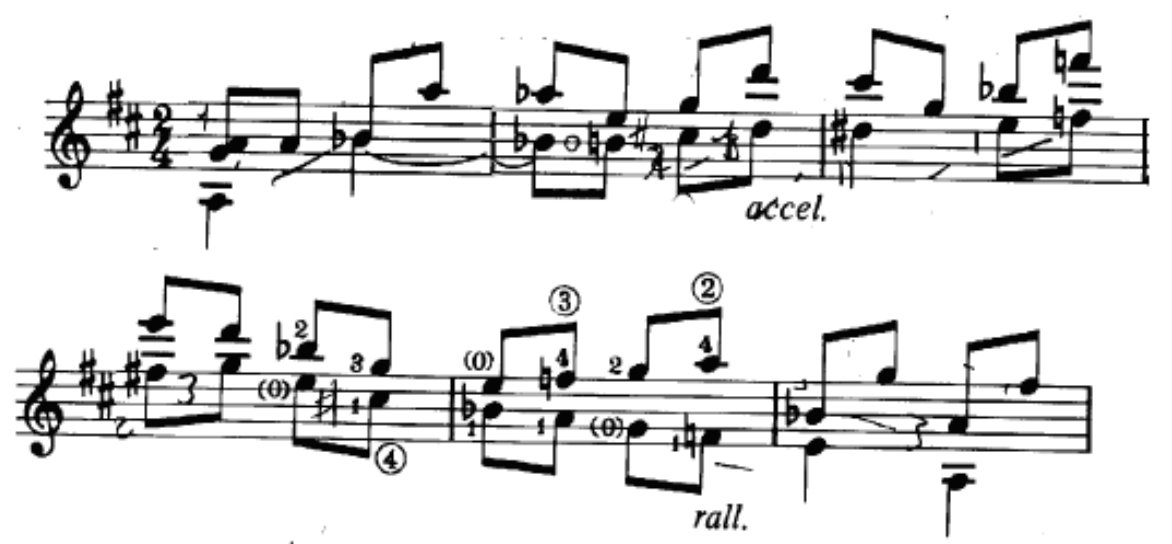

Prelúdio e Toccatina compassos 10 a 15

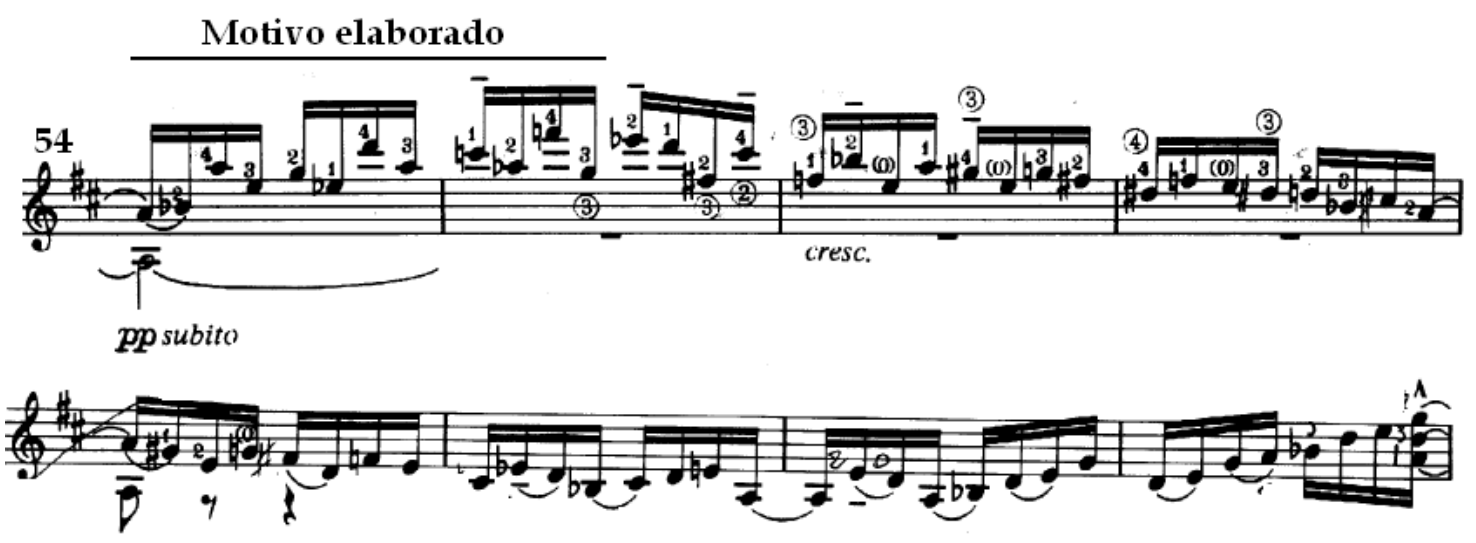

Prelúdio e Toccatina compassos 44 a 49

A anacruse do compasso 61 apresenta uma variação do motivo 1 incluindo variação rítmica e textura coral com a substituição da primeira nota (fá\#) pela nota sol, e apresentação de apenas a segunda parte da elaboração deste tema (encontrada entre os compassos 5 e 9). Deve-se ressaltar nesta passagem a utilização simultânea da elaboração do motivo 2 presente entre os compasso 44 e 49 na voz intermediária. Este trecho se estende até o compasso 66 , sendo variado no compasso seguinte em forma de resposta à frase anterior pela reapresentação do mesmo tema um grau acima dentro do modo utilizado (neste caso, ré eólio). Esta variação é concluída no compasso 71. 
Motivo 1 Elaborado
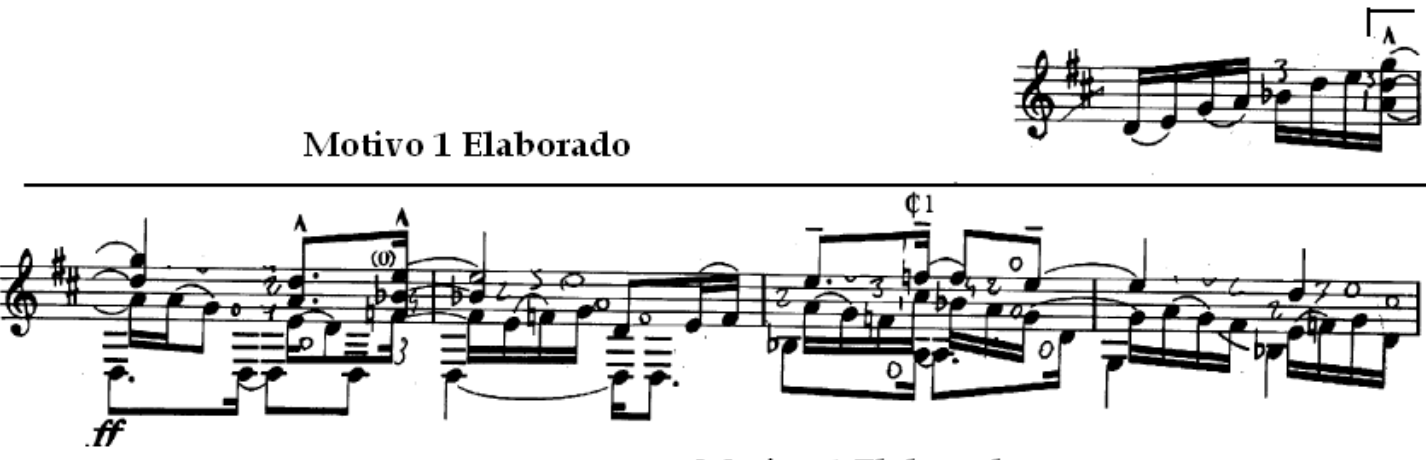

Motivo 1 Elaborado
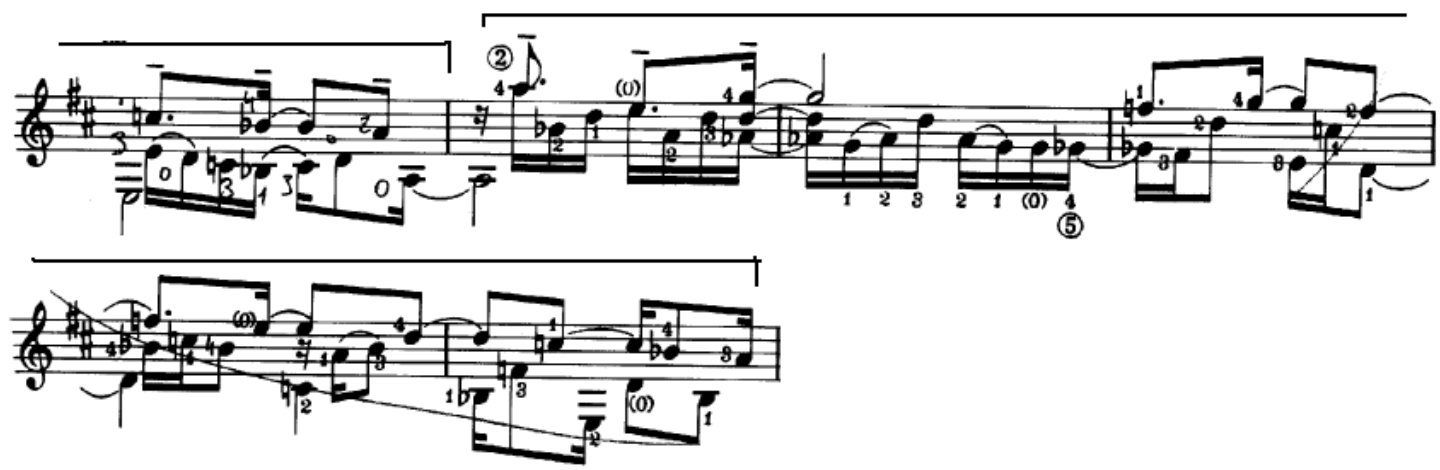

Prelúdio e Toccatina compassos 61 a 71

Entre os compassos 72 e 79, o Motivo 1 é novamente elaborado de maneira similar a presente no compasso 58 , demonstrando a maneira com que Assad varia uma elaboração motívica gerando novo material.

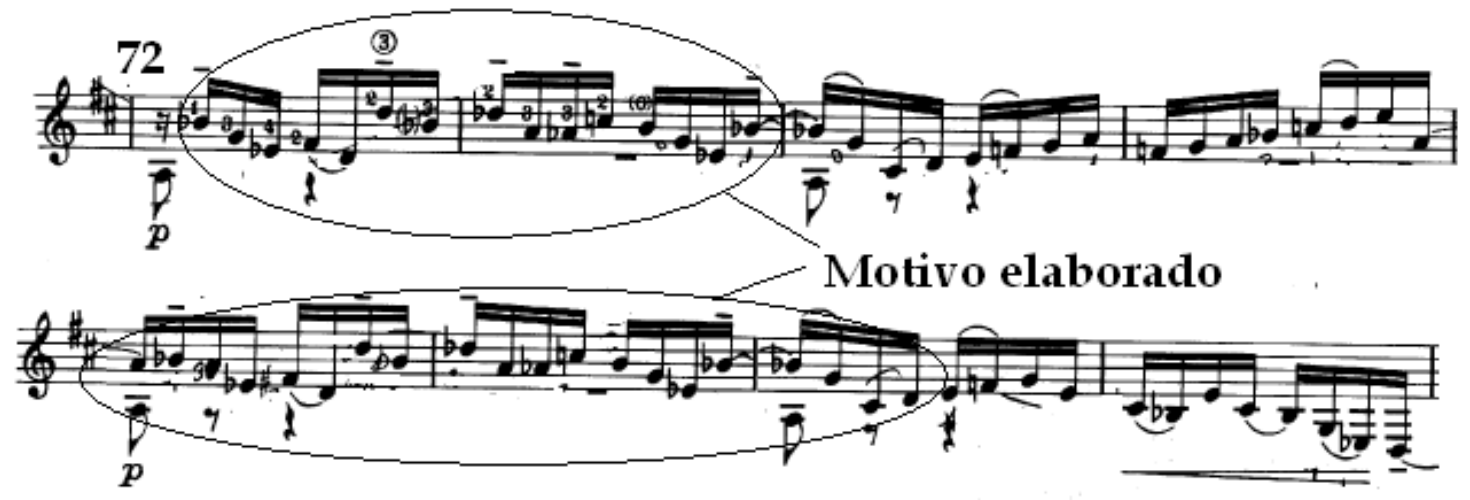

Prelúdio e Toccatina compassos 72 a 79

Entre os compassos 80 e 96, uma passagem atua como ponte entre as elaborações cromáticas da sessão da Toccatina e uma seção que remonta à música nordestina brasileira dada a sua concepção melódica e rítmica entre os compassos 97 a 115. O que se faz notar é a elaboração de pequenos fragmentos melódicos de três notas, derivados do Motivo 1 na passagem nos 
compassos 82, 86 e 90 e que atuam como motivo para a elaboração "nordestina" entre os compassos 97 a 115. Passagens como estas demonstram o rigor para com a elaboração motívica de Assad e demonstram que isto ocorre inclusive em passagens claramente influenciadas pela música popular.

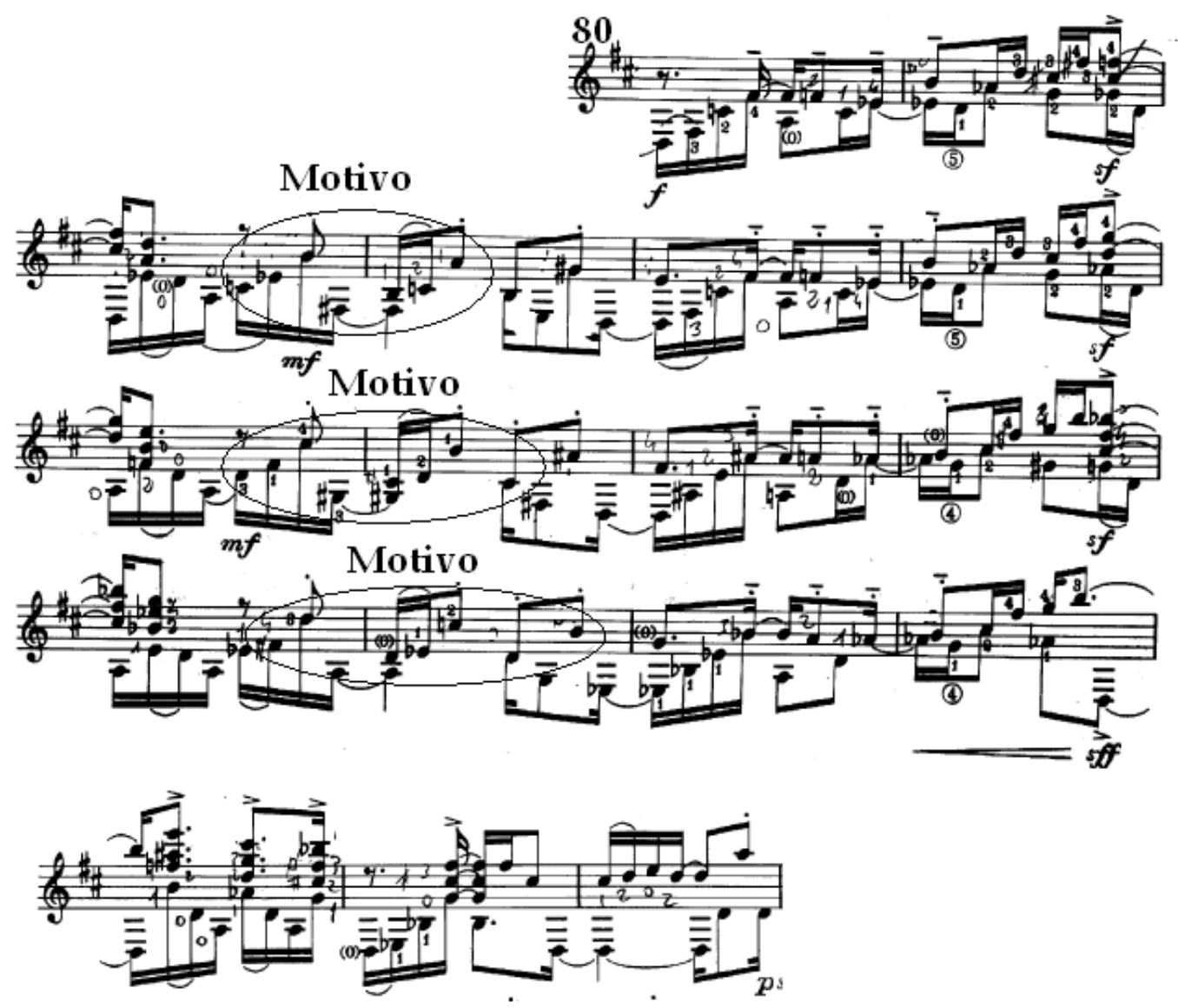

Prelúdio e Toccatina compassos 80 a 96 


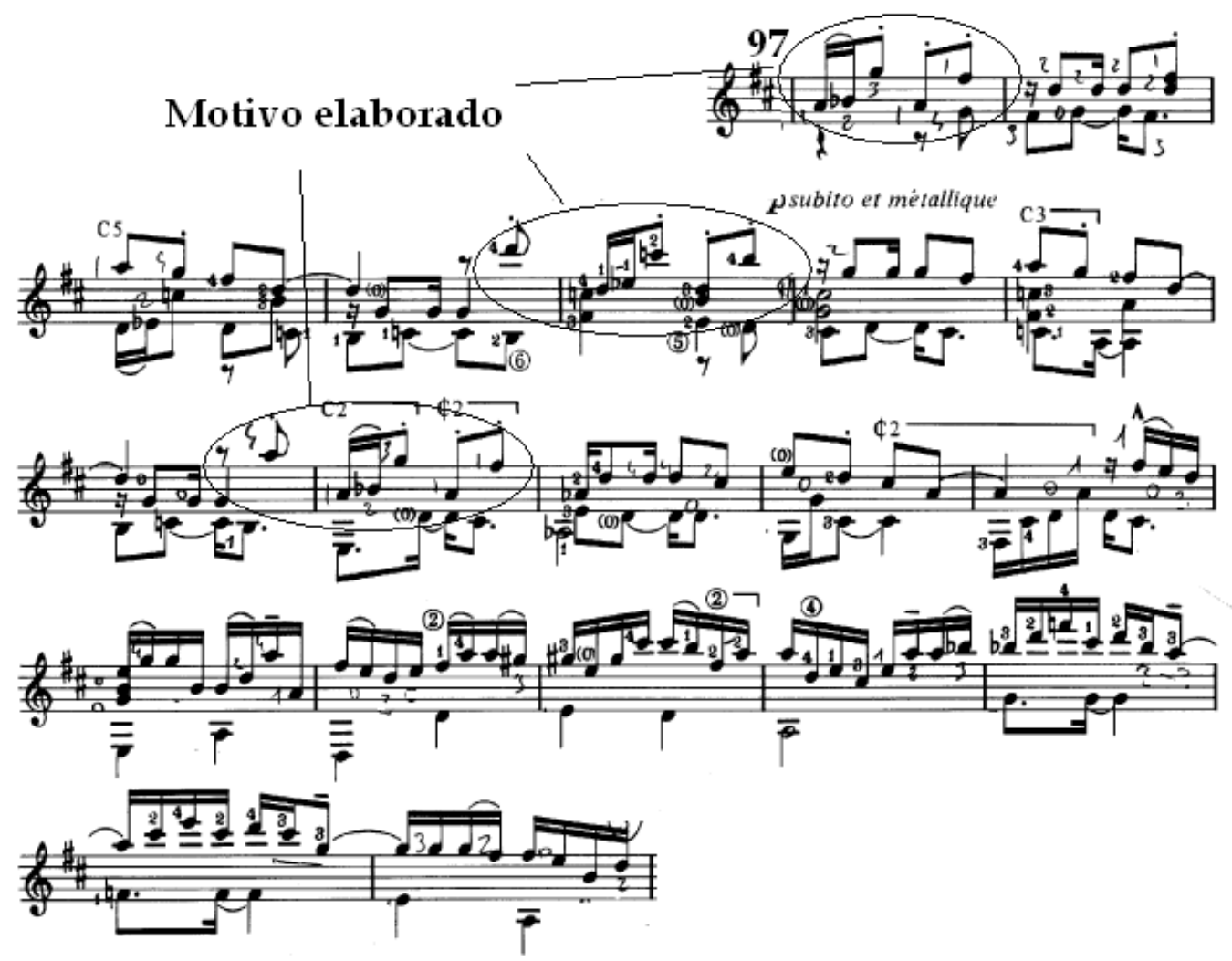

Prelúdio e Toccatina compassos 97 a 115

O final da obra presente entre os compassos 124 e 126 reapresentam o tema gerado pela sessão nordestina novamente de maneira elaborada. Nesta passagem o padrão rítmico é mantido e a melodia é elaborada sobre blocos de acordes.

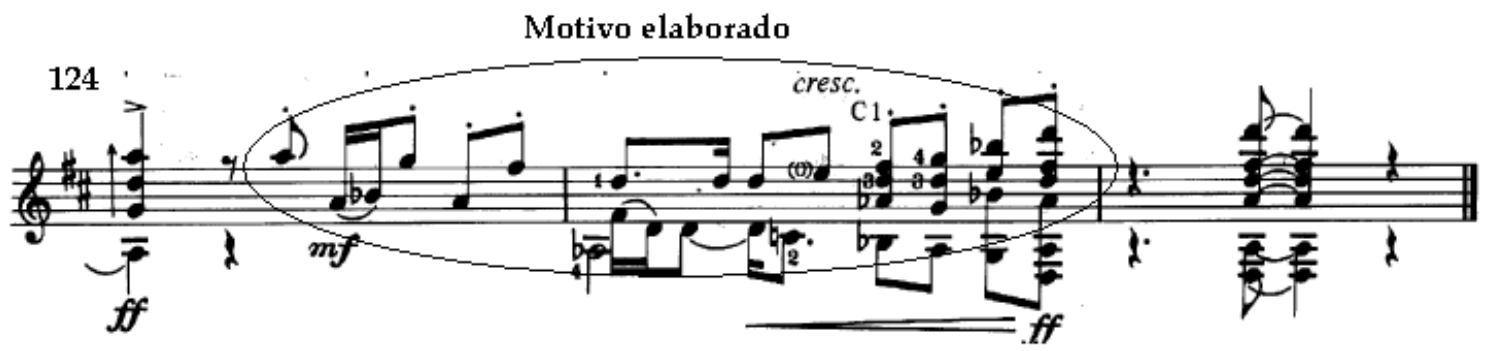

Prelúdio e Toccatina compassos 124 a 126

Verificamos neste item diversos aspectos presentes na elaboração de motivos em Aquarelle. Dentre os diversos procedimentos apontados, percebemos a recorrência da construção gradual de temas em diversos momentos, isto é, o motivo é apresentado de maneira simples e gradualmente 
se transforma temas mais complexos como verificado em diversas elaborações presentes na obra.

\subsection{Análise Rítmica}

De acordo com Vianna (2005), uma das principais características da música de Assad é a utilização de ritmos sincopados de origens afrobrasileiras. O Dicionário Grove (2001) descreve: "A característica peculiar da música brasileira, contudo, é o ritmo, tanto pela acentuação irregular, como pela antecipação. A síncope é geralmente contrastada com uma pulsação rítmica regular (geralmente representada em unidades de semicolcheias)" (tradução nossa). Brooke-Ball (1993) descreve a síncope como "Uma alteração do arranjo normal do pulso em um compasso. Isto é feito (...) pela colocação de acentuações em tempos ou contratempos onde isto normalmente não ocorre." 72 (tradução nossa). Assad em entrevista concedida a Gonsalo Molano (2003) descreve a rítmica brasileira como de origem africana:

"Nós temos muitos tipos de ritmos que você caracteriza como ritmos brasileiros, mas eles são baseados em ritmos africanos, assim como os ritmos de outras culturas latinas. Você sabe, eles tiveram a influência negra. Até se você for ao Uruguai e Argentina, você tem o mesmo tipo de música baseado[...] neste ritmo cubano[...] Que é três, três e dois [...]. Eles criaram o Danson com ele. O estilo também é chamado de Habaneras, feito deste ritmo." ${ }^{\prime 3}$ (tradução nossa)

As figuras em três, três e dois descritas pelo compositor podem ser identificadas como grupos de colcheias pontuadas seguidas de colcheias regulares, e comumente encontradas também em danças e estilos brasileiros e exemplificados no dicionário Grove (2001) como "figuras isométricas simples" e tidas como "bem comuns "74.

\footnotetext{
72 BALL B. Concise Dictionary of Music. Londres: Tiger Books International PLC, 1993. 448p.

${ }^{73}$ INTERVIEW WITH SÉRGIO ASSAD. Revista eletrônica guitarra. Madrid n.9, out. 2003.

Disponível em: http://www.guitarramagazine.com/lssue42/interview_assad.asp. Acesso em 30 de janeiro 2004.

${ }^{74}$ DIVERSOS AUTORES. Grove Dictionary for Musicians. Macmillan Publishers Ltd. 2001.
} 
Estas figuras pontuadas e outras, comuns à música brasileira, foram abundantemente empregadas no Divertimento assim como no Prelúdio e Toccatina. As ocorrências no primeiro movimento são as que demonstramos a seguir.

\subsubsection{Divertimento}

Em Divertimento, primeiro movimento, como vimos anteriormente, podemos associar o uso de ritmos sincopados com o gênero da marcha rancho. Com base nestas informações, podemos relacionar o emprego do termo "divertimento" pelo compositor com o aspecto dançante encontrados em ambos os gêneros, a marcha rancho e o divertimento clássico.

A utilização de síncopes no Divertimento é iniciada no compasso 21 ,após a exposição do motivo inicial. Neste ponto a peça muda de andamento, passado de trés calme para semínima a $116 \mathrm{bpm}$, momento em que temos um grupo de seis notas repetidas em colcheias pontuadas, escritas em compasso quaternário. A partir do compasso 220 tema inicial é reapresentado com um uma nova rítmica, sendo duas colcheias pontuadas, duas colcheias regulares e outra colcheia pontuada. Esta figura é modificada com o acréscimo de harmônicos artificiais, em contexto de quatro colcheias pontuadas e duas regulares.

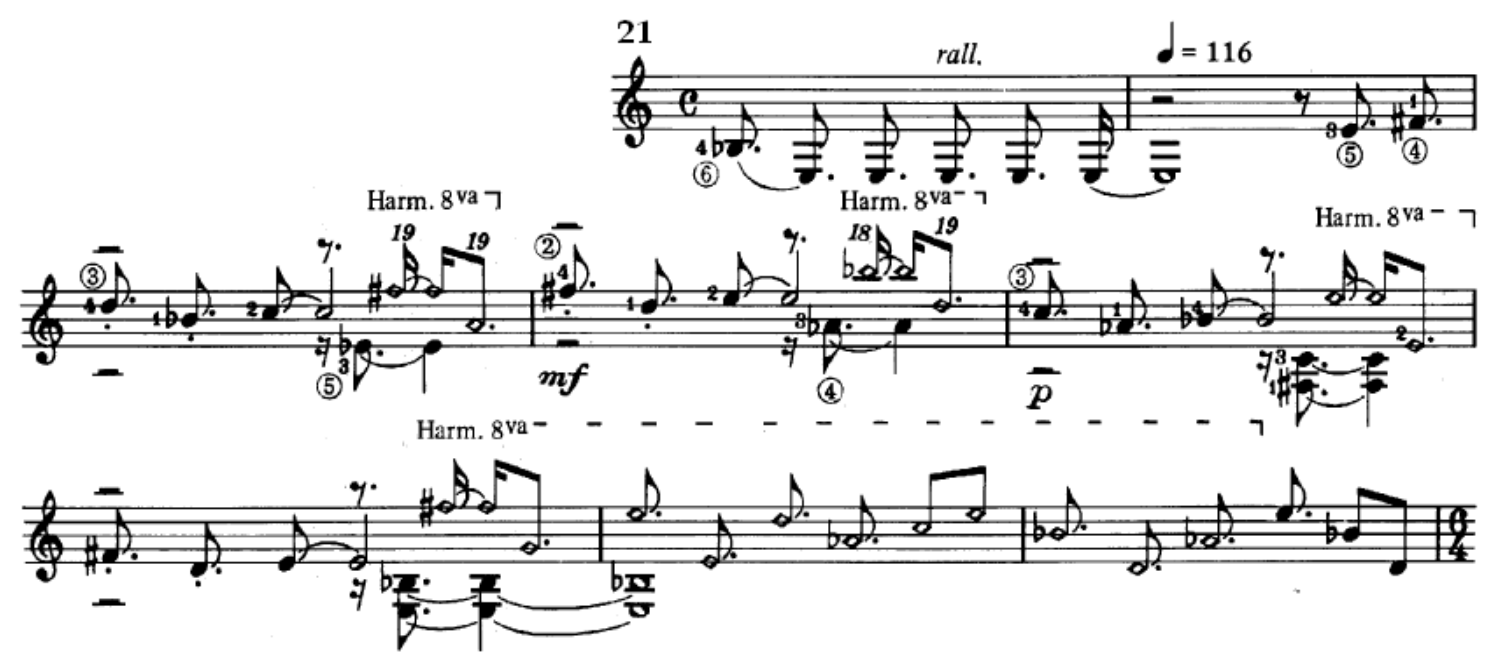

Divertimento compassos 21 a 28 
No compasso 29, a métrica adotada é a de $6 / 4$ com somente colcheias pontuadas.

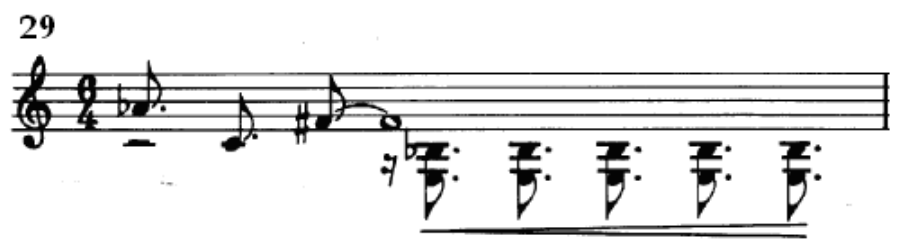

Divertimento compasso 29

A partir do compasso 31 uma nota ré executada na corda sol é repetida sobre uma base formada por um ostinato executado sobre a ré grave aberta e ré sustenido na corda lá. Este ostinato é formado por um grupo de semicolcheias e dois grupos consecutivos de seis semicolcheias.

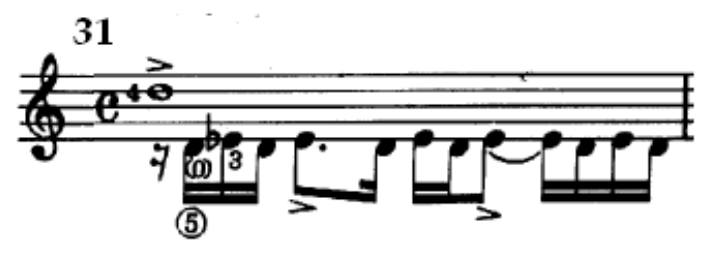

Divertimento, compasso 31

Entre os compassos 38 a 41 o tema principal é novamente reapresentado de maneira variada, constatamos, porém, que ritmicamente e melodicamente esta variação é idêntica à presente entre os compassos 23 a 26. Entretanto, a passagem citada possui uma textura distinta em seu acompanhamento que consiste de uma voz secundária cromática que cujo padrão rítmico que preenche as lacunas existentes entre notas do motivo variado, criando uma densa textura polifônica que remete à sonoridade de dois violões, o que nos leva a crer que a experiência de Sérgio Assad como compositor e arranjador para o Duo Assad encontra reflexos em seu processo criativo. 

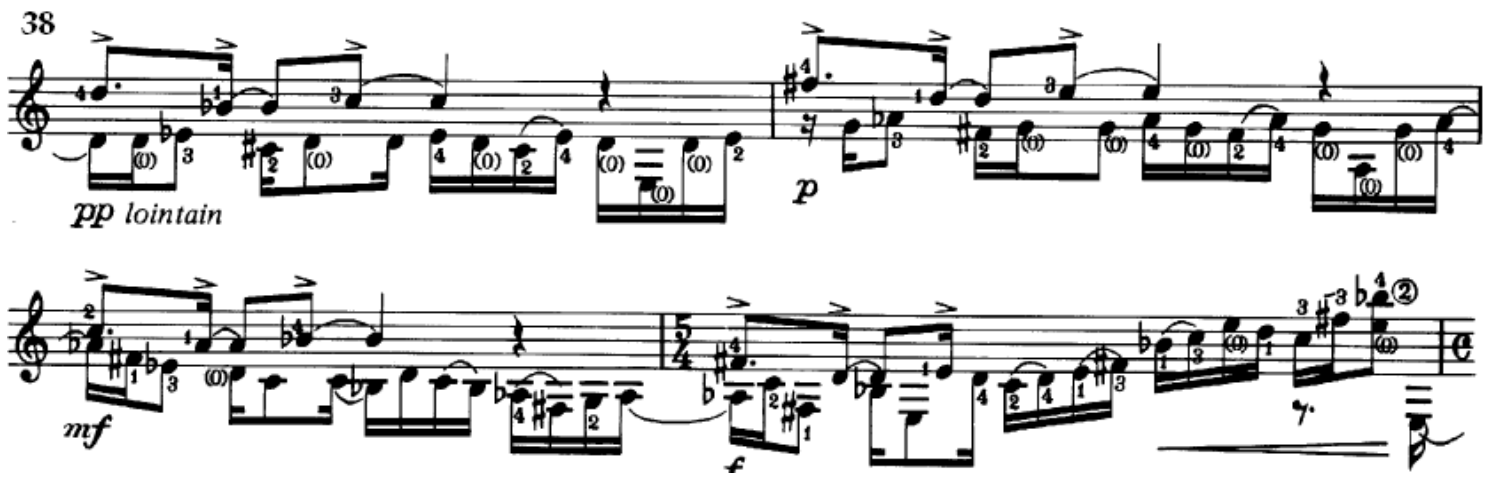

Divertimento, compasso 38 a 41

Após a elaboração citada, colcheias pontuadas são novamente elaboradas na corda Mi (6) acompanhando uma tríade aumentada entre os compassos 42 e 44.

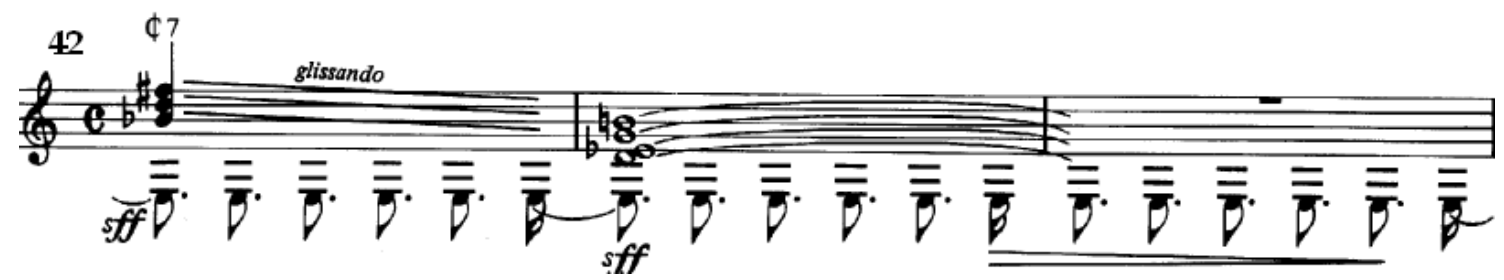

Divertimento, compassos 42 a 44

Entre os compassos 45 e 49, Assad explora as possibilidades de escrita de ritmos sincopados ao empregar o uso do compasso 7/8. Nesta elaboração encontramos novamente o emprego de figuras rítmicas que, intercaladas, produzem um efeito rítmico inusitado.
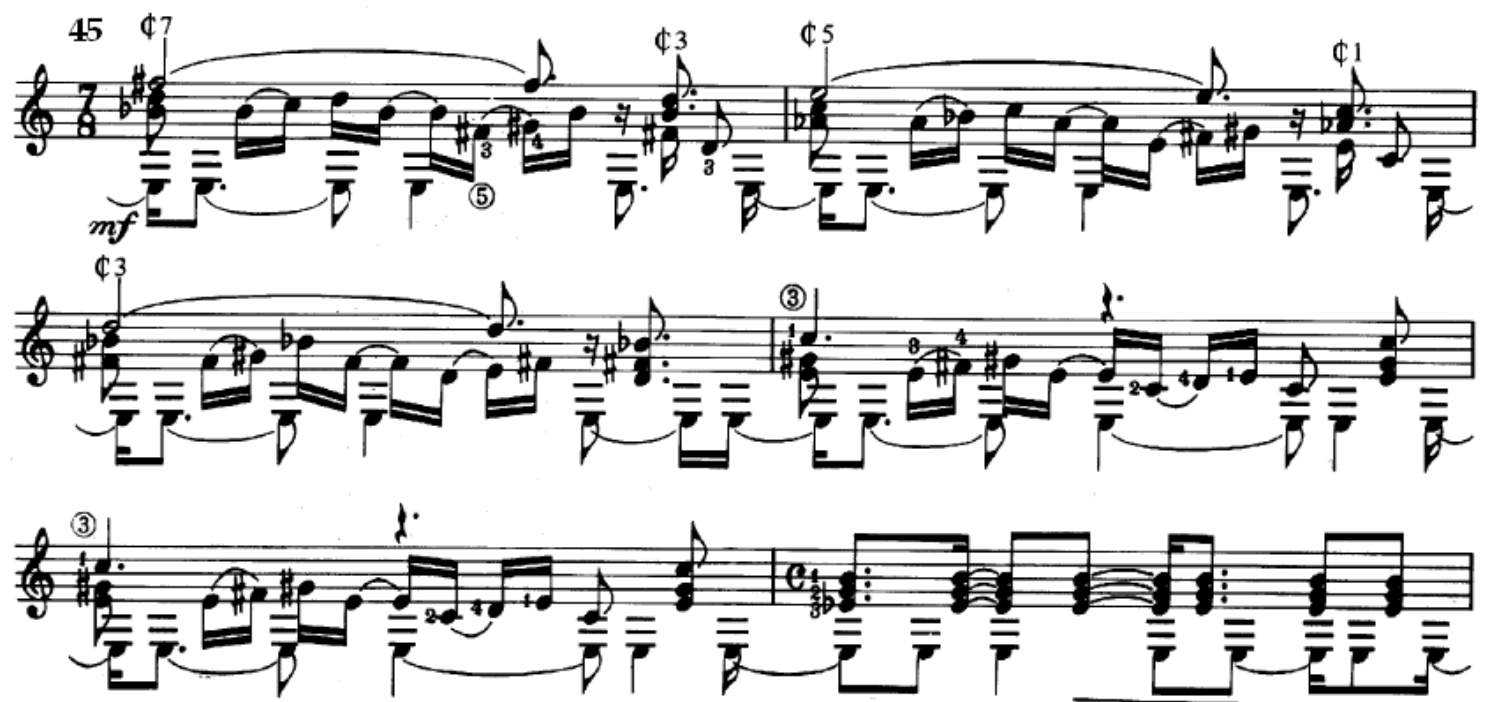

Divertimento compassos 45 a 49 
Novamente, entre os compassos 50 e 51, Assad demonstra sua predileção pelo emprego de síncopes, ao elaborar um grupo de quatro colcheias pontuadas seguidas de duas colcheias regulares executadas em um acorde de $\mathrm{Eb}(\# 5)$. Outra vez o compositor remete a ritmos brasileiros ao intercalar entre os acordes uma nota pedal mi com ostinato rítmico executada na sexta corda (6). Obtém-se como resultado sonoro um padrão rítmico típico do gênero samba.

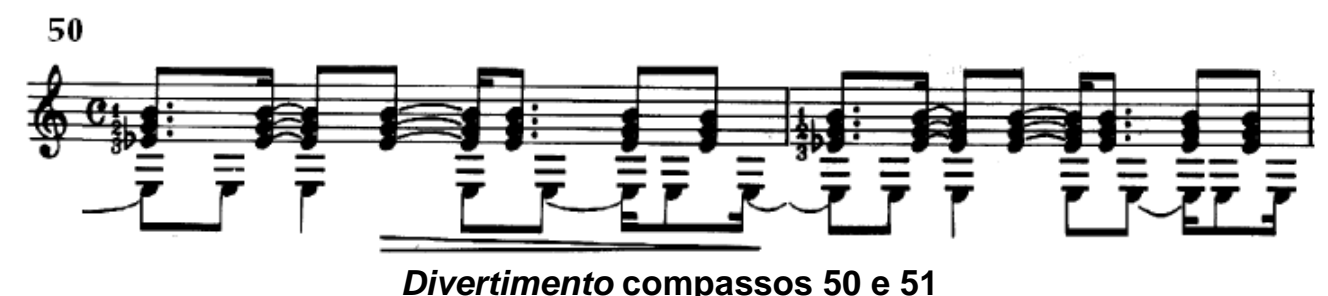

Outras figuras formadas por colcheias pontuadas, similares à descrita neste item, podem ser encontradas nos compassos: 79, 88, 89, 91, 97, 99, 101 e no trecho que compreende do compasso 121 a 131 . Com ilustrativos deste procedimento, citamos o compasso 88 por possuir acordes em colcheias pontuadas e uma linha melódica em anacruse na voz superior, o que remete a gêneros de música popular brasileira.

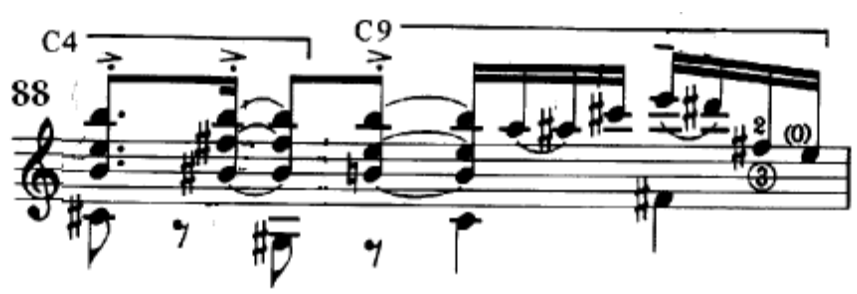

Divertimento compasso 88

Em diversas passagens o padrão rítmico explorado pelo compositor serve de moldura para diferentes elaborações. Um exemplo do emprego deste recurso pode ser encontrado na associação presente entre os compassos 88 a 89 e 121 a 124. Nesses compassos é possível perceber padrões rítmicos similares que são elaborados para ambas as passagens e que também se repetem no Prelúdio e Toccatina entre os compassos 16 e 23. 


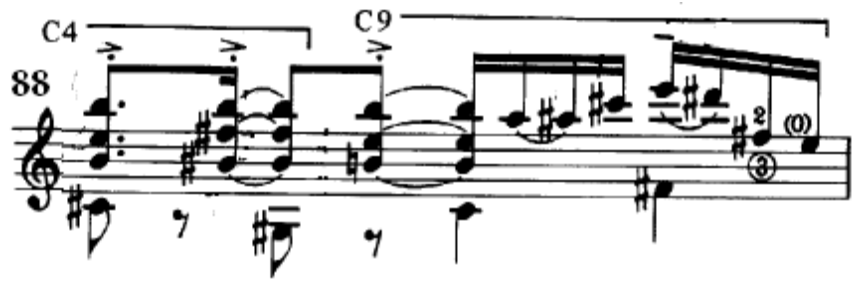

Divertimento compasso 88

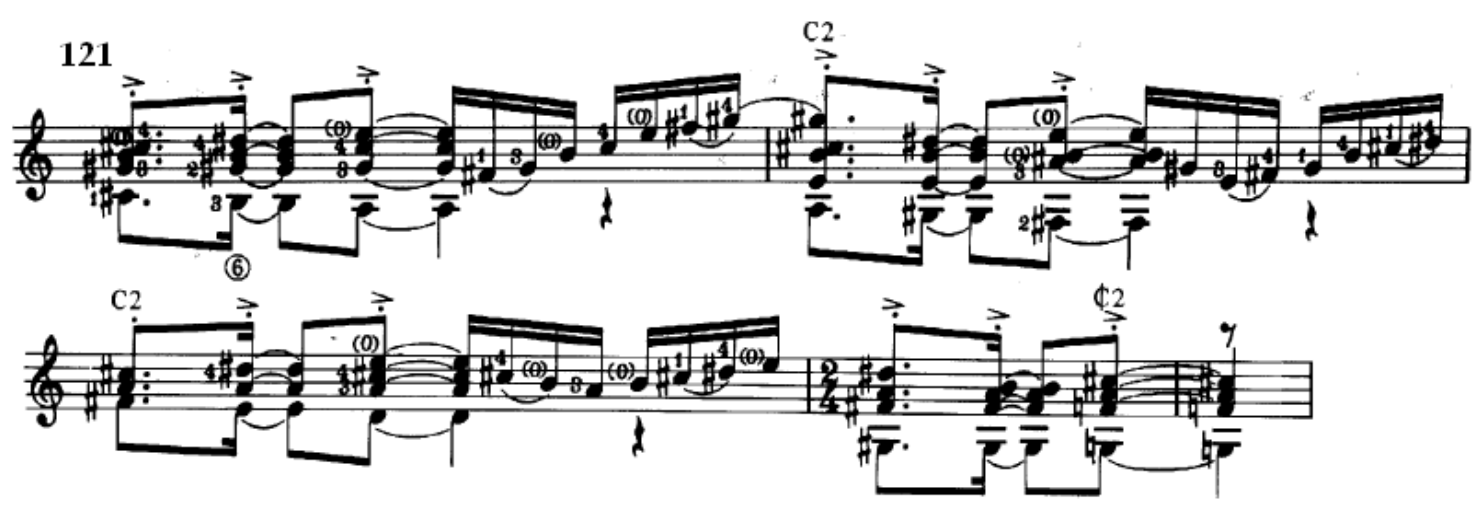

Divertimento compassos 121 a 124

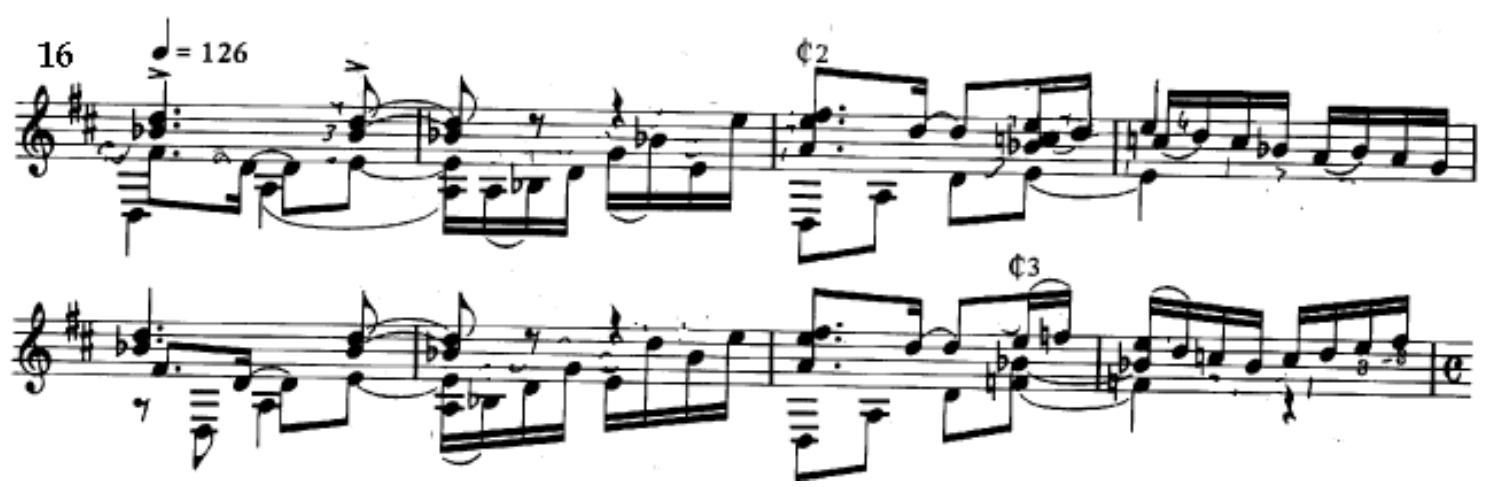

Prelúdio e Toccatina compassos 16 a 23

Tal relação é também verificada entre os compassos 96 a 101 e 125 a 132 , onde podemos supor uma relação entre ambas visto que a construção rítmica é similar e a função destas passagens servirem de ponte a outras elaborações. 


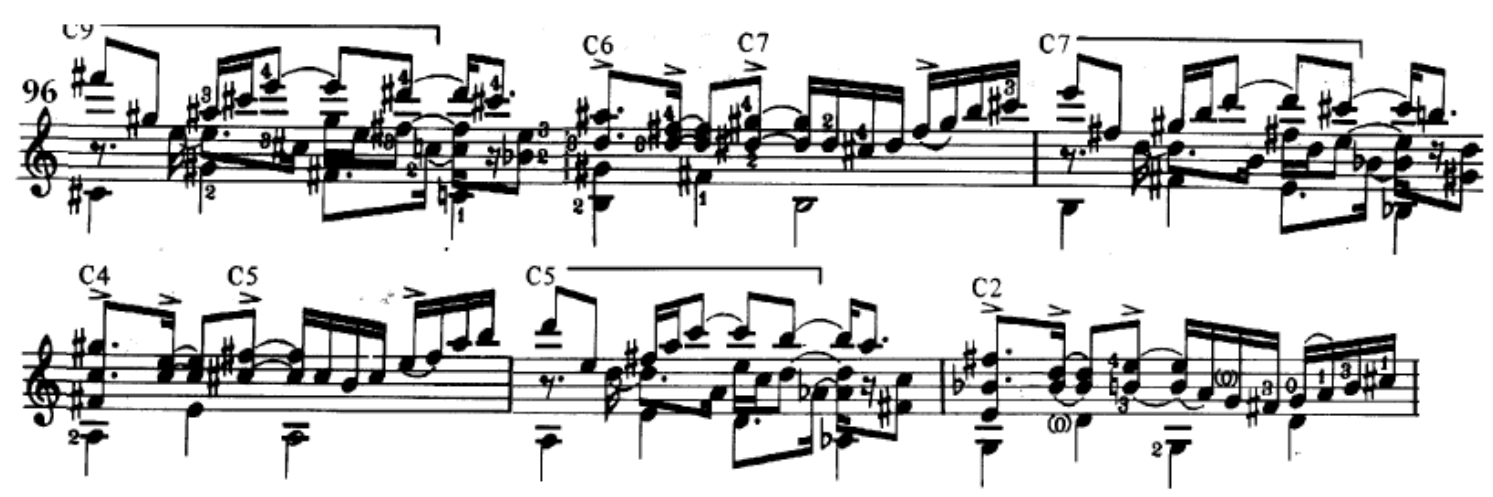

Divertimento compasso 96 a 101
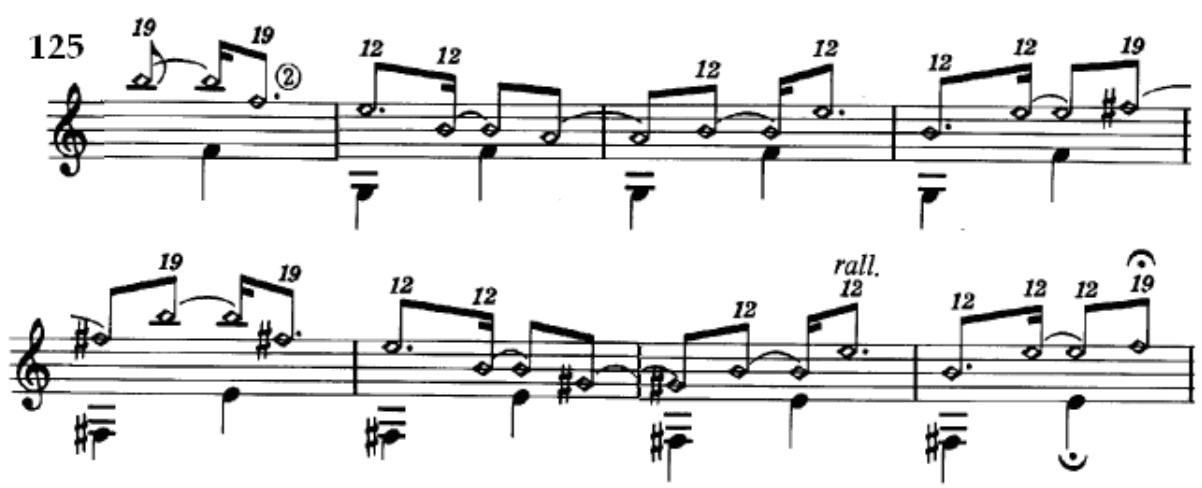

Divertimento compasso 125 a 132

\subsubsection{Prelúdio e Toccatina}

Neste item serão analisadas as figuras rítmicas sincopadas encontradas no Prelúdio Toccatina.

Deve-se ressaltar que a seção do Prelúdio apresenta em sua maioria uma rítmica formada de figuras regulares não havendo sincopas ou deslocamento de acentuação. A exceção é feita ao compasso 03 onde é elaborado um trecho em polirritmia ${ }^{75}$. Na passagem citada é utilizado na voz de soprano um grupo de colcheias pontuadas, sendo implícita uma idéia rítmica de sincopa, enquanto é desenvolvida na voz intermediária uma linha melódica em tercinas.

\footnotetext{
${ }^{75}$ Efeito musical em que duas células rítmicas de valores diferentes são sobrepostas.
} 


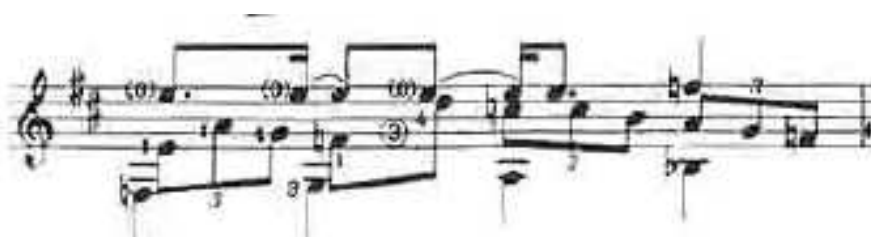

Prelúdio e Toccatina compasso 3

Novamente verificamos o recurso da utilização do ritmo como elemento unificador, visto que em todas as passagens lentas da obra, como a citada anteriormente, foram empregadas tercinas como veremos a seguir:

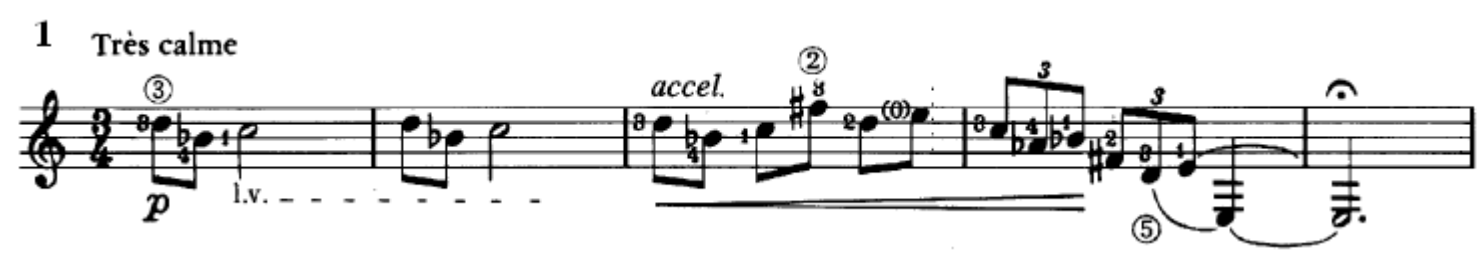

Divertimento compassos 1 a 5

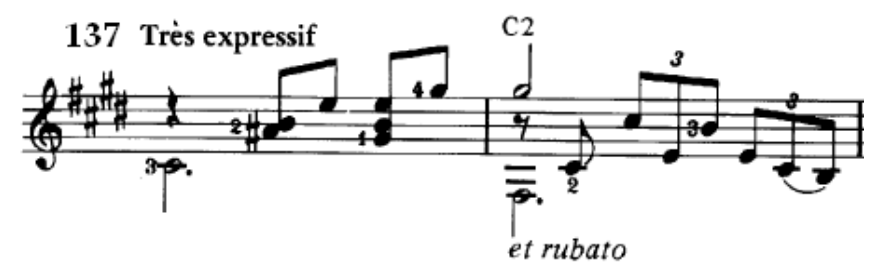

Divertimento compassos 137 e 138

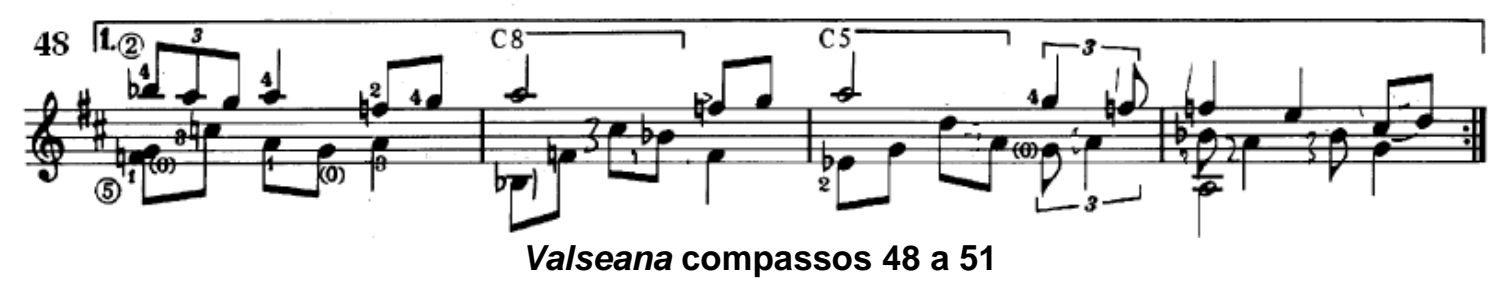

A entrada da Toccatina é iniciada em 2/4 no compasso 16 com uma figura de colcheias pontuadas seguidas de um grupo de semicolcheias iniciado em anacruse no compasso seguinte. Neste compasso 16, as notas constituintes da voz do baixo se encontram na cabeça de cada tempo, agindo como marcação de tempo forte para os deslocamentos de ritmo encontrados nas vozes superiores. Uma rítmica semelhante à encontrada no compasso 16 é repetida entre os compassos 20 e 23, porém havendo o deslocamento da nota ré na melodia do baixo no compasso 20 , do tempo forte para 0 contratempo. 

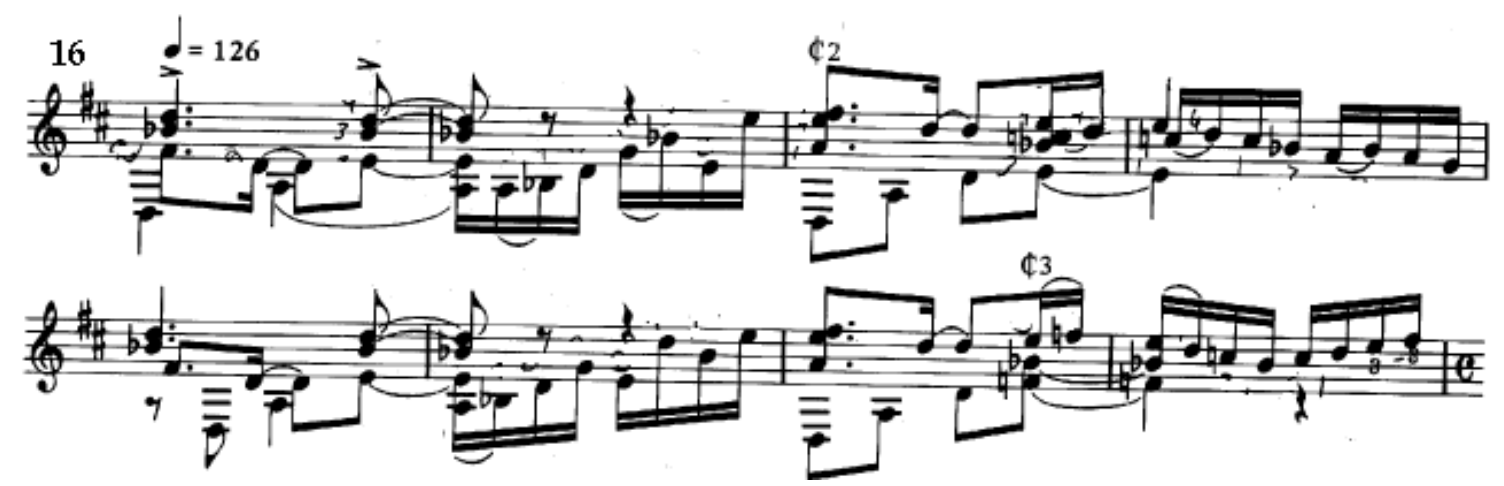

Prelúdio e Toccatina compassos 16 a 23

A partir do compasso 24 detectamos uma figura de acompanhamento em semicolcheias contínuas com o deslocamento rítmico implícito no padrão melódico elaborado. O padrão rítmico adotado é de dois grupos de seis semicolcheias (que corresponde à semínima pontuada) e um grupo com quatro semicolcheias em compasso 4/4. Tal padrão rítmico, referido acima por Assad $(3+3+2)$ também é comum na música nordestina.

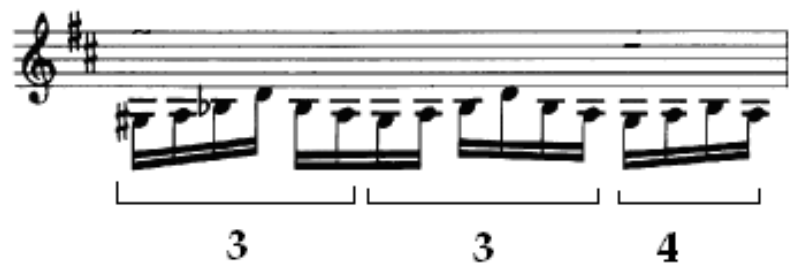

Padrão de acompanhamento de Prelúdio e Toccatina

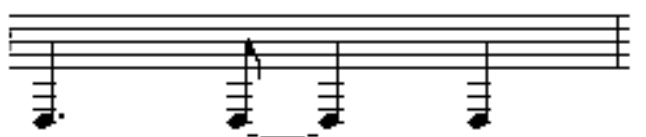

Padrão rítmico derivado do acompanhamento

A elaboração do Motivo 1 sobre o acompanhamento descrito presente entre os compassos 26 e 34, possui momentos em que o emprego de colcheias pontuadas enfatizam a natureza sincopada do acompanhamento e que novamente remontam à concepção de escrita para violão solo como um pequeno grupo de câmara. 


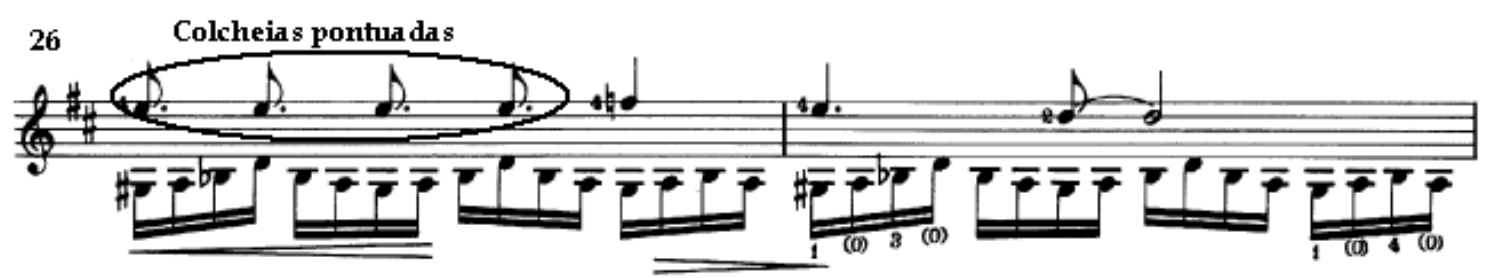

Prelúdio e Toccatina compassos 26 e 27

Entre os compassos 44 e 54 encontramos o efeito de deslocamento do pulso via a escrita da melodia elaborada em contratempo. Assim como em diversas elaborações de mesma natureza em outras peças de Assad, encontramos o efeito de continuidade e deslocamento obtidos pelo emprego de semicolcheias contínuas ou iniciadas em suspensão no tema principal na voz superior e a presença da melodia realizada pelo baixo intercalando os contratempos e tempos fortes. O emprego deste tipo de textura novamente reforça a hipótese de que a ótica da escrita influi para os dois instrumentos nas elaborações para violão solo no idioma composicional de Sérgio Assad.

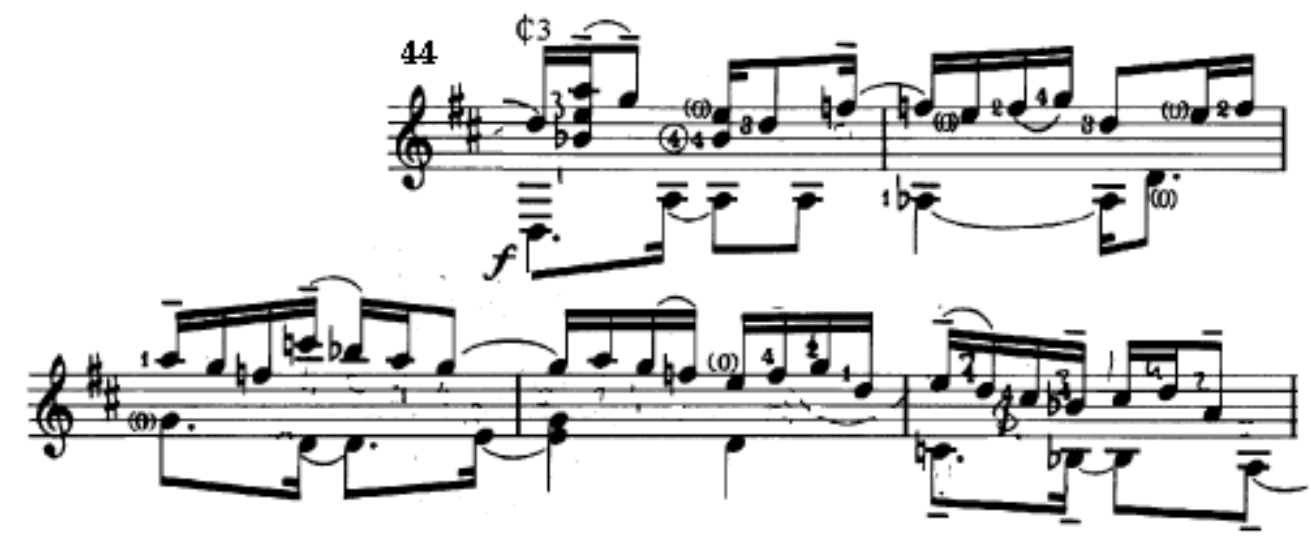

Prelúdio e Toccatina compassos 44 a 48

A elaboração encontrada entre os compassos 62 e 71 apresenta uma concepção similar com a entrada do tema do soprano deslocada como suspensão para o compasso 63, causando deslocamento das acentuações durante o restante da elaboração. 

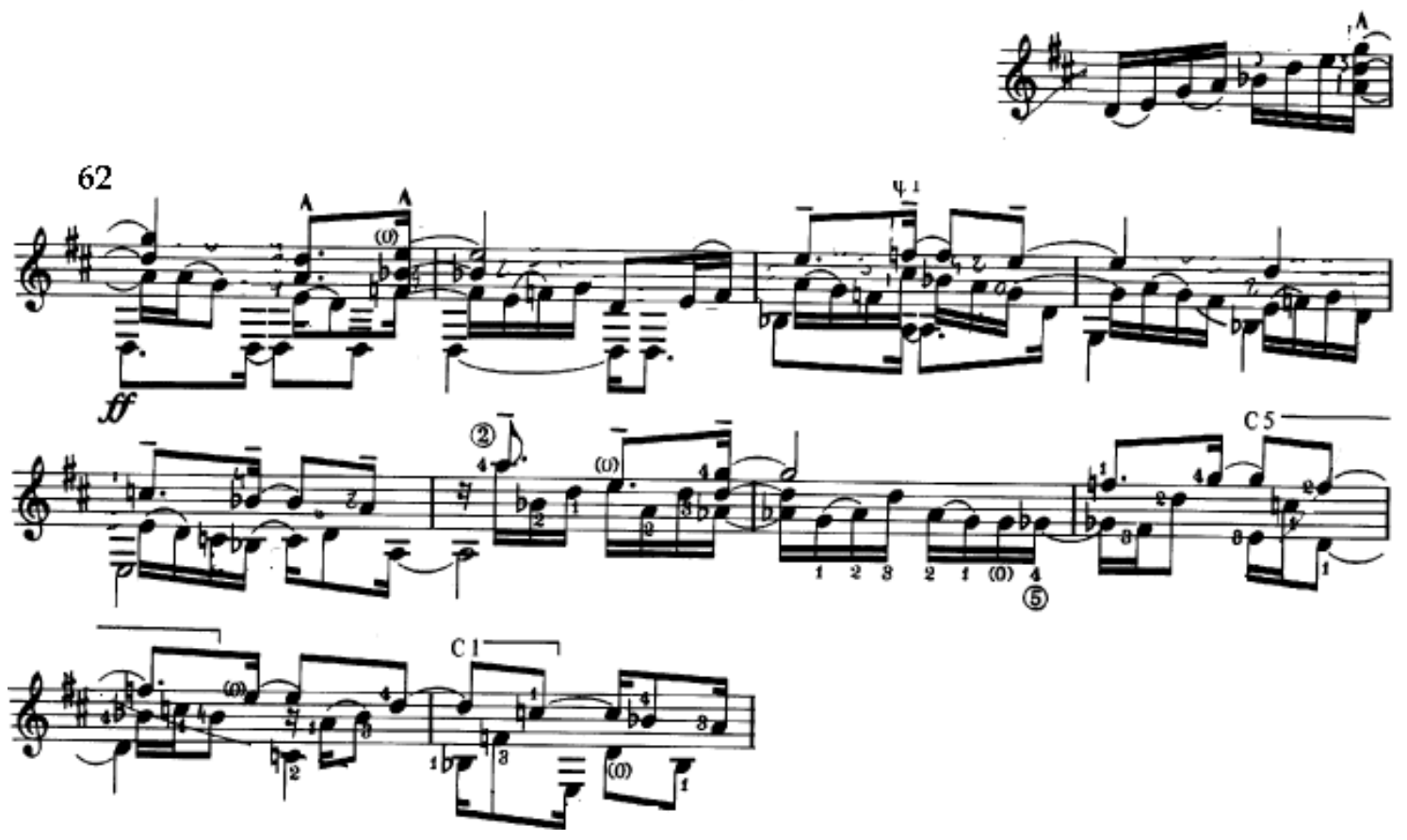

Prelúdio e Toccatina compassos 62 a 71

Entre os compassos 80 e 96, o diálogo entre as vozes se torna mais denso, havendo figuras alternadas em síncopas e semicolcheias em ambas as vozes com acentuações nos deslocamentos rítmicos da voz aguda. Encontramos também nesta elaboração, uma célula formada por duas semicolcheias ligadas e uma colcheia em articulação staccato ${ }^{76}$. Esta célula está presente na elaboração seguinte entre os compassos 97 e 116. Neste trecho vemos uma passagem em que o gênero do baião é citado através de clichês rítmicos e melódicos. Entre estes clichês encontramos figuras rítmicas de síncopas formadas por semicolcheia, colcheia e semicolcheia articulações staccato em colcheias, figuras de colcheias pontuadas no acompanhamento no baixo e passagens melódicas em semicolcheias repetidas, os quais podemos deduzir tratarem-se de influências do "repente nordestino" 77 dada a presença de duas vozes organizadas em forma de pergunta e resposta.

\footnotetext{
${ }^{76}$ Tipo de articulação em que a nota é executada de maneira mais curta e seca.

77 Gênero musical improvisado por um "cantador", com o acompanhamento de viola ou não, oriunda da Península Ibérica por influência dos mouros. No Brasil, o repente desembarcou, há mais de 200 anos, trazido pelos portugueses. Caracterizado pelo improviso, os "cantadores" fazem os versos "de repente", em um desafio com outro "cantador". Tal duelo enfatiza o ritmo e a agilidade mental que permita encurralar o oponente apenas com a força do discurso. (Lopes, 2001)
} 
Articulaçóes em Staccato
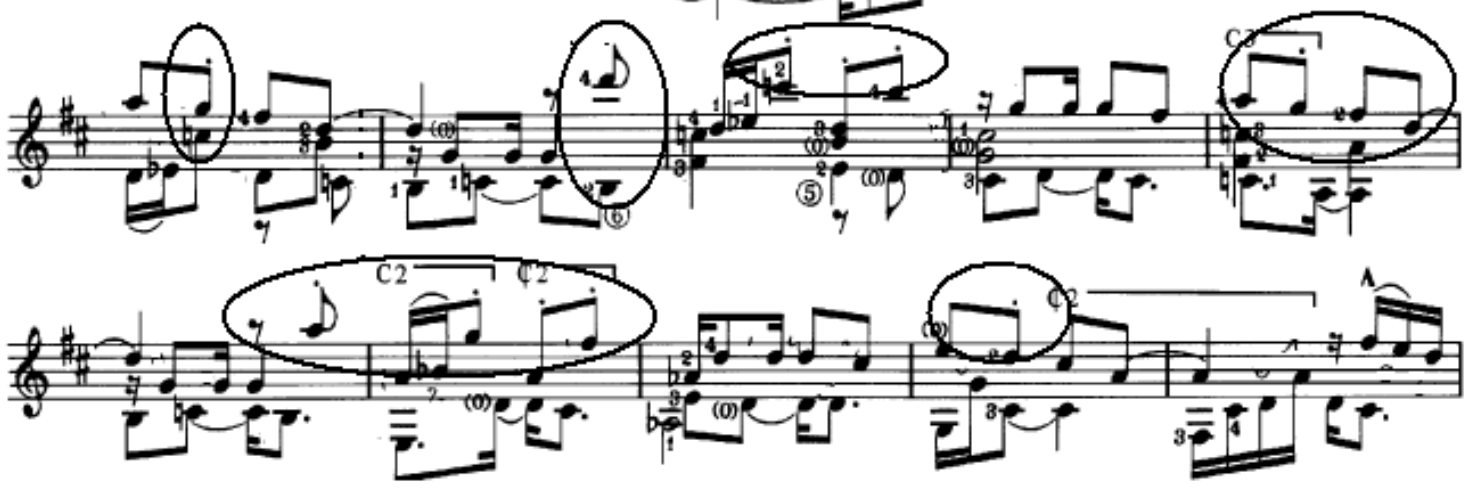

Clichês rítmicos do baião
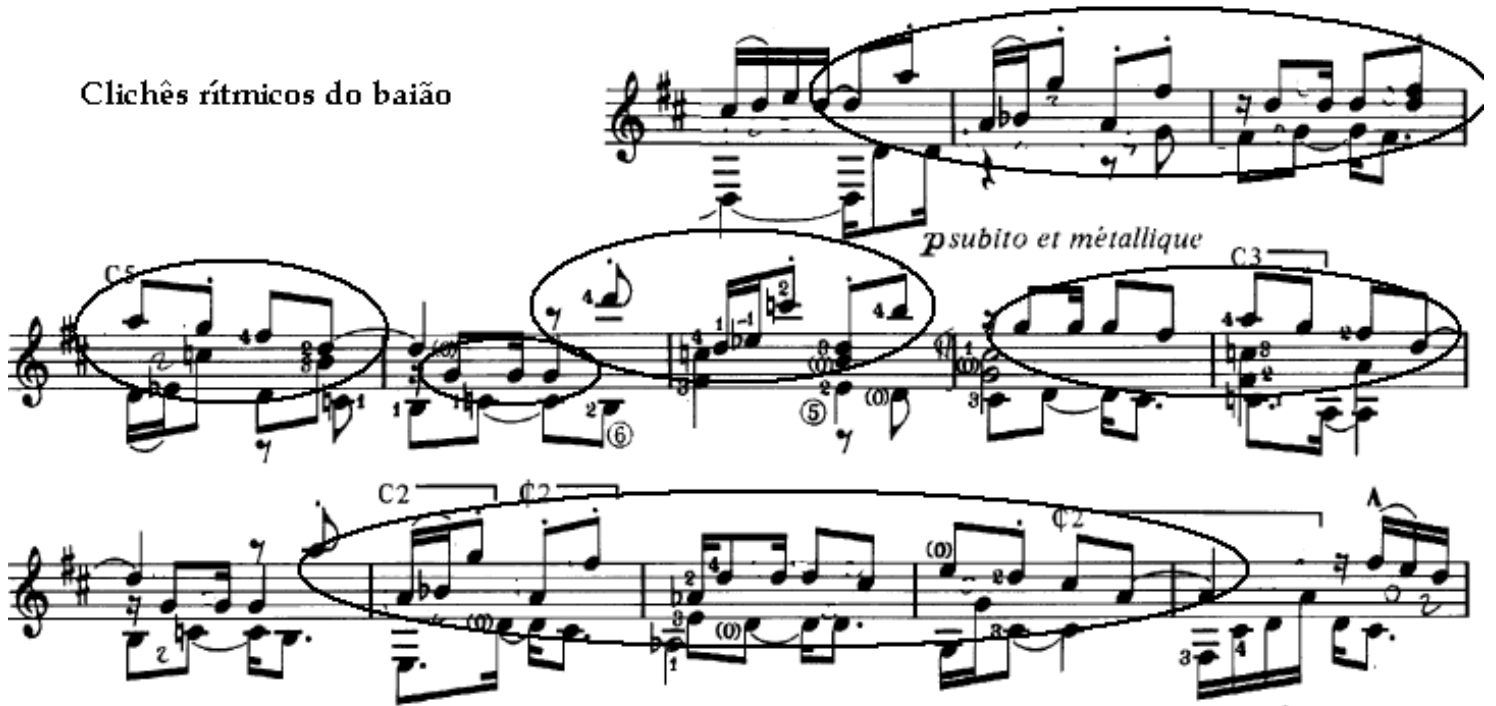

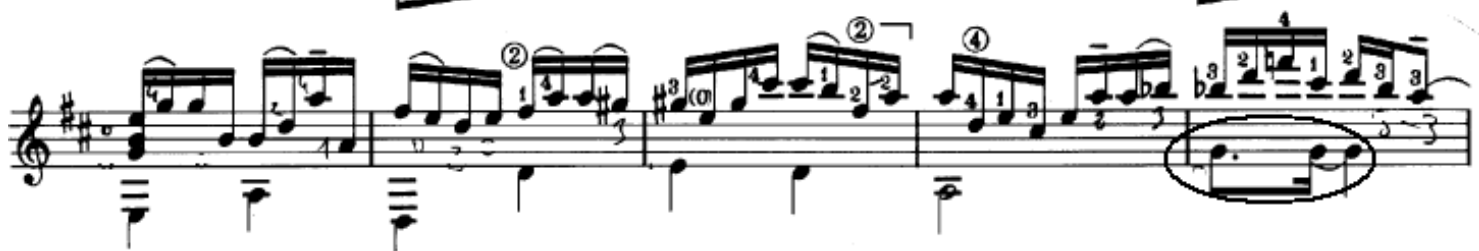

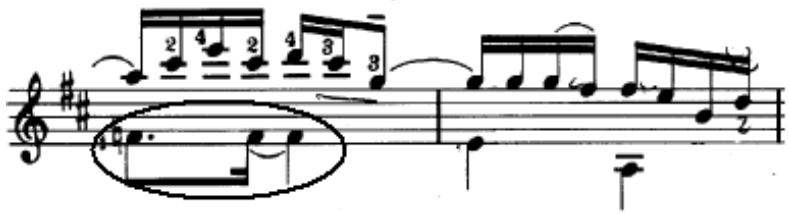



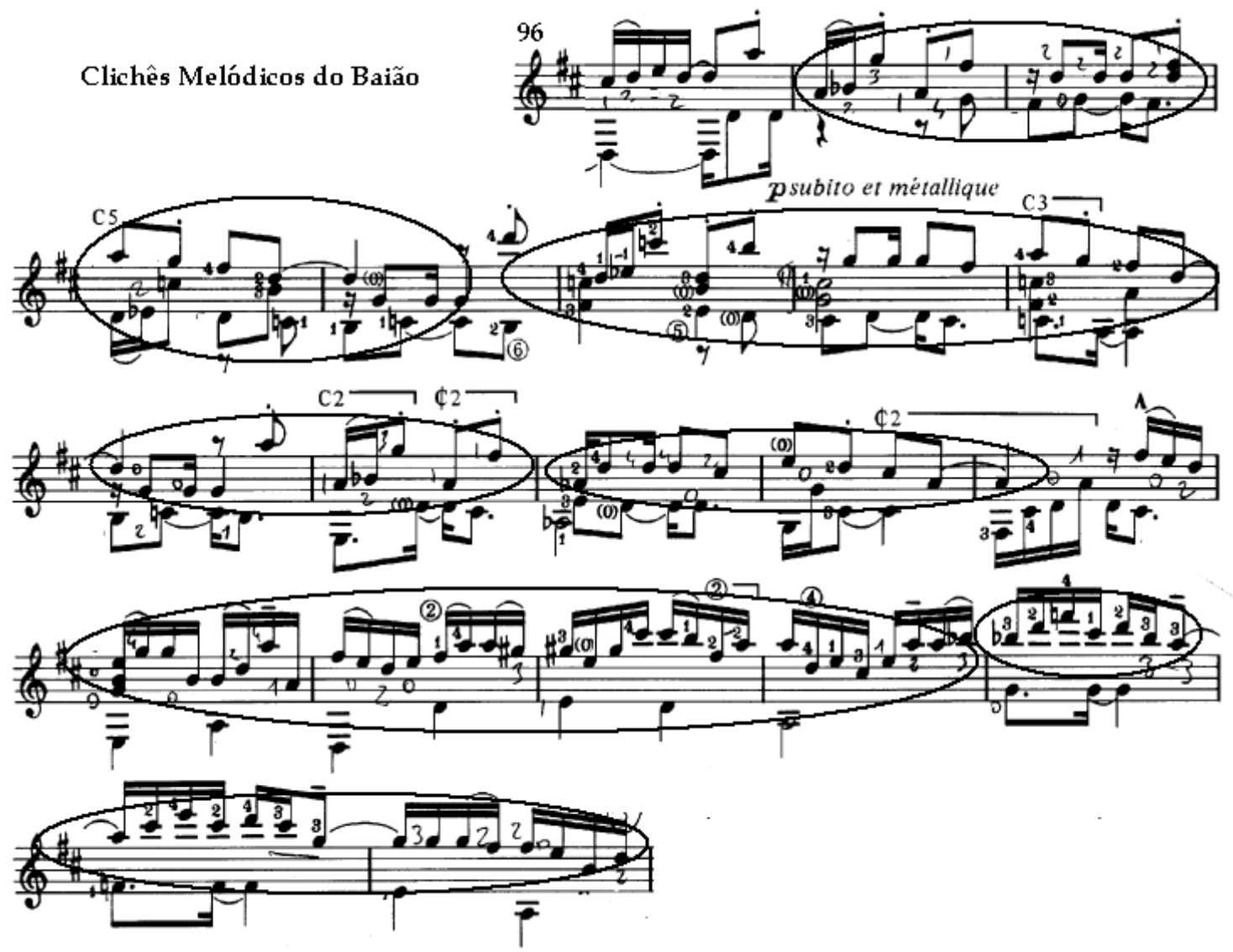

Prelúdio e Toccatina, compassos 96 a 115

Entre os compassos 116 e 120 o ostinato é retomado pelo baixo (como no início da Toccatina, compassos 24 e 35) e a fórmula de compasso é modificada para $4 / 4$ até o desfecho da peça. No compasso 120, encontramos uma figura em dois grupos de seis semicolcheias e um de quatro, com acentuação em cada grupo. Os dois compassos seguintes (122 e 123) apresentam acentuações deslocadas em cada figura rítmica utilizada.

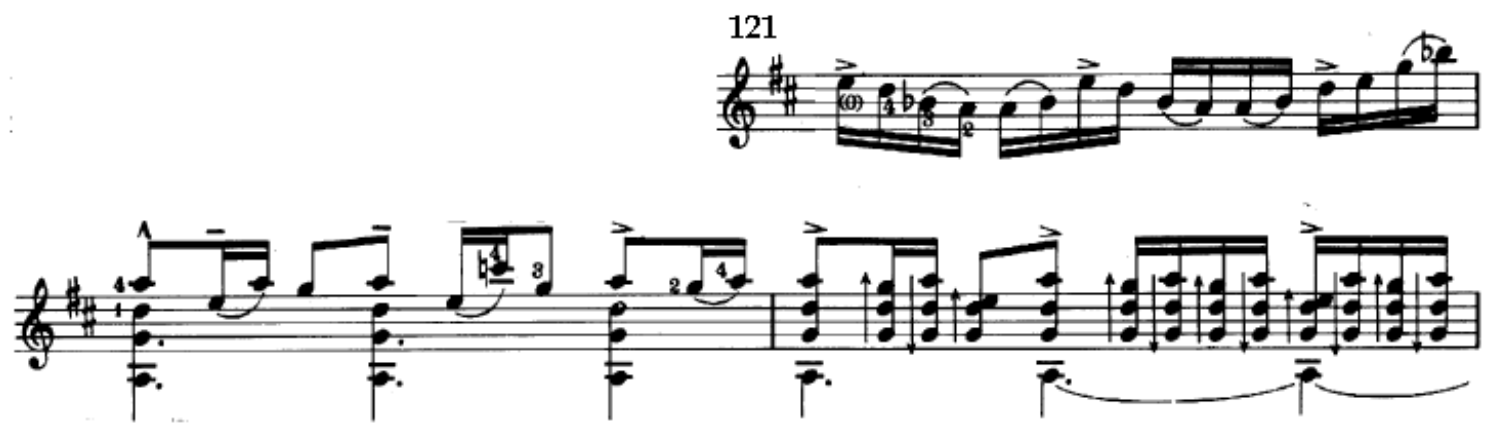

Prelúdio e Toccatina, compassos 121 a 123

O desfecho da peça (compasso 124) reapresenta um motivo de colcheias em staccato presente na elaboração iniciada no compasso 97. Este 
motivo é elaborado no compasso 125 com o deslocamento rítmico do acorde final da peça (compasso 126).

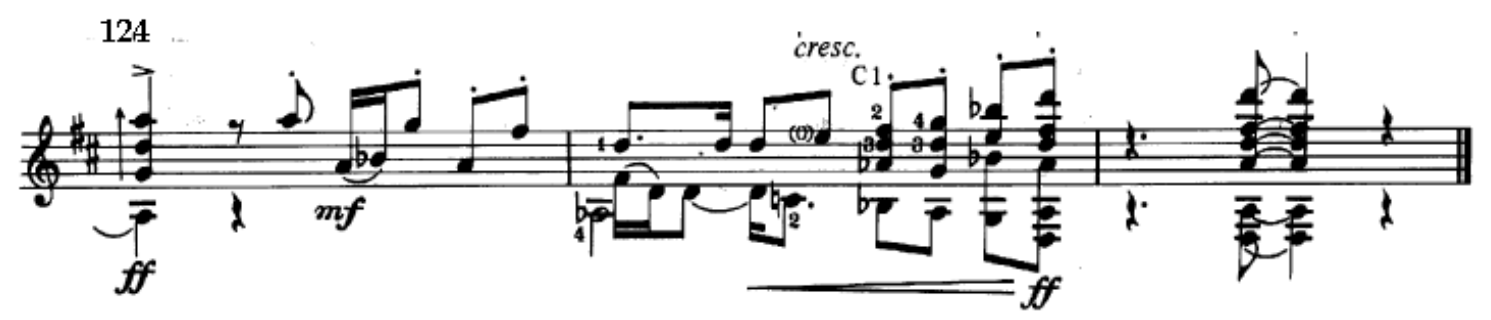

Prelúdio e Toccatina, compassos 124 a 126

Neste item verificamos o emprego do aspecto rítmico como um elemento unificador da obra como um todo dado os diversos recursos e convenções recorrentes detectados.

\subsection{Análise Harmônica}

Este tópico tem como objetivo demonstrar alguns processos de elaboração harmônica e a utilização de estruturas associadas a determinadas escalas pelo compositor, dentre as quais foram elaboradas em texturas arpejadas, polifônicas, homofônicas e corais.

Visto que em diversos momentos a obra transita entre uma linguagem harmônica que transita entre $o$ atonal livre e tonal permeada por diversos acordes em que a utilização de tensões se faz presente sem estas tenham a função de ornamentação, se tornando assim entidades harmônicas autônomas, como ocorre na música popular instrumental e no jazz, sentimos que esta análise deve ser executada utilizando-se métodos de ambas as orientações estéticas onde sentimos que seja aplicável. Esta abordagem foi baseada em precedentes encontrados em dois trabalhos acadêmicos que abordavam a 
linguagem de Radamés Gnattali ${ }^{78}$, outro compositor cuja estética apresenta os mesmos desafios com relação à análise harmônica.

Para a execução desta análise utilizamos alguns tratados de harmonia de Joachin Koellreutter ${ }^{79}$, Arnold Schoenberg ${ }^{80}$, Robert Ottman ${ }^{81}$, Vicent Persichetti $^{82}$, Nelson Farias ${ }^{83}$, Almir Chediak ${ }^{84}$ e Sérgio Freitas ${ }^{85}$.

A nomenclatura de cada acorde será feita por extenso seguida pela sua respectiva cifra para que haja um maior entendimento desta análise.

\subsubsection{Divertimento}

Durante a introdução de Divertimento (compassos 1 a 83) Assad emprega predominantemente a escala de tons inteiros, também conhecida como escala hexafônica, e suas estruturas harmônicas ${ }^{86}$.

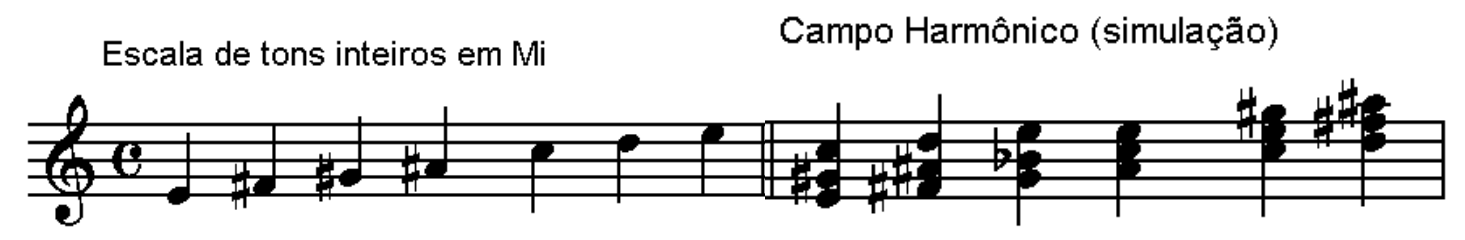

Escala de tons inteiros

Como exemplo do emprego desta escala, selecionamos a passagem contida entre os compassos 45 a 49 , onde estão intercaladas tríades aumentadas com melodias provenientes da escala de tons inteiros.

\footnotetext{
${ }^{78}$ OLIVEIRA, Ledice Fernandes de. Radamés Gnattali e o Violão: Relação entre os campos de produção da música. Universidade Federal do Rio de Janeiro, Rio de Janeiro, 1999.

CORREA, Márcio Guedes, As Escolhas Instrumentais de Radamés Gnattali no Concerto Carioca nº 1 . São Paulo Escola Estadual Paulista "Júlio de Mesquita Filho" Instituto de Artes - São Paulo, São Paulo, 2007.

${ }^{79}$ KOELLREUTER, Hans. Joachin. Harmonia Funcional: introdução à teoria da funções harmônicas. São Paulo: Editora Ricordi, 1978.

${ }^{80}$ SCHOENBERG, Arnold. Harmonia, São Paulo: Editora Unesp, 2001.

${ }^{81}$ OTTMAN, Robert W. Advanced Harmony, Theory and Practice. New Jersey: Prentice Hall, 2000.

${ }^{82}$ PERSICHETTI, Vicent. Armonia Del Siglo XX. Madri: Real Madrid Editores, 1985.

${ }^{83}$ FARIAS, Nelson. A arte da improvisação. São Paulo, Lumiar Editora, 1991.

${ }^{84}$ CHEDIAK, Almir. Harmonia e Improvisação Volumes 1 e 2. São Paulo: Lumiar Editora 1979.

${ }^{85}$ FREITAS, Sergio Paulo Ribeiro de. Teoria da harmonia na música popular: uma definição das relações de combinação entre os acordes na harmonia tonal. Dissertação de Mestrado. São Paulo: Universidade Estadual Paulista, 1995.

${ }^{86}$ Esta escala é constituída por apenas intervalos de um tom e tem como estrutura harmônica derivada tríades com quinta aumenta a cada grau da escala. (BERNARD,SAKER 2003, p.231)
} 

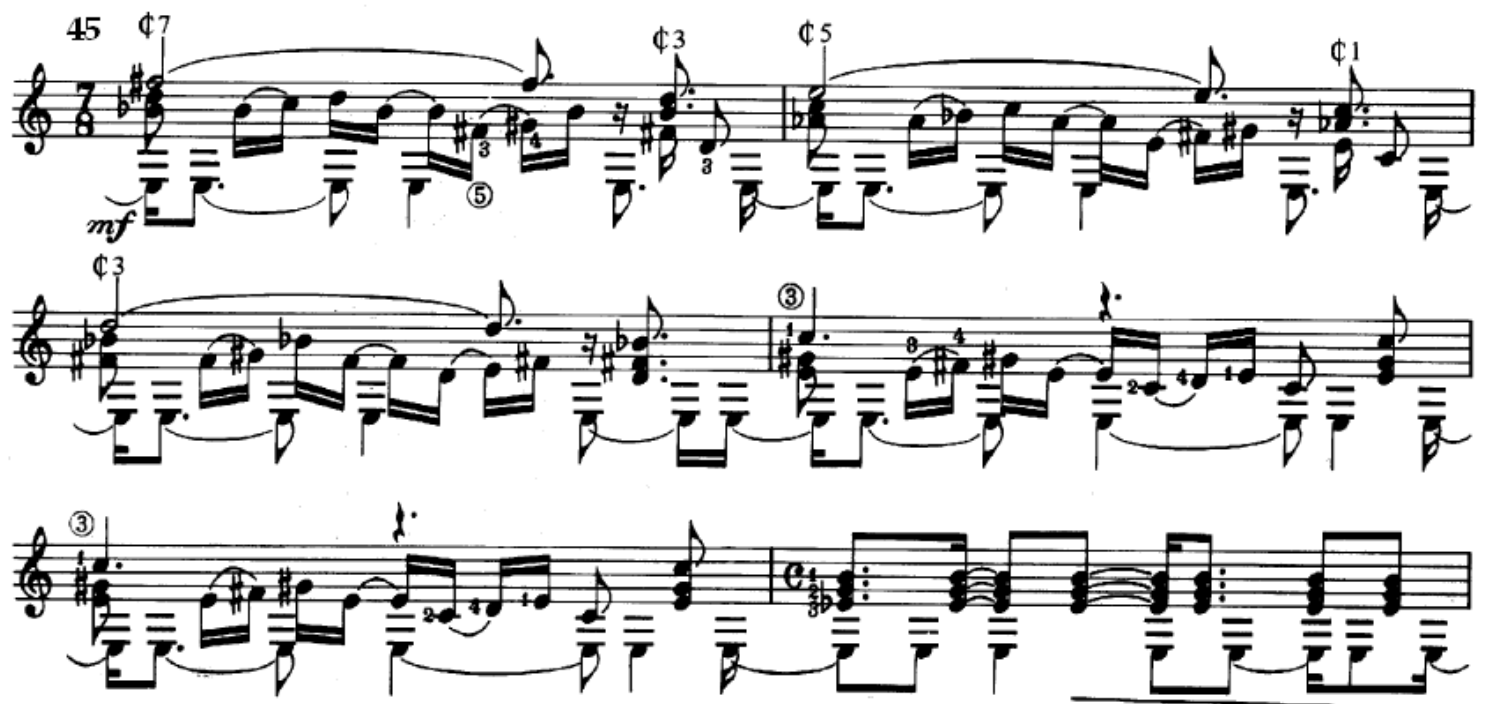

Divertimento, compassos 45 a 49

A seção A do Divertimento (compassos 84 a 136), entretanto é elaborada por procedimentos que nos possibilitam em classificá-la como tonal. O que ocorre, porém, é a ausência de uma tonalidade específica, havendo citação passageira de diversas tonalidades e a ocorrência de diversas modulações para outros tons e modos.

Esta seção é iniciada por um acorde de lá maior com sétima maior $(A 7 M)$, seguido de lá menor com sétima maior (Am7M), no compasso 84, estes são seguidos de um acorde de dó sustenido menor com nona (C\#m9), criando uma sonoridade de lá lídio. Ainda neste compasso há um acorde de mi com sétima com baixo em si bemol (E7/Bb), (como dominante individual), sendo resolvido em mi maior com sétima maior (E7M).

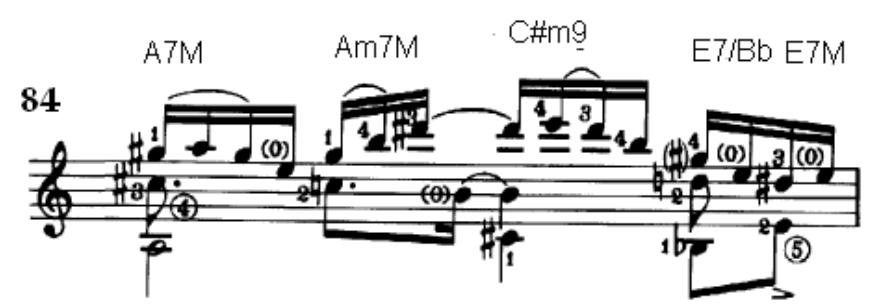

Divertimento, compasso 84 
No compasso 85, um acorde de dó menor com nona $(\mathrm{Cm} 9)$ dá inicio a uma marcha harmônica ${ }^{87}$ em intervalos de quartas em acordes dominantes, com o uso de Sub $V$ invertidos com a quinta no baixo ${ }^{88}$. Esta é iniciada por um acorde de mi bemol com sétima (Eb7), seguido de ré com sétima com baixo em lá (D7/A), sol com sétima com baixo em lá bemol (G7/Ab), dó com sétima com baixo em sol (C7/G), si com sétima com baixo em fá sustenido (B7/F\#) e sol com baixo em fá (G/F).

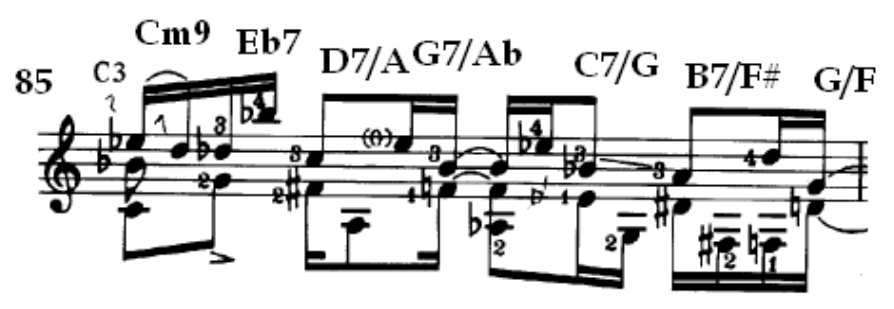

Divertimento, compasso 85

Esta progressão é resolvida num acorde de mi menor sétima (Em7) no compasso 86 , seguido de um lá com sétima e nona $(A 7 / 9)$ ainda no mesmo compasso. Esta é uma progressão característica do modo Dórico ${ }^{89}$, neste caso na tonalidade de mi. A continuidade desta sonoridade é dada pela utilização dos acordes mi menor com nona (Em9) e sol maior com sétima maior (G7M) no compasso 87.

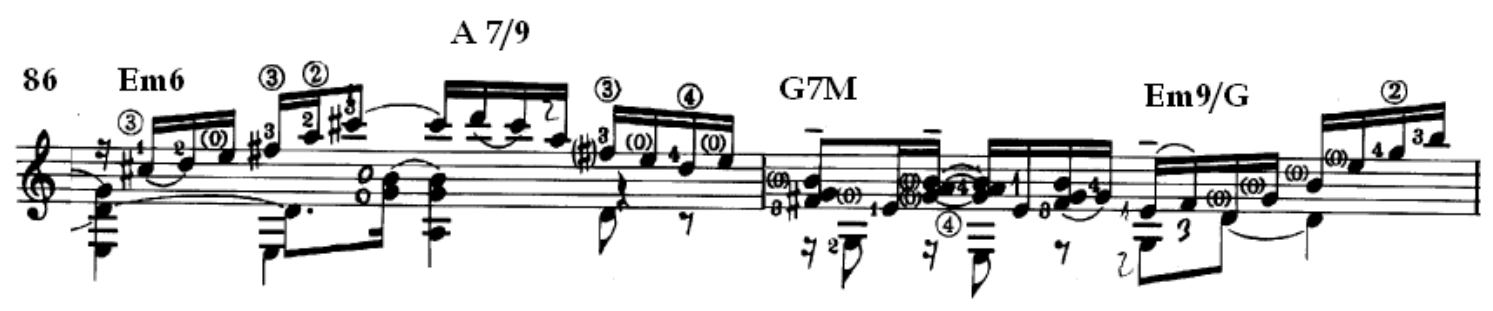

Divertimento compassos 86 a 87

A harmonia sofre então uma modulação ao compasso seguinte (compasso 88) sendo conduzida a Si maior, com o acorde de dó sustenido

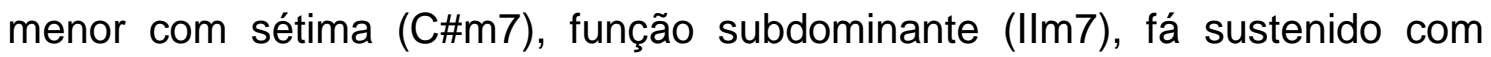
sétima (F\#7) função dominante (V7) chegando à tônica si maior com sétima maior (B7M) no compasso 89.

\footnotetext{
${ }^{87}$ Trecho formado por progressões curtas ou acordes que tem como função a modulação de um tom a outro. (FREITAS 1995, p.50).

${ }^{88}$ Acordes dominantes invertidos, meio tom acima da tônica que substituem a função de dominante ao possuir a mesma função. (Ibdem, p 97)

${ }^{89}$ Modo gerado a partir do segundo grau da escala maior formado pelos intervalos, $\mathrm{T}, 2 \mathrm{M}, 3 \mathrm{~m}$, 4J, 5J, 6M e 7m. (FARIAS, 1991, p31.).
} 


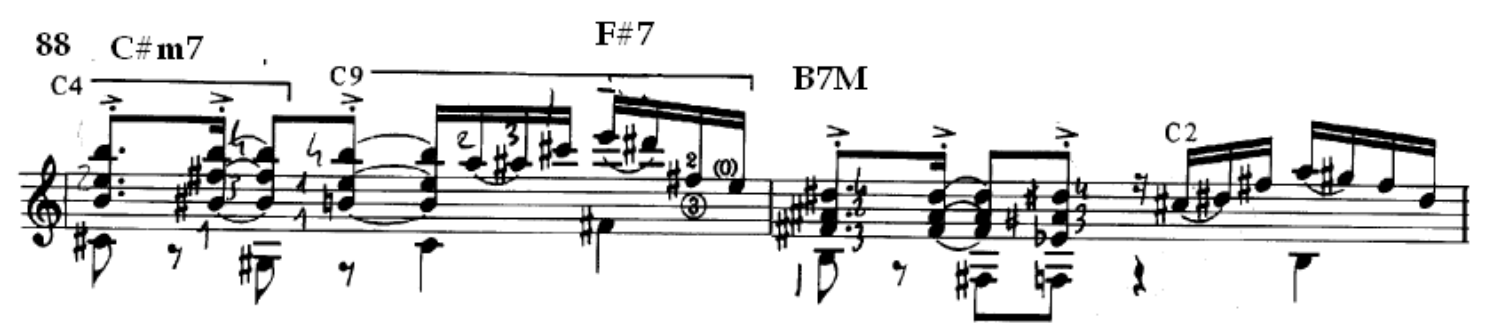

Divertimento, compassos 88 a 89

No compasso 89, é utilizado um acorde de fá maior com sétima e décima terceira $(F 7 / 13)$, que é uma dominante secundária para o quarto grau de Si maior mi maior com sétima maior, (E7M), seguido um si com sétima (B7), que atua como um acorde de dominante substituto para o acorde lá sustenido menor (A\#m) no compasso 90. Este acorde é resolvido no acorde seguinte lá com décima primeira aumentada $[A(\# 11)]$, seguido de sol com sétima maior (G7M), dó sustenido menor com sexta (C\#m6). Esta progressão pode ser analisada como uma progressão modal contendo as seguintes escalas: A lídio ${ }^{90}$, G jônio ${ }^{91}$ e C\# dórico ${ }^{92}$.

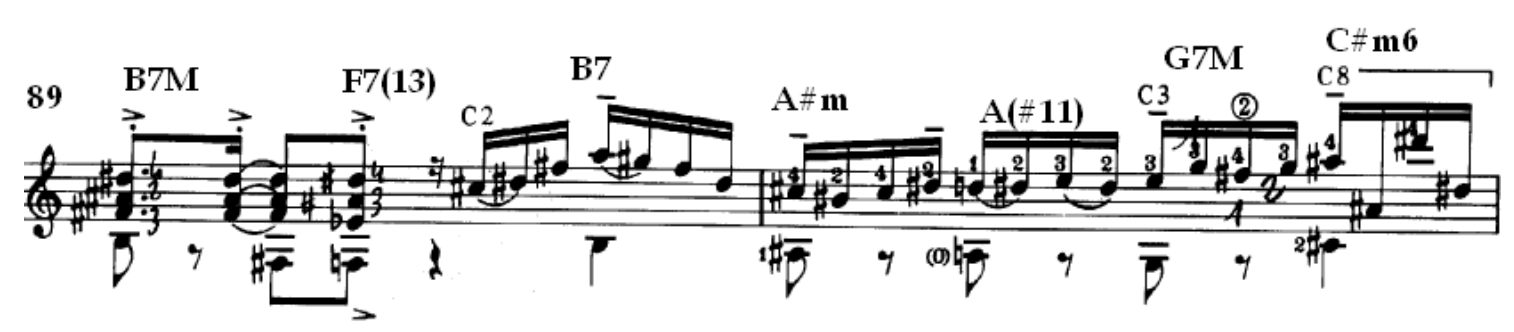

Divertimento, compassos 89 a 90

O compasso 91 é estruturado sobre os acordes mi diminuto $\left(E^{\circ}\right)$, mi bemol com sétima e décima terceira $[\mathrm{Eb} 7(13)]$ e dó sustenido diminuto $\left(\mathrm{CH}{ }^{\circ}\right)$.

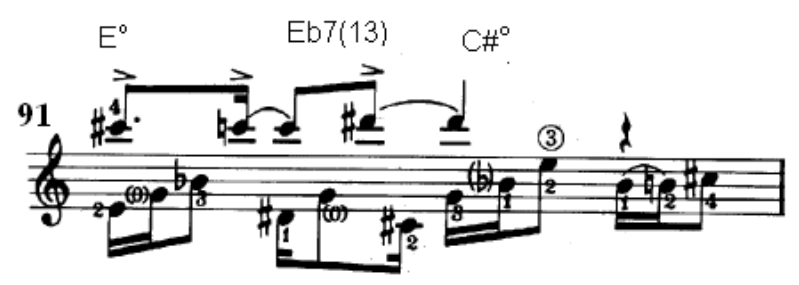

\footnotetext{
${ }^{90}$ Modo derivado do quarto grau da escala maior formado pelos intervalos $\mathrm{T}, 2 \mathrm{M}, 3 \mathrm{M}, 4 \#, 5 \mathrm{~J}$, 6M e 7M. FARIAS (1991), p31.

${ }^{91}$ Modo derivado do primeiro grau da escala maior formado pelos intervalos $\mathrm{T}, 2 \mathrm{M}, 3 \mathrm{M}, 4 \mathrm{~J}, 5 \mathrm{~J}$, 6M e 7M. FARIAS (1991) p.30.

${ }_{92}$ Modo derivado do segundo grau da escala maior formado pelos intervalos $\mathrm{T}, 2 \mathrm{M}, 3 \mathrm{~m}, 4 \mathrm{~J}, 5 \mathrm{~J}$, $6 \mathrm{M} \mathrm{e} 7 \mathrm{~m}$. Farias (1991) p 31.
} 


\section{Divertimento, compasso 91}

O trecho que compreende os compassos 92 a 95, não possui estruturação sobre blocos de acordes, o que detectamos, contudo é o emprego de melodias construídas sobre diversas escalas que são elaboradas a partir de pequenos fragmentos melódicos. Na passagem detectamos a presença das seguintes escalas: dó menor, mi menor harmônica, sol bemol e lá alterada ${ }^{93}$.

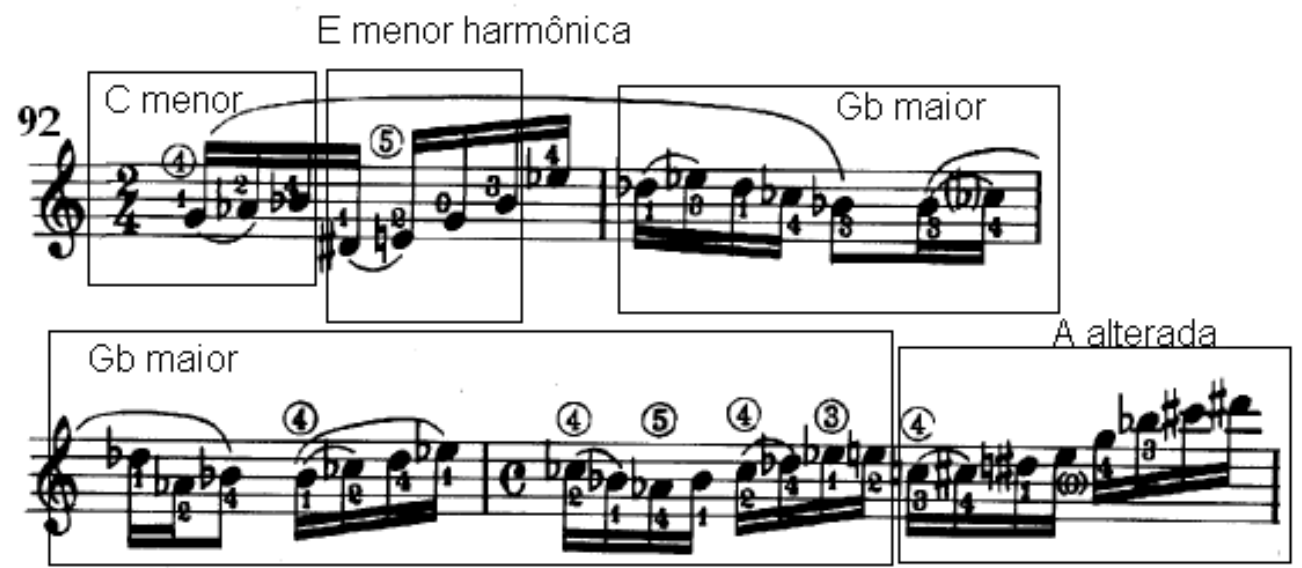

Divertimento, compassos 92 a 95

Uma nova elaboração na tonalidade de Si maior surge nos compassos 96 e 97, são utilizados os acordes de fá sustenido com sétima e baixo em dó sustenido (F\#7/C\#), d[o com sétima e nona bemol [C7(b9)] (atuando como subV) si menor com sétima maior (Bm7M) e si maior (B). As escalas utilizadas no trecho são F\# mixolídio, C alterada, B menor melódica, e B maior.

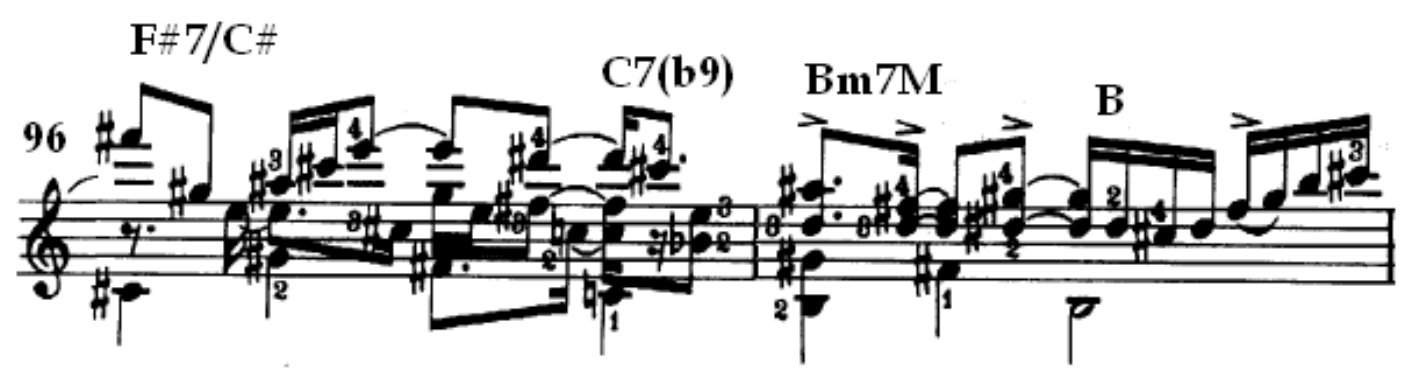

Divertimento, compassos 96 a 97

\footnotetext{
${ }^{93}$ Escala derivada a partir do sétimo grau da escala menor melódica. Seus intervalos são: $\mathrm{T}$, 2m, \#2, 3M, b5, 6m e 7m. FARIAS (1991) p 41.
} 
Este trecho é então repetido um tom abaixo, na tonalidade de A maior, a partir do compasso $98 \mathrm{com}$ os acordes de mi com sétima com baixo em si (E7/B), si bemol com sétima e nona bemol [Bb7(b9)], lá menor com sétima maior ( $A m 7 M)$ e lá maior $(A)$. A escalas são $E$ mixolídio, Bb alterada, $A$ menor melódica e lá maior. Há então a última repetição (compassos 100 e 101), na tonalidade de sol maior, em que são empregados os acordes ré com sétima com baixo em lá (D7/A), lá bemol com sétima e nona [Ab7(b9)] sol menor com sétima maior (Gm7M) e sol (G).
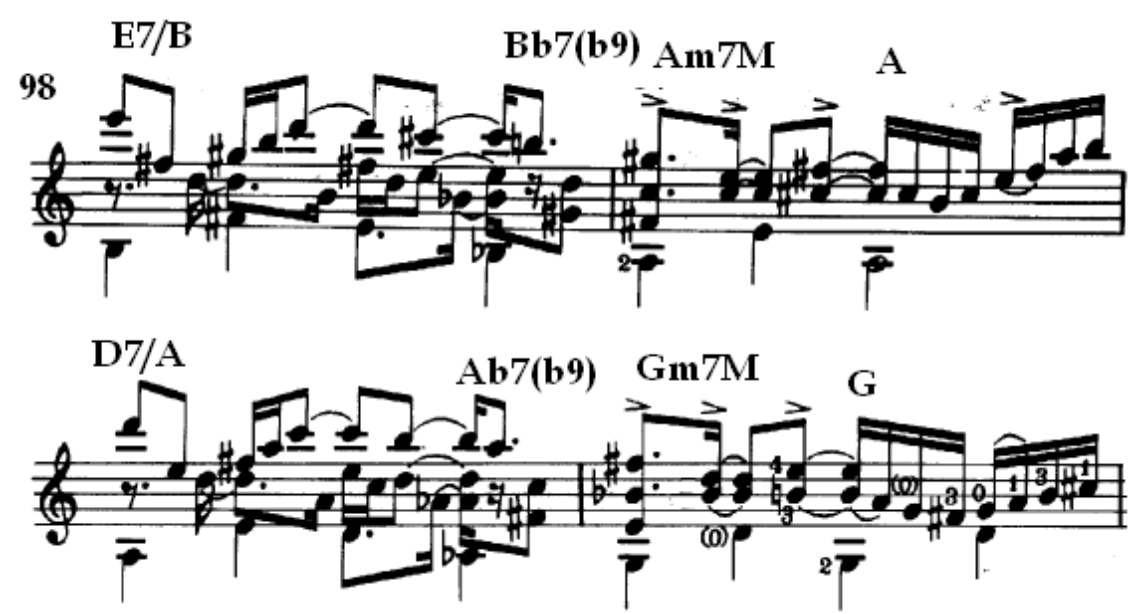

Divertimento, compassos 98 a 101

A partir do compasso 102 são utilizados acordes que servirão de passagem à elaboração iniciada no compasso 103. Estes acordes são sol sustenido menor com sétima e quinta bemol [G\#m7(b5)], ré bemol com sétima (Db7) e fá sustenido maior (F\#), que servem de cadência $\operatorname{llm7(b5)~V7~I,~}$ seguido de um acorde sol com sétima e baixo em fá (G7/F) que será empregado como subV do acorde fá sustenido menor ( $F \# m)$ na elaboração iniciada no compasso 103.

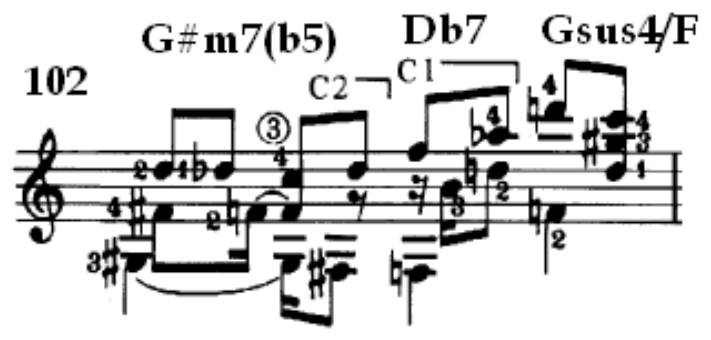

Divertimento, compasso 102 
A elaboração iniciada no compasso 103 é formada pelos acordes fá sustenido menor $(\mathrm{F \# m})$ e si com sétima com nona bemol e décima terceira bemol [B7(b9)(b13)] em mi maior, sendo resolvidos nos acordes mi menor (Em) e lá com sétima com nona bemol e décima terceira bemol $[A 7(b 9)(b 13)]$ em ré maior, seguido por ré menor $(\mathrm{Dm})$ e si com sétima com nona bemol e décima terceira bemol [G7(b9)(b13)] em dó maior, sendo resolvido no acorde de dó maior no compasso 109. Estas marchas harmônicas têm função de IIm Valt para cada uma das tonalidades citadas.

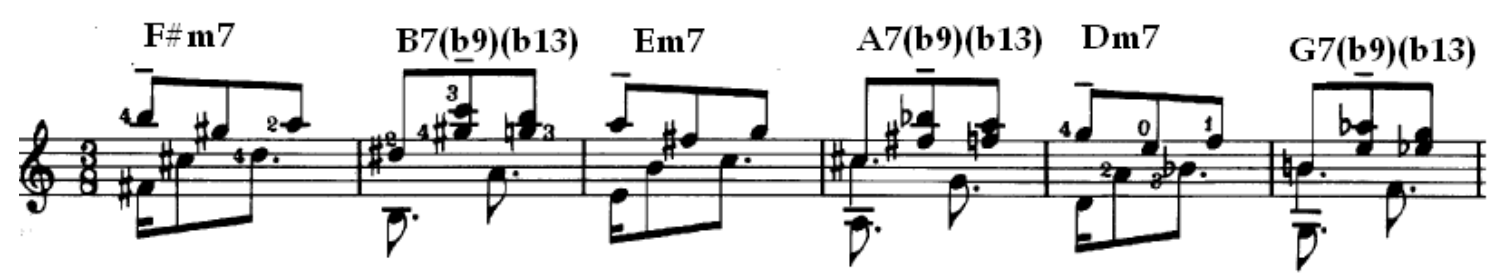

Divertimento, compassos 103 a 108

A seção A do Divertimento é então concluída pelos compassos $109 \mathrm{e}$ 110 constituídos pelos acordes dó (C) (tônica), si (B) (dominante) lá menor (AM) (tônica relativa), sol (G) (dominante), fá ( $F$ ) (subdominante) si com sétima e baixo em dó (B7/C) (dominante individual do V7/VI) e mi com sétima (E7) (que servirá de dominante para a entrada da repetição da seção $A$ iniciada pelo acorde A7M). Tal passagem demonstra um raro momento de estruturação harmônica tonal e o emprego de tríades por Sérgio Assad.

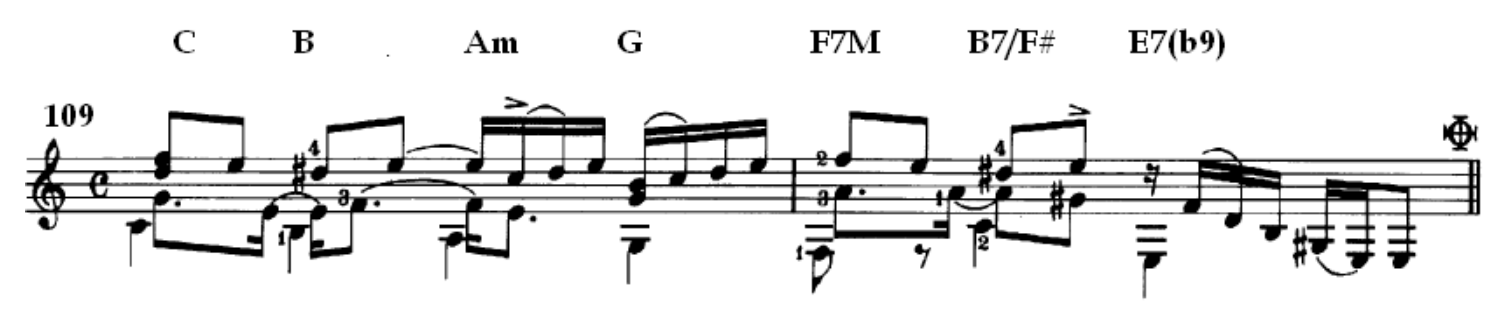

Divertimento, compassos 109 e 110

Após a repetição dos sete primeiros compassos da seção $A$ (compassos 111 a 117) uma nova elaboração será iniciada no terceiro tempo do compasso 118 com o acorde mi bemol com baixo em dó sustenido (Eb/C\#) seguido de dó menor $(\mathrm{Cm})$ no compasso 118. Neste mesmo compasso é iniciado um novo trecho escalar que se estende até o compasso 120, esta passagem é iniciada 
com uma escala de lá menor melódica, seguida de um arpejo de ré sustenido diminuto (D\#9) finalizando o trecho em uma escala de $E$ mixolídio b6 ${ }^{94}$ elaborada em intervalos de sexta.
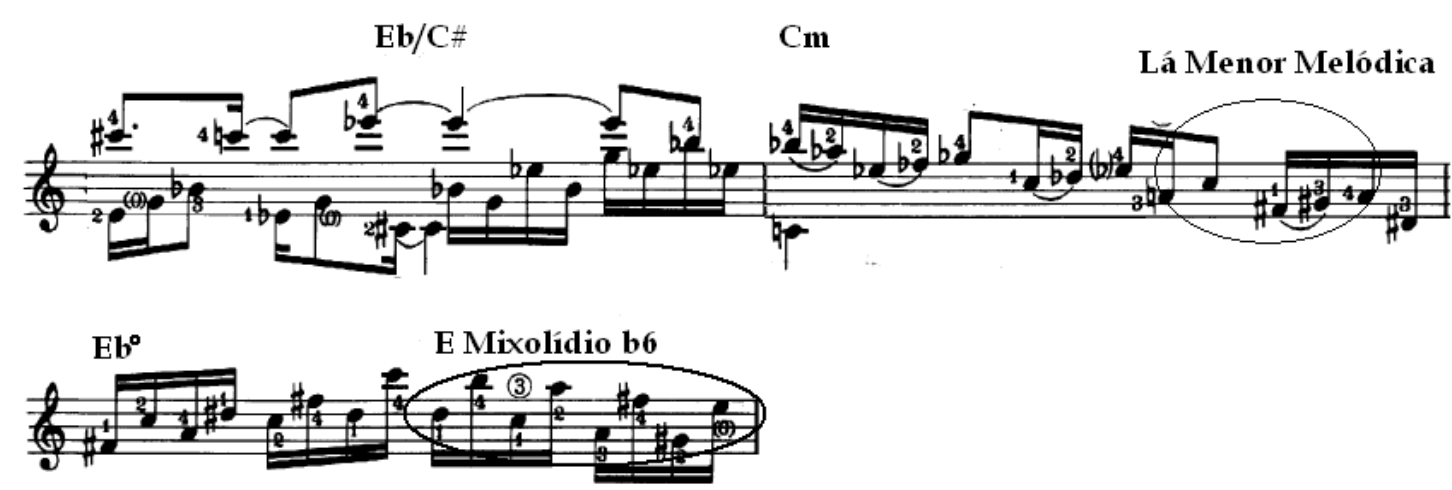

\section{Divertimento compassos 111 a 117}

Uma nova elaboração é iniciada no compasso 121 e é concluída no compasso 124. Os acordes empregados no compasso 121, o primeiro desta passagem são os de dó sustenido menor com sétima (C\#m7), sol sustenido menor com sétima e baixo em si (G\#m7/B) e lá maior com sétima maior e nona [A7M(9)], sobre um modo que pode ser identificado como lá lídio. Estes são seguidos no compasso 122 por lá maior com sétima maior e nona [A7M(9)], mi maior com sétima maior e baixo em sol sustenido (E7M/G\#) e fá sustenido com sétima e décima primeira $[F \# 7(11)]$ sobre o modo Fá\# mixolídio. No compasso seguinte (123), a elaboração emprega os acordes de fá sustenido menor $(\mathrm{F} \# \mathrm{~m})$, mi maior com sétima maior $(E 7 \mathrm{M})$ e ré maior com sétima maior e nona [D7M(9)] sobre uma escala de mi maior. A elaboração é concluída pelos acordes sol sustenido menor com nona bemol [G\#m(b9)], vinda do modo de G\# frígio e sol com sétima e nona e décima primeira aumentada [G7(9)(\#11)], acorde vindo do modo Sol mixolídio \#4 derivado da escala de ré menor melódica.

\footnotetext{
${ }_{94}$ Modo derivado do quinto grau da escala menor melódica formado pelos intervalos $\mathrm{T}, 2 \mathrm{M}, 3 \mathrm{M}$, 4J, 5J, 6m, 7m. FARIAS (1991) p. 34.
} 
C\# $\#$ m $\quad$ G\# $\# \mathbf{m} \quad$ A7M

A7M E7M/G\# F\#7sus4

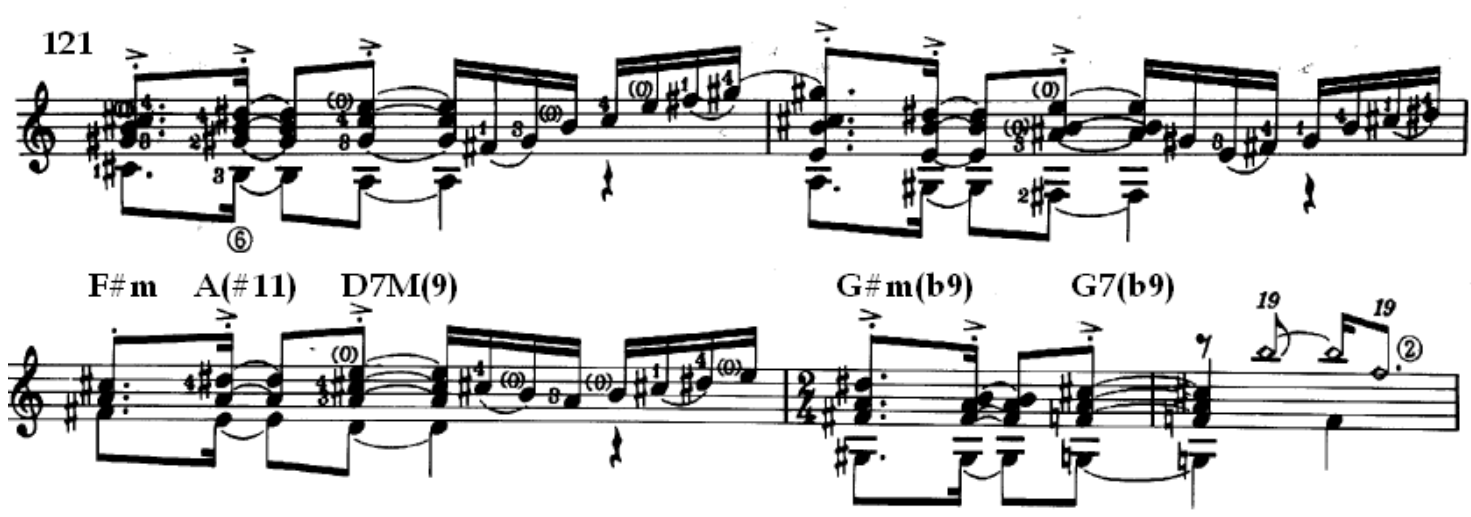

Divertimento compassos 121 a 124

Do compasso 125 ao compasso 132 são empregados os acordes sol com sétima e nona [G7(9)] e fá sustenido com quarta e nona [F\#sus4(9) ${ }^{95}$. Entre os compassos 125 a 128 o acorde sol com sétima e nona [G7(9)] advém do modo de sol mixolídio enquanto na melodia na voz superior são executados harmônicos do modo de sol Jônio gerando bimodalidade ${ }^{96}$, enquanto entre os compassos 129 a 132 é utilizado o modo de fá sustenido mixolídio apenas.
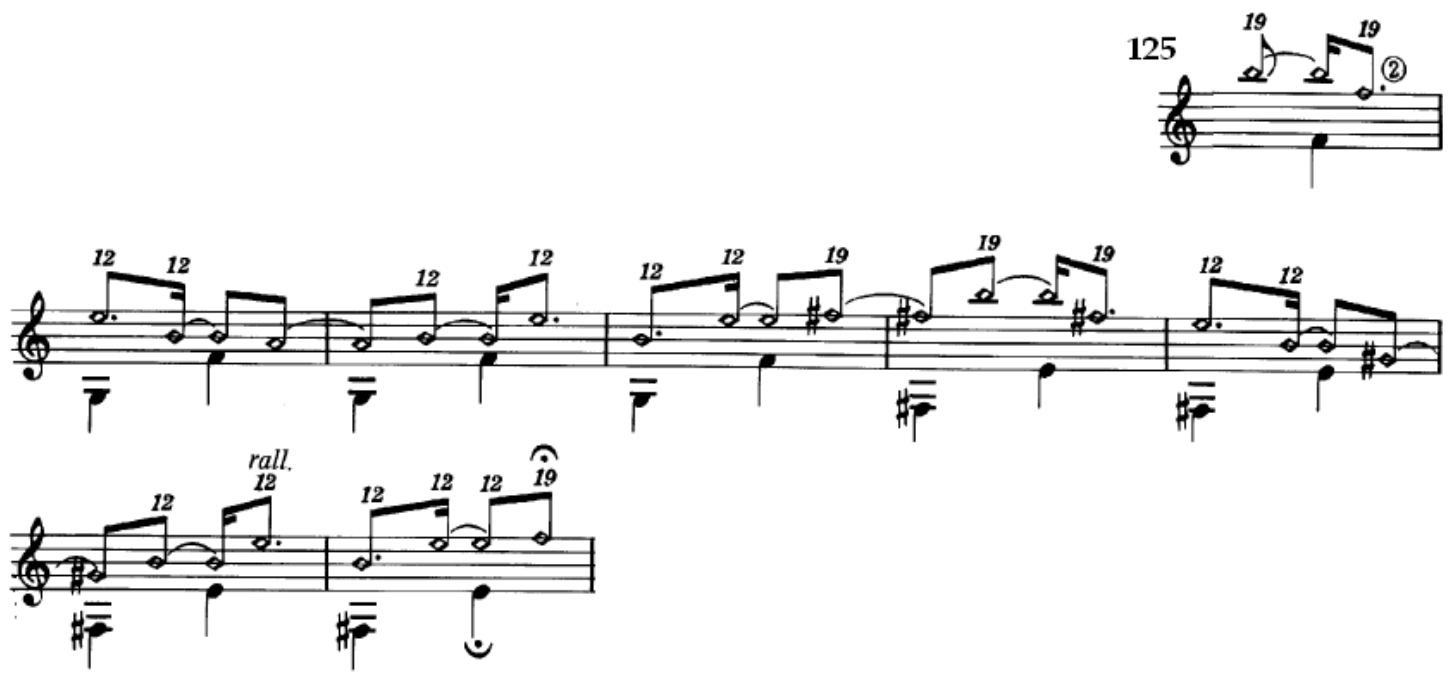

Divertimento, compassos 125 a 132

No trecho que compreende o compasso 133 até o compasso 136 são utilizados os acordes dó sustenido menor com décima primeira [C\#m(11)] e fá sustenido menor com décima primeira [F\#m(11)], esta progressão de acordes é derivada do modo de C\# eólio.

\footnotetext{
${ }^{95}$ Acorde de função dominante sem terça cujos intervalos são a sétima menor, a quarta e a nona. FREITAS (1995) p 103.

${ }^{96}$ Uso simultâneo de dois modos distintos sobre uma estrutura de mesma tonalidade. Barroud (1968) p 67.
} 


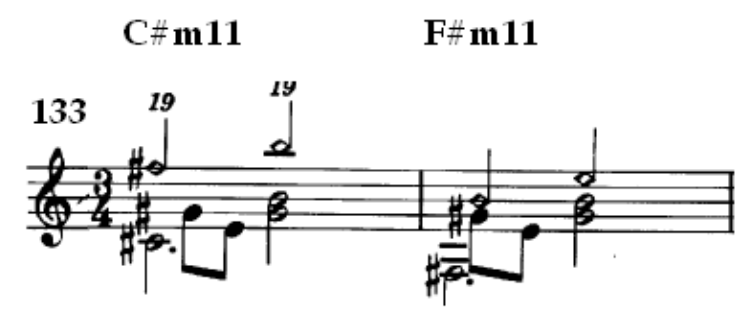

Divertimento, compassos 133 a 134

A partir do compasso 137 é iniciada a seção B da peça, em que esta se encontra inicialmente na tonalidade de C\# menor e é iniciada com um acorde de dó sustenido menor com sétima e décima terceira [C\#m7(13)] seguido de um fá sustenido menor com sétima e nona [F\#m7(9)], caracterizando o modo de C \# dórico no compasso 138. Estes acordes são seguidos por um acorde de lá sustenido menor com sétima (A\#m7) vindo do campo harmônico de $\mathrm{C \#}$ maior no compasso 139.

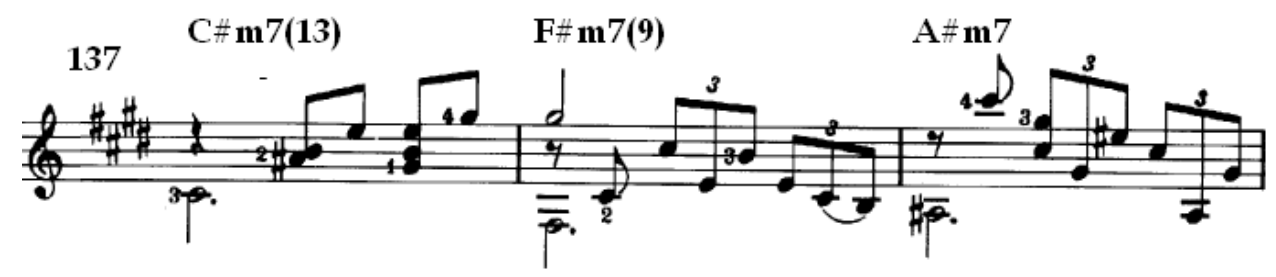

Divertimento, compassos 137 a 139

Durante os compassos 140 e 141 há uma estrutura harmônica semelhante à detectada entre os compassos 125 a 128, havendo novamente a elaboração do acorde sol com sétima e décima primeira aumentada [G7(\#11)]. Este acorde funciona como sub $\mathrm{V}$ para o acorde fá sustenido menor com sétima e nona [F\#m7(9)] (função subdominante) seguido de um fá com sétima e décima terceira [F7(b13)] (função de sub V), a resolução de ambos os acordes é feita pelo acorde mi com sétima maior (E7M) no compasso 143. Tal passagem evidencia a maneira com que o compositor reutiliza estruturas harmônicas em diferentes contextos. 


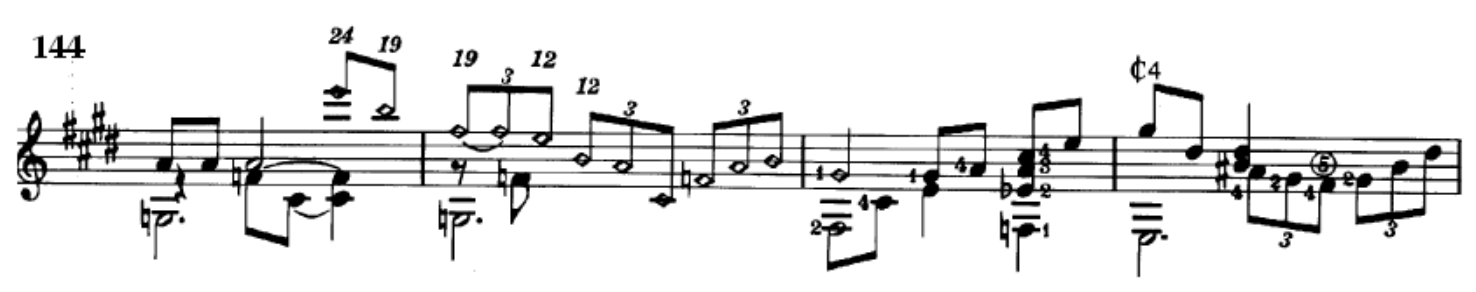

Divertimento, compassos 137 a 139

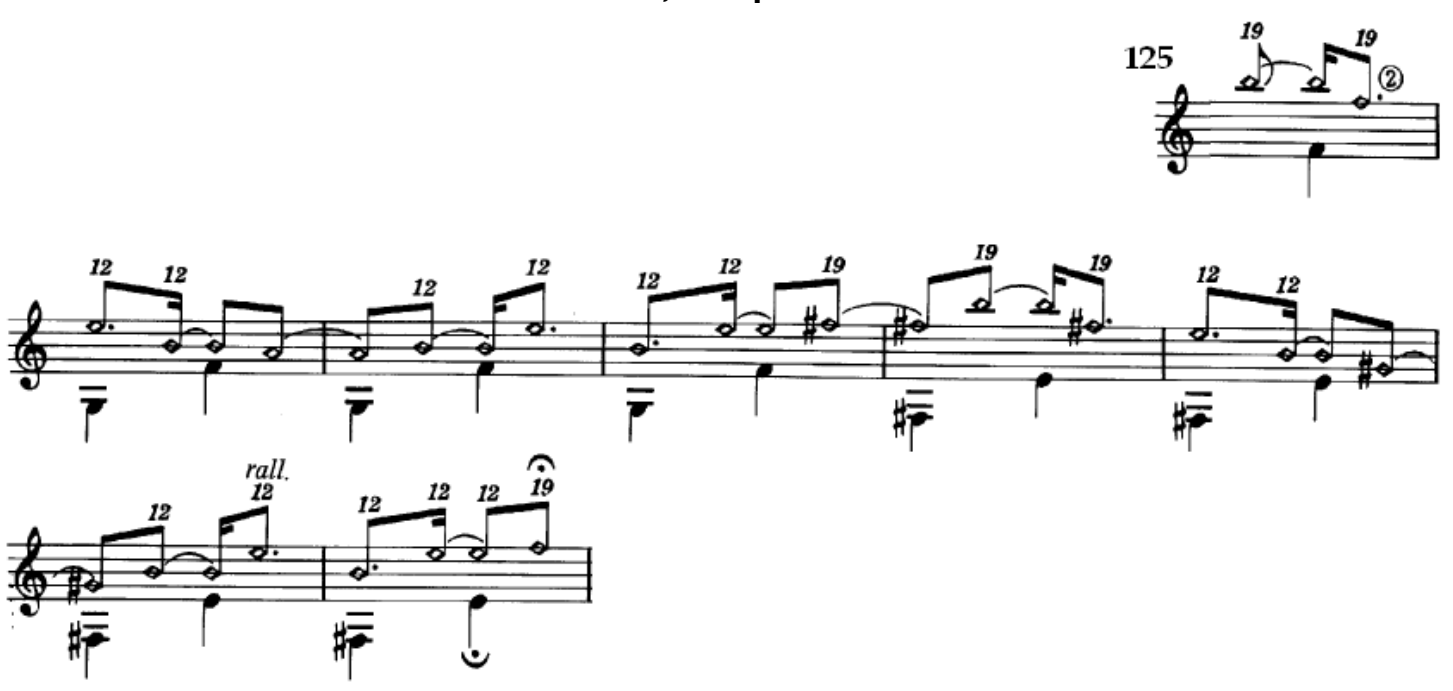

Divertimento, compassos 125 a 132

O compasso seguinte (144) é composto pelos acordes lá com sétima A7 e mi bemol com sétima e nona aumentada [Eb7(\#9)] que servirão de dominante e subV7 para o acorde ré maior com sétima maior (D7M) no compasso 145. Este ré maior com sétima maior (D7M) é seguido por um sol com sétima (G7) no compasso 146 (subV do F\#m), que é seguido por um acorde de ré maior (D) que tem função de subdominate interpolado ${ }^{97}$.

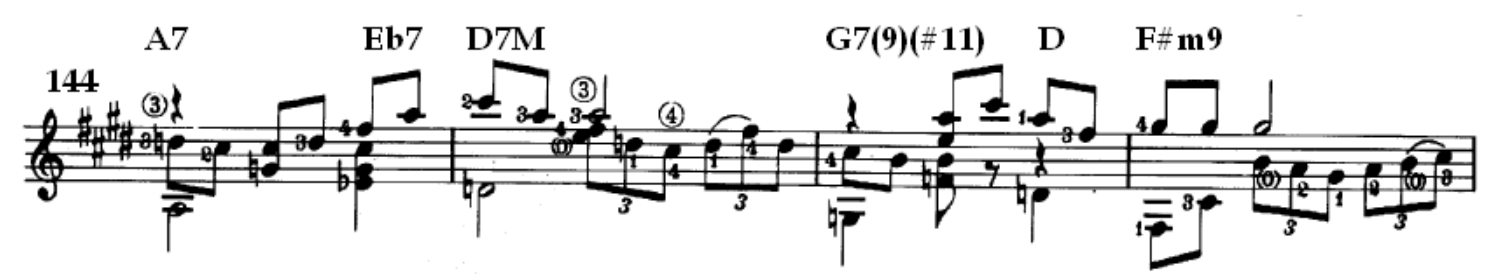

Divertimento, compassos 144 a 147

\footnotetext{
${ }^{97}$ Acorde de função subdominante que é interpolado entre uma cadência V7 I. FREITAS (1995) p 113.
} 
O fá sustenido menor ( $F \# m)$ no compasso 147 é seguido por um fá com sétima (F7) que funcionará como SubV do acorde mi menor com nona (Em9) do compasso seguinte (compasso 149).

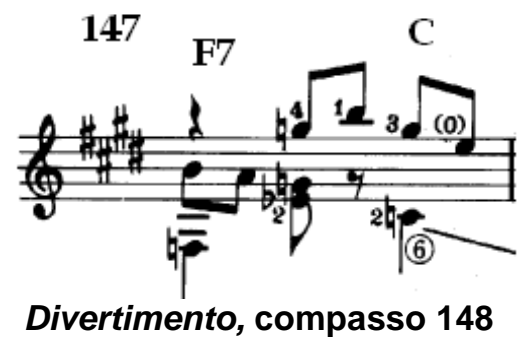

Entre os compassos 149 e 154 haverá a repetição da progressão formada pelos acordes mi menor com nona (Em9), lá com sétima (A7) e mi bemol (Eb). Esta pode ser analisada como uma progressão vinda do modo de Mi dórico tendo o mi bemol como subV para o mi menor com nona (Em9) presente no compasso seguinte.

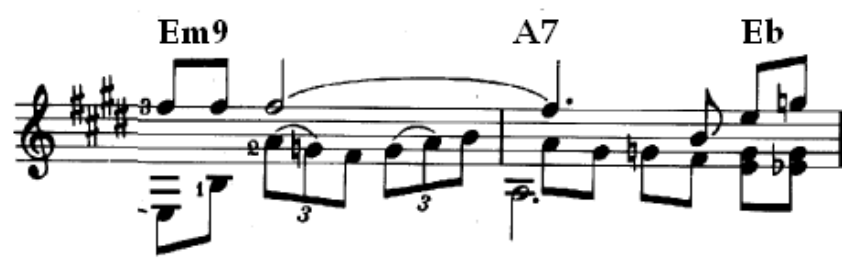

Divertimento, compassos 149 e 150

Os compasso 155 e 156 marcam uma modulação à tonalidade de mi maior, representada pelos acordes mi maior com sétima maior (E7M) e lá com sétima maior e décima primeira aumentada [A7M (\#11)] sendo repetida (compassos 157 e 158). Uma nova modulação à tonalidade de sol maior ocorre nos compassos 159 e 160, com os acordes sol com sétima maior (G7M) e dó com sétima maior $(\mathrm{C} 7 \mathrm{M})$.

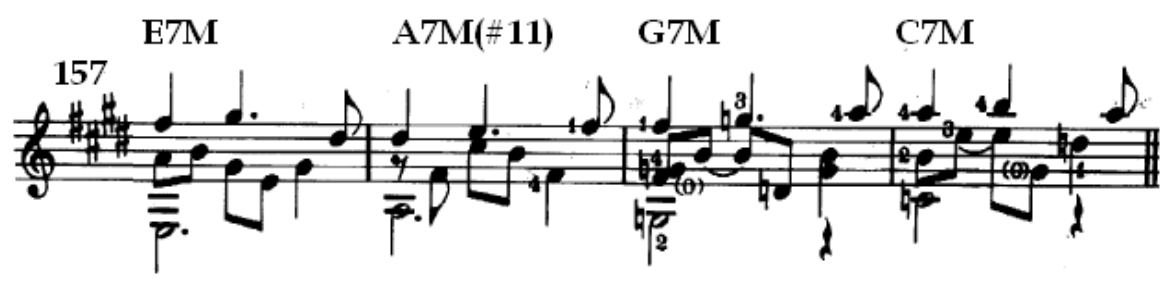

Divertimento, compassos 157 a 160 
O trecho compreendido entre os compassos 161 e 183 sofre modulação para a tonalidade de lá menor e atua como ligação à reapresentação da Seção A. Esta passagem se encontra no modo de lá dórico, possuindo trechos estruturados sobre a escala de Lá menor melódica. São empregados os acordes de lá menor com nona e décima terceira [Am9(13)] até o compasso 170 e uma progressão constituída pelos acordes mi menor com décima primeira [Em(11)] e lá menor com décima primeira [Am(11)] do compasso 171 até o compasso 179.

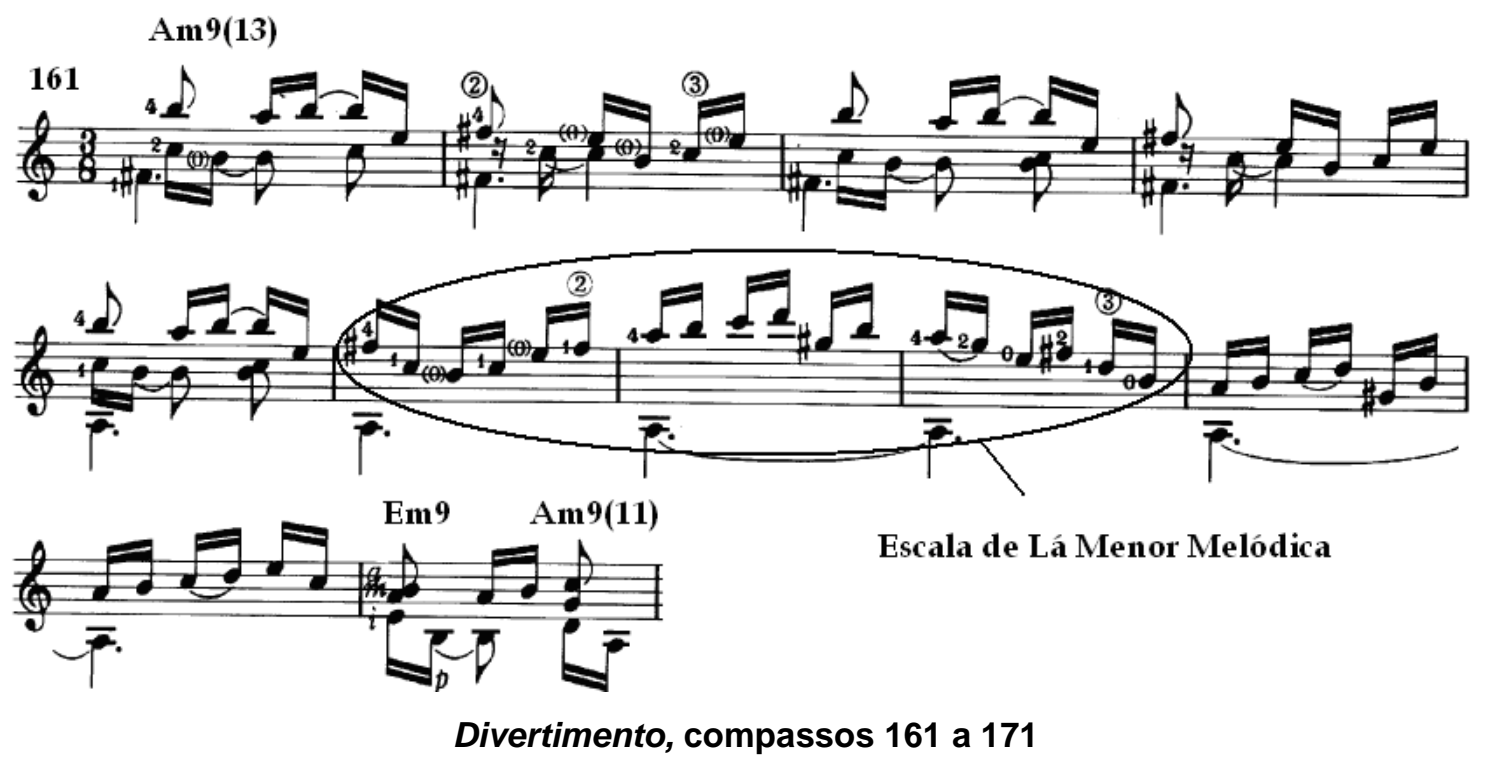

É encontrado no compasso 180 um padrão melódico em sextas maiores descendentes em tons inteiros que novamente formam uma escala de tons inteiros. O baixo utilizado é a nota lá nos compassos 180 e 181 e nos compassos 182 e 183 a nota mi é enfatizada. Podemos deduzir então pela estrutura harmônica posterior (acorde de lá com sétima maior no início da seção A) que a harmonia deste trecho é constituída pelos acordes mi com sétima e décima terceira com baixo em lá $[E 7(b 13) / A]$ e mi com sétima e décima terceira bemol $[E 7(b 13)]$ tendo função dominante para a repetição da Seção A. 


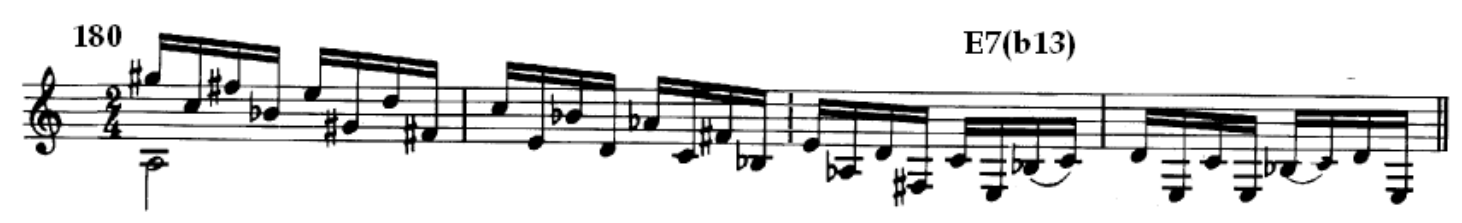

Divertimento, compassos 180 a 183

A coda do Divertimento é iniciada no compasso 184 com o acorde lá maior com sétima e décima primeira aumentada $[A 7 M(\# 11)]$, caracterizando o modo de lá lídio, seguido de si menor com baixo em lá $(\mathrm{Bm} / \mathrm{A})$ sobre uma melodia em si eólio no compasso 185 e fá com sétima maior e baixo em lá (FM7/A) sobre um modo de Fá lídio no compasso 186.

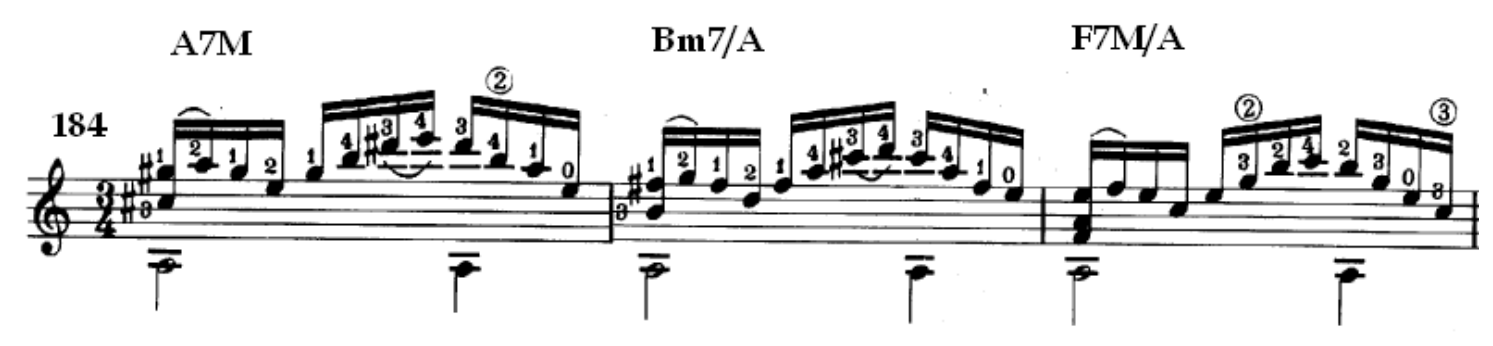

Divertimento, compassos 184 a 186

Há então a elaboração deste trecho com a utilização de um acorde de si com sétima com baixo em lá (B7/A) nos compassos 187 e 188 e o uso do modo Frígio Dominante ${ }^{98}$. Este trecho servirá como ligação ao término da Coda que será iniciado no compasso 189 por uma tríade de mi maior $(E)$, seguido por lá menor com sétima (Am7) (sendo este acorde de empréstimo do modo menor), mi maior (E) e ré com sétima (D7) (compassos 190 e 191), mi maior (E) e lá menor (Am) (compasso 192) sendo finalmente concluída sobre um acorde de mi menor com baixo em dó Em/G (compasso 193), numa espécie de terça de picardia já que se trata de uma conclusão com um acorde menor sobre uma progressão maior. No trecho que compreende os compassos 188 a 192 são utilizados os modos de mi mixolídio b6 ${ }^{99}$ para as progressões de mi maior (E) e ré com sétima (D7) e mi frígio dominante para a progressão de mi maior (E) e lá menor (Am).

\footnotetext{
${ }^{98}$ Modo derivado do $5^{\circ}$ grau da escala menor harmônica formado pelos intervalos $\mathrm{T}, 2 \mathrm{~b}, 3 \mathrm{M}$, $4 \mathrm{~J}, 5 \mathrm{~J}, 6 \mathrm{~m}, 7 \mathrm{~m}$. Farias (1991) p. 32.

${ }^{99}$ Modo derivado do $5^{\circ}$ grau da escala menor melódica. Farias (1991).
} 


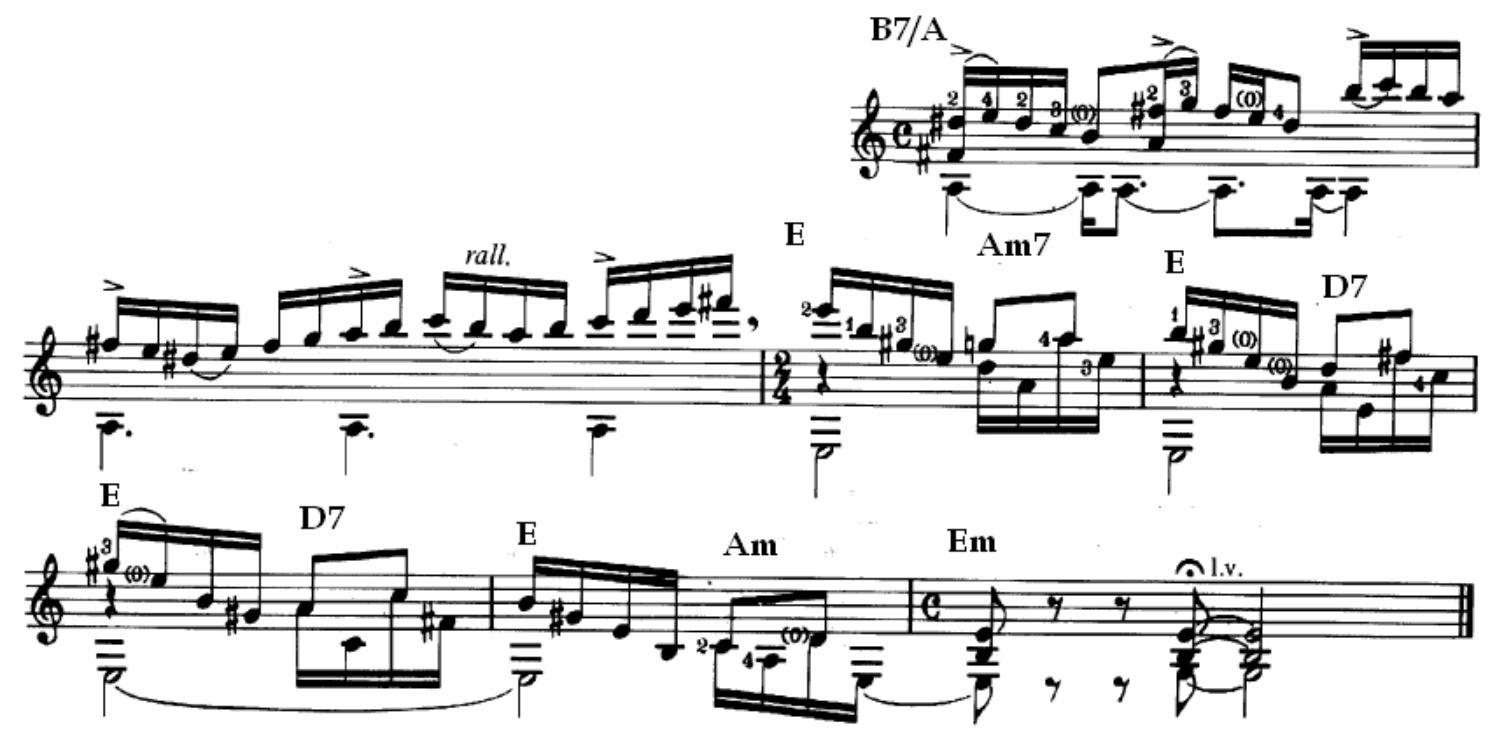

Divertimento, compassos 187 a 193

\subsubsection{Valseana}

A Valseana é uma obra escrita na tonalidade de Ré maior com modulações passageiras ${ }^{100}$, acordes dominantes secundários ${ }^{101}$ e acordes de empréstimo modal ${ }^{102}$.

Nos quatro primeiros compassos podemos verificar um movimento harmônico de Dominante e Tônica, respectivamente acordes de lá com sétima (A7) e ré com sétima maior (D7M). Este padrão é quebrado no sexto compasso com a resolução em um acorde de (F7M), que pode ser interpretado tanto como uma resolução deceptiva, quanto como um acorde de empréstimo modal (neste caso o F7M viria do campo harmônico do modo ré eólio). O fá com

\footnotetext{
${ }^{100}$ Série de pequenas modulações que se repetem para chegar de uma tonalidade a outra.

${ }^{101}$ Dominantes dos demais graus diatônicos. Freitas (1995) p. 81

102 De acordo com Freitas (1995) p.132 são acordes vindos dos modos maior ou menor homônimos.
} 
sétima maior (F7M) aparece seguido de um mi bemol com sétima maior e décima primeira aumentada [Eb7M (\#11)], derivado do modo de Ré frígio e de lá com sétima (A7), o último acorde da introdução.

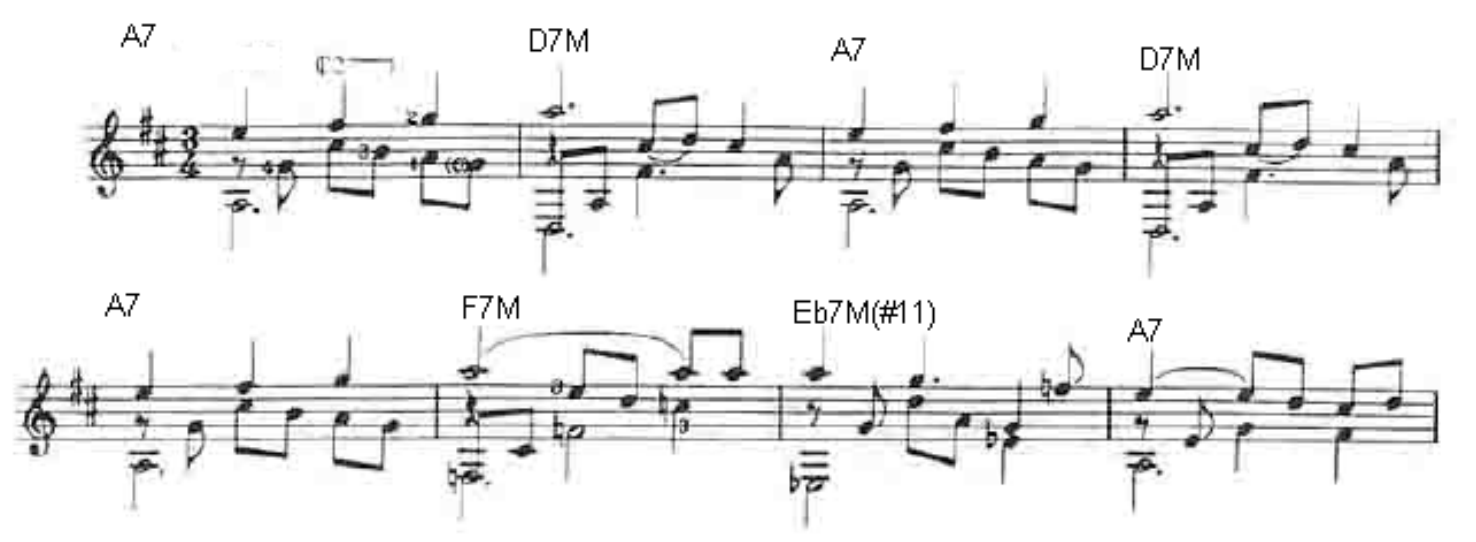

Valseana, compassos 1 a 8

A Seção A da Valseana (compasso $10 \mathrm{em}$ diante) inicia-se sobre ré maior com sétima maior e nona (D7M9), seguido pelos acordes fá sustenido menor com nona (F\#m9), acorde vindo do modo de ré lídio, mi menor (Em), lá sus (Asus) e ré com sétima maior nona décima primeira aumentada e décima terceira [D7M9(\#11)(13)], voltando ao ré lídio. A base harmônica destes quatro compassos é repetida até o compasso 16. A partir de então no compasso 17, temos os acordes de lá sus (Asus) e de lá com sétima e nona bemol [A7(b9)] onde o compositor se prepara para desenvolver a segunda metade do tema principal da Seção A.

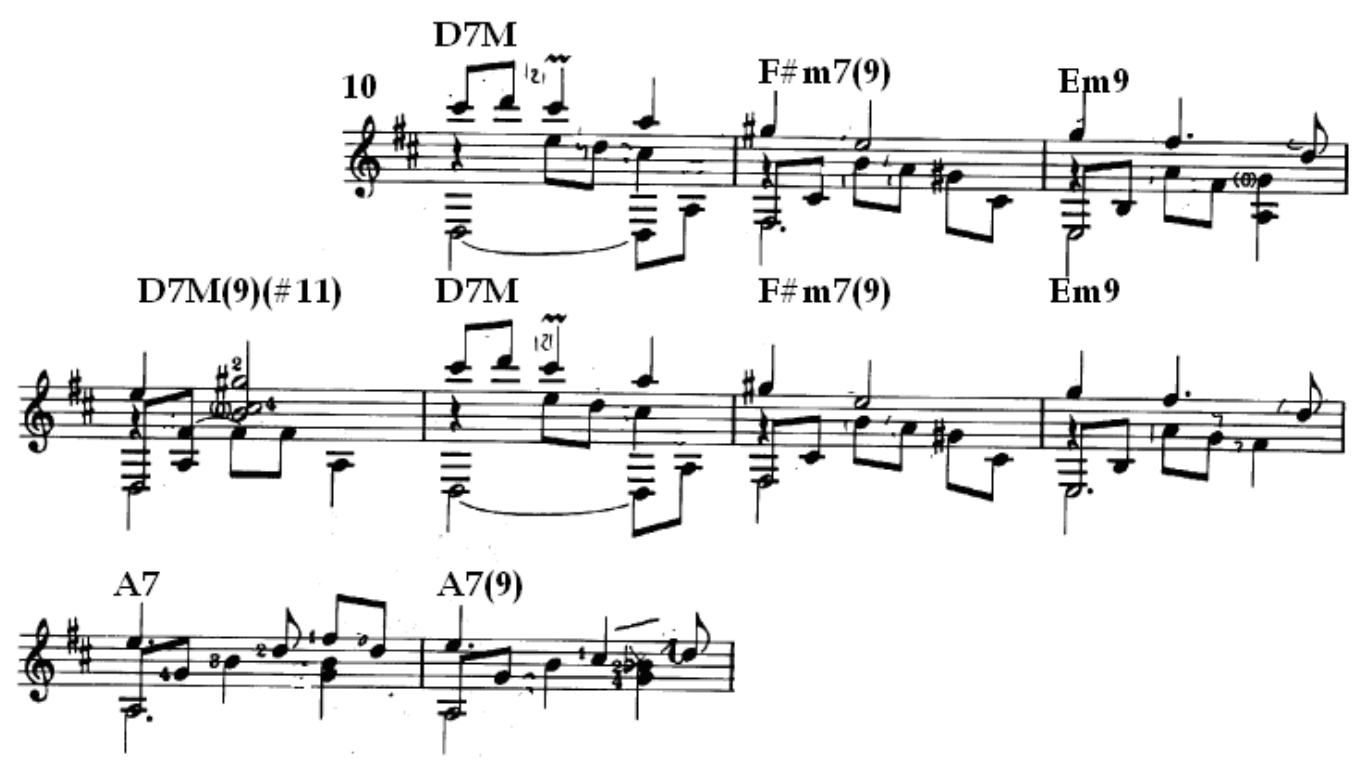

Valseana compassos 10 a 18 
A segunda metade da seção A é iniciada pelo acorde ré com sétima maior (D7M) no compasso 19, seguido do acorde ré com sétima (D7), neste caso o ré com sétima desempenha a função de dominante secundária do quarto grau, V/IV. No compasso 21 é utilizado um acorde de sol com sétima maior com baixo em ré $(G 7 M / D)$, como subdominante no quarto grau. Os próximos três acordes; dó com sétima (C7), fá com sétima maior (F7M) e si bemol com sétima maior (Bb7M) são uma modulação passageira à tonalidade de Fá maior, sendo resolvida por uma cadência de IIm7, V7 e I formada pelos acordes de mi menor com sétima (Em7), lá com sétima (A7) e ré com sétima maior (D7M). A harmonia dos três primeiros acordes desta metade da seção $A$ (D7M, D7 e G7M/D) é repetida do compasso 27 ao compasso 30, sendo seguida dos acordes sol menor com baixo em ré $(G m / D)$, acorde de empréstimo modal vindo do modo de ré eólio, ré com sétima maior (D7M), fá sustenido menor com sétima e nona [F\#m7(9)], mi menor com sétima (Em7) e lá com sétima (A7).
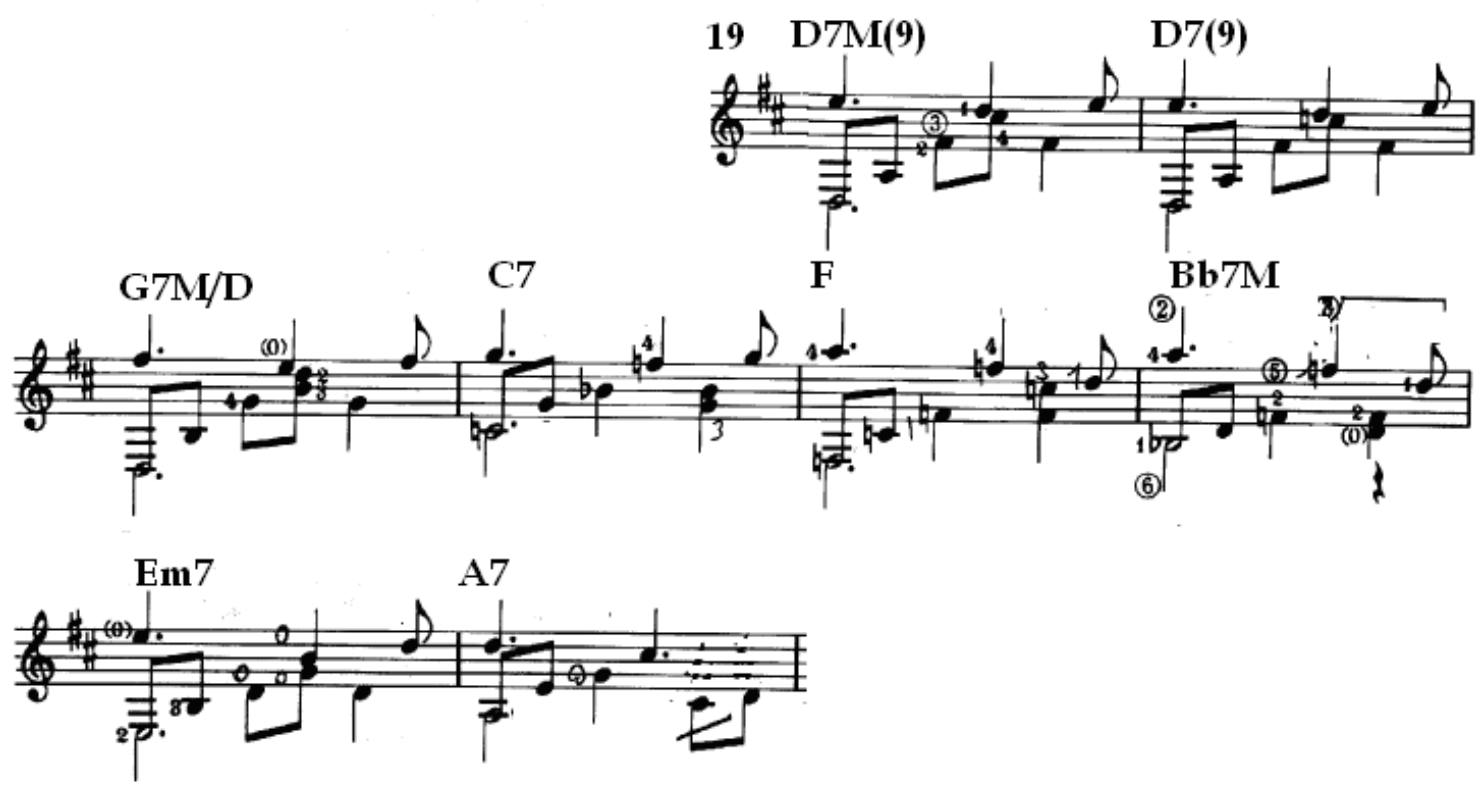

Valseana compassos 19 a 26

As estruturas harmônicas iniciadas nos compassos 10 a 34 são repetidas entre os compassos 36 e 55 na seção A', servindo como base para as variações melódicas e de textura operadas pelo compositor. Vale salientar 
também as substituições ${ }^{103}$ dos acordes si bemol com sétima maior (Bb7M) e fá sustenido menor com sétima e nona [F\#m7(9)] pelos acordes mi bemol com sétima maior e décima primeira aumentada [Eb7M(\#11)] e si menor com sétima (Bm7) respectivamente.

A peça é então concluída em um acorde de ré com sétima maior nona aumentada e décima primeira aumentada [D7M(\#9)(\#11)] no compasso 58. Uma interpretação possível deste acorde é a de enquadrá-lo como proveniente da escala sintética de ré lídio, alterado com uma segunda aumentada ${ }^{104}$.

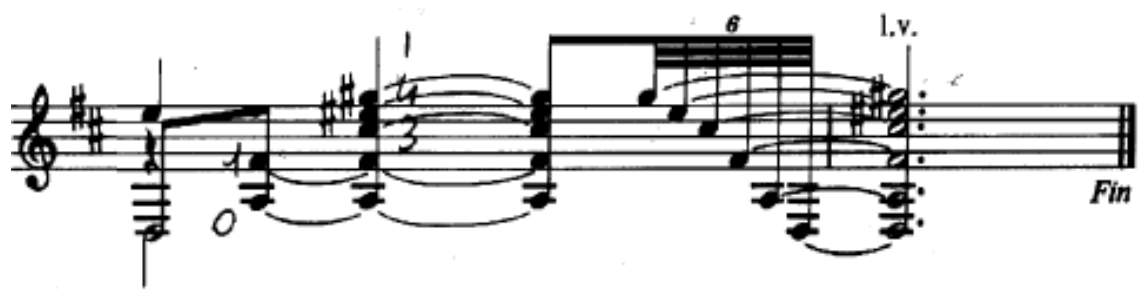

Valseana, compassos 57 e 58

\subsubsection{Prelúdio e Toccatina}

Prelúdio e Toccatina, apesar da indicação de tonalidade de ré maior, apresentam na maior parte de sua extensão o uso de estruturas modais em ré e cromatismo.

A peça é iniciada por um acorde de ré com décima primeira aumentada e décima terceira $[\mathrm{D}(\# 11)(13)]$ no primeiro compasso, cuja tensão de \#11 caracteriza o modo de ré lídio, sendo seguido por pelo acorde dó com sétima com baixo em ré $(C 7 / D)$ causando a mudança de modo para ré eólio. Ressaltamos a utilização do modo eólio ${ }^{105}$ em várias passagens da peça.

\footnotetext{
${ }^{103}$ Em uma dada progressão harmônica um acorde pode ser substituído por outro de mesma função. Farias (1991).

104 Uma escala sintética é formada pela alteração à uma determinada escala por um compositor. No caso descrito, a escala de ré lídio (re, mi, fa\#, sol, lá, si e dó\#) passaria por uma alteração no segundo grau tornando-se re, mi\#, fa\#, sol\#, lá, si e dó\#.

${ }_{105}$ Modo derivado do sexto grau da escala maior e formado pelos intervalos T, 2M, 3m, 4J, 5J, $6 \mathrm{~m}, 7 \mathrm{~m}$. Farias (1991).
} 


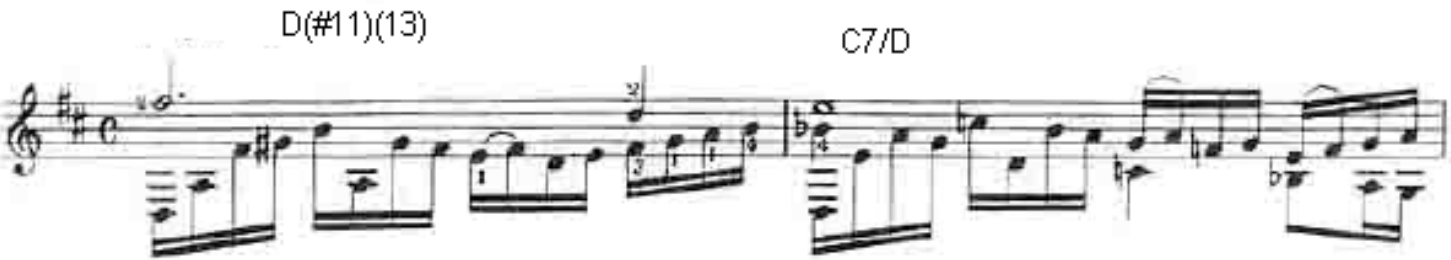

Prelúdio e Toccatina, compassos 1 e 2

O compasso 3 marca uma mudança ao modo de ré dórico, com a utilização dos acordes de fá com sétima maior (F7M), sol com sétima (G7), lá menor com nona (Am9), retornando ao modo eólio no último tempo com o acorde de si bemol com sétima maior (Bb7M).

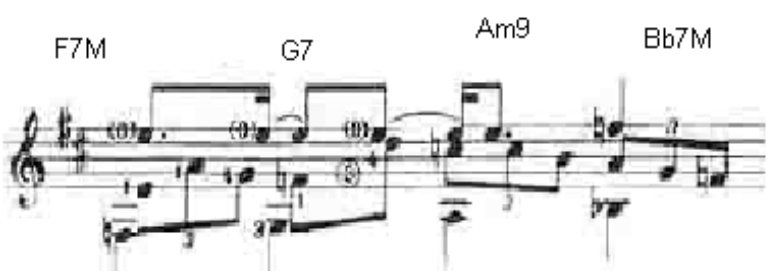

Prelúdio e Toccatina, compasso 3

No compasso 4 vemos um acorde de si com sétima e quarta e quinta diminuta [Bsus4(b5)] que servirá de SubV para o acorde seguinte, si bemol com sétima maior $(\mathrm{Bb} 7 \mathrm{M})$, seguido de um acorde de lá bemol com quinta aumentada $[\mathrm{Ab}(\# 5)]$ que servirá de SubV para o acorde de sol com sétima maior (G7M) no compasso 5.

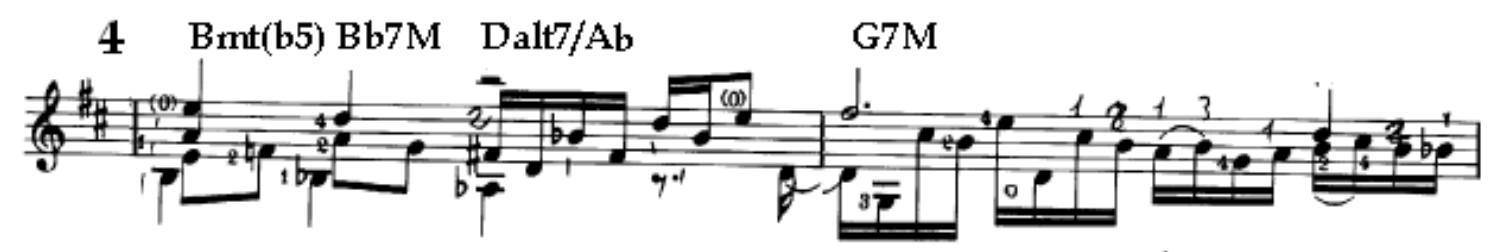

Prelúdio e Toccatina, compassos 4 e 5

A utilização do modo eólio é retomada no compasso 6 com o acorde de fá com sétima maior (F7M), tendo continuidade até o compasso 9 onde se encontram os acordes si bemol com sétima maior (Bb7M), si bemol com sétima maior com baixo em lá (Bb7M/A), dó com sétima e baixo em sol $(C 7 / G)$, si 
bemol com sétima e baixo em fá (Bb7M/F), dó com sétima e baixo em mi $\mathrm{C} 7 / \mathrm{E}$ e si bemol com a décima primeira aumentada $[\mathrm{Bb}(\# 11)]$.
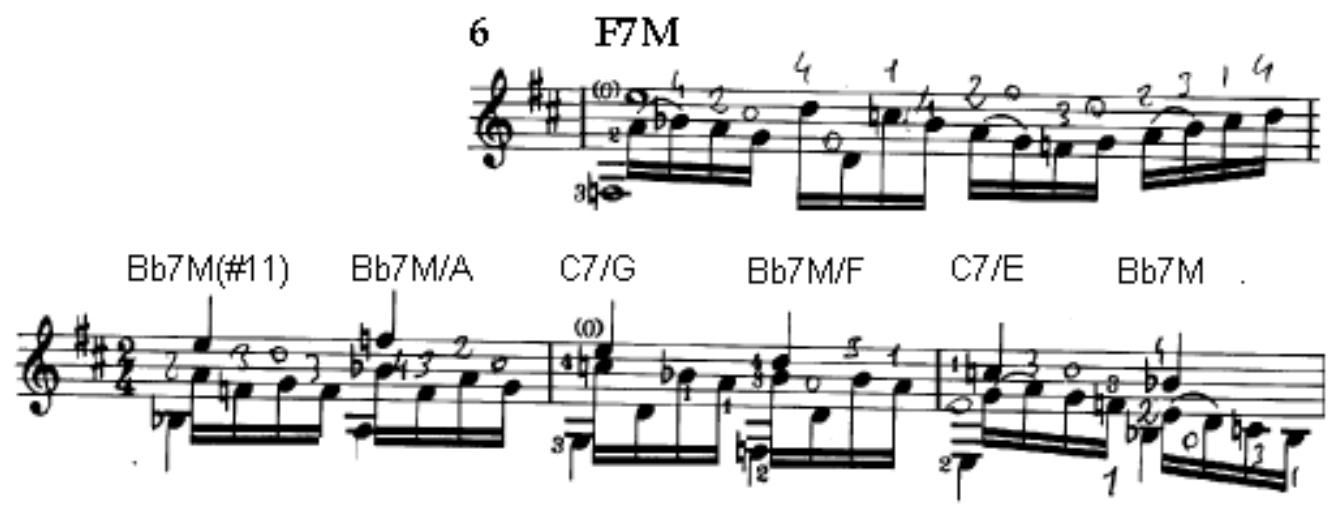

Prelúdio e Toccatina, compassos 6 a 9

A seção do Prelúdio é concluída por um trecho do compasso 10 ao compasso 15 em que se utiliza uma passagem cromática sobre um baixo na nota lá. Por se tratar da tonalidade de Ré maior cuja dominante é um acorde de lá com sétima (A7), analisaremos a harmonia desta passagem como de lá com sétima alterado ${ }^{106}$ (A7alt), pelo cromatismo presente no trecho.

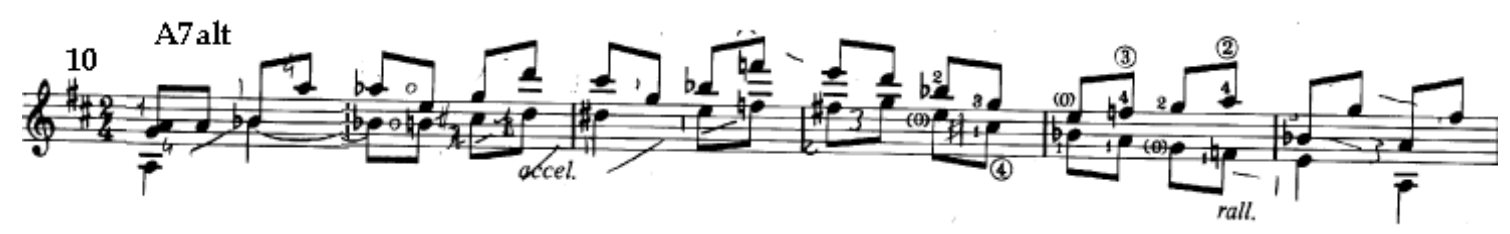

Prelúdio e Toccatina, compassos 10 a 15

A seção da Toccatina é iniciada no compasso 16 por um acorde de $D$ (b6) seguido de $A 7(b 9)$ sobre o modo eólio. No compasso seguinte há o acorde de D9 seguido de C7/E ainda sobre o modo de ré eólio. Esta mesma seqüência harmônica é repetida entre os compassos 20 a 23.

\footnotetext{
${ }^{106}$ Acorde dominante possuidor de diversas dissonâncias como b9, \#2, b5 e b6. Farias (1991) p41.
} 


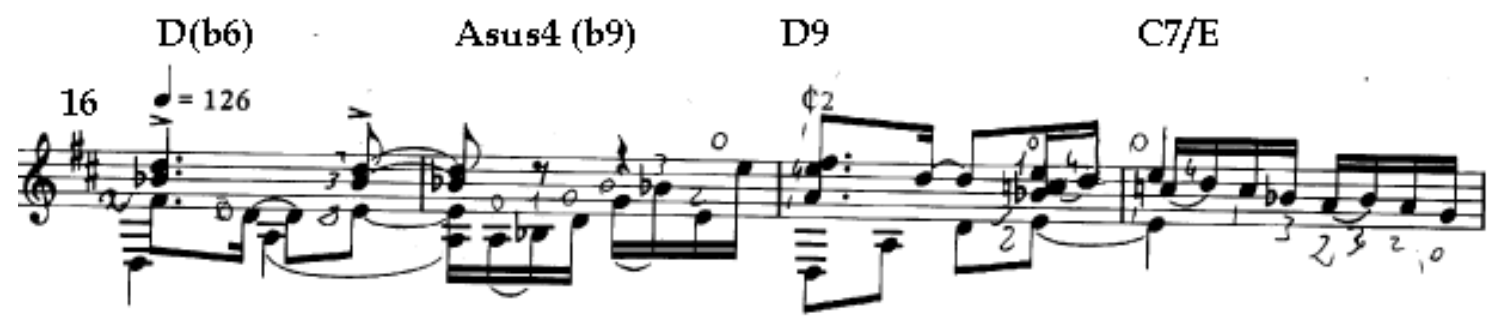

Prelúdio e Toccatina, compassos 16 a 19

Entre os compassos 24 e 35 é elaborada uma passagem em que a linha de baixo se encontra sobre um ostinato enquanto o Motivo 1 da peça é reapresentado sobre este novo contexto. Neste trecho não há uma função clara quanto à harmonia, podendo-se afirmar apenas de se tratar de um trecho cromático com tonalidade em Ré.

Após a reapresentação do motivo 1, vemos no compasso 36 a elaboração do motivo 2 sobre o acorde de lá com sétima e nona bemol [A7(b9)] no modo eólio estendendo-se até o compasso 42, cuja harmonia traz os acordes fá com sétima maior (F7M) e dó com sétima (C7) elaborados de forma similar à estruturação harmônica presente na sessão do prelúdio.

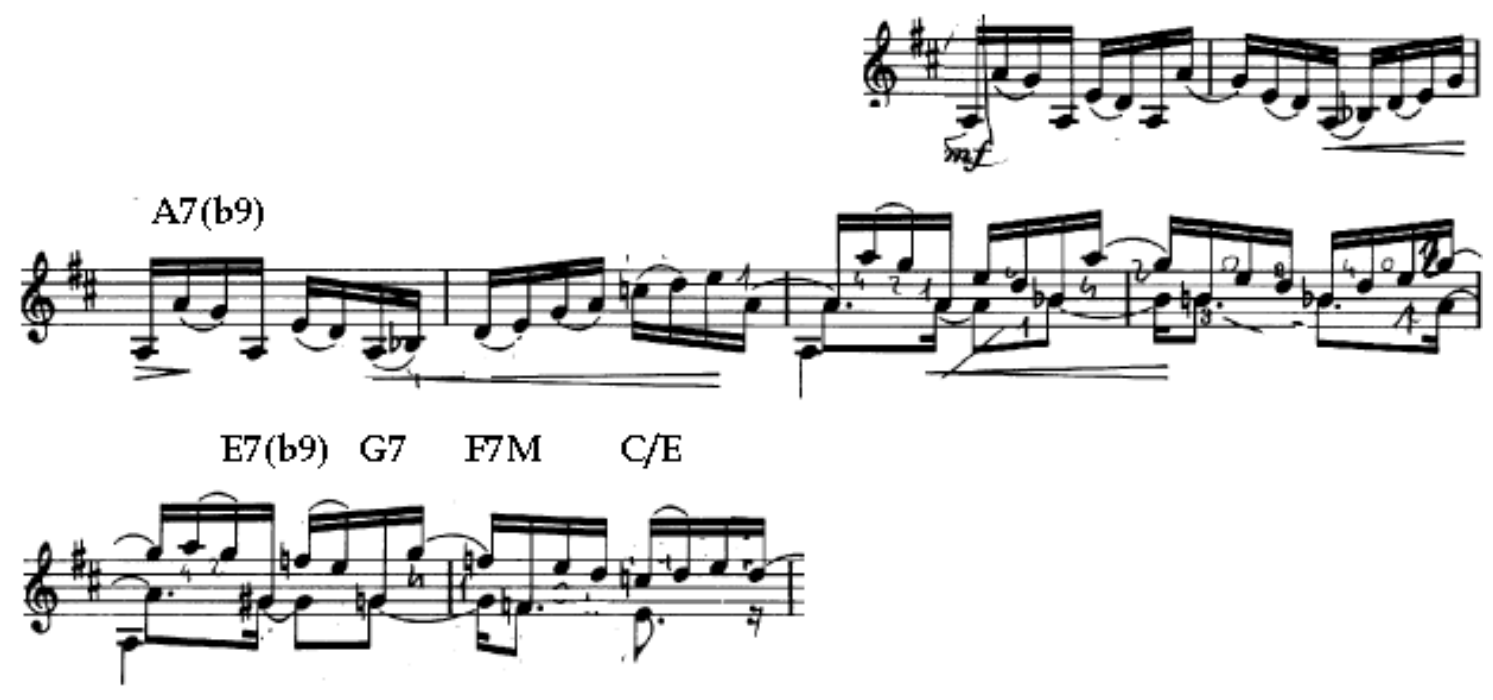

Prelúdio e Toccatina, compassos 36 a 43

O compasso 44 marca uma nova elaboração do motivo 2 sobre o modo de ré eólio onde é utilizado o acorde ré menor com nona e décima terceira bemol $[\mathrm{Dm}(9)(\mathrm{b} 13)]$, no compasso 45, lá bemol diminuto (Ab9) (possuindo a 
função de cromático auxiliar ${ }^{107}$ ) e ré menor (DM) no compasso 46 , o acorde sol menor $(\mathrm{Gm})$ no compasso 47, mi menor (Em) e ré menor (DM) no compasso 48 e dó (C), si bemol (BB) e lá (A) no compasso 49. Esta elaboração é repetida entre os compassos 50 e 54 .

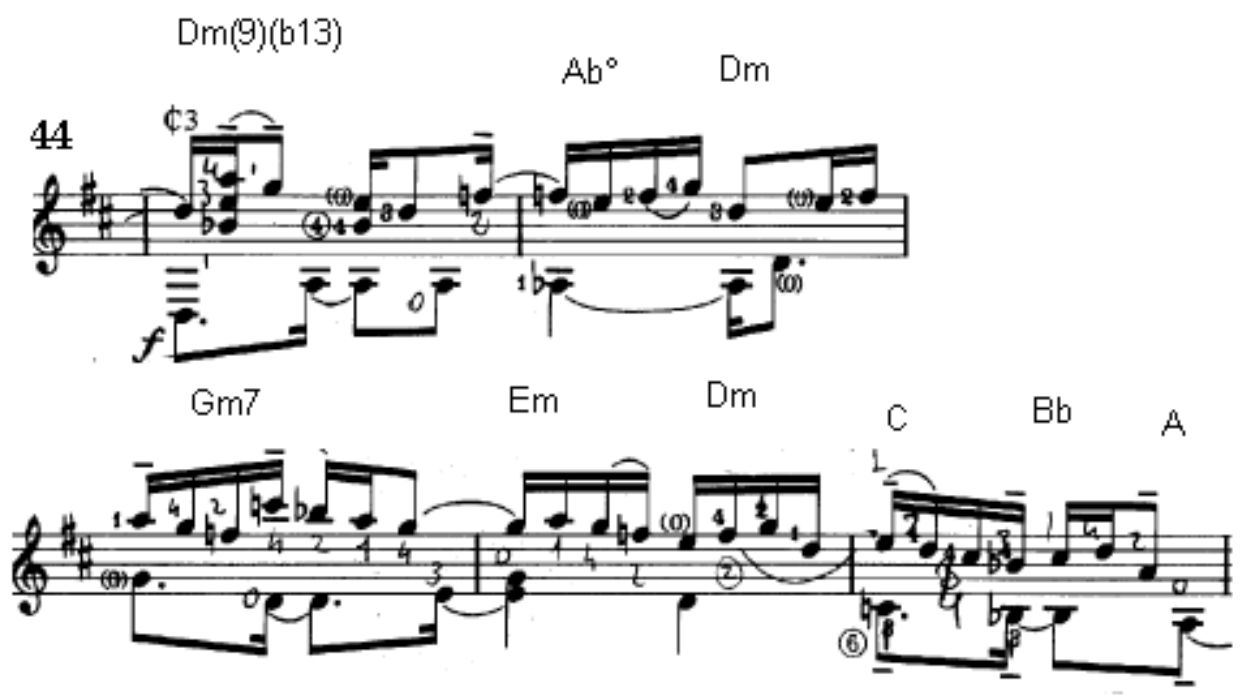

Prelúdio e Toccatina, compassos 44 a 48

A seguir, entre os compassos 55 e 62 é encontrado um trecho similar ao encontrado entre os compassos 10 e 15, sendo encontrada a mesma harmonia de A7alt (dominante alterado).

A elaboração do motivo 1 iniciada na anacruse do compasso 62 ,apresenta o acorde ré com quarta e nona [Dsus4(9)] seguido de si bemol com décima primeira aumentada e baixo em ré $[\mathrm{Bb}(\# 11) / \mathrm{D}]$ no compasso 63 . Esta seqüência harmônica é seguida entre os compassos 65 e 67 pelos acordes si bemol com sétima maior (Bb7M), si bemol com sétima maior com baixo em lá ( $B b 7 M / A)$, dó com sétima e baixo em sol (C7/G), si bemol com décima primeira aumentada (Bb\#11), dó com sétima e baixo em mi (C7/E) e si bemol (BB). Pode-se ressaltar a semelhança da harmonia presente entre os compassos 65 e 67 com a harmonia apresentada entre os compassos 7 e 9 na seção do prelúdio.

\footnotetext{
${ }^{107}$ Acorde diminuto sem função e que têm a sua classificação justificada pela movimentação melódica da harmonia presente. Freitas (1995) p 153.
} 
Dsus4(9) $\mathrm{Bb}(\# 11) / \mathrm{D}$

Bb7M Bb7M/A C/G $\mathrm{Bb} 7 \mathrm{M}$
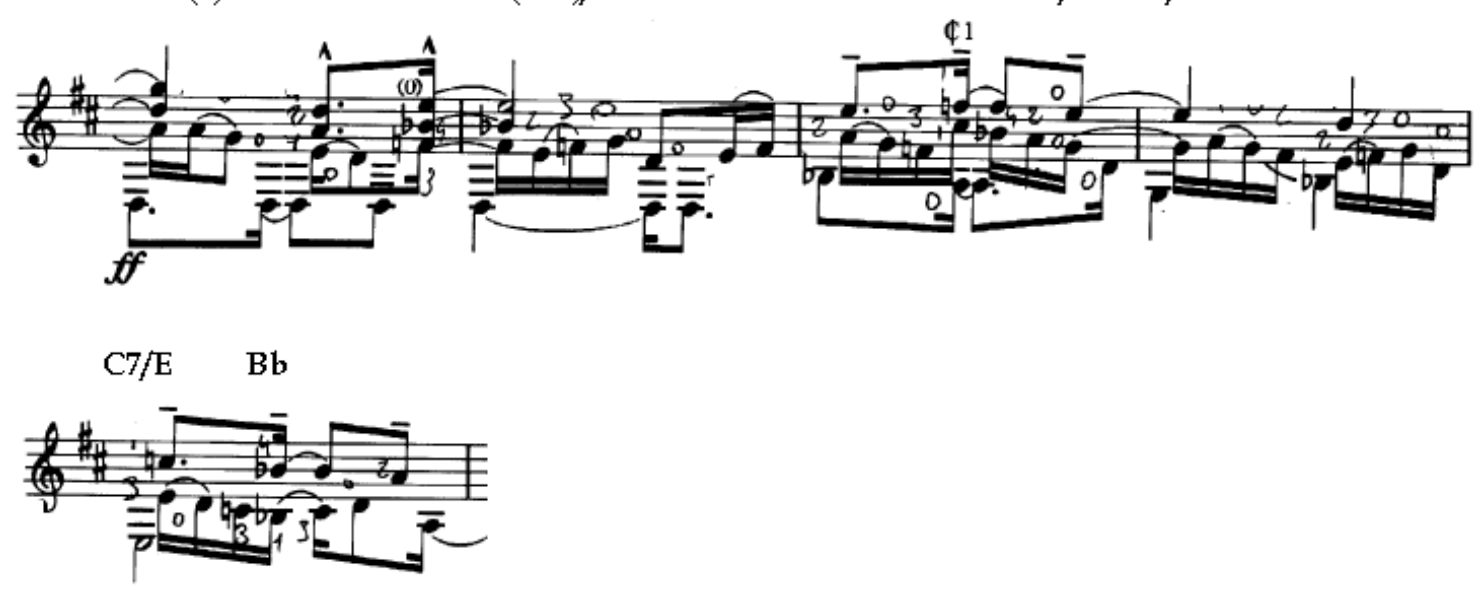

Prelúdio e Toccatina, compassos 62 a 66
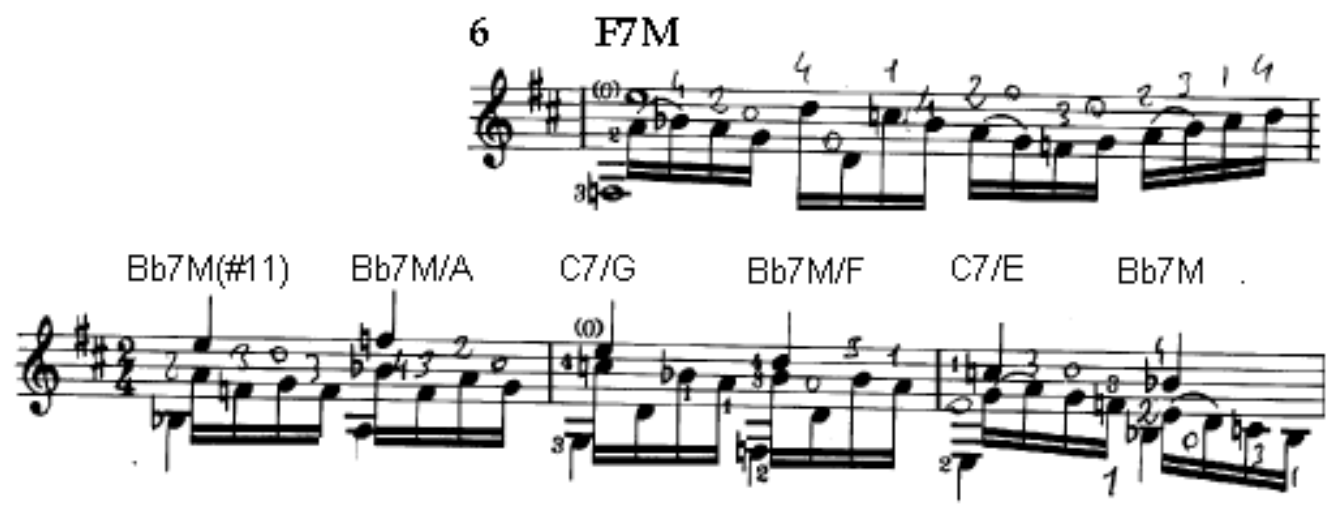

Prelúdio e Toccatina, compassos 6 a 9

A variação do motivo 1 elaborada a partir do compasso 67 é iniciada sobre um acorde de lá alterado (A7alt) até o compasso 68, sendo então sucedido entre os compassos 69 e 70 pelos acordes ré menor (DM), do com sétima ( $C 7)$, si bemol com baixo em ré $(B b / D)$, dó sétima $(C 7)$, si bemol $(B b)$ e dó com sétima $(\mathrm{C} 7)$, pertencentes ao modo de ré éolio. 

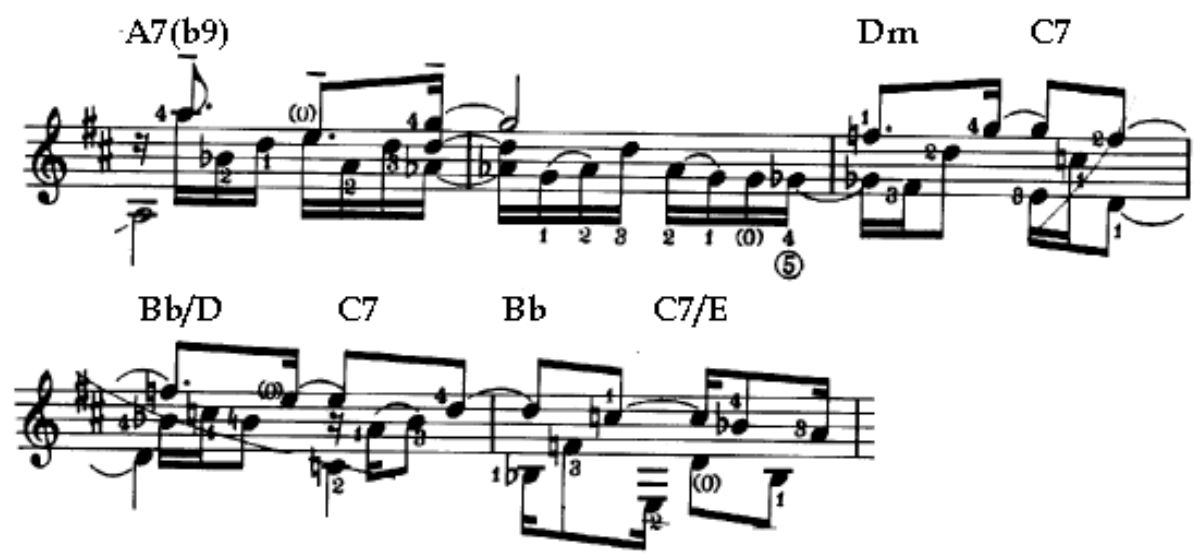

Prelúdio e Toccatina, compassos 67 a 71

A elaboração seguinte, presente entre os compassos 72 e 75 apresenta inicialmente uma melodia cromática sobre um acorde de lá com sétima alterado (A7alt) sendo concluído por uma escala ascendente de ré menor harmônica seguida de uma escala ascendente no modo de ré eólio nos compassos $74 \mathrm{e}$ 75. A repetição desta elaboração no compasso 77 é concluída por um desenho melódico cromático descendente que conduzirá à elaboração seguinte.

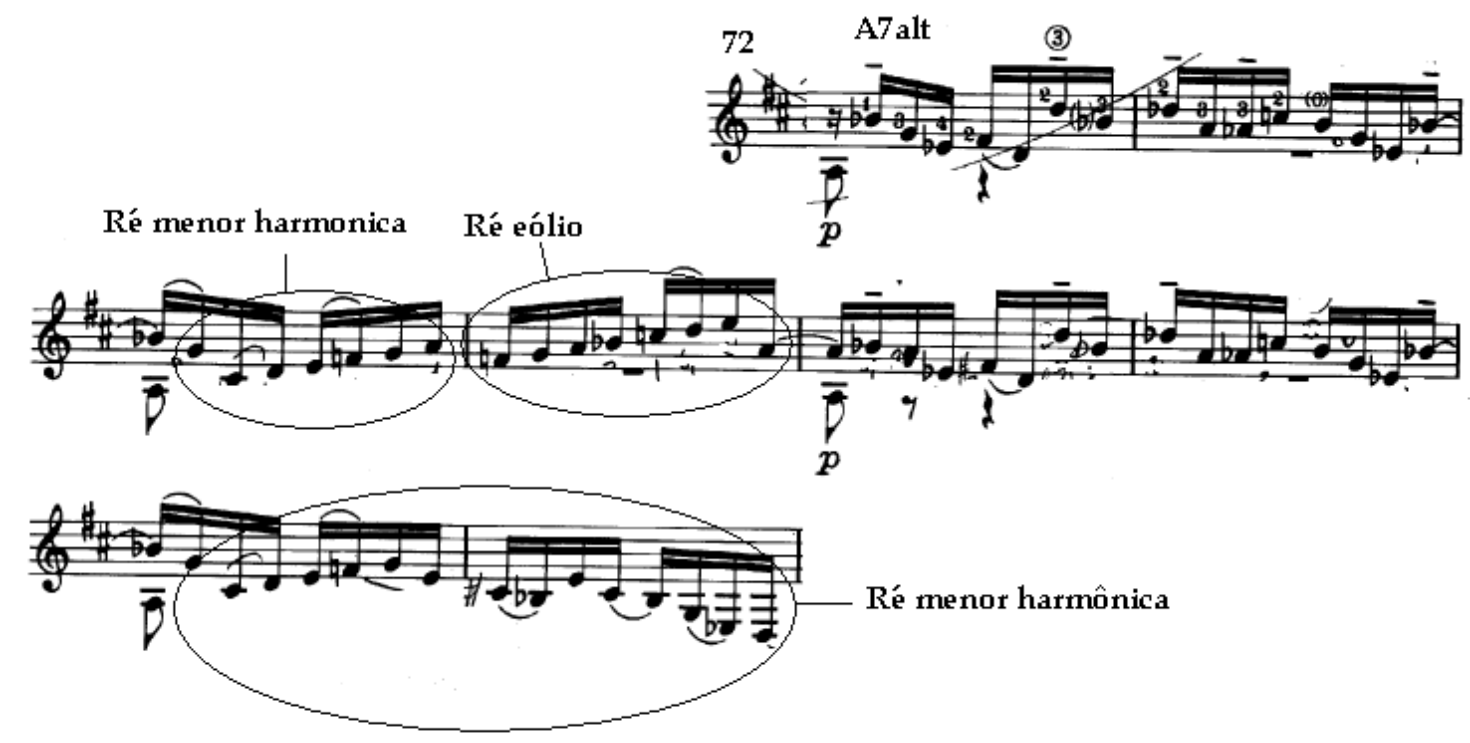

Prelúdio e Toccatina, compassos 72 a 79

A elaboração iniciada no compasso 80 , concluída no compasso 96 , é formada por grupos de frases formadas de quatro compassos. As duas 
primeiras têm como estrutura a utilização de diversas tensões cromáticas sobre um acorde de ré com sétima alterado (D7alt), sendo que as duas restantes seriam sobre um acorde de de ré com sétima alterado com baixo em lá D7alt/A. A cada grupo de duas frases a harmonia apresenta tensões similares. Nos compassos 82 e 83, 86 e 87 e finalmente 90 e 91; são encontrados acordes quartais $^{108}$ sobre um baixo pedal sendo que em cada frase de quatro compassos estes acordes se apresentam em registro mais agudo a cada repetição. O compasso 95 apresenta a conclusão da elaboração com emprego de acordes simétricos vindos da escala de mi octatônica ${ }^{109}$ sobre um baixo em ré.

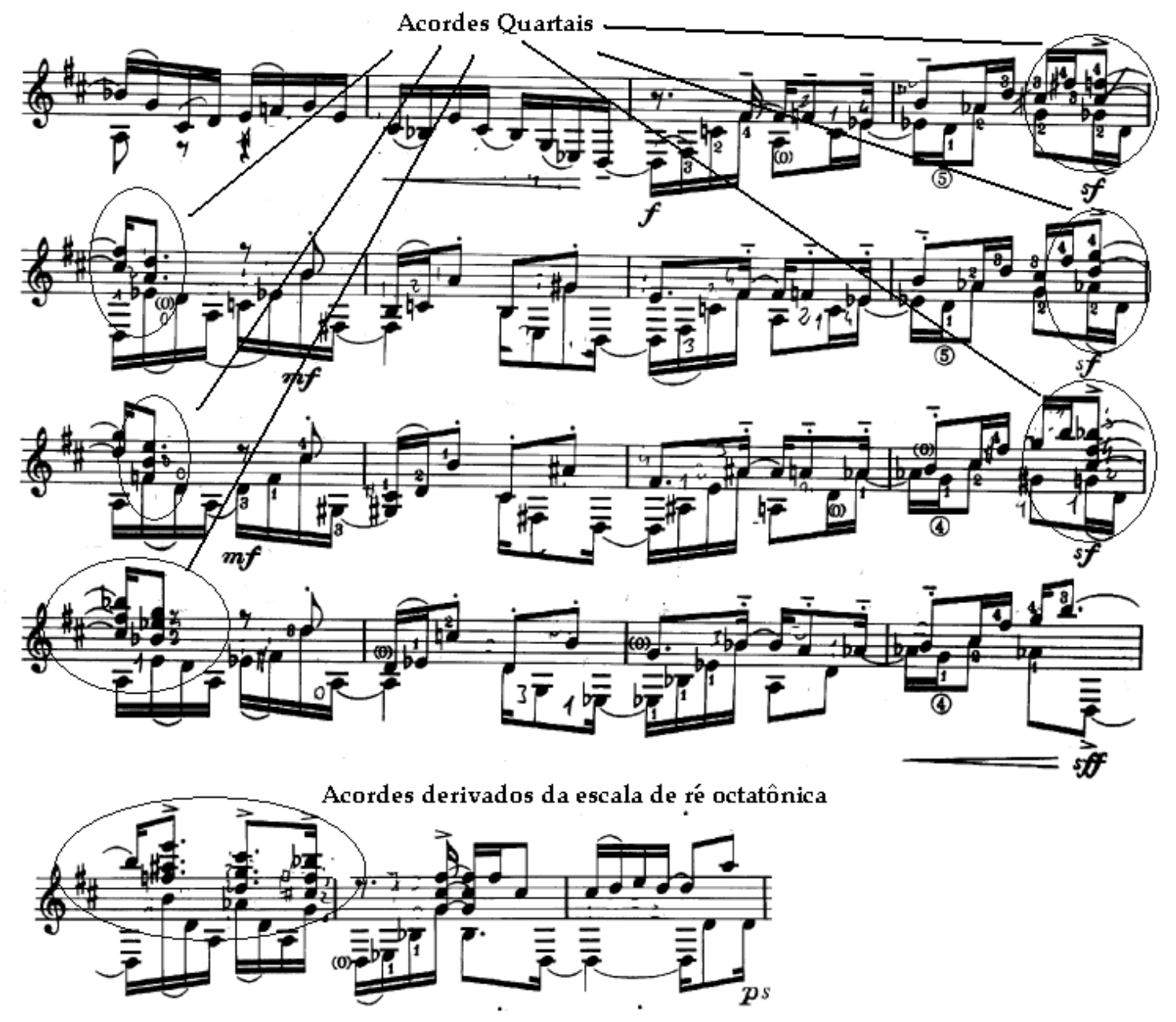

Prelúdio e Toccatina, compassos 78 a 96

\footnotetext{
${ }^{108}$ Acordes formados pela sobreposição de quartas. Ottman (2000) p. 379.

${ }^{109}$ Escala simétrica formada pelos intervalos T, 2m, 2\#, 3M, 4\#, 5J, 6M, 7m. Farias (1991).
} 
O compositor explora o gênero baião em uma passagem a partir do compasso 97. Neste a polifonia se torna menos densa, momento em que se verifica também o emprego do modo de ré mixolídio. Esta passagem é iniciada por um acorde de ré (D) no compasso 97, seguido de sol (G) no compasso 99 e de ré com sétima e nona bemol [D7(b9)] (dominante) e sol (G) nos compassos 99 e 100. O compasso seguinte (101) é formado pelos acordes ré com sétima (D7) e sol (G), sendo então sucedidos pelo acorde dó (C) ${ }^{110}$ no compasso 102 e ré com sétima (D7) no compasso 103, este último resolvido no acorde sol (G) do compasso 104. Uma cadência de mi menor com sétima e quinta bemol [Em7(b5)] e lá com sétima A7 [formando as funções IIm7(b5) V7] é elaborada no compasso 105, havendo uma resolução de engano com o acorde lá bemol com sétima e quinta bemol [Ab7(b5)] no compasso 106 que atua como sub $\vee$ do acorde sol $(G)$ presente no compasso 107. Neste mesmo compasso é encontrado um acorde de lá com sétima e baixo em dó sustenido (A7/C\#) que servirá de dominante para a volta à tonalidade de Ré maior no compasso 108 (acorde de ré maior).

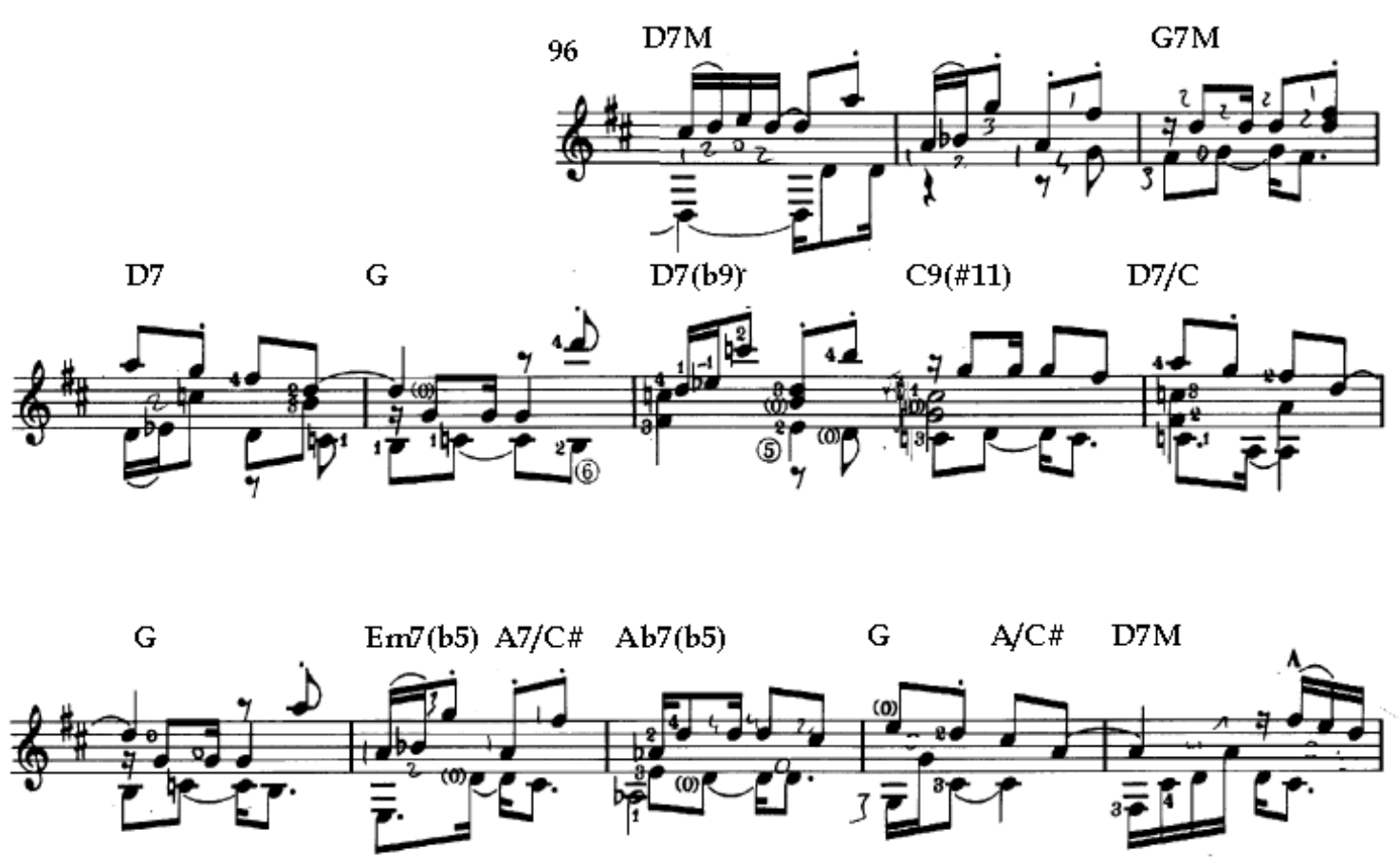

Prelúdio e Toccatina, compassos 96 a 108

\footnotetext{
${ }^{110}$ Detectamos neste compasso um pequeno erro de edição, ao se omitir o sinal de bequadro no compasso. Tal detecção foi dada a incongruência entre a digitação presente na passagem e à modulação presente na passagem.
} 
Uma cadencia de mi menor (Em) A maior (formando IIm V) no compasso 109 é resolvida por um acorde de ré maior com décima primeira aumentada [D(\#11)] característico ao modo lídio no compasso 110, sendo sucedido pelos acordes mi (E) e ré com sétima maior (D7M) no mesmo modo no compasso 111. Encontram-se entre os compassos 112 e 114 os acordes de lá com sétima e nona bemol [A7(b9)] sol menor com sétima $(\mathrm{Gm} 7)$ e fá com sétima e quinta aumentada [F7(\#5)] (vindos da escala de ré menor harmônica). O retorno ao ostinato (o mesmo do compasso 24) é precedido por uma cadencia II - V formada pelos acordes mi menor (Em) e lá com sétima (A7) no compasso 115.
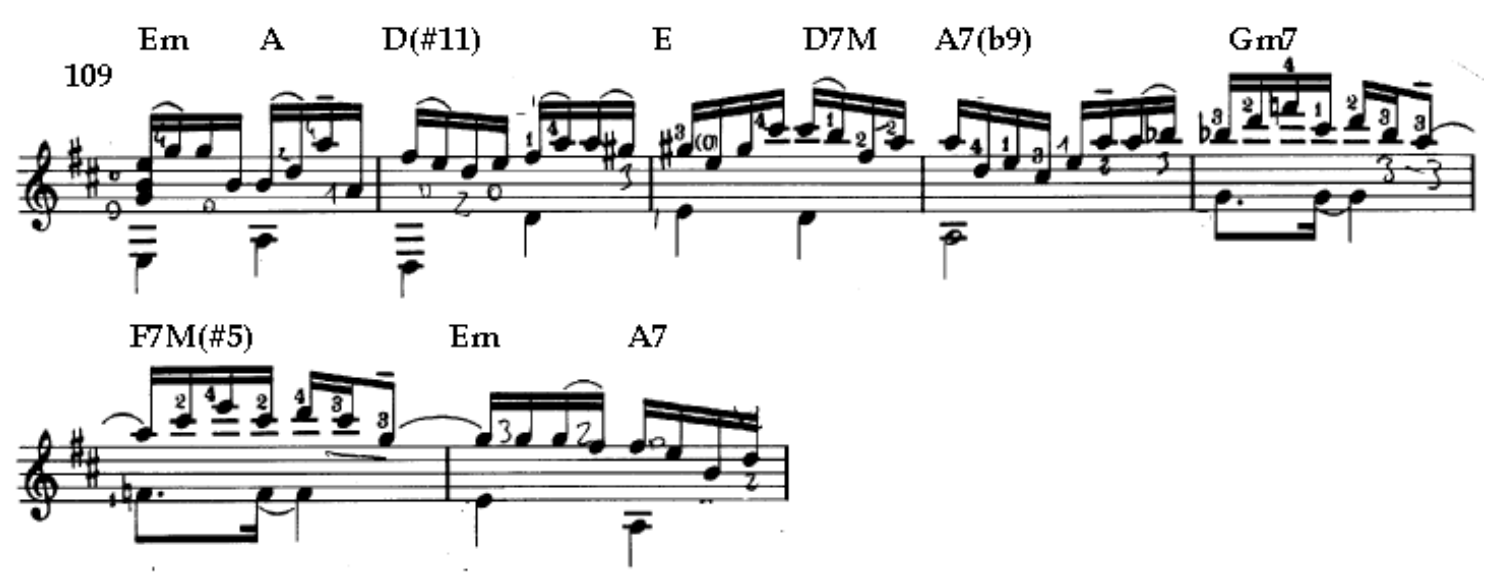

Prelúdio e Toccatina, compassos 109 a 115

O ostinato iniciado no compasso 116 é concluído no compasso 120 por um arpejo de sol menor com sexta $(\mathrm{Gm} 6)$ vindo do modo eólio e seguido de uma frase sincopada no mesmo modo no compasso seguinte (121). Este trecho servirá de ligação à elaboração iniciada por um acorde de lá menor com sétima e décima primeira $[A m 7(11)]$ iniciada no compasso 122 e concluída no compasso 123. 

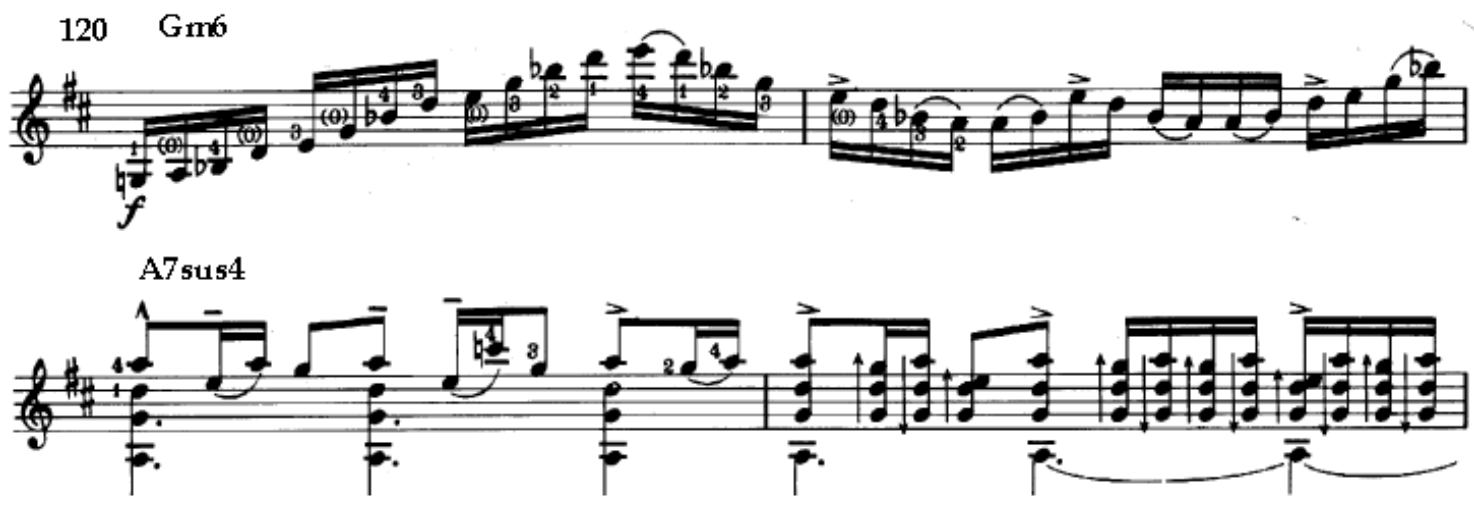

Prelúdio e Toccatina, compassos 120 a 123

O desfecho do Prelúdio e Toccatina é iniciado no compasso 124 pelo motivo encontrado nos compasso 97 a 99, sendo este elaborado sobre os acordes ré com sétima e baixo em lá bemol (D7/Ab), si bemol com sétima e quinta aumentada $[\mathrm{Bb} 7(\# 5)]$, lá com sétima e décima primeira $[A 7(11)]$, sol menor com sexta $(G m 6)$ e ré $(D)$. Neste trecho, destaca-se o movimento contrário das vozes do baixo (descendente) e soprano (ascendente).

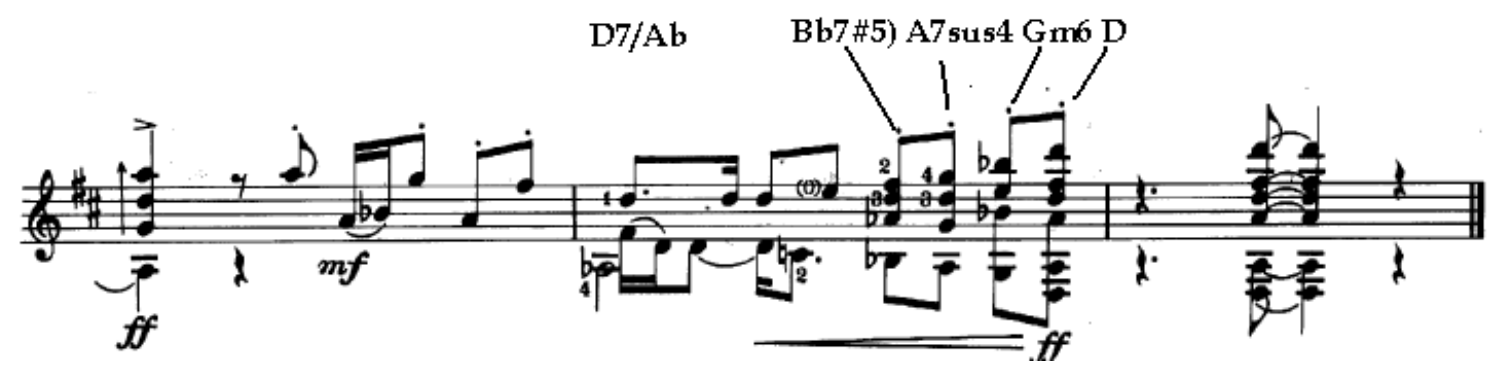

Prelúdio e Toccatina, compassos 124 a 126

Neste item pudemos verificar a existência de um vocabulário harmônico em que se verificam passagens em que se alterna a estruturação atonal, tonal e modal. Dentre as estruturas detectadas como tonais e modais pudemos perceber a predominância de acordes com tensões acrescentadas. Dentro da estruturação atonal, pudemos perceber predominância de estruturação gerada pela escala de tons inteiros e polarização para com certas estruturas harmônicas. Outro aspecto importante detectado é que a linguagem empregada foi elaborada em função da estruturação da obra, tornando a linguagem harmônica um elemento estrutural. 


\subsection{Análise da Escrita Violonística de Aquarelle}

Visto que Sérgio Assad desenvolveu uma sólida carreira como interprete e ao percebermos uma complexa elaboração instrumental em Aquarelle, houve a necessidade de uma análise de sua linguagem instrumental ao não encontrarmos publicações ou artigos sobre sua técnica violonística.

Neste tópico a análise de sua linguagem instrumental foi baseada no estudo e execução da obra. Tal prática nos propiciou a observação de diversas passagens em que peculiaridade ou a dificuldade gerada situação técnica presente nos forneceu diversas pistas quanto a sua concepção violonística formando um retrato de seu vocabulário instrumental.

Ao analisarmos diversas passagens cujas implicações técnicas geram dificuldades de execução, proporemos soluções alternativas para a execução ao sentirmos que uma nova digitação traria uma execução mais fluente.

A seguir uma análise da escrita instrumental dos três movimentos de Aquarelle.

\subsubsection{Divertimento}

Neste tópico será feita a análise das principais características violonísticas presentes no primeiro movimento da obra, Divertimento, assim como suas implicações técnicas e propostas de soluções alternativas a determinados trechos.

Na prática de passagens de escalas ao violão o uso alternado de notas presas e soltas em registro mais agudo é evitado devido à diferença de timbre entre as diferentes cordas. Na Suíte Aquarelle o compositor indica este tipo de digitação, normalmente evitado, em três situações: devido à densidade das texturas polifônicas utilizadas, a fim de se conseguir o efeito desejado em termos de andamento e quando em uma determinada passagem há a necessidade de um salto de uma posição no braço do instrumento a outra. 
Este tipo de digitação pode ser encontrada em diversas peças do repertório violonístico e é um recurso comumente empregado por compositores violonistas e compositores não-violonistas quando trabalhadas com um instrumentista. Um exemplo característico é o encontrado no Prelúdio Americano no3, Campo do compositor e violonista uruguaio Abel Carlevaro (1916 - 2001), em que há a indicação de salto da $2^{\underline{a}}$ até a $6^{\underline{a}}$ posição após duas cordas soltas, si (2) e mi (1) encontradas no segundo tempo do compasso.

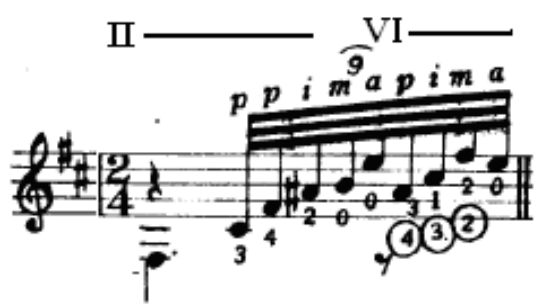

Prelúdios Americanos № 3, Campo - Abel Carlevaro

No Divertimento este expediente é encontrado em profusão, podendo ser observado nos compassos $3,10,15$ a 21, 65, 70,71, 75, 78, 81, 84, 85, 86, $88,92,95,148,161,162,165,184,185,186,187,189$ e 190. Veremos a seguir, com fins ilustrativos, alguns exemplos significativos deste recurso.

A linha melódica presente no primeiro tempo do compasso 10 apresenta as notas láb corda si (2) mi (1), e f\# (2) e é executada na $7^{a}$ posição. Pode-se ressaltar que a utilização da corda mi aberta presente no trecho, apesar de causar uma diferença de timbre na linha melódica, pode ser justificada pelo acelerando no andamento empregado pelo compositor e pela facilidade técnica que esta digitação traz à passagem.

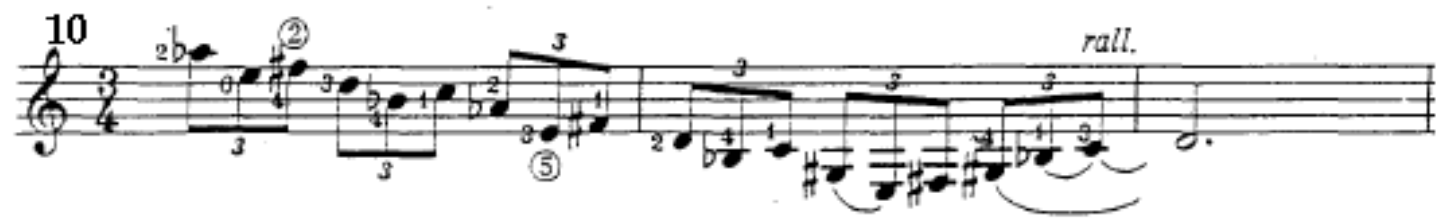

Divertimento compassos 10 a 12

É encontrado no compasso 88 uma melodia na 9a posição em que são

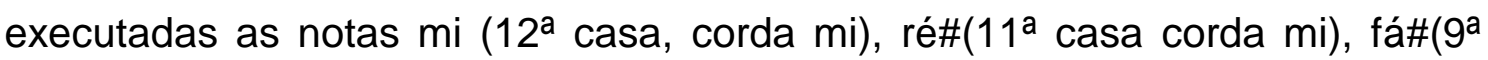


casa corda sol) e mi (corda mi solta), havendo então um salto à segunda posição. Para facilitar a mudança de posição há o emprego da nota mi solta enquanto é executado o salto citado.

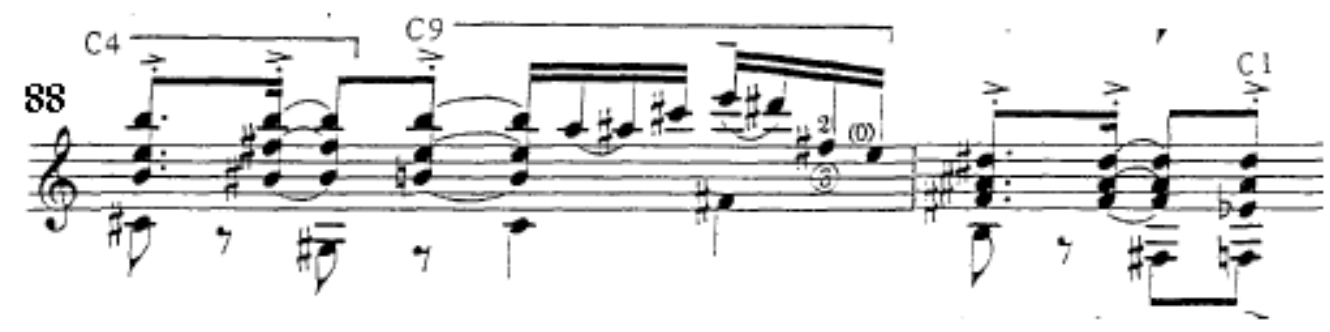

Divertimento, compassos 88 a 89

Durante a Coda (compassos 184 a 193) encontram-se entre os compassos 189 e 192 inversões sobre a tríade de mi maior onde a cada uma destas há uma mudança de posição em que são utilizadas cordas soltas para uma maior fluência instrumental.

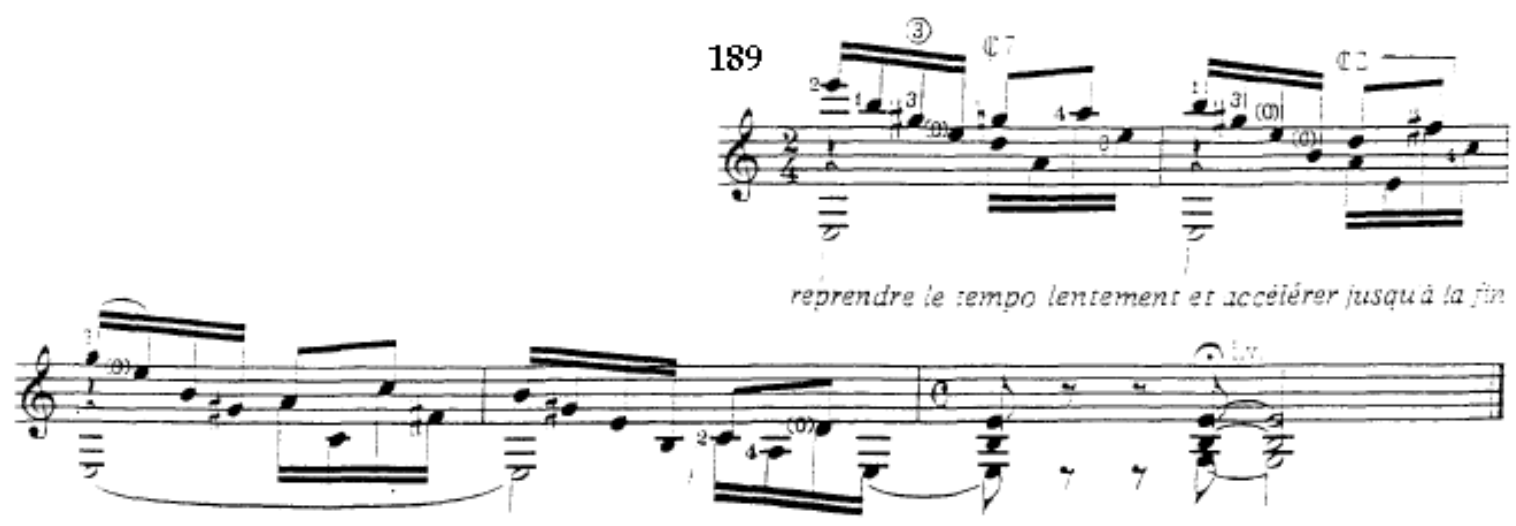

Divertimento compassos 189 a 193

Encontramos um paralelo em elaborações que contêm tríades e suas inversões, tal como exposto no parágrafo anterior em obras escritas para violão durante o período clássico. Vianna (2005) ${ }^{111}$ compara Assad ao compositor do período clássico Mauro Giuliani (1781 - 1829) quanto a sua atitude perante a escrita violonística, em que se busca uma complexidade instrumental maior evitando assim restrições quanto à dificuldade técnica da peça. Como ilustração deste recurso no restante da literatura para violão, podemos tomar como exemplo o Estudo n. 14 Opus 48 de Giuliani, quando no compasso 18 encontramos o emprego de uma tríade de lá maior em várias inversões.

${ }^{111}$ Entrevista concedida por Aliéksey Vianna em 2005, ver seção anexos, página 243. 


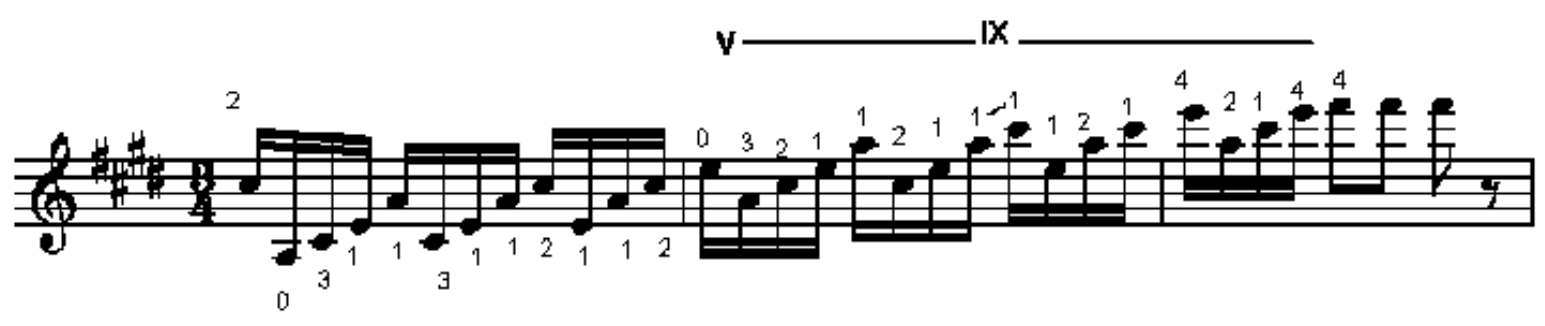

Estudo n. 14 Opus 48 de Mauro Giuliani

Em Divertimento detectamos em diversas passagens o emprego de escalas em digitações indicadas pelo compositor que produzem o efeito de campanela ${ }^{112}$. Nesta técnica notas próximas são executadas em cordas diferentes, sobrepondo-se em intervalos próximos. O efeito de sonoro desta sobreposição no violão é similar à ressonância de uma harpa.

Como exemplo deste recurso, detectamos no compasso 31 uma escala de sol menor harmônica iniciada em seu quinto grau (ré). No primeiro e segundo tempos são executadas as notas mib, fá\#, e sol, na quinta, quarta e terceira cordas respectivamente, havendo a sobreposição sonora destas, devido à digitação indicada na partitura. No terceiro tempo deste compasso são executadas as notas do\# ( $5^{\underline{a}}$ corda) sib ( $6^{\underline{a}}$ corda) e ré ( $4^{\underline{a}}$ corda), havendo a repetição da mesma fôrma anterior e o mesmo efeito citado. No quarto tempo a primeira fôrma é repetida, havendo uma escala comum no quinto tempo e a repetição do padrão inicial ao final do compasso.

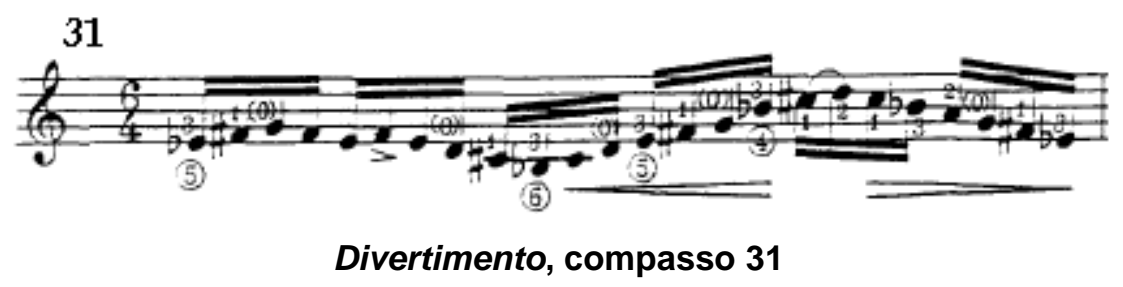

O mesmo efeito é explorado novamente no compasso 33, ao apresentar em seu primeiro tempo as notas lá ( $6^{\underline{a}}$ corda) ré ( $4^{\underline{a}}$ corda) e mib ( $5^{\text {a }}$ corda) formando o efeito de campanela. O próximo tempo apresenta nova

\footnotetext{
112 O termo campanela se refere, em termos gerais, a passagens de texturas escalares ou arpejadas onde as notas de intervalos próximos são executadas de maneira a ressoar umas contra as outras. Podemos tomar como exemplo dessa prática o estudo para piano do compositor Franz Liszt (1811 - 1886), La Campanela Op. 141, que teve como inspiração o terceiro movimento do Concerto no 2 em Si Menor de Nicolo Paganini (1782 - 1840). O termo foi utilizado na literatura violonística moderna por Emílio Pujol (1886 - 1980) em seu tratado, La Escuela Razonada de la Guitarra, ao se referir às digitações utilizadas pelo guitarrista espanhol Gaspar Sanz (1629 - 1678) para a execução de escalas e arpejos em cordas alternadas.
} 


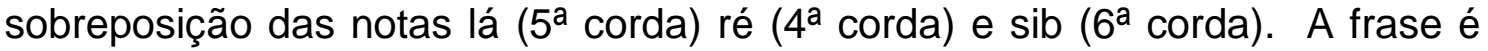
então concluída com as mesmas fôrmas presentes na campanela do compasso 31 (mib/ fá\# /sol e ré dó\# e sib)

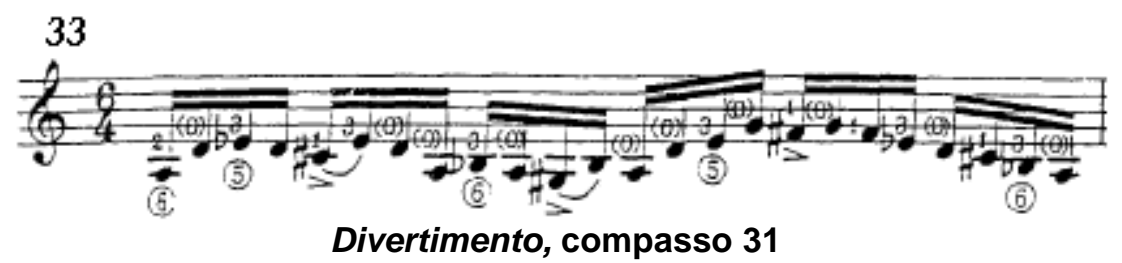

Dentre os elementos do vocabulário instrumental empregada em Aquarelle, encontramos o recurso de melodia acompanhada, em que o compositor indica o destaque de uma determinada textura sobre as demais. Para a execução destas passagens pode ser utilizado o toque com apoio ${ }^{113}$ ou sem apoio, dependendo do interprete ${ }^{114}$.

Exemplificaremos 0 emprego de melodias acompanhadas com a passagem presente entre os compassos 34 a 41, onde os temas desenvolvidos na voz de soprano devem ser ressaltados em relação às texturas mais graves. Tal passagem é reapresentada de forma variada entre os compassos 59 a 66. Recomendamos para uma execução fluente destas passagens e a manutenção da articulação em legato dos temas a antecipação dos dedos da mão esquerda dada a facilidade que este recurso proporciona nas passagens citadas.

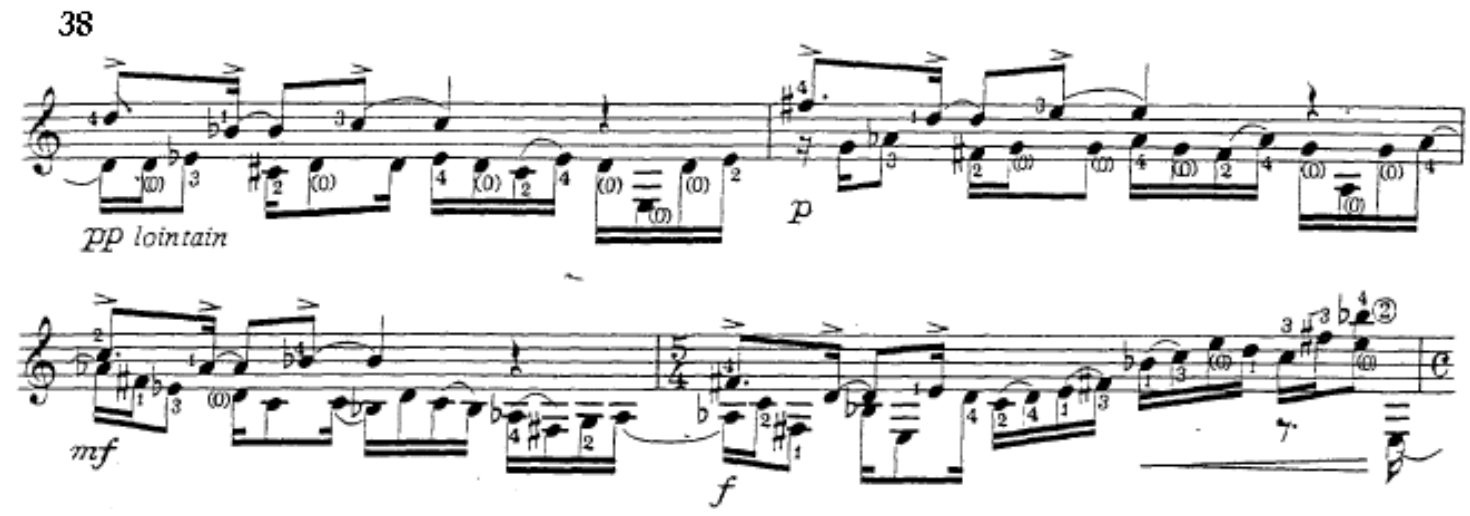

${ }^{113} \mathrm{O}$ apoio, de acordo com Tennant (1995), é uma técnica de mão direita em que a corda é pinçada na direção do tampo do violão, tendo como resultado físico é uma maior ressonância no corpo e tampo do violão. O efeito percebido é de uma sonoridade mais "cheia" que a do toque sem apoio.

${ }^{114}$ Existem controvérsias com relação à utilização do apoio. Em um curso de verão promovido pela Escola de Música de Brasília em 2005 o autor deste trabalho se recorda do Prof. Dr. Eduardo Meirinhos defendendo a utilização do "semi apoio" afirmando que haverá a mesma sonoridade sem as implicações de mudança de posição de mão direita presentes na técnica do apoio. 


\section{Divertimento, compassos 38 a 41}

Dentre as dificuldades técnicas encontradas ao se executar a Aquarelle, encontram-se a execução de diversas aberturas na mão esquerda ${ }^{115}$.

Encontramos nos compassos 35 e 61 um trecho cuja abertura proposta pelo compositor causa dificuldades da mão esquerda. No trecho indicado é executada a nota ré na $3^{\underline{a}}$ corda na $7^{\underline{a}}$ posição, há a execução da notas re e mib nas cordas ré e lá respectivamente, e enquanto é executada a nota f\# na 6 corda. Esta configuração leva o intérprete a uma abertura de duas casas entre os dedos nas primeiras posições ${ }^{116}$. De acordo com Carlevaro (1988, p.54) em Abel Carlevaro Guitar Masterclass Vol. III, em situações como a descrita, recomenda-se o uso da musculatura do braço a fim de auxiliar a execução da abertura.

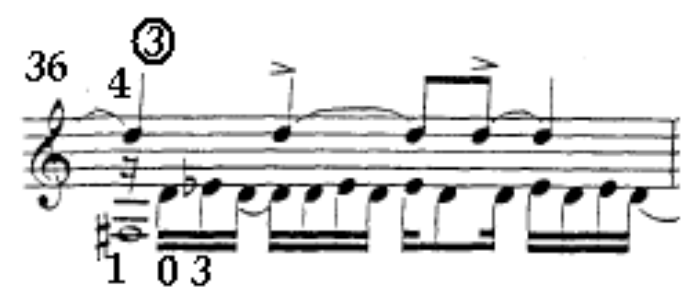

Divertimento, compassos 36

A passagem contida no compasso 65 por sua vez apresentou dificuldades técnicas, dada a apresentação simultânea de motivos. Houve a necessidade que o motivo elaborado presente na voz intermediária fosse ressaltado para que houvesse coerência interpretativa com a apresentação anterior desta elaboração. Tal concepção causou dificuldades técnicas dado o controle sonoro exigido para mão direita, a fim de que o objetivo musical seja atingido, visto que o toque com apoio não pôde ser realizado sempre que possível na passagem, dada a sua densidade polifônica.

\footnotetext{
${ }^{115}$ Técnica em que os dedos da mão esquerda do executante se abrem a fim de que se executem certos acordes ou passagens.

${ }_{116}$ A construção do braço do violão implica na maior distância entre os trastes nas primeiras posições, causando maior dificuldade ao violonista ao se executar aberturas nestas regiões do braço.
} 


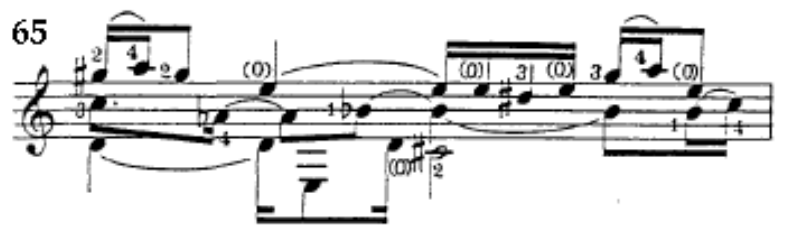

Divertimento, compassos 65

A elaboração encontrada entre os compassos, 96 a 101 apresenta duas aberturas que geram o que consideramos a maior dificuldade técnica de toda a obra. Este trecho, que se encontra construído em frases de dois compassos cada, possui no primeiro compasso de cada grupo (96, 98 e 100) uma pestana $^{117}$ onde na voz de soprano há a exigência de uma abertura de duas casas. O grupo de compassos seguintes (97 e 99) apresenta uma abertura de três casas entre os dedos 3 e 1 . À medida que a passagem citada atinge tons mais baixos e há o aumento da distância das casas, tornando a aberturas de execução mais complexa a cada transposição. Esta passagem se diferencia de outras, devido à ausência da facilidade técnica proporcionada pelo uso de cordas soltas que são substituídas por pestanas, cuja execução é mais complexa.

\footnotetext{
117 Técnica instrumental também conhecida como "capotasto" em que os dedo 1 da mão esquerda é pressionado sobre duas ou mais cordas para a execução de passagens em que se encontram uma ou mais notas presentes na mesma casa. Essa técnica pode ser variada para o uso de outros dedos da mão esquerda executando a pestana como encontrado na obra do violonista Aníbal Augusto Sardinha, o "Garoto" (1915 - 1995) ou a pestana em mais de uma casa como visto na obra Romance do compositor e violonista Nikita Koshkin (1956).
} 


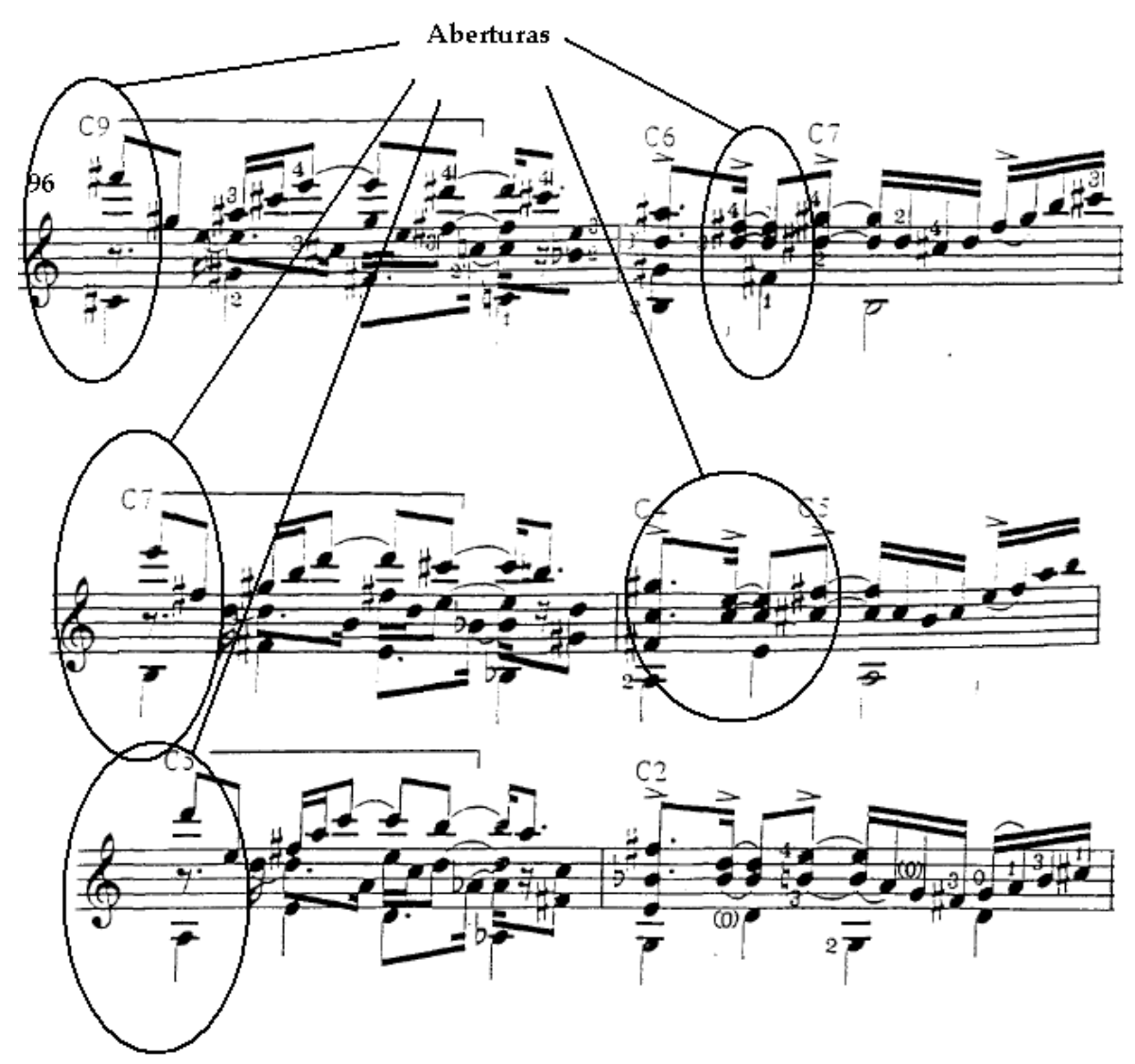

Divertimento, compassos 96 a 101

Uma dos recursos comuns à escrita violonística é a possibilidade de se transpor facilmente uma fôrma de acorde ou padrão instrumental havendo em muitos casos o uso de nota pedal em corda solta.

As elaborações presentes entre os compassos 42 e 58 demonstram como Assad utiliza este recurso e a partir de uma fôrma de acorde violonístico, neste caso uma tríade aumentada, desenvolve diferentes idéias musicais.

No compasso 42 é executada com a técnica de glissando ${ }^{118}$, uma tríade de Si bemol aumentado com um ostinato realizando na $6^{\underline{a}}$ corda mi.

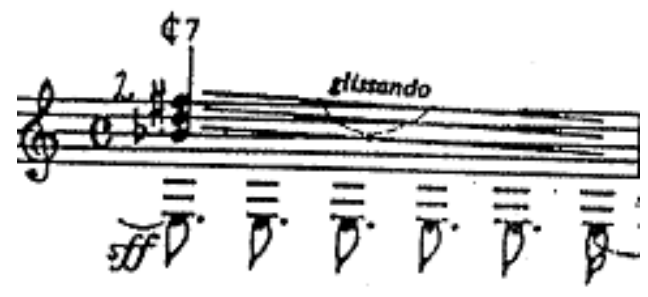

Divertimento, compasso 42

\footnotetext{
${ }^{118}$ Quando há a execução da técnica do glissando, uma determinada nota ou acorde na mão esquerda é deslizada cromaticamente após a execução da mão direita.
} 
Essa mesma tríade é reutilizada pelo compositor novamente no compasso 45, em que a fórmula de compasso passa de 4/4 a 7/8 e uma figura melódica formada por uma escala de tons inteiros é utilizada. Este tema é transposto um tom abaixo quatro vezes com a utilização da nota mi grave com pedal no baixo. Primeiramente é utilizado o tema com uma tríade de si bemol aumentado havendo transposições a láb aumentado, fá\# aumentado e mi aumentado respectivamente.

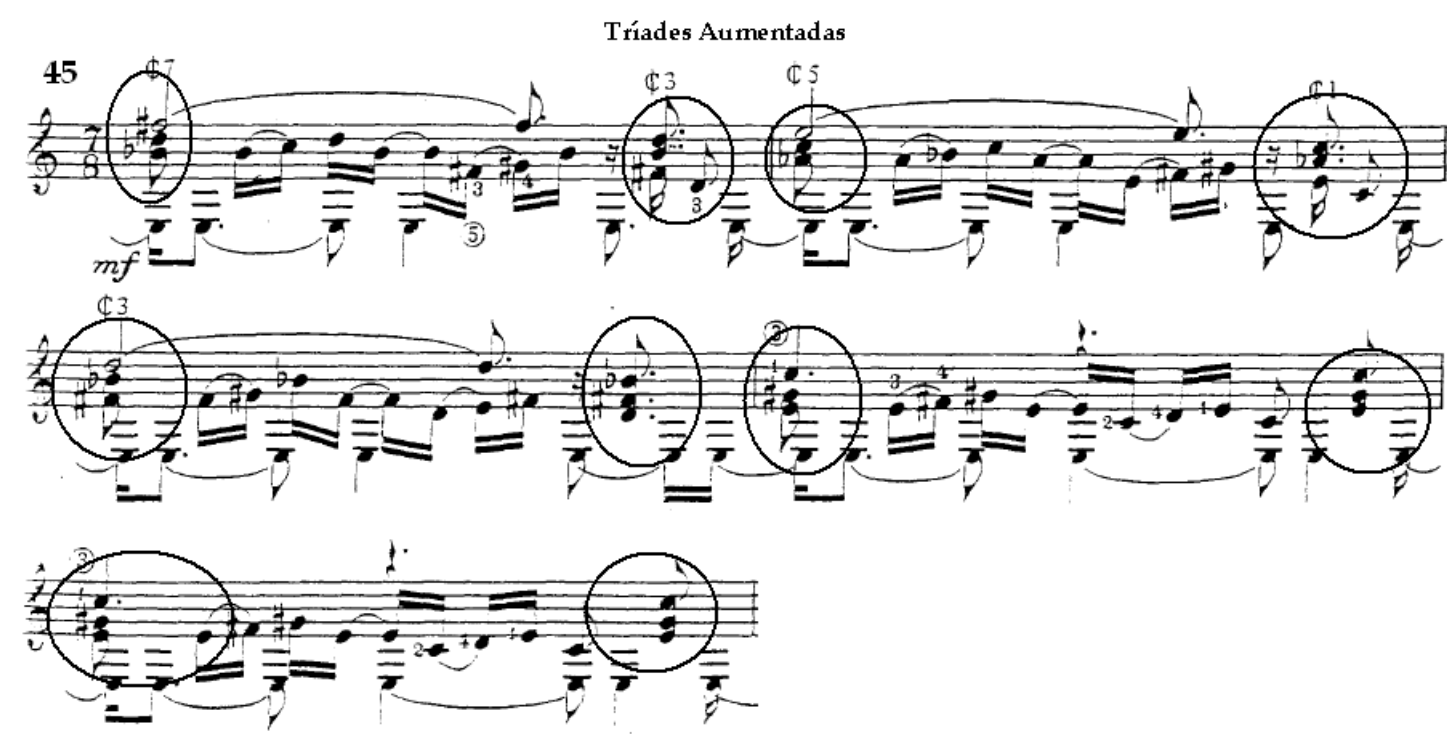

Divertimento compassos 45 a 49

A tríade aumentada é utilizada novamente como material nos compassos 50 e 51 . Nestes compassos, a tríade aumentada de Mi bemol é apresentada de maneira rítmica juntamente com uma nota Mi no baixo pedal, em uma métrica quaternária.

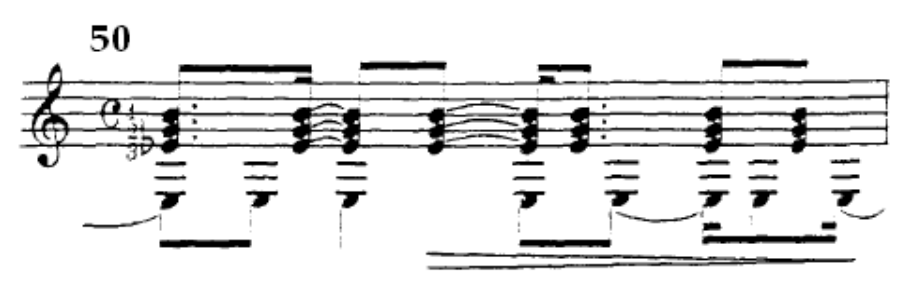

Divertimento, compasso 50

A mesma tríade é novamente empregada nos compassos seguintes, havendo variação melódica e uma mudança para a métrica de $3 / 8$, passando 
por 2/8. Devemos ressaltar a ocorrência de um erro de edição pela adição da nota dó sobre a tríade aumentada. Tal erro foi detectado ao ouvirmos as gravações de Boris Gaquere e Aliéksey Vianna, ambas supervisionadas pelo compositor, em que a nota si da tríade aumentada é mantida nos compassos 55 e 56.

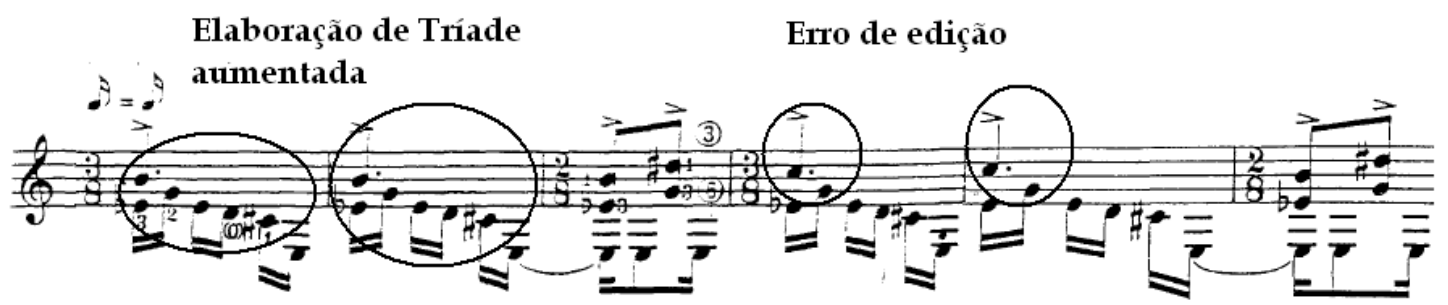

Divertimento, compassos 52 a 57

A técnica de campanelas é novamente empregada no compasso 58 finalizando esta elaboração sobre a fôrma de acorde presente na elaboração entre os compassos 50 e 57. Este trecho é iniciado pelo acorde citado arpejado nas cordas lá, ré e sol e que é estendido em forma de pequenas células em campanelas, que quando executadas no andamento indicado pelo compositor darão a impressão de um acorde arpejado.

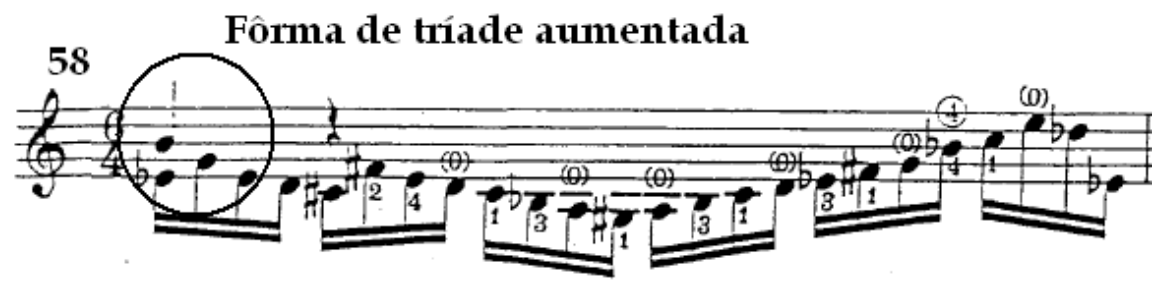

Divertimento, compasso 58

Após a reapresentação variada da elaboração do Motivo 1 de Aquarelle, detectamos novas idéias musicais geradas a partir de uma outra fôrma violonística entre os compassos 67 e 83. O desenho violonístico elaborado nesta passagem é composto pelas notas sol\# (voz de soprano), dó (voz do tenor) e ré (voz do baixo e que por ser executada em uma corda aberta servirá em muitos dos casos como baixo pedal) formando uma tríade de $D(\# 5)$. Tal elaboração é iniciada no compasso 67 e é derivada da elaboração presente no compasso 42, onde novamente um glissando é realizado sobre a tríade 
aumentada, com a presença do mesmo ostinato realizado anteriormente, porém realizado na corda ré (4) aberta.

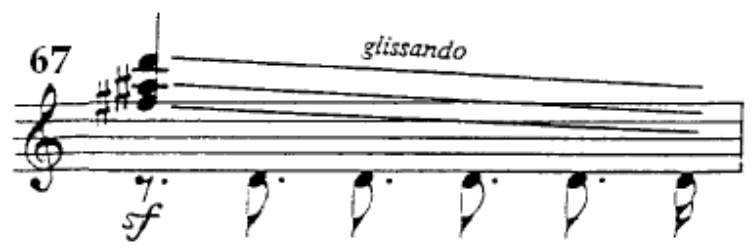

Divertimento compasso 67

Esta mesma tríade é reelaborada polifonicamente no compasso 70 e esta elaboração é repetida no compasso seguinte. O que podemos destacar nesta passagem é a reapresentação da simultaneidade de motivos presente no compasso 65 de forma elaborada.

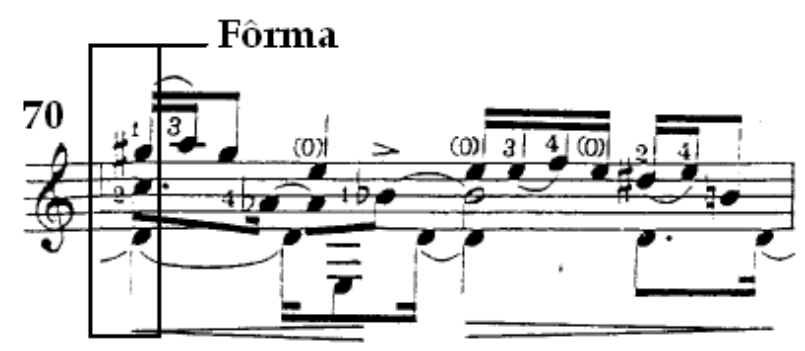

Divertimento, compasso 70

São realizadas entre os compassos 72 e 75 três transposições sobre a forma abordada no compasso $70 \mathrm{com}$ a mudança para a fórmula compasso para $3 / 8$ e o uso da nota ré como pedal.

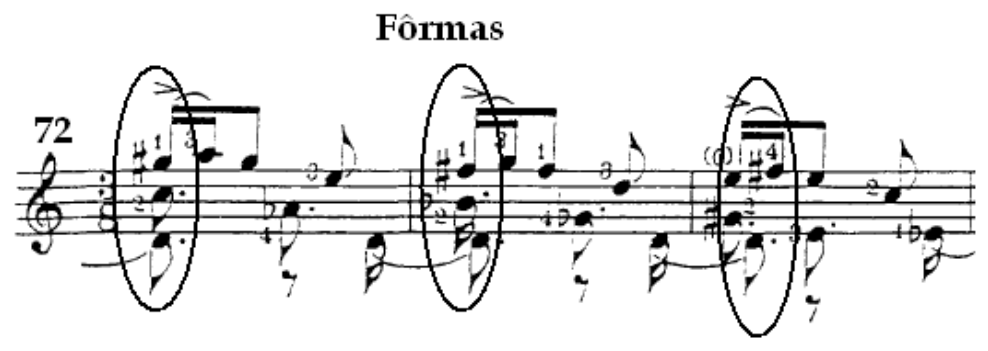

Divertimento, compassos 72 a 74

O compasso 76 apresenta a mudança para métrica quaternária, um fraseado mais longo contendo saltos e polifonia. Esta elaboração é repetida no compasso 77 um tom abaixo da presente no compasso 76 e no compasso 78 dois tons abaixo. 
Fôrmas
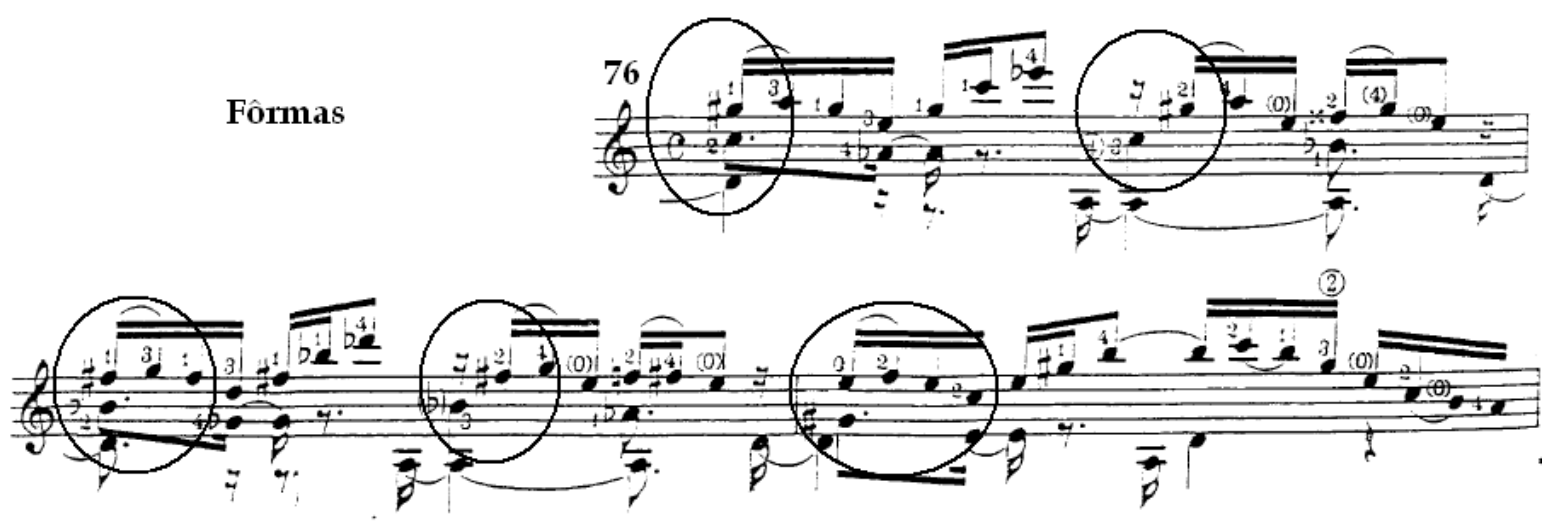

Divertimento, compassos 76 a 78

O compasso 80 apresenta uma nova elaboração desta tríade havendo a mudança no baixo pedal à 6a corda mi implicando na mudança harmônica ao acorde $E 7(b 13)$. No terceiro tempo do compasso 80 se encontra uma seqüência baseada na fôrma desta tríade aumentada em acordes executados em rítmica de semicolcheias utilizando-se da técnica de rasqueado; esta frase é repetida posteriormente no compasso $82{ }^{119}$.

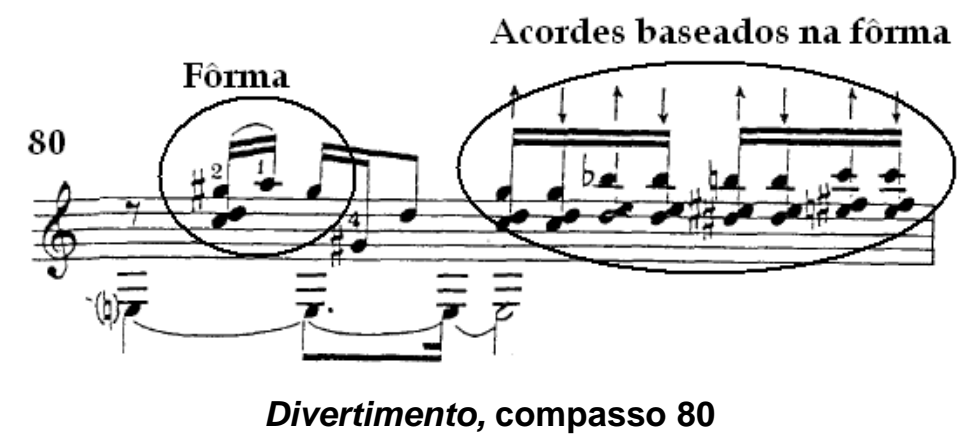

Na seção A de Divertimento, há a presença de uma fôrma de acorde com sétima no compasso 85 , este desenho de acorde é transposto a cada meio tom de forma descendente.

\footnotetext{
$119 \mathrm{Em}$ ambas as gravações utilizadas como referência para este trabalho, feitas pelos violonistas Boris Gaquere e Aliéksey Vianna, este trecho apresenta a utilização de rasqueado em ambas as passagens. Considerando que a gravação feita por Vianna foi supervisionada pelo compositor e a de Gaquere pelo violonista Odair Assad (irmão do compositor) pode-se concluir que há erro neste trecho na edição da peça feita pela editora Henri Lemoine que indicaria no compasso 82 a passagem de acordes pinçados normalmente.
} 


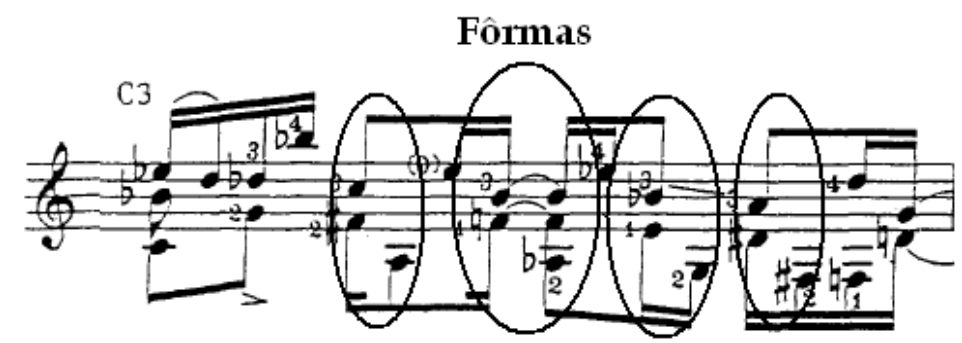

Divertimento, compasso 85

A elaboração presente entre os compassos 103 a 108 apresenta duas fôrmas de acordes Estas são baseados nos acordes $\mathrm{m} 7$ (menor como sétima) e 7 (b13) (sétima com décima terceira bemol).

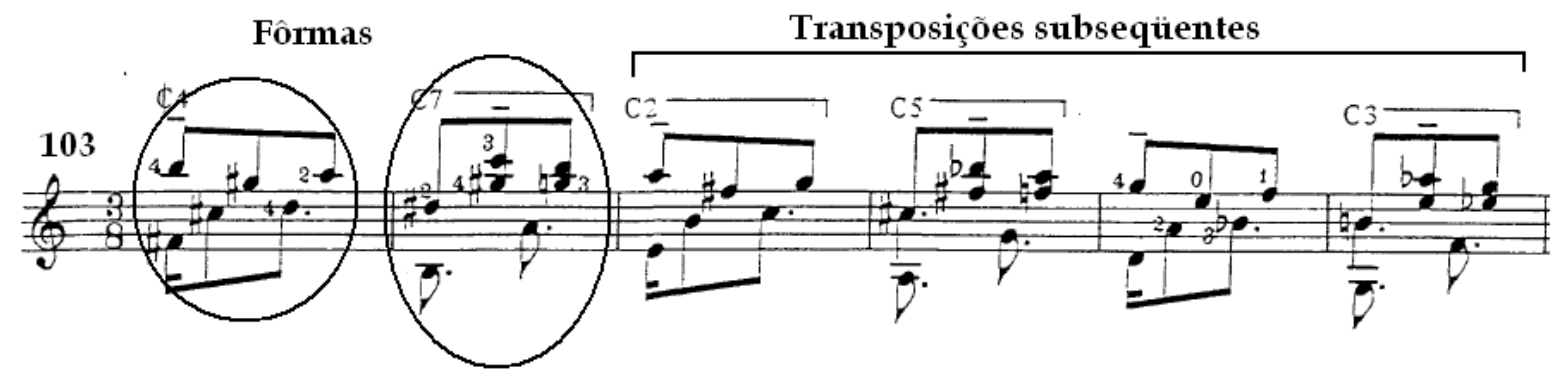

Divertimento, compassos 103 a 108

Entre os compassos 125 e 132, um único desenho de acorde serve como voz de baixo à melodia na voz de soprano executada em harmônicos. Inicialmente esta fôrma é constituída pelas notas sol, fá e lá entre compassos 125 e 128 sendo posteriormente transposta meio tom abaixo sendo formada pelas notas fá\#,mi e sol\# até o compasso 132, que marca o fim desta elaboração.

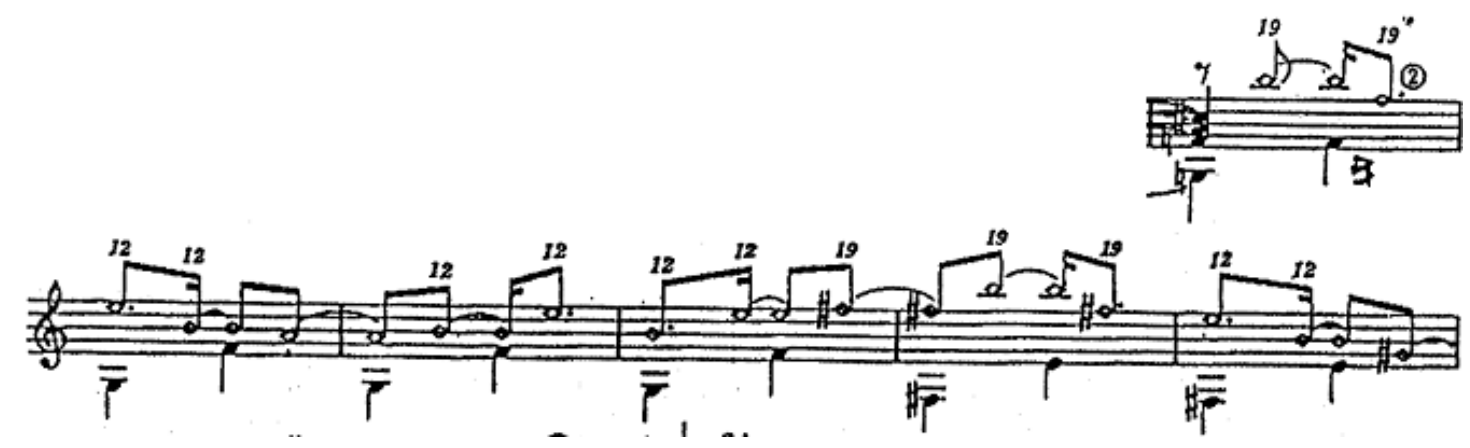




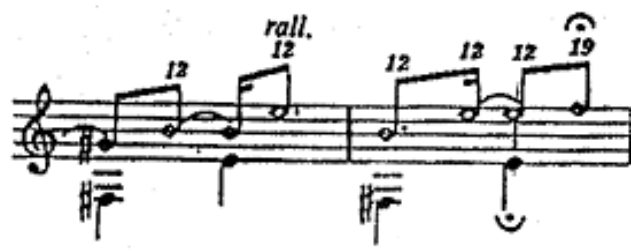

Divertimento, compassos 125 a 132

Durante várias passagens de Aquarelle a escrita em vozes independentes presente em várias passagens gerou diversas dificuldades técnicas e situações instrumentais incomuns que segundo Vianna (2005), geram dificuldades na mão esquerda. A seguir, alguns exemplos de situações técnicas geradas por estes procedimentos musicais.

No compasso 23 o motivo inicial é reapresentado executado na corda sol apenas ${ }^{120}$ sendo acompanhado por uma linha de baixo na quinta corda e tendo como textura superior o uso de harmônicos naturais. O mesmo padrão é repetido nos compassos 24, 25 e 26. A partir do compasso 27, os harmônicos passam a ser a melodia principal juntamente com notas executadas com a técnica tradicional. A passagem citada pode apresentar certa dificuldade devido à junção destas técnicas em uma frase unitária.

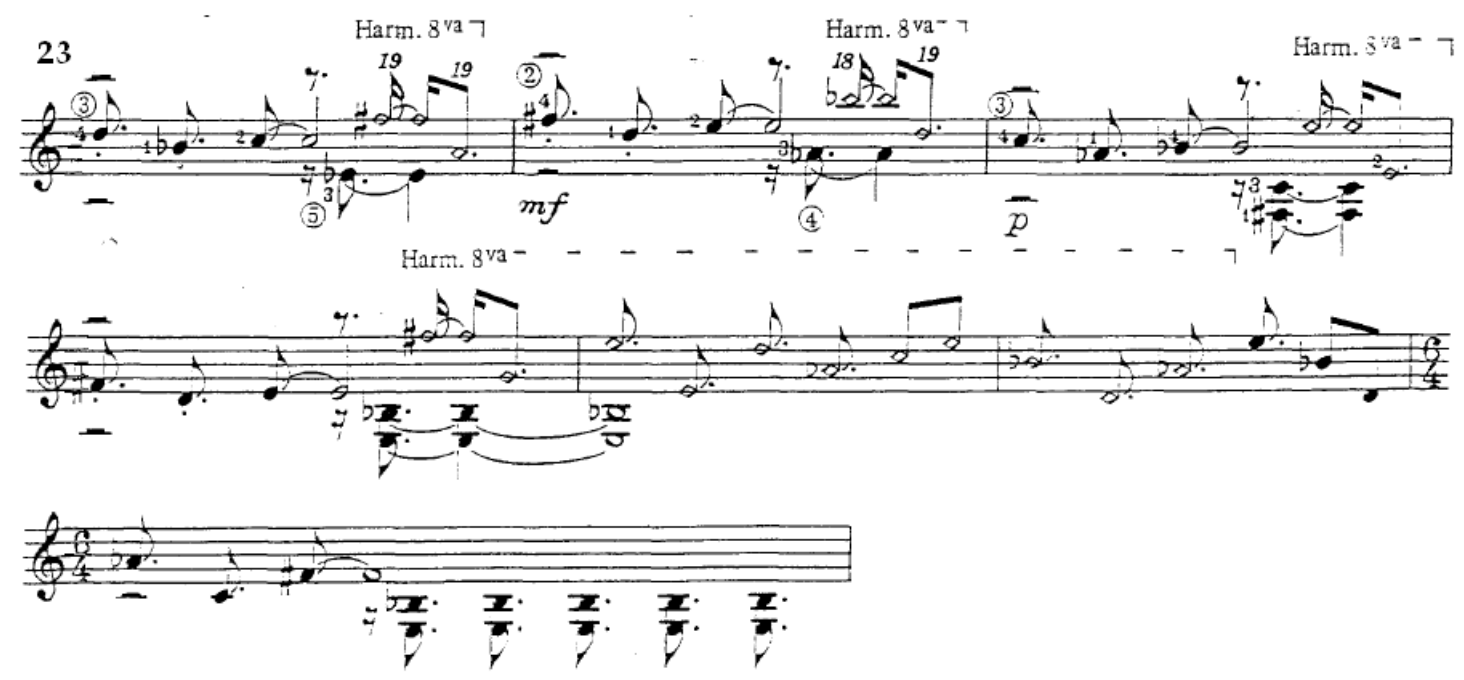

Divertimento, compassos 23 a 29

Encontra-se entre os compassos 38 e 41 uma elaboração em que a reapresentação do Motivo 1 em quatro frases em que o motivo é transposto a

\footnotetext{
${ }^{120}$ A execução de uma frase em apenas uma corda é feita a fim de que se preservar o timbre da mesma.
} 
cada repetição. A primeira elaboração encontrada no compasso 38, apresenta o motivo 1 na corda sol é acompanhada por um desenho melódico estruturado nas três cordas mais graves do violão utilizando-se de algumas cordas soltas na voz de baixo. Na segunda elaboração (compasso 39), a mesma idéia é repetida uma quarta justa acima, valendo-se da facilidade encontrada no violão a este tipo de transposição ${ }^{121}$. A terceira variação do motivo 1 nesta elaboração (compasso 40) se encontra um tom abaixo da primeira (compasso 38), havendo mudança na melodia da voz de baixo, não havendo a facilidade proporcionada pelas cordas soltas encontrada nas repetições anteriores. A quarta e última elaboração (compasso 41) apresenta o motivo 1 em uma região mais grave do instrumento ( $4^{a}$ corda), neste compasso a voz de baixo é elaborada em uma escala ascendente marcando o fim desta passagem.

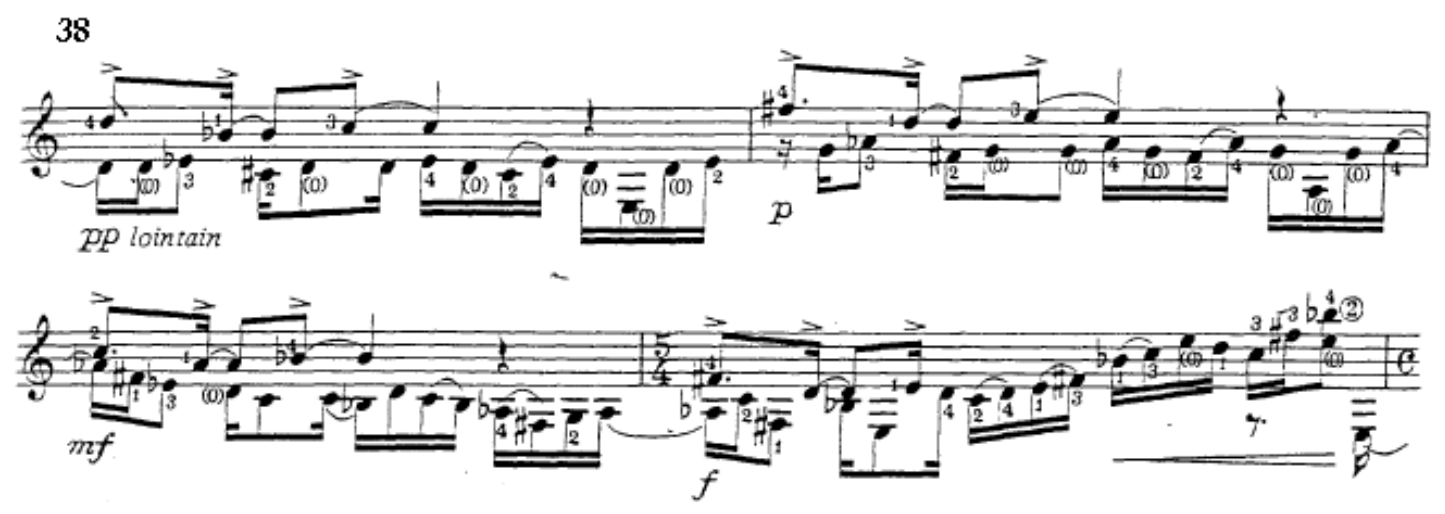

Divertimento, compassos 38 a 41

Encontra-se entre os compassos 63 e 66 uma variação da elaboração encontrada entre os compassos 38 e 41 . Nesta reapresentação, a elaboração do Motivo1 é mantida, porém há uma variação na linha de baixo e uma maior complexidade nas duas citações finais do motivo. O compasso 65 , apresenta a primeira apresentação do motivo 2 na peça, havendo nesta, a presença de 3 vozes em texturas independentes. Novamente a passagem apresenta o desafio de se articular todos os motivos de forma clara para o entendimento do texto musical concebido pelo compositor.

\footnotetext{
${ }^{121}$ Afinação padrão do violão privilegia em muitas situações o intervalo de quarta justa entre as cordas soltas, facilitando a transposição de melodias de um grupo de cordas a outro.
} 


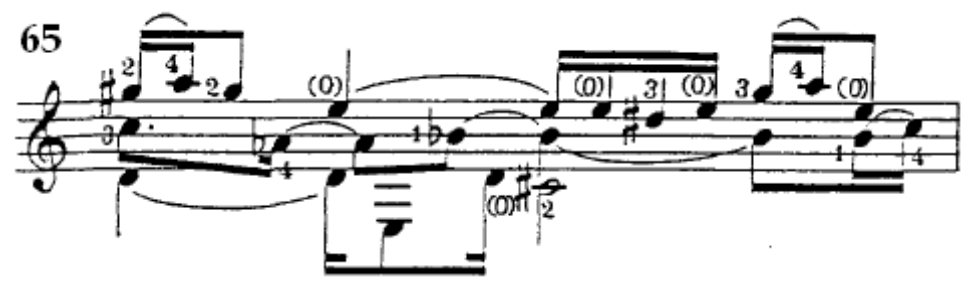

Divertimento, compasso 65

A repetição final do motivo 1 nesta elaboração, apresenta-se na voz de tenor da polifonia. Novamente a dificuldade de se articular as três vozes elaboradas se apresenta dada a impossibilidade de se tocar a melodia com apoio e a dificuldade de se manter o volume da nota fá \#, executada com o dedo indicador (i) e as demais notas do motivo (ré e mi) executadas com o polegar.

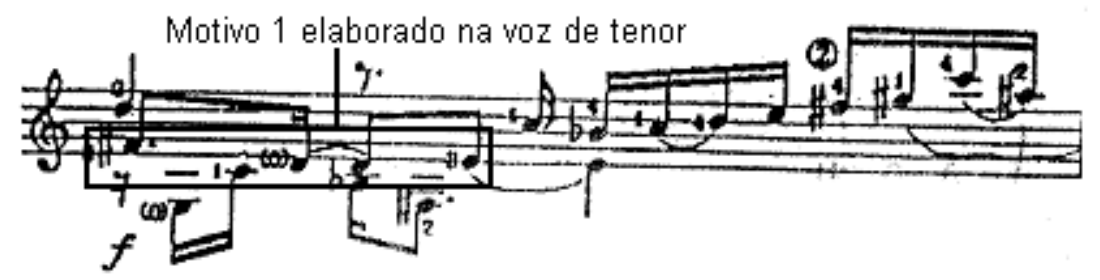

Divertimento, compasso 66

O que podemos ressaltar nesta elaboração citada no parágrafo anterior, e em diversas outras nesta obra, é uma particularidade da escrita instrumental de Assad que é a escrita concebida na ótica de um pequeno grupo de câmara ou duo de violões. Esta concepção se transpõe para a escrita para violão solo, fato de que na maioria de suas elaborações a voz de acompanhamento não é estática, tornando-se uma voz autônoma em uma textura polifônica.

A elaboração do motivo 2 do Divertimento (sol\#, lá e sol\#) no primeiro compasso da seção A do Divertimento (compasso 84) apresenta de acordo com Vianna (2005) um dos trechos mais desafiadores tecnicamente na Aquarelle. A complexidade presente se dá pela escrita polifônica, pela de se executar o ligado descendente pelos dedos 3 e $4{ }^{122}$ e a independência imposta aos dedos da mão esquerda.

\footnotetext{
${ }^{122} \mathrm{~A}$ execução de ligados descendentes entre os dedos 3 e 4 causa dificuldades à maioria dos violonistas devido à constituição anatômica mais frágil e conseqüentemente menos eficaz do dedo mínimo da mão esquerda.
} 
A utilização da 1 ${ }^{\text {a }}$ corda solta na digitação presente na versão editada pela Henri Lemoine apresenta uma quebra na linha melódica e o uso de mudança de angulação de ataque na mão direita ou digitações alternativas se fazem necessárias à clareza melódica da passagem ${ }^{123}$. Propomos para uma execução fluente do trecho, a antecipação do dedo 3 para a nota ré\# no segundo tempo, tal procedimento facilitará a execução do ligado ascendente entre as notas sol\# e si e a execução da passagem no andamento exigido pelo compositor.

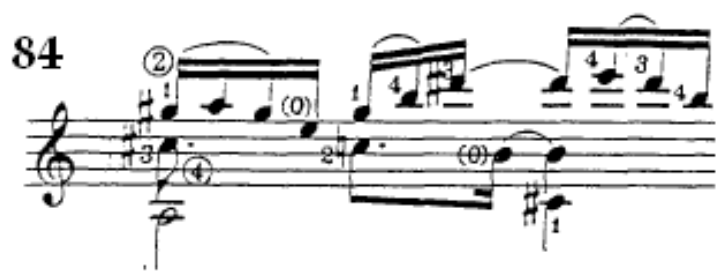

Divertimento, compasso 84 digitação original

O violonista Randall Avers ${ }^{124}$ em depoimento via correio (2005) eletrônico sugere uma digitação alternativa ao trecho.

No primeiro movimento no começo do samba (Acorde de A7+ após o E7 dominante). Eu preparo as notas de abertura (sol \# lá \# sol\# e mi) tocadas na quarta posição e daí saltando para a nona posição. Não é um salto fácil, mas, dá mais clareza à linha melódica. (Tradução nossa)

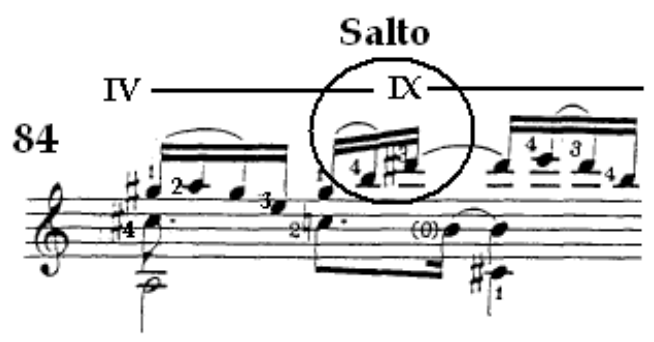

Digitação de Randall Avers

Propomos como digitação alternativa, o uso de uma meia pestana na $9^{\text {a }}$ posição proporcionando assim o uso da nota mi executada na $3^{\text {a }}$ corda, amenizando assim as diferenças tímbricas presentes no trecho.

\footnotetext{
${ }^{123}$ A mudança de angulação do ataque pela mão direita do violonista ameniza as diferenças de timbre entre as cordas e digitações realizadas em regiões diferentes do braço do violão.

${ }_{124}$ Violonista norte americano cujo primeiro CD Vistas (1996) contem uma gravação de Aquarelle. Ver sessão anexos página 249.
} 


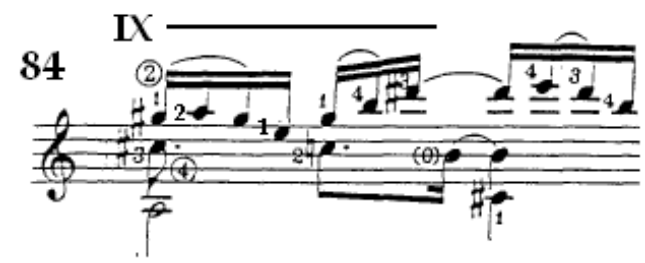

Digitação nossa

A passagem presente entre os compassos 125 e 132 se utiliza de harmônicos como voz de soprano, havendo a presença das notas sol e fá no acompanhamento e posteriormente fá \# e mi na voz de baixo. Neste trecho o uso se faz por harmônicos naturais na $19^{\mathrm{a}}$ e $12^{\mathrm{a}}$ casa, juntamente com harmônicos artificiais obtidos pela execução de notas presas, executadas em harmônicos uma oitava acima.

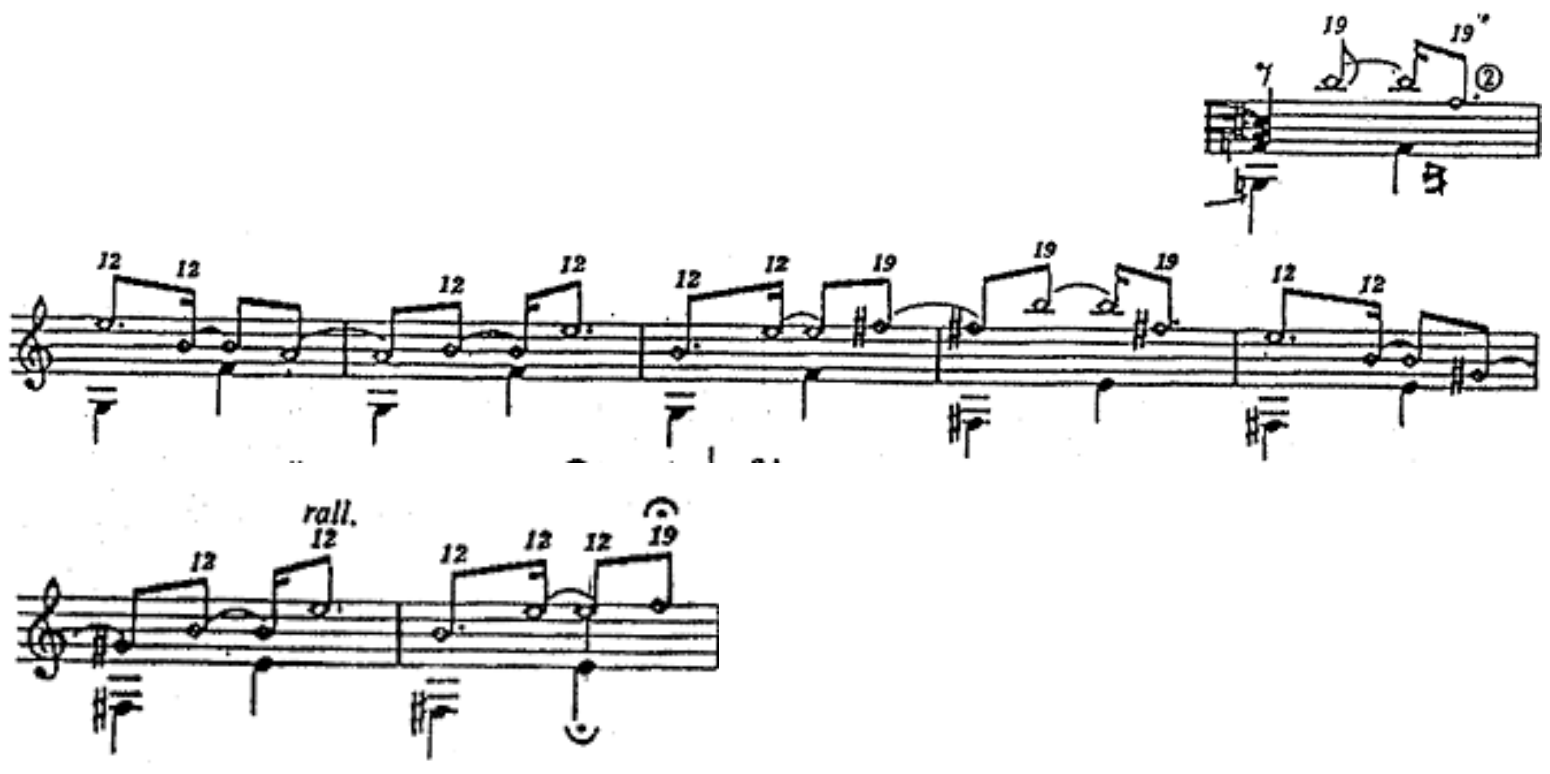

Divertimento, compassos 125 a 132

Entre os compassos 133 e 136 são utilizados harmônicos naturais juntamente com acordes para a obtenção de diferentes vozes na polifonia. Os harmônicos são utilizados como voz superior e as vozes mais graves são executadas simultaneamente aos harmônicos. 


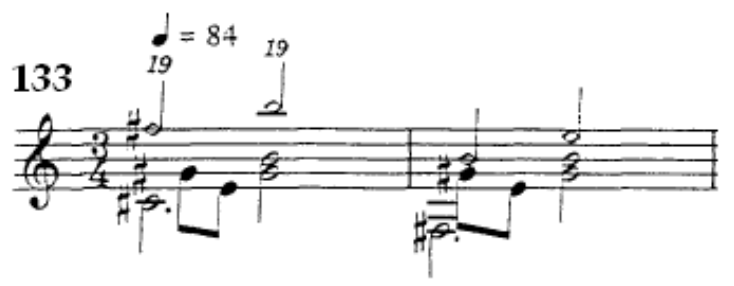

Divertimento, compassos 133 a 134

Um recurso engenhoso é apresentado no último tempo do compasso 140, com a voz superior da passagem novamente executada como harmônicos. Neste mesmo ponto, é tocado um harmônico natural na 24aㅗ casa na voz de soprano, ${ }^{125}$ seguido de outros na $19^{a}$ casa que no compasso seguinte são executados como um arpejo formado por sons harmônicos na $12^{\underline{a}}$ casa e com uma nota sol na terceira casa da sexta corda na voz de baixo.

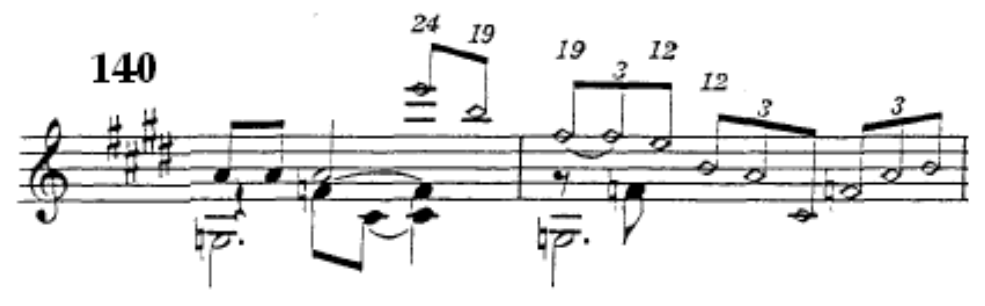

Divertimento, compassos 140 e 141

No compasso 119, detectamos um erro de edição devido a uma incongruência entre o texto musical e a marcação de pestana na nona posição, quando a grafia correta seria na oitava posição.

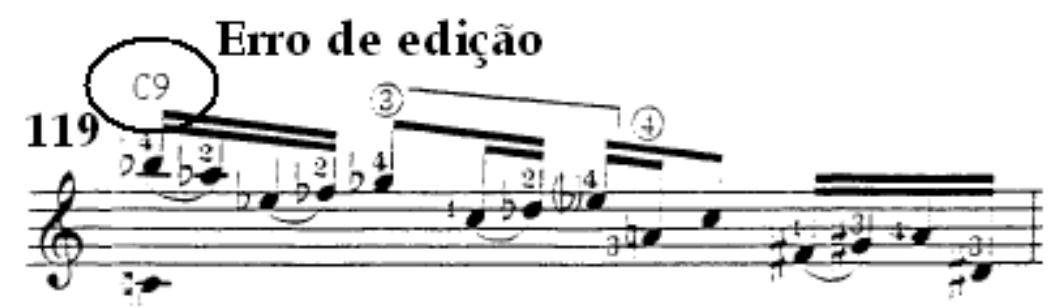

Divertimento, compasso 119

\footnotetext{
${ }^{125} \mathrm{~A}$ execução de harmônicos na $24^{\mathrm{a}}$ casa apresenta dificuldade técnica devido à inexistência de traste nesta região havendo a necessidade do interprete encontrar a região do harmônico sem o auxílio de referência visual.
} 


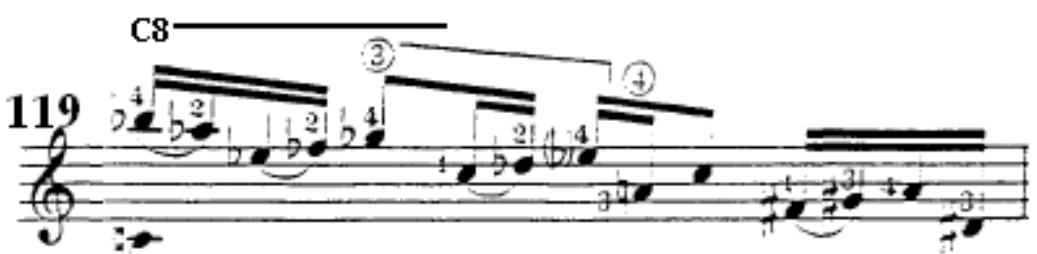

Divertimento, compasso 119 com erro de edição corrigido

Propomos ao final de Divertimento, nos compassos 184 e 185 uma digitação alternativa à apresentada originalmente. $\mathrm{Na}$ passagem citada propomos a execução de ambos os compassos utilizando-se pestanas nas casas 9 e 10 sucessivamente, evitando assim as dificuldades técnicas geradas pela execução da notas mi e ré com o dedo 2 .

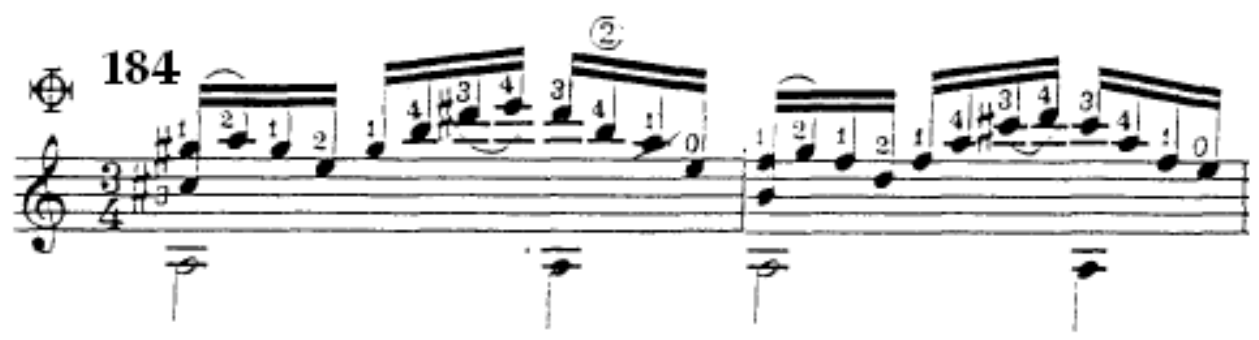

Divertimento compassos 184 e 185 com a digitação original

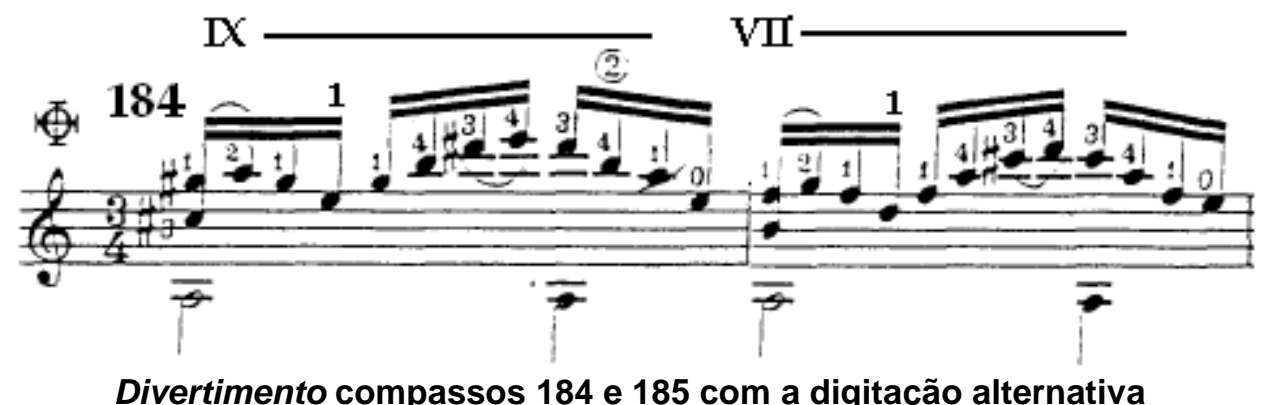

\subsubsection{Valseana}

Este item tratará da escrita violonística do segundo movimento de Aquarelle, Valseana, trazendo comentários quanto a sua execução pelo autor 
assim como algumas digitações e soluções alternativas para algumas passagens da peça.

A escrita violonística utilizada será abordada neste segundo movimento como um todo devido ao fato de que neste movimento, ao contrário dos outros, Assad não emprega nenhuma mudança de caráter, fazendo com que não haja mudanças drásticas na técnica empregada, exceção feita ao compasso 55, onde é executada e sustentada uma nota lá na décima sétima casa na voz soprano e no baixo um lá aberto, enquanto na voz intermediária são executados harmônicos naturais com a mão direita na décima nona e décima segunda casa. Em toda a extensão de Valseana a escrita utilizada é a de melodia acompanhada por contrapontos, variando-se apenas o registro da melodia dentro de uma ampla gama de tessitura.

Chama-nos atenção no compasso 7, uma abertura de mão esquerda considerável devido à necessidade de sustentação da nota lá (1) na voz de soprano, simultaneamente a movimentação contrária do baixo (este encontrase inicialmente na nota fá no terceiro e se movimenta descendentemente rumo ao mi bemol, na primeira casa).

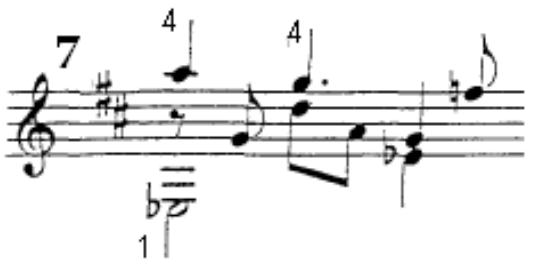

Valseana, compasso 7

A variação melódica do tema principal da peça no compasso 35, apresenta em sua execução uma abertura realizada devida à sustentação da nota mi na $12^{\text {a }}$ casa no soprano, enquanto no baixo o movimento melódico realizado faz com que soe a nota mi na $7^{\underline{a}}$ casa na quinta corda. Propomos como sugestão de digitação a utilização do dedo 2 do trecho descrito na nota fá\# do baixo, ocasionando uma abertura de uma casa entre os dedos 1 e 2 . Um recurso instrumental igualmente útil para a execução desta passagem consiste em soltar o polegar da mão esquerda para facilitar a mudança de posição e a abertura. 


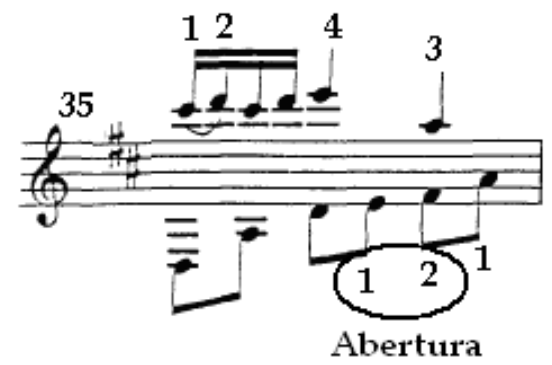

Valseana, compasso 35

Outra digitação para a execução do compasso 35 consiste em se executar a nota lá na voz de soprano com o dedo 4 da mão esquerda e a nota fá\# na voz de baixo no dedo 3. Apesar de se tratar de uma digitação que evita aberturas, pode-se encontrar dificuldades na transposição do dedo 4 da nota mi para a nota lá na voz de soprano.

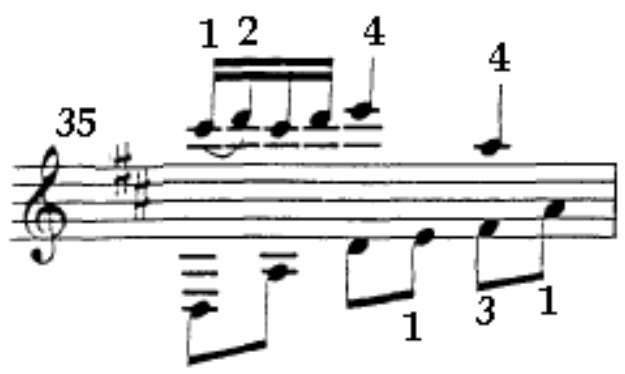

Valseana, compasso 35

O trecho nos dois primeiros tempos do compasso 47 apresentou a maior dificuldade técnica da Valseana para o autor deste texto. Temos uma variação melódica do material do compasso 22 , que consiste na realização de um contraponto, com movimentação contrária das vozes, formada por uma melodia ascendente com um grupo de quatro semicolcheias e duas colcheias pelo soprano, uma melodia descendente em colcheias na voz intermediária enquanto uma nota dó é sustentada por dois tempos na voz de baixo. Esta sustentação em meio a polifonia implica em uma abertura de duas casas entre os dedos 1 e 2 com pestana no dedo 1 .

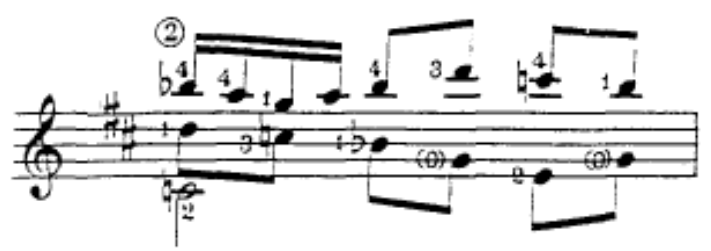

Valseana, compasso 47 digitação original 
Propomos como solução à dificuldade encontrada uma digitação alternativa em que o trecho é executado na terceira posição, tal alternativa proporciona uma menor tensão na mão esquerda do executante ao se tratar de uma posição no braço do violão em que a altura ${ }^{126}$ das cordas é mais baixa, facilitando a execução do trecho. Apesar de se tratar de uma solução em que não é possível a sustentação da nota dó na voz de baixo nos dois tempos como indicado pelo compositor, tal solução possui uma maior fluência instrumental e o corte presente não prejudica o texto musical.

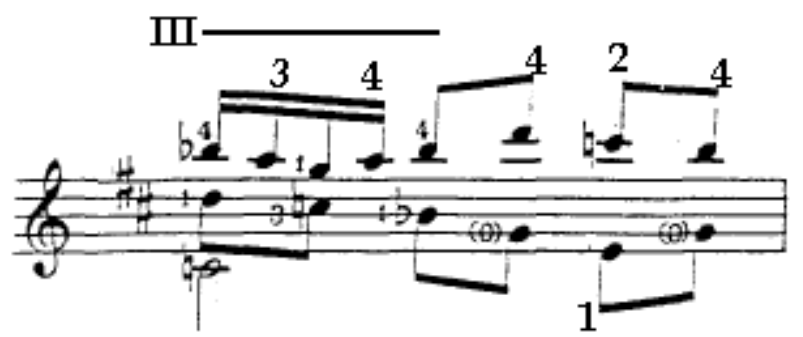

Valseana, compasso 47 digitação alternativa

Outra solução encontrada é a execução da passagem empregando-se duas pestanas sucessivas na sétima e oitava posição. Apesar de se tratar de uma digitação complexa tecnicamente, esta mantém o texto original como concebido originalmente por Assad.

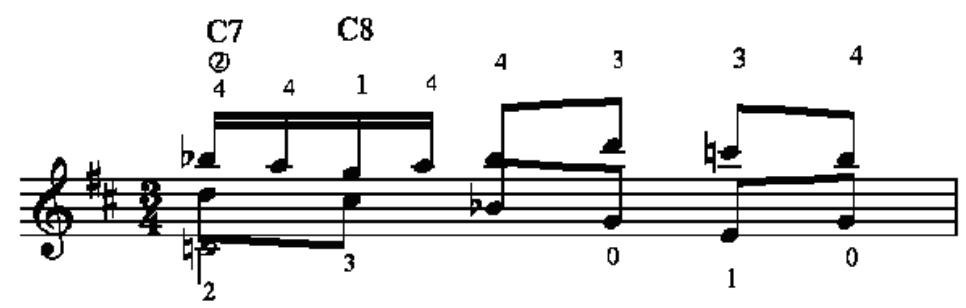

Valseana, compasso 47 digitação alternativa

A ausência da passagem descrita na versão improvisada da peça presente no disco Latin American Music for Two Guitars, sugere que o mesmo foi elaborado sem a presença do violão ${ }^{127}$. Por outro lado, em entrevista à

${ }^{126}$ Distancia entre o braço do instrumento e as cordas.

127 Segundo Vianna (2005), as dificuldades técnicas encontradas por toda a obra de Sérgio Assad são ocasionadas devido a este método de escrita empregado pelo compositor, em que o violão é dispensado como ferramenta necessária à elaboração de uma peça, dado seu pleno domínio do instrumento. 
revista Soundboard ${ }^{128}$, o compositor comenta que a escrita da segunda parte da Valseana teria sido fruto de uma nova improvisação sobre a estrutura harmônica da primeira parte. Este depoimento nos esclarece que a linguagem de Assad como improvisador presente neste segundo movimento da Aquarelle demonstra complexidade instrumental, dados os diversos recursos instrumentais apontados neste item.

\subsubsection{Prelúdio e Toccatina}

No início da seção do Prelúdio entre os compassos 1 a 10 encontra-se o tema executado na voz de soprano realizado nas cordas agudas e um acompanhamento que alterna entre acordes arpejados e melodias articuladas na voz de baixo. Este trecho apresenta a possibilidade de execução com apoio para o destaque da melodia na voz de soprano ${ }^{129}$.

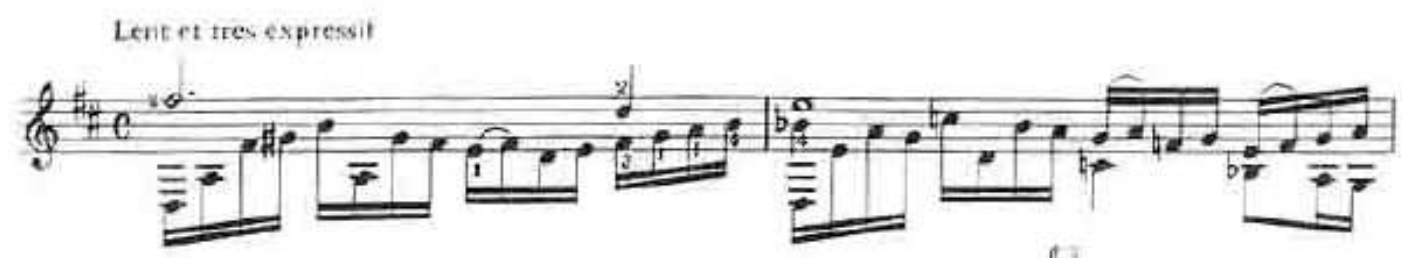

Prelúdio e Toccatina, compassos 1 e 2

No compasso 3, detectamos uma abertura com necessidade da extensão de 1 casa entre os dedos 1 e 2 . Neste compasso, a execução das notas mi e lá nas cordas ré e sol na segunda casa simultaneamente a nota mi (corda solta) é realizada com uma meia pestana nas cordas graves com dobramento da falange para a execução desta nota mi executada na corda (1) mi solta.

\footnotetext{
${ }^{128}$ GROTMOL, Tom. Sérgio and Odair Assad, Soundboard Magazine, vol. XXIII n.3, Guitar Foundation of America, Claremont, 1997, p 13 a 16.

${ }^{129}$ Ver item 2.1.5.
} 


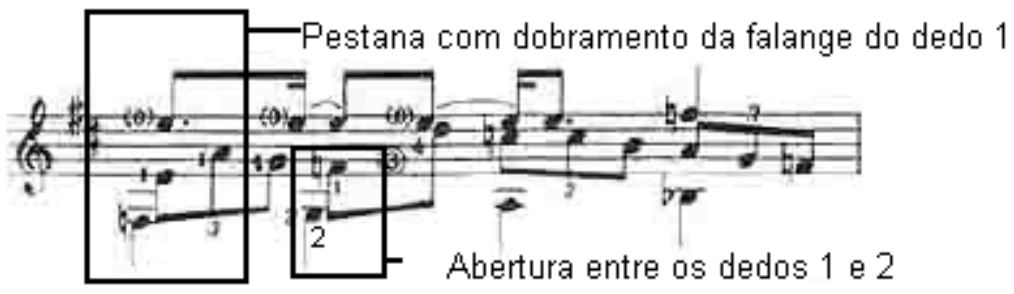

Prelúdio e Toccatina, compasso 3

Assim como na toccata barroca a segunda seção da peça, Toccatina, (compassos 16 e 127) é virtuosística, ou seja, de difícil execução principalmente devido à textura polifônica e o andamento rápido. Segundo o violonista Eduardo Meirinhos, no comentário que segue abaixo, a dificuldade técnica e a densidade musical permeiam esta segunda seção. ${ }^{130}$,

“(...) nós vamos também ver todo o virtuosismo presente, que é uma tônica do primeiro e terceiro movimentos, especialmente do terceiro, com uma exploração muito grande com vários cromatismos (...) em vozes diferentes com uma simultaneidade do contraponto com o movimento cromático das vozes, com movimentos paralelos e contrários o tempo inteiro."

No trecho entre os compassos 24 e 36 da Toccatina podemos utilizar o toque de apoio na corda sol enquanto nas cordas ré, lá e mi ocorre o ostinato.

Foi detectado um erro de edição no compasso 24 dada a indicação de execução do ostinato na corda si (2) quando o correto seria a indicação na corda sol (3).

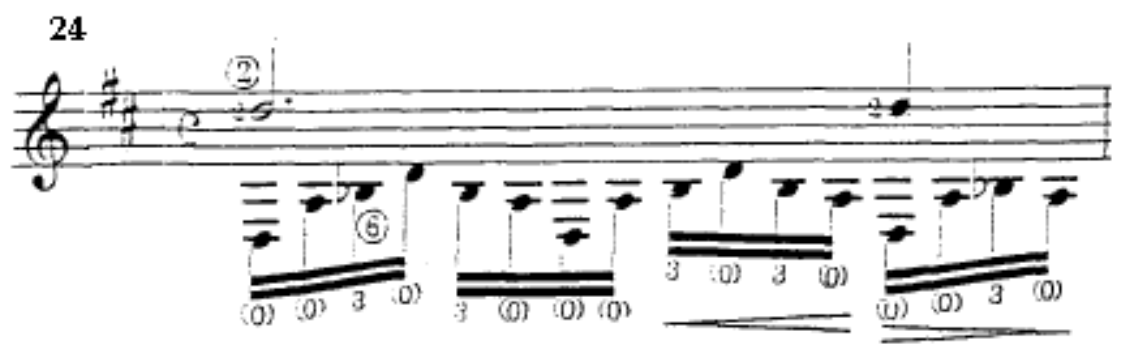

Prelúdio e Toccatina compasso 24

${ }^{130}$ Entrevista. O Prof. Dr. Eduardo Meirinhos é docente na Universidade Federal de Goiás. 


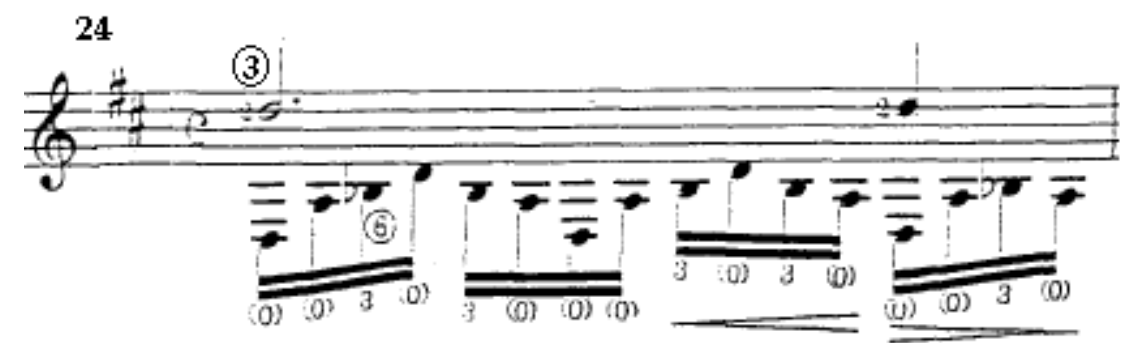

Prelúdio e Toccatina compasso 24 corrigido

A abertura de mão esquerda na reapresentação do tema entre nos compassos 28 e 32 é uma digitação alternativa que propomos por razões anatômicas, de facilidade técnica ${ }^{131}$ e da preservação de timbre pela execução do tema apenas na $3^{3}$ corda $^{132}$. Neste trecho, a digitação proposta obriga 0 intérprete a uma abertura de uma casa entre os dedos 3 e 4 enquanto é realizado o ostinato presente nas cordas mais graves.

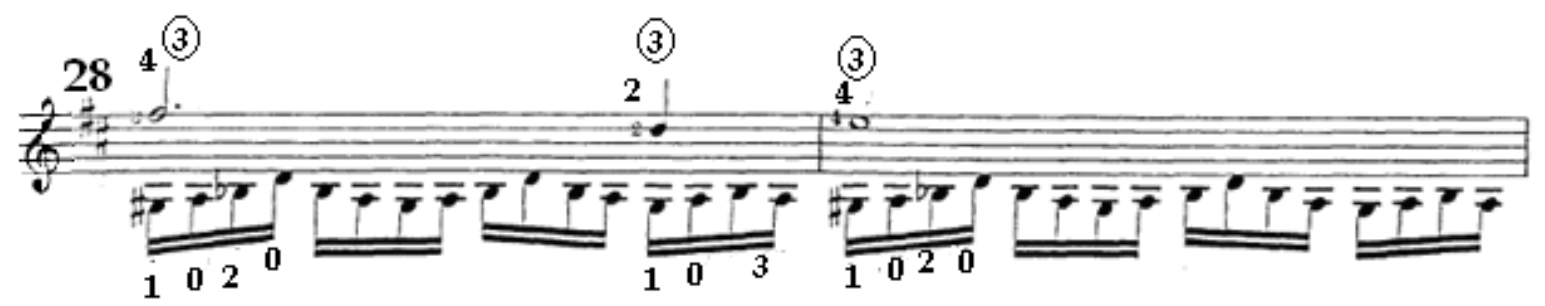

Prelúdio e Toccatina, compassos 28 e 29 com digitação alternativa

Detectamos no compasso 35 uma mudança que se faz necessária no texto musical dado o andamento da obra e a impossibilidade de se alcançar uma digitação alternativa ${ }^{133}$. Na passagem indicada, foi necessária a articulação em staccato da voz soprano dada a necessidade de se executar um salto até a primeira posição e a impossibilidade de sem manter a sustentação da nota dó.

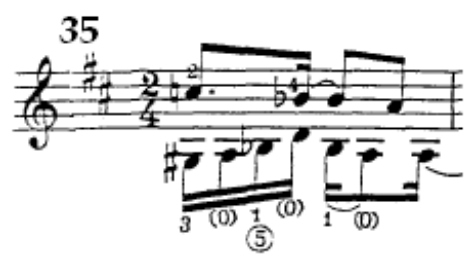

Prelúdio e Toccatina, compasso 35

\footnotetext{
${ }^{131}$ Deve-se ressaltar que a realização técnica de uma determinada passagem pode apresentar mudança de digitação obedecendo a critérios e facilidade de cada intérprete.

${ }_{132}$ A digitação original previa a execução do tema nas $2^{\mathrm{a}}$ e $3^{\mathrm{a}}$ cordas.

${ }^{133}$ Foram testadas algumas soluções quanto à digitação, porém sem conseguirmos alcançar um resultado satisfatório quanto à fluência do texto e um bom desempenho técnico.
} 
Detectamos igualmente entre os compassos 44 e 48, uma elaboração polifônica do Motivo 2 da peça, repetida entre os compassos 50 e 54, ambas de elevada dificuldade técnica em função da fluência necessária à execução das mesmas. A realização autônoma das vozes e a clareza de articulação são um desafio a todo tempo, principalmente nas passagens cromáticas em que se alternam cordas soltas e presas na voz aguda ${ }^{134}$. Este tipo de digitação está presente nos compassos 44, 45 e 48, com repetições nos compassos 50, 51 e 53.

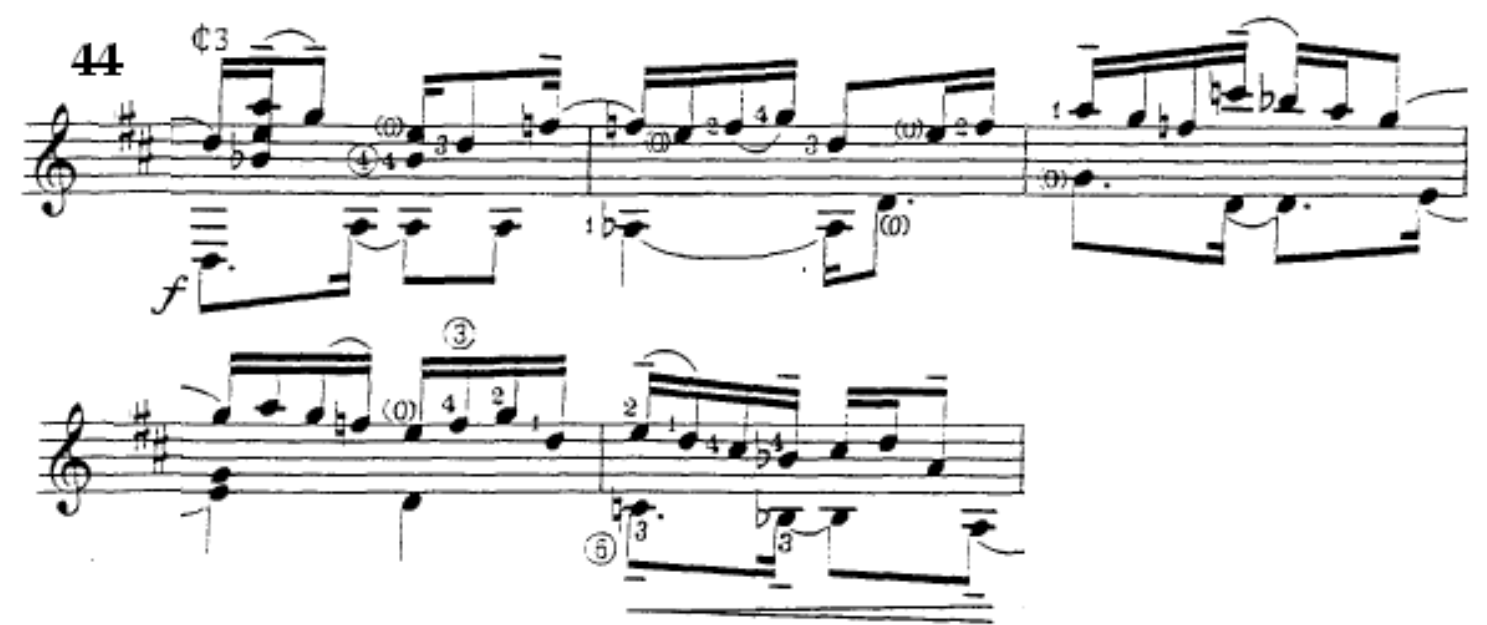

Prelúdio e Toccatina, compassos 44 a 48

Um desafio instrumental passagem e que é gerado pela simultaneidade de elementos técnicos sobrepostos se apresenta entre nos compassos 49 e 53. Esta passagem gera uma abertura entre os dedos 1 e 2 contendo um ligado descendente entre ambos e simultaneamente a execução da voz de baixo. Tal junção de elementos técnicos causa grande dificuldade de execução da passagem no andamento exigido pelo compositor ${ }^{135}$. Propomos uma digitação alternativa ao trecho no compasso 49 , ao se executar a passagem com pestana na terceira posição, o que eliminaria a abertura presente entre os dedos 1 e 2, porém a digitação original haveria de ser mantida no compasso 53 dada a nota lá ao final da elaboração que propomos que seja executada com o polegar para um maior efeito de crescendo.

\footnotetext{
${ }^{134}$ Ver item 2.1.5.

${ }^{135}$ A dificuldade desta passagem foi amenizada ao se antecipar o dedo 4 para a nota dó executada na corda ré (4), o que facilita a execução do ligado.
} 
Junção de abertura com ligado

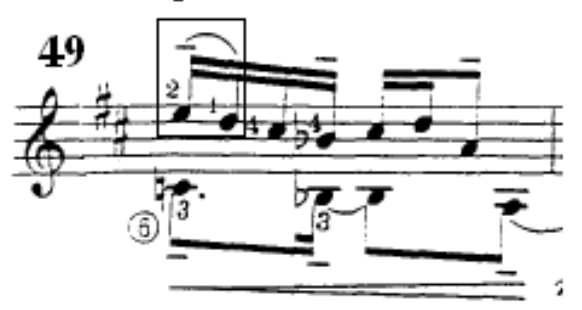

Prelúdio e Toccatina compasso 49 com a digitação original

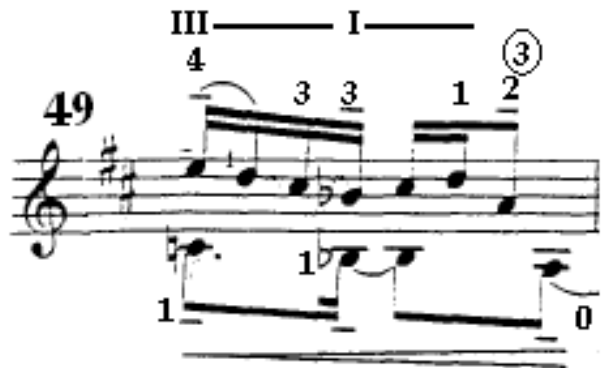

Prelúdio e Toccatina, compasso 49 com a digitação alternativa

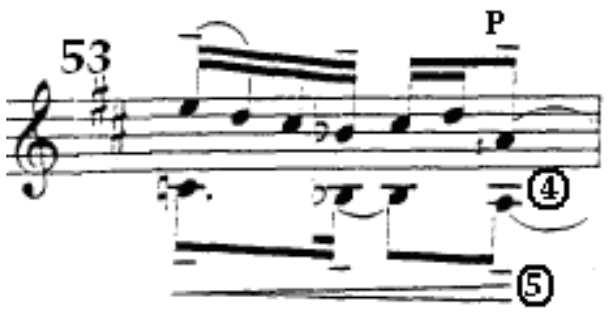

Prelúdio e Toccatina, compasso 54

O trecho que compreende os compassos 55 a 59 apresenta em sua constituição um uma melodia cromática em semicolcheias e a digitação proposta pelo compositor contempla novamente o uso de cordas soltas num desenho peculiar. Neste caso, o cromatismo presente implica em uma digitação com o uso de diversas cordas soltas e presas intercaladas dada a sua complexidade, gerando uma passagem cuja manutenção da intenção melódica se torna um desafio dada a diferença de timbres entre as notas.

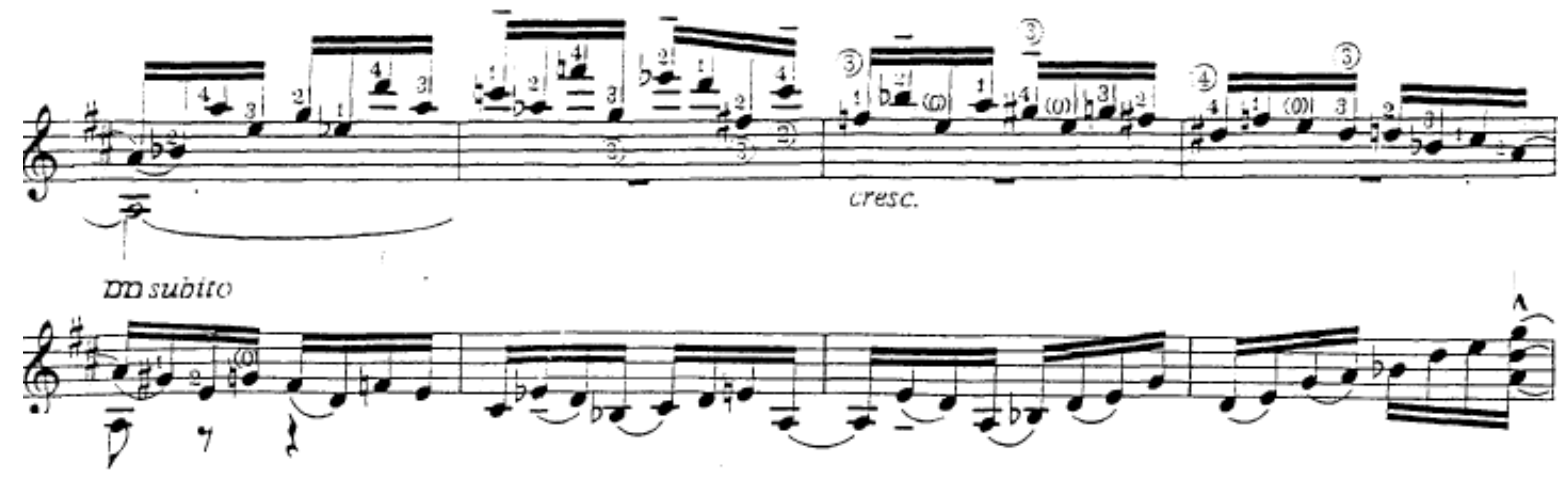

Prelúdio e Toccatina, compassos 54 a 61 
Entre os compassos 62 a 66 o compositor elabora uma passagem em que os Moivos 1 e 2 da peça são elaborados simultaneamente gerando uma densidade polifônica que torna-se um desafio técnico instrumental dada a necessidade de manter o andamento exigido e a clareza necessária para se articular corretamente o texto concebido pelo compositor. Nesta elaboração o Motivo 1 é reapresentado na voz superior em forma de acordes, o Motivo 2 é reapresentada uma oitava abaixo da elaboração entre os compassos 44 e 48 na voz intermediária e ainda há a presença de uma voz na linha de baixo. A complexidade presente em tal passagem retifica as declarações de Aliéksey Vianna que afirmavam o método composicional empregado por Assad prescinde o uso do instrumento para a prática da composição.
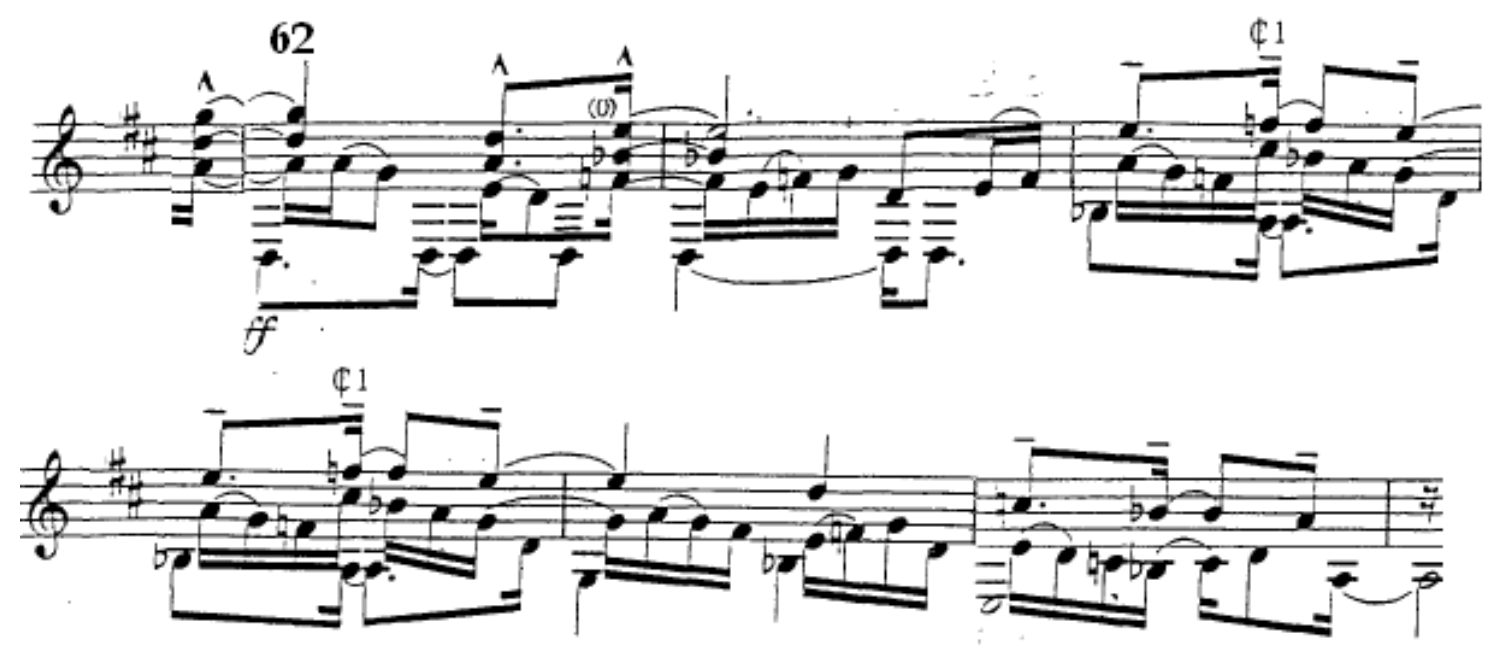

Prelúdio e Toccatina, compassos 62 a 66

A elaboração presente entre os compassos 67 e 71 apresenta como opção técnica novamente o toque com apoio na voz aguda para o seu destaque sobre o acompanhamento. Pode-se ressaltar a digitação presentes nos compassos 67 e 71, em que a melodia aguda constituída pelas notas lá (2ª corda), mi ( $1^{\underline{a}}$ corda solta) e sol ( $2^{\underline{a}}$ corda) no compasso 67 e fá ( $2^{\underline{a}}$ corda) mi ( $1^{\text {a }}$ corda solta) e ré ( $2^{\underline{a}}$ corda) no compasso 69 apresenta diferenças de timbre entre as cordas e os registros em que estas se apresentam. A escolha desta digitação se deu devido à polifonia ao que tudo indica, e o choque entre timbres causado pelo dedilhado, pode ser amenizado pelo intérprete com adequações do ângulo de ataque da mão direita. 

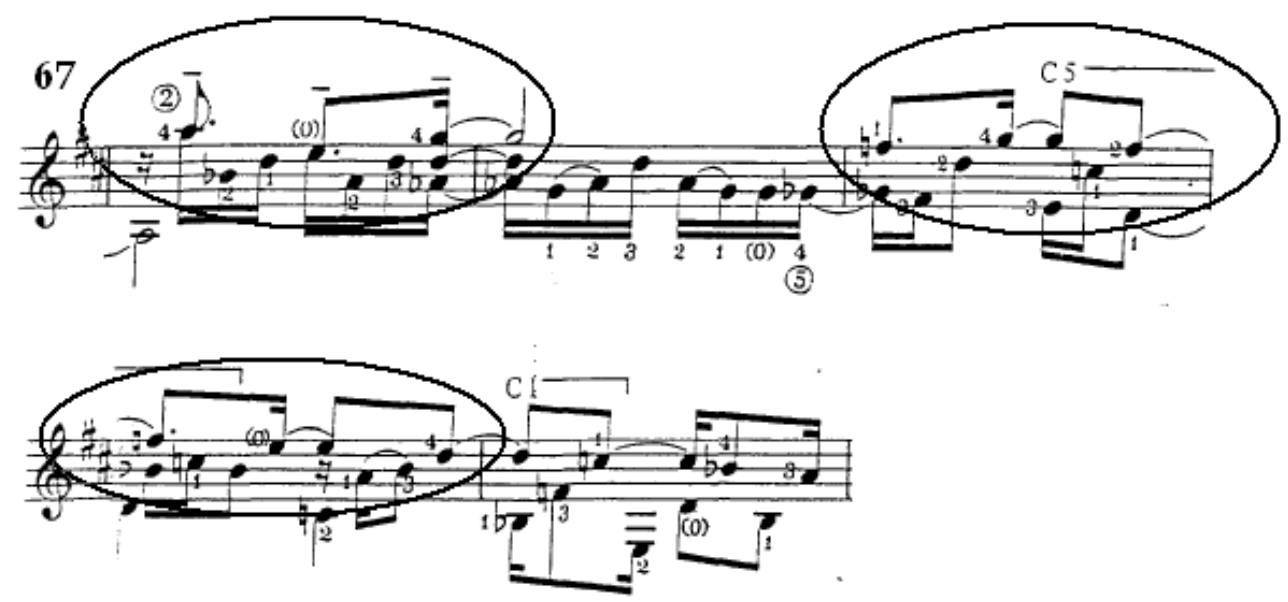

Prelúdio e Toccatina, compassos 67 a 71

Entre os compassos 80 a 93 e 96 a 110 são elaborados novos trechos em escrita polifônica com o desafio da execução em certos pontos da articulação em staccato no soprano e enquanto a voz de baixo em legato. Estas articulações apresentam a possibilidade de execução da articulação em staccato pela mão esquerda ou pela mão direita ${ }^{136}$. Ambas as opções apresentam dificuldades devida à densidade do texto. O violonista Aliéksey Vianna considera este trecho um dos mais complexos musicalmente em toda a suíte devido a esta articulação empregada ${ }^{137}$.

\footnotetext{
${ }^{136} \mathrm{O}$ corte das notas pode ser feito pelo uso de dedo "abafador" pela mão direita ou corte pela mão esquerda.

${ }^{137}$ Ver entrevista com o violonista em 2005, Belo Horizonte na seção de anexos, página 241.
} 
Articulaçổes simultâneas em Legato e staccato
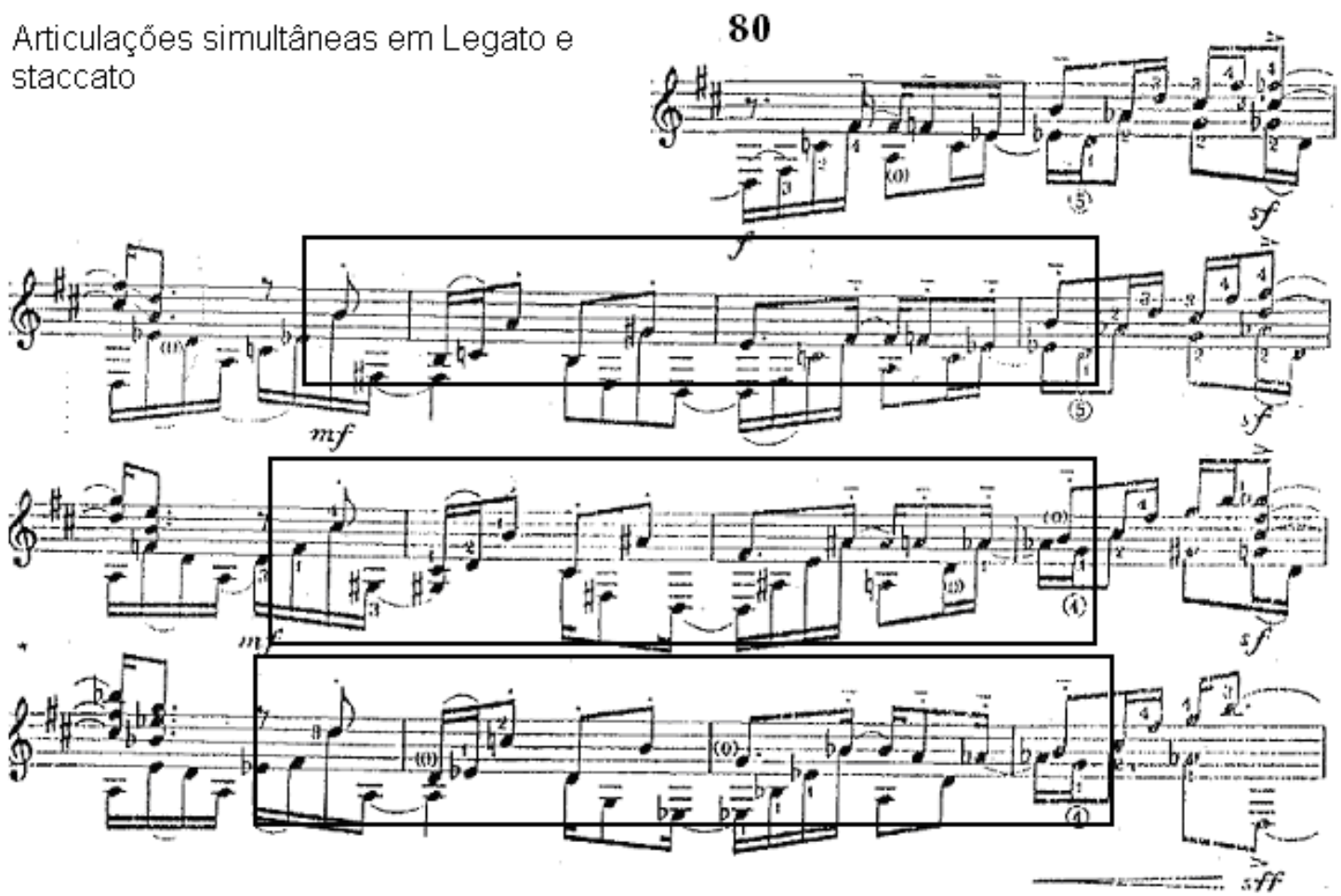

Prelúdio e Toccatina, compassos 80 a 93

Os compassos 83 e 87 têm característica técnica predominante à articulação citada no parágrafo anterior e possuem o mesmo desenho violonístico. Apresentamos como alternativa o uso de pestanas e a execução da articulação em staccato na voz aguda pela mão esquerda. Nesta opção, o staccato é executado pela retirada dos dedos da mão esquerda enquanto o legato no grave é mantido pelas pestanas.

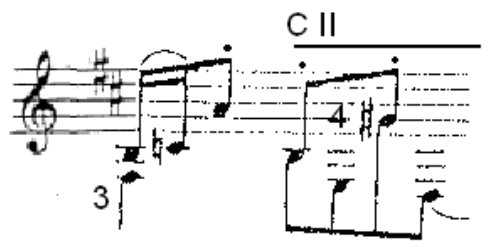

Prelúdio e Toccatina, fragmento do compasso 83

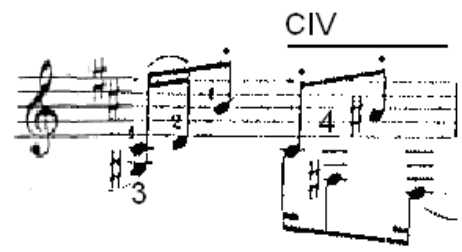

Prelúdio e Toccatina, fragmento do compasso 87 
O compasso 92 apresenta a utilização de uma pestana com a presença das cordas agudas soltas na região aguda ${ }^{138}$. Neste trecho há a execução das notas mib, sib, e mib (oitava acima) nas $6^{\underline{a}}, 5^{\mathrm{a}}$ e $4^{\mathrm{a}}$ cordas enquanto é executada a nota sol na $3^{\mathrm{a}}$ corda aberta.

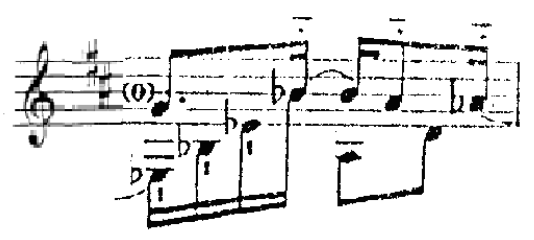

Prelúdio e Toccatina, compasso 92

A elaboração presente entre os compassos 96 a 115 além da articulação necessária para uma caracterização correta do ritmo nordestino apresenta dificuldades técnicas geradas pelos saltos envolvidos, como os dos compassos 100, 107 e 110.

Entre os compassos 120 e 121 é elaborado um arpejo de Gm6. Este arpejo é iniciado na $5^{\underline{a}}$ posição havendo então a presença de um salto até a $10^{\text {a }}$ posição e outro salto que implica em mudança entre a $10^{\underline{a}}$ e $1^{\text {a }}$ posições. Ambos utilizam a $1^{\text {a }}$ corda solta para as movimentações ${ }^{139}$.

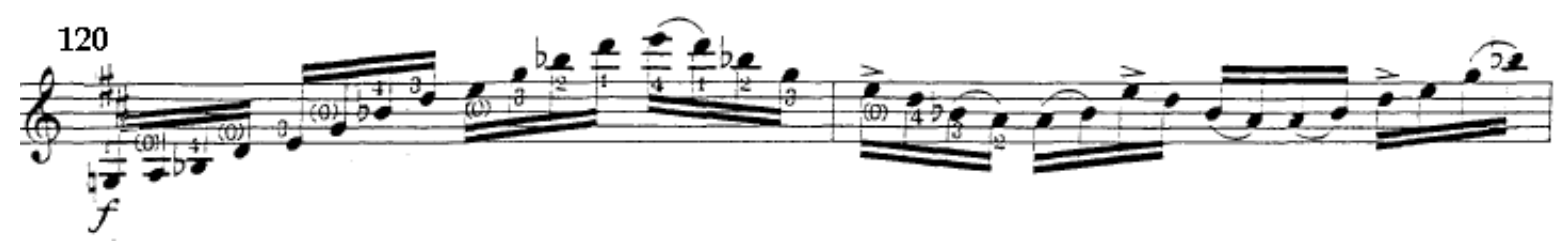

Prelúdio e Toccatina, compassos 120 a 121

No compasso 122 são executadas seqüências de acordes sincopadas sendo que no compasso 123 a mesma seqüência é executada em

\footnotetext{
${ }^{138}$ A técnica de pestana com corda solta difere da convencional quanto à seleção de cordas. Em pestanas convencionais pode prender-se todas as cordas em uma única posição, ou dependendo da situação, pode-se deixar as cordas graves soltas e se utilizar meia pestana. $\mathrm{Na}$ pestana com cordas agudas soltas há o dobramento da falange para que se consiga a pestana nas notas mais graves, porém com a utilização de cordas soltas no registro mais agudo.

${ }^{139}$ Elemento técnico em que os saltos de posição são auxiliados por cordas soltas, ver item 2.5.1.
} 
rasqueado $^{140}$. Ao final deste compasso é executada uma seqüência de semicolcheias, novamente executadas utilizando-se da técnica de rasqueado a fim de se obter um efeito de crescendo e clímax, marcando o término impactante da suíte.

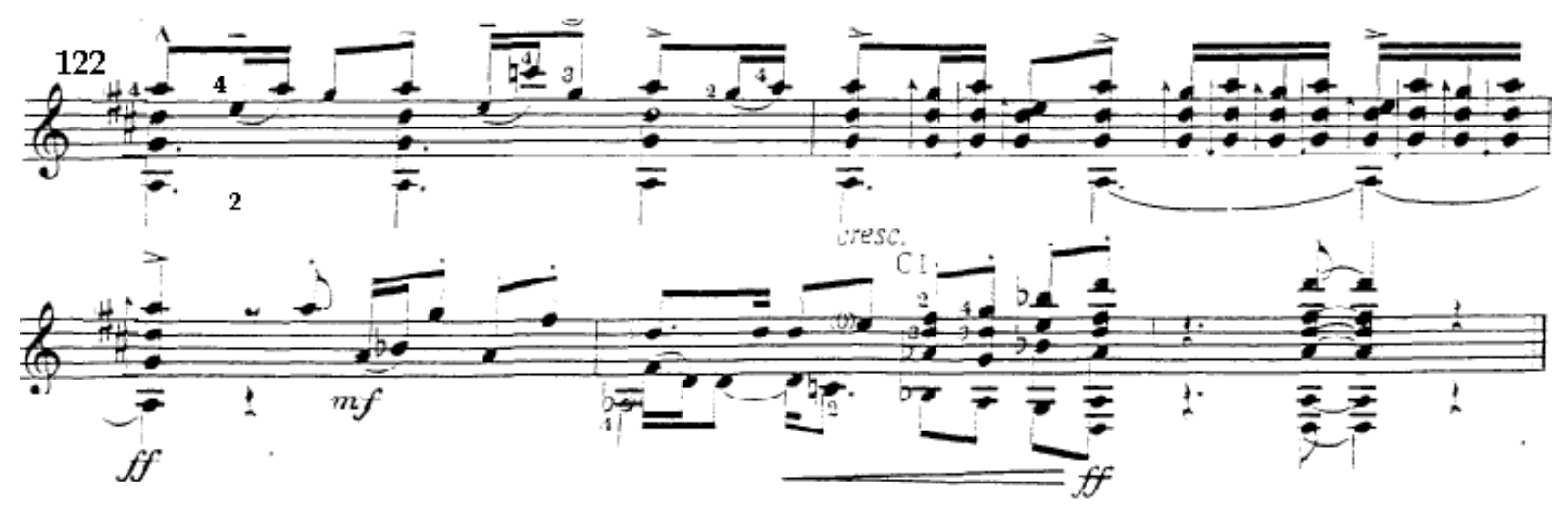

Prelúdio e Toccatina, compassos 122 a 126

Neste item pudemos analisar a complexa linguagem instrumental elaborada em Aquarelle. Ao executar esta pesquisa sobre a obra percebemos que a elaboração instrumental de Sérgio Assad se encontra atrelada à sua concepção de compositor e arranjador para duo de violões, visto que em diversos momentos diferentes texturas independentes são elaboradas polifonicamente. Tal concepção, é também geradora de diversos desafios instrumentais observando que o compositor utiliza um método composicional híbrido entre a elaboração que prescinde o instrumento e a improvisação numa complexidade musical alta, é válido verificar que há um pleno domínio do instrumento.

\subsection{As influências estéticas em Aquarelle}

Ao realizarmos uma análise de Aquarelle foram detectadas influências de diversas correntes estéticas e que se manifestam de diversas formas na

\footnotetext{
140 Técnica bastante comum no violão flamenco e na música espanhola. De acordo com Tennant (1995) a técnica de rasqueado consiste em acertar as cordas do violão com a parte posterior das unhas, obtendo-s um efeito predominantemente rítmico e percussivo.
} 
obra. Tais correntes estéticas foram detectadas em diversas citações de gêneros de música popular urbana ao mesmo tempo em que esta se apresenta sobre uma rígida estrutura formal e desenvolvimento temático.

A liberdade estética detectada na obra a liga à concepção composicional da corrente Pós-Modernista, corrente estética iniciada na década de 70 e que se fortaleceu na década seguinte como reação á estética modernista que era dominante no ambiente acadêmico como exposto em O Pequeno Pomo ${ }^{141}$, do compositor holandês Boudewijn Bucknix (1945).

(...) o Pomo começa ainda que de forma não convincente, em 1973, atinge um momento de ruptura em 1980 e por volta de 1985 um primeiro ponto culminante. (...) e inicia-se uma fase na qual todos estão ou deveriam estar conscientes desta estética. (p. 23)

Tal associação se deu devida às citações encontradas na obra e a uma multiplicidade linhas estéticas detectadas. Esta característica é a base da corrente pós-modernista e tal variedade é defendida por seus teóricos.

Grandes Oradores citam outras fontes ou remetem a elementos estranhos a seus textos. Acredite, pode-se ir muito mais longe com estas comparações entre linguagens: todo vocabulário, cada ramificação, sim, a linguagem em sua totalidade é uma herança. Nenhuma literatura se opõe a isso, muito pelo contrário. ( $\mathrm{p} 51$ )

Como exposto no primeiro capítulo, Assad foi exposto durante a sua trajetória a diversas correntes estéticas, que em certos momentos eram conflitantes, mas que em sua obra encontram um terreno comum que se traduz em um diálogo e que refletem a sua vivência musical. "O pós - modernista diz. Eu vou escrever uma obra onde eu me reconheça por inteiro". (BUCKNIX, 1994, p. 97)

Apesar de todas as citações que fazem com que Aquarelle e conseqüentemente o restante de sua obra, a estética de Assad se diferencia do pós-modernismo ao alcançar uma marca pessoal em suas composições e se atendo a esta, o que não ocorre no pós- modernismo. "O pomo é o choque

\footnotetext{
${ }^{141}$ BUCKNIX, Boudewijn. O Pequeno Pomo, ou a história da música do pós-modernismo. Ateliê editorial, Cotia, 1994.
} 
multicultural, é essencialmente uma arte tolerante, mas conseqüentemente diversa e dissidente." (BUCKNIX, 1994, p. 98).

Tal concepção estética teve seu conteúdo atrelado às diversas manifestações de música popular urbana e conseqüentemente à indústria cultural, como exposto por Alex Ross (2007) ${ }^{142}$.

..."Essa filosofia difere radicalmente do serialismo integral de Boulez (...). A música de Reich transpira ao ar livre, com todos os movimentos audíveis. Reconhecem-se nela as múltiplas características do mundo do seu criador, jazz modal, transe psicodélico, a fúria livre do protesto afro americano, o sensual balanço do rock 'n' roll. (...) Agora o compositor se tornava uma antena que recebia sinais, um satélite que captava mensagens de todo o planeta" (p. 525)

Nos últimos vinte anos uma nova geração de compositores, com nomes como Stepan Rak, Carlo Domeniconi e Andrew York têm se destacado ao produzir um gênero de música que transita entre as esferas do erudito e do popular. Este gênero híbrido de escrita tem sido denominado pelos críticos em geral como crossover. Em sua resenha ao CD Vianna plays Assad, Andrew Hull destaca Sérgio Assad como um dos mais importantes compositores desta geração:

Da geração que definiu o papel do compositor violonista, nomes tais como Bogdanovic, Dyens, York e Rak, nenhum teve o amplo apelo crossover conseguido por Sérgio Assad. A geração desde compositores (certamente de transição) parece ser definida pelas fontes de suas inspirações. Em sua maioria, estes compositores vieram de ambientes tradicionais, mas se desviaram do repertório tradicional ou até se rebelaram conta ele ao fundir o seu estilo com outro tal como o jazz, rock, bossa nova. (...) Deve-se admitir que eles não são líderes de cruzadas com legiões os seguindo em novo território musical, mas eremitas cavando seu espaço em uma floresta tomada pela tradição espanhola.

As composições (de Assad) devem a sua gênese às danças estilizadas de Bach, (...). A aplicação de técnicas composicionais à música popular da época, mostram que os estilos e técnicas se esgotaram de materiais e devem se aproveitar de carne fresca dos estilos populares para sobreviver.

\footnotetext{
${ }^{142}$ ROSS, Alex. O Resto é Ruído, escutando o século XX. Companhia das Letras, São Paulo, 2007.
} 
Pode-se imaginar, ao fim desta era de onde a nova música virá." (tradução nossa) ${ }^{143}$

Neste item foram selecionadas diversas passagens onde as várias influências de Sérgio Assad se manifestam em Aquarelle.

\subsubsection{1 - Radamés Gnattali}

Considerado uma das principais influências estéticas na obra de Sérgio Assad, o compositor gaúcho Radamés Gnattali (1906-1988) foi uma figura atípica no meio da música de concerto brasileira.

Após um promissor início de carreira como pianista de concerto em 1924, Gnattali se enveredou pela música popular como arranjador e pianista em emissoras de Rádio e Gravadoras obtendo grande êxito comercial. Como regente e arranjador realizou diversos experimentos musicais ao elaborar arranjos orquestrais complexos a canções populares ao mesmo tempo em que compunha obras de concerto dedicadas a músicos populares.

Este experimentalismo do compositor o levou a conceber diversas obras em que utilizava a música popular urbana em seus diversos gêneros como matéria prima para suas composições de concerto, contrastando com a estética nacionalista que buscava inspiração no folclore. Tal inventividade aliada ao domínio da técnica composicional e a uma forte inserção na mídia na música popular, fez com que Gnatalli estivesse envolvido nas mais diversas transformações dentro da música brasileira tal como descreve Assad à publicação norte americana Soundboard ao citar suas principais influências.

Toda a grande mudança por trás da música brasileira ele estava mais ou menos por trás, (...) o choro sofreu duas transformações por causa dele. "Não há como pensar na música brasileira e seu desenvolvimento sem pensar em Radamés Gnattali." (Tradução nossa) ${ }^{144}$

\footnotetext{
${ }^{143}$ HULL A. guitarra http://www.guitarramagazine.com/ViannaPlaysAssad acesso em 15/04/2006.

${ }^{144}$ Revista Soundboard, XXIII, no 3, p 15.
} 
Este tipo de estilo encontra sua gênese no compositor norte americano George Gershwin (1898 - 1937), um músico que obteve uma sólida formação como pianista de concerto e compositor, mas que alcançou a fama como compositor de música popular na Broadway em Nova lorque juntamente com seu irmão Ira Gershwin.

O sucesso como compositor popular trouxe ao jovem Gerswshin ambições maiores como compositor. Havia uma busca em elaborar música de concerto que tinha material temático inspirado no Jazz, música urbana de seu país de origem. Tal conceito fez com que o compositor criasse um conjunto de obras de concerto tais como: a ópera Porgy and Bass (1935) em que é constituído um drama musical tendo como base o canto dos negros do sul dos Estados Unidos e o concerto para piano Rhapsody in Blue (1924), em que Gershwin utiliza as células melódicas e rítmicas típicas do jazz norte americano como material temático para a obra.

Apesar de influente, a obra de Gershwin é pequena devida a sua morte precoce. Assim como Radamés Gnatalli, Assad cita igualmente a influência de Gershwin como algo marcante em seu crescimento como músico, tal admiração é demonstrada no arranjo para dois violões para a obra para piano e orquestra Rhapsody em Blue, registrada no CD Jardim Abandonado do Duo Assad ${ }^{145}$.

"Eu a escutei (Rhapsody in Blue) quando tinha doze anos, e ela me trouxe ao mundo da música clássica. Ela era jazz e era clássica. (...) Eu a escutei por anos até decidir fazer um arranjo dela." ${ }^{146}$ (tradução nossa)

A trajetória de músico de Radamés Gnattali e George Gershwin nos permite traçar diversos paralelos, visto que em que ambos os casos possuem sólida formação como instrumentistas e compositores e obtiveram sucesso comercial dentro da música popular e mais tarde se aventuraram na escrita de obras de concerto que se valiam da música popular urbana de seus respectivos países como material a ser abordado.

\footnotetext{
${ }^{145}$ DUO ASSAD, Jardim abandonado, 2007, Nonesuch, B000UKW4ZO.

${ }^{146}$ Revista Soundboard, XXIII, no 3, p $15-16$.
} 
Antes de sua iniciação como compositor, a influência de Gnattali se fazia presente na carreira de Sérgio Assad como interprete, visto que uma das primeiras gravações do Duo Assad era de seu Concerto para Dois Violões e Oboé $(1970)^{147}$. Neste momento a música de Gnattali marcou uma forte impressão sobre o jovem concertista.

“(..) quando eu pequei a partitura e comecei (,,,) a tocar aqueles acordes do Radamés, eram os acordes que eu gostava de fazer. Era exatamente o que eu tocava." ${ }^{148}$

Desde então, o Duo Assad obteve distinção no meio violonístico por apresentar arranjos de Sérgio Assad para composições de caráter híbrido, dentre estas, as composições de Gnattali como a Suíte retratos, deixando clara a predileção de Assad pelo trabalho do compositor. Tal influência seria posteriormente encontrada na produção de Assad como compositor, dado o material trabalhado por ambos, a música popular urbana e a concepção harmônica, que possuem similaridades evidentes.

A concepção estética de Gnattali encontra reflexos em Aquarelle dada a sua elaboração composicional sobre gêneros populares como veremos a seguir.

\subsubsection{2. - Exemplos}

Podemos encontrar similaridades entre as sonoridades empregadas por ambos compositores nas nos compassos 11 e 12 da obra Toccata em Ritmo de Samba no 1 (1950) e nos compassos 94 e 95 do terceiro movimento da Aquarelle, Prelúdio e Toccatina, onde a influência da peça de Gnattali é observada com clareza.

\footnotetext{
${ }^{147}$ DUO ASSAD. Latino America, com a Orquestra Armorial, 1974. Continental, (1- 035- 404 006).

${ }^{148}$ Assad, Sérgio. Entrevista conduzida por Luciano César Morais em São Paulo/SP 08/2006.
} 


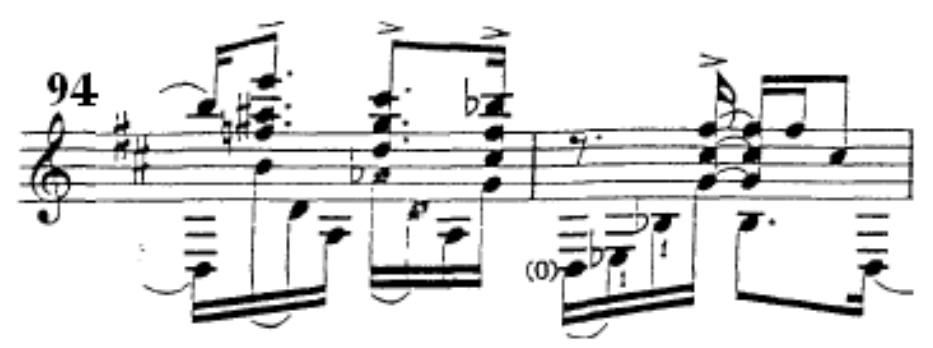

Prelúdio e Toccatina, compassos 94 e 95

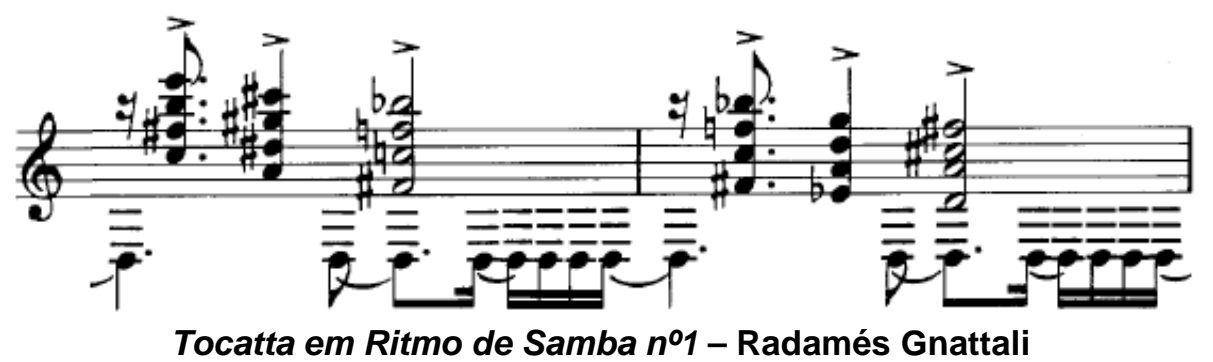

Encontramos uma versão elaborada dos ritmos do nordeste brasileiro na obra Petit Suíte (1985), obra dedicada ao violonista maranhense Turíbio Santos, onde três gêneros nordestinos (Pastoral, Toada e Frevo) são apresentados de modo elaborado pelo compositor. No Prelúdio e Toccatina, há uma passagem contida entre os compassos 96 e 115 onde uma abordagem similar à música nordestina é tomada.

A abordagem elaborada sobre o gênero da Bossa-Nova é encontrada no primeiro movimento Samba Bossa Nova, da Brasiliana №13 (1983) onde os acordes sincopados típicos do gênero são intercalados com fragmentos melódicos assim como encontrados na sessão A do Divertimento de Sérgio Assad.

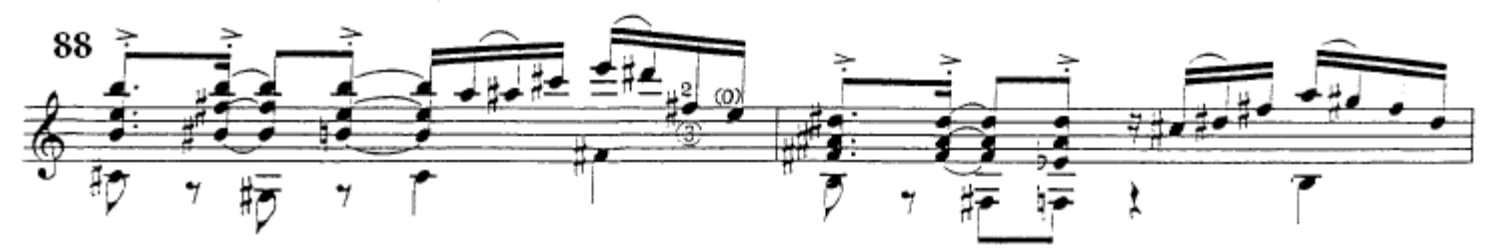

Divertimento, compassos 88 e 89 

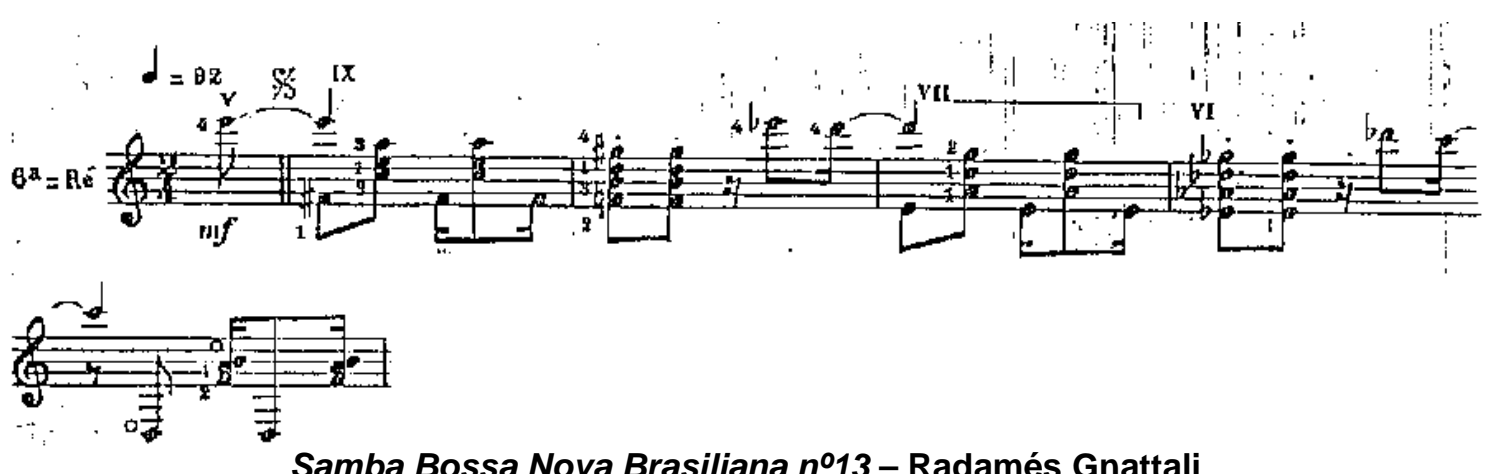

Samba Bossa Nova Brasiliana nº13 - Radamés Gnattali

\subsubsection{Villa Lobos}

Durante a análise de Aquarelle detectamos alguns elementos que remetem tanto à escrita instrumental quanto à concepção musical de Heitor Villa - Lobos (1887 - 1959). O peso da influência de Villa-Lobos para o que foi posteriormente denominado "violão brasileiro" é enorme devido à sua concepção musical que abraçava as manifestações musicais do país e as transportava a obras arrojadas escritas para o instrumento.

Visto que Sérgio Assad gravou juntamente com o seu irmão Odair a integral para violão solo de Villa - Lobos ${ }^{149}$. Podemos concluir que o seu contato com a sua idiomática para violão solo teve reflexos em sua produção como compositor. Tal constatação nos demonstra o alcance da influência de Villa-Lobos para com toda a produção posterior para o instrumento no Brasil.

Um recurso característico do idiomatismo da produção para violão solo de Villa-Lobos é o da utilização de formas de acordes violonísticos transpostas para a construção de diversas elaborações. No vocabulário violonístico do compositor, detectamos tais transposições de duas maneiras: utilizando-se cordas soltas e com pestanas.

Um exemplo característico da utilização deste recurso com cordas soltas é o da passagem presente entre os compassos 9 e 11 do Prelúdio $n .3$ da série dos 5 Prelúdios para violão (1940). Nesta peça, a fôrma do acorde F\#m7(b5) é

${ }^{149}$ DUO ASSAD. Heitor Villa-Lobos: Obra Completa Para Violão Solo, 1978. Kuarup KCD 139. 
transposta melodicamente havendo a utilização de uma corda lá solta no baixo pelo compositor.

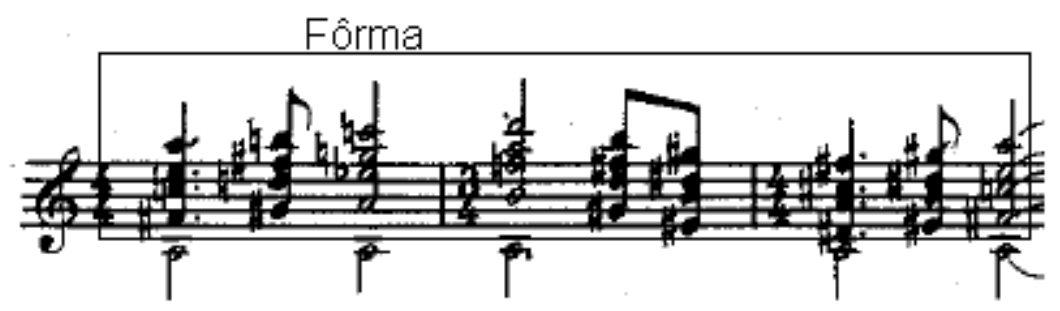

Prelúdio n. 3 - Heitor Villa-Lobos

$\mathrm{Na}$ introdução de Divertimento entre os compassos 1 a 83, tal recurso é explorado em profusão com cordas soltas. Exemplificaremos tal procedimento com a elaboração presente entre os compassos 45 e 49 onde a fôrma de tríade aumentada é elaborada juntamente com a corda mi (6) solta atuando como baixo pedal.

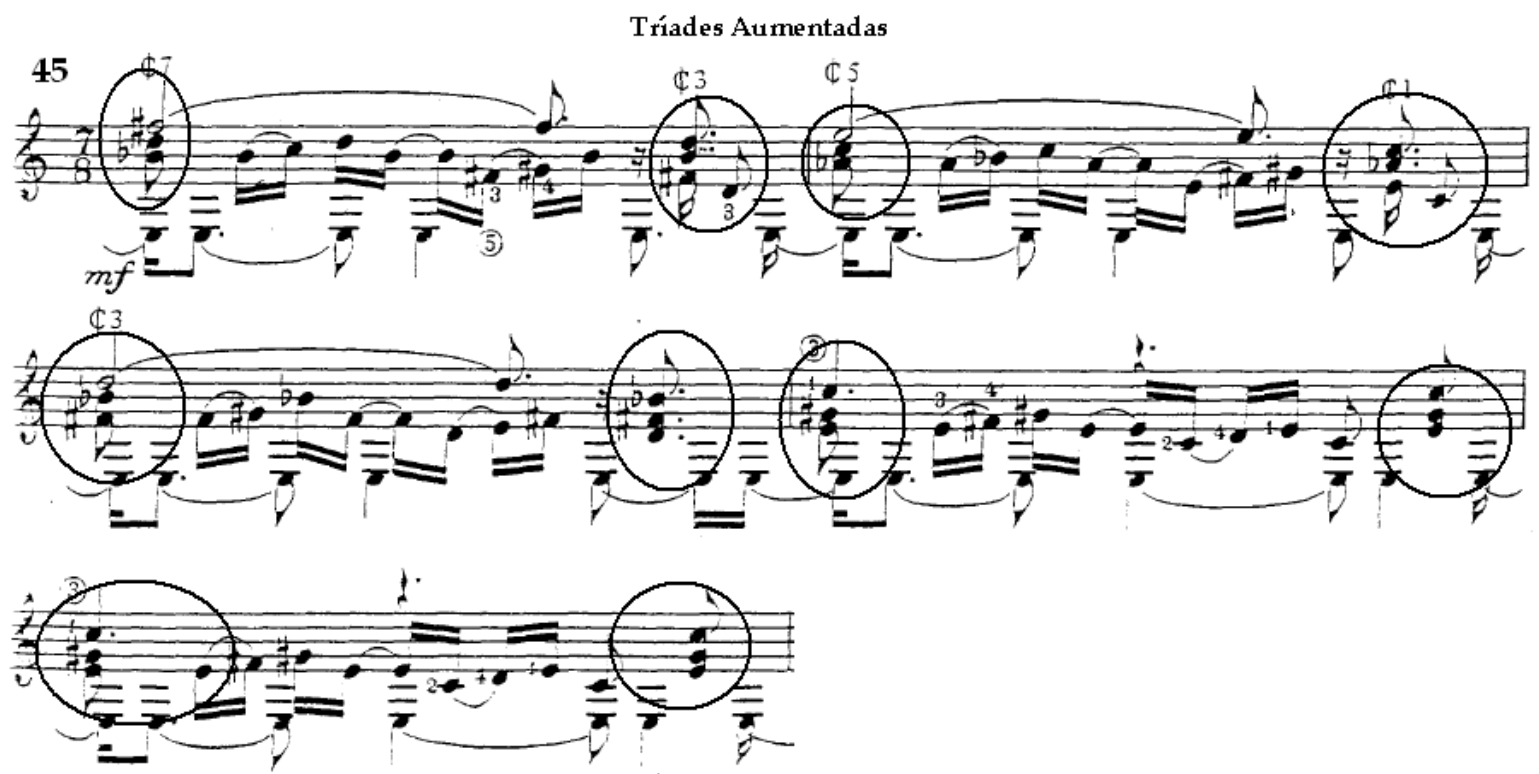

Divertimento, compassos 45 a 49

A outra forma de transposição, a elaboração com pestanas é encontrada no Prelúdio n. 2 (1940) para violão e encontra diversas configurações similares 
em Divertimento. Dentre estas, selecionamos uma passagem entre os compassos 103 a 108, onde tal recurso instrumental é aplicado.

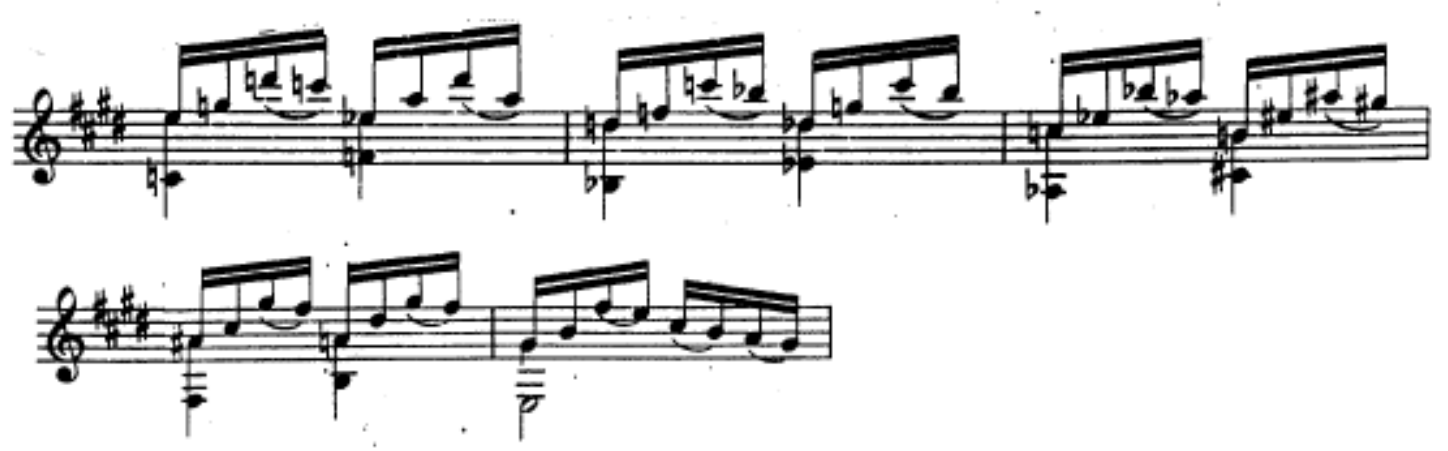

Prelúdio n. 2- Heitor Villa-Lobos

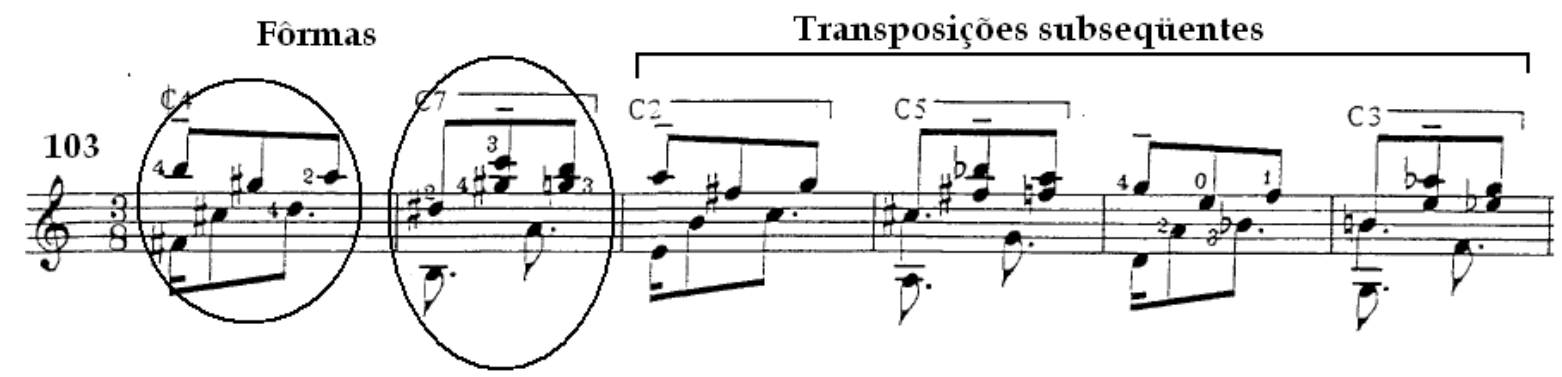

Divertimento, compassos 103 a 108

A influência do vocabulário instrumental de Villa-Lobos é novamente encontrada na reapresentação da elaboração do tema principal de Valseana entre os compassos 26 e 36. Na passagem, o tema é elaborado uma oitava abaixo e acompanhado por acordes em uma textura mais aguda. Esse procedimento é encontrado em obras como: Prelúdio $n^{\circ} 1$, Prelúdio $n \stackrel{0}{\circ} \mathrm{e}$ Estudo $n \cong 11$. Tais obras indicam a origem de recursos na escrita instrumental de Assad. 
144
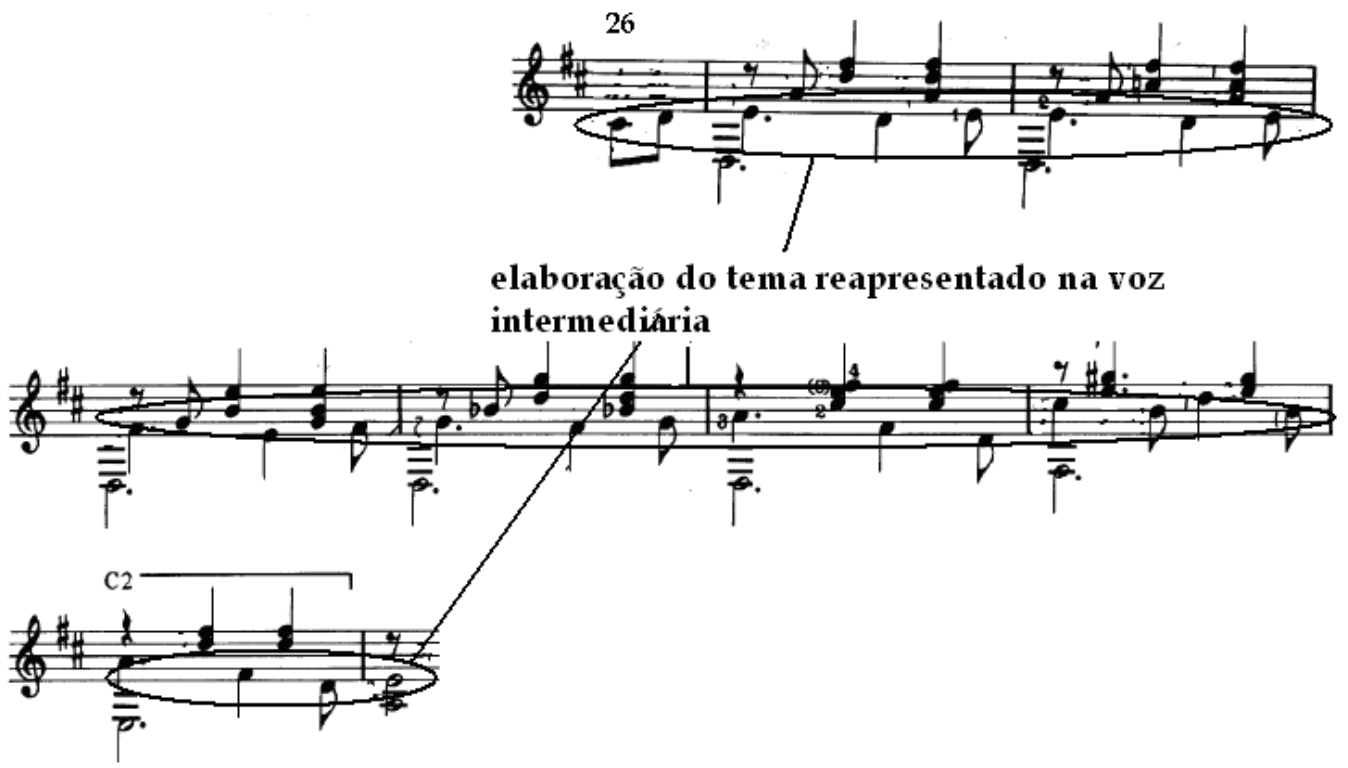

Valseana, compassos 26 a 33
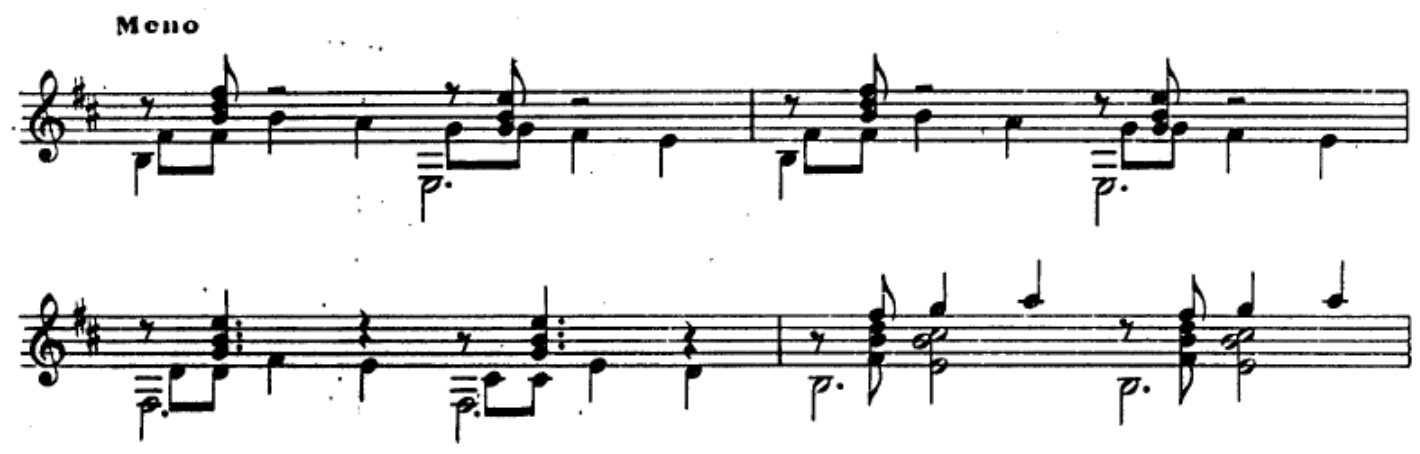

Heitor Villa-Lobos, Prelúdio $n 5$

A influência de Villa Lobos em Aquarelle se torna mais evidente devido a uma citação do tema da peça para violão solo Choros $n^{\circ} 1$ (1920), onde o motivo inicial composto pelas notas si, mi e sol (que formam um arpejo de mi menor) é citada no compasso 154 de Divertimento.

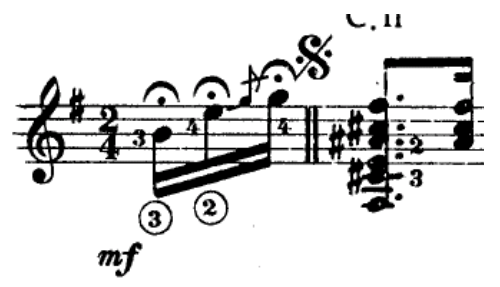

Choros nำ, Heitor Villa - Lobos 154

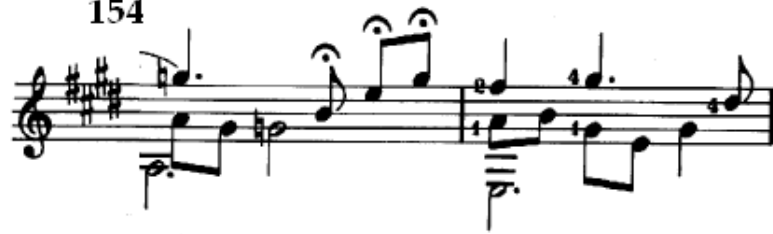

Divertimento, compasso 154 


\subsubsection{1 - Música Popular Urbana}

Como indicado previamente neste trabalho, Sérgio Assad sofreu grande influência de diversos gêneros da música popular urbana brasileira. Esta amálgama toma contornos ainda mais acentuados se levarmos em conta a rica e arrojada produção para música instrumental brasileira, que é personificada em nomes como Egberto Gismonti (1947) e Hermeto Pascoal (1936) e a grande produção para violão na música popular onde além de possuir um lugar de destaque nos diversos gêneros, produziu instrumentistas à altura de sua profusão em nomes tais como Aníbal Sardinha (1915 - 1955), Rafael Rabello (1962 - 1995), Dilermando Reis (1916 - 1977) entre vários outros.

No caso de Aquarelle, a música popular urbana pós-bossa nova serve de matéria prima às várias transformações, elaborações e demais técnicas composicionais aplicadas pelo compositor.

O compositor escolhe um conceito musical básico, por exemplo, um concerto barroco, uma musiquinha popular, um poema sinfônico romântico ou um serviço religioso. Depois aplica técnicas apropriadas sejam elas da tradição, de uma cultura que lhe é estranha, ou da música folclórica. ${ }^{150}$ (p 60)

Neste caso, ao se citar gêneros populares como o baião, a marcha rancho e a bossa nova, Assad novamente remete ao recurso de citação que novamente encontra respaldo na estética pós-moderna ${ }^{151}$.

É o grande procedimento de Schnittke. Joga-se um estilo contra o outro, Naturalmente diversos estilos fazem-se necessários. Schnittke chama isto de Poliestética" ( $p$ 62)

Foram desenvolvidas técnicas alusivas bastante interessantes. Por exemplo: procurar que uma coisa leve a outra que já se conhece vagamente. Será que isto que eu estou ouvindo? Ou será que não? Torna-se evidente que hoje, atinge-se quando muito de passagem o que era antes um 'estilo' ou um 'conceito'. A tonalidade é extremamente tonal, mas não segundo as regras. Ela já não oferece não é um critério, mas um sujeito. ( $p$ 61)

\footnotetext{
${ }^{150}$ BUCKNIX, Boudewijn. O Pequeno Pomo, ou a história da música do pós-modernismo. Ateliê editorial, Cotia, 1994.

151 lbidem.
} 
Selecionamos aqui alguns exemplos destas influências em Aquarelle, e posteriormente neste trabalho comentaremos como estas influências se refletem no restante da obra para violão do compositor.

\subsubsection{Exemplos da influência da música popular urbana em} Aquarelle

Dentre as diversas passagens em que a influência da música popular se faz presente, selecionamos a elaboração presente entre os compassos 108 e 116 do terceiro movimento, Prelúdio e Toccatina. Constatamos nesta passagem da obra uma influência da música nordestina brasileira, mais precisamente do gênero do baião, e também da obra Lôro de Egberto Gismonti presente no disco Sanfona (1980) ${ }^{152}$. A passagem se compara à peça de Gismonti na utilização de células melódicas, formadas por duas semicolcheias repetidas que também são comuns à música desta região do Brasil.
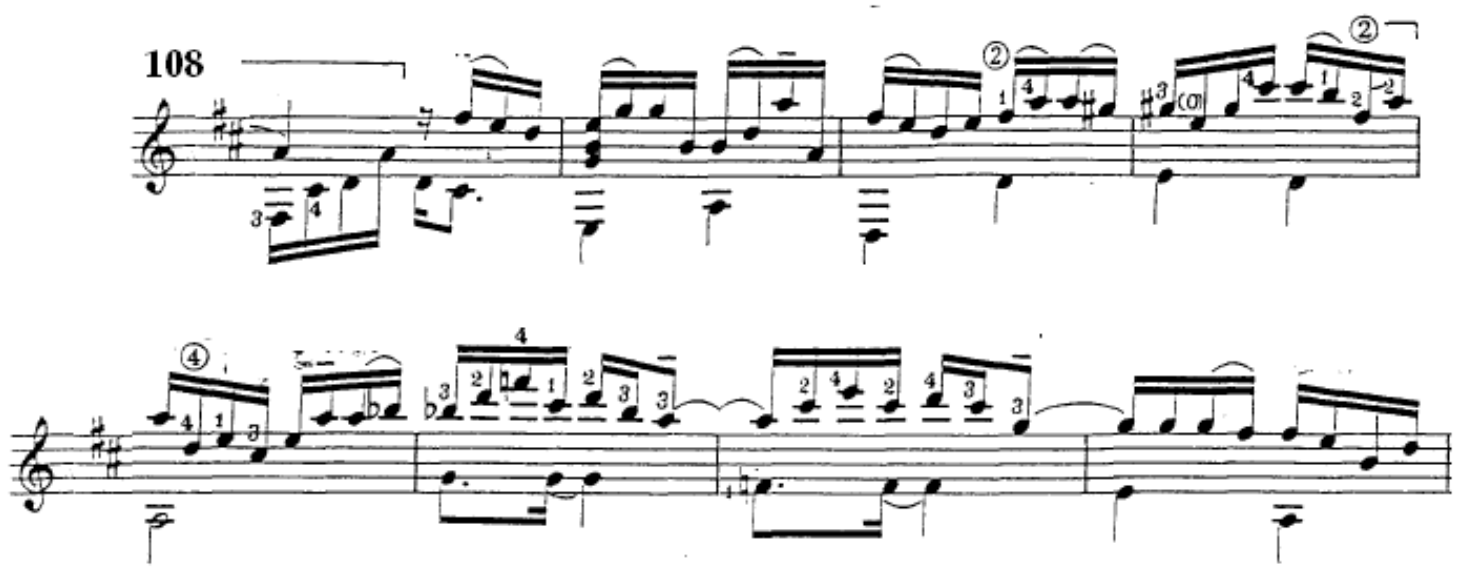

Prelúdio e Toccatina, compassos 108 a 116

152 GISMONTI, Egberto. Sanfona, ECM Records, 1980 B00000DTEU. 


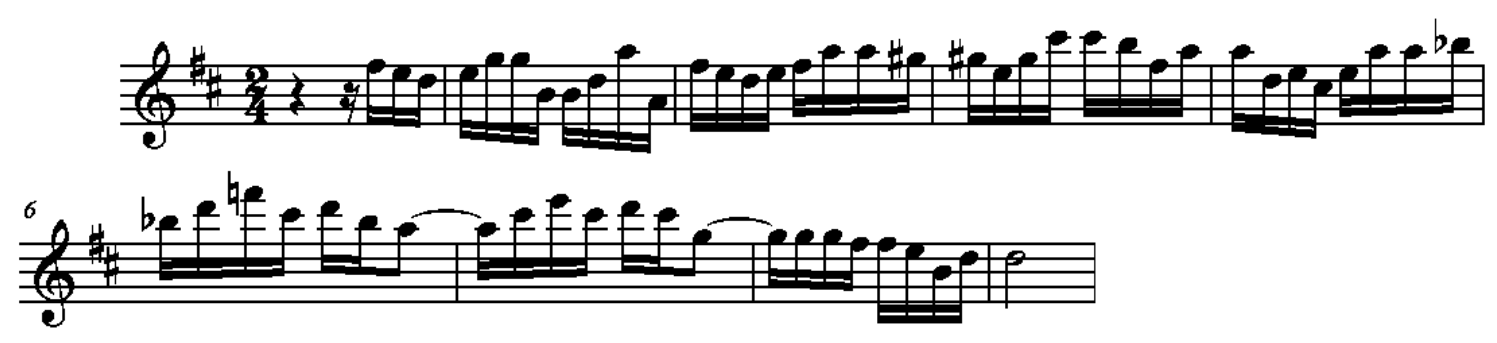

Linha melódica em Prelúdio e Toccatina, compassos 108 a 116

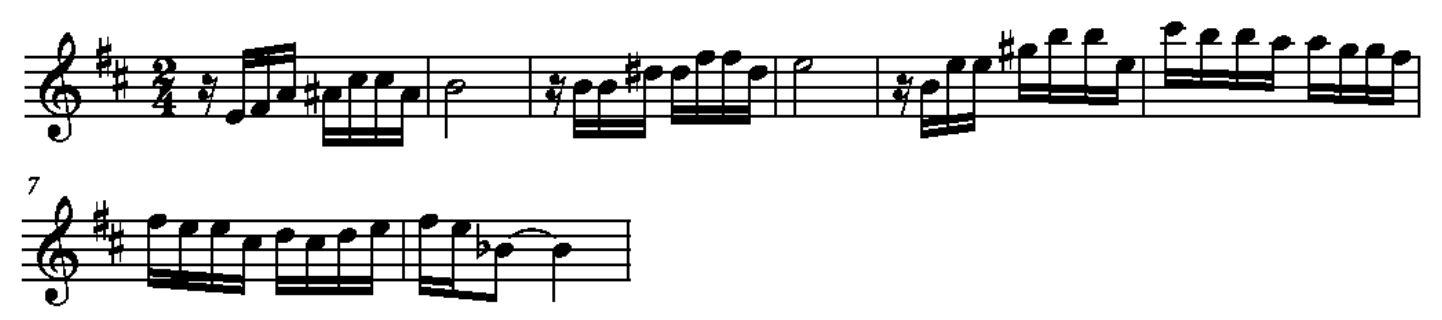

Linha melódica de Loro - Egberto Gismonti

Novamente a influência de Gismonti pode ser exemplificada através da comparação da figura melódica formada por saltos de sextas encontrada no compasso 120 da sessão A do Divertimento, pode ser comparada à melodia inicial do Frevo de Gismonti (1980) ${ }^{153}$, em que o mesmo tipo de fragmento melódico é empregado.

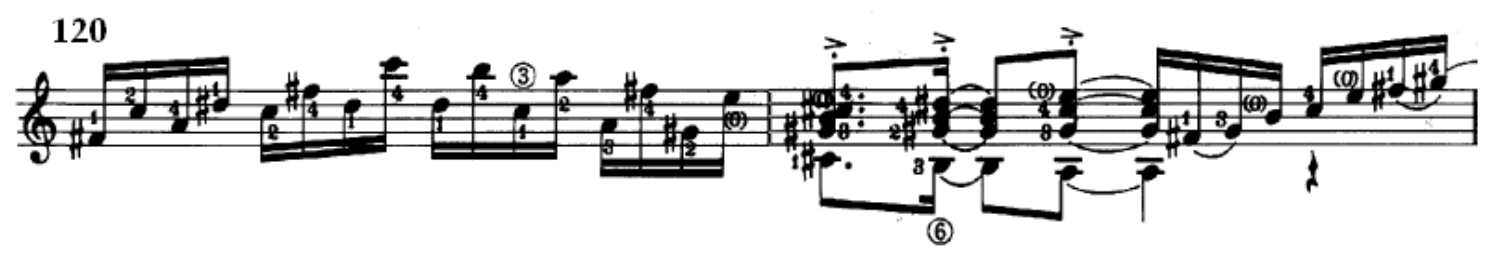

Divertimento, compassos 120 e 121

$d=170$
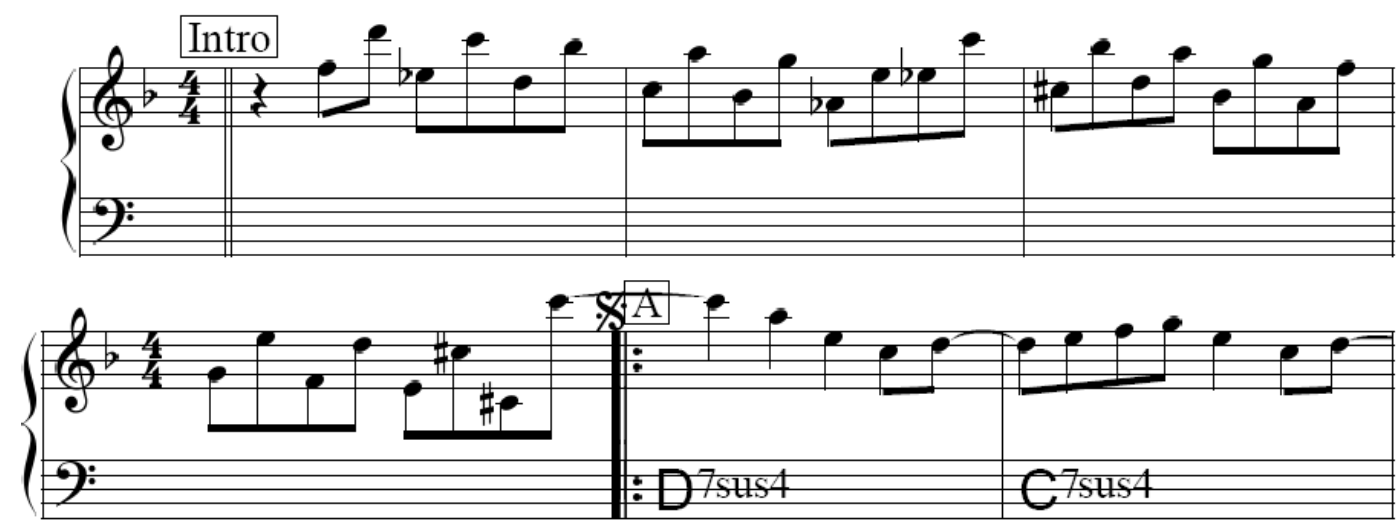

${ }^{153}$ Também presente no disco Sanfona (1980). 


\section{Frevo - Egberto Gismonti}

Como detectado no item 2.5, foi encontrado no compasso 140 do Divertimento um harmônico natural em uma região da boca do instrumento em que seria encontrada a nota mi na 24a posição na corda mi (1). Em um show ao vivo gravado em vídeo ${ }^{154}$, Egberto Gismonti utilizou uma técnica similar em diversos momentos em que explora harmônicos naturais e artificiais numa mesma região. Tal comparação nos revela a influência da técnica instrumental peculiar de Gismonti sobre Sérgio Assad.

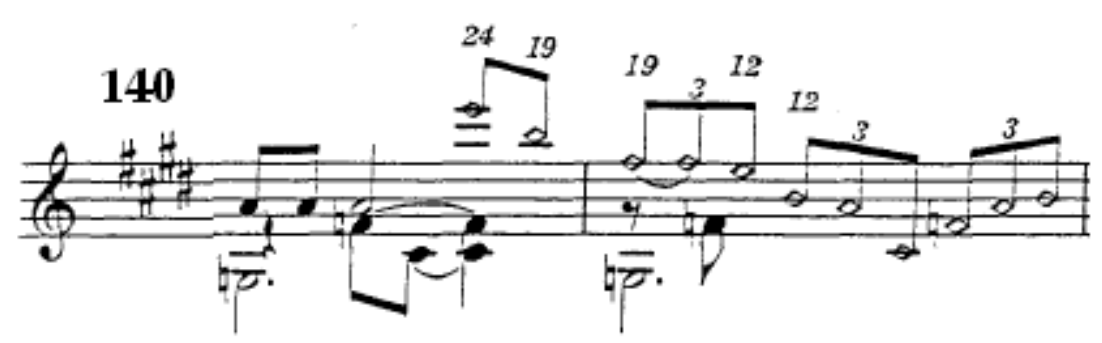

Divertimento, compassos 140 e 141

Talvez a linha estética da música popular urbana mais seja associada à música de Sérgio Assad seja a bossa nova. O movimento, surgido nos anos 50, no Rio de Janeiro cuja linguagem harmônica elaborada associada a ritmos brasileiros e uma sutileza interpretativa maior, que contrastava com os arroubos sentimentais da geração anterior. O movimento trouxe a compositores como João Gilberto (1931) e Antonio Carlos Jobim (1927 - 1994) a fama internacional e uma grande exposição do Brasil no exterior na época. Na obra de Assad, a série Jobinianas, presta tributo a Tom Jobim e na Aquarelle a influência da Bossa Nova é visível principalmente no compasso 88 na sessão $A$ do Divertimento, onde os acordes menores com sétima em rítmica sincopada remetem claramente a este estilo.

\footnotetext{
${ }^{154}$ GISMONTI, Egberto. Live at the 87 Festival in Freiburg Proscenium - CDV - Germany , 6301293304,1993 .
} 


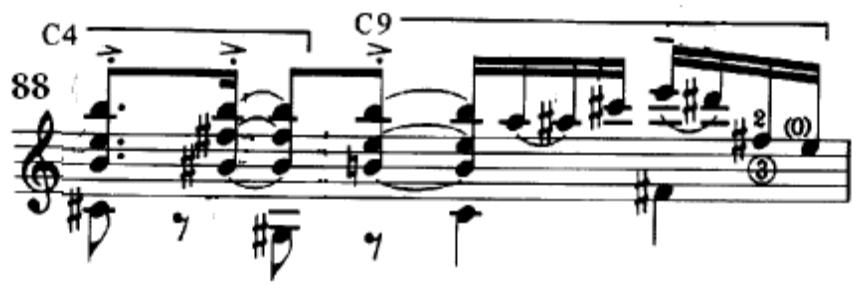

Divertimento, compasso 88

Em depoimento colhido em novembro de 2005, o violonista Aliéksey Vianna, citou em diversos momentos a presença de traços de marcha rancho na escrita da Aquarelle. Pela rítmica sincopada empregada em diversas passagens da obra, podemos atribuir à influência do gênero citado por Vianna ao detectarmos diversas elaborações em que ocorre polifonicamente como nos compassos 38 a 41 , onde a melodia sincopada entrelaçada por uma voz secundária torna a textura mais densa e faz com que a intenção rítmica seja mais clara.
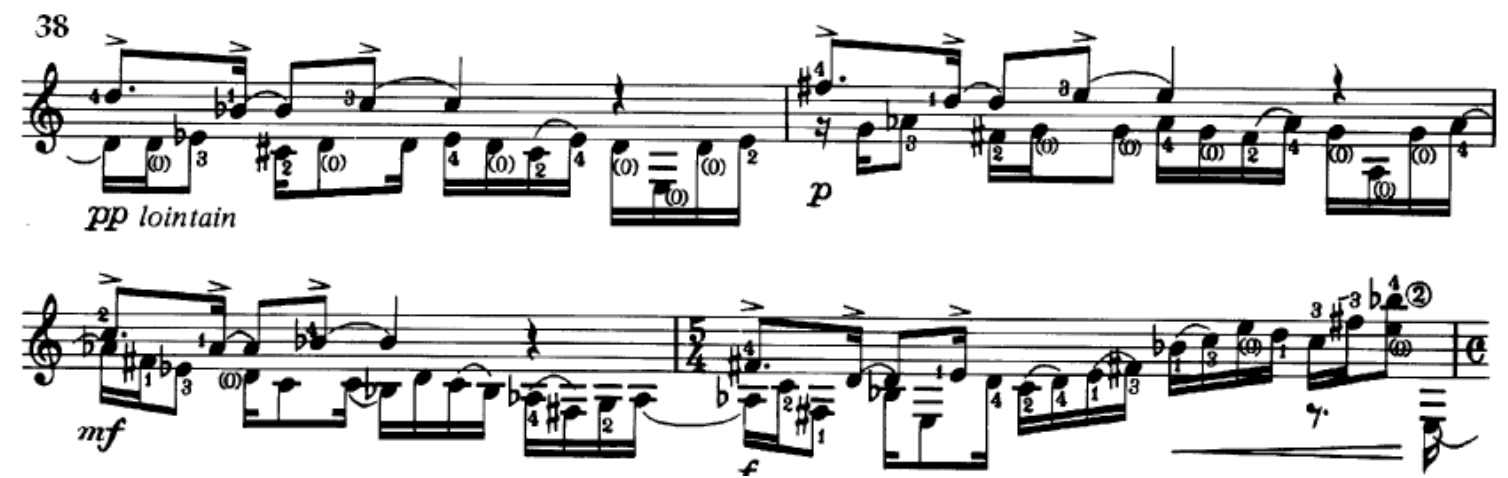

Divertimento, compassos 38 a 41

Nos compassos 42 a 44 e 67 a 69 do Divertimento, encontramos um acompanhamento formado por colcheias pontuadas elaboradas em forma de baixo pedal que novamente remetem a ritmos brasileiros. Este ostinato é reelaborado em blocos nos compassos 50 e 51, acompanhado por uma linha de baixo, tornando mais rica a textura e trazendo à tona mais elementos rítmicos extraídos do gênero da marcha rancho.

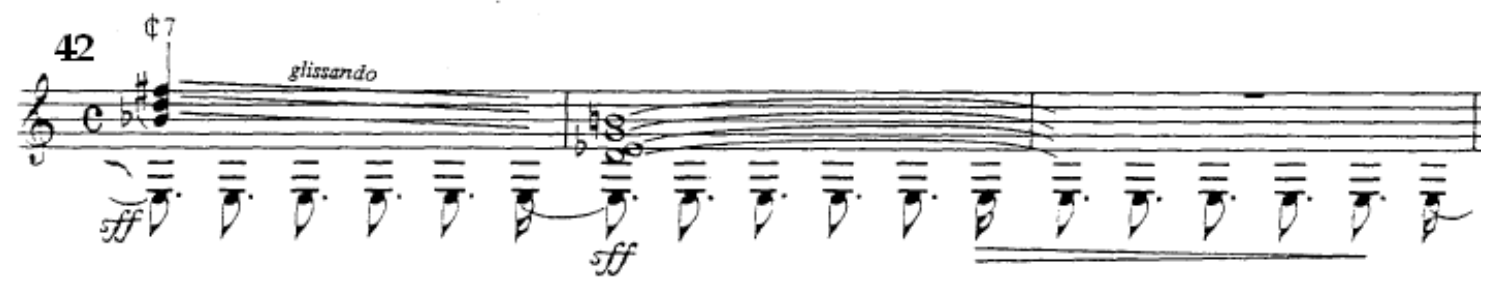




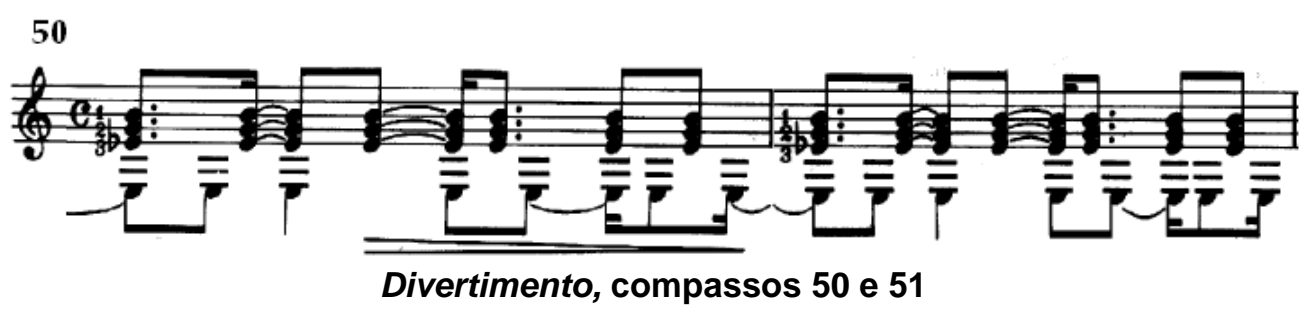

Como visto anteriormente no item 2.3.2, o início da sessão da Toccatina do Prelúdio e Toccatina, apresenta uma linha de baixo contínuo acompanhando a melodia principal na voz de soprano entre os compassos 24 e 34 e reapresentada entre os compassos 116 e 119. O ritmo do acompanhamento nesta passagem se encontra subdivido em dois grupos de seis semicolcheias (que corresponde à semínima pontuada) e um grupo de duas colcheias, em um compasso quaternário. A divisão produz um ritmo de 3 + 3+ 2 típico da música popular brasileira, mais especificamente com o gênero do baião, uma das influências estéticas que permeiam este terceiro movimento de Aquarelle, tal qual pode ser exemplificado na figura abaixo.

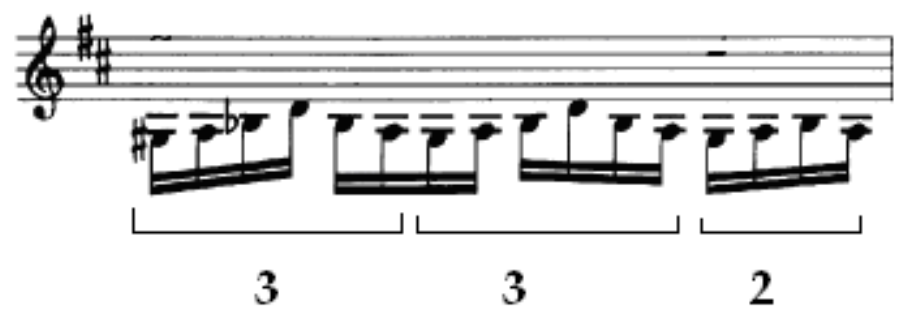

Padrão de acompanhamento de Prelúdio e Toccatina

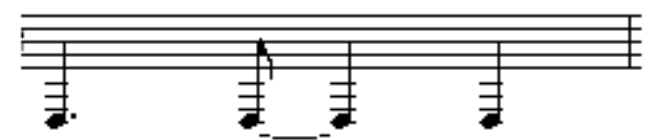

Padrão rítmico derivado do acompanhamento

Uma influência que nasceu no ambiente familiar de Sérgio Assad, vinda do choro, pode ser exemplificada na linha de baixo cromática típica do estilo presente no compasso 85 do primeiro movimento de Aquarelle, Divertimento. Na passagem apontada, Assad simula a prática da improvisação de linhas de baixo, conhecidas como "baixarias" pelos seus praticantes, ao elaborar uma passagem com linha de baixo cromática descendente e de rítmica sincopada remanescente do estilo citado. 


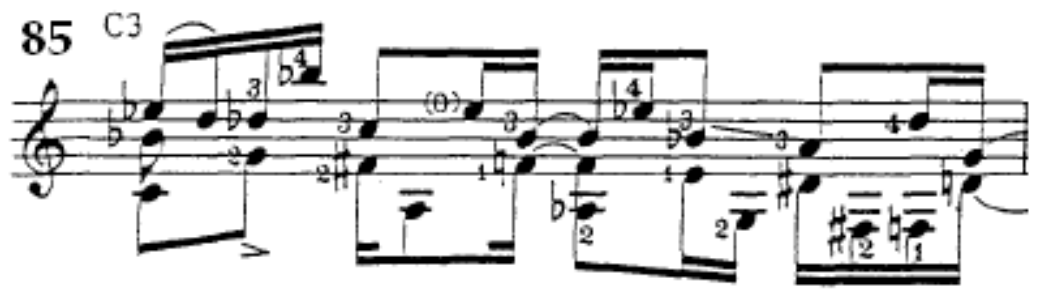

Divertimento - compasso 85

\subsubsection{Linguagem Harmônica}

Em Aquarelle, detectamos diversos procedimentos harmônicos que indicam diferentes correntes estéticas. Dentre estas destacamos 0 impressionismo francês e a música popular brasileira.

O impressionismo francês se manifesta em Aquarelle através do emprego de diversas estruturas harmônicas típicas como o uso de acordes quartais, escalas de tons inteiros e acordes de empréstimo modal.

Durante a introdução de Divertimento (compassos 1 a 83), Sérgio Assad demonstra a influência do compositor francês Claude Debussy (1862-1918) ao utilizar estruturas advindas da escala de tons inteiros. Esta escala, também conhecida como escala hexafônica, normalmente é associada a uma tentativa pelos compositores impressionistas em organizar o som da escala cromática a um grupo específico de notas ${ }^{155}$, porém outras fontes citam a sua origem como mais remota e originária da escola russa do Séc. $\mathrm{XIX}^{156}$.

A formação da escala de tons inteiros se dá por uma sucessão de seis notas divididas em tons inteiros e gera um campo harmônico formado por tríades aumentadas para cada grau da escala.

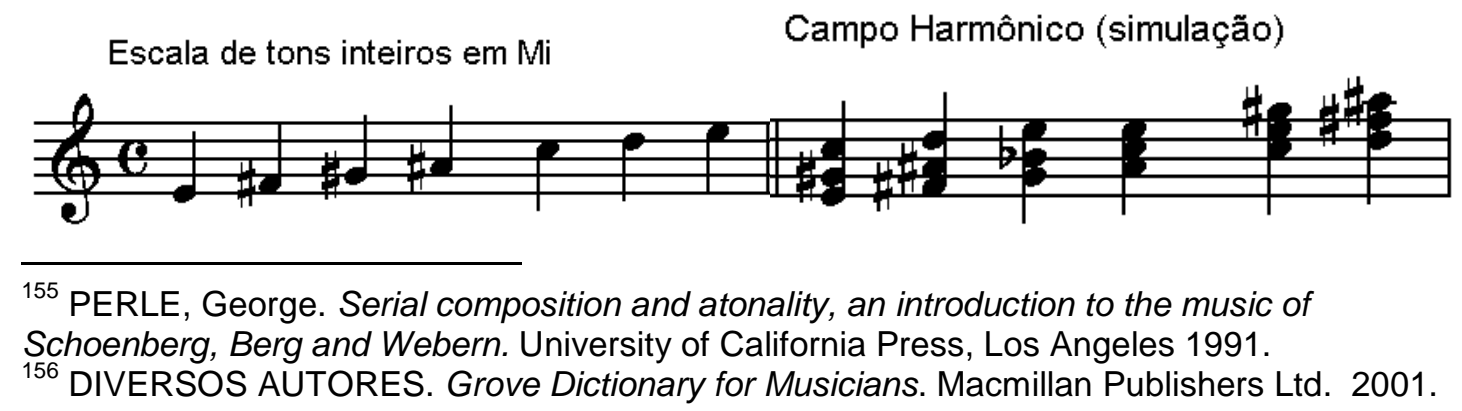


Um exemplo característico do emprego desta escala por Debussy é encontrado no prelúdio para piano "Voilés" Livro I no 2 . Nesta peça a primeira parte é construída sobre a escala de tons inteiros e suas estruturas harmônicas derivadas.

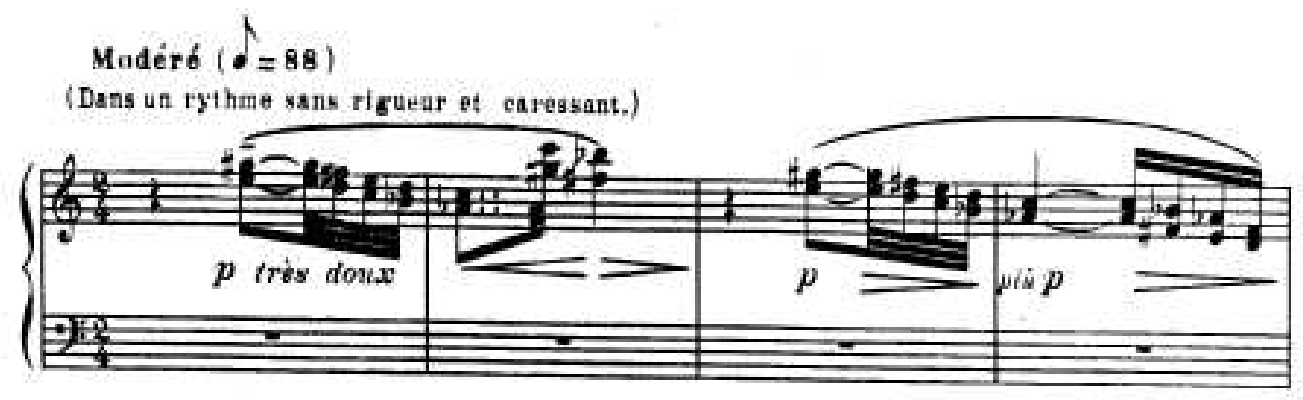

Claude Debussy Prelúdio para piano Voiles, Livro I N. II

Devido à simetria presente na escala de tons inteiros, o campo harmônico desta não possui funções específicas, a introdução de Divertimento, que possui em sua maior parte estruturas geradas por escalas de tons inteiros intercaladas com trechos cromáticos, não possuindo tonalidade ou funções harmônicas definidas como na figura abaixo, localizada entre os compassos 1 a 21 da peça. 


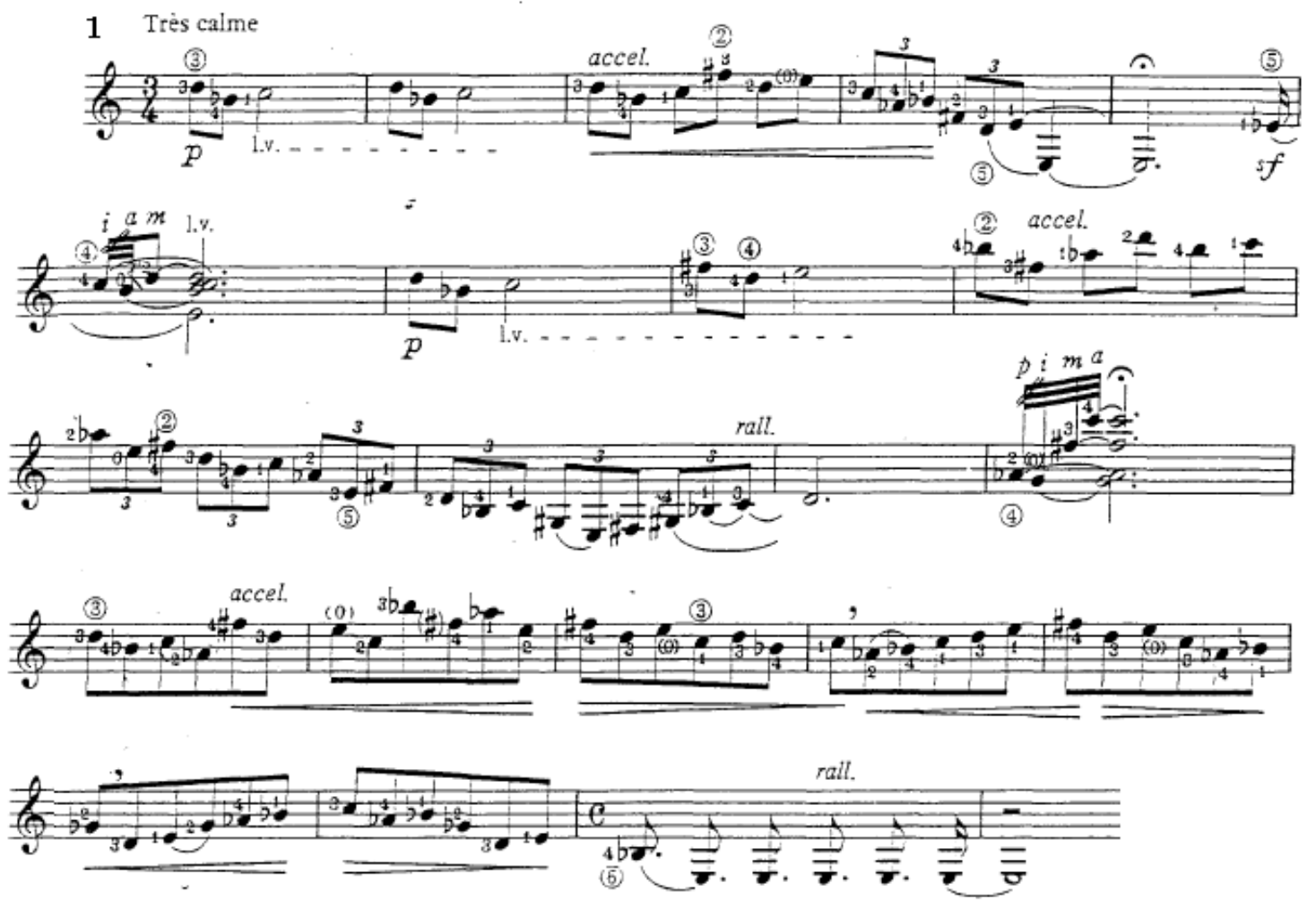

Divertimento, compassos 1 a 21

Um procedimento composicional comum na estética impressionista é o da elaboração de notas pedais sobre diferentes acordes, relacionados harmonicamente ou não. Este recurso é encontrado na música para piano de Claude Debussy em peças como o Prelúde no 2 Livro I "Voiles", onde diversas sonoridades baseadas em escalas de tons inteiros são elaboradas sobre uma nota pedal si bemol em ostinato. 

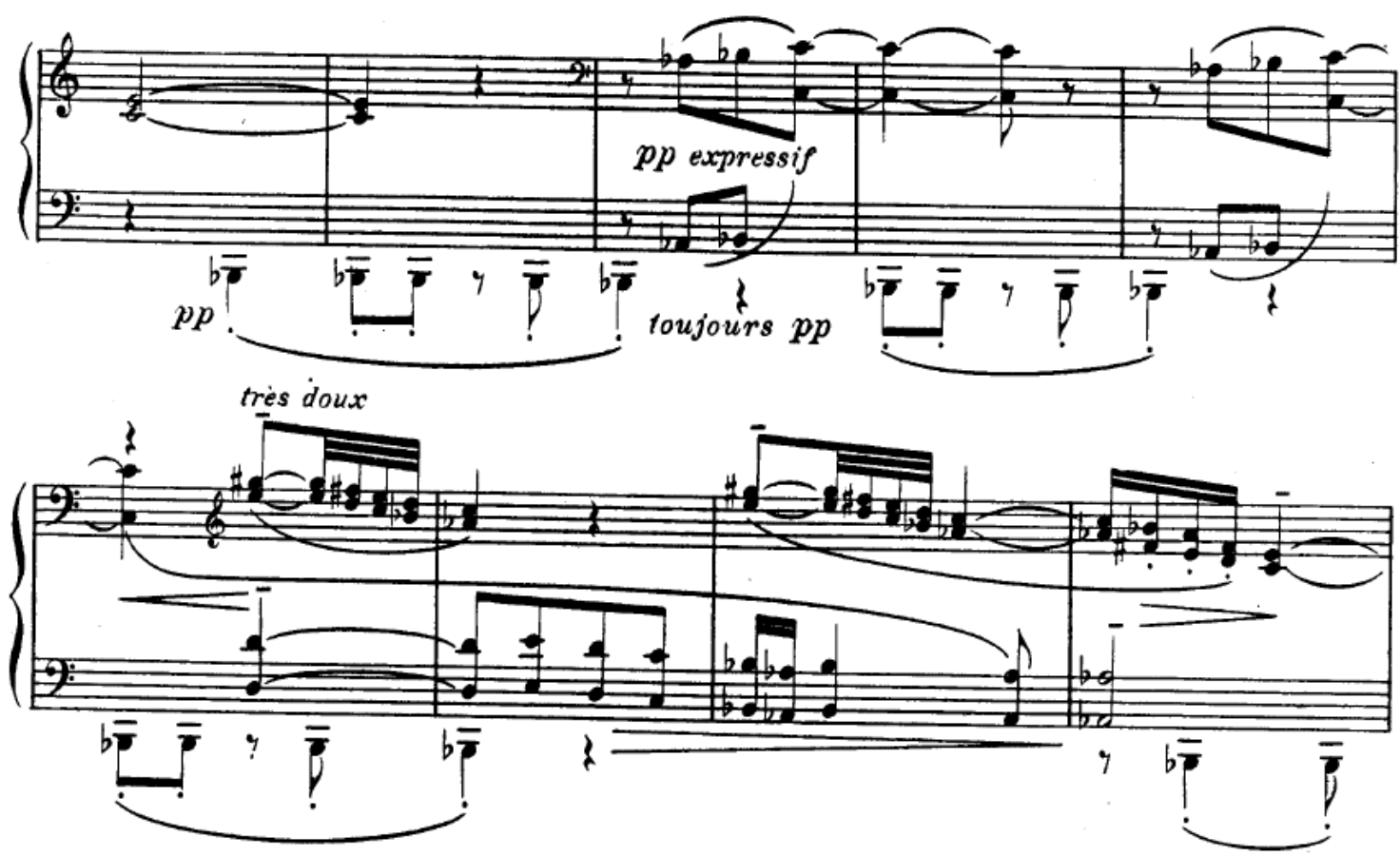

Voiles - Claude Debussy compassos 5 a 13

Em Aquarelle, este procedimento encontrado na música de Debussy encontra reflexos dado o material harmônico explorado e a estruturação sobre notas pedal. Em Divertimento, tríades aumentadas são executadas em sobre uma nota pedal mi entre os compassos 45 e 48, remetendo à estética impressionista.

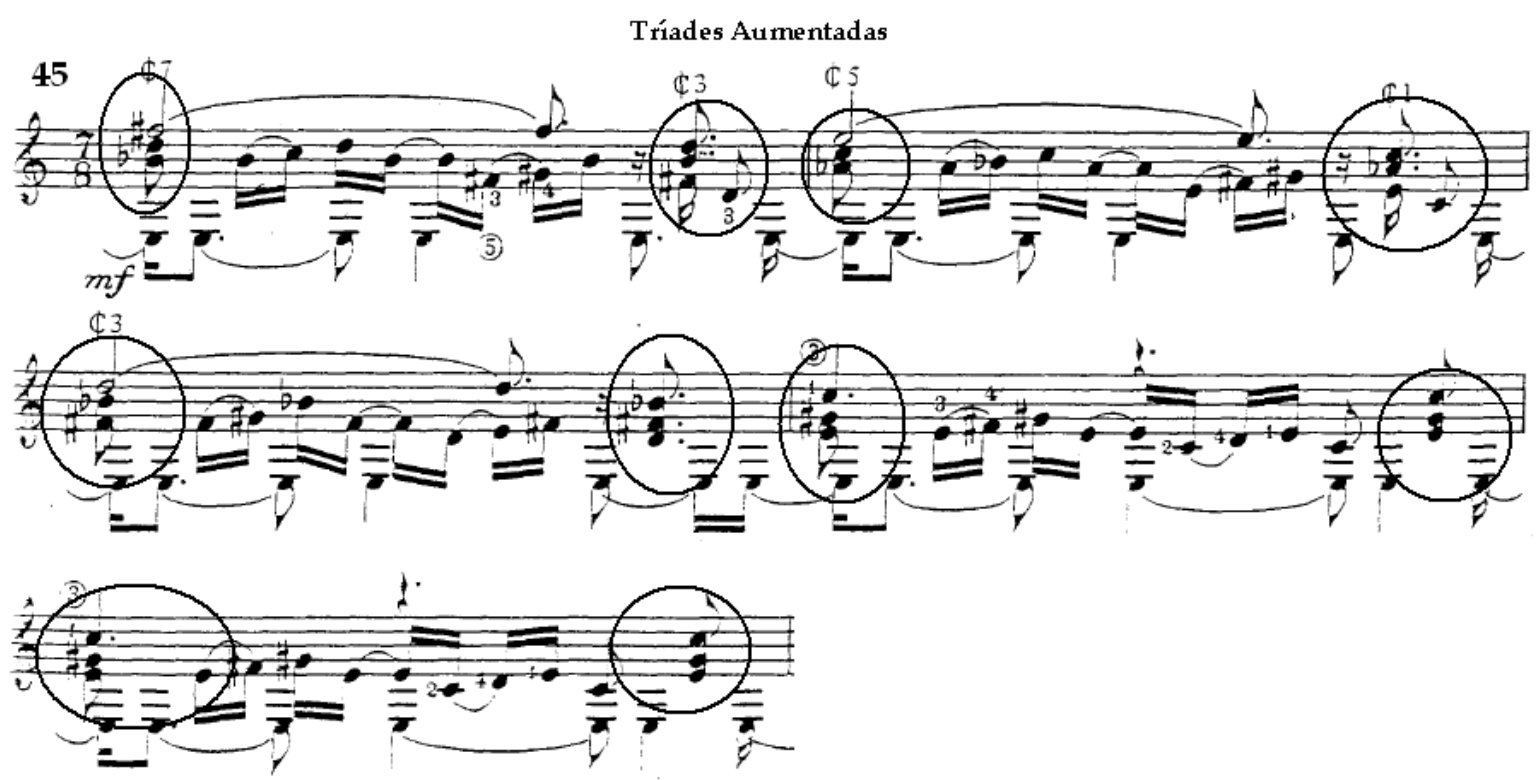

Divertimento, compassos 45 a 49 
Acordes quartais, isto é, cuja constituição é formada por quartas justas sobrepostas, são encontrados em profusão em obras impressionistas. Em Prelude №10 Livro I "La catedral Engloutie”, de Claude Debussy (1862-1918) é percetível esta sonoridade é explorada como nos compassos 1 a 3 . Segue a exemplificação:

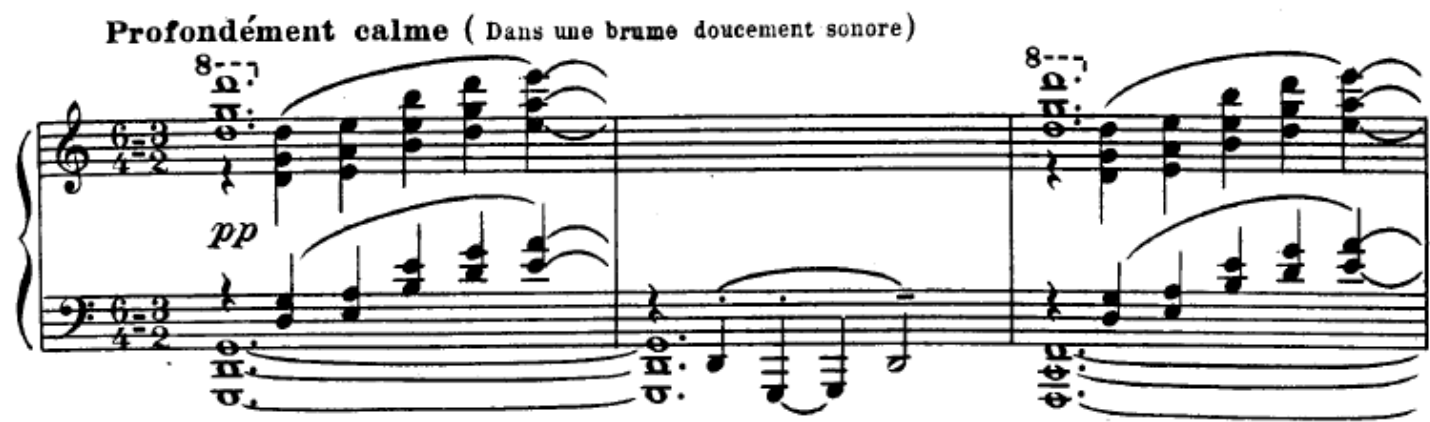

La Catedral Engloutie - Claude Debussy compassos 1 a 3

Em Divertimento (e em), Prelúdio e Toccatina estes acordes também são empregados e exemplificaremos a adoção do procedimento harmônico com a passagem encontrada entre os compassos 62 e 66 de Prelúdio e Toccatina onde tal sonoridade é elaborada.

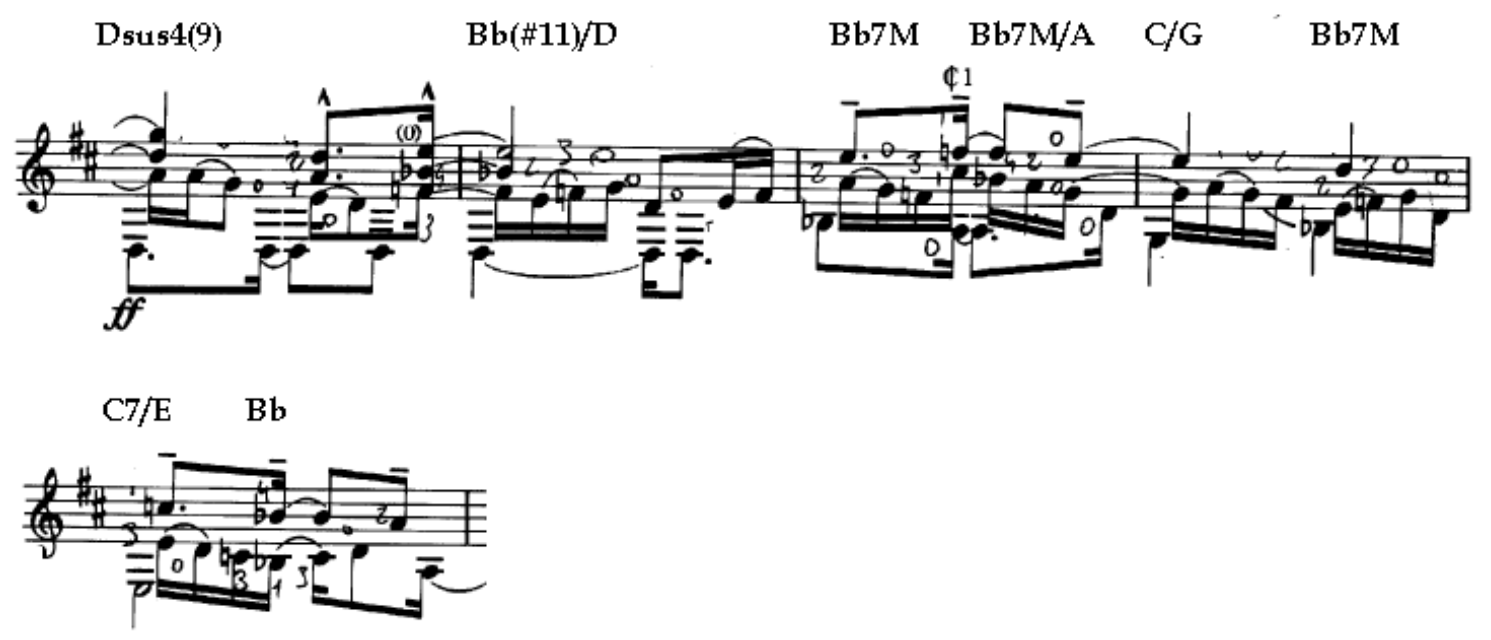

Prelúdio e Toccatina, compassos 62 e 66

Ao final de Valseana novamente encontramos resquícios da estética impressionista pela elaboração de um acorde de D7M(\#9)(\#11) no compasso 
58 que, de acordo com Bernard e Saker (1997) ${ }^{157}$ seria um acorde maior com uma segunda aumentada, tendo no caso uma função de tônica, o que é descrito pelos autores como um procedimento harmônico comum à estética impressionista adotada por compositores como Maurice Ravel (1875 - 1937).

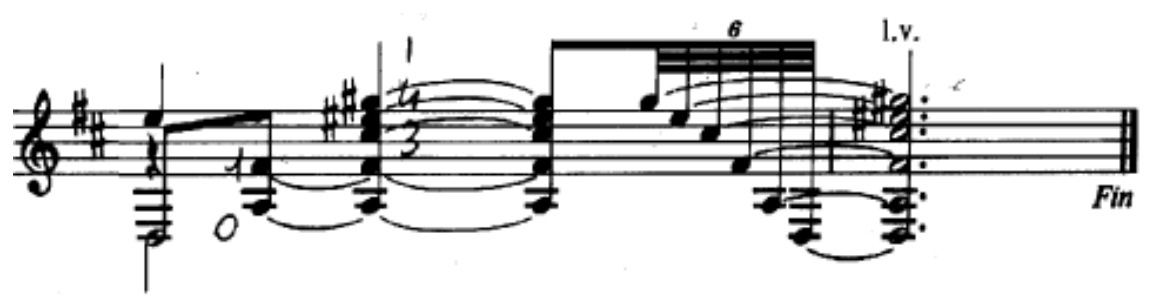

Valseana, compassos 57 e 58

Nos anos 50 e 60 a música popular brasileira, sob a influência da música norte americana e francesa ${ }^{158}$, se enriqueceu harmonicamente. Tal característica é presente de maneira clara no gênero da bossa-nova e se cristalizou nos gêneros populares surgidos posteriormente. $O$ compositor Antônio Carlos Jobim (1927 - 1994), em depoimento colhido por Almir Chediak $^{159}$, aponta a influência da estética impressionista em sua música e como esta foi confundida com o jazz "bebop" norte americano.

Villa Lobos e Debussy são influências profundas (...). Ao jazz (...) eu não tive muito acesso. O negócio do jazz era pra colecionador. (...) Não sou um profundo conhecedor de jazz. Quando esse pessoal dizia que a bossa nova era americana eu achava engraçado, porque essa mesma harmonia já estava em Debussy. Não era americana coisa nenhuma. (...) Esses acordes de décima primeira, décima terceira, alteradas com tensões (...) isso você não pode chamar de americano. $O$ norte-americano pegou a bossa nova porque achou interessante. Se fosse cópia do jazz não interessaria. (...) Eu enfrentei preconceitos enormes. Tocava uma nona e diziam "O Tom toca bebop". Diziam que o João Donato era bebopeiro, (...) A gente tocava uma quarta aumentada, uma décima primeira e aparecia logo aquele cara pra dizer, "olha só bebopeiro.

\footnotetext{
${ }^{157}$ BERNWARD, Bruce, SACKER, Marilyn. Music in Theory and Practice, volume II. McGraw Hill Higher Education Nova lorque, 1997, 347p.

${ }^{158}$ Tal influência ainda é motivo de debate por parte dos historiadores da música popular e um consenso ainda não foi alcançado. Alguns teóricos afirmam a influência do jazz norte americano enquanto outros apontam a estética impressionista francesa como fonte.

${ }^{159}$ CHEDIAK, Almir. Songbook Tom Jobim, volume 3. São Paulo, Lumiar Editora, 1990.
} 
Apesar da associação da música brasileira ao jazz feita por diversos teóricos da música popular como José Ramos Tinhorão em A Pequena História da Música Popular ${ }^{160}$, encontramos a raiz do enriquecimento harmônico na música popular americana no impressionismo francês. Tal raiz é relatada no depoimento do trompetista norte americano Dizzie Gillespie (1917 - 1993), um dos mais importantes expoentes do jazz.

Quando inseriu as notas de abertura da Sagração da Primavera em Salt Peanuts, Charlie Parker estava mostrando respeito e ao mesmo tempo declarando sua liberdade com um ar impudente. (...) Coltrane condimentava acordes com quarta do Concerto para Orquestra de Bartok.. 'tinhamos alguma formação básica em harmonia européia e em teoria musical, que foi superposta ao nosso conhecimento de tradição musical afro-americana.', escreveu Gillespie. ${ }^{161}$ (p. 500)

Tal linguagem harmônica, presente na música popular brasileira teve uma grande influência na linguagem composicional de Sérgio Assad. Em entrevista à revista eletrônica Guitarra ${ }^{162}$, Assad cita a sua apreciação por esta característica.

O desenvolvimento musical nos países da América Latina teria sido o mesmo. Os colonizadores foram mais ou menos os mesmos, bom exceto no Brasil que foi colonizado por portugueses, mas nós tínhamos os mesmos tipos de elementos musicais. Mas (...) a harmonia brasileira se desenvolveu mais que em outros países. Veja bem, a coisa mais encantadora da música brasileira é a harmonia. (tradução nossa).

Outra característica típica da música popular e que é citada por Assad seria a influência do gênero do choro, suas diversas modulações e o fato de ter se tornado progressivamente mais complexo e elaborado visto que harmonicamente se tornava mais denso, dadas as influências externas citadas anteriormente.

\footnotetext{
${ }^{160}$ TINHORÃO, José Ramos. Pequena História da Música Popular. São Paulo, 1978, Círculo do Livro.

${ }^{161}$ ROSS, Alex. O Resto é Ruído, escutando o século XX. Companhia das Letras, São Paulo, 2007.

162 INTERVIEW WITH SÉRGIO ASSAD. Revista eletrônica guitarra. Madrid n.9, out. 2003. Disponível em: http://www.guitarramagazine.com/lssue42/interview_assad.asp. Acesso em 30 de janeiro 2004
} 
Vamos pensar. Eu acho que quando o estilo chamado choro foi introduzido já tinha muitas modulações. Então a música de Ernesto Nazareth e dos que estavam fazendo os primeiros protótipos do choro já alcançaram uma espécie de modulação em sua música. Os acordes foram enriquecidos mais tarde, sob a influência do jazz. Quando chegamos aos anos 50 e 60, se tornaram mais complexos e mais ricos. No estilo de se tocar choro, que era um gênero de música instrumental, um dos desafios era o de se criar peças que outros músicos não conseguiriam tocar na primeira audição. A música era uma atividade de lazer então as pessoas se juntariam para tocar por diversão. Uma das atividades mais encantadoras era alguém criar um choro e todas as outras pessoas teriam que seguir na hora. Então havia este jogo de se criar modulações complexas que as pessoas não conseguiriam seguir na primeira audição. (Tradução nossa) ${ }^{163}$

A síntese dos estilos citados anteriormente como a bossa nova, o choro e o impressionismo francês se tornam uma amalgama em Aquarelle. A fusão de linhas estéticas se dá pela estruturação harmônica em que notas de tensão são acrescentadas a acordes dentro de uma estrutura tonal, diversas modulações e a rítmica que é tipicamente brasileira. $\mathrm{Na}$ parte $\mathrm{A}$ do Divertimento estas características se manifestam de maneira clara como visto a seguir nos compassos 84 a 91 da peça:

163 INTERVIEW WITH SÉRGIO ASSAD. Revista eletrônica guitarra. Madrid n.9, out. 2003. Disponível em: http://www.guitarramagazine.com/lssue42/interview_assad.asp. Acesso em 30 de janeiro 2004 


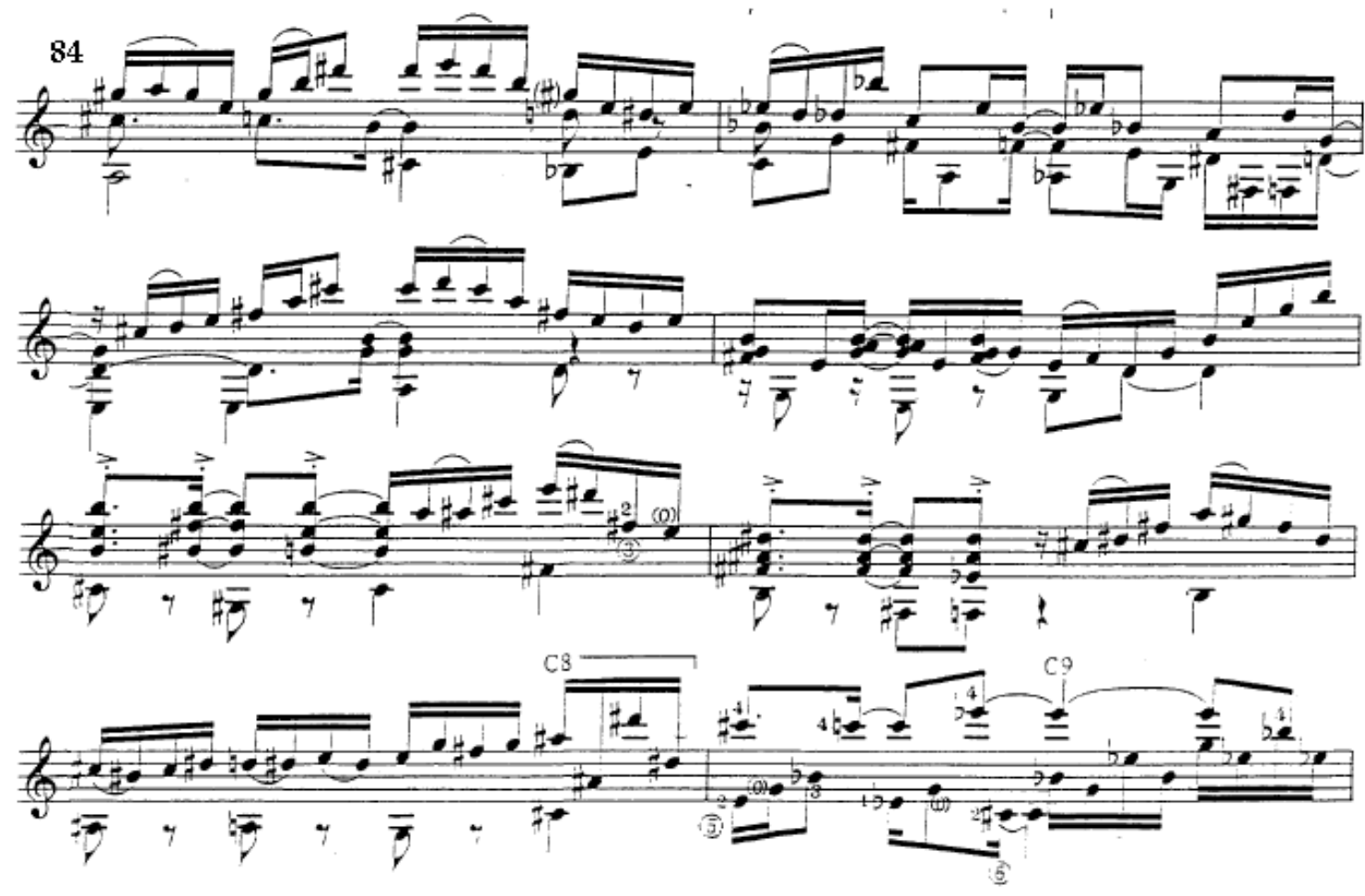

Divertimento, compassos 84 a 91

Durante o romantismo tardio, diversos compositores que procuravam maneiras de desvencilhar das relações tonais ao mesmo tempo em que ainda se valiam de estruturas simples auditivamente. Uma solução encontrada por estes compositores e mais tarde cristalizada por compositores impressionistas é o emprego de acordes de empréstimo modal e de demais estruturas advindas destas escalas. Um exemplo característico deste procedimento harmônico é detectado no terceiro movimento de Suíte Bergamasque de Claude Debussy para piano solo, Claire de Lune. Entre os compassos 27 a 37 o compositor adiciona diversos acordes de empréstimo modal à tonalidade de Ré bemol maior, explorando as diversas sonoridades geradas por este recurso. Exemplificaremos a seguir o procedimento com os quatro primeiros compassos da passagem (27 a 31): 


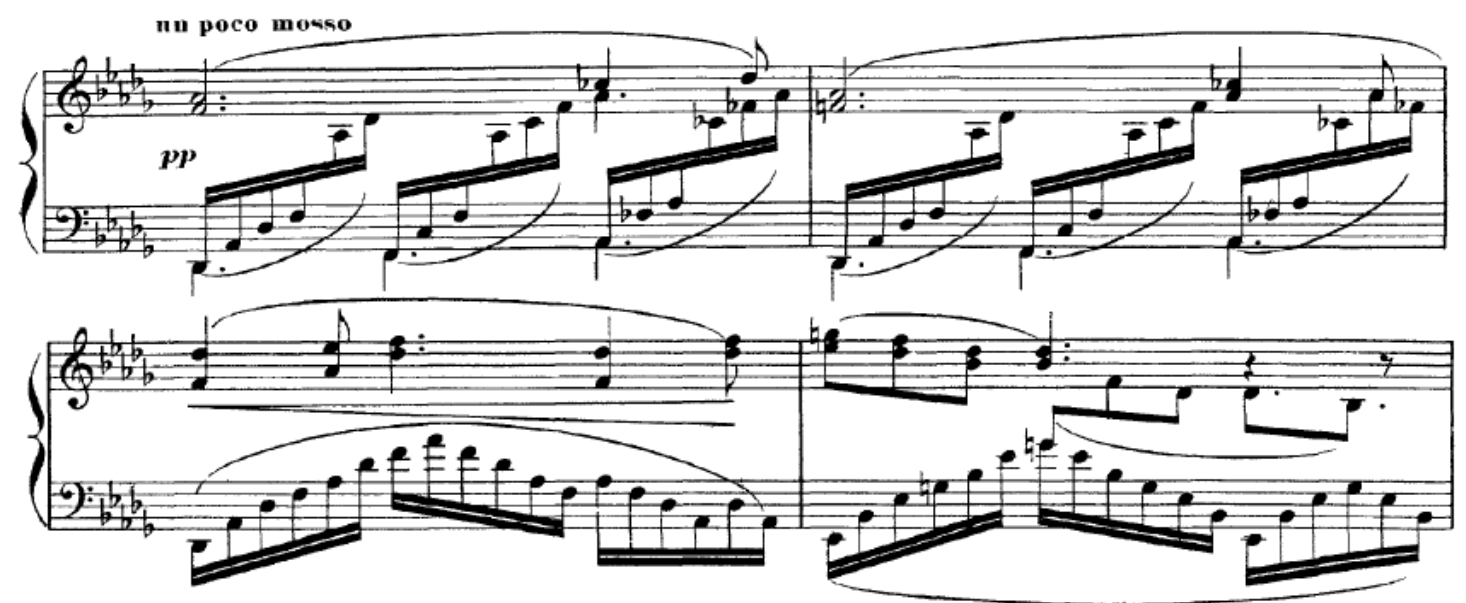

Claire de lune - Claude Debussy compassos 27 a 31

O movimento da música popular brasileira, mais associado com a escrita de música modal e que em diversos momentos remonta à utilização deste tipo de estruturação desta natureza por Assad foi o denominado "Clube da Esquina"; um grupo formado por compositores, instrumentistas e arranjadores vindos de Minas Gerais que tinham uma influência acentuada da música francesa e do Jazz.

Exemplificamos tal aplicação de estruturas modais em canções populares na canção Vera Cruz de autoria de Milton Nascimento (1942) ${ }^{164} \mathrm{e}$ Márcio Borges ${ }^{165}$. Nesta canção, de tonalidade Sol menor, encontramos no compasso 17 um acorde Bm7, emprestado do modo de Sol jônio (escala maior) e ao final da passagem encontramos diversos acordes acrescidos de notas de tensão cuja tônica é uma nota pedal, outra característica comum ao impressionismo francês demonstrada anteriormente.

\footnotetext{
${ }^{164}$ Compositor de MPB, considerado o principal expoente do Clube da Esquina.

${ }^{165}$ Letrista e Parceiro de Milton Nascimento em diversas composições de sucesso. É irmão de Lô Borges, outro expoente do Clube da Esquina.
} 

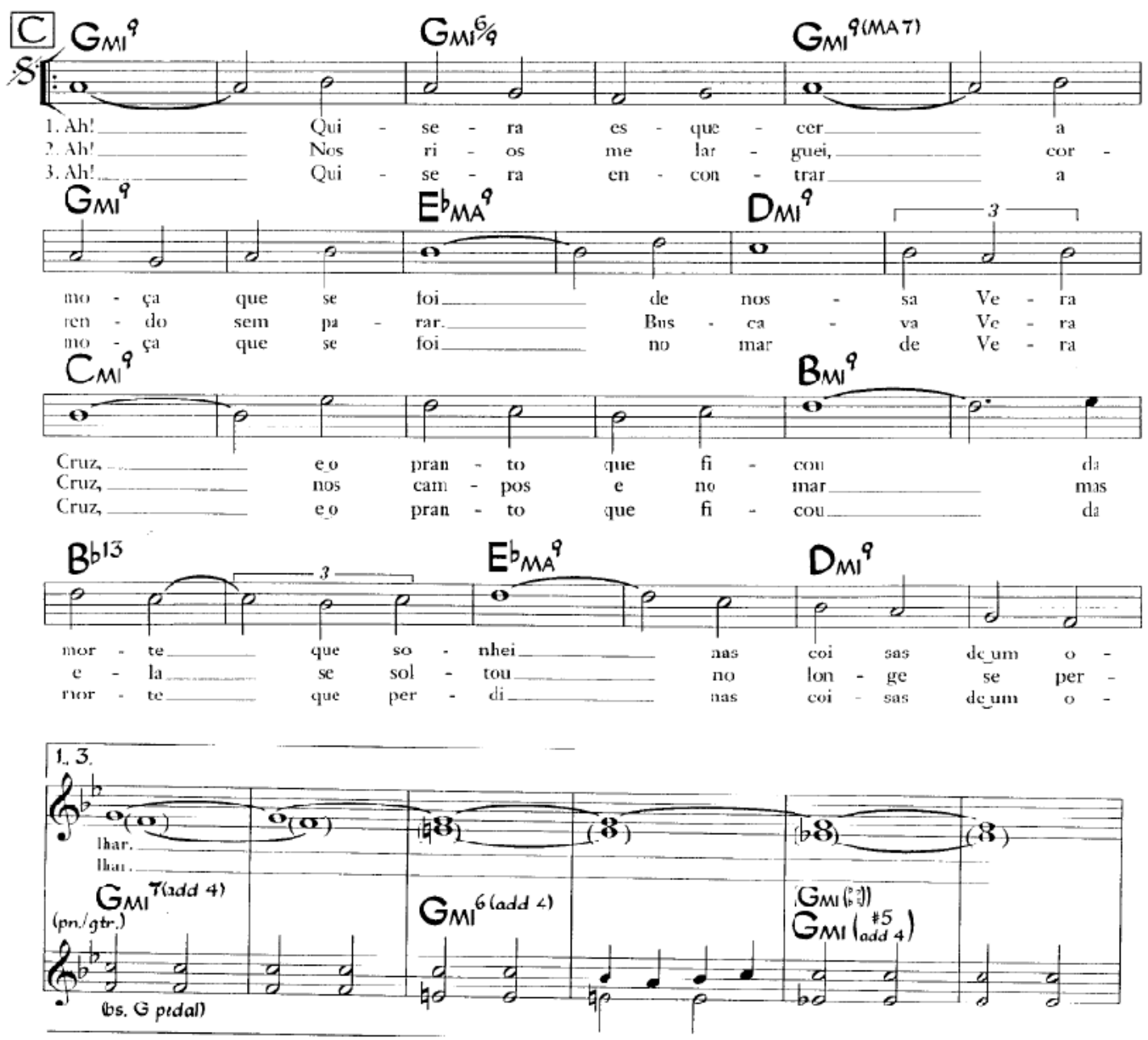

Vera Cruz - Milton Nascimento e Márcio Borges

O procedimento harmônico foi detectado anteriormente em Aquarelle. Em Valseana, como em diversas outras passagens do restante da obra, o emprego de acordes de empréstimo modal na tonalidade de ré maior é detectado nos compassos 6 e 7, produzindo sonoridades inusitadas dentro da estrutura harmônica adotada pelo compositor.
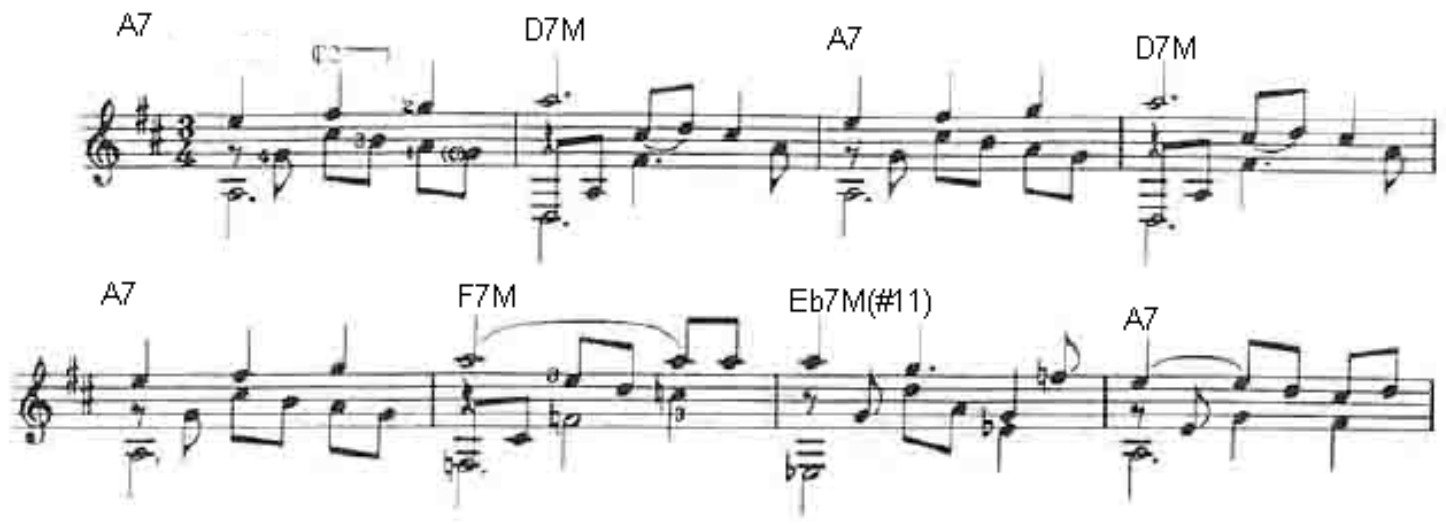
Em alguns momentos de Aquarelle, a elaboração de melodias modais é empregada para se alcançar a citação de gêneros populares brasileiros. Em Prelúdio e Toccatina, o gênero do baião é citado através da elaboração de melodias no modo de Ré mixolídio, porém dentro desta elaboração o modo é acrescido de outros procedimentos harmônicos que criam uma textura mais densa na composição. Tal concepção é comum à música erudita brasileira ao adotar o modalismo folclórico como matéria prima composicional segundo Ermelinda Paz (2003) ${ }^{166}$.

Diferentemente da música folclórica, em que os modos se mostram claros e nítidos na sua simplicidade, através de melodias, na música dita erudita, de uma maneira geral, eles se apresentam muitas vezes obscurecidos por melodias construídas através de técnicas composicionais complexas e sofisticadas.

Nos compassos 96 a 108 de Prelúdio e Toccatina, a citação do gênero segue as características descritas por Paz, visto que Assad elabora a citação do gênero acrescido de uma elaboração polifônica e de acordes de empréstimo modal.

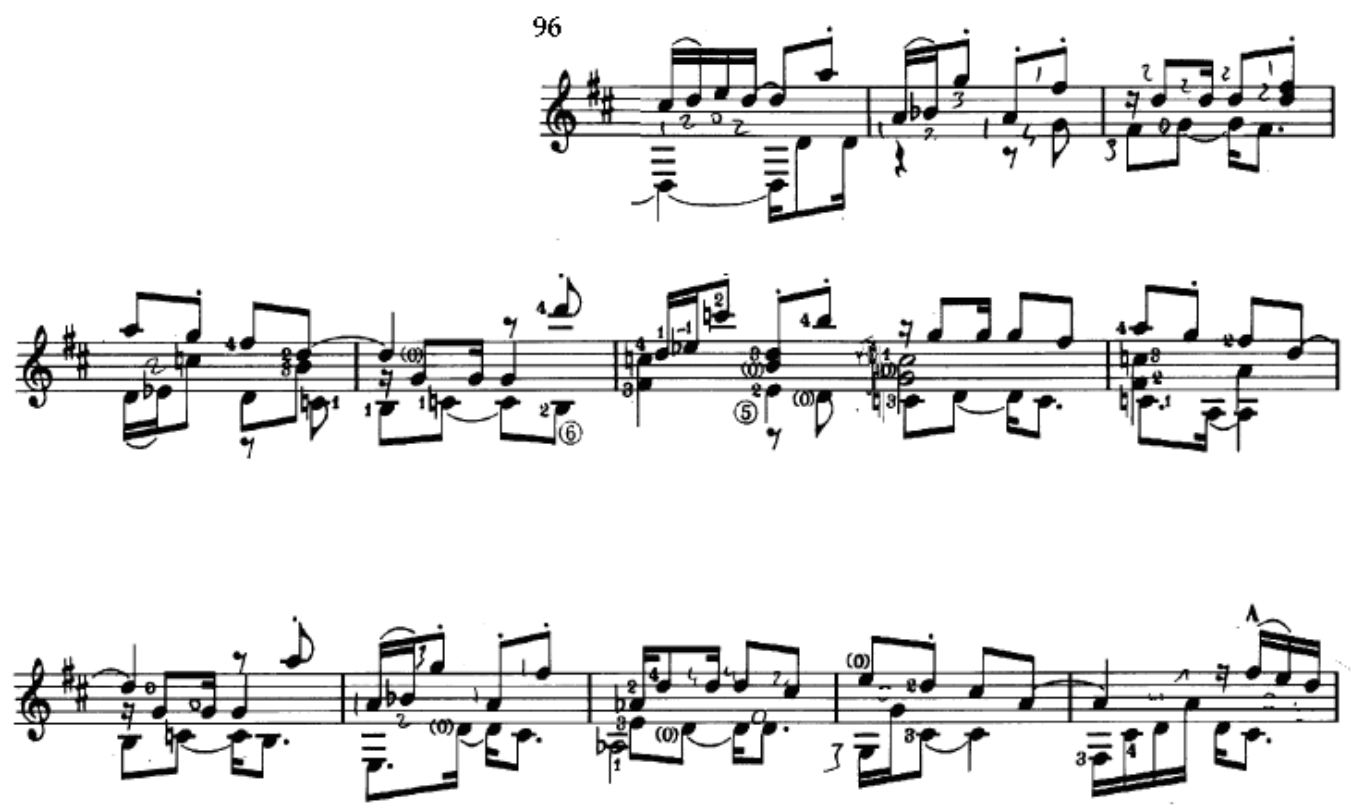

${ }^{166}$ PAZ, Ermelinda A. O Modalismo na Música Brasileira. Editora Musimed, Brasília, 2003, 229 p. 130. 
Durante os compassos 109 a 115 é elaborado um modo misto de mixolídio com uma quarta aumentada, que de acordo com Paz (2003) ${ }^{167}$ também é comum à música nordestina. Nos compassos seguintes (112 a 114) da passagem, são elaboradas novas estruturas de empréstimo modal que servem de ligação a cadência de Subdominante - Dominante que conclui a elaboração no compasso 115.

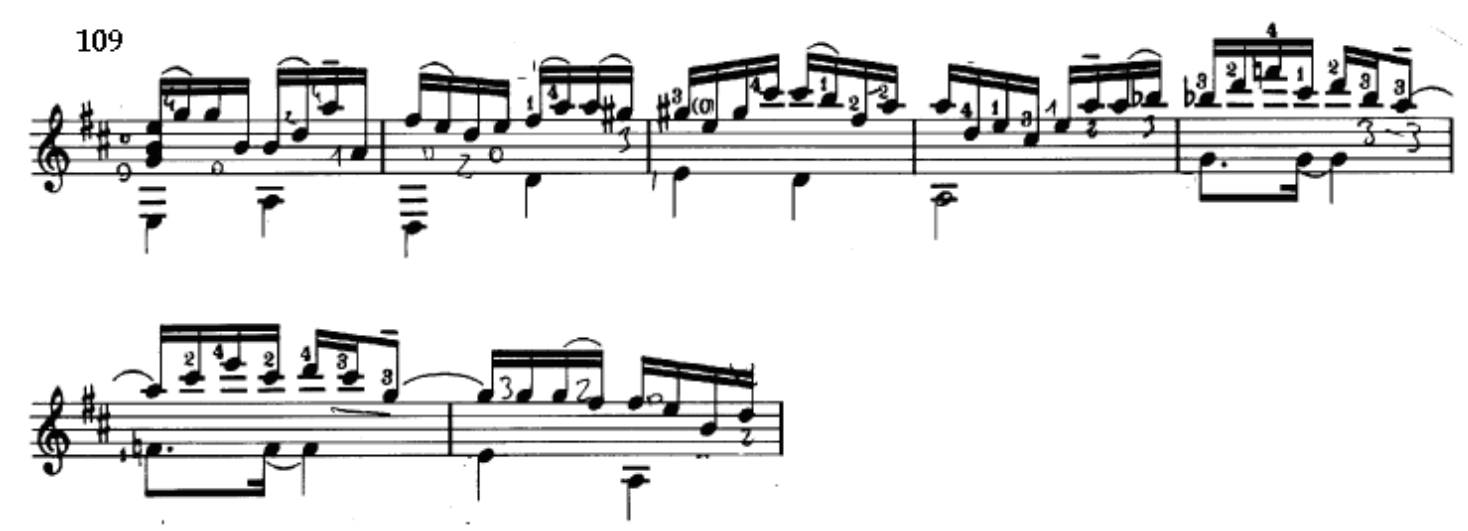

Prelúdio e Toccatina, compassos 109 a 115

Apesar de se manifestar em diferentes gêneros musicais, a estruturação harmônica presente em Aquarelle tem a sua origem no impressionismo francês e nos diversos gêneros populares que sofreram a sua influência.

Ao tomarmos consciência de que todos os recursos apontados neste item são encontrados na música de Debussy, de que segundo Vianna (2005) a linguagem harmônica de Debussy desempenha um importante papel na concepção harmônica de Assad e de que encontramos no último CD do Duo Assad $^{168}$ a presença de transcrições de três movimentos da Suíte Berbamasque $^{169}$ a única conclusão possível é de apontar Claude Debussy como a principal influência na linguagem harmônica de Sérgio Assad.

\footnotetext{
${ }^{167}$ In: O Modalismo na Música Brasileira (2003).

168 DUO ASSAD, Jardim abandonado, 2007, Nonesuch, B000UKW4ZO.

$169 \mathrm{O}$ autor deste trabalho se recorda de um concerto dos irmãos Assad em agosto de $2004 \mathrm{em}$ Uberlândia (MG) em que houve a inclusão de uma transcrição de Sérgio para a Suíte Bergamasque de Claude Debussy no programa, o que nos faz supor se tratar de um compositor importante no universo musical do objeto de estudo desta dissertação.
} 


\subsubsection{Estruturação}

Apesar do choque do jovem compositor com a estética vanguardista como visto no primeiro capítulo, ela não se encontra totalmente dissociada de sua música e se manifesta em diversos momentos em Aquarelle, especialmente em sua elaboração motívica. $O$ fenômeno encontra explicação no fato de que na estética pós-moderna as diversas correntes estéticas e seus conceitos musicais são aplicados como uma ferramenta a serviço do compositor.

O conteúdo determina quais técnicas serão aplicadas" (p. 59) De fato os artistas agora passam a considerar a vanguarda (na qual a técnica composicional é o conteúdo) mais como um dos conceitos musicais possíveis. (p.59) ${ }^{170}$

Como exposto anteriormente, Assad teve contato com a estética vanguardista e linhas composicionais tradicionais enquanto estudante do Conservatório Brasileiro de Música nos anos 70. Nesta instituição, foi aluno da compositora e pianista Esther Scliar (1926 - 1978) por dois anos, numa época em que era o serialismo era predominante no meio acadêmico, o que contrastava com a sua vivência em música popular e a sua predileção por compositores nacionalistas como Radamés Gnattali e Heitor Villa-Lobos.

Apesar deste conflito e da proximidade da obra e carreira de Assad com a música popular brasileira, detectamos em Aquarelle diversos elementos que refletem uma formação composicional sólida aliada a um domínio da técnica composicional.

O primeiro aspecto que nos chama a atenção é a maneira em que a obra é organizada seguindo padrões tradicionais de forma. Tal coesão formal é considerada imprescindível para a clareza do discurso musical para diversos compositores tais como Arnold Schoenberg (1954) ${ }^{171}$.

\footnotetext{
${ }^{170}$ BUCKNIX, Boudewijn. O Pequeno Pomo, ou a história da música do pós-modernismo. Ateliê editorial, Cotia, 1994.

${ }_{171}$ SCHOENBERG, Arnold. Princípios Fundamentais da Composição Musical. Edusp, São Paulo, 2001.
} 
Sem organização a música seria uma massa amorfa, tão ininteligível quanto um ensaio sem pontuação, ou tão desconexa quanto um diálogo que saltasse de um argumento a outro. (p.27)

Em Aquarelle, como exposto no primeiro item deste capítulo, o primeiro movimento, Divertimento, possui forma ternária adicionada a uma seção introdutória. No segundo movimento, Valseana, a primeira seção improvisada é acrescida de uma segunda seção em que a estruturação harmônica é mantida. No terceiro movimento, detectamos uma separação coerente de duas seções, sendo que a segunda seção diversos elementos da primeira são reelaborados. Além dos elementos formais apontados em cada movimento, a organização da obra em três movimentos de andamento Rápido - Lento - Rápido, associa à obra à tradição, dada a profusão de obras de três movimentos que são organizadas desta maneira.

Tal rigor em que Assad organiza o material a ser elaborado também é detectado na elaboração de motivos, que se tornam o fio condutor desta obra em diversos momentos. Em Divertimento, o desenvolvimento temático segue a tradição da elaboração sobre motivos curtos como adotada por Schoenberg ${ }^{172}$.

Schoenberg explica em uma carta como (...) ele começou a buscar conscientemente maneiras de criar formas musicais "em uma idéia unificadora" (...). Ele já havia atingido tal técnica em suas primeiras composições atonais e, as suas Peças para Piano opus 11, (1909), na qual como muitos analistas nos mostraram, que usa uma célula de três notas que forma temas e acordes de acompanhamento. ( $p$ 161) (Tradução Nossa)

Tal concepção pode ser verificada em Cinco Peças para Piano opus 23 n. 1, onde um motivo de três notas (constituído pelas notas mib, ré e fá), similar ao Motivo 1 encontrado em Divertimento é elaborado por Schoenberg.

\footnotetext{
${ }^{172}$ WHITTALL, Arnold. Musical Composition in the Twentieth Century. Oxford University Press, Oxford, 1999.
} 


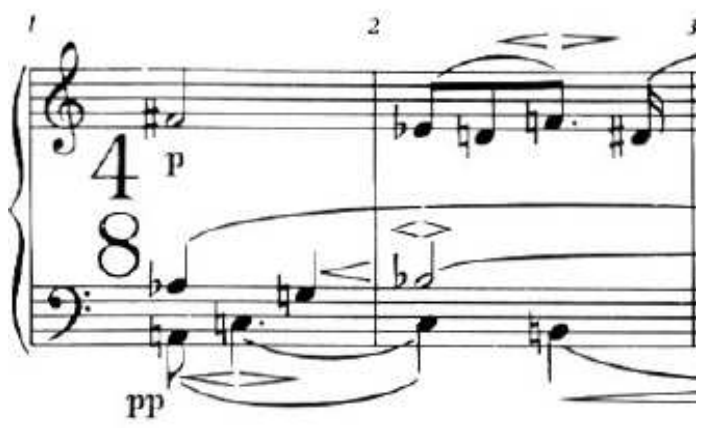

Arnold Schoenberg - Opus 23 n.1

Em Aquarelle, assim como na obra de Schoenberg, detectamos diversos recursos composicionais aplicados sobre fragmentos melódicos curtos. Nos primeiros compassos do Divertimento tais técnicas são explicitadas pela formação de uma escala de tons inteiros pela variação de fragmentos melódicos (compassos 3, 10 a 12e 14 a 20) e pela formação de acordes baseados na elaboração na elaboração motívica (compassos 6 e 13).
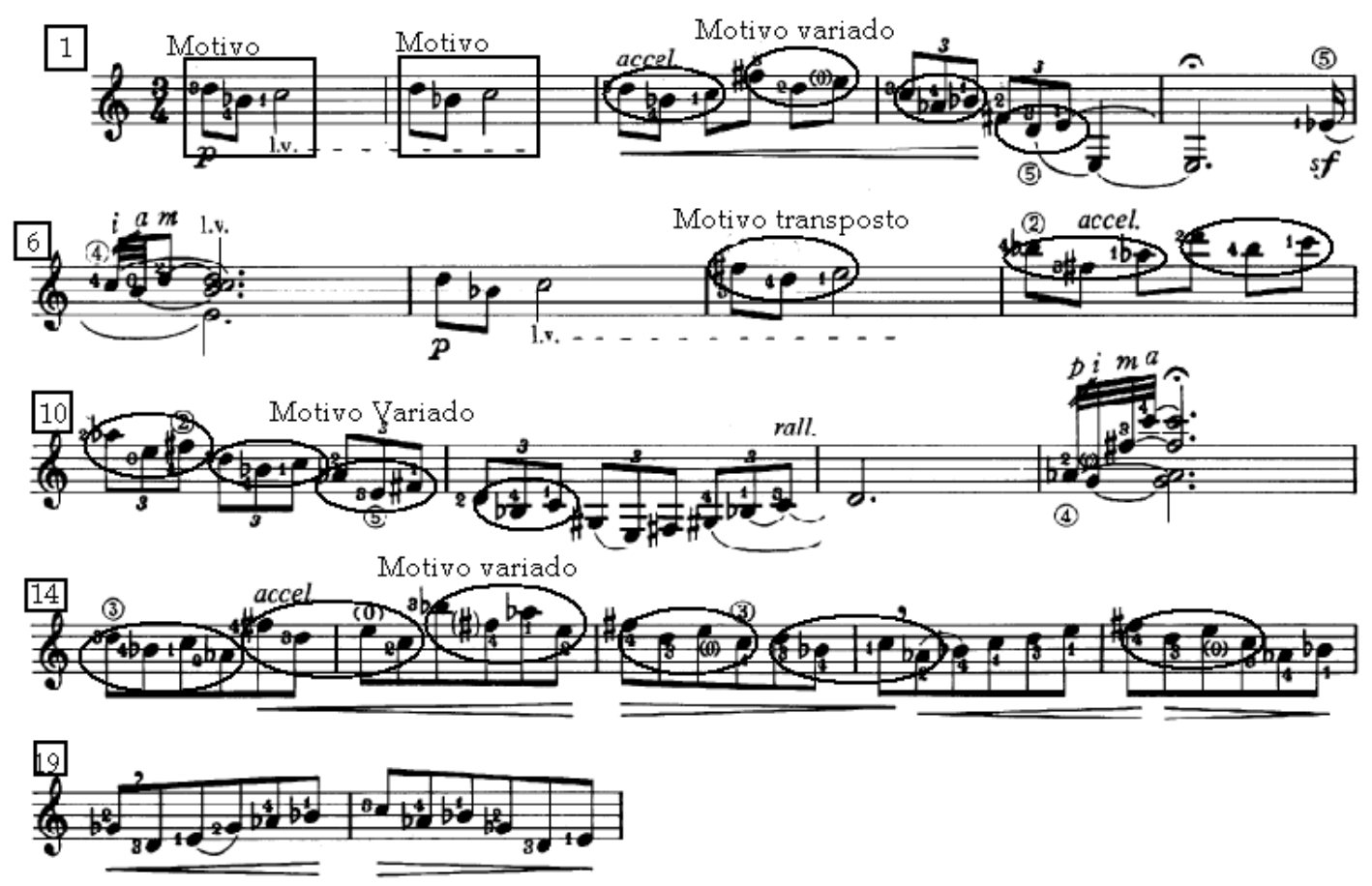

\section{Divertimento, compassos 1 a 20}

Durante a análise de Aquarelle, detectamos em Divertimento a elaboração de dois motivos que são reelaborados nos movimentos 
subseqüentes e os unificam. Como novamente exposto por Perle (1991) ${ }^{173}$, se trata de um procedimento comumente adotado para conferir unidade composicional a obras longas ou que possuam vários movimentos.

Acordes ou padrões melódicos derivados de operações de uma única célula intervalar são particularmente úteis na formulação de procedimentos unificadores, no contexto imediato ou na obra como um todo. (p. 16) (tradução nossa)

Um exemplo de procedimento composicional que retrata a complexidade da elaboração temática em Aquarelle é encontrado foi detectado em Divertimento e Prelúdio e Toccatina nestes movimentos, encontramos a elaboração simultânea de motivos obra. Em Perle (1991) ${ }^{174}$, tal procedimento é apontado como uma técnica comum em elaborações polifônicas de música atonal.

A associação vertical de elementos não adjacentes é normalmente o resultado da elaboração de dois ou mais (...) membros de uma série. Quando duas ou mais séries são empregadas, um procedimento polifônico primário, o problema de seleção é complicado pela ausência de um padrão preconcebido de referência harmônica. P 96 (tradução nossa)

A seguir será exemplificada a espécie de procedimento composicional com a passagem presente no compasso 65 do Divertimento. No compasso apontado, os dois motivos principais da obra são elaborados simultaneamente em uma textura polifônica.

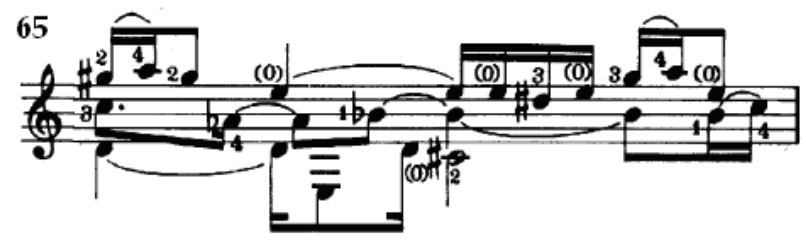

Divertimento,compasso 65

\footnotetext{
${ }^{173}$ PERLE, George. Serial composition and atonality, an introduction to the music of Schoenberg, Berg and Webern. University of California Press, Los angeles 1991.

${ }^{174}$ Idem, ibdem.
} 


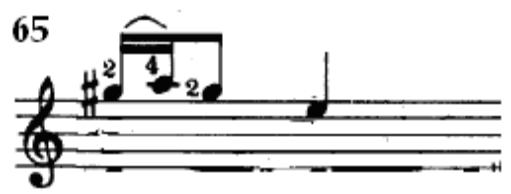

Motivo 2

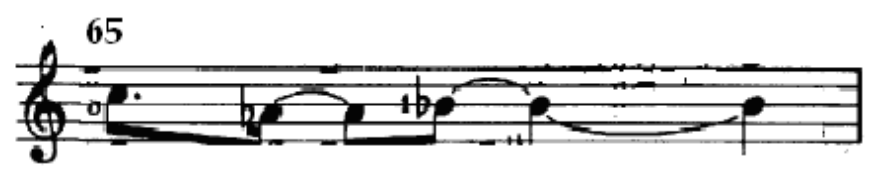

Motivo 1 variado

Dentre as características observadas na música de Claude Debussy e que encontra reflexos no estilo composicional de Sérgio Assad em Aquarelle, detectamos similaridades na estruturação de frases. Em ambos foram detectadas frases que são reapresentadas de forma a reafirmar a idéia musical elaborada. Nos primeiros seis compassos de Estampas nô "Pagodes" Debussy repetem-se as três primeiras frases elaboradas.
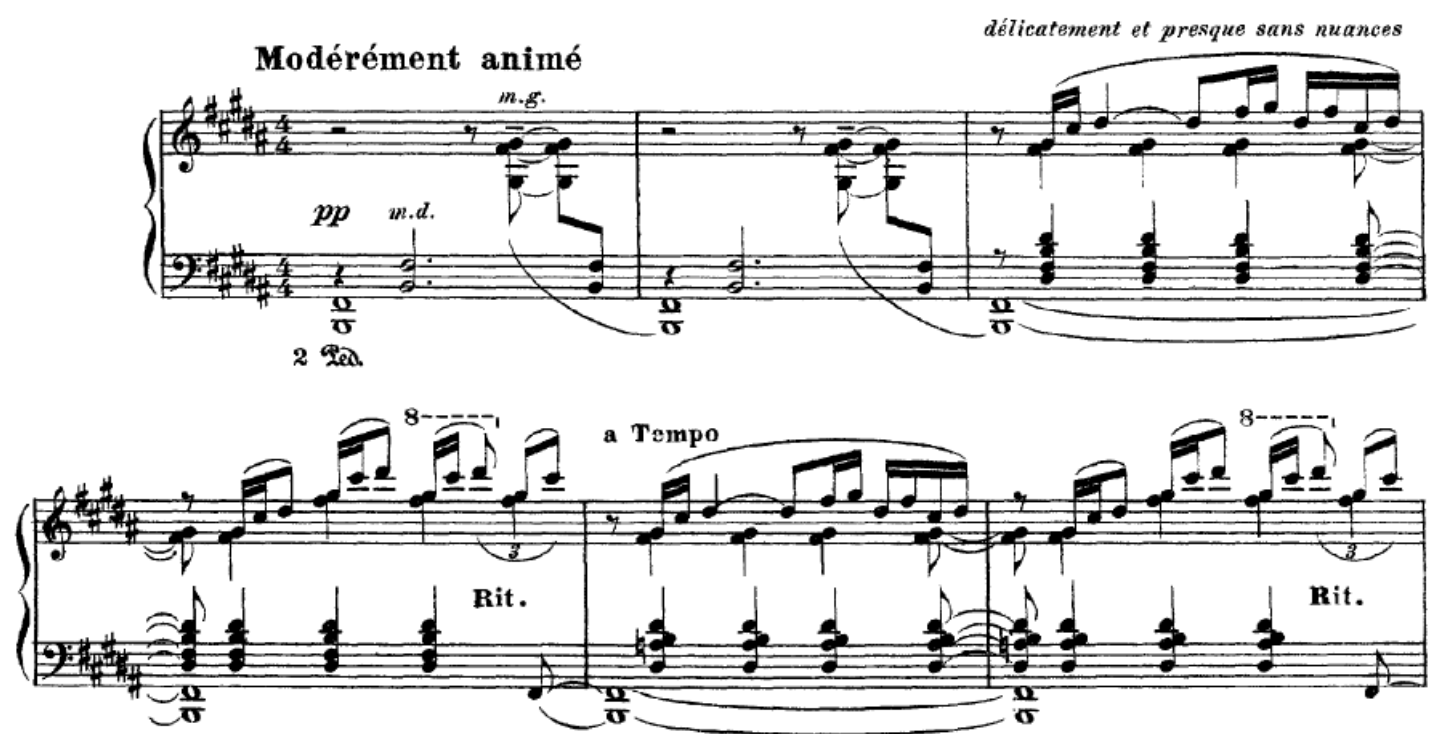

Pagodes,Claude Debussy compassos 1 a 6

Em Aquarelle encontramos diversas elaborações em que a influência Debussyana se faz presente dado à estruturação sobre duas frases. Exemplificaremos o recurso com a passagem presente entre os compassos 161 a 179 onde cada frase elaborada é repetida imediatamente após a sua apresentação. 

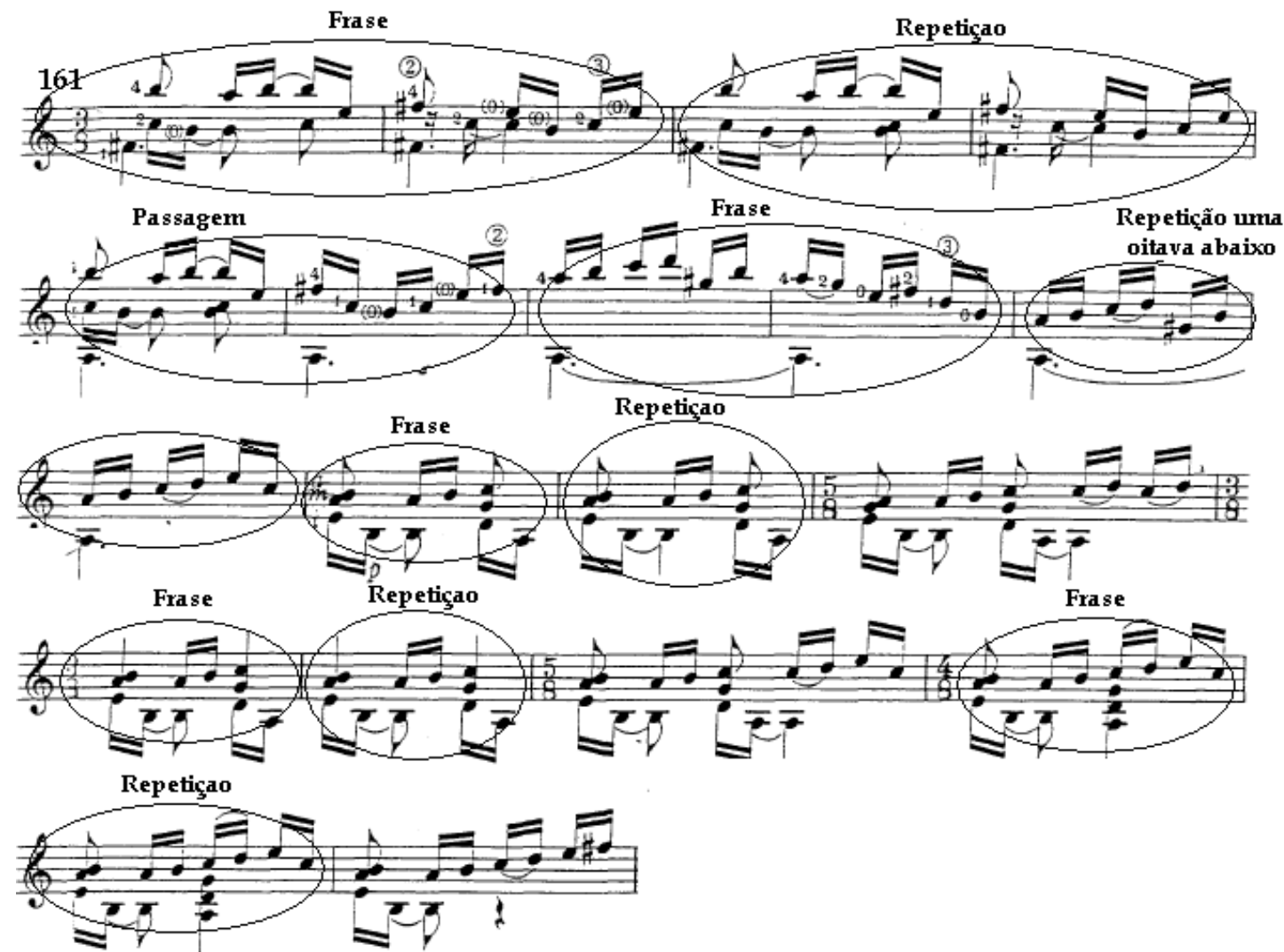

Divertimento, compassos 161 a 179

Neste item vimos como diversas escolas estéticas se fazem presente em Aquarelle. Essa variedade é fruto de uma era pós-moderna na música de concerto, fazendo com que as diversas manifestações musicais presentes na formação musical composicionais do autor se manifeste em sua linguagem composicional. 


\subsection{Os reflexos de Aquarelle na obra para violão solo de Sérgio}

Assad

Visto que Sérgio Assad possui uma produção constante para violão, decidimos investigar a relação entre Aquarelle e o restante de suas obras. A pesquisa foi instigada pelo fato de que, submetidas a uma análise prévia, tais peças demonstraram diversos aspectos recorrentes e que remetem à Aquarelle, o que nos levou se esta seria uma obra referencial da produção de Sérgio Assad.

Desde a estréia e o subseqüente sucesso de Aquarelle em 1988, Sérgio Assad tem produzido consistentemente tanto para violão quanto em diversas formações, nas quais o instrumento estivesse presente. Isso ocorreu em função de projetos e gravações em que estivesse envolvido, devido ao seu prestígio no meio violonístico e a reputação como compositor conquistada através de diversas obras foram comissionadas por músicos não violonistas ${ }^{175}$.

Neste trabalho, escolhemos para delimitar o escopo deste capítulo, a obra para violão solo de Assad justamente por tratar-se de um compositor com uma produção constante para o instrumento e sendo assim, com um número de obras que nos possibilitou um levantamento comparativo quanto a sua produção.

As observações contidas neste capítulo foram baseadas na leitura e na audição $^{176}$ de cada peça, focadas nos recursos instrumentais utilizados, na estruturação, na elaboração temática e no vocabulário harmônico. A partir destas observações, relacionamos os elementos comentados e os comparamos com Aquarelle, por acreditarmos tratar-se de uma obra cuja linguagem do compositor demonstra características que permeiam toda a sua obra e que se torna referência para seu trabalho subseqüente.

\footnotetext{
175 Dentre a produção do compositor houveram encomendas de obras como as feitas pelo clarinetista Gabrielle Mirabbasi, o Quarteto de Cordas da Cidade de São Paulo dentre diversas outras.

${ }^{176} \mathrm{Em}$ alguns casos de obras recentes do compositor, não pudemos realizar uma audição, o que fez com que algumas análises fossem baseadas apenas na leitura da peça abordada.
} 
A lista de suas obras até o ano de 2008 seguirá ordem cronológica ${ }^{177}$ e será acompanhada por alguns breves comentários relativos a recursos recorrentes utilizados pelo compositor.

\begin{tabular}{|c|c|c|c|}
\hline Obra & Ano & Ano de Publicação & Editora \\
\hline Aquarelle & 1988 & 1992 & Éditions Henry Lemoine \\
\hline Children's Corner & 1992 & & (c) Sérgio Assad Music \\
\hline Fantasia Carioca & 1994 & 2006 & Chanterelle Verlag \\
\hline Jobiniana $n^{\circ} 3$ & 1996 & 1998 & Éditions Henry Lemoine \\
\hline Sonata & 1999 & 2001 & Gendai Magazine \\
\hline $\begin{array}{l}\text { Three Greek } \\
\text { Letters }\end{array}$ & 2000 & 2005 & Éditions Henry Lemoine \\
\hline 3 Divertimentos & 2002 & 2002 & Guitar Solo Publications \\
\hline Eli's Portrait & 2004 & & (C) Sérgio Assad Music \\
\hline Valsa de Outono & 2008 & 2008 & $\begin{array}{l}\text { Les Éditions Doberman - } \\
\text { Ypan }\end{array}$ \\
\hline 6 Brevidades & 2008 & & (C) Sérgio Assad Music \\
\hline
\end{tabular}

\subsection{Estruturação das obras}

Neste item serão comentados elementos estruturais e estéticos das obras do compositor, bem como sua relação com Aquarelle.

\subsubsection{Fantasia carioca}

A Fantasia carioca (1994) de Assad foi concebida como obra para violão solo e posteriormente recebeu uma versão para duo de violões e orquestra de câmara. De acordo com o compositor, a versão posterior,

177 Excluiremos deste capítulo a Aquarelle, os diversos arranjos para violão solo e a coleção Children's Craddle. A primeira não está inclusa por se tratar do obviamente do objeto principal de estudo deste trabalho e conseqüentemente por contar com uma análise no capítulo anterior deste trabalho. A série de peças Children's Corner, (1992) formada pelos movimentos Berceuse, Dreams e Morning's Rag foi omitida por não obtermos uma cópia do manuscrito com o compositor. 
intitulada Fantasia Carioca Bis, possui uma textura mais elaborada dada a formação utilizada que a do original para violão solo, como veremos adiante.

\subsubsection{Sonata}

A obra Sonata (1999) foi concebida como uma encomenda do luthier japonês Masaru Kohno (1926 - 1998) e obteve sua publicação através da revista especializada Japonesa Gendai em 2001. A encomenda para obra surgiu como um pedido feito pelo violonista japonês Shin Ichi Fukuda (1955), que estreou a obra em 2000 como comenta o violonista japonês.

Eu Ihe pedi que a escrevesse a Sonata em 1997, e apesar da obra ter sido finalizada no mês de maio de 1999 em Chicago, várias discussões ocorreram em Tóquio três meses mais tarde até a versão final ser completa. Foram vários meses até a estréia e esta obra foi executada pela primeira vez no Festival Internacional de Cuba em Havana em maio de 2000. ${ }^{178}$ (tradução nossa)

Esta peça, composta de três movimentos: Allegro Moderato, Andante e Presto, é estruturada utilizando-se da forma tradicional de estruturação de uma sonata em seu primeiro movimento. Segundo Schöenberg (1967) a unidade da obra é mantida pelas relações motívicas entre os movimentos e tonalidade, o que se verifica da Sonata de Assad nos três movimentos.

O conceito de sonata implica em um ciclo de dois ou mais movimentos com diferentes características. A grande maioria das sonatas, quartetos de cordas, sinfonias e concertos, desde os tempos de Haydn utilizam este princípio estrutural. Contrastes de tonalidade, andamento, compasso, forma e caráter expressivo distinguem os vários movimentos entre si. A unidade é garantida pelo relacionamento das tonalidades empregadas (...) e pelas relações motívicas, que podem ser evidentes ou disfarçadas com raras sutilezas. ${ }^{179}$

Assim como os primeiros movimentos de sonatas, que denominados por Schoenberg em seu tratado de Allegro de Sonata, a sonata de Assad

\footnotetext{
${ }_{178}^{178}$ ASSAD, Sérgio. Sonata, Tókio, Gendai Magazine, 1999.

179 SCHOENBERG, Arnold. Princípios Fundamentais da Composição Musical, p. 241, Edusp, São Paulo, 2001.
} 
segue o modelo clássico consagrado em seu primeiro movimento. Neste modelo, a primeira parte possui dois temas, seguida por uma seção central modulatória, cujos temas são reelaborados, seguindo até a reexposição onde os temas são reapresentados e seguidos por uma coda.

A obra é iniciada com um fragmento melódico curto que serve de motivo para construção do primeiro tema desta sonata, que denominaremos "tema A". Podemos observar nesta preferência por células curtas um padrão recorrente que também é observado em Aquarelle e em obras subseqüentes do compositor.

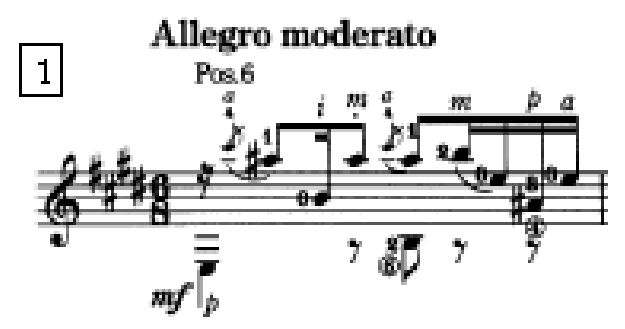

Sonata - Sérgio Assad (1\% Movimento)

O motivo é sempre reapresentado no começo de cada compasso de maneira persistente até a formação de frase mais longa no quarto compasso. Esta frase se torna um esboço do contorno melódico do segundo tema deste primeiro movimento no compasso 10 , se transformando no tema $B$ no compasso 20. Essa semelhança deve-se a utilização da mesma nota inicial e a mesma estruturação harmônica num contexto diverso, no qual a natureza predominantemente rítmica do primeiro tema é substituída pela sustentação em cantabile na ocorrência do tema B.

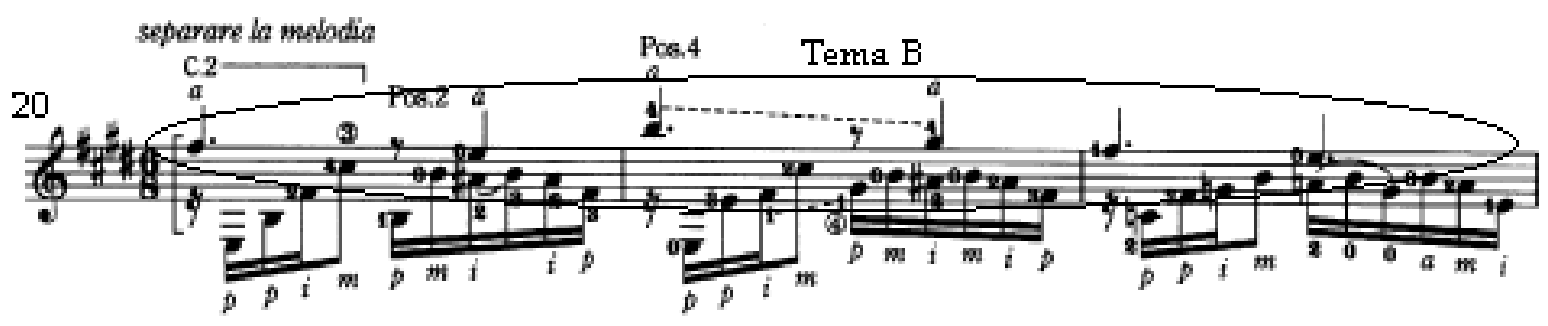

Sonata - Sérgio Assad (1\% Movimento) 
O compasso 72 marca o início do desenvolvimento, onde ambos os temas citados serão reelaborados gerando novos materiais explorados pelo compositor. O motivo inicial é citado no compasso 77 , sendo a base para o material temático presente nos compassos subseqüentes até o compasso 87.
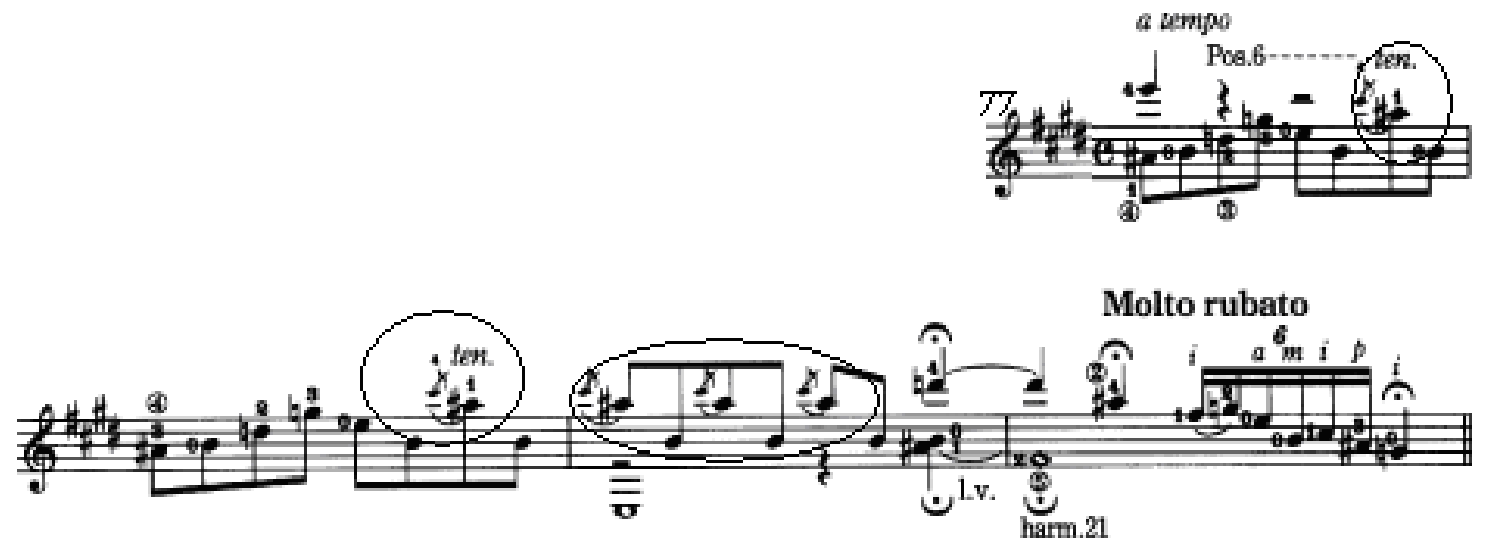

Sonata - Sérgio Assad (1ำ Movimento)

Após as diversas elaborações derivadas do tema $A$, detectamos a partir do compasso 88 a adoção do tema $\mathrm{B}$ como material motívico a ser explorado no desenvolvimento desta forma sonata. Este tema é citado novamente e em seguida são elaboradas diversas variações melódicas sobre este material que são concluídas no compasso 171 marcado por um retorno ao tema $B$, que se torna uma passagem até a coda desta obra.

No segundo movimento da obra, o compositor explora possibilidades de texturas independentes sob a ótica de uma escrita para duo de violões. Isto é explicitado pela adoção de dois sistemas utilizados na elaboração deste segundo movimento, onde a adoção deste procedimento torna mais clara a divisão das vozes.

O primeiro compasso deste segundo movimento desta obra é iniciado com uma citação do motivo presente no primeiro compasso do primeiro movimento, trazendo assim, unidade temática aos dois movimentos. Este motivo servirá de alicerce melódico para os outros temas deste movimento ao passar pelas diversas elaborações temáticas durante a extensão da peça. $\mathrm{A}$ adoção deste fragmento melódico como motivo principal, gerador dos temas seguintes de ambos os movimentos da Sonata explicita o rigor do compositor para com o desenvolvimento temático de uma obra como um todo, deixando 
claro o papel da elaboração motívica para Assad na construção de uma obra. Este rigor temático é observado nas demais obras do compositor, assim como em Aquarelle, que também possui dois motivos os quais são citados de maneira elaborada em seus três movimentos.

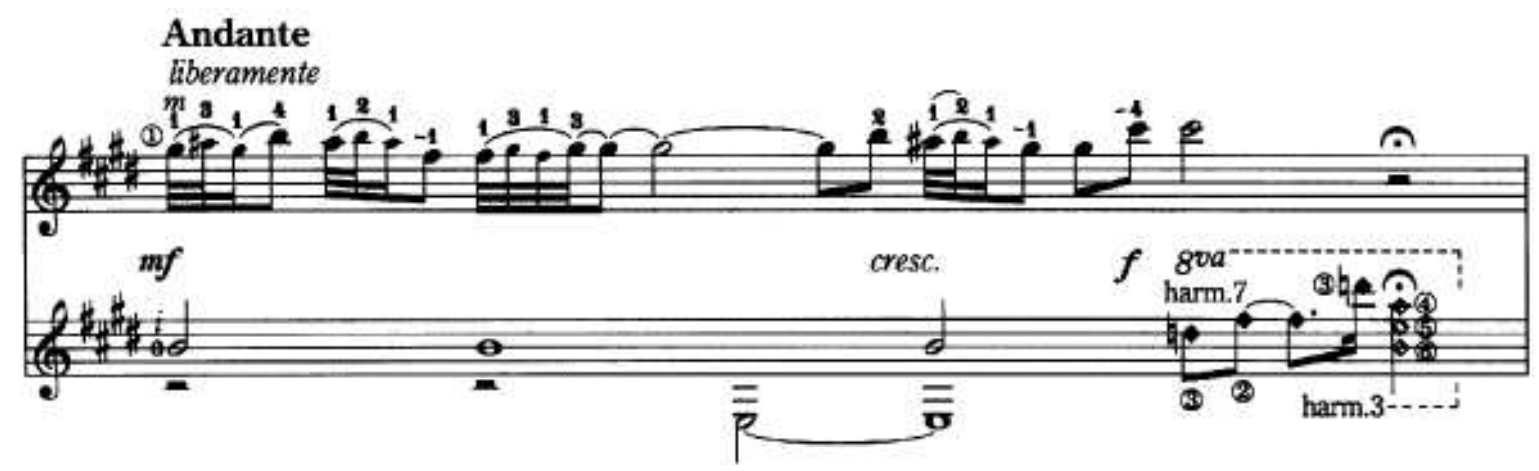

Sonata - Sérgio Assad (2 Movimento)

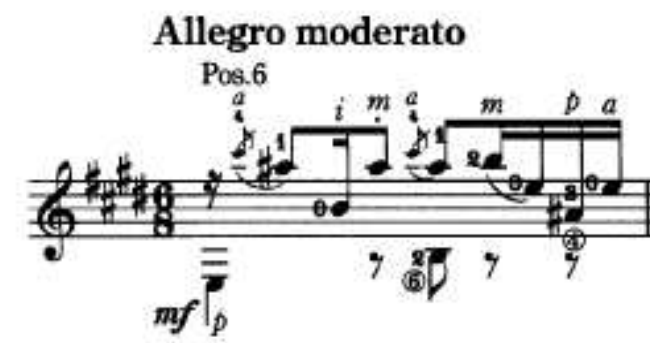

Sonata - Sérgio Assad (1\% Movimento)

O terceiro movimento desta obra possui similaridades com o terceiro movimento da Sonata (1990) do compositor cubano Leo Brouwer, La Toccata de Pasquini, comparação que se faz presente pelo caráter e andamento de ambas as obras, pela fórmula de compasso em 6/8 adotado e por tratar-se em ambos os casos do terceiro movimento de uma forma sonata. Nos exemplos a seguir, podemos perceber inclusive um fragmento melódico formado por duas colcheias que se destacam ritmicamente em ambas as peças trazendo novamente à tona uma comparação entre ambas e assim demonstrando a proximidade estética na obra de ambos os compositores.

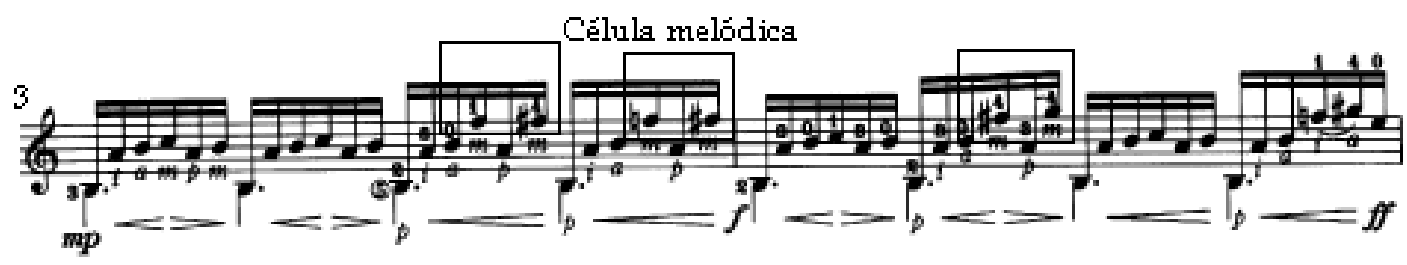

Sonata - Sérgio Assad (3 Movimento) 


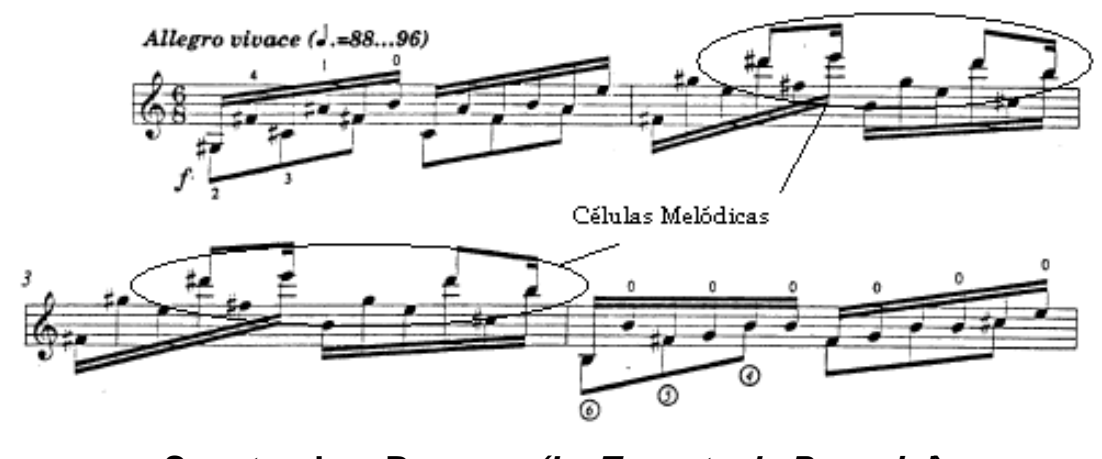

Sonata - Leo Brouwer (La Toccata de Pasquini)

A reprise dos temas anteriores da Sonata faz presente no compasso 40 deste terceiro movimento, trazendo assim unidade temática aos três movimentos desta obra e neste exemplo demonstrando a maneira com que Assad utiliza os diversos recursos de variação melódica e rítmica em uma determinada peça.

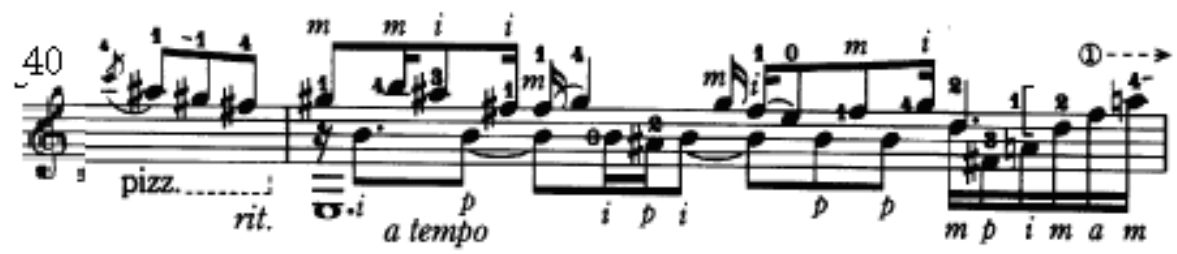

Sonata - Sérgio Assad (3 Movimento)

\subsubsection{Jobiniana $n^{\circ} 3$}

Inspirada pelo compositor popular Antônio Carlos Jobim (1927 - 1994), a série de peças intitulada Jobinianas, teve sua primeira composta para ${ }^{180}$ duo de violões em 1986, a Jobiniana no2 escrita para violão e flauta em 1988 e a Jobiniana $n^{\circ} 4$, composta para violão e a violoncelo. A peça comentada, Jobiniana $n^{\circ} 3$, foi escrita para violão solo em 1996, recebendo a sua estréia e primeira gravação pelo violonista japonês Shin Ichi Fukuda.

${ }^{180}$ Presente no CD Alma Brasileira, Nonesutch, B000005IYY (1988). 
Em vários momentos desta obra, mais precisamente nos compassos 37 , 40, 41, 44, 69 145, 146, 147 e 148, podemos constatar a influência da estética minimalista $^{181}$ ao depararmos com a escrita cujos diversos fragmentos melódicos são repetidos continuamente em alguns momentos com uma indicação de quantidade de repetições e em outras sem estas indicações. Estes fragmentos se encontram nesta obra em momentos em que o ritmo é livre e tornam-se um tipo de cadenza instrumental virtuosística.

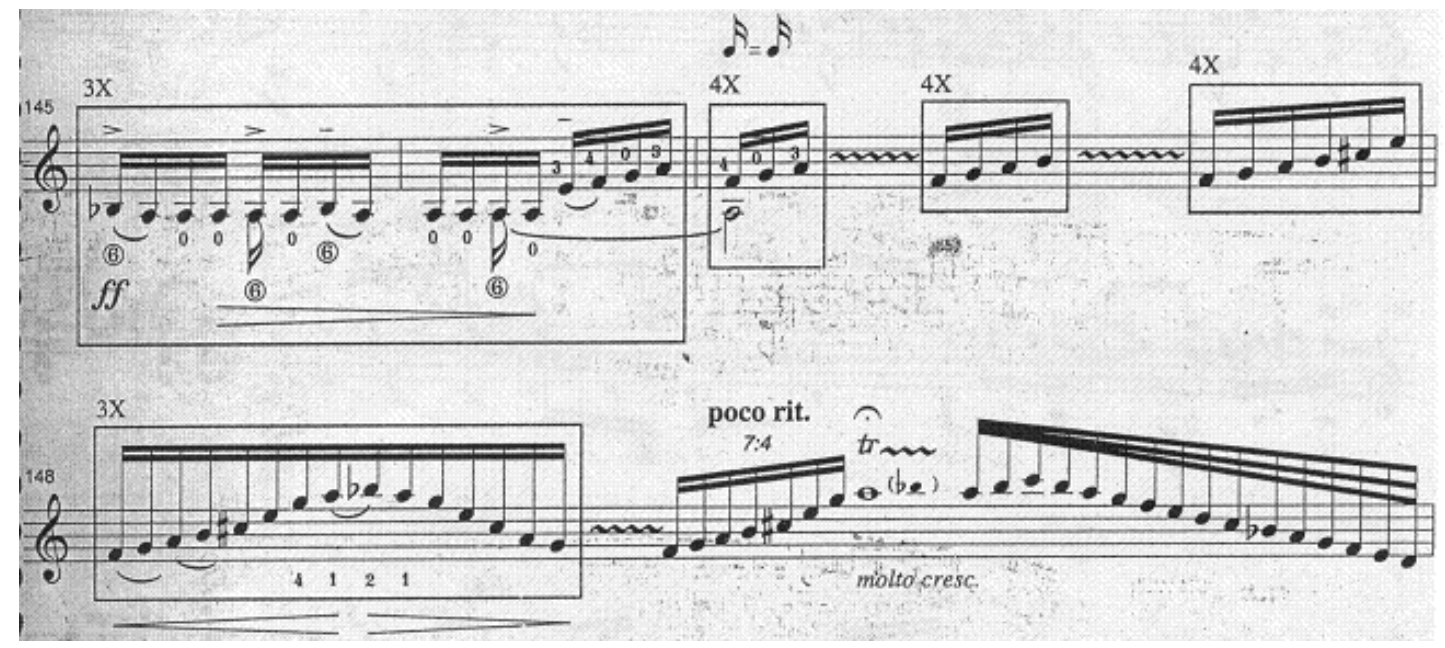

Jobiniana $n^{\circ} 3$

Um compositor violonista que adotou este tipo de procedimento em sua escrita para o instrumento foi o cubano Leo Brouwer (1939). Tomamos aqui como exemplo a sua obra Variações sobre um Tema de Django Reinhardt (1984), na qual um fragmento melódico é repetido em uma das variações da peça, criando um efeito hipnótico.

${ }^{181}$ De acordo com Griffits, p. 129 o minimaslismo foi um movimento musical, com raízes na música oriental cujas principais características seriam a repetição de elementos musicais e estaticidade. Apesar de tratar-se de um recurso não presente em Aquarelle, e que, portanto se manifesta posteriormente na produção de Assad, trata-se de uma passagem de maior interesse e que nos levou a comentar seu emprego nesta obra. 

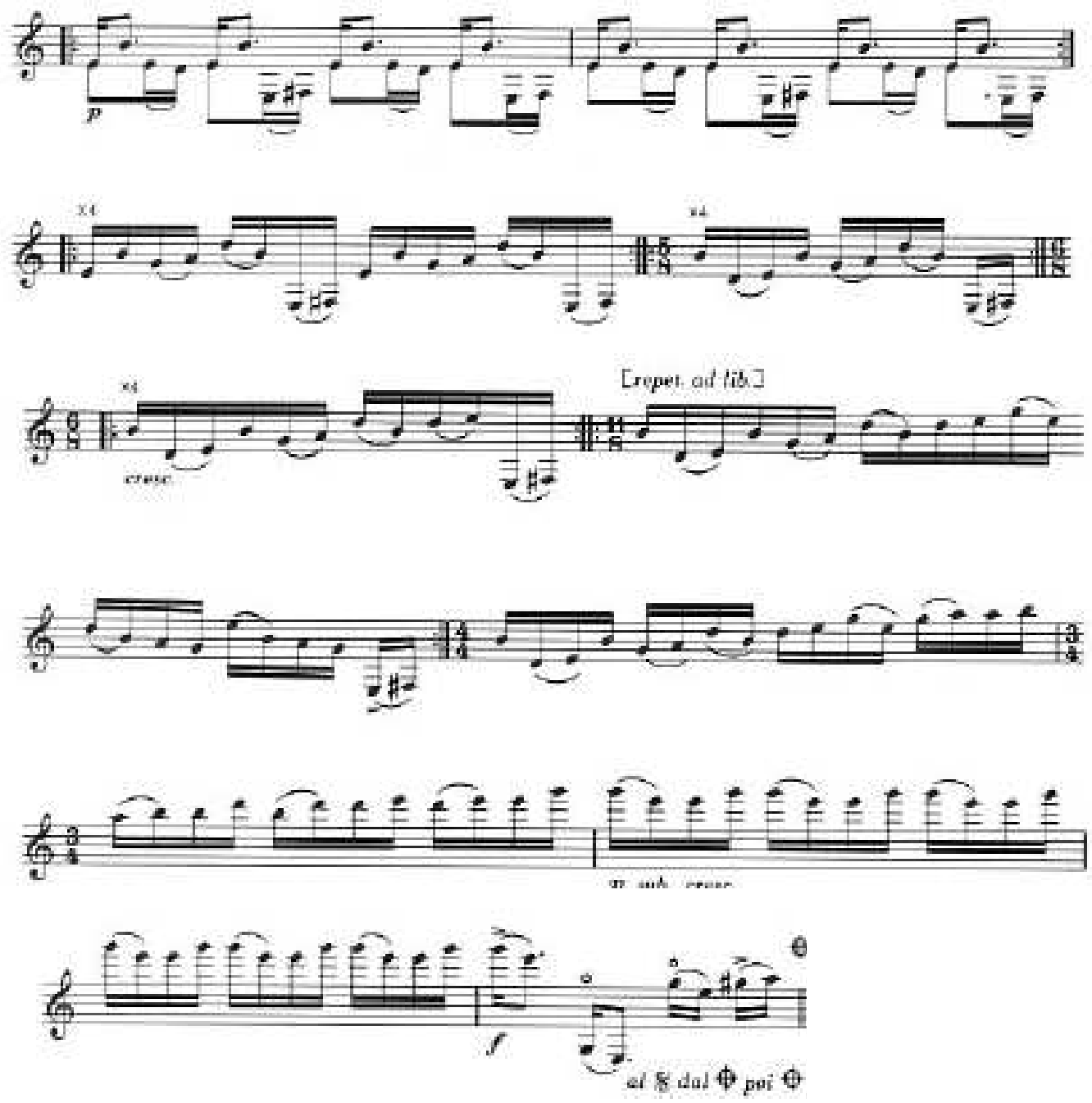

Variações sobre um tema de Django Reinhardt- Leo Brouwer

\subsubsection{Three greek letters}

Dedicada à violonista grega Antigoni Goni (1969), a coleção de peças Three Greek Letters é formada por três movimentos Pi, Sigma e Psi, e de acordo com Assad é uma homenagem à civilização grega e suas contribuições para com a cultura ocidental ${ }^{182}$.

Estas peças não foram elaboradas a partir de elementos da música grega, mas sim uma homenagem pessoal a essa importante cultura e civilização. Ao escrevê-las

\footnotetext{
182 In. VIANNA, Aliéksey. Vianna plays Assad. GSP Recordings, San Francisco. GSP1027 CD (2005).
} 
deliberadamente evitei as síncopes, para me manter distante de minhas tradicionais influências brasileiras.

Segundo o violonista Aliéksey Vianna (2005) ${ }^{183}$, a violonista grega havia feito um pedido ao compositor que não compusesse peças muito complexas tecnicamente, o que pode ser constatado neste trabalho.

No segundo movimento do conjunto, Sigma, assim como em diversas outras peças descritas neste trabalho como Valseana (Aquarelle) e Arpoador (Três Divertimentos), Assad emprega novamente o uso da técnica de melodia acompanhada em uma peça de andamento lento. O posicionamento deste andamento lento como segundo movimento destas obras, nos revela a predileção do compositor por este tipo de ordenamento em uma suíte ou coletânea de três peças.

Seguindo esta norma na construção de uma suíte de três movimentos, Sigma, tem como características marcantes a propulsão rítmica constante e um andamento veloz de semínima pontuada a 150 bpm em uma fórmula de compasso de $12 / 8$.

\subsubsection{Três Divertimentos}

A coletânea Três Divertimentos, datada de 2002 e editada pela Guitar Solo Publications (GSP) é composta de três peças curtas na forma A B A: Abaeté, dedicado a Aliéksey Vianna(1977), Arpoador, dedicado a Boris Gaquere (1977)e Parati dedicado à violonista Sophie Sandront (1976), Foram dedicadas a três violonistas mais jovens e que tiveram contato com ambos os irmãos Sérgio e Odair Assad ${ }^{184}$.

Parati, a terceira peça deste conjunto curiosamente é a única a possuir afinação normal, mas ao observarmos a seqüência das peças, podemos notar

\footnotetext{
${ }^{183}$ Vianna, Aliéksey. Entrevista conduzida por Thiago Oliveira em Belo Horizonte (MG) em 11/2005. Ver anexos página 242.

${ }^{184} \mathrm{Em}$ entrevista via email, Sophie Sandront, que era aluna de Sérgio Assad revelou que Parati foi criada dada a necessidade de uma peça extra para a prova do Conservatório de Bruxelas, onde era aluna do compositor. A violonista pediu, como uma brincadeira, que Assad escrevesse uma peça para a prova e ele a compôs de fato.
} 
que a afinação da sexta corda segue um padrão ascendente, visto que no primeiro movimento, Abaeté a sexta corda se encontra afinada em ré, no segundo, Arpoador, se encontra em mi bemol e no terceiro movimento Parati em mi.

\subsubsection{Eli’s Portrait}

A obra Eli's Portrait (2004), dedicada ao fundador da sociedade violonística de Toronto Eli Kassner ${ }^{185}$ foi uma encomenda em virtude da comemoração de seu aniversário de oitenta anos.

A obra é divida em duas seções distintas, a primeira parte, que denominaremos Parte $\mathrm{A}$, lenta e introspectiva, que abrange os compassos 1 a 47 , e a segunda que denominaremos parte $B$, que abrange os compassos 48 a 82 de andamento rápido e rítmica sincopada, o primeiro tempo é então retomado no compasso 83 até a conclusão da obra no compasso 128. 0 compasso 70 marca uma mudança na estruturação harmônica e mudança no material temático abordado e passando a contar com diversas modulações modais. Podemos considerar esta mudança como uma subseção da parte $\mathrm{B} e$ é mantida até o fim da Parte B da obra presente no compasso 82.

\subsubsection{Valsa de Outono}

A Valsa de Outono foi comissionada como peça de confronto para o concurso internacional promovido pela Guitar Foundation of America em 2008 e foi dedicada ao arquivista de Sérgio Assad, Byron Fogo. Fomos agraciados

\footnotetext{
${ }^{185}$ A sociedade violonística de Toronto ganhou uma enorme importância para a história do instrumento por ter sido sede de um grande festival internacional dedicado ao violão. Tal evento revelou diversos talentos que vieram se tornar famosos no meio musical através do seu concurso foi palco para estréia de importantes obras do repertório e diversos dos recitais do festival se tornaram históricos. A obra de Assad presente neste item foi estreada em 2004 pelo violonista David Russell, um dos vencedores da competição de Toronto.
} 
com a gentileza do compositor em nos ceder uma cópia eletrônica da obra que posteriormente seria editada pela editora canadense Doberman - Yppan ${ }^{186}$.

A peça se dá a partir de uma valsa que possui uma introdução livre (compassos 1 a 5): Parte A, de caráter lírico e linguagem harmônica modal, similar a de Valseana e outras obras com o mesmo caráter do compositor, na tonalidade de fá sustenido maior (compassos 6 a 22) que é então reapresentada com algumas variações na melodia. A tonalidade é alterada na parte $B$ (compassos 39 a 74) para lá maior e o caráter se torna vivo e energético, havendo mudança para a fórmula de compasso $6 / 8$, a parte $A$ reaparece no compasso 76 e é seguida por uma curta coda (compassos 90 a 96).

\subsubsection{Seis Brevidades}

O conjunto Seis Brevidades (2008), de acordo com o próprio compositor via correio eletrônico é constituído por seis peças curtas, despretensiosas e que foram fruto de uma série de momentos de improvisação ao violão registrados posteriormente em partitura. Apesar da simplicidade desta coleção citada, o método composicional baseado em improvisação utilizado nesta obra pôde nos revelar diversos recursos instrumentais comuns ao vocabulário instrumental de Assad, assim como seu vocabulário harmônico e temático dentro de uma improvisação. Após a confecção, este conjunto de peças foi dedicado ao violonista Odair Assad, irmão e companheiro de duo.

A primeira peça desta coleção, Chuva possui um caráter lento e introspectivo, realçado pela estruturação harmônica predominantemente baseada no modo de fá lídio.

O segundo movimento desta coleção, Tarde, apresenta um andamento mais acelerado em compasso ternário e maior complexidade tanto quanto a estruturação quanto a escrita instrumental.

${ }^{186}$ ASSAD, Sérgio. Valsa de Outono. Quebec, Editora Doberman - Ypan, DO 654, (2008). 
A terceira brevidade, Feliz, apresenta tonalidade de ré maior, compasso 6/8 e apesar de não possuir indicação de andamento pelo compositor a tonalidade baseada em escala maior e o título que sugere leveza musical, nos sugerem um andamento em allegro. Estruturalmente, esta miniatura apresenta nos primeiros compassos, o que podemos denominar de parte "A" até o compasso 16, seguida de uma parte "B" onde os temas presentes na primeira parte são variados harmonicamente havendo a reprise da parte inicial no compasso 65 até o fim da peça.

Ginga, a quarta brevidade possui uma estruturação em forma "A B A" em que a rítmica sincopada tipicamente brasileira da parte "A" é contrastada pela alternância nas fórmulas de compassos da parte $\mathrm{B}$.

O compasso final de Cantiga, a quinta brevidade, apresenta duas opções para o fim da peça, uma com um acorde de sétima dominante (A7) e a indicação de Attaca para o próximo movimento, Saltitante, que se encontra na tonalidade de ré maior e a outra opção consiste de uma nota ré em três oitavas como acorde final da peça. Estas opções de execução sugerem que Assad planejou que a coleção Seis Brevidades, exatamente por se tratar de obras despretensiosas e surgidas de improvisação, podia ser executada em sua totalidade ou separadamente de acordo com o executante.

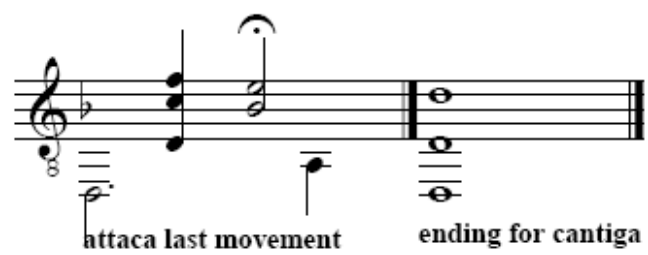

Cantiga - Sérgio Assad

A última peça deste conjunto, Saltitante, se caracteriza por se tratar de uma peça veloz e que apresenta diversos trechos de execução violonística ágil e idiomática ao instrumento.

3.3 Exemplos da influência da música popular urbana na obra para violão solo de Sérgio Assad 
Uma das mais proeminentes características da música de Sérgio Assad - encontrada pela primeira vez na obra pra violão solo em Aquarelle - o emprego de ritmos tipicamente brasileiros, influenciados pela música popular urbana.

Tal característica, presente igualmente na produção posterior do compositor, manifesta-se entre os compassos 98 e 116 da Fantasia Carioca (1994). Nesta passagem, grupos de semicolcheias regulares são executados de modo que certos elementos do acompanhamento, tais como acordes e notas executadas na voz superior sejam incorporados aos tempos fracos do compasso e notas mais graves, as quais normalmente são associadas ao acompanhamento em uma textura, em tempos fortes, causando assim um efeito rítmico de síncope, que produz uma rítmica que remete a ritmos da música popular brasileira. Devemos ressaltar a passagem citada, novamente apresenta o motivo principal da obra de modo variado melódica e ritmicamente, originando um novo tema que se trata de uma citação do movimento Samba, da Suíte Brasileira para dois violões (1986).

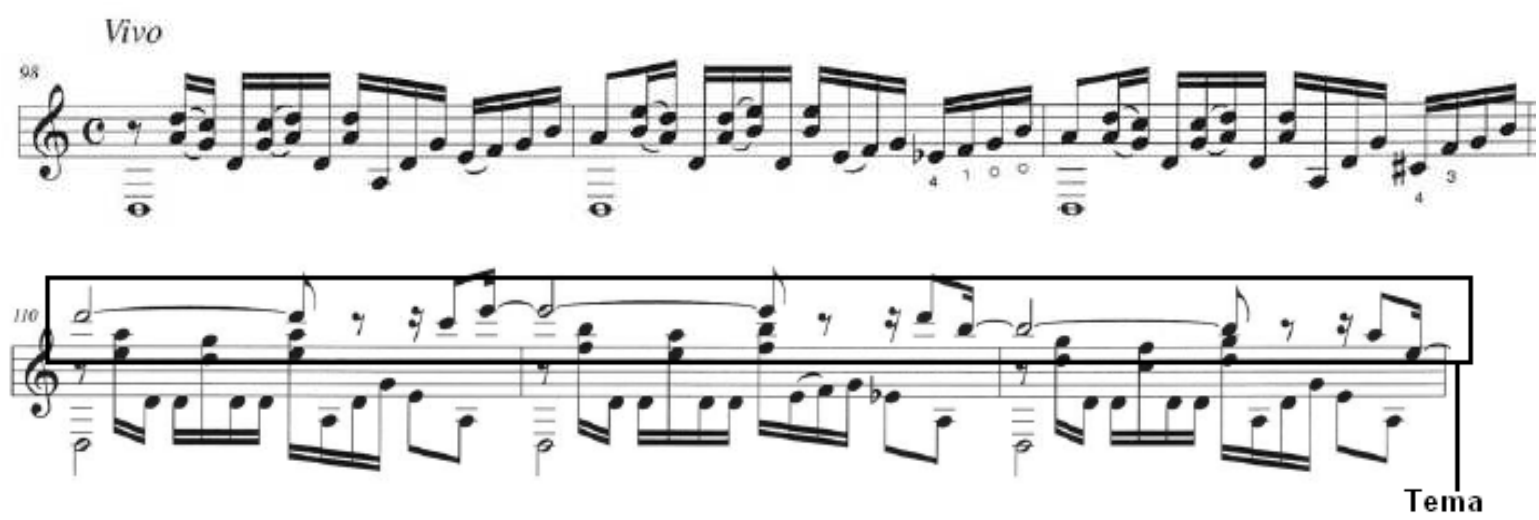

Fantasia Carioca - Sérgio Assad

Este mesmo recurso é novamente explorado na obra Jobiniana 3 (1996) nas passagens compreendidas entre os compassos 95 a 144 e a retomada como coda entre os compassos 151 e 175. Nestes compassos citados são elaborados a partir de um recurso recorrente na escrita para violão de Assad, o uso da técnica de melodia acompanhada, em que a voz superior é escrita em figuras rítmicas sincopadas e em staccato. Acompanhando estas melodias é encontrada uma segunda voz em acompanhamento cujo ritmo preenche as pausas existentes na voz superior criadas pela rítmica 
empregada. O efeito obtido causa a impressão ao ouvinte da presença de dois instrumentistas executando o trecho citado, gerando um resultado musical remanescente a vários gêneros da música brasileira, dada a complexidade rítmica citada. Este tipo de elaboração instrumental nos leva a crer que se trata de uma adaptação da sua experiência como arranjador e concertista em duo de violão para violão solo numa emulação da textura obtida por este tipo de formação.

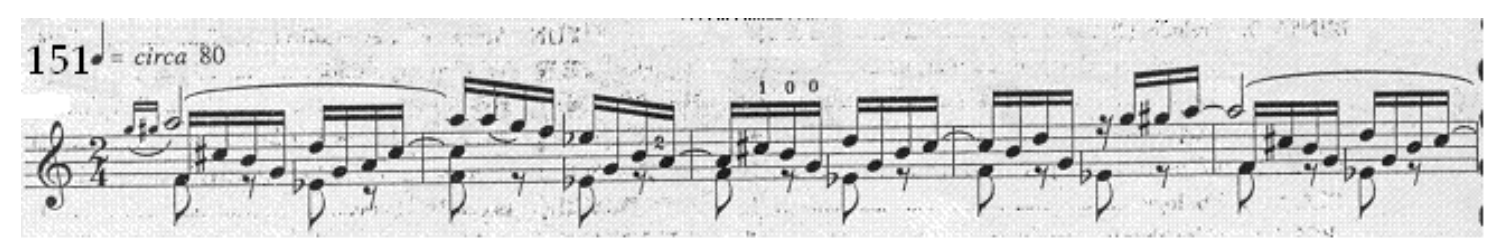

\section{Jobiniana no 3 - Sérgio Assad}

O exemplo citado no parágrafo anterior advém de um recurso explorado em Aquarelle o qual serviu de modelo para as elaborações posteriores do compositor. Exemplificaremos tal prática com a passagem contida entre os compassos 38 a 41 onde o procedimento é aplicado.

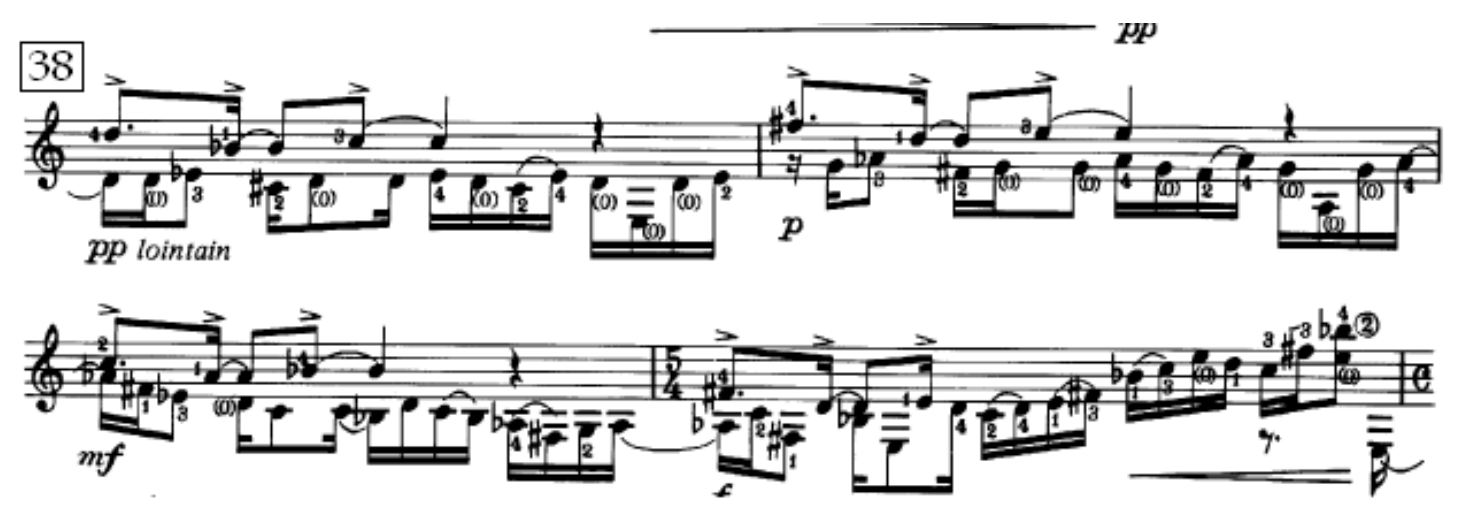

Aquarelle - Sérgio Assad compassos 38 a 41

Outro exemplo desta prática encontra-se no compasso 54 da peça Eli's Portrait (2004) no qual detectamos um que é variado melodicamente pela maioria da segunda parte da obra. Podemos perceber na gravação da peça disponível via internet no site "myspace" ${ }^{187}$ do violonista mineiro Guilherme Vincens (1977), cujo tema citado da Parte B da obra, o violonista acentua as

187 VINCENS, Guilherme. Myspace do violonista Guilherme Vincens. Disponível em WWW.myspace.com/guilhermevincens. Acesso em 01/03/2009. 
notas agudas sincopadas melodia sincopada e toca de maneira mais leve e em staccato a penúltima nota do tema desta seção, remetendo assim à rítmica típica da música Brasileira.

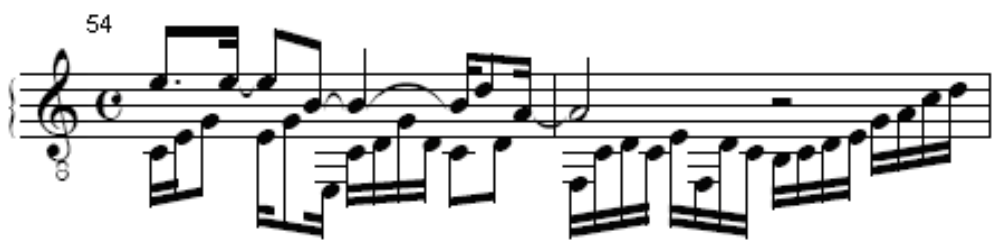

Eli's Portrait - Sérgio Assad

Em diversos momentos de Aquarelle são encontradas fórmulas de compasso composto em rítmica sincopada, como nos compassos 45 a 49 do Divertimento onde é empregado o compasso de sete por oito.

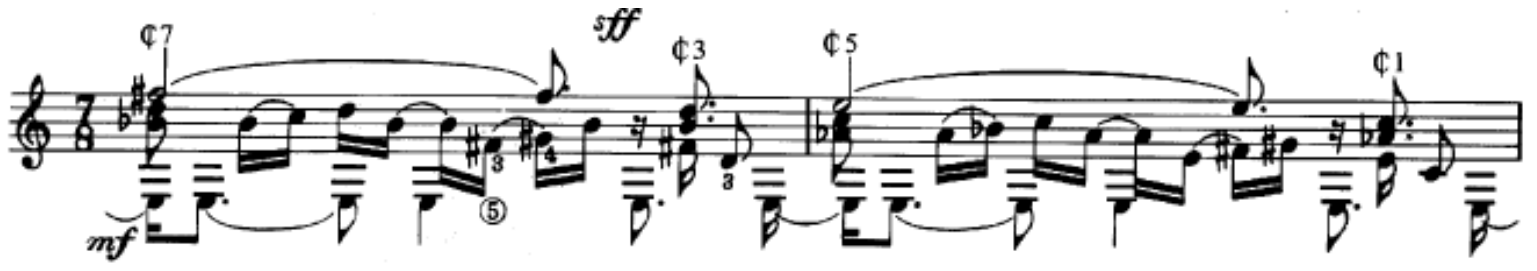

Aquarelle - Sérgio Assad compassos 45 a 46

Este tipo de elaboração rítmica é encontrada igualmente na seção B da obra Valsa de Outono (2008), em que o compasso de seis por oito é utilizado em grupos de dois compassos formando acentuações sincopadas. $\mathrm{Na}$ passagem citada são alternados acordes acentuados, no primeiro acorde de cada grupo a acentuação se dá em grupos de três colcheias enquanto no segundo grupo a acentuação é formada em cada grupo de duas colcheias, causando assim um efeito rítmico característico.

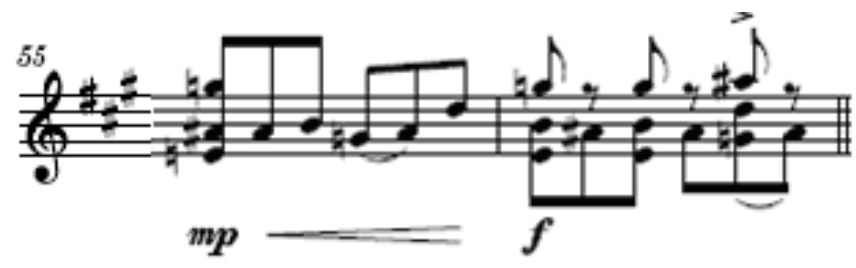

Valsa de Outono - Sérgio Assad

$\mathrm{Na}$ peça Ginga, Assad aborda pela primeira vez na coleção Seis Brevidades a rítmica tipicamente brasileira, tomando como fonte de inspiração 
gêneros como o samba e o choro. Neste contexto, a expressão "Ginga" utilizada para intitular a peça, refere às inflexões rítmicas da música popular brasileira, o que sugere que o compositor tenha como intenção interpretativa para com a execução desta miniatura.

Outra característica comum associada aos músicos populares e que se encontra no vocabulário musical de Assad - o da improvisação - foi detectada na composição do segundo movimento da Aquarelle, Valseana, dados os diversos depoimentos sobre a gravação da primeira versão e subseqüente elaboração da segunda versão presente na suíte ${ }^{188}$. Devemos, porém apontar que o estilo repleto de improvisos de Assad, talvez pela influência das professoras com quem estudou ${ }^{189}$, possui um refinamento incomum já que na Valseana detectamos uma escrita instrumental contrapontística e desenvolvimento temático ${ }^{190}$. Algo que se verifica em outras peças improvisadas e que foram grafadas posteriormente pelo compositor tal como as Seis Brevidades (2008) ${ }^{191}$.

\section{4 Linguagem harmônica}

No segundo capítulo, vimos como o impressionismo francês e as linhas estéticas da música popular que sofreram sua influência se fazem presentes sobre a estruturação harmônica detectada em Aquarelle. Neste item veremos como este tipo de construção harmônica se reflete no restante da produção para violão solo de Sérgio Assad.

O segundo movimento de Sonata possui estruturação harmônica modal; na obra de Assad, tal recurso é explorado em Aquarelle o qual refletese em outras peças tal como a primeira peça da coleção Seis Brevidades, Chuva $^{192}$. Tal prática pode ser exemplificada no segundo movimento de Sonata

\footnotetext{
${ }^{188}$ Ver capítulo 2.

189 Ver capítulo 1.

${ }^{190}$ Ver capítulo 2.

${ }^{191}$ Durante a aquisição da coleção Seis Brevidades, nos foi revelado pelo compositor o método de escrita das peças.

192 Chuva trata-se de uma peça lenta e introspectiva, estruturada harmonicamente e melodicamente sobre o modo de fá lídio.
} 
pela a utilização da tonalidade de mi maior com uma ênfase na dissonância do quarto grau aumentado (lá \#), formando assim o modo de mi lídio, intercalada com a escala maior com o sétimo grau menor (ré) formando um modo de mi mixolídio.

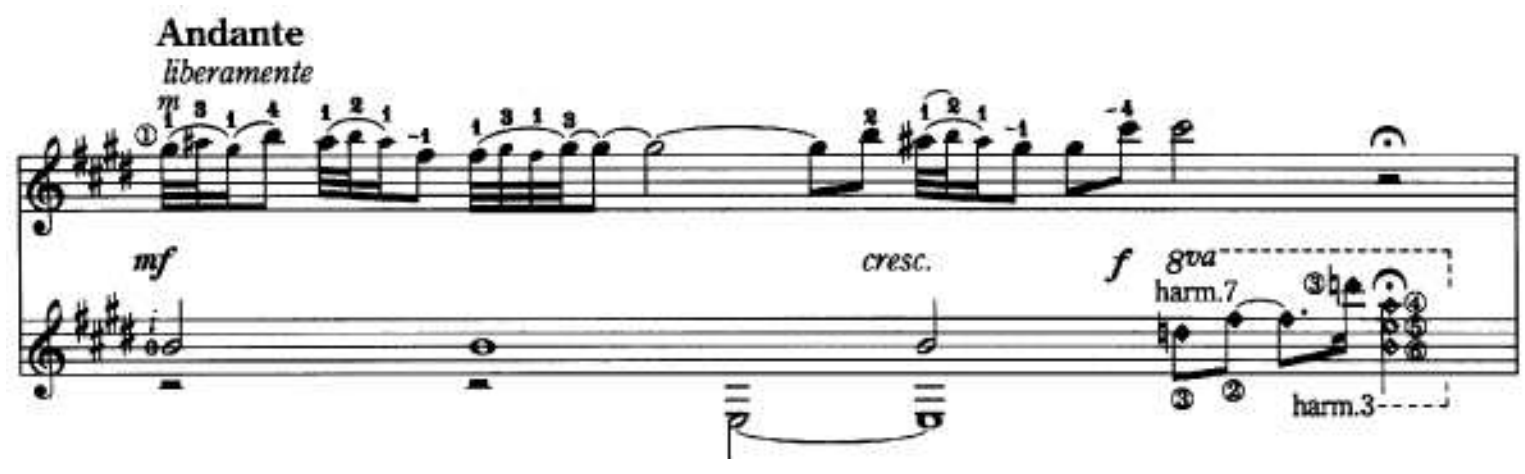

Sonata - Sérgio Assad (2ำ Movimento)

A organização de ambos os modos em claves separadas nos indica 0 emprego da escrita polimodal por Assad, assim como analisado previamente no Item 2.4.1 do capítulo anterior, no qual a sonoridade é empregada nos compassos 125 a 132 de Divertimento.

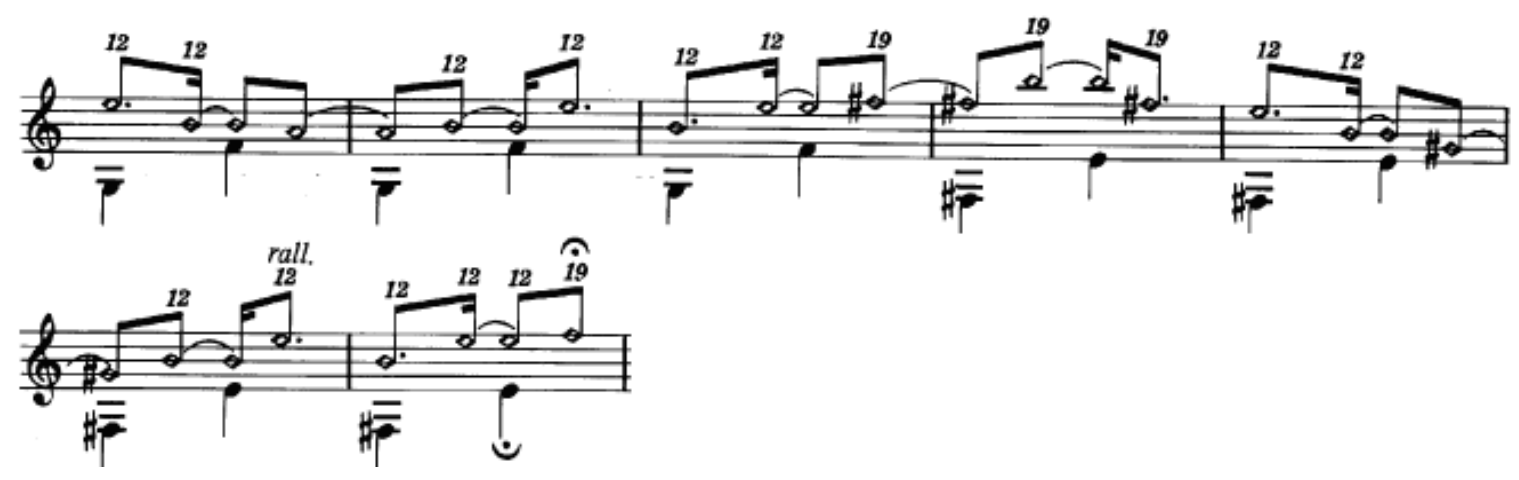

Divertimento - Sérgio Assad compassos 125 a 132

Outro recurso comum à linguagem harmônica utilizada por Assad e demonstrada anteriormente no capítulo anterior na análise harmônica de Aquarelle é a utilização dos acordes de empréstimo modal. Esta prática pode ser encontrada no compasso 13 do segundo movimento de Sonata onde um 
acorde Sol maior com sétima maior (G7M) ${ }^{193}$ é formado em uma textura arpejada.

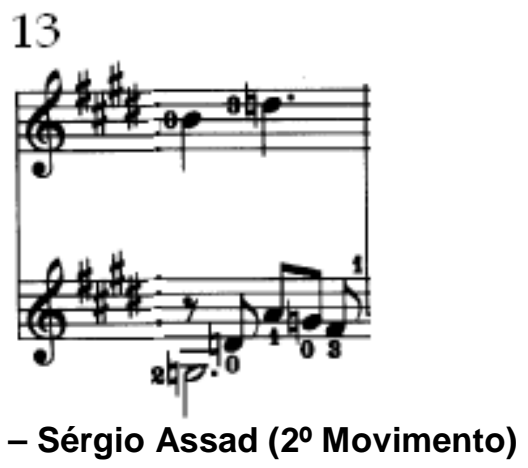

Em Valseana encontramos o mesmo tipo de acorde de empréstimo modal no compasso 5, cuja tonalidade de ré maior é suspensa pelo emprego de um acorde de fá maior com sétima maior (F7M), advindo do modo éolio de ré.

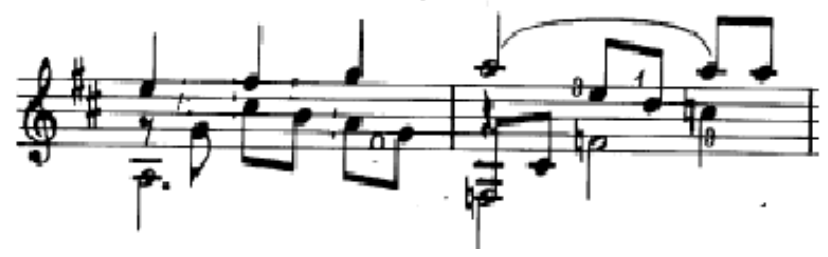

Valsena - Sérgio Assad compassos 4 e 5

Podemos perceber no primeiro compasso de Psi, da coleção Three greek letters, o emprego do modo mixolídio com a quarta aumentada. 0 emprego dessa escala demonstra uma variável da escrita modal de Assad e possui uma sonoridade que remonta à música típica nordestina.

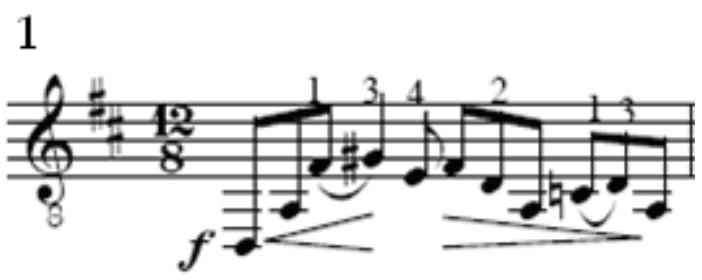

Psi-Sérgio Assad

${ }^{193}$ Acorde maior com sétima maior a uma terça menor acima da tônica. Neste caso, na tonalidade de mi maior o acorde é um blll7M. 
Apesar de possuir a tonalidade de ré maior, Psi e além de possuir o emprego de vários modos na tonalidade de ré, não segue esta tonalidade em sua extensão apenas possuindo uma relação de tônica com o acorde de ré maior. Essa escrita harmônica não tonal também é encontrada em Prelúdio e Toccatina, possuindo inclusive a mesma tonalidade em ambas as peças.

Harmonicamente, Cantiga, da obra Seis Brevidades, difere-se das demais por apresentar uma linguagem predominantemente tonal. A peça de Assad se assemelha a canções tais como Insensatez de Tom Jobim, que são estruturadas harmonicamente sobre acordes cuja linha de baixo apresenta um cromatismo descendente utilizado para acomodar as diversas mudanças de acordes cujas notas fora da tonalidade são inversões de acordes de dominante auxiliar.

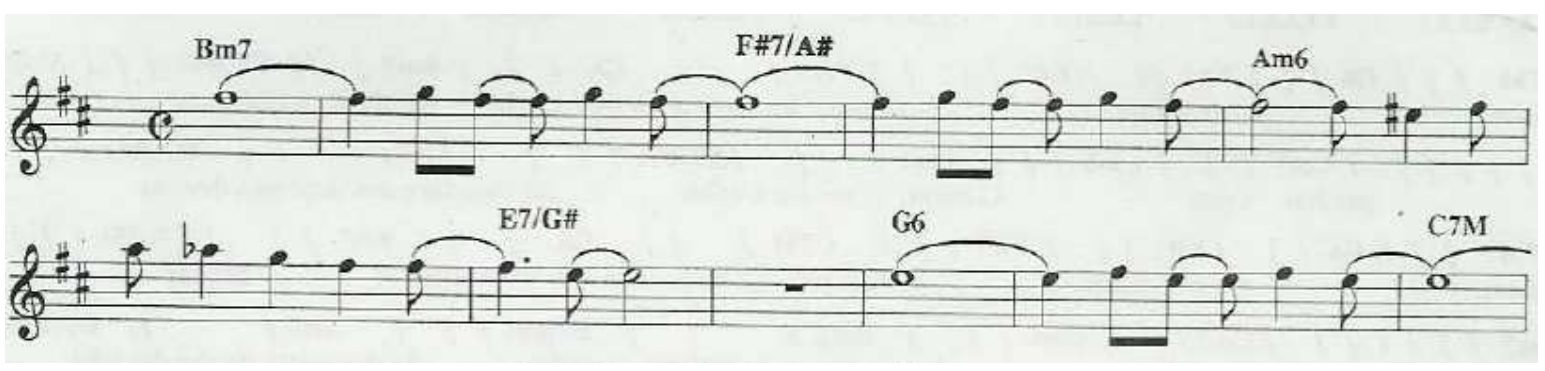

\section{Insensatez - Tom Jobim}

Podemos observar a abordagem de Assad sobre este recurso harmônico no trecho presente entre os compassos 4 e 17 de Cantiga, onde a linha melódica presente na voz de baixo apresenta um cromatismo descendente típico de canções populares.

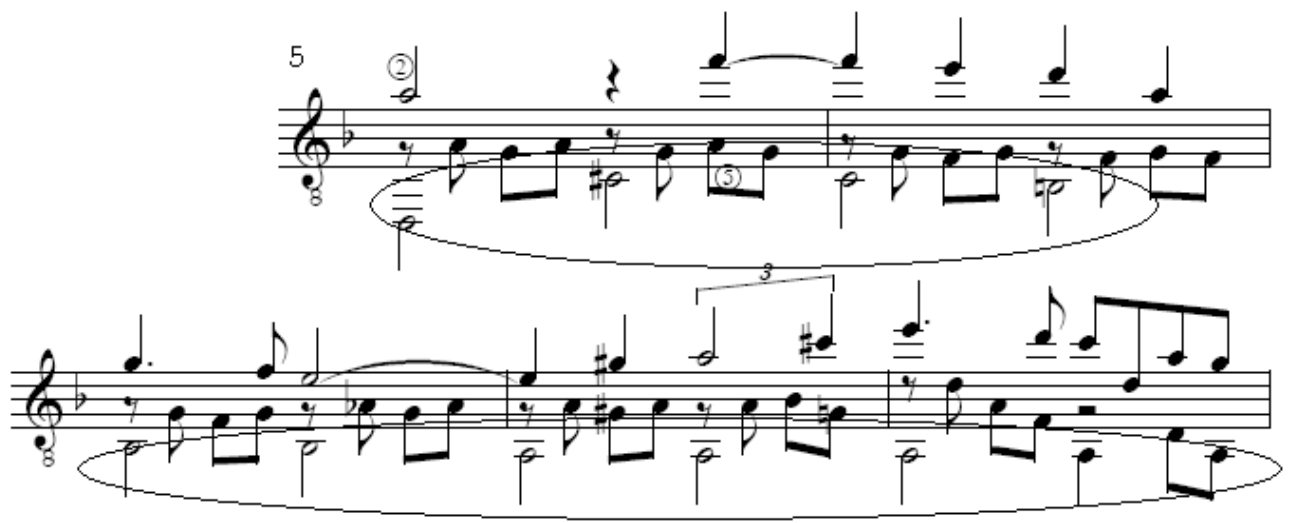

Linha de Baixo Cromática

Cantiga - Sérgio Assad 
Detectamos no compasso 76 de Parati, uma escala ascendente de mi pentatônica menor, que nos revela a influência do impressionismo francês na obra de Assad ao adotar tal escala nesta elaboração.

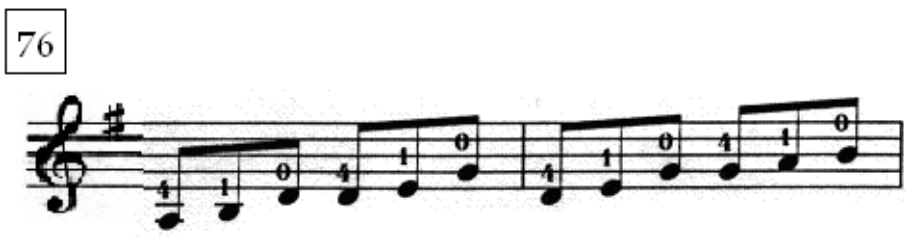

Parati-Sérgio Assad

\subsection{Elaboração motívica}

No primeiro compasso de Fantasia Carioca, detectamos o motivo principal da peça, que denominamos Motivo1. Deve-se ressaltar que o fragmento citado origina-se do primeiro motivo da Aquarelle, variado utilizandose a técnica da retrogradação ${ }^{194}$.

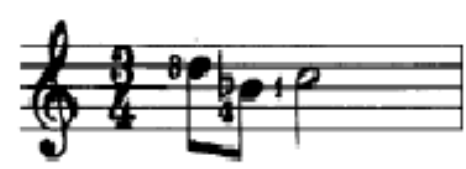

Motivo 1 de Aquarelle

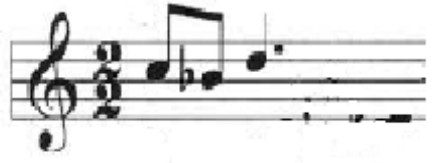

Motivo de Fantasia Carioca

Durante toda a obra, o Motivo1 desta fantasia é constantemente variado, utilizando-se diversas possibilidades. Dentre estas, selecionamos alguns exemplos que demonstram as técnicas de variação motívica utilizadas pelo compositor.

Detectamos entre os compassos 6 e 9 o motivo 1 utilizado como melodia principal na voz superior e acompanhamento na voz inferior de maneira simultânea. $O$ motivo transposto a uma quinta diminuta abaixo é utilizado nos compassos 6,7 , e 8 como uma célula de acompanhamento devido às repetições e a partir do quarto tempo do compasso oito é transposta

\footnotetext{
${ }^{194}$ Nesta técnica de variação melódica: temas, motivos e outros fragmentos melódicos são elaborados de maneira em que a seqüência de notas será executada de maneira inversa à apresentada na melodia original.
} 
sucessivamente em terças maiores. Essas transposições formam uma escala de tons inteiros e apresentam similaridades com Aquarelle, por ambas utilizarem do mesmo material em suas introduções.

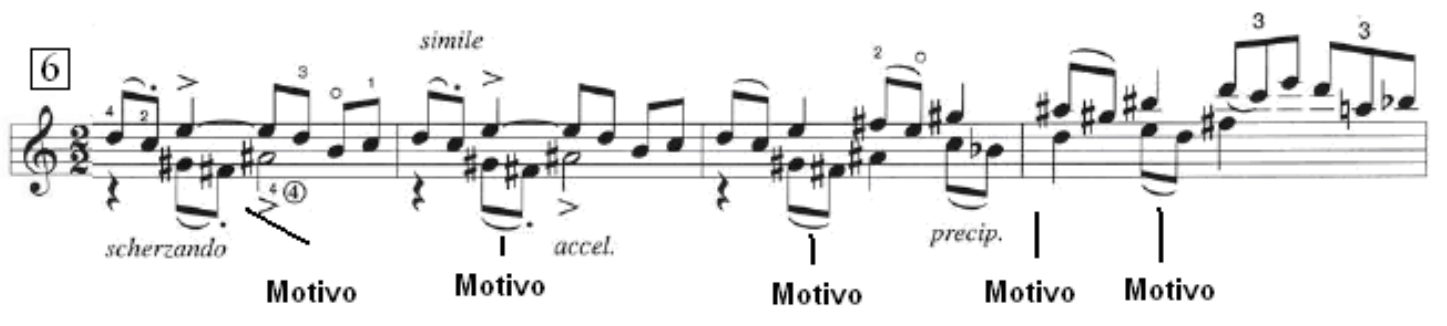

Fantasia Carioca - Sérgio Assad

A introdução da obra Valsa de Outono é iniciada por um agrupamento sucessivo de colcheias executadas livremente em grupos de seis notas, que são transpostas um tom abaixo sucessivamente e desembocam em uma escala de tons inteiros no segundo compasso.

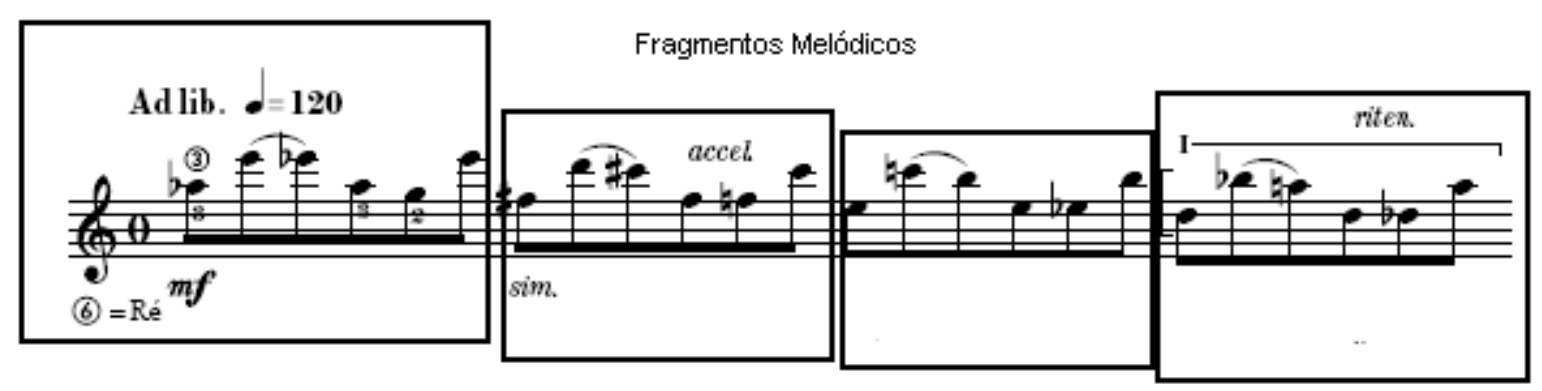

\section{Valsa de Outono - Sérgio Assad}

Podemos relacionar esta obra com Aquarelle e Fantasia Carioca ao tratar-se de um tipo de introdução similar em ambas, ao utilizar fragmentos melódicos curtos e escalas de tons inteiros em sua constituição. O que diferencia Fantasia Carioca, é o fato desta apresentar uma elaboração formada por vozes independentes, portanto de maior complexidade.

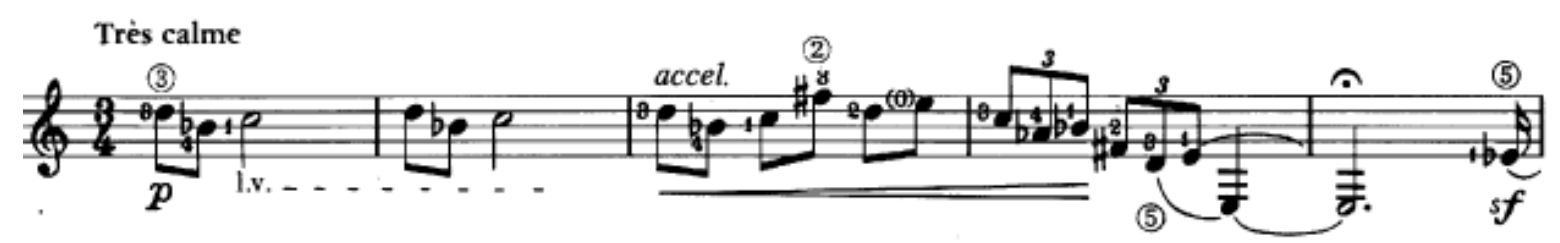

Divertimento - Sérgio Assad compassos 1 a 5 
A passagem contida entre os compassos 70 e 73 demonstra o Motivo 1 variado em forma de cânone ${ }^{195}$. Na passagem citada, o motivo é introduzido no primeiro tempo do compasso 70 , havendo a repetição da célula uma oitava abaixo no terceiro tempo do mesmo compasso, o processo é então repetido nos compassos 72 e 73.

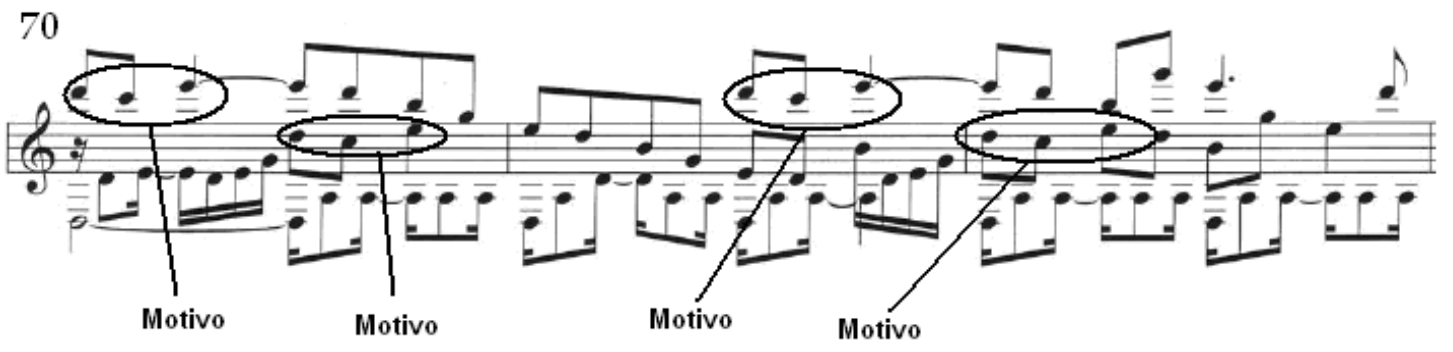

Fantasia Carioca - Sérgio Assad

Entre os compassos 117 e 132 encontramos uma nova mudança de textura e andamento na obra. Novamente o Motivo1 é variado, tornando-se um novo tema, que neste trecho gera interesse ao se tratar de uma melodia executada na região mais grave do instrumento acompanhada por acordes na região aguda.

\footnotetext{
${ }^{195}$ Forma de organização temática na qual o tema elaborado é repetido de forma transposta
} um ou dois tempos após o início do tema, causando um efeito de atraso na melodia. 

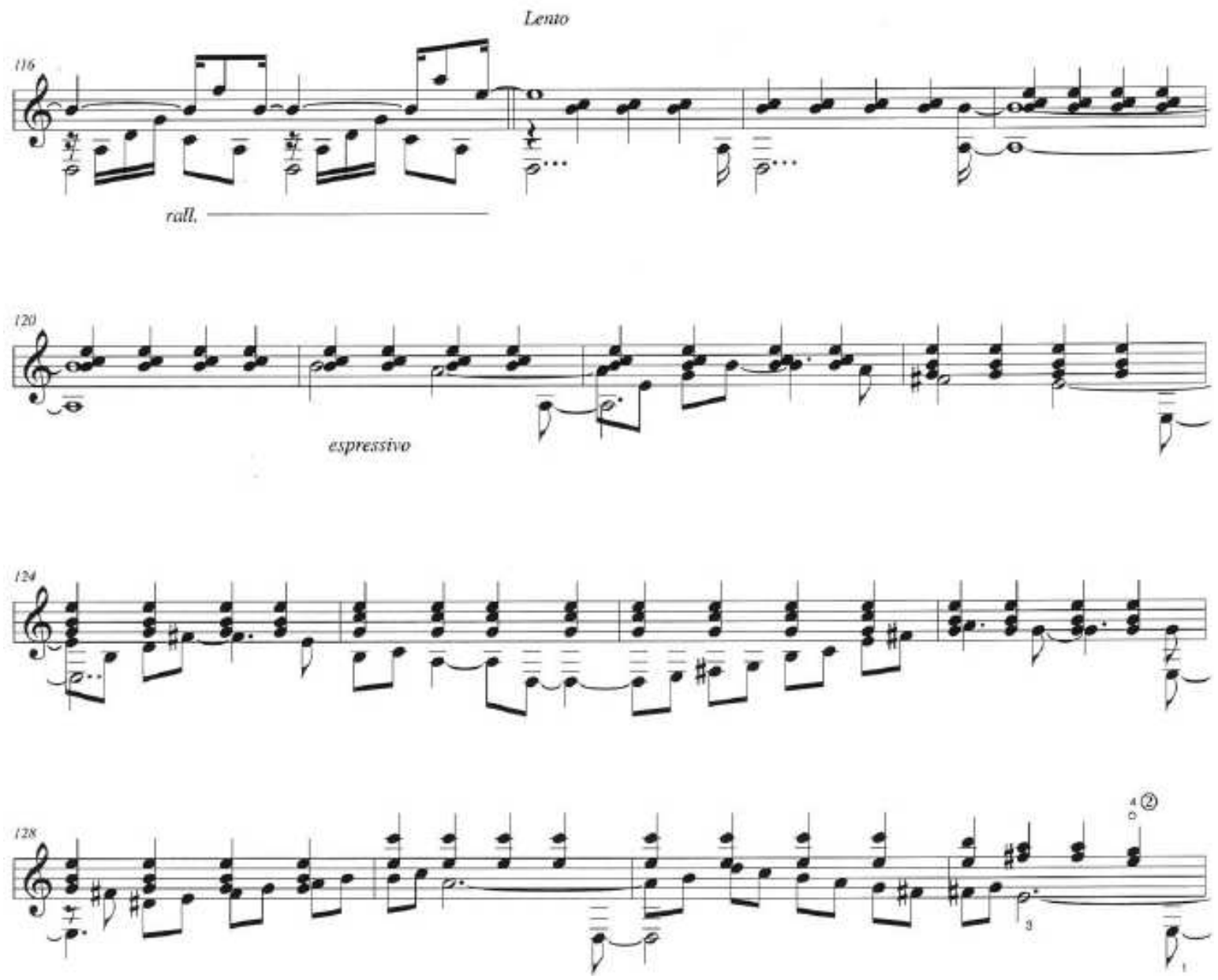

Fantasia Carioca - Sérgio Assad

O recurso utilizado gera uma textura instrumental similar à explorada pelo compositor Heitor Villa-Lobos (1887 - 1959) na parte "A" do Prelúdio no1 da série de Cinco Prelúdios para violão solo (1940). O emprego dessa textura instrumental também é verificada em outras obras lentas do compositor como Valseana e Psi. 

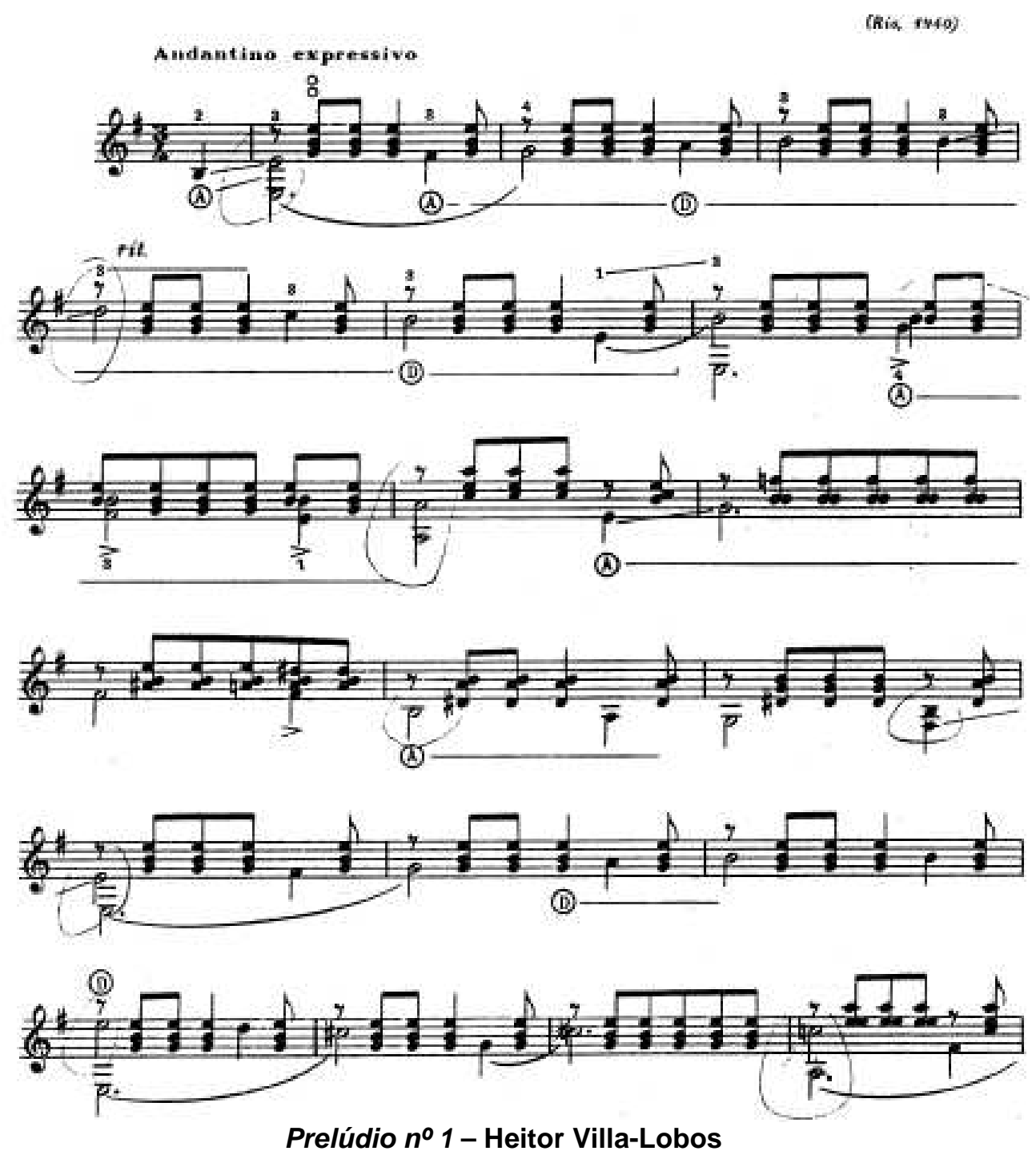

O compasso 150 exprime uma nova variação onde o Motivo1 novamente apresenta como acompanhamento uma célula melódica cíclica.

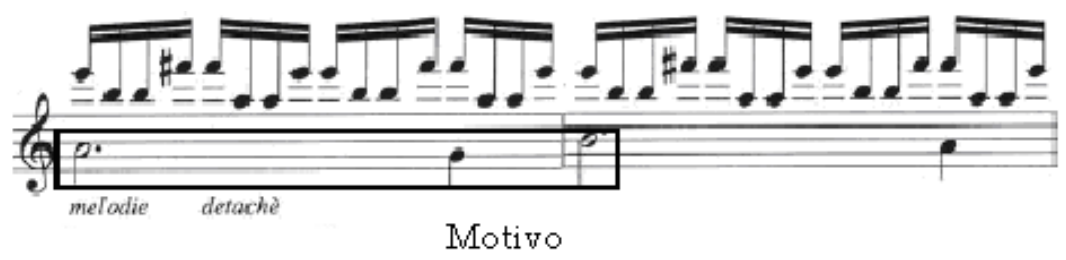

Fantasia Carioca - Sérgio Assad

Tal concepção musical pode ser encontrada em um contexto diverso na parte do piano da peça instrumental Maracatu de Egberto Gismonti (1947), 
do disco Sanfona (1980) ${ }^{196}$, no qual o mesmo recurso é explorado, revelando assim afinidades de Gismonti sobre a obra de Assad.

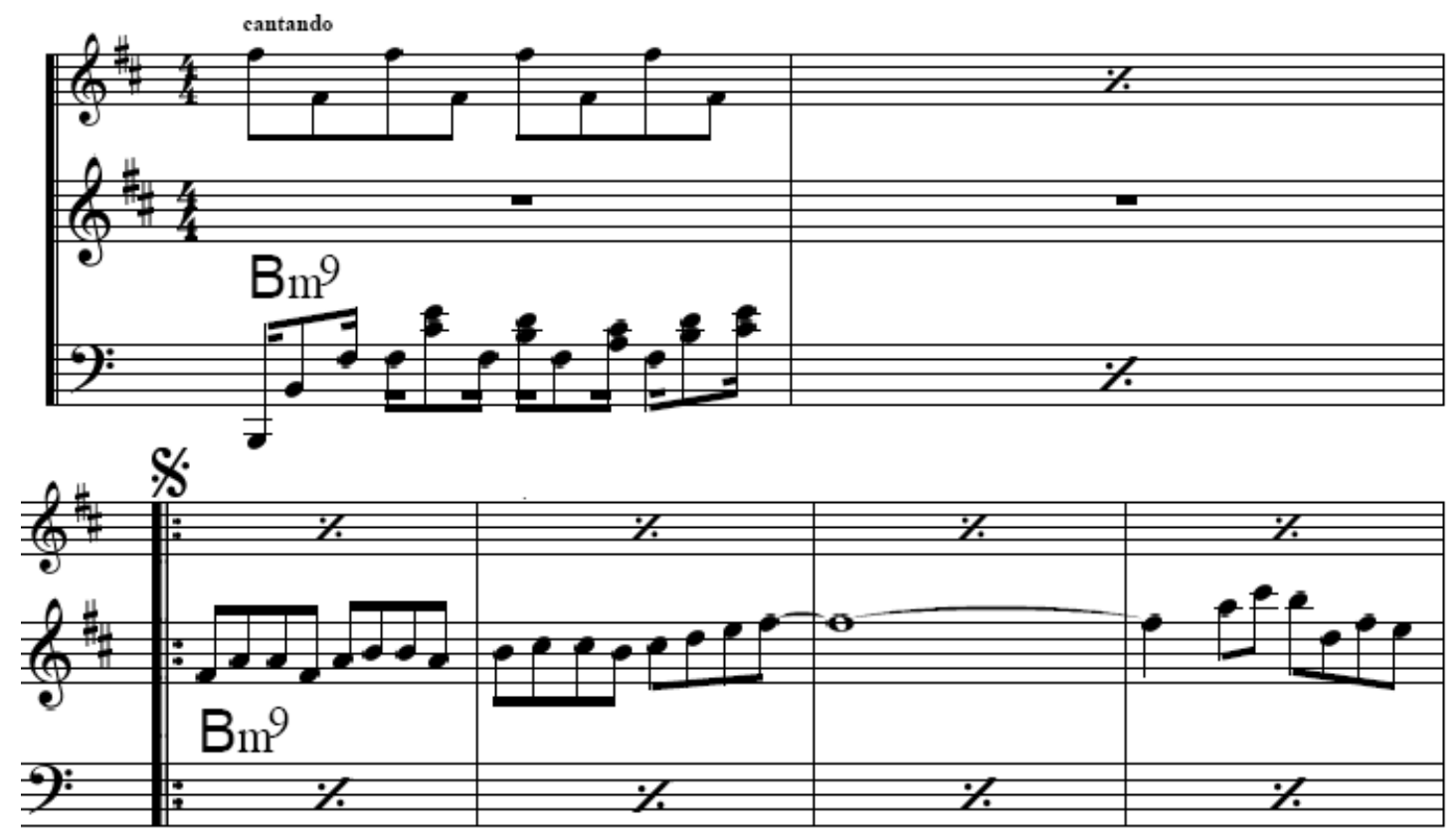

Maracatu - Egberto Gismonti

Em Jobiniana 3, por sua vez, o motivo principal da obra se trata de uma citação variada e transposta meio tom abaixo do os primeiros compassos do tema da canção Desafinado de Tom Jobim, encontrada no compasso 34. Nesta peça este fragmento torna o fio condutor da obra ao sofrer diversas variações, transformações e elaborações assim como ocorre em Aquarelle.

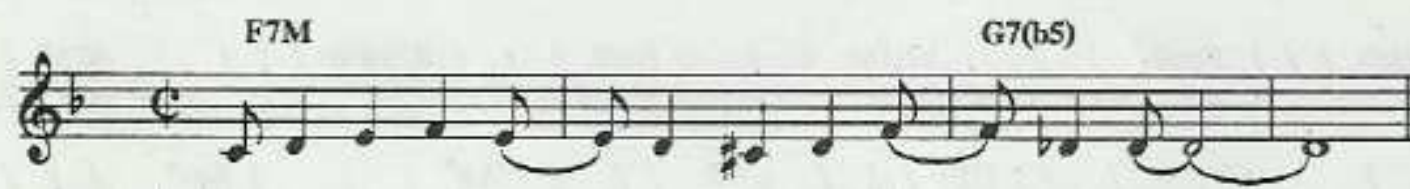

Fragmento do tema da canção Desafinado

${ }^{196}$ GISMONTI, Egberto. Sanfona Ecm Records, 1980 B00000DTEU. 


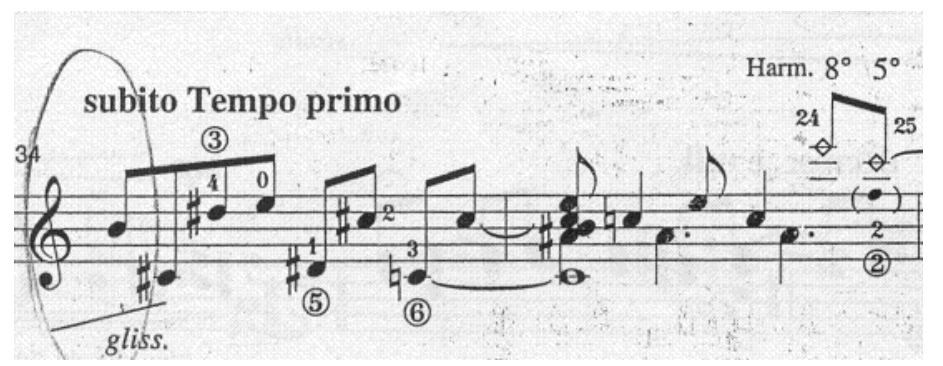

Fragmento do tema da canção Desafinado em Jobiniana n³

O compasso 38 de Jobiniana 3 apresenta um trêmolo ${ }^{197}$ violonístico, sendo a melodia existente na voz inferior uma variação gerada pelo motivo da canção de Jobim.

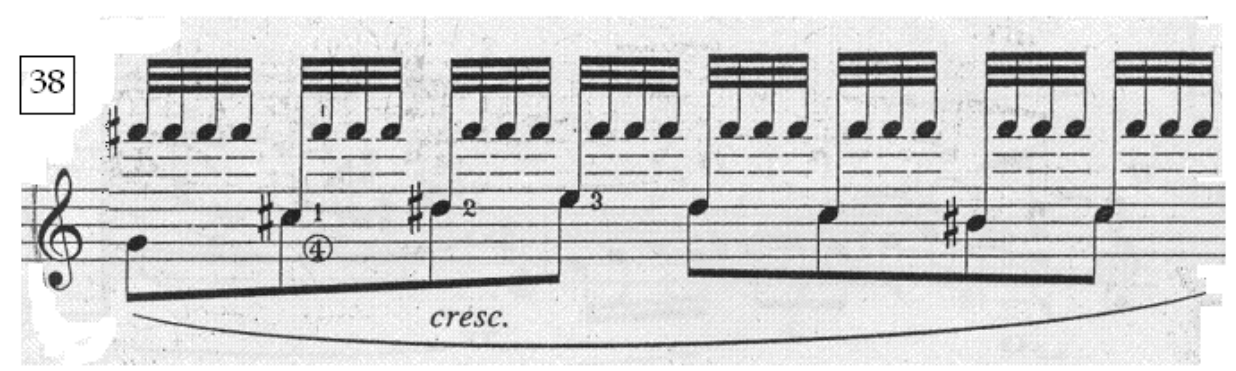

Jobiniana nº - Sérgio Assad

Estruturalmente, a peça Sigma, da coleção Three Greek Letters, apresenta uma série de curtos construídos a partir de padrões rítmicos e que são variados melodicamente por toda a sua extensão. Identificamos o primeiro tema no primeiro compasso 1 e as variações deste nos compasso 3 e 5.

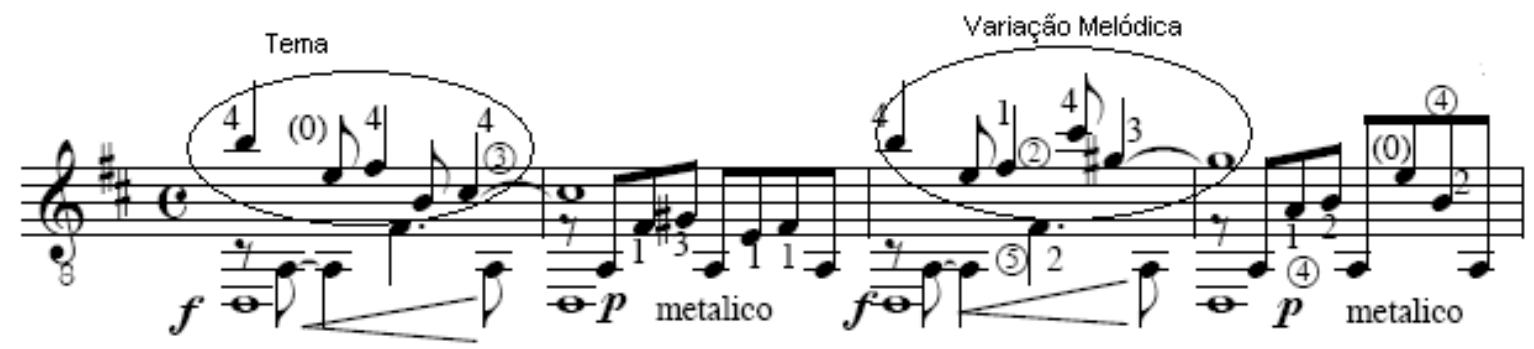

Sigma - Sérgio Assad

197 Recurso instrumental onde uma determinada nota é executada de maneira contínua, gerando um efeito de notas longas sustentadas devido à velocidade das notas repetidas. Tal recurso, apesar de incomum no vocabulário instrumental de Assad, é comum no repertório violonístico particularmente da segunda metade do séc. XIX através de obras de Francisco Tárrega (1852 - 1909) tais como Sueño e Recuerdos de la Alhambra. 
O compasso 20 apresenta o segundo motivo, que é constituído de notas repetidas em pares e que apresentam deslocamento rítmico.

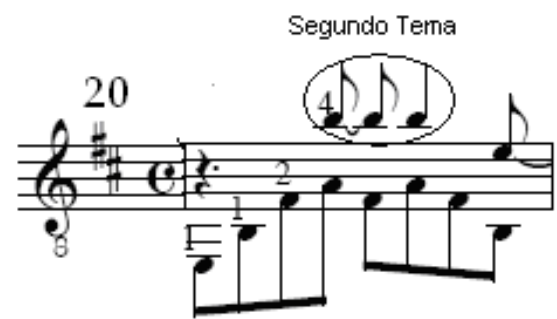

Sigma - Sérgio Assad

Novamente a obra apresenta como característica temática principal o interesse rítmico, ao tratar-se de uma melodia formada por quiálteras de três semínimas sobre um acompanhamento de colcheias, formando assim um motivo polirrítmico. Como exemplos do tema, escolhemos a sua primeira ocorrência no compasso 23 e uma de suas variações melódicas presentes no compasso 48 onde o tema citado é transposto a uma oitava abaixo, havendo assim a exploração de desta possibilidade musical.

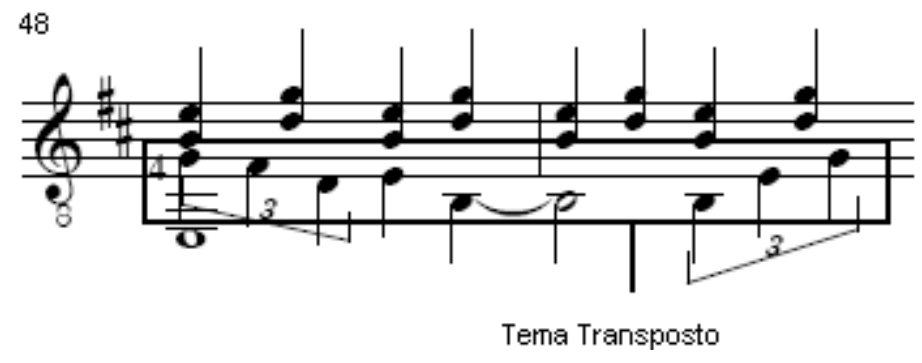

Sigma - Sérgio Assad (3ํㅡovimento)

Esse recurso rítmico é encontrado igualmente na Valseana e na seção do prelúdio em Prelúdio e Toccatina, o que nos leva a acreditar de se tratar dos primeiros exemplos da utilização deste recurso na escrita de Assad, refletindo posteriormente no restante de sua obra ${ }^{198}$.

\footnotetext{
${ }^{198}$ Devemos ressaltar a recorrência da utilização deste tipo de polirritmia em momentos ou movimentos de andamento lento de suas obras se tornando uma característica de sua produção.
} 


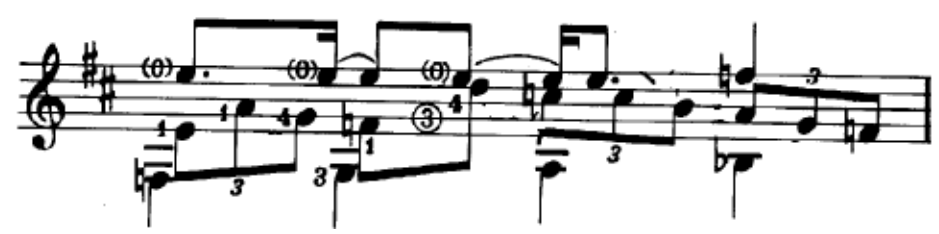

Prelúdio e Toccatina Sérgio Assad compasso 3

A segunda peça de Divertimentos, Arpoador, possui uma scordatura incomum na literatura violonística ao afinar a sexta corda mi meio tom abaixo. Dedicada ao violonista belga Boris Gaquere (1977), ex-aluno de Sérgio e Odair Assad em Bruxelas a peça possui uma escrita similar ao do segundo movimento de Aquarelle, Valseana, pela textura de melodia acompanhada, acordes com tensões adicionadas e acordes de empréstimo modal.

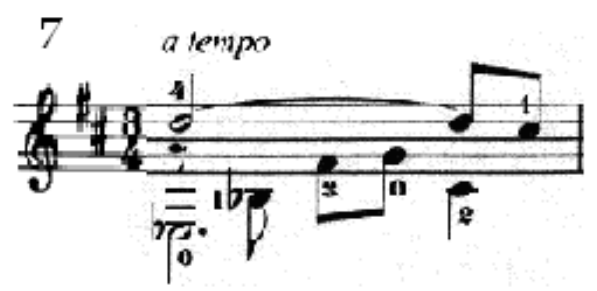

Valseana

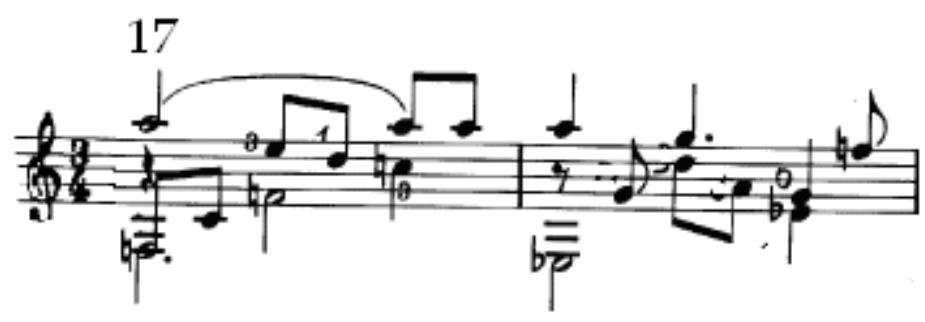

Arpoador

A peça é iniciada com um motivo formado por terças paralelas formando o tema principal no primeiro compasso, que é posteriormente reprisado no compasso 19 uma oitava abaixo.

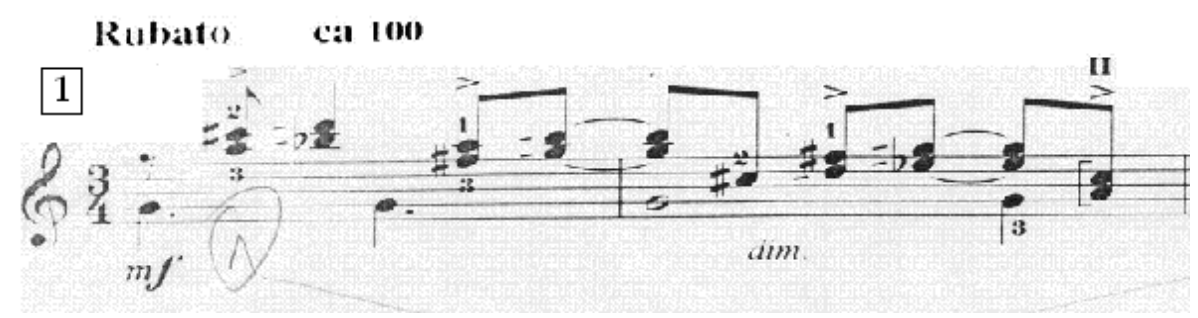




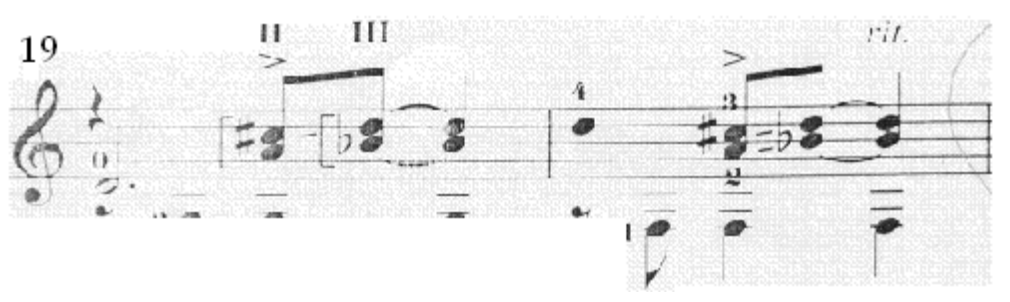

Arpoador

No primeiro compasso da obra, Ely's Portrait, detectamos a apresentação do motivo inicial, o qual é reapresentado e transposto a uma região mais grave do instrumento nos compassos 5 e 6 . O recurso mencionado é explorado em Valseana e se mostra recorrente no vocabulário composicional de Assad.
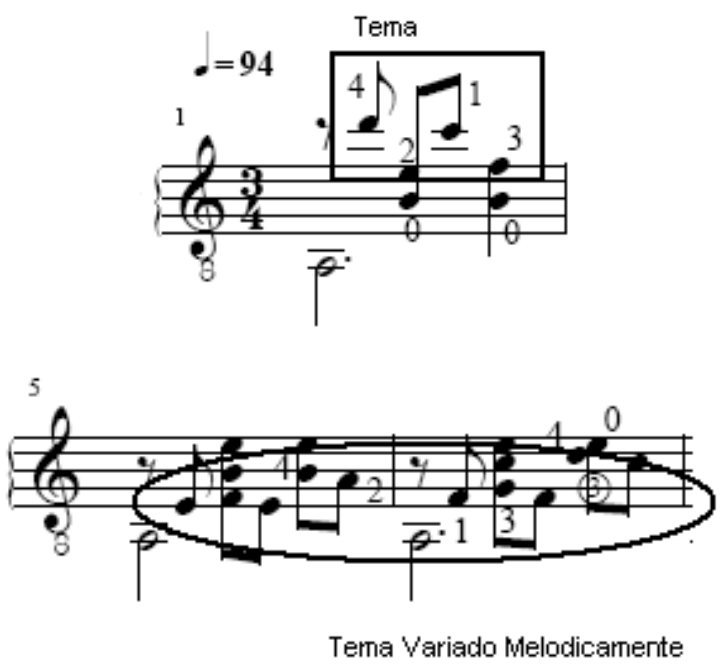

Eli's Portrait - Sérgio Assad

Harmônicos que são a citação do nome de Eli Kassner e são reapresentados no compasso seguinte. Nesta passagem o compositor deixa claro ao intérprete a função daquele fragmento melódico na obra ao grafar na partitura as letras do nome do violonista canadense.

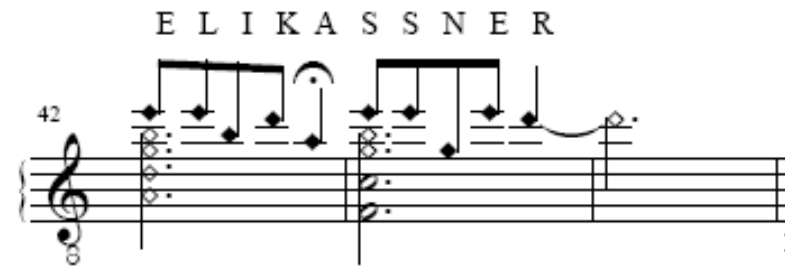

Ely's Portrait - Sérgio Assad 
$\mathrm{Na}$ introdução de Valsa de Outono, detectamos acordes no compasso 1 que são reutilizados como material estrutural da segunda seção da obra no compasso 55, demonstrando que o rigor estrutural de Assad presente em Aquarelle se mantém em sua produção recente.
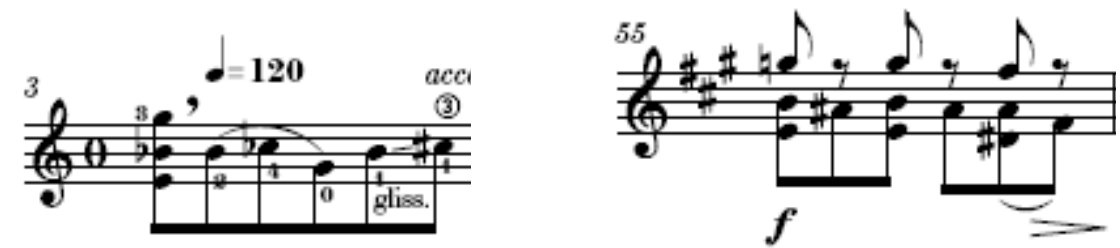

Valsa de Outono - Sérgio Assad

Algumas passagens de Tarde, da coleção Seis Brevidades, nos revelam que Assad emprega mudanças de tonalidade e variações motívicas de maneira natural dentro de seu vocabulário de improvisador. Encontramos nos compassos 2 um motivo executado na voz de baixo e que é reapresentado em diversos compassos posteriores de maneira variada quanto ao modo e tonalidade.
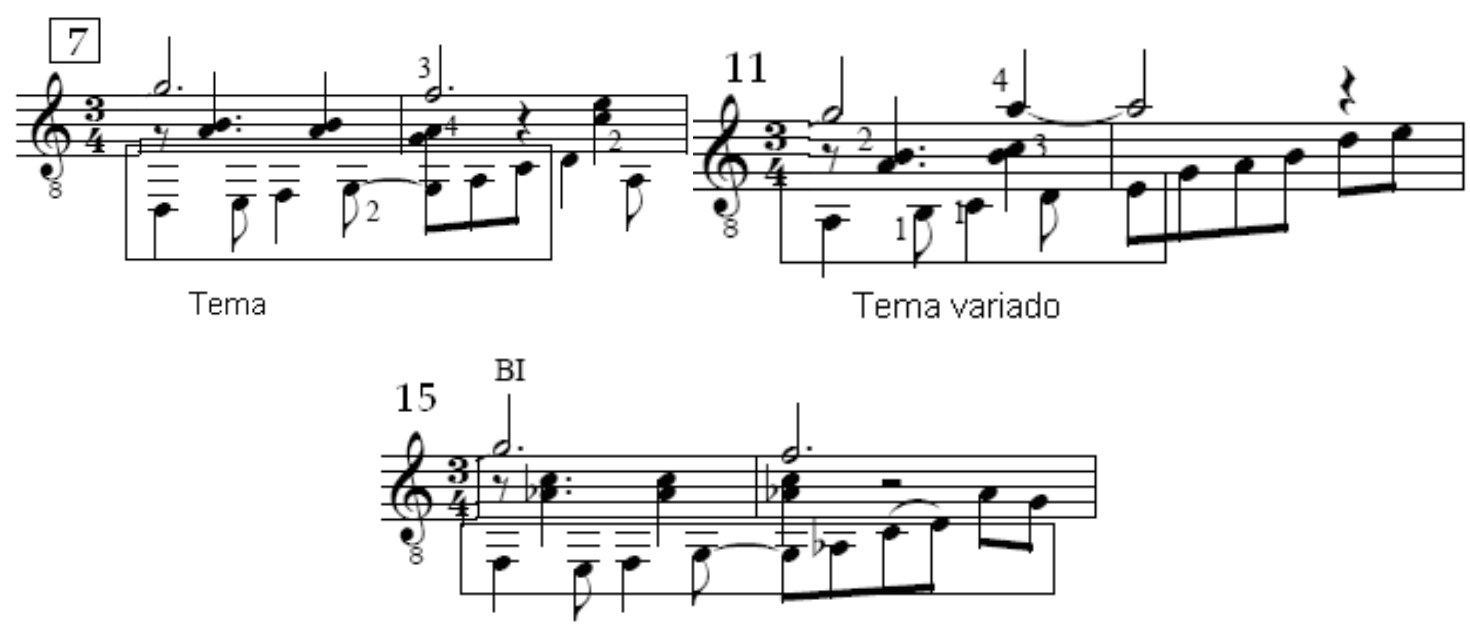

Tema transposto

Tarde - Sérgio Assad

Estruturalmente a peça Ginga, extraída da mesma coleção, apresenta uma estrutura ternária simples A B A', com a seção B apresentando alternância de fórmula de compasso e elaboração motívica baseada em fragmentos melódicos provenientes da primeira seção. 


\subsection{Escrita Instrumental}

Durante o trabalho de pesquisa sobre Aquarelle, foram detectados diversos aspectos técnicos instrumentais que se mostraram recorrentes em obras de Assad que vieram mais tarde em sua produção. Selecionamos neste item algumas passagens acrescidas de comentários quanto à sua elaboração e sua relação com Aquarelle.

Um recurso que é explorado em profusão no primeiro movimento de Aquarelle, Divertimento, é a escrita de escalas com digitação em campanelas. Em Fantasia Carioca, o mesmo recurso é explorado no compasso 105, 109, 215 e 219, onde uma escala em fusas é elaborada pelo compositor e a execução no andamento proposto é facilitada por este tipo de digitação.

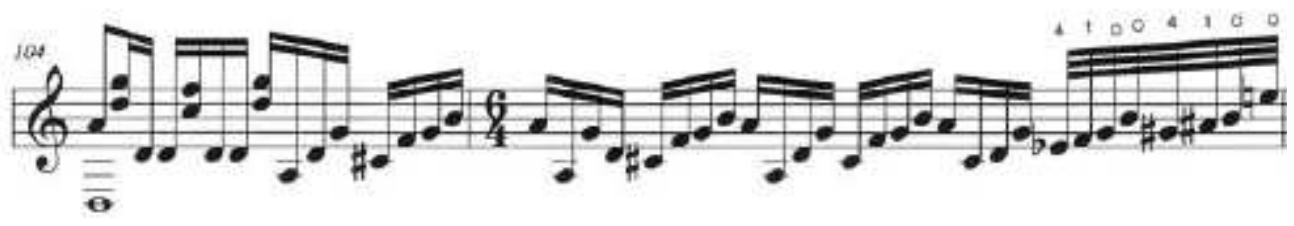

Fantasia Carioca - Sérgio Assad

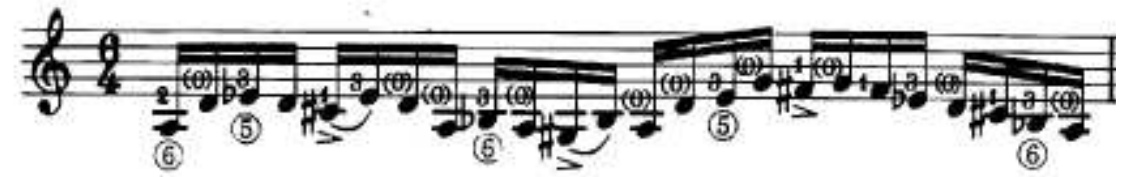

Divertimento - Sérgio Assad compasso 31

Outra passagem que emprega a escrita de escala em campanelas encontra-se no compasso 76 de Parati, da coleção Três Divertimentos, este artifício, que se mostra recorrente na obra de Assad, é empregado no compasso 76 em uma escala ascendente de mi pentatônica menor.

76

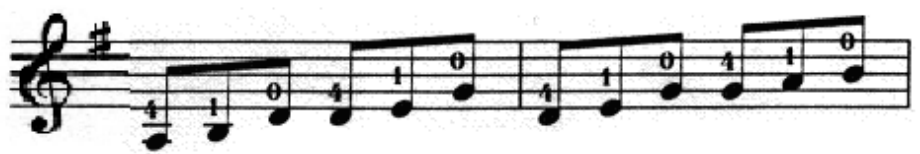




\section{Parati-Sérgio Assad}

Apesar do andamento mais lento, a escrita em vozes independentes citada anteriormente no segundo movimento da Sonata, gera algumas dificuldades técnicas. Isto pode ser comprovado no terceiro e quarto sistema da peça, onde várias técnicas são sobrepostas, obrigando o intérprete a adaptarse a situações instrumentais incomuns. No exemplo citado, são exploradas várias junções de técnicas instrumentais como melodia acompanhada por harmônicos, harmônicos naturais acompanhados por escalas em campanela e trinados acompanhados por um ostinato na corda si (2). Podemos constatar que este tipo de escrita presente no segundo movimento desta sonata trata-se de uma versão mais elaborada e, portanto mais complexa da escrita contrapontística em Aquarelle.
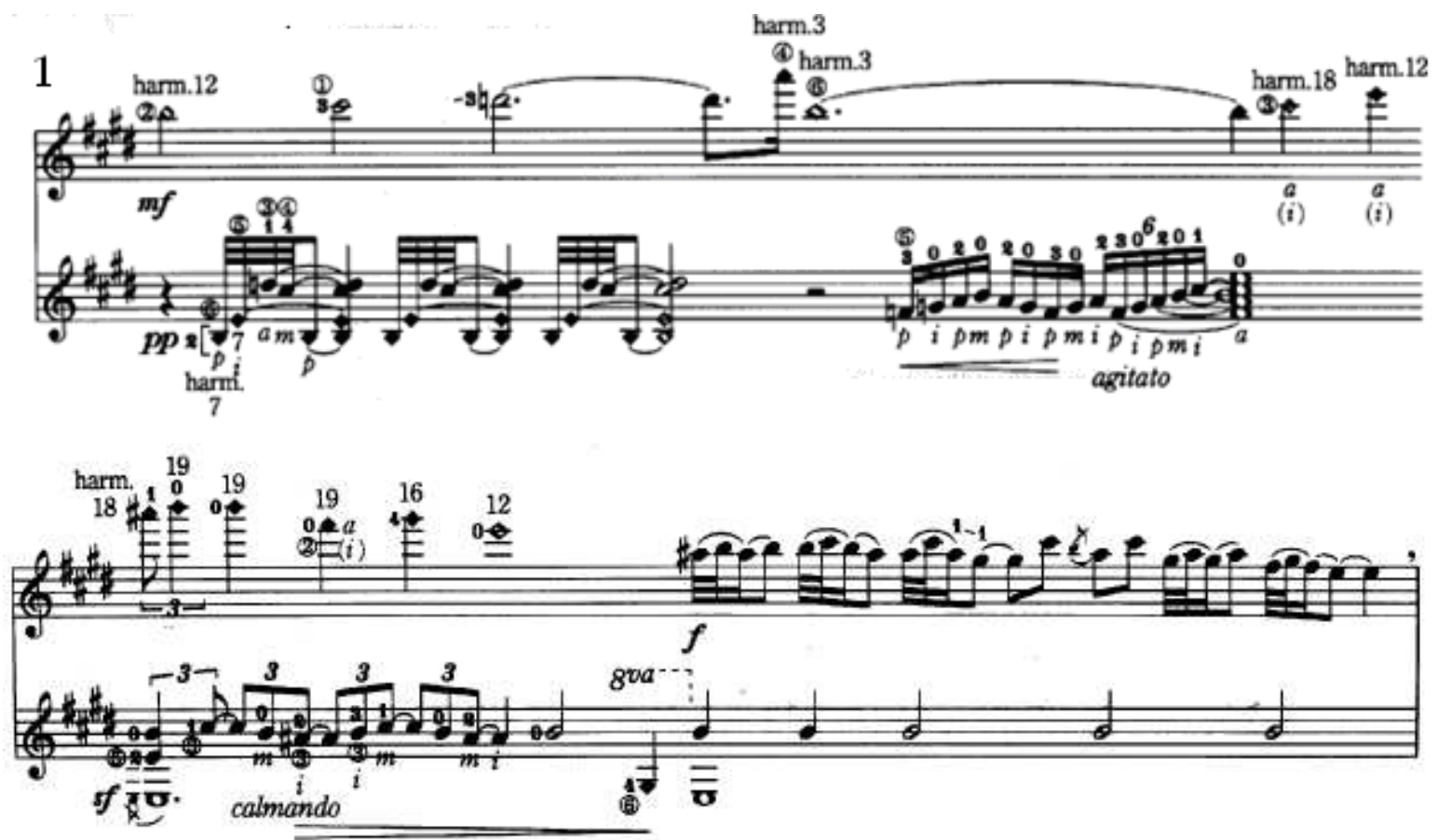

Sonata - Sérgio Assad (2ำ Movimento)

No compasso 33, primeiro tempo, apresenta-se a junção das técnicas de ligado com aberturas na mão esquerda, gerando desafio mecânico assim como no compasso 54 de Prelúdio e Toccatina, em que este tipo de situação técnica ocorre. 


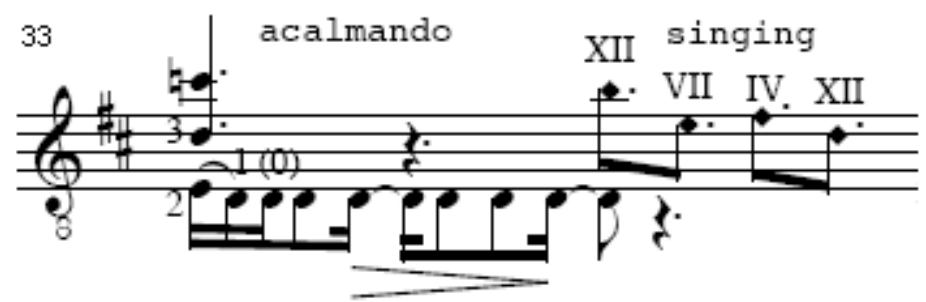

PI-Sérgio Assad

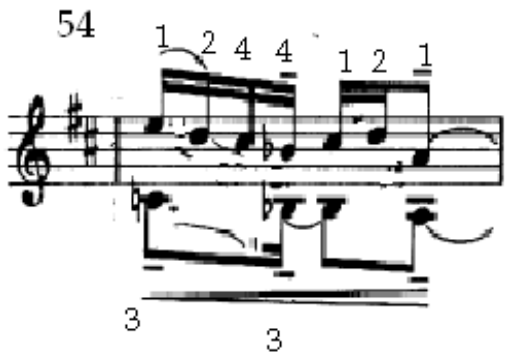

Prelúdio e Toccatina - Sérgio Assad

O compasso 46 de $\mathrm{Pi}$, encontra-se uma mudança de caráter e andamento. No trecho citado, o compositor emprega a técnica de rasgueado em diversos momentos nos compassos 54, 55, 58, 59, 67,68 e 70, tornando assim a seção final mais rítmica e vibrante. Ao detectar esta passagem podemos constatar que a técnica citada, assim como vista anteriormente em Divertimento e em Prelúdio e Toccatina, é executada apenas com o dedo indicador da mão direita (i) numa modalidade denominada de dedillo por alguns violonistas, revelando assim outro aspecto recorrente na escrita instrumental de Sérgio Assad.

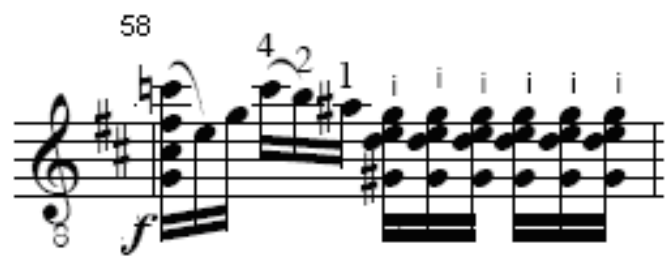

PI - Sérgio Assad

Uma variante técnica dessa natureza é encontrada no terceiro movimento do conjunto Three Greek Letters, Psi. Detectamos ao final da peça no compasso 99, a técnica de rasgueado com a utilização do polegar em cada tempo forte do compasso, padrão que realça as acentuações presentes tornando mais clara a intenção rítmica do compositor. 


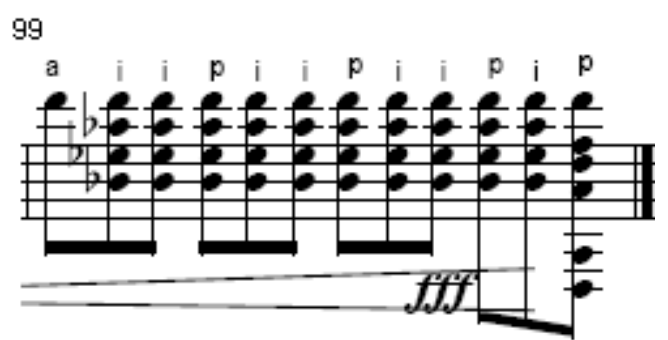

PI-Sérgio Assad

Uma variante para a técnica de rasgueado foi detectada ao final da Parte B da peça Eli's Portrait entre os compassos 80 a 82 e demonstra novamente a habilidade de Assad na fusão de diferentes recursos instrumentais. Nesta passagem, o compositor funde a execução de harmônicos naturais do instrumento com a técnica de rasgueado, obtendo um efeito incomum e eficaz.

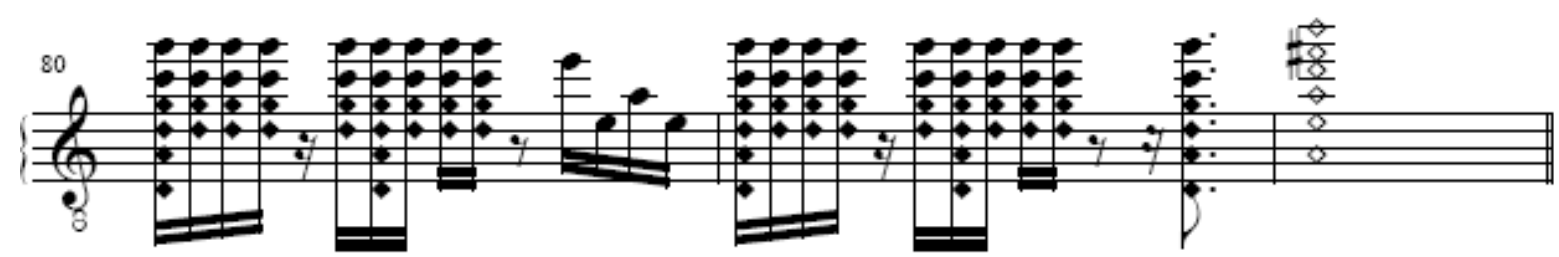

Eli's Portrait - Sérgio Assad

Recordamos ao entrevistar o violonista Aliéksey Vianna em $2005^{199}$, de algumas declarações feitas referindo-se às diversas dificuldades na sua técnica de mão esquerda ${ }^{200}$. Na mesma entrevista o violonista cita os Três Divertimentos como uma obra didática escrita para seus alunos. Devemos supor então que, pela profusão de ligados encontrados nesta peça e pelas declarações do violonista dedicatário da mesma, Abaeté trata-se na verdade de um estudo de ligados com enfoque na dificuldade de execução técnica da mão esquerda. No compasso 13 de Abaeté, encontramos uma passagem em que tais dificuldades vêm à tona no se tratar de uma abertura entre os dedos um (1) e três (3) em um ligado ascendente que é seguido por uma nota si bemol

\footnotetext{
199 Vianna, Aliéksey. Entrevista conduzida por Thiago Oliveira em Belo Horizonte (MG) em 11/2005. Ver seção Anexos.

200 Devemos citar que, em diversas passagens da gravação desta peça de Aliéksey Vianna para o CD Vianna Plays Assad, diversos ligados foram suprimidos, o que nos leva a supor que estas modificações foram feitas para facilitar a execução da peça.
} 
executada pelo dedo quatro (4). Assim como no compasso 87 de Divertimento, propomos que se use a antecipação na mão esquerda, mais precisamente para a nota si bemol no dedo quatro (4), que antecipada durante o ligado propiciará uma execução fluente da passagem.

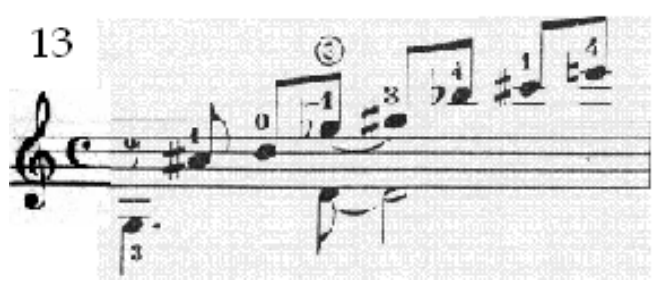

Abaeté - Sérgio Assad

Encontramos no compasso 24 de Ginga, da coleção Seis Brevidades, um trecho de similar situação técnica, com junção de técnicas de ligado com abertura da mão esquerda e que uma execução fluente da passagem também depende da antecipação da mão esquerda. Propormos uma digitação ao trecho e para a sua execução o dedo quatro (4), que executará a nota mi na décima segunda casa deverá ser antecipado a fim de que a passagem seja facilitada e conseqüentemente soe fluente com a digitação proposta.

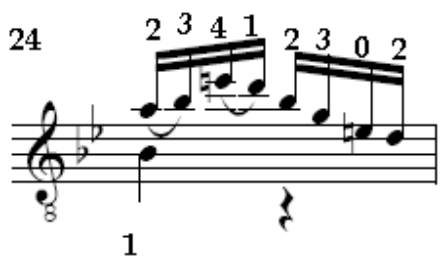

Ginga - Sérgio Assad

O compasso 9 de Parati nos revela outro aspecto recorrente na obra de Sérgio Assad, que trata-se do uso de melodias acompanhadas, recurso que é utilizado nesta peça em sua totalidade e para a sua execução fluente e requer o de cordas soltas para a realização de diversos saltos presentes. Exemplificaremos a prática através de uma passagem no compasso 14, na qual a melodia iniciada na nota sol na segunda corda é sucedida por uma nota mi executada na primeira corda aberta.

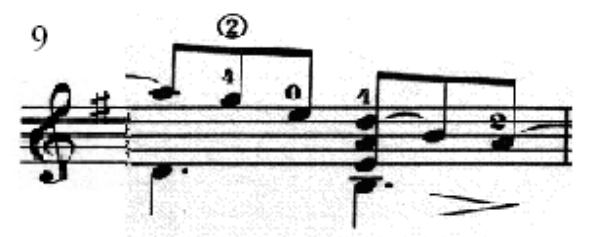




\section{Parati - Sérgio Assad}

Assim como em diversos estudos para violão, onde uma determinada técnica instrumental é explorada didaticamente, encontramos entre os compassos 23 a 42 um trecho em que ligados descendentes são executados sobre a corda mi (1) solta, havendo em alguns momentos notas presas nas cordas mais graves gerando um desafio técnico ao estudante do instrumento. Baseados nas passagens abaix, podemos traçar um paralelo entre Assad e vários compositores violonistas autores de obras didáticas em diversos períodos tais como: Fernando Sor (1778 - 1839), Mauro Giuliani (1780 - 1840), Matteo Carcassi (1792 - 1853) e Abel Carlevaro (1916 - 2001), demonstrando sua ligação com a história e a tradição de diversas escolas. Tomaremos como exemplo análogo a esta passagem o primeiro compasso do Estudo n-23 op. 60 de Matteo Carcassi, onde é explorado o recurso técnico da utilização de ligados descendentes em cordas soltas combinados com cordas presas na voz mais grave.

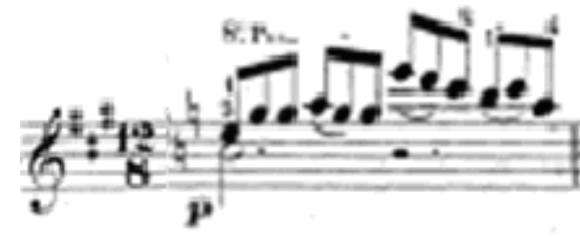

Estudo Op. 60 n. 23 de Carcassi, comp. 1

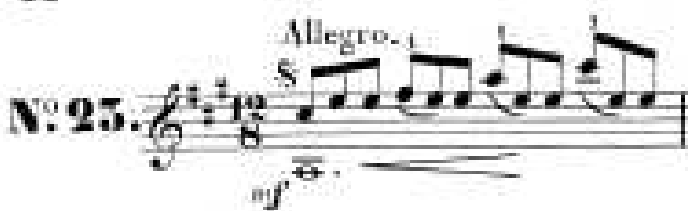

Estudo Op. 60 n. 23 de Carcassi, comp. 17

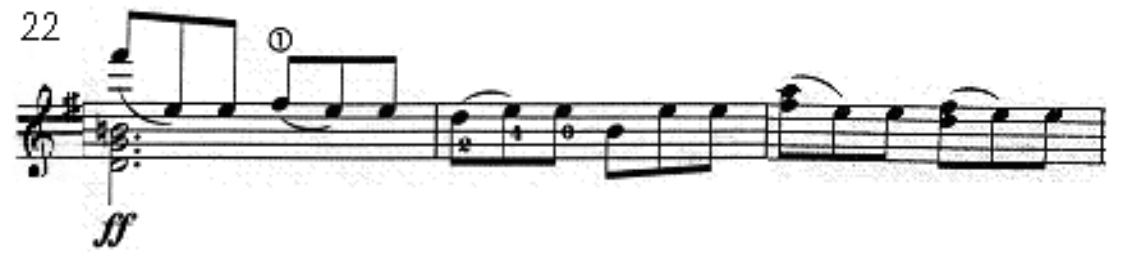

Parati - Sérgio Assad, comp. 22

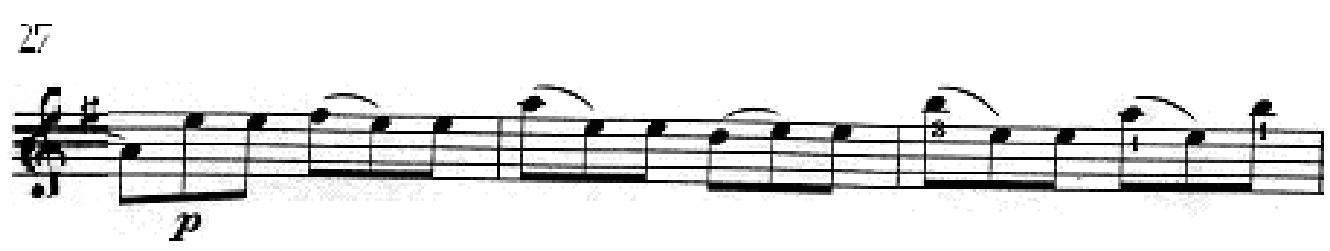

Parati - Sérgio Assad, comp. 27

Em Valsa de Outono detectamos algumas dificuldades técnicas para uma execução fluente da linha melódica e seu acompanhamento devido a 
várias aberturas presentes. Uma seção de escrita similar e situações instrumentais análogas, a parte B do Divertimento, também gera dificuldades técnicas ao exigir a execução de diversas aberturas de mão esquerda do executante. Selecionamos como exemplo destas dificuldades em Valsa de Outono o trecho presente no compasso 8, onde uma abertura entre os dedos 1 e 4 que abrange 6 casas no violão enquanto uma meia pestana é executada com o dedo 1 nas cordas 4,5 e 6 para que a linha melódica possa ser executada legato.

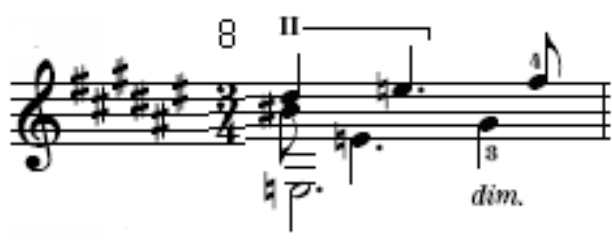

Valsa de Outono - Sérgio Assad

Encontramos um pequeno erro na edição desta valsa feita pela editora Doberman - Yppan, na digitação correta a passagem seria executada com os dedos 4 e 3 .

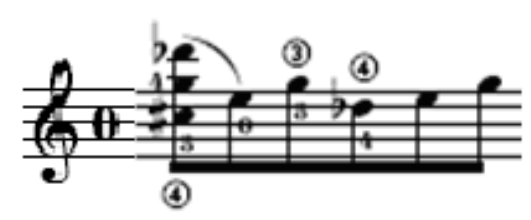

Digitação Original

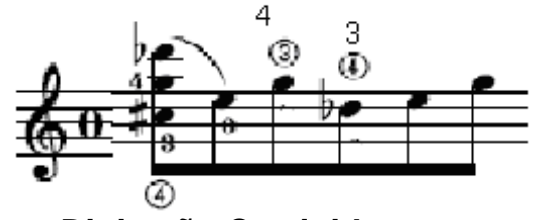

Digitação Corrigida

Nos primeiros 12 compassos da parte B da Valsa de Outono encontram-se diversas escalas e arpejos em semicolcheias. Nestas passagens as cordas soltas e as digitações propostas propiciam facilidade técnica e fluência instrumental para a sua execução e demonstram o conhecimento da escrita instrumental do compositor quando lhe é requerida a escrita de obras de dificuldade moderada como no caso desta, que foi concebida como peça de confronto para um concurso de interpretação violonística. Tomamos como exemplo o presente trecho no compasso 40 para exemplificar a escrita: 


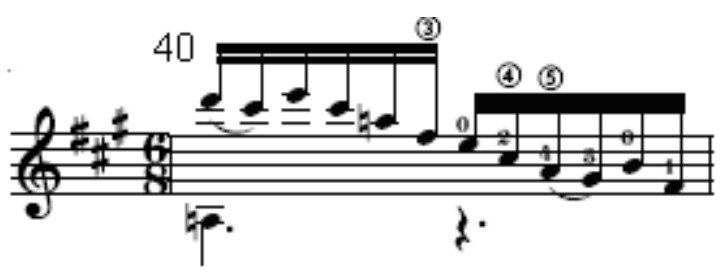

Valsa de Outono - Sérgio Assad

A utilização de cordas soltas em passagens de tal natureza é uma constante na escrita instrumental de Sérgio Assad e assim como em Valsa de Outono, esse recurso é explorado pela primeira vez na obra para violão solo na coda de Divertimento.

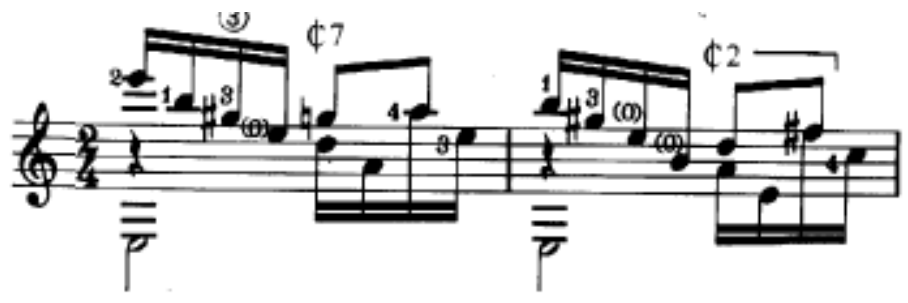

Divertimento - Sérgio Assad, coda

Encontramos no comp. 9 de Saltitante, da coleção Seis Brevidades, um trecho em que vários ligados descendentes são executados sobre cordas soltas, tornando a passagem fluente instrumentalmente. A facilidade técnica proporcionadas pelas cordas soltas presente no trecho, nos sugere que 0 compositor elaborou a peça como uma obra de virtuosismo técnico em andamento rápido. Percebemos que em diversas obras de Assad que o emprego de cordas soltas é utilizado para que passagens velozes se tornem fluentes no andamento proposto pelo compositor.

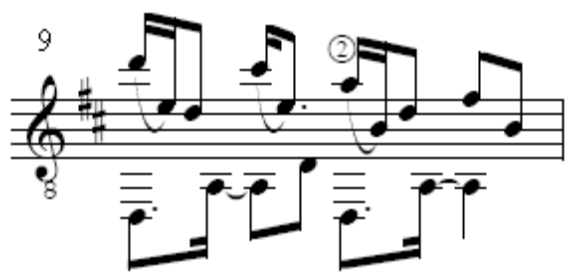

Saltitante - Sérgio Assad 
Chuva, a primeira peça da coleção Seis Brevidades, o compositor utilizou o modo fá lídio e uma scordattura ${ }^{201}$ em que a corda mi (6), é afinada meio tom acima. Tal afinação facilita a execução ao prover o executante com a tônica desta peça na sexta corda e outros graus da escala de fá lídio através das demais cordas soltas.

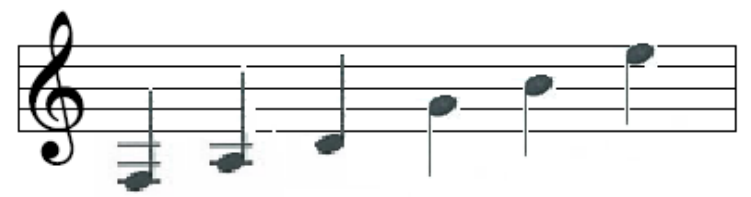

Afinação para Chuva - Sérgio Assad

Apesar de tratar-se de uma afinação incomum na literatura violonística, encontramos um precedente para esta afinação em diversas obras do compositor e violonista espanhol Fernando Sor $(1778-1839)^{202}$.

Nos compassos 9 e 10 de Chuva, sugerimos como digitação alternativa, a utilização da corda sol (3) para a execução da linha melódica iniciada no terceiro tempo do nono compasso, preservando assim a unidade timbrística ao utilizar apenas uma corda na execução da melodia citada.

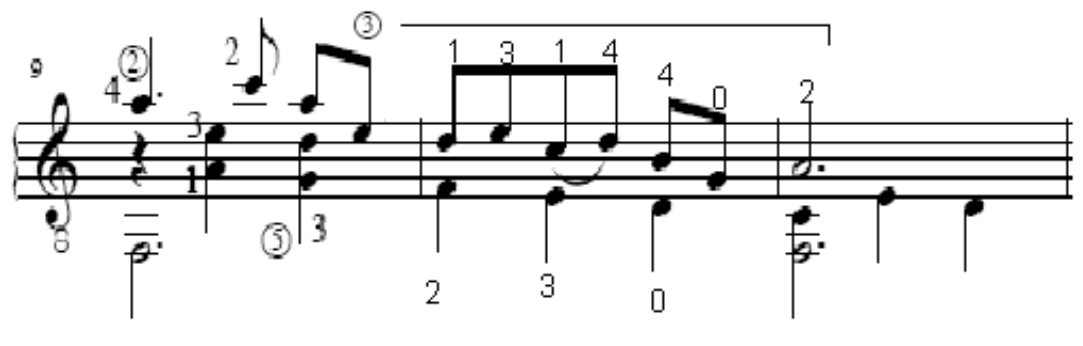

Chuva - Sérgio Assad

Por inferir a uma obra ainda não editada, sem digitação em diversos trechos, sugerimos aos compassos 13, 14 e 25, dedilhados que foram elaborados pelo autor deste texto visando uma maior facilidade de execução às passagens citadas.

${ }^{201}$ Alteração sobre a afinação usual do instrumento.

202 SOR, Fernando, Complete Guitar Works, The New Complete Works for Guitar Solo and Guitar Duet, Tecla editions, Londres 2004. 

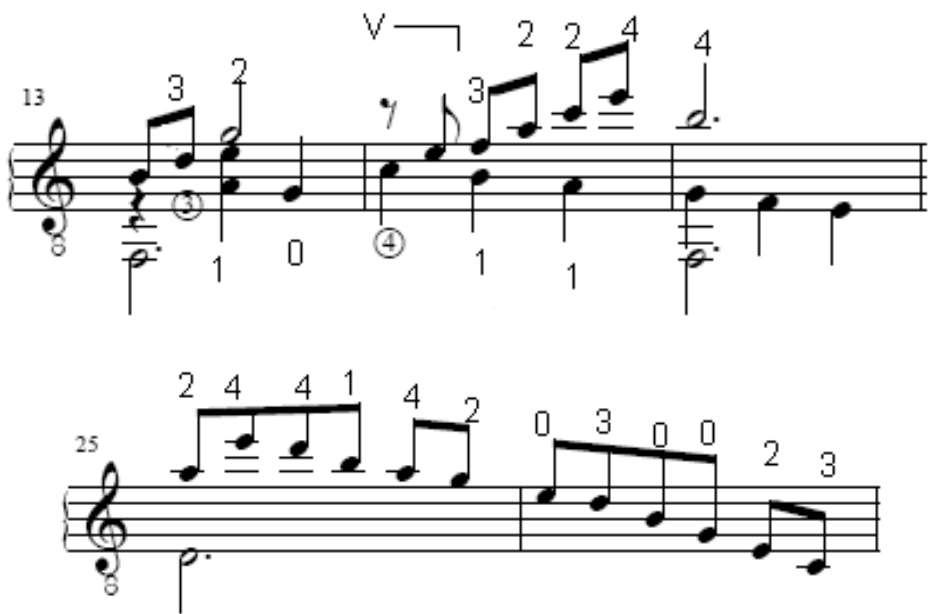

Chuva - Sérgio Assad

Em Tarde, da mesma coleção, um aspecto observado presente na elaboração desta peça foram algumas dificuldades técnicas geradas pelas diversas modulações presentes. Em diversas obras do compositor, muitas dificuldades são geradas por recursos musicais que precedem a prática instrumental assim como em diversos momentos de Aquarelle, onde (tal) prática é iniciada. Alguns dos trechos quando transpostos a uma nova tonalidade apresentaram dificuldades como o trecho presente no compasso 15 a 21, onde as notas sustentadas na voz de soprano somadas ao tema na voz de baixo e o acompanhamento nos levaram a procura de uma digitação alternativa para a resolução técnica da passagem ${ }^{203}$.

${ }^{203}$ Devemos ressaltar a correção na digitação encontrada no compasso 17 cujo sinal para a execução da pestana encontrada na nona casa foi corrigida para a oitava para uma grafia correta das notas presentes. 


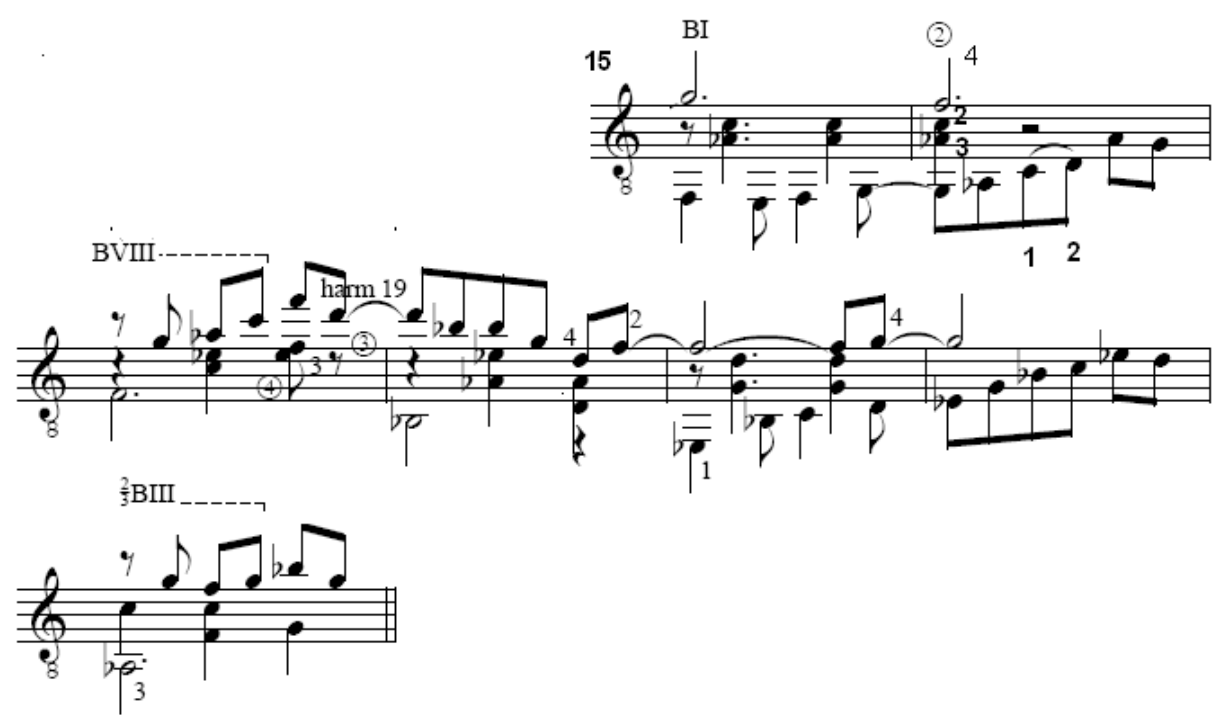

Tarde-Sérgio Assad

Um recurso instrumental explorado por Assad em Feliz é a repetição de uma determinada passagem em cordas diferentes, obtendo assim variação timbrística em um determinado trecho. Este recurso é indicado pelo compositor no comp. 18 pela indicação de digitação em uma repetição da passagem presente no terceiro compasso.

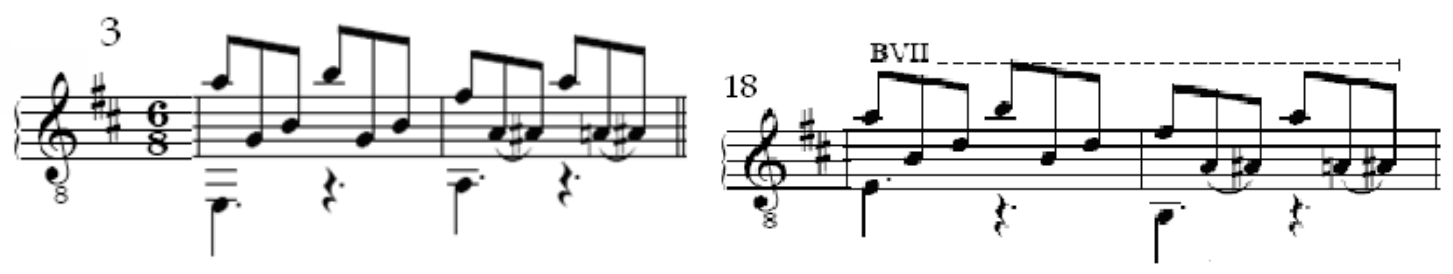

Feliz - Sérgio Assad

Nos compassos 23, 39 e 56, de Feliz, sugerimos algumas opções de digitação que podem ser adotadas pelo executante desta peça devida às dificuldades instrumentais das passagens e ausência de sugestões pelo compositor. 


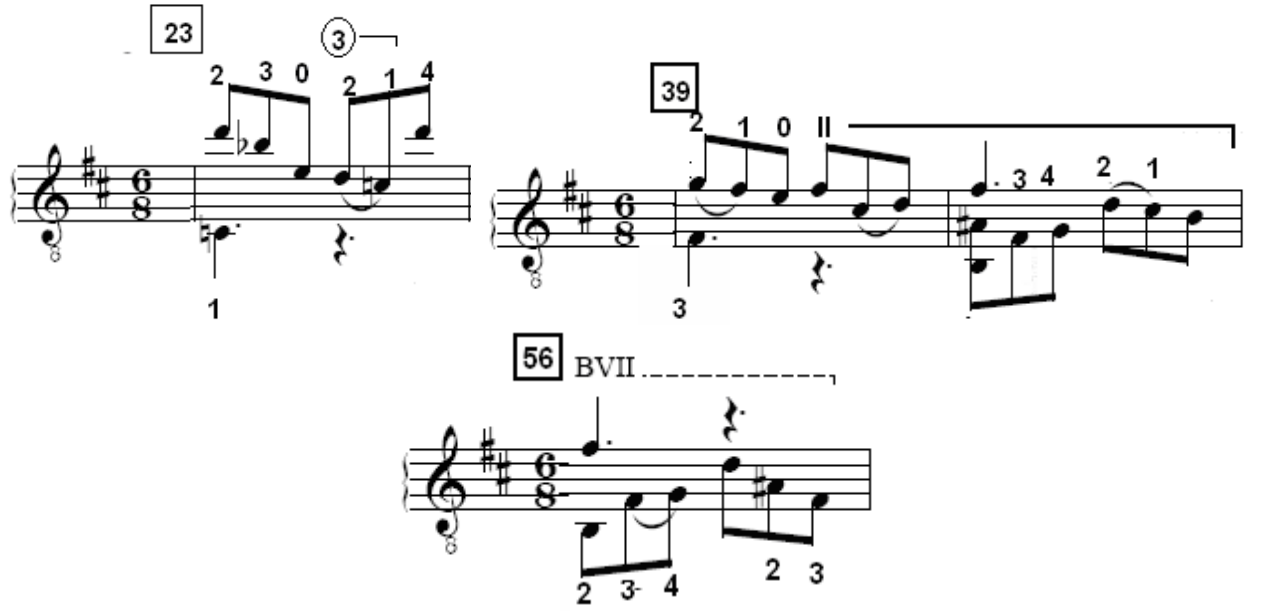

O primeiro compasso de Saltitante apresenta uma frase rítmica que é repetida diversas vezes durante a obra. Tecnicamente a passagem é facilitada por uma digitação com pestanas e nos compassos 3 e 5 apresenta uma dificuldade completar pela adição de notas sustentadas na voz de soprano, assim como detectada em diversos momentos no capítulo anterior em que a simultaneidade de elementos musicais geram situações técnicas complexas em Aquarelle. Recomendamos que seja utilizado o toque com apoio para a maior sustentação das notas longas da voz superior.

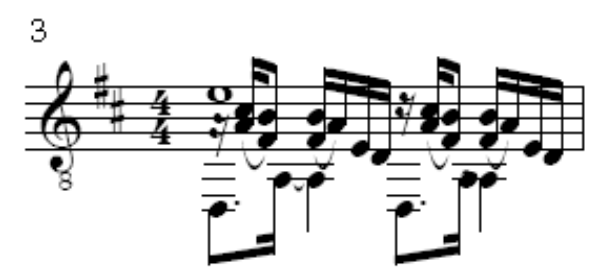

Saltitante - Sérgio Assad

O trecho presente entre os compassos 25 a 33 apresenta a maior complexidade instrumental desta peça devida à densidade da textura empregada e as diversas aberturas instrumentais necessárias para a sua execução. Podemos destacar a abertura presente no quarto tempo do compasso 30 em que há a execução da nota ré na voz de soprano na décima casa na corda mi (1), enquanto simultaneamente no baixo é executada uma nota sol na corda mi (6) causando a abertura. Devemos ressaltar que a nota 
presente na voz de soprano é sustentada nos compassos seguintes, porém devida às características estruturais do violão e sua sustentação de notas limitada, consideramos a passagem como apenas a intenção musical do compositor, sem uma possibilidade prática de execução.

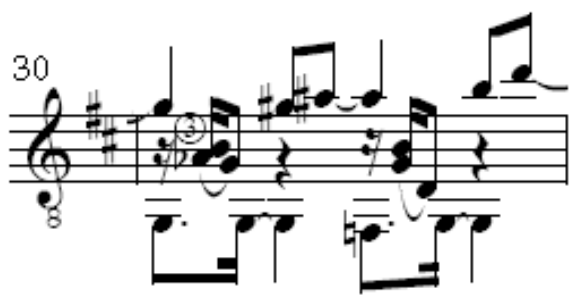

Saltitante - Sérgio Assad

No compasso 15 do terceiro movimento de Sonata encontramos uma passagem onde é elaborada melodia acompanhada sobre uma textura arpejada de maneira similar à encontrada na seção da toccatina do terceiro movimento de Aquarelle, demonstrando na recorrência deste recurso uma das características da escrita instrumental de Assad.

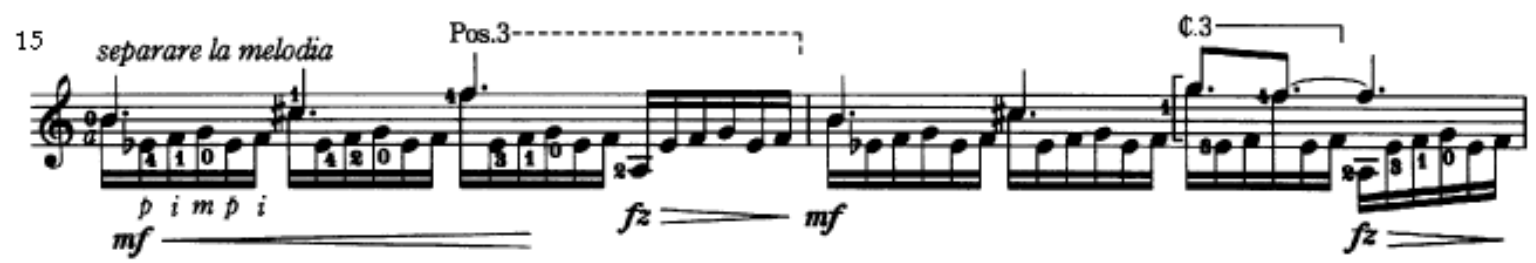

Sonata - Sérgio Assad (3 Movimento)

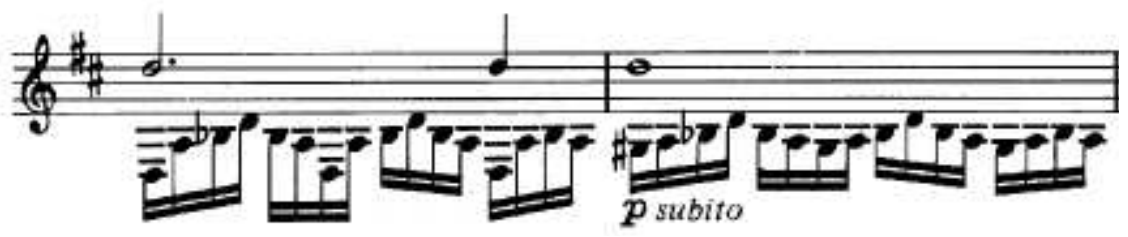

Prelúdio e Toccatina - Sérgio Assad compasso 117

\subsection{Técnicas estendidas}


Embora tenha sido analisado no capítulo anterior que em Aquarelle Sérgio Assad se baseou em sua maior parte na técnica tradicional do instrumento, percebemos que em suas obras posteriores foram utilizadas técnicas incomuns à escrita violonística. Neste item comentaremos a utilização destas técnicas e seu emprego na obra para violão solo do compositor.

Ao final de Fantasia Carioca, detectamos uma passagem contida entre os compassos 227 a 236 onde são executados arpejos em que as notas de baixo são percutidas com apenas a mão esquerda apenas, gerando uma sonoridade incomum à passagem ${ }^{204}$.

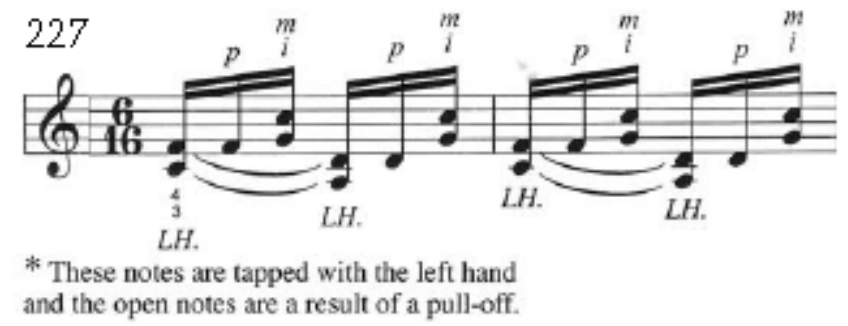

Fantasia Carioca - Sérgio Assad

Um recurso incomum utilizado nos primeiros oito compassos da obra Jobiniana $n^{\circ}$ 3, é a utilização de harmônicos artificiais ${ }^{205}$ em conjunção com notas pinçadas. Esta técnica produz um efeito inusitado ao unir harmônicos executados nas cordas mais graves juntamente com notas com a um tom de distância nas primas. Este efeito cria uma textura semelhante ao que ouvimos em escalas executadas em campanelas ${ }^{206}$ e em obras para duo de violões, cuja junção de diversas sonoridades instrumentais em instrumentos diferentes cria uma determinada sonoridade explorada pelo compositor. Este exemplo ilustra a maneira em que a experiência como arranjador para o Duo Assad transporta-se à escrita para violão solo, gerando recursos incomuns.

\footnotetext{
${ }^{204}$ Apesar de peculiar, novamente encontramos um precedente para o emprego deste recurso na linguagem improvisatória de Egberto Gismonti.

${ }^{205}$ São harmônicos obtidos a partir de uma nota executada ao braço do violão com a execução do harmônico pelo instrumentista uma oitava acima da nota digitada. O recurso de junção de notas pinçadas com harmônicos artificiais é explorado pela primeira vez na escrita para violão solo em Aquarelle no compasso 133 a 136 do primeiro movimento Divertimento, porém com os harmônicos na voz superior e as notas pinçadas na voz inferior.

${ }^{206}$ Ver item 2.5.
} 


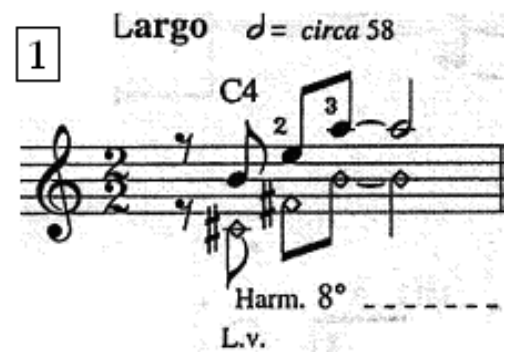

Jobiniana nº3 - Sérgio Assad

No segundo compasso da mesma obra, encontramos a textura citada anteriormente sendo transposta meio tom abaixo seguindo uma forma de acorde formado por intervalos de quartas justas. Esta passagem demonstra a preferência do compositor pelas transposições naturais do instrumento, porém atendo à sua marca pessoal, que seria este tipo de recurso utilizado de maneira complexa, ao tratar-se de uma transposição acrescida dos harmônicos artificiais citados no anteriormente. Durante diversos momentos de Divertimento, como entre os compassos 96 a 101, detectamos este tipo de transposição instrumental ${ }^{207}$.

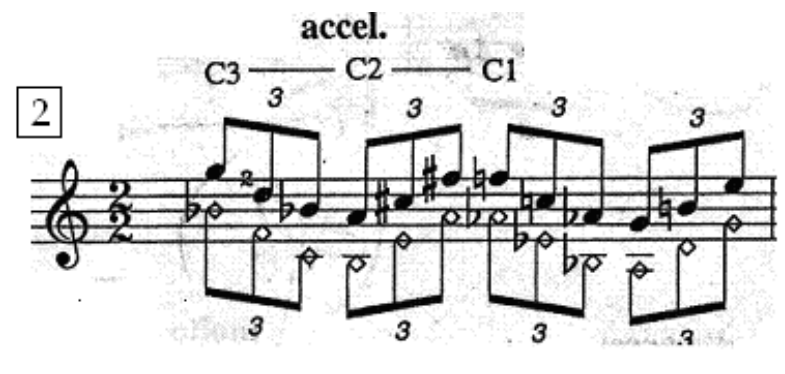

Jobiniana nº3 - Sérgio Assad

O compasso 36 da mesma obra demonstra novamente a utilização do recurso de harmônicos naturais e artificiais com uma peculiaridade que desta vez se traduz em um harmônico que deve ser executado sobre a nota fá no que seria a vigésima quinta casa, assim como detectado no compasso 140 de Divertimento. Ao referir-se a uma região inexistente na maioria dos violões utilizados por concertistas, este trecho gera uma dificuldade em executar 0 harmônico citado por não haver um traste para a utilização como referência visual $^{208}$.

\footnotetext{
${ }^{207}$ Ver capítulo 2 item 2.5.1.

${ }^{208}$ Novamente remetendo à peculiar técnica instrumental de Egberto Gismonti como vimos anteriormente no item 2.5.1.
} 


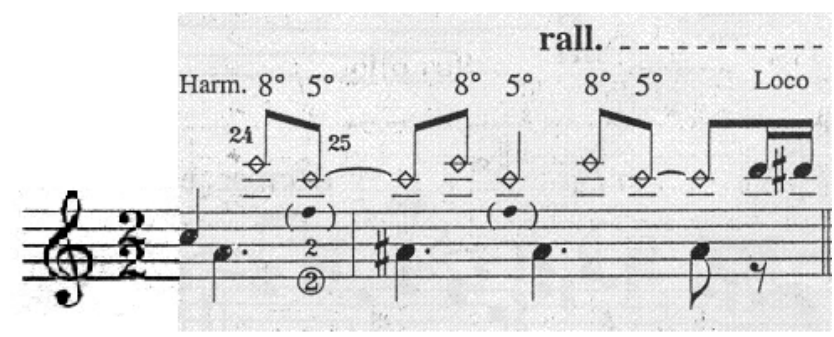

Jobiniana no3 - Sérgio Assad

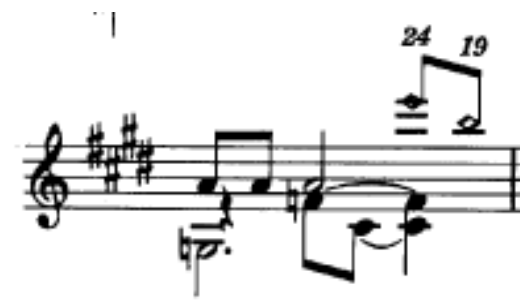

Divertimento - Sérgio Assad comp. 140

O primeiro movimento da obra Three Greek Letters, $\mathrm{Pi}$, apresenta em seu primeiro compasso a utilização da execução de bends ${ }^{209}$ de um quarto de tom, remetendo assim à música folclórica da região do sudeste europeu. Essas notas formam no terceiro compasso o tema principal da peça, que é acompanhado por harmônicos naturais executados na décima segunda casa até o compasso 12 .

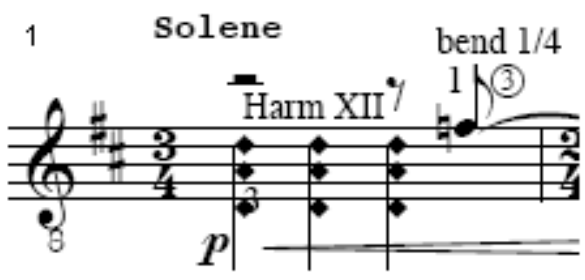

PI-Sérgio Assad

Detectamos na obra no compasso 2 da peça Abaeté, da série Três

Divertimentos, um ligado executado pela mão esquerda com uma ligeira distorção na altura na nota tocada ${ }^{210}$.

\footnotetext{
${ }^{209}$ Técnica que consiste em puxar as cordas do instrumento lateralmente, obtendo assim um efeito de alteração da afinação para cima com um leve glissando da nota natural. Por tratar-se de uma técnica incomum ao instrumento e conseqüentemente à obra do compositor pesquisado, incluímos o comentário sobre a passagem citada como curiosidade e como exemplo da utilização desta técnica na obra.

${ }^{210} \mathrm{Na}$ partitura encontramos em inglês a seguinte instrução: "Tapping left hand with slight distortion." Ou seja: "Tapping" com a mão esquerda com leve distorção. (tradução nossa). Novamente decidimos comentar a passagem, haja vista a técnica incomum dentro da literatura do instrumento, porém encontrada em profusão em improvisações ao violão executadas por Egberto Gismonti e apontar um exemplo da utilização de tal efeito por Assad.
} 


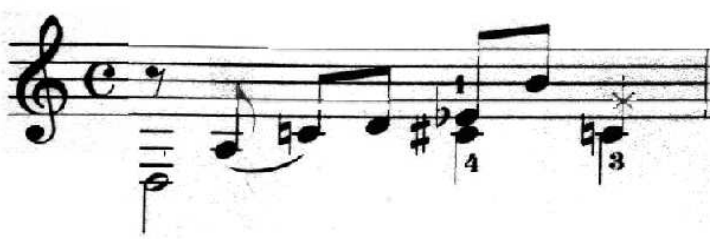

Abaeté - Sérgio Assad

Alguns compassos a seguir, mais precisamente nos compassos 4, 8, 9 e 10, encontram-se mordentes escritos em tercina de semicolcheia, um artifício instrumental comum na escrita violonística do compositor ${ }^{211}$.

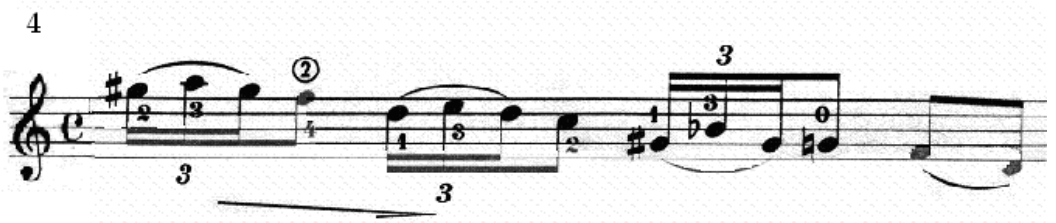

Abaeté - Sérgio Assad

Ao fim de Chuva, no compasso 44, o compositor instrui que se mude a afinação da sexta corda (6) de fá meio tom abaixo de volta a mi. Não possuindo informações precisas sobre esta passagem, indagamos ao compositor sobre esta passagem via correio eletrônico e este nos instruiu a executá-la com uma rápida mudança de afinação enquanto as cordas soltas do arpejo existente na passagem são executadas.

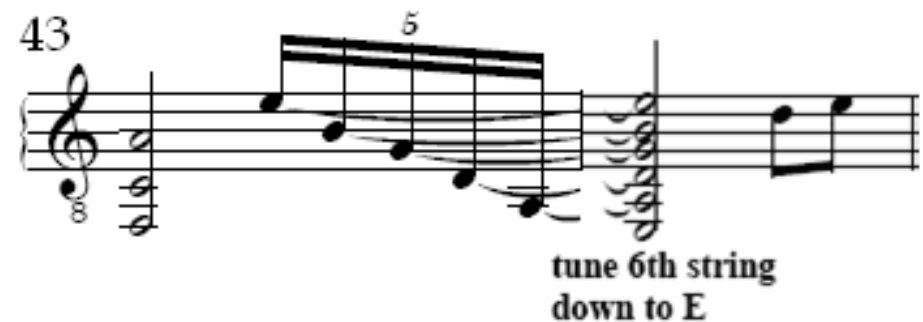

Chuva - Sérgio Assad

Neste capítulo percebemos o papel que Aquarelle teve como obra matriz para com o restante da produção para violão solo de Sérgio Assad ao detectarmos como diversos de seus aspectos se refletem sistematicamente em diversas de suas obras posteriores. Verificamos também que a escrita de

${ }^{211}$ Este recurso encontra-se em profusão nas obras do compositor tal como Valseana, Sonata, Three Greek Letters e Jobinana no3. 
Aquarelle revela um compositor que já havia alcançado a maturidade musical, visto que esta obra se torna referencia para a sua estética composicional. 


\section{Conclusão}

Neste trabalho foi possível reconhecer que a linguagem estética praticada por Sérgio Assad foi a princípio, fruto de um conflito entre seu ambiente familiar que praticava a música popular, com a rigorosa formação que recebeu como intérprete da professora Monina Távora e em parte de compositor, da professora Esther Scliar. Partindo deste princípio, atuaram as diversas influências vindas de um amplo campo da música popular tendo como referência o percurso de compositores como Radamés Gnattali e Astor Piazzolla, um exemplo gerado pela motivação de Assad para a atividade composicional resultante da sua vocação natural de arranjador que foi revelada por seu público.

A dicotomia entre a fusão dos campos do popular e do erudito, gerou uma obra para violão que pelos seus conteúdos, pode ser considerada como híbrida e admitida em um contexto estético voltado ao pós-modernismo.

Em sua produção para violão solo destacamos a sua primeira obra, Aquarelle, por se tratar de uma composição em que são percebidos diversos traços de uma linguagem estética, que mesmo se tratando de sua primeira obra para violão solo, já se encontrava estabelecida. Tal fato nos levou a uma análise musical de Aquarelle com o objetivo de detecção destas influências e sua manifestação na obra.

Constatamos ao analisar a obra que o fato de Sérgio Assad ter desenvolvido um sólido trabalho como arranjador e compositor para o duo de violões, influiu na sua escrita para violão solo, visto que em diversas passagens a concepção polifônica é predominante, gerando passagens desafiadoras aos interpretes de sua música. Ao analisarmos a estruturação harmônica de Aquarelle vimos que sua linguagem se encontra atrelada ao impressionismo francês e aos gêneros populares que sofreram a sua influência. Sua abordagem rítmica remete a diversos gêneros populares brasileiros ao adotar figuras rítmicas sincopadas cujas diversas variações e similaridades detectadas fazem com que este aspecto se torne um elemento de coesão. Detectamos em sua elaboração motívica elementos que conferem à obra uma unidade temática 
e demonstram a capacidade do compositor na criação de uma obra que desafia o instrumentista ao gerar diversas situações interpretativas que impõem o pleno domínio do texto musical e de práticas de execução instrumental.

A análise de Aquarelle conduziu também a concluir o fato de tratar-se de uma obra matriz na produção de Assad, visto que encontramos reflexos desta por toda a produção subseqüente para violão solo até o momento, como visto anteriormente em aspectos como elaboração motívica, estruturação harmônica, elaboração rítmica e escrita instrumental. Tal observação nos leva a crer que Aquarelle é uma obra modelar dentro da produção de Sérgio Assad e que serve de referência para o entendimento de sua obra como um todo.

Visto que o compositor se encontra em plena atividade, propomos que este trabalho seja visto como um ponto de partida para investigações futuras. 


\section{Bibliografia}

\section{Livros, Tratados, Métodos e Similares}

BERNWARD, Bruce, SACKER, Marilyn. Music in Theory and Practice, vol. II, Nova lorque: McGraw Hill Higher Education, 1997.

BUCKNIX, Boudewijn. O Pequeno Pomo, ou a história da música do pósmodernismo. Cotia: Ateliê editorial, 1994.

CARLEVARO, Abel. Escuela de la Guitarra: exposicion de la teoria instrumental. Bueno Aires: Barry Editorial, 1979.

CARLEVARO, Abel. Guitar masterclass vol. 3. Heidelberg: Chaterelle, 1988.

CHEDIAK, Almir. Harmonia e Improvisação, vol.1 e 2. São Paulo: Lumiar Editora 1979.

CHEDIAK, Almir. Songbook Tom Jobim, vol. 2. São Paulo: Lumiar Editora, 1990.

CHEDIAK, Almir. Songbook Tom Jobim, vol. 3. São Paulo: Lumiar Editora, 1990.

FARIAS, Nelson. A arte da improvisação. São Paulo: Lumiar Editora, 1991.

KOELLREUTER, Hans. Joachin. Harmonia Funcional: introdução à teoria da funções harmônicas. São Paulo: Editora Ricordi, 1978.

MENESES, Flôrivaldo. Apoteose de Schoenberg. Cotia: Ateliê Editoria, 2002.

OTTMAN, Robert W. Advanced Harmony, Theory and Practice. New Jersey: Prentice Hall, 2000.

PAZ, Ermelinda A. O Modalismo na Música Brasileira. Brasília: Editora Musimed, 2003.

PERLE, George. Serial composition and atonality, an introduction to the music of Schoenberg, Berg and Webern. Los Angeles: University of California Press, 1991.

PERSICHETTI, Vicent. Armonia Del Siglo XX. Madri: Real Madrid Editores, 1985.

PUJOL, Emilio. La Escuela Razonada de La Guitarra, vol. IV. Buenos Aires: Ricordi Americana, 1971.

ROSS, Alex. O Resto é Ruído, escutando o século XX. São Paulo: Companhia das Letras, 2007. 
SCHOENBERG, Arnold. Harmonia, São Paulo: Editora Unesp, 2001.

SCHOENBERG, Arnold. Princípios Fundamentais da Composição Musical. Tradução de Eduardo Seincmann, São Paulo: Edusp, 2001.

SHER, Chuck. The Latin Real Book. Petaluma: Sher Music, 1999.

TENNANT, S. Pumping Nylon, Van Nuys: Alfred Publishing, 1995.

TINHORÃO, José Ramos. Pequena História da Música Popular, São Paulo: Círculo do Livro, 1978.

WADE, Graham. Segovia: A celebration of the man and his music by Graham Wade. London: Alisson \& Busby, 1993.

WHITTALL, Arnold. Musical Composition in the Twentieth Century. Oxford: University Press, 1999.

\section{Teses e Monografias}

CORREA, Márcio Guedes, As Escolhas Instrumentais de Radamés Gnattali no Concerto Carioca nำ. São Paulo Escola Estadual Paulista "Júlio de Mesquita Filho" Instituto de Artes - São Paulo, São Paulo, 2007.

GLOEDEN, Edelton. O Ressurgimento do Violão no Século XX: Miguel Llobet, Emilio Pujol e Andrés Segovia. São Paulo Escola de Comunicação e Artes, Universidade de São Paulo, São Paulo, 1996.

FREITAS, Sergio Paulo Ribeiro de. Teoria da harmonia na música popular: uma definição das relações de combinação entre os acordes na harmonia tonal. Dissertação de Mestrado. São Paulo: Universidade Estadual Paulista, São Paulo, 1995.

LOPES, Gustavo Magalhães. De pés-de-parede a festivais: um estudo de caso sobre o repente nordestino na grande São Paulo. Dissertação de Mestrado. Campinas, Universidade Estadual de Campinas, Campinas, 2001.

MORAIS, Luciano César. Sérgio Abreu: sua herança histórica, poética e contribuição musical através de suas transcrições para violão. São Paulo Escola de Comunicação e Artes, Universidade de São Paulo, São Paulo, 2007.

OLIVEIRA, Ledice Fernandes de. Radamés Gnattali e o Violão: Relação entre os campos de produção da música. Universidade Federal do Rio de Janeiro, Rio de Janeiro, 1999. 
OLIVEIRA, Thiago Chaves de Andrade. Análise Estético-instrumental da obra Aquarelle de Sérgio Assad. Departamento de Música e Artes Cênicas, Universidade Federal de Uberlândia, Uberlândia, 2006.

PRANDO, Flávia Rejane. Othon Salleiro: Um Barrios Brasileiro? Análise da linguagem instrumental do compositor-violonista. (1910 - 1999). Escola de Comunicação e Artes, Universidade de São Paulo, São Paulo, 2008.

\section{Revistas Especializadas}

CASTAGNA, Paulo \& ANTUNES, Gilson. 1916, O Violão Brasileiro já é uma arte. Revista Cultura Vozes, №1, ano 88, jan./fev., p. 37 - 51,1994.

GODOY, Sibila. Dança das Cabeças: A trajetória Musical de Egberto Gismonti. Revista Pesquisa e Música, Conservatório Brasileiro de Música, Rio de Janeiro vol. 5, p $58-65,2000$.

GROTMOL, Tom. Sérgio and Odair Assad. Soundboard Magazine, vol. XXIII n.3 Guitar Foundation of America, Claremont, 1997, p 13 a 16.

HODEL, Brian. 20th Century Music and the Guitar, Part 2: 1945 - 2000. Guitar Review, Agustin Publishers, Nova lorque, dezembro 2000. p. 8 - 18.

LIMA, Daniel de. Progressão dos conjuntos em Paisaje Cubana con Campañas de Leo Brouwer. Trabalho apresentado no I Simpósio Acadêmico da EMBAP. Out 2007.

OLIVEIRA, Ledice Fernandes de. Radamés Gnattali's Guitar Works. Soundboard Magazine, vol. XXVII n.1 Guitar Foundation of America, Claremont, 2002, p 43 a 48.

REVISTA VIOLÃO PRÓ, Entrevista com os Irmãos Assad, n, 10. Editora Música e Mercado, São Paulo janeiro de 2007 p 22 a 27.

SABA, Théresè Wassily. Roberto Aussell - Tristón. Classical Magazine, Março de 2007, Ashley Mark Publishing Company, Blayton Upon Tyne, 2007, p 11 a 16.

TABORDA, Marcia. The Birth of the Choro. Soundboard Magazine, vol. XXIX n.2 Guitar Foundation of America, Claremont, 2002, p 9 a 15.

\section{Partituras}

ASSAD, Sérgio. Aquarelle. Cópia de partitura em manuscrito, Paris Abril 1988.

ASSAD, Sérgio. Aquarelle. Paris: Henry Lemoine Editions, 1992. 13p. 
ASSAD, Sérgio. 3 Divertimentos. San Francisco: Guitar Solo Publications, 1996.

ASSAD, Sérgio. Fantasia Carioca. Cópia de partitura em manuscrito, 1998.

ASSAD, Sérgio. Fantasia Carioca. Chanterelle 2001.

ASSAD, Sérgio. Sonata. Tókio Gendai Magazine, 1999.

ASSAD, Sérgio Three Greek Letters GSP, 2000.

ASSAD, Sérgio. Valsa de Outono. Quebec, Editora Doberman - Ypan, DO 654, 2008.

BARRIOS A., The Complete Guitar Works of Agustín Barrios Mangoré. Edited By Richard Stover. Belwin Mills Publishing Corp. Melville 1977.

CARLEVARO, Abel. Prelúdios Americanos. Bueno Aires: Barry Editorial, 1969.

DEBUSSY, Claude. Complete Preludes, Books 1 And 2,

DEBUSSY, Claude. Estampes,. Editions Durand, Paris DD1568100.

DEBUSSY, Claude. Suite Bergamasque. Dover Edition. HN381,

GIULIANI, Mauro. 24 Estudos para Violão Opus 48, editado por Hans Ritter. Nova lorque: Schott Music Corp.

KOSHKIN, Nikita. Romance. Cambridge Music Works. Cambridge, 1996.

PIAZZOLLA, A. Adiós Nonino. Arranjo para violão solo de agustín Carlevaro. Guitar Solo Publications GSP03 San Francisco.

SCHOENBERG, Arnold. Fünf Klavierstücke op. 23. Edition Wilhelm Hansen, Copenhague, MS.WH18298.

SOR, Fernando, Complete Guitar Works, The New Complete Works for Guitar Solo and Guitar Duet, Tecla editions, Londres 2004.

VILLA-LOBOS, Heitor. Cinco Prelúdios para Violão. Editora Max Eching. Paris 1951.

WALTON W. Five Bagatelles for Guitar.Oxford University Press, Oxford,1974.

\section{Gravações em CD e MP3}

AVERS, Randall. Vistas, 20th Century Music From the Americas, PIMA Productions 1996. 
AVERS, R., Valseana: download de arquivo em mp3. Madrid 2003. Disponível em: http://www.guitarramagazine.com. Acesso em 23/05/2004.

BARRUECO, Manuel. Nylon and Steel, Angel Records, B00005ICL0, 2000.

BARRUECO, Manuel. Sometime Ago, EMI, B000002SKO, 1998.

DEVINE, Graham. Guitar Collection - Manha De Carnaval, Naxos B0001N9ZE8, 2004.

DUO ASSAD. Alma Brasileira, Nonesutch, B000005IYY,1988.

DUO ASSAD. Heitor Villa-Lobos: Obra Completa Para Violão Solo, Kuarup KCD 139, 1978.

DUO ASSAD, Jardim abandonado, Nonesuch, B000UKW4ZO, 2007.

DUO ASSAD. Latin American Music for Two Guitars. Nonesutch, B000005IYY 1985, relançado em 1993.

DUO ASSAD. Latino America, com a Orquestra Armorial, Continental, (1- 035404 - 006). Elektra/Asylum/Nonesuch \#79116, 1974.

FERNANDEZ, Eduardo. J.S.Bach: Complete Suites for Lute, Decca 421-434-2, 1989.

FERNANDEZ, Eduardo. Legnani - Giuliani Diabelli - Paganini - Sor. Decca 414160-1,1990.

FUKUDA, Shin-Ichi. Aquarelle, Jvc Victor, B00005GVL5, 1994.

GAQUERE, Boris. Xeque Mate. VGo Recordings VG 1004, 2001.

GISMONTI, Egberto. Sanfona Ecm Records, B00000DTEU, 1980.

GISMONTI, Egberto. Live at the 87 Festival in Freiburg Proscenium - CDV Germany, 6301293304, 1993.

ISAAC, Eduardo. 20th Century Guitar Music Vol.II, GHA 126019, 1995.

RUSSELL, David. Aire Latino. Telarc, 80612, 2004.

RUSSELL, David. For David, Music Written for David Russell, Guitar Telarc International - 80707, 2009.

RUSSELL, David. Message of the Sea Telarc International - 80525, 1998.

VIANNA, Aliéksey. Vianna plays Assad. GSP Recordings San Francisco, GSP 1027 CD, 2005. 


\section{Dicionários}

BALL B. Concise Dictionary of Music. Tiger Books International PLC, Londres, 1993.

DIVERSOS AUTORES. Grove Dictionary for Musicians. Macmillan Publishers Ltd. 2001.

DIVERSOS AUTORES, Hal Leonard Pocket Music Dictionary. Hal Leonard Music Publishing, Londres 1993.

MICHAELS, Ulrich. Atlas de Música Vol. II: Do barroco à Actulidade. Gradiva Publicações LTDA. Lisboa, 2007.

\section{Internet e demais recursos eletrônicos}

ANTIGONI GONI CLASSICAL GUITAR. Website oficial da violonista Antigoni Goni. Disponível em http://www.antigonigoni.com/main.htm. Acesso em $\underline{15 / 02 / 2009}$.

BOUDEWIJN BUCKINIX, Website oficial do compositor Boudewijn Buckinx, disponível em http://www.boudewijnbuckinx.com/. Acesso em 17/03/2009.

CONTRERAS, A. La Técnica de David Russell en 165 Consejos, edição autorizada em arquivo PDF disponível em http://guitarra.artelinkado.com/guitarra/archivos/david_russell_165.pdf, Sevilha, 2004

DAVID RUSSELL OFFICIAL WEBSITE, website oficial do violonista David Russell, disponível em: http://www.davidrussellguitar.com/. Acesso em 01/03/2008.

GNATTALI, Radamés, Website do Compositor Radamés Gnattali. Disponível em: http://www.radamesgnattali.com.br/site/index.aspx?lang=port. Acesso em01/05/2009.

HULL Andrew. Guitarra http://www.guitarramagazine.com/ViannaPlaysAssad acesso em 15/04/2006.

EDUARDO FERNANDEZ: Official Website. Disponível em: http://www.seiscuerdas.com/fernandez/ acesso em 31/03/2008.

INTERVIEW WITH SÉRGIO ASSAD. Revista eletrônica guitarra. Madrid n.9, out. $2003 . \quad$ Disponível em: 
http://www.guitarramagazine.com/Issue42/interview_assad.asp. Acesso em 30 de janeiro 2004

INSTITUTO JACOB DO BANDOLIM. Website em homenagem ao Bandolinista Jacob do Bandolim. Disponível em: http://www.jacobdobandolim.com.br. Acesso em 30/03/2009.

KENION J.: lista de composições de Sérgio Assad. The Assad's Unofficial Website. Disponível em: http://net.indra.com/ jkenyon/assad.html

THE OFFICIAL WEBSITE OF GEORGE AND IRA GERSHWIN, Website oficial dos irmãos Gershwin. Disponível em http://www.gershwin.com, acesso em 01/04/09.

VINCENS, Guilherme. Myspace do violonista Guilherme Vincens. Disponível em WWW.myspace.com/guilhermevincens. Acesso em 01/03/2009.

VIOLÃO MANDRIÃO. Website dedicado ao violão. Disponível em: www.violaomandriao.mus.br/ acesso em 31/03/2008.

ZANON, Fábio, Fórum de Violão Erudito: $A$ Arte do Violão, Roteiro do Programa 24. São Paulo 10/2003. Disponível em: http://www.geocities.com/thiagomagalhaes. Acesso em 15/11/2004.

ZANON, Fábio. O violão no Brasil depois de Villa-Lobos. Revista do Itamaraty. Disponível em: http://www.mre.gov.br/dc/textos/revista12-mat12.pdf. Acesso em 15/12/2008. Acesso em 15/12/2008.

ZANON, Fábio, Violão com Fábio Zanon. Áudio do programa de rádio dedicado a Radamés Gnatalli I. Disponível em: http://vcfz.blogspot.com/2006/08/35-srgioassad.html. Acesso em01/05/2009.

ZANON, Fábio, Violão com Fábio Zanon. Áudio do programa de rádio dedicado a Radamés Gnatalli II. Disponível em: http://vcfz.blogspot.com/2006/08/35srgio-assad.html. Acesso em01/05/2009.

ZANON, Fábio, Violão com Fábio Zanon. Áudio do programa de rádio dedicado a Radamés Gnatalli III. Disponível em: http://vcfz.blogspot.com/2006/08/35srgio-assad.html. Acesso em01/05/2009.

ZANON, Fábio, Violão com Fábio Zanon. Áudio do programa de rádio dedicado a Radamés Gnatalli IV. Disponível em: http://vcfz.blogspot.com/2006/08/35srgio-assad.html. Acesso em01/05/2009.

ZANON, Fábio, Violão com Fábio Zanon. Áudio do programa de rádio dedicado a Sérgio Assad. Disponível em: http://vcfz.blogspot.com/2006/08/35-srgioassad.html Acesso em 15/11/2007.

\section{Entrevistas}


Assad, Sérgio. Entrevista conduzida por Luciano César Morais em São Paulo/SP 08/2006.

Avers, Randall. Entrevista conduzida via E-mail por Thiago Oliveira em 2005.

Meirinhos, Eduardo. Entrevista conduzida em Uberlândia por Thiago Oliveira (MG) em 08/2005.

Russell, David. Entrevista conduzida via E-mail por Thiago Oliveira em 2005

Vianna, Aliéksey. Entrevista conduzida por Thiago Oliveira em Belo Horizonte (MG) em 11/2005. 


\section{ANEXOS}

Lista de Gravações de Aquarelle.

Discografia de Sérgio Assad.

Lista de Composições de Sérgio Assad.

Entrevista com Aliéksey Vianna.

Entrevista com David Russell.

Entrevista com Eduardo Meirinhos.

Entrevista com Randall Avers.

Entrevista com Sérgio Assad.

Cópia Xerografada de Aquarelle. 
Lista de Gravações de Aquarelle.

Título: Latin American Music for Two Guitars.

Ano: 1985

Nota: apenas a Valseana com Sérgio Assad ao violão.

Artista: Adam Holzman.

Título: Aquarelle.

Ano: 1991

Artista: Shin-Ichi Fukuda

Título Aquarelle

Ano: 1994

Artista: Eduardo Isaac

Título: 20th Century Guitar Music Vol.II

Ano: 1995

Artista Randall Avers

Título Vistas 20th Century Music From the Americas

Ano: 1996

Artista: Boris Gaquere

Título: Xeque Mate

Ano: 2001

Artista: Graham Devine

Título: Guitar Collection - Manha De Carnaval

Ano: 2004

Artista: Wang Yameng

Título: Aquarelle, Un Sueno en la Floresta

Ano: 2004 
Artista: Aliéksey Vianna

Título: Aliéksey Vianna plays Assad: Solo Guitar Works

Ano: 2005

Artista: David Russell

Título: For David: Music written for David Russell, Guitar.

Ano: 2009

Discografia de Sérgio Assad

International Rostrum of Young Performers (ano desconheçido)

Opus 9110041/2. LP duplo de vários artistas. Os irmãos Assad tocam as sonatas K303 e K432 de Scarlatti, A Lenda do Caboclo (Villa-Lobos), e Tarantelle (Petit).

Título desconheçido, música latino americana, gravado juntamente recorded com a orquestra Armorial (1977)

Continental 1-035-404-006

Os Choros de Camera (1977)

Kuarup MKCD-002. Sérgio toca o Choros n.1 (Villa Lobos).

Complete Villa-Lobos works for solo guitar (1978)

Kuarup Discos KLP 003/4

Musica Nova do Brasil (gravação solo de Sérgio) (1981)

Funarte/Promemus MMB 81.022

Marlos Nobre/Yanomani (1983)

EMI-Odeon 31 C 0634422921 
Gnattali, Rodrigo, Piazzolla (1984, CD lançado1993) GHA \#126021

Latin American Music for two guitars (1985, relançado em 1993) Elektra/Asylum/Nonesuch \#79116

Concert at the "Y" (February 3, 1983)

Cassete gratuíto ditribuido aos assinantes da revista Guitar Review. Gravado ao vivo no YMJA, Nova lorque. A maior parte deste material aparece no primeiro lançamento do Duo Assad pela gravadora GHA.

Alma Brasileira (1988, elançado em 1993)

Elektra/Asylum/Nonesuch \#79179

Violões: Projeto Memória Brasileira (1989)

Crescente CR 0009 (Brasil). O Duo Assad toca a peça Baião Malandro de egberto Gismonti ao vivo neste álbum, que é uma coletâneo de vários violonistas.

Two Concertos for Two Guitars (1991)

GHA \#126018

Play Rameau/Scarlatti/Couperin/Bach (1993)

Elektra/Asylum/Nonesuch \#79292

Natsu no Niwa Suite (1994)

GHA \#126029

The Other Side of Jobim (1992)

Chesky JD73. Nota: Este é um álbum de Ana Caram. Sérgio Assad fez os arranjos e toca neste álbum.

White Moon: Songs to Morpheus (1995) 
Elektra/Asylum/Nonesuch \#79364. Nota: Este é um album da soprano Dawn Upshaw. O duo a acompanha nas faixas 3 e 12; os arranjos das três peças são de Sérgio Assad.

Saga Dos Migrantes (1996)

Elektra/Asylum/Nonesuch \#79365.

El Tango (1997)

Elektra/Asylum/Nonesuch \#79462-2. Nota: Este é um album de Gidon Kremer, tocando a música de Astor Piazzolla. O Duo Assad acompanha nas faixas 1 e 10; os arranjos são de Sérgio além de uma outra peça em que nenhum dos Assad tocam.

Soul of the Tango (1997)

Sony SK63122. Nota: Este é um album de Yo Yo Ma; os irmãos Assad tocam a Tango Suite de Astor Piazzolla.

Fuga y misterio (1998)

GHA \#126027. Nota: Este é um album de Odair Assad (Sérgio Assad toca em duas faixas). Odair e Sérgio Assad, o violoncelista Edmond Carlier, e o violinista Fernando Suarez Paz tocam obras de Piazzolla, Lucky, e Gnattali.

Velho Retrato (1999)

EGEA Edizioni Discografiche SCA 068. Nota: Este é um álbum de duetos entre Sérgio Assad e a clarinetista Gabrielle Mirabassi. Algumas das composições são de Sérgio Assad, uma é de sua filha Clarice.

Clarice Assad (1999)

Disponível privadamente de trowbridge@guitarsudio.com. Nota: Sérgio Assad toca violão neste CD; Clarice toca piano e voz, Ethan Startzman toca contrabaixo. As composições são de Clarice e outras de compositores populares brasileiros. 
A Very Special Album (1999)

GHA 126.045. Um album lançado com vários artistas da gravadora GHA. As primeiras faixas são de Tom Jobim (Crônica da casa assassinada), em arranjos de Sérgio Assad. Há também um dueto entre Sérgio Assad e Philip Catherine (Arthur Rainbow).

Nadja Salerno-Sonnenberg Sérgio and Odair Assad (2000)

Elektra/Asylum/Nonesuch \#79505-2.

Sérgio and Odair Assad Play Piazzolla (2001)

Elektra/Asylum/Nonesuch \#79632-2. Nota: Este album contém algumas peças lançadas anteriormente dos albuns Saga Dos Migrantes e Fuga y misterio.

Obrigado, Brazil (2003)

Sony SK89935. Nota:Este é um album de Yo Yo Ma; os irmãos Assad tocam no arranjo de Sérgio da peça de Villa Lobos A Lenda do Caboclo e na peça de Sérgio Assad, Menino.

Obrigado, Brazil Live in Concert (2004)

Sony SK90970. Nota: Este é um album de Yo Yo Ma; os irmãos Assad tocam em sete das 14 faixas.

Live in Brussels (2004)

GHA 126.055. Composições de Bittencourt, Gardel, Piazzolla, Gismonti, Pixinguinha, e Chaplin.

Sérgio and Odair Assad and their Family: A Brazilian Songbook (2005) . GHA 125.158

Um momento de puro amor (2006)

GHA 125.460. (DVD) gravado juntamente com outros membros da família Assad. 
The Debut concert: Bruxelas 1983. (2006)

GHA 125.057

Jardim Abandonado (2007)

(Warner/Nonesuch $278140-2$ )

Concierto de Volos - Concierto de Aranjuez - Serenade opus 50 (ano desconheçido)

GHA 126.025. Nota: Este album é da Orquestra de Córdoba, regido por Leo Brouwer Odair é o solista na Serenade opus 50 de Malcolm Arnold.

Three Double Concertos (ano desconheçido).

GHA 126.046. Nota: Este album é da Orquestra de Córdoba, regido por Leo Brouwer. Sérgio e Odair Assad são solistas no concerto de edino Krieger, Concerto Para Dois Violóes e Cordas.

Lista de composições de Sérgio Assad

As partituras editadas foram publicadas por Èditions Lemoine (França), GSP (EUA), Doberman Editions (Canadá) ou Sérgio Assad Music (SAM).

- Três Cenas Brasileiras (1984) (dois violões) - partitura editada.

- Recife dos corais

- Vitoria Regia

- Pinote

- Suite Brasileira (1986) (dois violões)

- Baião

- Canção e Samba

- Aquarelle (1986) (violão solo) - 25315 HL. Esta foi a peça obrigatória no concurso de 2002 do GFA. 
- Divertimento

- Valseana

- Prelúdio e toccatina

- Jobiniana \#1 (1986) (dois violões) -- Edition Henry Lemoine

- Jobiniana \#2 (1988) (flauta e violão) -- Edition Henry Lemoine

- Children's Cradle (1992) (violão solo) -- Sérgio Assad Music - gravado no CD Quiet Time de Ricardo Cobo.

- Cradle Song

- Dreams

- Morning's Rag

- Saga dos Migrantes (1992) (dois violões) -- Sérgio Assad Music

- Retirantes

- Trem da llusão

- Metropolis

- Saudades

- Dança Antagonica

- Giornatta a Nettuno (1993) (orquestra violões) (Vogt \& Fritz Alemanha). Estréia pela Guitar Orchestra in Netuno, regida por Manuel Barrueco.

- Fantasia Carioca (1994) (violão solo) (SAM) Gravada por Aliéksey Vianna

- Suite "Summer Garden" (1994) (dois violões) - Gendai Magazine

- Opening

- Summer Garden

- Farewell

- The Friends

- Unbalanced

- Train of Thoughts

- First Encounter

- The Old Man

- Walk on a Bridge

- The Morgue

- Invitation

- The Well 

- Water Frenzy
- Watermelon
- Helping Hands
- Rain Storm
- Remembrance
- A Search
- Dreams
- Passage
- Butterflies

- Winter Impressions (1996) (flauta, viola, e violão) -- Edition Henry Lemoine -- gravado por Trio Con Brio's no CD Impressions, Koch Discover International DICD920497).

- Jobiniana \#3 (1996) (violão solo) -- Edition Henry Lemoine -- gravado por Shin-Ichi Fukuda

- The Chase (1996) (dois violões) Sérgio Assad Music

- Campusca (dois violões) (1996) Sérgio Assad Music

- Eterna (dois violões) (1996) Sérgio Assad Music

- Peças para violino e dois violões (1996)

- Andalucia

- Fantasy on Dark Eyes

- Istanbul (Awakening, Turkish Dance)

- Tatras (violino e dois violões)

- Gypsy Songs (violino e dois violões)

- Vardar's Boat (violino e dois violões)

- Circulo Mágico (1997) (flauta e violão) -- Edition Henry Lemoine

- Uarekena (1997) (quarto violões). Escrita para o Los Angelas Guitar Quartet.
- The Frozen Garden
- Blue Solitude
- Fire Place 
- Fantasia Carioca bis (1998) (dois violões e orquestra de câmara), ASCAP. Estréia em 1998 com a Orquestra St. Paul Orchestra, regida por John Adams.

- Peças para Clarinete e Violão

- Un abbraccio a João

- Menino (clarinete e violão)

- Grumari (clarinete e violão)

- Violetas Azuis (clarinete e violão)

- Champ (clarinete e violão)

- Velho Retrato (clarinete e violão)

- Hopscotch (clarinete e violão)

- Mangabeira (clarinete e violão)

- Angela (clarinete e violão)

Gravado por Gabriele Mirabassi e Sérgio Assad

- Espantalho (1998)(Ballet) (orquestra de câmara) -- Sérgio Assad Music Estréia pela Orquestra Sinfônica Municipal de São Paulo.

- Sonata (1999) (violão solo) -- Gendai Magazine -- gravado por Shin-Ichi Fukada
- Allegro Moderato
- Andante
- Presto

- Mikis Concerto Fantasia (1999) (violão e orquestra de cordas) - estréia em Atenas por Costas Cotsiolis a Orquestra de Cordas Ateniense.

- Allegro

- Andante

- Vivace

- Three Greek letters (2000) (violão solo) -- Guitar Solo Productions (GSP).

- Jobiniana \#4 (2001) (cello e violão) -- Edition Henry Lemoine -- gravado por Shin-Ichi Fukuda.

- Concerto Originis (concerto triplo para violino, dois violões, e orquestra de câmara) - estréia pela St. Paul Orchestra. (2001) 
- Três divertimentos - Arpoador Abaeté e Parati (violão solo) (GSP) (2002)

- Menino (2003) (cello e dois violões) -- Gravado por Yo Yo Ma, Sony.

- Menino (2003) (flute, viola, e violão) -- gravado por Trio con Brio.

- Five World Dances - Oriente médio, africana, celta, balcans e latino americana (violão e quarteto de cordas) (SAM) (2002)

- Eli's Portrait (violão solo)(SAM) (2004) - Estréia por David Russell.

- Dos Canciones - Hop, Certitumbre (canto e violão) (SAM) (2004) Gravado por Liliana Rodriguez e Raphaela Smiths.

- Itaipava (flauta violino e clarinete violoncelo e piano) (SAM) (2006) Estréia pelo Maverick Ensamble.

- Tahia Li Ossoulina (dois violões) (SAM) (2006)

- Trois Brésiliens à Saint Paul - Le Naif, La jouyesse, Le reveur, Rencontre a Tricastin (Orquestra de violões) (SAM)(2007)Encomendado pelo festival de violão de Tricastin, França;

- Piatã (coro e dois violões) (SAM) (2007) Encomendado pelo Vancouver Cantata Singers.

- Valsa de Outono (violão solo) (2008) (SAM) Peça de confronto para o GFA International Guitar Competition.

- Seis Brevidades - Chuva, Tarde, Feliz, Ginga Cantiga e Saltitante (violão solo) (2008) (SAM) Dedicadas a Odair Assad. 


\section{Entrevista com Aliéksey Vianna}

\section{Pelas peças do Sérgio (Assad) quais as características que mais chamaram a atenção?}

Pra mim,...Bom eu fui assistir um concerto dos Assad, eu já morava nos Estados Unidos, tinha dezoito anos eu já conhecia algumas gravações, já conhecia, eu acho que eu já conhecia uma gravação só, o Alma Brasileira; e eu fui ver o Sérgio e o Odair em concerto eu tinha chegado no Arizona, eu tava estudando, eu tinha chegado, fora tinham, não sei, uns dois meses que eu tinha saído do Brasil, eu fui ver o concerto e logo depois a gente saiu pra jantar assim, os caras foram super legais, e eu fiquei encantado, deslumbrado, com o concerto deles, eu nunca tinha visto nada parecido ao vivo. E o meu professor, na época, que foi o cara que me levou pra fora do Brasil, Thomas Patterson também tava começando a me conhecer assim, o tipo de música que eu tocava, porque eu tocava música popular ao mesmo tempo que música erudita e me dedicava pra caramba a isso na época e o Tom achou que tinha muito a ver, ele é muito amigo do Sérgio e ele tinha uma cópia autografada da peça, que o Sérgio tinha dado pra ele uns anos antes, que ele tinha guardado, nunca tinha animado a tocar, e também nunca tinha passado pra ninguém. $E$, bom da afinidade que eu tinha com a musicalidade dos caras, com aquele concerto que a gente viu junto, e toda história que eu tinha com música brasileira, o Tom achou que eu devia estudar a peça. E aí eu acho que passou, isso foi começinho de noventa e quatro, eu acho que passou um ano, não, passaram dois anos eu acho com o Tom falando "Ah! Você tem que estudar isso, você tem que estudar isso" e a gente, e eu no começo, assim no começo da trajetória, sempre rola um pouco de preguiça, sei lá, rola umas, rola prioridades, né? E eu finalmente peguei a peça em noventa e seis, nas minhas férias, tipo um ano, é, uns dois anos depois desse primeiro encontro com o Sérgio. Aí eu tava de férias no Brasil, minhas férias de verão lá, quer dizer eu tava aqui em Julho, aí eu comecei a estudar a peça, eu comecei a estudar a peça, eu tinha um concerto em Belo Horizonte, num projeto chamado "Articulações" que era continuação do Ciclo de Música Contemporânea, e eu pus a peça no programa e falei "Vou Encarar, né, vamo ver" tinha assim, uns dois meses pra aprender, e nesse meio tempo os Assad vieram aqui, tocar um concerto aqui em $\mathrm{BH}$. Eu acho que foi final de Julho de noventa e seis. E eu conheci através de um amigo em comum, Magno, eu conheci a produtora do show deles aqui, que é a Rose Pidney, que hoje em dia trabalha comigo também. E bom, através do Magno, do baterista de dele na época que era o Nenê, que era casado com a Rose, eu procurei o Sérgio, liguei pra Rose e falei "Eu tô tocando uma peça dele, eu queria, se possível ter oportunidade, de tocar isso pra ele e tal".Ela falou "Ah você liga amanhã, os caras tão chegando, eu vou almoçar com eles, você pode me ligar". Aí eu liguei, ela no celular, ela falou "Peraí, um minutinho que eu vou falar com o Sérgio a respeito." Ela explicou e o Sérgio falou, "Ah, fala pra ele ir lá no concerto". Eu acho que o Sérgio não lembrava quem eu era, a gente tinha se encontrado dois anos antes e tal. "Fala, pra ele ir no concerto e levar o violão". Ela me passou o recado e fui eu no concerto dos caras no Sesi Minas com o meu estojinho (risos). Ė pô (sic), eu 
tinha vinte anos na época, dez anos atrás isso. Aí fui no concerto, no final das contas aquele tanto de gente no camarim, não tinha a menor condição do Sérgio me ouvir né? Mas eu acho que ele viu que eu tava insistindo muito (risos) e falou "Vai no hotel. Te espero na porta do hotel sete e meia da manhã". (mais risos). Tinha três semanas que eu tava lendo a peça. Aí eu fui lá tava o Sérgio me esperando, acordadão, já tinha tomado o café e tudo, com a esposa dele, com a Ângela. E o Roberto, inclusive um amigo meu, paulista tava aqui, o Roberto Capoque, violonista também, tinha acabado de chegar aquela manhã, eu busquei, fui buscar ele na rodoviária e a gente foi direto lá pro hotel do Sérgio. Pois é, eu tocando a peça a três semanas aquela hora da manhã, não tinha a menor condição de fazer nada bem feito né? $\mathrm{E}$, enfim, passei com ele, ele foi super generoso, super cuidadoso, deu uma atenção, assim, foi bem detalhadamente, acho que a gente passou os três movimentos inclusive.

$\mathrm{E}$, bom, a gente se despediu, e a gente não se viu mais até uns três anos depois quando eu já tinha mudado pra São Francisco, Califórnia, pra estudar com o Tannembaum, e Sérgio foi tocar um concerto com a Nádia Salerno Sonnenberg, que era um concerto engraçado, num lugar que era tipo um clube de jazz assim, num era um teatro, é um lugar onde as pessoas ficavam tomando cerveja e escutando os Assad e a Nádia. Depois do concerto, eu fui procurar o Sérgio, e aí, bom, noventa e seis, foi quando eu toquei pra ele aqui, noventa e sete foi quando eu comecei a fazer concursos né, internacionais. Eu fiz o Stotzenberg, no primeiro ano, fiquei em segundo lugar, tocando a peça do Sérgio, tocando essa peça. Aí bom, em noventa e nove quando a gente se encontrou, nessa ocasião aí do concerto com a Nádia, ele veio já quando me viu ele falou, "Pô cara, quanto tempo! $E$ tal. Fiquei sabendo que você tá ganhando um monte de coisa tocando a peça e tal”. Pô, eu acho que ele ouviu falar pelo Matanya Orphee, um cara, que é lá do Canadá, que eu tava ganhando um monte de coisa, finalmente alguém tava tocando essa peça dele e tal. Quer dizer, a essa altura já existiam duas gravações eu acho, do Adam Holzmann e do Randy (Randall Avers). E o Sérgio falou "Pô, me dá o seu endereço que eu quero te mandar um negócio". E nesse meio tempo eu pedi uns arranjos, eu tinha conhecido um arranjo..., alguém me disse que tinha um arranjo do Frevo, eu não sei e eu conheci um arranjo das coisas do Ralph Towner. Aí eu pedi o Sérgio me mandar isso. Aí duas semanas chegou no correio um calhamaço assim, a partitura da Sonata, o manuscrito da sonata nova. Aí pô, aquilo eu fiquei,... Eu me lembro sempre do conto da Clarice Lispector da menina que ganha um presente e fica andando com o embrulho debaixo do braço sem nem conseguir abrir. Eu sei que eu liguei pro Sérgio super feliz. E disse pra ele, isso era no começo de noventa e nove, eu disse pra ele que eu queria gravar a peça, que eu queria fazer um disco e ele me mandou a Sonata e os dois arranjos que eu tinha pedido. E eu disse pra ele que eu queria fazer um disco com a Sonata, a Aquarela, os arranjos de Towner, de Gismonti e de Piazzolla, tinham os arranjos das Quatro Estações nessa época também. Ai ele falou "Ah, tudo, vamo ver a gente vai falando". Ele não me botou pra baixo, mas também não me pareceu tão entusiasmado com a idéia. Na verdade ele só me tinha visto tocar só três anos antes, quando eu tinha acabado de começar a peça. E até então ele só tinha notícia de que eu tava tocando e até então ele só tinha notícia de que eu tava tocando as coisas e tal. Aí foi mais um ano e eu fui pro GFA, em 2000 e o Sérgio tava tocando, aí 
a gente se encontrou um dia à tarde, e eu disse pra ele a gente foi almoçar e eu falei que eu queria muito tocar pra ele, que eu tava tocando a Sonata e tal. Aí eu lembro que o Odair queria sair pra tomar um café, e o Odair falou "Não bixo. Tocar violão, não vamo mexer com isso, festival de violão". Aí o Sérgio falou, "Não pô o menino quer ouvir, o menino quer que eu ouça, quer tocar, vamo lá" Aí ficou aquela coisa, entramos os três no quarto do Sérgio, e o Odair falou, "Então eu também vou ficar aqui" sentou do lado do braço do violão e ficou com o nariz colado no violão (risos) aí fui tocar, a Aquarela e a Sonata. E nessa ocasião ele, aí ele se entusiasmou. "Rapaz, mas você melhorou demais!" Mas eu falei "Pô, Sérgio, tinha quando você me viu tocar tinham três semanas que eu tava tocando a peça eram sete e meia da manhã. Então não tinha muito jeito". Eu acho que a primeira impressão que ele teve de mim não tinha sido uma das melhores assim. E bom eu acho que nesse período também entre, noventa e seis e noventa e nove, eu mudei muito o meu jeito de tocar, eu cresci bastante, tava estudando pra caramba nessa época. E quando eu vi que ele se entusiasmou e que ele gostou das coisas, eu falei insisti na idéia da gravação "Eu to a fim de gravar um disco com as suas coisas" Ele foi e olhou pra mim e falou "o que eu posso fazer é estar presente na gravação, produzir a sua gravação". Aí, pô, foi melhor que as partituras que tinham chegado no correio. Isso foi aí, isso pode um negócio que pode mudar a minha vida. E daí, bom, respondi uma pergunta pequena com uma estória longa. Daí o Sérgio começou a me mandar outras coisas, começou a me mandar as outras peças todas solo, inclusive a Fantasia Carioca, que pintou um mês antes da gravação, que ele tinha até esquecido sei lá, que existia a versão, que foi o Byron Fogo, que é o arquivista dele que deu um toque. Um dia o Sérgio me ligou e falou "Olha Aliéksey tem mais uma peça" e eu falei "Ah é? Legal" eu achei que era sei lá uma peçinha de três páginas assim no máximo, falou "Ė, bom, uma peça que eu escrevi e tal, tem uma versão pra violão solo, uma versão pra violoncelo e uma versão pra dois violões e orquestra, mas eu não tenho mais a partitura, quem tem essa 'part' e o Byron, escreve pra ele". Aí eu escrevi, o cara me mandou uma gravação ao vivo da versão pra dois violões e orquestra, e a partitura na versão pra violão solo que não existia a gravação. Mas enfim, o Sérgio começou a me mandar as coisas, e eu também sempre fui muito interessado por música de câmara então eu acabei me envolvendo até o pescoço com as coisas do Sérgio. Eu conheço muita coisa, mas eu creio que o interesse inicial mesmo surgiu até por uma insistência do Tom Patterson na época que eu acho que, por um lado ele via que eu... Que tinha a ver com a minha personalidade a coisa de tocar música popular brasileira e tal, e por outro lado eu acho que era um desafio pra mim e ele, meu professor tava preocupado sob um ponto de vista didático, assim, queria alguma coisa que me colocasse pra frente. Então é isso. Vamo passar pra segunda?

\section{Quais os desafios musicais que podem ser encontrados na obra pra violão solo do Sérgio?}

Eu acho q o grande lance das coisas do Sérgio, e o contraponto né? O cara conhece o violão como ninguém. Assim, ele encontra possibilidades ali que pouca gente consegue imaginar. $E$ o interessante é que $p$ Sérgio escreve sem 
o violão ele me falou uma vez que foi um conselho do Brower assim, e que ele resolveu adotar. Que ele escreve, e, se for o caso, depois ele vai conferir se o negócio encaixa, mas ele escreve da cabeça dele pra que as idéias não fiquem restritas à coisa da sua mão, seus próprios vícios técnicos, então ele tem uma idéia musical e depois ele escreve aquilo, e depois ele vai procurar saber se é possível ou não. Mas seu acho que o cara já chegou num ponto agora que ele nem precisa pegar o violão pra conferir, se o negócio é tocável ou não é. E é claro que a definição, a noção de tocável pra ele é bem diferente porque ele está acostumado a escrever pro Odair desde ele era pequeno. Bom, então eu acho que é a coisa do contraponto pra não fugir muito da questão. É o primeiro grande problema, você tem que saber mesmo; diferenciar as camadas tem sempre, normalmente a linha de acompanhamento do Sérgio tende sempre a ser uma linha mais rápida assim, mais cromática, e as melodias são muitas vezes são notas longas mesmo como é o caso do Prelúdio e Toccatina, quando começa aquela toccatina e um acompanhamento super rápido e aquela melodia com duas notas por compasso assim. O outro grande desafio é a questão do caráter brasileiro das coisas dele. $O$ caráter rítmico em geral, mesmo quando ele não está escrevendo no caráter brasileiro, mas o caráter brasileiro que eu acho que é o grande problema dos violonistas clássicos em geral, pra tocar esse tipo de música. Principalmente os estrangeiros né? Eu acho que as pessoas num se dão conta de que na verdade, pôxa isso vem do choro, mais do que nada. O Sérgio cresceu tocando choro e ele... E é o que pra mim tá mais do que claro. Choro e samba e bossa nova ali, o tempo todo. Então muitas vezes ali, você vê gravações, dessa peça mesmo que foi tão gravada, você vê gravações assim, super legais tecnicamente, e rápidas pra caramba, e limpinhas e tudo, mas sem a menor noção desse caráter brasileiro. Eu acho que isso também é um grande desafio.

\section{(Aliéksey lê uma pergunta em relação a desafios técnicos referentes à obra de Sérgio Assad)}

Quanto a desafios técnicos, eu acho que eu volto à estória do contraponto né, que pra duas mãos, tanto pra mão direita quanto pra mão esquerda, você tem que saber destacar as vozes, você tem que saber, articular um voz de uma forma, outra voz de outra. Eu, muito particularmente, tenho mais dificuldade de mão esquerda, então muitas vezes o Sérgio ele usa muito os dedos, anular e mindinho, os dedos três e quatro, de formas, tipo aquele primeiro movimento da Aquarela que ele vai estendendo muito, e você tem que ter muita independência principalmente nesses dois dedos. É aquela (Solfeja o primeiro tema da parte A do Divertimento) aquilo ali a sua dedo três já vai fazendo assim né?(mostra gesticulado) então eu acho que é por aí. E tem uma coisa assim de sempre, haver com o ritmo, os acentos, e articulação. Ritmo e articulação. Sabe, quando você tem que acentuar algumas coisa, tem que tocar uma voz legato, quando a outra está fazendo uma coisa totalmente rítmica, assim rapidinho. Eu acho que os desafios técnicos e musicais meio que se encontram por aí. Nos problemas rítmicos e de articulação e de dinâmica conseqüentemente.

\section{(Aliéksey lê pergunta sobre as influências musicais do Compositor)}


As influências musicais que a gente vê na Aquarela, eu acho que, bom primeiramente a coisa da música brasileira mesmo né? Tem um forró, um baião, naquele último movimento e tem uma coisa bem bossa nova, aquela história no primeiro movimento que o Sérgio chama de "Marcha Rancho", uma marchinha. Eu lembro quando a gente tava gravando ele falou "Poxa, essa peça muita gente tende a dar um caráter", assim... como é que ele falou?... "Um caráter grandioso, assim, uma coisa brilhante, virtuosa, quando na verdade isso tem soar fácil, isso aí é uma marcha rancho". (neste momento Aliéksy solfeja o primeiro tema da parte $A$, desta vez enfatizando o caráter percussivo deste, fazendo com que soe como um samba). O Sérgio, o tempo todo durante a gravação, ele ficava cantando ritmos e percussão na minha cabeça, o cara queria saber do negócio "groovar", ele queria saber do "swing" mesmo. Que eu acho que... Como eu disse é uma grande dificuldade, muitas vezes as pessoas conseguem tocar, mas se esquecem desse caráter. $E$ eu acho que a outra grande influência é um negócio que também fica muito claro pra mim assim, o Sérgio é fascinado com música impressionista, com Debussy, Ravel, eu acho a Aquarela, bom, é claro, é fácil cair no lugar comum de dizer que ela começa com uma escala de tons inteiros e tal, mas eu acho que as sonoridades em geral na peça, são sonoridades impressionistas, os acordes sempre... que é também, o impressionismo é também uma influência muito forte na bossa nova então essa influência harmônica vem dos dois lados assim. A coisa, de pouca tríade tem sempre muita nota de tensão assim, muita sétima maior, às vezes umas sextas, umas quintas aumentadas, na própria Valseana, aquele último acorde da Valseana, aquilo é um acorde de duas terças, um acorde maior com a nona aumentada. Então eu acho que é isso: o impressionismo e a música brasileira eu acho que o Sérgio é por aí.

\section{(Aliéksey, lê outra pergunta)}

Os trechos mais complexos musicalmente... Eu não sei, tem um trecho no final da terceira página da toccatina (solfeja o trecho ao final da toccatina, anterior á entrada do baião), sabe, aquela parte? Que ele repete a mesma frase quatro vezes, e ele vai subindo, eu acho aquilo ali, difícil por causa da articulação.

\section{(Lê pergunta sobre trechos complexos tecnicamente)}

Uns trechos mais complexos tecnicamente... Eu acho que o primeiro movimento é muito difícil, até pelo que você falou, da extensão dele, praticamente não pára. Eu acho que quando entra mesmo aquele tema em lá maior (Solfeja novamente o tema inicial da parte A do Divertimento) não sei, depois você vê o compasso, eu acho que por ali é bem casca grossa. E o (solfeja trecho do início da toccatina), essas duas partes são complicadas. Pela própria polifonia, que envolve.

\section{(lê perguntas)}

Quando foi a estréia da peça, eu já disse, eu sei que foi pelo David Russell, deve ter sido no começinho dos anos noventa... A peça é de oitenta e seis? 
(entrevistador: a peça é de oitenta e oito) Não, a edição é de oitenta e oito. (entrevistador: a peça é de oitenta e oito e a edição de noventa e dois). Tem que conferir isso aqui. (pára e confere o encarte do próprio CD) A peça é de oitenta e oito, ele escreveu aqui. É bicho, deve ter sido por aí. Eu acredito que o cara tenha aprendido isso, se bem que na época o cara tinha mais pique assim. È, por aí, no final da década de oitenta, começo da década de noventa.

\section{(Lê pergunta sobre o boato da Valseana ter sido um improviso em estúdio)}

Essa coisa do boato; isso aí eu tenho certeza que isso não é boato não. Eu li isso em algum lugar, e eu já discuti isso com o Sérgio. Realmente aquilo ali foi uma improvisação porque ele queria contrabalançar as peças as três peças que tinha naquele disco, Latin American Music For Two Guitars. As três pecinhas do Sérgio que tinhas ali, eram muito rápidas e ele queria um negócio mais lento que desse um contrapeso, um equilíbrio mesmo de andamento. Um dia ele entrou no estúdio e improvisou. Pode ter certeza, que isso não é boato não, isso é verdade.

\section{(Lê: David Russell, comentou que nas peças do Sérgio existem vários} trechos que os dedos fazem coisas que não estão acostumados a fazer. Quais seriam esses trechos?) Ai cara, eu vou ter que dar uma paradinha. (pausa) Vamo la'!

Existem vários trechos que os dedos fazer o que não estão acostumados... (pausa) O que seriam essas técnicas? Cara, eu acho que o... Eu acho que passa meio por aí, o Sérgio, ele escreve sempre polifônico eu acho que ele sempre escuta mais de um violão de uma vez. E ele não se restringe muito tecnicamente, a única peça que eu me lembro assim, tem os divertimentos curtinhos que ele fez pra alunos e eu lembro que teve uma peça, As Três Letras Gregas, que a Antigoni pediu deliberadamente pra que ele fizesse algo não muito difícil assim. Mas eu acho que Sérgio raramente se restringe por questões técnicas, o que dá na telha ele senta e escreve. Então, pra mim pessoalmente passa pela mão esquerda de novo. Eu acho que tem umas coisas de independência dos dedos três e quatro, umas extensões assim que, deve ser o Russell diz assim. Eu, não sei, eu acho que música pra violão muitas vezes se restringe a certas fôrmas, a gente tem os acordes, a fôrma de lá maior, a fôrma de mi maior, a fôrma de ré a fôrma de dó e a fôrma de sol. Tudo é meio construído em cima disso, eu acho que o Sérgio ele foge disso, exatamente por pensar mais polifonicamente, mais do que qualquer outro compositor assim. Se você pensar, por exemplo, no Leo Brower, ou no Villa, são compositores que sempre confiaram nas sonoridades peculiares do violão, e em fôrmas. O Villa, por exemplo, usa sempre uma fôrma que vai subindo e descendo, o Brower também faz isso; e o Sérgio eu acho que ele difere deles muito assim nesse sentido. O Sérgio pra mim, violonísticamente falando, ele é como se fosse, um... não sei... um Giulianni talvez assim, que explora coisas... 
claro que estamos falando de duzentos séculos, duzentos anos de distância; e - Giulianni trabalhava ali dentro de uma estrutura harmônica muito simples da época dele. Então o Sérgio hoje, com a liberdade harmônica que ele tem, eu acho que ele não se restringe tanto tecnicamente. Eu acho que é por aí. É isso né?

Se tem alguma coisa que eu diria sobre a peça, sobre essa peça em particular. Eu não sei, eu acho que o meu comentário seria que essa é a primeira coisa que o Sérgio registrou na vida dele pra violão solo, a primeira vez que o cara sentou e falou, vou escrever uma peça pra violão solo. E eu acho isso muito impressionante, porque a peça é de uma profundidade musical brilhante assim. Surpreendente assim, pra ser uma primeira peça, entendeu? Eu acho que ele tem crescido muito desde então, o Sérgio está escrevendo cada vez mais, se dedica cada vez mais à caneta né. E pôxa, se você parar pra pensar que a primeira coisa que alguém escreve é nesse nível, eu acho que uma indicação realmente de uma mente brilhante. E eu acho que prova disso são as coisas que já saíram depois disso, eu acho que as pessoas têm que começar a se ligar aí na Sonata, na Fantasia, nas próprias Letras Gregas, na Jobiniana, sabe e principalmente, muito mais nas coisas de música de câmara. O disco dele com Gabrielle Mirabassi, um quinteto novo que ta aí, o concerto escrito pro Costas Cotsiolis, o concerto triplo com o Nádia Salerno Sonnenberg, que é uma coisa maravilhosa, as coisas que ele escreve que não envolvem violão, a série das Jobinianas. Quer dizer, eu sou suspeito pra falar do Sérgio, mas eu acho que ele é dos caras que realmente têm levado o violão a novos níveis assim. Outros lugares, que ninguém tinha encontrado antes. Então é isso, eu acho que o comentário é esse. 


\section{Entrevista com David Russell}

How did the dedication on the Aquarelle Suite come up?

That was Sergio's idea. It was a surprise for me.

Foi idéia do Sérgio. Foi uma surpresa para mim.

When was it premiered?

I don't have that information. Sergio recorded the Valseana years before he finished the suite.

Eu não tenho essa informação. Sérgio gravou a Valseana anos antes de terminar a Suíte.

Were there ever any plans of recording it?

Some guitarists have recorded it, but not me.

Alguns violonistas têm gravado ela, mas eu não.

What musical aspects did you find more interesting about this piece, and what points of it you can point out as of interest?

The first movement is beautifully constructed, on a very simple theme, which is stated at the beginning. The more you study the piece, the more layers you find in it.

O primeiro movimento é muito bem construído sobre um tema muito simples, que é exposto no início da peça. Quanto mais você estuda a peça, mais camadas você encontra.

What points could you say were more technically demanding on this piece? Sergio asks you to do things with your fingers that we don't normally find in many pieces of our repertoire. It is hard to play and the first movement doesn't give you much rest.

Sérgio pede para você fazer com seus dedos, que nós normalmente não encontramos em muitas peças do nosso repertório. É muito difícil de tocar e o primeiro movimento não dá muito descanso.

What points could you say were more musically demanding on this piece? For me it was a slightly new style and it took me some months to feel confident to perform it.

Para mim foi um estilo levemente novo e me levou alguns meses para me sentir confiante para tocá-la.

Were there any points you had to find any technical alternatives or fingerings for the piece to work?

No.

Não.

Do you have any more considerations on regarding this piece? I love the piece. I have played it at different times and I will always consider playing it again. This year I played the Valseana in concert together with another of Sergio's pieces. 
The Brazilian rhythms that Sergio uses are new to players who have not played in this style. They are fun to learn and rewarding to perfect.

Eu amo a peça. Eu tenho a tocado em várias ocasiões diferentes e sempre considerarei toca-la novamente. Este ano eu toquei a Valseana juntamento com outra das peças de Sérgio. Os ritmos brasileiros que Sérgio utiliza são novidade para violonistas que não tocaram este estilo. Eles são divertidos de aprender e uma recompensa para aperfeiçoar. 


\section{Entrevista com Eduardo Meirinhos}

\section{Como surgiu a idéia de incluir a Suíte Aquarelle em seu repertório de concerto?}

A primeira coisa que me despertou foi a beleza da peça e eu sempre reservo um tempo no meu repertório para incluir peças de compositores brasileiros sejam eles os compositores tradicionais como Villa-Lobos, como Francisco Mignone, como toquei no meu último concerto, mesmo Guerra-Peixe, Guarnieri também. Mas eu resolvi desta feita aplicar um pouco mais em cima de compositores que trabalham um pouco mais em cima da música assim chamada música de fronteira, essa música "Cross-Over", que é o tipo de música que eu acho que a Aquarela se enquadra. Eu acredito também que o Sérgio Assad é um compositor que tem um conhecimento profundo da idiomática técnico-violonísitica a ponto de fazer com que a coisas soem muito mais complexas e que soem violonísticas. Eu acho que estes são os motivos principais, agora sem sombra de dúvida o fato de eu gostar da peça, esta é uma condição "si-ne-quas-non" para que eu comece estudar uma peça.

\section{Quais aspectos musicais você achou mais interessantes nesta peça? Quais pontos podem ser destacados musicalmente?}

É muito difícil você destacar especificamente um ou outro ponto, dado a completude da peça. É uma peça que explora muitos aspectos composicionais e técnicos do instrumento, idiomáticos do instrumento. Se nós formos analisar com muita calma, nós vamos apontar na verdade todos os elementos composicionais disponíveis. $\mathrm{O}$ aspecto contrapontístico muito presente no terceiro movimento, o aspecto do melodismo tão brasileiro na Valseana e mesmo no primeiro movimento, o Divertimento, nós vamos também ver todo o virtuosismo presente, que é uma tônica do primeiro e terceiro movimentos, especialmente do terceiro, com uma exploração muito grande com vários cromatismos e cromatismos em vozes diferentes com uma simultaneidade do contraponto com o movimento cromático das vozes, com movimentos paralelos e contrários o tempo inteiro. Há o aspecto harmônico e tonal também extremamente variado e complexo com modulações que ele usa, nem que sejam momentâneas ou de passagem, são modulações que usam todos os recursos possíveis de modulação, todas as formas possíveis. Sempre dentro de uma idiomática à Brasileira. A música brasileira presente, o elemento folclórico e popular brasileiro é presente o tempo inteiro. Desde a bossa nova até a música nordestina e tudo isso, esses elementos ligados a um virtuosismo e bom gosto ímpares.

\section{Quais trechos você poderia destacar como mais complexos musicalmente?}

Ela inteira ... eu acredito que o primeiro e o terceiro movimento, especialmente o terceiro movimento, dada a simultaneidade dos elementos composicionais usados, eu diria que ele é o mais complexo. E nem por isso difícil, você me perguntou qual é o mais complexo, mais complexo eu diria de entendimento, 
eu diria o terceiro movimento, muito embora o primeiro movimento também apresenta alguns momentos que sejam ... não imediatamente inteligíveis no primeiro momento; mas certamente numa segunda ou terceira leitura você vai entender. Eu acredito que o terceiro movimento sob aspecto musical, ele é mais complexo, dada a simultaneidade dos elementos usados.

\section{Quais trechos você poderia destacar como mais complexos tecnicamente?}

Volto a dizer sobre o primeiro e terceiro movimentos. Eu acredito que o terceiro movimento é especialmente complicado pela textura musical que é desenvolvida. $O$ aspecto polifônico, cromático num andamento de semínima 120, quer dizer, isso é muito difícil de você conseguir atingir esse andamento com a clareza necessária à abordagem interpretativa polifônica e uma textura musical tão rica e tão densa. Eu acho q essa é a tônica de dificuldade do terceiro movimento; especialmente ao que tange à textura da peça.

Houveram trechos em que você teve de encontrar diferentes soluções técnicas ou digitações alternativas?

Bem, eu devo confessar que eu não me recordo agora, mas se eu não me recordo, é um sinal de que eu não tive de buscar muito. As digitações do próprio compositor que é um dos expoentes do violão mundial atualmente, já nos deu, ao compor, ele já nos deu as soluções técnicas dentro de uma de um idiomatismo característico de sua abordagem composicional.

\section{Você tem mais alguma consideração em relação a esta peça?}

Eu acredito que um dos aspectos principais que devem ser considerados para estudar essa peça é a que a clareza das idéias deva estar em primeiro plano acima do virtuosismo. Ela impressiona pelo virtuosismo, (...) musical uma articulação confusa, isso não pode acontecer. Então eu diria que a articulação e a clareza musical antes do virtuosismo agora se você conseguir juntar os dois, nota dez pra você. Importante: nunca toque esta peça mais rápido do que você consegue pensar. [Em off e com o gravador desligado: porque senão você se ferra! (risos gerais)] 


\section{Entrevista com Randall Avers}

O álbum Vistas foi gravado em 1994 e 1995 durante o meu ano Júnior no Conservatório Oberlin. O meu professor de violão, Stephen Aron, me aconselhou a gravar um repertório dos meus anos passados de estudo que encaixaria sob um mesmo tema. Após alguma procura, eu vim com uma lista de peças que seriam "Música Americana e Sul - Americana do Séc. XX".

Eu já sabia que queria gravar a Aquarelle, ela tinha um significado especial para mim. Nesta época muitos dos violonistas que eu admiro muito demonstraram enorme respeito por ela, tanto composicionalmente quanto tecnicamente. Eu já tinha a ouvido sendo executada várias vezes, por diferentes violonistas, inclusive uma das primeiras performances de David Russell na Convenção do GFA em 1988 em Ohio. Em 1992, o professor de violão do Conservatório de New England, Neil Anderson, me presenteou com uma cópia manuscrita da partitura e eu prontamente comecei a estudá-la. Um ano depois durante o meu primeiro ano $\mathrm{Na}$ escola de Artes da Carolina do Norte, eu toquei o primeiro movimento para ambos Sérgio e Odair Assad.

NOTA: diferenças da versão manuscrita e editada, digitações? Tentar arrumar manuscrito, qdo a peça foi composta primeira audição em 1988.

2 - No primeiro movimento, "Divertimento" desenvolve uma simples idéia melódica de três notas em várias maneiras, melodicamente, harmonicamente, ritmicamente, textura, etc. O músico tem um vislumbre do vocabulário composicional criativo de Assad no seu tratamento desta idéia temática simples.

3 A seção de samba no primeiro movimento é extremamente complicada. Ambas as mãos são muito difíceis e fazer qualquer coisa além de tocar as notas requer muito tempo e prática. Existem poucas peças no repertório que exigem tamanho domínio técnico quanto o primeiro movimento da Aquarelle. Existem alguns trechos na Toccata (o trecho com os acordes diminutos) apesar de não tão difíceis quanto o samba no Divertimento.

Nota Quais compassos?

4 - As três peças são exigentes por diferentes razões:

Divertimento - controle de articulação e ritmo e a manutenção da tensão musical por toda a peça.

Valseana - legato e simplicidade da linha melódica

Toccatina - combinação dos elementos encontrados nos dois primeiros elementos.

5 - No primeiro movimento no começo do samba (Acorde de A7+ após o E7 dominate). Eu preparo as notas de abertura (sol \# lá \# sol\# e mi) tocadas na quarta posição e daí saltando para a nona posição. Não é um salto fácil, mas, dá mais clareza na linha melódica. 
NOTA mp3 do divertimento.

Elementos estilísticos

Compositores nacionalistas

One thing that I have been speculating is that the Assads always have played some compositions by Sérgio, but the impression that I get is that, people only started to take Sérgio seriosly as a composer after David Russell started playing the Aquarelle 


\section{Entrevista com Sérgio Assad.}

Esta entrevista foi gentilmente cedida à Luciano César Morais e Fábio Zanon na residência deste último no Bairro de Higienópolis, São Paulo, no dia 22 de maio de 2006, após uma série de concertos que o Duo Assad realizou na capital paulista. Como há a fala de mais de um entrevistador, optamos por deixar em negrito as falas de Fábio Zanon, em itálico as minhas, e em fonte normal as falas de Sérgio Assad. Entre colchetes estão transcritas as palavras da maneira como foi possível deduzir do que soam, mas sem garantia da sua correta grafia. Ou trechos em que não há preocupação em acertar exatamente a palavra como seria para um texto escrito, mas que dão o sentido anotado no contexto expressivo da comunicação no momento.

As questões em que se basearam a entrevista foram:

Idade, data de nascimento, local.

Onde você está residindo atualmente?

E seu irmão Odair?

1) Gostaria que iniciasse contando o que era a sua referência de violão na época em que tudo começou; como era, ou o que era o violão para vocês na infância e juventude? Como era o seu pai bandolinista?

2) Como surgiu a idéia de se mudar para o Rio de Janeiro?

3) Como era a rotina de trabalho com a Professora Monina?

4)Quem apresentou vocês?

Pelo que sabemos dela, ela vinha de um universo musical que não se conectava muito com o do choro, da musica popular ou mesmo do violão como era praticado no Rio daquela época. Quais seriam os campos de interesse musical dela?

5) Sobre as aulas com Adolfina Raitizin Távora:

Como eram as aulas com a professora Monina?

O que era importante para ela no trabalho com vocês?

Como ela escolhia o repertório a ser trabalhado?

E como era o trabalho com esse repertório, havia um padrão, uma seqüência metódica?

Como era construída uma interpretação musical no tempo em que vocês tinham aulas com ela?

O que o marcou mais profundamente com o trabalho com a Monina?

5) Houve alguma dificuldade em encontrar obras originais para constituir o repertório? E quais eram os critérios técnicos e/ou musicais para a escolha das obras?

6) Qual era a repercussão do Duo Abreu na época em que vocês chegaram ao Rio?

Quais foram as outras influencias musicais - e violonísticas - que te marcaram?

7) Pode falar um pouco do seu trabalho no concurso de violão da FUNARTE? Vocês fazem recitais solo?

8) Vocês começaram a trabalhar mais com ensino a partir de que época?

9) Há algo de interessante a ser destacado no violão de hoje, na sua visão? 
Há algo que falte hoje na forma como o violão é ensinado, na sua visão? 10) Partindo de Tárrega, qual foi a seu ver, a importância do arranjo para a história do violão?

11) E os seus arranjos? O que motivou seu trabalho com arranjos? A seu ver, qual a relação entre o seu trabalho de arranjador e compositor? Que utilidade você acha que teve na sua vida de músico, trabalhar com esses arranjos, para si mesmo?

\section{Entrevista}

Sabemos que você estudou primeiro, aprendeu violão com seu pai. O que você tem de referência disso?

Isso! A nossa casa vivia repleta de músicos. Tinha músicos o tempo todo, mas músicos amadores. Meu pai era muito itinerante, ele não fixava raízes em nenhum lugar, vivia se mudando. Eu nasci em Mococa, o Odair também... A gente saiu de Mococa assim, logo depois do nascimento do Odair, fomos pra Ribeirão Preto. Ali a gente ficou uns dez anos. A gente saiu de Ribeirão, foi pra São João da Boa vista, e foi exatamente nessa fase aí que a gente começou a aprender a tocar. Eu quis tocar violão mais cedo, quando eu tinha sete ou oito anos. Mas... Não funcionou, meu pai achou que era muito cedo, mas aquela vontade continuou existindo.. Dado que eu não consegui que o meu pai me ensinasse nenhum acorde, eu pedi a um tio meu que tocava violão que me ensinasse um ré menor básico, aqueles acordes... Eu aprendi uma sequenciazinha básica...Depois ,eu vivia atrás da minha mãe pra ela cantar e eu acompanhar. Quando meu pai viu aquilo acontecendo ele disse: "Bom, se você consegue fazer isso, deve conseguir acompanhar meu bandolim." Aí tudo começou; me ensinou um chorinho e logo no dia seguinte o Odair começou a aprender também. "Ah, quero aprender, já que ele tá fazendo eu também quero".

O Odair é mais novo do que você quantos anos?

Quatro anos.

\section{Vocês têm mais irmãos?}

Temos um irmão mais velho.

Ah, um mais velho.

Então começamos ali, praticamente juntos, né?, Um dia de diferença.

O teu pai alguma vez trabalhou profissionalmente com música?

Não. Meu pai não sabia música; ele aprendeu tudo de ouvido e o que ele passava pra gente era aquela noção de harmonia, aquele método do Paraguassu: primeira, segunda, terceira posição, e é assim que ele faz até hoje. Este é um método que na realidade funciona $\left(\left(_{-}\right)\right.$; uma coisa super prática na qual você aprende o nome dos acordes rapidamente (se tiver um bom ouvido), e você mesmo se desenvolve. $E$ o que aconteceu foi exatamente isso; a gente começou a tocar todo o repertório de choro. A gente tocou com uma rapidez incrível a ponto de ele mesmo ficar impressionado... Alguns meses após, oito ou nove meses após, a gente veio aqui pra São Paulo pra tocar num 
programa de televisão que era o "Bossaudade; um programa comandado pela Eliseth Cardoso. Nos apresentamos com o Jacob Bitencourt. Quer dizer que nos chegamos a tocar com o Jacob. Acho que pouca gente da nossa geração pode se gabar de haver tocado com ele . mas nos, enfim....

Vocês se desenvolveram muito rápido então. E aí a ir pro Rio de Janeiro...

Pois é! meu pai tinha uns amigos que tocavam bem violão. Bem lá no interior de São Paulo, em São João da Boa Vista tinha um violonista , o José Lansac que pertencia ao núcleo violonístico que havia aqui em São Paulo.

Ele era daqui de São Paulo mas morava lá no interior. Ele chegou a formar alguns alunos por lá, um deles chegou a ser nosso professor, o Jose Lopes . E o José Lansac era muito amigo do Martins Sobrinho, outro ilustre violonista amador aqui de São Paulo. Este era o universo violonístico que a gente conhecia naquela época.

Antes de vir a São Paulo e antes de ir pro Rio eu não sabia quem era Segovia; nunca tinha ouvido falar em violão clássico; a gente nem sabia o que que era. Violão clássico pra mim era Agustín Barrios.

\section{$4: 20$}

Agora, São João da Boa Vista... Que é que tem na água lá? Porque tem a Guiomar Novaes também, né? Tem alguma tradição musical na cidade, particular ou é pura sorte?

Pode ser coincidência, mas a cidade tem bastante musicalidade. Eu conheço várias pessoas que praticam música ali num nível excelente embora sejam amadores. Então, tem alguma coisa especial por lá. Alguma ligação com música que é muito forte, né?

Tem um conservatório lá? Escola...

Não que eu saiba!. Mas tem projetos. Por exemplo, tem um que se chama "Afinando as Cordas" que é produzido pelo João Batista Rodrigues daqui de São Paulo, que foi pra lá, implantou esse projeto, e financiado pela prefeitura, está formando bons violonistas. Há dois anos, quando ganhamos o título de cidadãos sanjoanenses, durante a festa de entrega do título veio esse grupo tocar. Era um octeto. Eles tocando Bach, tocando concerto de Brandenburgo. Eles tinham uns violões horríveis e são pessoas simples ali do interior mas fazem um trabalho muito sério e bonito.

Você disse que vocês então vieram pra São Paulo antes de ir para o Rio de Janeiro.

$\mathrm{Na}$ realidade, como existia o Zé Lansac em São João da Boa Vista existiam outras pessoas na capital que também conheciam um pouco mais de violão... Quer dizer que a única solução aparente pra nós era vir pra São Paulo, procurar alguém como o Isaias Sávio. E foi exatamente o que o meu pai fez através do nosso contato que era o Martins Sobrinho e a gente foi procurar o Sávio. Só que o meu pai, ele tinha... uma noção, talvez equivocada, de que nós éramos gênios. Ele achava que a gente era o supra do supra sumo, e não sei por que também! Mas como ele tinha pouca experiência, enfim... Ele dizia "Ah, isso eu nunca vi". Mas claro, nunca tinha visto nenhuma outra coisa também. né? Não havia nenhum parâmetro de comparação com nada. Ele 
trouxe a gente pro Sávio mas achou que o Sávio não ficou tão entusiasmado com a gente o tanto quanto deveria ter ficado. Aí ele disse: "Ah, vocês não vão estudar com esse cara não!" $E$ voltou pro interior e pronto! . Nessa época a gente morava em São João da Boa Vista mas logo depois, em 66 ou 67 nós fomos pra Ribeirão Preto. E lá, passamos a viver num ambiente de violões . Haviam dois irmãos lá do interior que tocavam violão muito bem. Eram os Irmãos Penha. Eles tinham todo o enfoque da música popular, eram bastante conhecidos dos músicos profissionais de São Paulo e eu já me via metido naquela história deles e me parecia que era absolutamente aquilo que eu queria fazer. Aí, alguém do Rio, mudou-se pra Ribeirão Preto. Um delegado, um delegado de polícia. . Um cara do Rio. E como ele gostava muito de violão acabou vendo a gente tocar em uma roda de choro. Ele conversou com meu pai, falou dos irmãos Abreu (Foi a primeira vez que eu ouvi o nome dos irmãos Abreu). Disse que era uma coisa muito séria, que não sei o que, que a gente tinha que ouvir pra saber do que se tratava e que ele tinha uma fita ou algo assim. Quando a gente ouviu a fita... Não entendemos nada! Nosso universo de violão era iniciante e aquilo que eles faziam nem era violão, aquilo era... outra coisa.

\section{O teu contato com música clássica era zero nesse momento.}

Zero. Mesma coisa que zero. Bem, não era zero, na realidade. A gente tinha ouvido os índios Tabajara tocar. Eles fizeram entre outros dois discos de música clássica com um repertorio digamos meio "Carro Chefe", nem sei o que... Mas eles tocavam muito bem! Eram incrivelmente musicais; era bonito o que eles faziam. Aquela foi a primeira referência. É... Quem mais que eu cheguei a conhecer? O Henrique, a gente conheceu o Henrique Pinto aqui num concurso da Di Giorgio. Primeiro concurso da Di Giorgio.

Em que ano foi isso!?

Ah, deve ter sido... Por aí, 66, 67, essa época aí mesmo.

Mas vocês participaram do concurso ou foi mesmo pra...

Nós participamos. Eram três categorias: tinha violão clássico, violão popular e o infanto juvenil. Ah, eu tinha 15 anos nessa época, o Odair tinha 11. Mas a gente não queria concorrer um contra o outro. Então o Odair participou do infanto-juvenil e eu fui pra categoria popular. E nos ganhamos!!!! .Pro Odair foi um passeio! Pra mim havia um concorrente forte que era o Eduardo Gudin. Ele acabou ficando em segundo lugar. $E$ até hoje ele tem esse negócio na cabeça, na garganta. Um destes dias estivemos lá no bar do Alemão e falamos disso. Ele me disse : "Ė, não engoli até hoje!".

Então, quem mais que a gente conheceu nessa época? Silvio Santisteban, o Macumbinha, falecido Macumbinha... $E$ isso foi antes da gente ir pro Rio em 69. Aí acabamos indo pro Rio. Meu pai foi convencido de nos levar pra conhecer a Monina Távora por um jornalista carioca.

Esse delegado foi o que falou primeiro do Duo Abreu...

É, e ele tinha esse amigo do Rio, que era um repórter do jornal O Globo e que também era fascinado por violão. Havia um grupo de violonistas no Rio liderado pelo Othon Saleiros. Este jornalista, o Oromar Terra, que fazia parte 
deste grupo veio nos falar da Monina também, dizendo que a gente tinha que ir lá conhecer a "grande professora" etc e tal. Aí meu pai nos levou pra lá. E finalmente acabou ouvindo o que ele queria ouvir. "Ah, esses meninos tem muito talento! Estou vendo o duo Abreu de novo..." Exatamente o que ele queria ouvir: que a gente era promissor, que era uma coisa fabulosa, não-sei-oque, pô... Aí, ele decidiu ir pro Rio. Pra gente poder estudar com ela com regularidade. Senão, de São Paulo pra lá, ainda mais no interior, seria muito esporádico. E acabou indo a família toda pra lá. E lá ficamos! Ficamos muitos anos no Rio, né? Estudamos com a Monina no Rio, antes dela voltar pra Buenos Aires, durante sete anos. A gente teve sete anos de aula com ela!!!! Isto foi um pouco de eco também ao que ela fez com o Segovia. Ele (Segovia )vivia em Montevidéu, na época da segunda Guerra e a Monina ia uma vez por mês de Buenos Aires pra estudar com ele. Isto durante sete anos também.

\section{Que doida, né, uma Carlevara também, não é?}

\section{$11: 40$}

Como é que era a rotina de trabalho com a professora? Freqüência das aulas...

A gente tinha uma aula por semana. As aulas eram aos domingos, e... tinha mais ou menos uma hora pra começar.; ali por volta das duas da tarde mas não tinha hora pra terminar. Ás vezes ela alongava muito. Quatro, cinco horas de aula. Não tinha... (não vou dizer que não tinha método algum). Existia alguma coisa na cabeça dela, que fazia as coisas funcionarem. Mas, metodologia mesmo era praticamente zero. Mas a Monina era uma pessoa musicalíssima,!!! E como toda pessoa musical, intuitiva, ela não tinha um preparo realmente forte, acadêmico não. Então era uma coisa intuitiva pura que ela conseguia passar de uma maneira maravilhosa. Da intuição ela dizia: quando a intuição falha, é que você botou alguma coisa cerebral no meio.Para ela a intuição não falharia nunca. Você pode até discutir este assunto, não é? Será que a intuição faz realmente as coisas funcionarem.? Mas ela apostava na intuição musical e fazia você tirar a música lá de dentro. Quer dizer: a gente tem que tirar tudo o que tá adormecido lá dentro. Então ela brigava muito com a gente dizendo: "Ah, vocês estão fazendo música, mas vocês não sentem nada". "Música se faz com as tripas".

Ela cantava muito, e mudava muito de opinião em relação ao que ela mesma determinava. Ela dizia que tinha que ser "assim" numa semana e na semana seguinte mudava tudo... Então, era um turbilhão de informações e uma flexibilidade monumental. Tanto que a gente passou a ser muito flexível. A gente nunca congelou interpretação alguma. A gente sempre levou algo pré preparado pro palco e as coisas acabam acontecendo lá.

\section{3:45}

Agora, ela tinha opiniões fortes em relação ao que se pensa, de refazer idéias musicais ou não. $E$ a gente tinha as nossas divergências também. Mas ela descortinou um mundo pra gente que era um conto de fadas, né? "Ah, vocês vão fazer uma carreira internacional, vocês vão conhecer o mundo..." que acabou acontecendo mesmo (risos), né? Mas aquilo, na realidade, quando a 
gente teve as aulas, era um sonho que a gente acalentou e parecia que não teria realmente futuro. Mas... demorou mas acabou acontecendo.

Tem alguma coisa que você possa, que a gente possa, talvez capturar assim, do que seja um campo de interesse, que pudesse ser alguma coisa comum ao longo do trabalho, assim, o que que importava pra ela no trabalho com vocês. O que era essa coisa central, o que poderia ser considerado central na poética dela, na forma como ela via a música?

Olha... Ela tinha um fascínio pela forma do Segovia tocar. Era algo muito forte!!! Então, na cabeça dela, o Segovia era e foi sempre insuperável .Mesmo quando ela falava dos Abreu, por exemplo, . ela fazia uma crítica até severa quanto a eles. A gente ouvia e discutia as coisas que os Abreu faziam na época e ela dizia, "Ah, falta muito ainda para eles!". Mas ficava uma coisa sem explicação. Falta, falta muito o que? Eu não achava que faltava nada. Mas... Ela tinha uma coisa filosófica de que faltava sofrimento, que o artista tinha que sofrer muito, tinha que passar fome, e que nenhum deles tinha passado fome 0 suficiente pra poder sentir a música na dimensão que a musica deveria ter... Tinha essa coisa romântica que era um pouco louca também.

No caso do Segovia, tinha que fazer também os outros sofrerem, né? (risos)

Mas... Eu não sei, acho que são pessoas assim que acabam empurrando, uma alavanca, né? que fazem as coisas funcionarem. E Monina tinha um prestígio musical lá no Rio que era impressionante. O Antonio Hernandez que foi um grande crítico de música do jornal O Globo no Rio admirava a Monina. Ele adorava conversar com ela, adorava as opiniões dela que sempre foram muito fortes.

Com o prestígio que ela tinha ela abria qualquer porta. $\mathrm{E}$ por isso nos acabamos tocando muito cedo no teatro municipal do Rio quando ela disse pros diretores do teatro: "Esses garotos tem que tocar aí!".

A Sala Cecília Meireles também, ela abriu as portas pra gente. E ela fazia um negócio que eu achava legal. Ela nunca comparou. Os Abreu estavam no apogeu já. $E$ a gente tava começando. Mas ela nunca incentivou esse negócio da competitividade com eles, ela , muito pelo contrário, dizia: "Vocês têm outra estória e vocês têm que apostar na estória de vocês e...". Não to falando de repertório não, porque o repertório que a gente viria a fazer posteriormente, e tudo mais, ela era completamente contra. Mas ela entendia essa coisa do astral de cada um e ela achava também que a gente devia se concentrar na estória do duo. Essa coisa da gente não fazer solos é por causa da Monina. Porque ela, de uma certa forma, dizia: "Isso os Abreu já fazem! solos e duos. Vocês deviam se concentrar na estória do duo e esquecer essa coisa de solistas pra não ficar muito parecidos com eles."

\section{Vocês só fizeram solo sob encomenda, não é?}

No início, se você pegar os velhos programas da gente, quando a gente tinha 16, 17 anos, tinha solo também. 
De qualquer forma o trabalho com solo não era uma coisa a que vocês se dedicaram especialmente.

Não, a partir dos meus 19, 20 anos, isso daí tinha acabado. Mas a gente tocava tão pouco...

Eu vi vocês tocando na TV uma vez, tocando Villa-Lobos. Vocês tocaram a Lenda do Cabloco, o Odair tocou alguns estudos, você tocou algum prelúdio, alguma coisa assim. (isso em que época foi, Fábio?) Bom, eu devia ter uns oito anos, então deve ter sido 74 ... Ah, é possível

75

Mas a estória do duo, quer dizer, esse negócio do duo, ficou muito forte, porque na realidade, um completava o outro. E desde o início foi sempre essa coisa muito forte. Aí, a gente lá no interior, sem saber o que fazer, não tínhamos partituras, coisa alguma pra dois violões, né?. O Odair desde aquela época sempre teve muita facilidade pra tocar, então tudo o que ele botava na mão ele fazia melhor que eu. Ele tocava, já com os seus nove anos o Choro da Saudade, tocava La Catedral de Barrios tocava essas coisas todas, bem! Bem, tem gravações do Odair desta fase que você não acredita! Tocava muito bem. $\mathrm{E}$ eu passei a fazer arranjos pra tocar com ele. Isso acabou determinando o que eu viria a fazer mais tarde.

Tinha alguma dificuldade de encontrar repertório, ou aqui ou mesmo no Rio de Janeiro...?

Sim pois não sabiamos onde buscar. Nosso professor de violão no interior que tinha sido o José Lopes, no máximo, chegava a botar umas coisas do Sagreras na frente da gente e pronto!

20:36

E o arranjo, a idéia de fazer arranjo, da sua parte, surgiu... pra tocar com o seu irmão...

É, a gente gostava de tocar junto? A gente tocava choro junto. Aí a partir do momento que ele foi tocando... Sei lá, fazendo o repertório dele de solos eu ia fazendo segundos violões. La Catedral eu não fiz não, mas, pô. Cheguei a fazer... É... (Para Fábio Zanon) o tremulo que você tocou, como é que é?

\section{Recuerdos?}

Recuerdos de la Alhambra, eu tinha um segundo violão pra aquilo. Fui fazendo as coisas.

Esse era um trabalho que a professora Monina incentivava a fazer quando vocês começaram a estudar com ela?

Não. Essa coisa minha de fazer arranjos, de tentar escrever música, isso foi sempre paralelo. Mas a vontade de fazer um duo, acho que era muito forte. Mais minha do que do próprio Odair. O Odair tinha facilidade pra fazer muita 
coisa. Então, poderia até ter deixado o violão de lado também. Acabou não deixando porque eu forcei muito a barra pra ele não deixar.

O que ele teria feito se não fosse, qual... No que ele era interessado?

O Odair era muito bom esportista. Muito bom! Ele era muito bom fisicamente. Muito forte, muito ágil, muito rápido. Então, não sei. Sei lá. Teria dado um atleta ou algo assim... Agora eu, provavelmente teria feito música mesmo, né? Era muito forte aquela estória de... de gostar de tocar! Eu vivia com o violão na mão. Inventando coisas, tentando compor, fazendo canções, né? Eu cheguei a fazer muita canção nessa época, 16, 17 até meus 18 anos, depois eu parei. É que eu entrei pra escola de música lá no Rio e todo mundo fazia música dodecafônica naquela época. Aí eu me sentia ridículo com as minhas coisinhas tonais, e não-sei-o-quê. Me senti tão diminuído que eu parei. Eu só fui retomar essa estória de escrever, bem mais tarde.

Fala um pouquinho do trabalho no concurso de violão. Quem foi o contato que colocou você lá pra fazer o... A gente não sabe exatamente se você foi contratado pra tocar as músicas ou se foi pra tocar as obras dos vencedores.

Do concurso de composição, você tá dizendo, esse da Funarte?

Que é o que tem os seus solos, né?

Eu acho que quem fazia isso na época era o Edino...? Era o Edino Krieger, foi a época da gestão do Edino na Funarte. Eu acho que foi o primeiro concurso de composição pra violão no Brasil. Eles fizeram uma pré-seleção. Tanto que na época eu mesmo coloquei música e não foi classificada talvez porque o que eu fazia neste tempo eram umas variações, assim, meio tonais e tal. $E$ tudo o que entrou era mais avant-garde. Mas tinha coisas muito boas realmente, acho que tinha coisas ótimas.

\section{Tem alguma coisa que você destaca?}

O que está no disco, original mesmo. Tem até uma música do Amaral (Vieira).... Que era uma boa composição mas era uma espécie de colagem do que ele ouviu dos discos do Bream... as coisas do Britten, aquilo era uma espécie de colagem. O que eu achava legal mesmo era a peça da Lina Pires de Campos. Aquilo eu achava legal.

E o ensino na sua vida, depois que você foi pra lá você $\left(^{* * *}\right)$ Duo Assad $\left({ }^{* * *}\right)$ Depois vocês se ligaram a instituições de... a escolas de violão. Como é que isso entrou na vida de vocês? A partir de que momento vocês começaram a dar aula?Mais sistematicamente?

Foi a partir de... Início dos anos noventa. Na realidade o Odair é que foi convidado pra dar aulas no conservatório de Bruxelas. E quando eu deixei Paris eu acabei indo pra lá também. E fiquei um pouco com ele lá. Até eu sair e mudar pra Chicago. E ele continua lá até hoje, né? Até hoje já tem o que? 15, 16 anos. E o Odair que não tinha estrutura muito boa pra esse tipo de coisa 
até virou um grande professor. Assim, fico admirado, com as aulas que ele dá nos dias de hoje..

E se o bom professor você diz pelos alunos, né? De fato ele tem excelência.

Você nunca quis trabalhar com ensino?

Eu cheguei a fazer parte do corpo docente da.... Roosevelt College for the Performing Arts. É uma boa escola de música que já tinha um programa de violão com dois professores. Eu acabei entrando ali tambem com um outro violonista que é o Denis Azabagic. Mas, nos últimos dois anos, talvez, já tava praticamente impossível pra mim ficar parado no mesmo lugar devido as nossas constantes viagens. E nestes últimos dois anos eu não tive tempo para os alunos de violão. Então eu decidi sair. Ta bem melhor assim, eu não me sinto devedor em relação a aluno nenhum. Porque é terrível, você ter um cara lá te esperando... Na realidade, pô, eu tinha alunos mas quem dava as aulas pra eles era o Denis. Então, pô, já que vai ser assim, é melhor eu sair e ficar só ele, né?

Mas aqui no Brasil, vocês davam aula bastante antes de morar fora. Vocês viviam de aula.

Muito. A gente vivia disso, né?

Eu fui ter uma aulinha com o Sérgio em 81, 82.

É não daria pra escapar disso.

É, eu morria de medo, porque eu era um garoto e ele era um cara que tocava já na tv e coisa e tal. E daí eu era muito amigo de um aluno dele, o Marcos Lopes. Ele falou, "Não, você tem que ir lá tocar pra ele". Bom, eu fui morrendo de medo. Ele foi super gentil e tal. Mas foi aquela excitação.

O Fábio tocava muito bem. Já foi preparado. Estava preparado.

Eu toquei, foi a única música que eu sabia, na verdade (Risos)

O que foi? O que você tocou?

Peça sem Título, do Brouwer. Alguma coisa a mais.

Você também dava muitas aulas aqui, né, Fábio? Antes de ir pra Londres?

Eu devia dar umas 30 horas de aula por semana.

Você chegou a formar alunos aqui, que continuam na ativa, o Barbieri, foi teu aluno? 
O Barbieri foi meu aluno. Ele, eu acho que de todos eles, dos meus alunos, foi o único que seguiu como musico. Os outros foram fazer outra coisa. Aliás há alguns meses... Os meus alunos, (risos)... O Carlos Augusto Goes, você conhece o Carlos Augusto, né? Fez uma reunião dos meus ex-alunos. Ah, foi muito gostoso, tinha gente que eu nem lembrava mais. Caras que foram meus alunos e eu dizia assim: "Pô, eu sinto muito, mas eu não o conheço!" (risos). Tem nenhum que é músico.

\section{O Marcos Lopes tá voltando, o Marcos Lopes ta voltando...}

Nunca mais vi o Marcos.

Ele mora em Manaus. Ah, é? É.

Mas o curioso é que nenhum deles se afastou do violão. A associação de violão lá no Rio é feita por esses caras. Antigos enamorados do instrumento. Muito legal.

E o Carlos Augusto chegou a tocar muito bem.

\section{Era inseguro pra burro, mas ele tocava super bem.}

Há pouco tempo a associação deu um recital dele e o Hélio Ribeiro. Os dois dividiram um recital como nos velhos tempos.

\section{Olha só...}

Sérgio, fala um pouquinho pra... Sobre arranjo, genericamente, assim, partindo um pouco, como o trabalho fala um pouco sobre arranjo, eu queria ter um pouco a sua visão. Qual foi a importância a seu ver, do arranjo do repertório do violão, desde, partindo das transcrições de Tárrega, que são as mais antigas que a gente conhece a partir de um ponto mais ostensivo. Tem as de Sor também, não é? E toda a história da transcrição, mas pensando no violão. Qual foi a importância das transcrições no repertório pra violão?

Eu acho que é crucial, porque e uma parte tão grande do repertório, né? Acho que arranjar virou uma coisa até tradicional. Acho que a maioria das pessoas deveria até aprender a fazer e não se limitar a pegar o que existe no mercado. Porque tem muita coisa no mercado, é verdade! Mas o fato de você se exercitar tentando fazer suas próprias coisas é bem enriquecedor pra o lado musical; pra você se desenvolver no instrumento um pouco melhor, conhecer o instrumento melhor. Eu acho importante. Eu acho que todo mundo deveria fazer um pouco... Uma tentativa de fazer arranjo, deveria tentar compor também.

Você acha que as duas coisas estão relacionadas, você se torna um compositor mais experiente com a prática de arranjo? Ou é uma coisa totalmente...

Acho! Arranjar é de uma certa forma, compor. Você usa muito os mesmos elementos que você usa na composição. Você pode reestruturar toda uma canção e fazer um belo arranjo. Vai construir uma introdução, você vai pegar 
motivos que tem ali e desenvolver também... É um trabalho de composição. É igual.

Como é o seu trabalho de arranjo e composição, ele é muito voltado pro duo de violões, pra coisas que vocês fazem com o duo... Duo com violoncello...?

Eu nunca tive um negócio assim, em termos de composição, sistemático, porque nunca tive tempo pra fazer. Também, com essa estória de fazer muito arranjo pro duo, e de nos últimos anos fazer tanto trabalho de colaboração com outros músicos deixou tudo ainda mais difícil. Eu gostaria de escrever mais. Até tenho vergonha, porque a maioria das coisas que eu escrevi foram comissionadas, na realidade. Parece aquele compositor que, pô, aquele que só escreve se pagarem. É ridículo, né?

É o caso dessa última composição que você apresentou nos recitais aqui? A "Homenagem a Nossas Raízes"?

Isso! Na realidade, na verdade sim, porque quem pediu essa música foi o [Shin Ichi Fukuda], um japonês. Aliás, é a segunda música que eu escrevi pra ele. Eu escrevi a Sonata pra ele também. Foi encomenda da Gendai. E esse troço eu escrevi pra violão solo. E quando a gente foi convidado para aquela coisa, aquela cúpula árabe latino-americana que aconteceu aqui no Brasil, nós fomos tocar lá em Brasília pros árabes. Aí pediram pra gente tocar algo árabe. Mas... O que? Aí eu simplesmente peguei aquilo que era pra violão solo e arranjei ali pra dois violões e pronto.

\section{É empolgante.}

Funciona. Isso aí funciona.

Acho que é difícil imaginar que essa é uma composição que deva ter partido de uma obra solo. Acho que essa que é a parte interessante do arranjo.

\section{Pegou bem aquilo.}

Agora na realidade, o que o Fukuda me pediu, ele queria uma peça que ele pudesse tocar com tabla. Então tinha uma percussão já. Aquela história do violão ficar fazendo percussão existe dessa forma.

Na tabla?

É.

\section{Vocês já tocaram no Oriente Médio?}

Nunca. Já se falou muito, mas não aconteceu. Pelo menos até agora, não houve. 
Sérgio, seu pai trabalhava com o que? Ele era violonista amador, mas qual era a atividade principal dele?

Ele era relojoeiro. Aliás, ele morre de rir assim: diz que a aposentadoria dele coincidiu com o termino da profissão de relojoeiro. Porque realmente se ele tivesse que viver como relojoeiro hoje, seria impossível, não é? É uma profissão que acabou. Mas uma das imagens do meu pai mais fortes na minha memoria é realmente a dele debruçado em cima de uma banca, aquele negócio no olho, abrindo relógio, tirando tije, trocando balanço e é isso.

\section{Eu acho que...}

Do que eu tinha pensado, pensei de você falar alguma coisa mais genérica enfim, de como você tenha visto o panorama do ensino do violão. Da sua perspectiva pra encerrar, assim. Pontos positivos, pontos negativos, lacunas...

Eu, pra te ser sincero, acho que o Fábio pode te responder isso melhor do que eu. Ele tá mais ligado a certos lugares, digamos. Eu acho que tem uma variável aí que é muito forte, que muda de país pra país. Por exemplo, eu não tenho experiência nenhuma em relação à Inglaterra porque é um país que a gente praticamente não vai. A gente foi muito pouco por lá, então eu não posso falar sobre o que não conheço. Eu sei que tem muita coisa que acontece lá em termo de violão, mas tem um problema lá crucial que é falta de dinheiro.

\section{É, a Inglaterra tem um problema muito sério, porque como todo mundo quer tocar lá porque é uma boa vitrine, os cachês baixam.}

Muita oferta...

\section{Exatamente.}

A gente fez uma turnê na Inglaterra, deve ter sido em $84 \ldots 85$. Tocamos dez, doze concertos. Depois que a gente terminou a turnê, a gente gastou o dinheiro todo com os hotéis, (com despesas) (de estadia) (do dia-a-dia) e a gente voltou literalmente duro. Eu falei ah, assim eu não quero voltar pra Inglaterra não.

Você não foi o primeiro não, sabe com quem que aconteceu isso? Liszt nos anos 1840, já era assim. Ele ficou três meses fazendo turnê e voltou duro.

Talvez fosse importante você tocar em Londres naquela época. Eu acho que pra nós não fez diferença nenhuma. Nenhuma, absolutamente nenhuma.

\section{É, porque vocês, a carreira discográfica é mais voltada pra Bélgica e pros Estados Unidos, inclusive...}

E na realidade, quer dizer, tocar em Londres, a gente tocou nas maiores salas.. Claro que não fomos solo, a gente dividiu, o Barbican Hall uma vez, com o 
Egberto. A gente tocou no Queen's Elizabeth Hall também, o último foi, com o Yo-yo Ma

Há muito tempo atrás a gente fez o tal do Wigmore Hall, chegamos a tocar no Wigmore Hall. Eu nem gostei muito pra te ser franco..

É, porque pra vocês tocarem lá teria que ser com uma estrutura de orquestra. Um cachê orquestral.

Eu não acredito que eles não possam pagar.

Eles não têm o hábito de ir atrás pra pagar, entendeu? Esse é que é o problema.

Eu não acredito. Na Alemanha as pessoas pagam cachês decentes. Na Itália!

É. É que são mais subsidiados. Tem mais grana de governo na Itália e na Alemanha. Mas é, ainda assim.

Você conhece mais os Estados Unidos e Bélgica. França,

Oriente, não é?

Um monte, temos uma carreira regular assim. A Inglaterra mesmo, realmente a gente passou batido.

É, mas ainda assim estão aí mencionando cinco, seis concertos grandes. Assim, lugares importantes.

Agora nos outros países a gente toca regularmente. A gente vai muito pra Ásia também. Mas o país forte pra gente são os Estados Unidos. Lá eles têm grandes agências de concertos, aí é diferente.

Uma pergunta de ordem prática. O fato de você morar em Chicago e o Odair morar na Bélgica meche com... Mudou um pouco?

Se atrapalha? Atrapalha um pouco essa questão de mudança de repertório a gente tem que planejar com muito cuidado essas coisas. Mas é claro que o fato de a gente ter tocado tantos anos juntos ajuda também, quer dizer, supera esse problema.

Você não sente a menor necessidade de ensaiar toda a semana ou o que quer que seja. Isso daí já é passado.

Não. Isso é passado.

Quando vocês eram crianças, jovens e tal, vocês trabalhavam muito juntos?

Juntos. Impressionante o número de horas que a gente tocava. Não era nem, vamos dizer, ensaiar, a gente adorava tocar. Juntos. 


\section{Alguma, enfim, você falou que o Odair talvez pudesse ter feito outra coisa na vida. Na tua cabeça nunca passou trabalhar com outra coisa?}

Antes de ir pra Universidade, antes de tentar fazer regência, que eu nunca terminei o curso de regência na Escola de Música, eu cheguei a pensar, "eu vou fazer medicina" que é um troço que vinha desde lá da minha infância. Eu queria ser médico e não sei o quê. Mas eu não tinha estrutura pra isso não. Não tinha mesmo. Mas eu achava que era impossível alguém viver de música. Tinha que fazer outra coisa, cheguei a entrar numa faculdade de filosofia. $E$ acabei desistindo, aí pensei, Ah! vou fazer música mesmo. Se eu virar um regente, quem sabe? E entrei na escola de música pra fazer regência.

Em que época você se convenceu de que a música podia...

Eu fazia música o tempo todo. Eu achava que se eu fosse fazer qualquer outra coisa eu ia ter que deixar a música de lado. E essa opção não me era válida (risos). Então, sei lá. Vamos lá. Vamos enfrentar a maré. E foi, eu acho que foi a decisão certa.

Eu também acho.

É, parece que...

Embora eu tenha entrado na escola de música lá do Rio, na época era muito divertido, porque eram uns professores muito... vai, aqueles do passado que insistem em estar presentes. Não vou mencionar nomes, mas... O Antônio Jardim, que era colega meu, que é compositor, e tal. Ele dizia: "Pelo amor de Deus, mas é uma velharia aqui nessa escola! Tem que reciclar esse negócio, um pessoal com idéias novas, tentando arejar tudo." Mas a escola foi sempre meio rançosa.

O Rio, o ensino no Rio sempre foi mais tradicional do que aqui, não é? 0 público do Rio também é muito mais (Tradicionalista). Tradicionalista do que aqui.

Achei boa a idéia que ele deu, Fábio, de você falar do ensino do violão de maneira geral.

(Rindo) Vai servir pra alguma coisa, pra você?

Eu acho que vai porque o trabalho tem a característica de ser voltado um pouco pro ensino. Tem uma tentativa aqui de

Trecho com defeito.

$\mathrm{Na}$ realidade aquele disco a Kuarup foi fazer esse disco um mês antes de lançar. Que era um disco de brinde da Coca-Cola. (Eles falaram), precisamos. Tem um mês.

A primeira gravação antes com o Turíbio parece que foi uma coisa parecida. 
Mas ele já tinha tocado, né? Ele já tinha tocado.

(A gente teve que aprender tudo). Não fazia solo...

Deixa eu perguntar pra não prolongar demais o negócio, a relação tua com compositores. 0 primeiro compositor que escreveu música pra vocês, quem que foi? Radamés?

Não, foi o Mignone.

Foi o Mignone? É? O que ele escreveu pra vocês?

Pecinhas. Que a gente chegou até a tocar, mas... tem coisas que eu tenho, que a gente nunca tocou.

Mas esse material está... Com vocês, está...?

Eu não tenho originais, eu tenho cópias. Ele não dava nada original. Material original quem dava era o Radamés. Não é? Tenho cópias. É, Miudinho, Lendas Sertanejas...

\section{Aquelas que vocês gravaram?}

"Momento Musical", tinha um negócio que parecia Scarlatti.

Bom, isso aí deve estar tudo na mão da mulher dele.

Bom, esse momento musical eu tenho o original.

Tá.

Porque foi uma coisa completamente fora de propósito, porque é uma peça barroca! Eu me lembro que a gente tocou isso na Sala, tava o Marlos Nobre, que veio ao camarim depois e falou: "Pô, o Mignone ficou louco?!".

Vocês tiveram um relacionamento profícuo com o Mignone ou foi uma coisa assim... Apareceu e...

Não, ele gostava muito de violão. Ele curtia essa história de violão. E ele viu a gente tocar talvez, eu acho que um concerto na Sala (Cecília Meireles) mesmo. Viu pela televisão também. Ele que chegou e ofereceu.

E o Radamés? Eu acho que, enfim, ele é uma outra história.

O Radamés é outra história porque nós fomos procurar o Radamés. Que a gente queria tocar o concerto, aquele que a gente acabou gravando.

$43: 25$ 
Ah, não foi feito pra vocês?

Não. O concerto já existia. E eu não sei porque cargas d'água... Não, foi a Monina que deu aquelas partes pra gente!

Mas ela não gostava da música dele.

Ela gostava do... gostava do Iberê Gomes Grosso. Ela gostava muito dele como músico.

E ele chegou a trabalhar a sonata, aquela pra dois violões e cello com os Abreu. Sob a supervisão dela. Então, onde ela podia botar o dedo e dizer: "Faz isso, faz aquilo", aí... Ela se sentia um pouco proprietária, não é? Acho que depois chegou essa coisa do concerto também que era pros Abreu fazerem. Ela acabou passando a parte pra gente. Só que quando eu levei a parte pra casa e comecei a tocar aqueles acorde do Radamés eram os mesmos acordes que eu gostava de fazer. Exatamente os que eu tocava em musica popular.

Você acha que de certa forma ele é um padrinho seu como compositor? Porque tem muita similaridade de estilo, na maneira de pensar 0 discurso...

Sim. Claro que sim. Sei. Era uma pessoa que na época pertencia ao passado, já tinha sido ultrapassado. Ninguem fazia aquele tipo de música mais, todo mundo tava fazendo música serial (mais experimental), é, exatamente.

Isso era anos 70, não é?

É. Então, acho que a combinação do Radamés na minha cabeça e do Piazzola foi assim importante pro futuro da gente mesmo. Aquela música mais acadêmica, aquele negócio todo de musica serial tava com um futuro finito, aquele troço ia acabar. Só que na época, aquele pessoal todo do meio acadêmico não sabia. Aquela música que o Radamés tava fazendo apontava pra uma outra direção. Porque estava fortemente apoiada na música tradicional. Ah, tinha uma proposta de renovação atrás daquilo. Eu era aluno da Esther Scliar, de composição; ela odiava aqueles negócios do Radamés. "Ah, me lembra música do... Parece que quando você ouve Radamés, você vai ouvir a Emilinha Borba". Né? Bom, é questão de gosto. Música é questão de gosto também.

O problema é que dentro da própria esfera, a impressão que eu tenho, da própria música clássica, de quem vai assistir a concertos de orquestra, de quem vai à casa de ópera, enfim, as pessoas estão trabalhando com uma linguagem de século XIX. Aquilo é o cerne da experiência musical das pessoas. Então no final das contas você trabalhar música nacionalista tem mais futuro (risos) dentro desse tipo de preferência musical do que uma coisa que, enfim, trabalha com um código totalmente diferente. Você renova por outras vias. 
É, a verdade é que hoje em dia fica muito mais difícil você estabelecer onde fica a linha divisória entre essa ou aquela música porque acabou esse negócio, não tem mais linha divisória. Existem trabalhos maravilhosos feitos no campo da música popular que sao de uma complexidade incrível. Quando a gente fez o disco Alma Brasileira em 88, eu já tinha isso tudo na minha cabeça, pois eu achava ridículo esse negócio dessa divisão. E eu fui lá e fiz uns arranjos, peguei umas coisas do Wagner Tiso, outras do Hermeto (Pascoal), botei Marlos Nobre, Villa Lobos, misturei tudo. De uma certa forma, eu queria provar pra mim mesmo que era possível tudo conviver junto. Por outro lado, as coisas mais complexas que tinham naquele disco eram coisas do Hermeto. Era o que tinha maior complexidade mesmo embora ele seja considerado um musico popular. Qual é entao o parâmetro pra estabelecer o que é clássico ou popular?

Isso é uma coisa que parece mais comum ou mais fácil de acontecer no violão. Talvez. Porque o violão é um instrumento que reúne essa possibilidade de maneira mais forte, assim.

Não, não, não! Grupos camerísticos também! Agora é tranqüilo você ver um grupo como o quinteto de sopros lá, como é? O... Quinteto Villa-Lobos que por sinal existe há muitos anos. Eles sempre fizeram uma coisa meio híbrida. E é um grupo camerístico.

É, e é uma coisa que acabou passando para os "figurões" da própria música clássica. Gidon Kremer, Yo-yo Ma, a Nadja, quer dizer... Você tocar as mesmas cinqüenta músicas pelo resto da sua vida é muito chato. E você precisa tocar música útil. Que você vai em qualquer lugar e as pessoas vão deglutir.

Pois é verdade. E esse troço de fazer concessão por exemplo, na cabeça da Monina era um problemão:: "Ah, você não faz concessão como artista". Não é concessão.

Concessão é quando você faz uma coisa que você não tá a fim, não é? (risos)

É. Se você gosta, acredita naquilo, entendeu? Você não tá fazendo concessão alguma, você ta fazendo o que acredita.

Agora, os anos setenta foram muito resistentes, não é verdade, ao nacionalismo. Porque aquilo ficava muito associado à ditadura militar, (Populismo) é. Então tinha toda uma política por trás da coisa. Então eu lembro assim, de assisti-los aqui em São Paulo em 80. E certos professores que a gente conhece muito bem: "Oh, eu acho essas músicas uma merda! Os caras tocam bem pra caralho, mas essas músicas são uma merda." (risos)

É verdade. Ah, coitado do Radamés. Meu Deus. 
Então é uma pena, porque você acaba perdendo um aspecto importante da formação dos alunos. Porque a hora em que você cair lá fora e você quiser... (e a história de vida deles). E a história de vida deles, porque a vasta maioria começou tocando violão popular de qualquer forma, e segundo a hora em que eles caírem lá fora, os sortudos que podem tocar fora do Brasil... Vão pedir música brasileira, cara! E você tem que saber tocar isso daí.

E o cara não tá preparado pra tocar. Brasileiro que não sabe tocar música brasileira. É. É verdade.

Perde um pouco de vista a realidade da profissão.

E você encontra os estrangeiros querendo fazer. Querendo tocar e não sabem.

Depois eu te mostro um disco, uns amigos meus lá da Inglaterra,a Cris e - Mark. Cara, dá a impressão de que eles pegaram as gravações desses caras aqui e mediram tudo com a régua. Assim, pra conseguir abserver 0 estilo. Porque, é muito meticuloso o trabalho de tentar entender... é.

É exatamente como se fosse um trabalho de musicologia, de música antiga, repertório de música barroca, pensar na música brasileira.

Entender como é que você levanta o contratempo, não sei o que, os caras fazem, brilhante assim. E o Marlos Nobre?

Que é que tem o Marlos Nobre?

\section{Escreveu pra vocês o concerto e os Ciclos Nordestinos?}

É, foi só. Não. Tem uma outra peça, que a gente nem tocou. Ih, caramba. Melhor nem falar disso (risos). Em off. Não, isso ta na pauta, a gente deveria ter tocado já. Mas o concerto dele é muito bom.

Vocês gravaram já, esse concerto?

Isso foi gravado ao vivo com a Osesp (durante um concerto na Sala São Paulo).

Eu tava nesse concerto. Tava? Eu fui testemunha daquela tosse que interrompeu o segundo movimento. O Neschiling ficou bravo lá e recomeçou a gravação do início.

A hora do "piti".

O Marlos escreve muito bem. Um compositor muito profissional.

Esse concerto é mais recente um pouco, não é?

Ah, foi, não é tão recente assim. 


\section{Os ciclos nordestinos foram pedidos de vocês?}

Não. Mas essas coisas são... Na nossa vida as coisas sempre aconteceram espontaneamente, entendeu? Essas peças são originais pra piano. O Marlos viu a gente tocar na Rede Globo, quando tinha aqueles programas matinais e acabou arranjando os ciclos pra nós.

O Marlos ficou muito enfim, muito desse conflito é do fato de que ele era associado à ditadura militar porque ele era primo do Sarney. Então...

Mas foi isso. Primeiro ele, como membro da Unesco, nos indicou pra representarmos o Brasil num concurso na Thecoslováquia. Primeira vez que a gente saiu daqui do Brasil, e era um concurso de música, não era um concurso de violão. (concurso de interpretação). De interpretação, obviamente. Nos não esperavamos ganhar nada mas a gente acabou sendo laureado. $O$ que foi super legal! E os participantes eram ótimos. Tava aquela Francis Springel, tava aquele Tatsaris (nossa, esse cara é genial). Tava... Flautista... flatuta doce? E. Michaela Petri. Estavam todos eles lá.

Você falou que vocês foram laureados?

Eram quatro prêmios iguais sem definição classificatoria. Aí, pô, a gente ficou cheio de lastro. No ano seguinte tinha uma estória de um concerto em Paris, que o Marlos tava por detrás e acabou botando a gente pra tocar também. Estavam la o Ravi Shankar e o Menuhin Foi lá na Sorbonne. Só que aí... "Voces vão tocar, mas vocês vão tocar a minha música". Aí nos levamos os Ciclo Nordestinos. Não tem almoço grátis, né? Mas foi super legal, e a música é boa.

\section{E nos anos oitenta vocês tocavam mais, não é? Ultimamente vocês não tem tocado tanto os Ciclos Nordestinos.}

Não, a gente parou de tocar. Depois que a gente gravou, quer dizer, nem gravamos tudo, assim. No disco Alma Brasileira a gente botou algumas peças. Mas nos tínhamos gravado os três ciclos no disco do Marlos feito pra Odeon. É, isso eu tenho.

Vocês tiveram alguma resistência pra tocar a música do Marlos no Brasil? Que fosse diferente de no exterior?

Não.

Tem gente que simplesmente não vai assistir.

Eu nem sabia dessa estória do Marlos, dessa resistência toda. Depois foi que eu comecei a ouvir essas histórias. "Ah, o Marlos matou o Santoro". E eu era muito amigo do Barbato (Silvio Barbato) que tinha sido aluno do Santoro. Então, nossa! Ele abominava o Marlos. Contei pro Barbato que a gente ia tocar o concerto do Marlos e ele disse assim: "Ah! Você não é mais meu amigo".

É. Essa é a resistência. E o Egberto, foi idéia tua fazer arranjo das músicas dele? 
Eu sempre gostei da música do Egberto, eu o achava um cara assim, híbrido. Eu achava assim, pô, essa cara faz um meio Jazz, meio clássico, porque tinha muita cor, a harmonia era muito interessante. Tinha muita dinâmica. Eu falava "ah, eu gosto, vou fazer". Então foi muito baseado no que eu gostava também. Piazzola foi igual.

\section{Como é que vocês conheceram o Piazzola?c}

Foi numa das primeira idas pra França. A gente conheceu o Roberto Aussel em 82 e o Piazzola ja tinha escrito as 5 piezas pra ele. As circunstâncias foram exatamente iguais. Os Aussell eram vizinhos do Jose Pons que era amissíssimo do Piazzola. E toda vez que o Piazzola ia tocar em Paris, , ele ia pra casa do Jose Pons pois ele adorava a comida da Jaqueline, a mulher do Jose.. Aí, o próprio Jose que nos viu tocar lá na rádio France fez o convite: vocês vêm tocar lá em casa pro Astor depois do concerto dele.

\section{E foi ali.}

E foi ali, foi naquela noite. $E$ a gente já tocava música dele, eu já tinha feito vários arranjos. A gente tocou as músicas dele. Ele ficou tão entusiasmado... $\mathrm{E}$ o que é curioso: ele gravou aquele negócio mesmo. Ele gostou muito mesmo porque quando ele escreveu o Tango Suíte, o final que eu tinha colocado numa peça dele, ele reproduziu na Tango Suite. Eram umas escalas diminutas, que iam descendo, não sei o quê, ele escreveu aquilo.

Esse é o final de que peça?

Do primeiro movimento. E ele disse naquela noite que ele iria escrever algo original pra gente. Eu achei assim: Bom, a gente diz nas festas, não faz. E menos de três meses depois eu recebi a partitura. A gente morava em Campo Grande, lá no Rio. Chega a partitura em casa. Um presente!

\section{Bom, você deve ter caído de costas.}

Um presentão. Quer dizer, na época ele não era o grande Piazzola que virou depois. Mas eu gostava tanto da música dele! A gente aprendeu com uma rapidez! A gente aprendeu no início de 84. A gente ia tocar em Liege, no festival de Liege na Bélgica. Foi a estréia da Tango Suíte. E ele estava nesse festival. Quando a gente acabou de tocar ele que tinha problema na perna, subiu ao palco com uma agilidade incrível, nos abraçando... e dizia: "Hijos de puta, hijos de puta!". Ele geralmente era um cara reservado, que fica ali, espera. Não, o cara foi ao palco, maior maravilha. E aquela peça abriu muitas portas pra nos. Foi uma seqüência assim, de eventos impressionantes. Logo depois de Liege a gente foi pros Estados Unidos. Tínhamos umas turnês americanas que eram pequenas. Tocamos naquele ano no Merkin Hall, em Nova York. E lá estava o [Bob Huwirtz] o cara que era produtor da Nonesuch Records. Ele estava começando na companhia e buscava gente nova pra gravar. O cara ouviu a Tango Suíte e falou, "eu quero gravar!".

Pô, que oportunidade, não é? Bom, isso só acontece em Nova York, não é? É uma coisa impressionante. 
A gente deu muita sorte também, das coisas acontecerem na hora certa.

Mas isso que é curioso a respeito de Nova York, porque isso acontece com muita gente. Você vai pra lá, vou tocar em Nova York, e daí? De repente tem alguém que, sabe? Que ta assistindo e pode fazer toda a diferença na (carreira).

Dá a impressão de que é uma coisa mais integrada. O ensino, conservatórios, universidades, o mercado musical, concertos, parece que existe mais circulação de informação entre essas instâncias.

Em Nova York particularmente, quem está lá está lá pra se dar bem. Então, tanto eles estavam lá pra dar um concerto e conseguir uma boa projeção, quanto o cara tava lá pra dar um bom começo pra companhia dele. Então você faz um casamento de interesse.

Pois é, depois a Nonesuch virou "a gravadora, a coqueluche". Você nem sabe que aquela gravadora, que esse produtor vai ser o grande produtor. Como é que você vai saber? Mas é um bom começo. E as coisas deram certo. A gente ate que fez muitos discos pra eles, porque, pô esse cara é muito difícil.

É, ele quer o produto exato que ele possa...

Muito difícil. Depois deu tão certo a companhia dele, do jeito que ele criou... Ele vende muito disco. Ele faz um trabalho legal e vende muito disco. Infelizmente nos nunca vendemos muitos discos.. Coisas de violão! Mas continuamos a gravar pra eles.

Sério, cara? Bom, comparado com seil lá, Kronos...

Kronos vende muito. Agora, não é só isso, depois o Hurwitz foi se afastando do universo dele, classico. Tanto que não ficou ninguém dos antigos artistas. Não sobrou praticamente ninguém. Ele grava Caetano Veloso, ele grava Buena Vista Social Club..e etc e tal. Mas tem o John Adams e o Phillip Glass.

Vocês vão ter que começar a cantar.

Acho que não! Ele gosta da gente pra caramba. Tanto que vai sair um outro disco novo. Ele passa por cima das atuais colaborações que temos feito $E$ diz: "Eu gosto de vocês, vocês sozinhos."

E vocês tem liberdade pra fazer o projeto que não interessa pra ele com a GHA?

Temos.

Então é uma maravilha.

Pois é! A gente não vai fazer um disco atrás do outro. Com ele de vez em quando a gente faz um disco. Ele é assim, uma pessoa aberta, legal. 
Você como compositor é um cara premeditado, você tem um plano na sua cabeça de coisas que você gostaria de fazer nos próximos anos ou vem de acordo com a demanda?

Eu tinha planos, mas os planos vão sendo alterados de acordo com as outras coisas que estão acontecendo. Eu me meti em tanta estória de colaboração nos últimos anos, que eu passei a fazer muitos arranjos. A gente fez um trabalho com o Paquito D'Rivera, onde eu tive que fazer todos os arranjos. Tem a mesma coisa com o Turtle Island String Quartet. Quarteto de Cordas que é um negócio que vai ser legal então vamos lá!

\section{É um trabalho boçal.}

Então em vez de escrever música eu estou lá adaptando coisas,

Bom, ainda bem que você pode carregar teu laptop por aí, não é?

Pois é. Mas eu escrevi, por exemplo, o concerto pra Naja pois tinha que escrever. Porque teria a chance de tocar. Porque você escrever também pra engavetar eu acho que...

Dessas colaborações que você teve Yo-yo Ma, Gidon Kremer, Naja, qual o apanhado que você faria? Qual que você achou que foi mais interessante, gratificante musicalmente?

O trabalho que a gente faz com a Nadja é muito forte. Tem oito anos já que dura. Então, acho que é a colaboração nossa que é mais forte.

As outras foram mais pontuais, não é?

É. Mas, por exemplo, a gente ta fazendo um trabalho que é legal com o Paquito, mas acho que não vai durar muito.

\section{Com o Gidon Kremer vocês chegaram a fazer uma turnê ou foi}

Chegamos a fazer uma turnê. (Uma turnê só?)

Uma só. Mas eu não faria de novo. Um déspota, ditador. (Em off?) Não, não tenho problema nenhum com isso, de falar. É um grande músico, mas como ser humano...

\section{Difícil de tratar.}

Muito arrogante, muito rei de tudo. Agora, ele sabe o que ele quer musicalmente. Ele realmente sabe o que quer musicalmente.

E o Yo-yo Ma?

Esse aí é exatamente o oposto. Uma figura maravilhosa. Um ser humano assim, no meu modo de ver inigualável. Porque uma pessoa daquele porte, a posição que ele tem, não é? Ele trata todo mundo super bem, igual, não faz 
distinção... Ele é capaz de, por exemplo, ser o último, ficar lá pra traz pra dar a gorjeta do cara que pegou as malas, abre porta pra todo mundo...

\section{Ele vem de uma família de diplomatas, não é?}

É, mas é uma maravilha. O jeito de falar, o jeito de ele lidar com as pessoas. Claro que voce pode sempre fazer críticas. "Ah, faz isso porque não sei o que". Não. Ele tem um coração...

\section{Ele não precisa disso. Genial}

Muito legal.

Tem alguma bala na agulha, tem alguma coisa que você vai fazer ainda...?

Eu acho que a gente acaba pisando nos mesmos caminhos. Voltando nos mesmos compositores. Tem um negócio que eu acho que pra a gente vai funcionar muito legal, porque eu devo ser a pessoa que mais fez versões diferentes das Quatro Estações de Piazzola. E eu fiz uma pra dois violões com orquestra. $\mathrm{E}$ a gente vai estrear isso agora em agosto lá em Belo Horizonte e a gente vai tocar no Hollywood Bowl também. Em setembro.

\section{Com o Esa-Pekka Salonen regendo?}

Exato. Como é Piazzola... E Piazzola é um negócio que a gente realmente sabe tocar bem.

\section{É, tem alguns anos de janela, não é? (risos)}

Fim da entrevista. 